\title{
Model van voorzieningen voor ouderen
}

\author{
Citation for published version (APA):
}

Huijsman, R. (1990). Model van voorzieningen voor ouderen. [Doctoral Thesis, Maastricht University]. Kerckebosch. https://doi.org/10.26481/dis.19901214rh

Document status and date:

Published: 01/01/1990

DOI:

10.26481/dis.19901214rh

Document Version:

Publisher's PDF, also known as Version of record

\section{Please check the document version of this publication:}

- A submitted manuscript is the version of the article upon submission and before peer-review. There can be important differences between the submitted version and the official published version of record.

People interested in the research are advised to contact the author for the final version of the publication, or visit the DOI to the publisher's website.

- The final author version and the galley proof are versions of the publication after peer review.

- The final published version features the final layout of the paper including the volume, issue and page numbers.

Link to publication

\footnotetext{
General rights rights.

- You may freely distribute the URL identifying the publication in the public portal. please follow below link for the End User Agreement:

www.umlib.nl/taverne-license

Take down policy

If you believe that this document breaches copyright please contact us at:

repository@maastrichtuniversity.nl

providing details and we will investigate your claim.
}

Copyright and moral rights for the publications made accessible in the public portal are retained by the authors and/or other copyright owners and it is a condition of accessing publications that users recognise and abide by the legal requirements associated with these

- Users may download and print one copy of any publication from the public portal for the purpose of private study or research.

- You may not further distribute the material or use it for any profit-making activity or commercial gain

If the publication is distributed under the terms of Article $25 \mathrm{fa}$ of the Dutch Copyright Act, indicated by the "Taverne" license above, 
MODEL VAN VOORZIENINGEN VOOR OUDEREN 



\section{MODEL VAN VOORZIENINGEN VOOR OUDEREN}

\section{PROEFSCHRIFT}

ter verkrijging van de graad van doctor aan de Rijksuniversiteit Limburg te Mazstricht, op gezag van de Rector Magnificus. Prof. Dr. F. I. M. Bonke. volgens het besluit van het College van Dekanen. in het openbant te verdedigen op vrijdag. 14 december 1990 om 14.00 uur

door

\section{Roblbert Huijsman}

geboren te Rotterdam op 26 januani 1962 
Promotor:

Beoordelingscommissie: Prof. dr. J. A. M. Maarse. Rijksuniversiteit Limburg (voorzitter)

Prof. dr. H. A. Becker, Rijksuniversiteit Utrecht

Dr. J. A. 1. Coolen. Universiteit Twente

Prof. dr. C. P. M. Knipscheer, Vrije Universiteit Amsterdam

Dr. A. Plı. Visser. International Health Foundation te Brussel

Het in dit boek beschreven onderzoek is uitgevoerd in opdracht van de (voormalige) Stuurgroep Onderzoek Ouderwordende Mens (SOOM) en het Ministerie van Welzijn. Volksgezondhaid en Cultuur.

Omslagonterverp: Frits Reijthst - Zeist

CIP/ISBN $90-6720-098-0$

(C) 1990. R. Huijsman / Kerckebosch bv. Zeist

Alle rechten woorbehouden. Niels unt deze uitgave nage worden verveelroudigd, opgeslagen in ect geatomatiserd gegevensbestand. of openbala gemaki, in enige vorm of op enige wijze. hetzij otektronisch. mechunisch, door fotokopiezh. opnanen, of enige andere manier, zonder wootafgande schriftelijke vestemming wn de vitgever.

Voor zover hot maken wn kopieèn uit deze uitgatee is toegestan op grond van artikel 16 b Auteurswer 1912 juncto het Besluit van 20 joni 197. S.b. 351 , zoals gewijzigd bij Besluit van 23 angustus $1985, \mathrm{Stb}, 471$ en artikel 17 Anteurswet 1912. dient men de dararoor wettelijk revschuldigde vergoedingen te voldoen ann de Stichting Reprorecht (Postbus $882,1180 \mathrm{AW}$

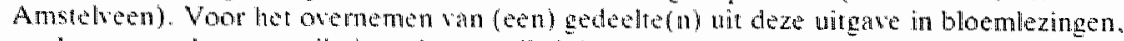
reaters en andere compilatiowerken (artikel lin Auteurswet 1912) dient men zich tot de vitgerar te wenden. 


\section{Kaar!}

(Aviek, anderhalf jaar oud, na voltooiing van elke handeling) 



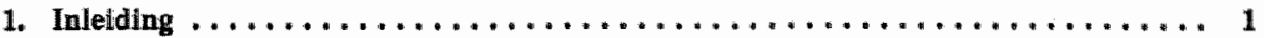

1.1. Het onderzoeksproject $\ldots \ldots \ldots \ldots \ldots \ldots \ldots \ldots \ldots \ldots \ldots \ldots \ldots \ldots$

1.2. Achtergronden van de studie $\ldots \ldots \ldots \ldots \ldots \ldots \ldots \ldots \ldots \ldots \ldots \ldots \ldots$

1.3. Probleemstellingen van het onderzoek $\ldots \ldots \ldots \ldots \ldots \ldots \ldots \ldots \ldots$

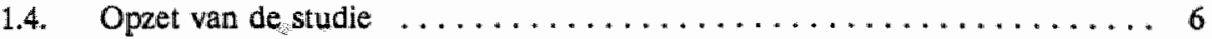

2. Demografische trends in Maastricht en Nederiand $\ldots \ldots \ldots \ldots \ldots \ldots \ldots \ldots$

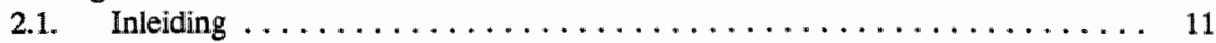

2.2. (Dubbele) vergrijzing in cijfers . . . . . . . . . . . . . . 11

2.3. De 65 -plussers naar burgerlijke staat en huishoudsamenstelling $\ldots \ldots \ldots 13$

2.4. Verwachtingen ten aanzien van de toekomst . . . . . . . . . . . 15

2.5. Vergrijzing en de invloed op voorzieningengebruik $\ldots \ldots \ldots \ldots \ldots \ldots$

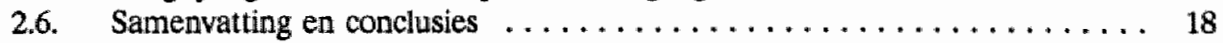

3. De ontwikkeling van ouderenbeleid in vogelwlucht $\ldots \ldots \ldots \ldots \ldots \ldots \ldots$

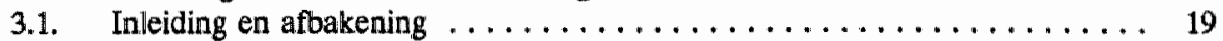

3.2. Belangrijkste ontwikkelingen in de gezondheidszorg voor $1945 \ldots \ldots \ldots$

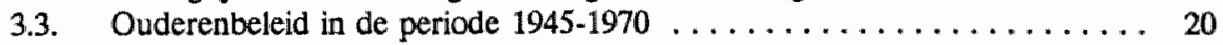

3.4. Ouderenbeleid in de periode $1970-1990 \ldots \ldots \ldots \ldots \ldots$

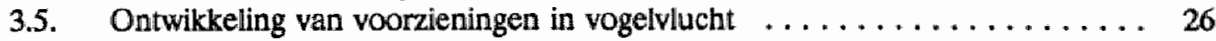

3.5.1. Korte beschrijving van de gezinsverzorging . . . . . . . . . . . . 26

3.5.2. Korte beschrijving van de wijkverpleging . . . . . . . . . . . 27

3.5.3. Korte beschrijving van het gecoördineerd ouderenwerk en dienstencentra 28

3.5.4. Korte beschrijwing wan de bejaardenoorden ................ 30

3.5.5. Korte beschrijving wan de verpleeghuizen . . . . . . . . . . . 32

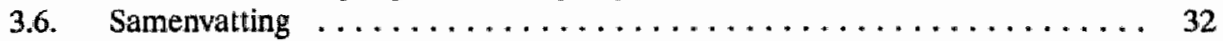

4. Het gebruik van voorzieningen door ouderen in Nederland $\ldots \ldots \ldots \ldots \ldots \ldots$

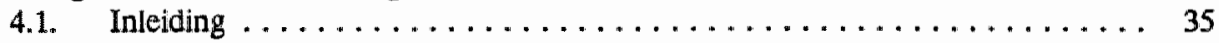

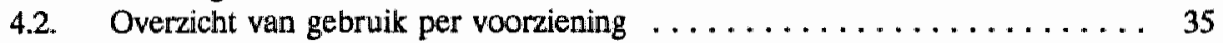

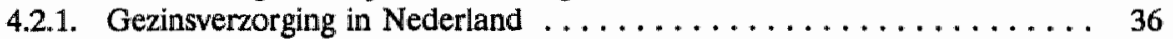

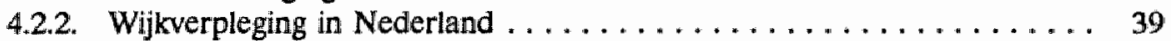

4.2.3. Gecoordineerd ouderenwerk in Nederland . . . . . . . . . . . . . . . 42

4.2.4. Bejaardenoorden in Nederland . . . . . . . . . . . . . . . 43

4.2.5. Verpleeghuizen in Nederland . . . . . . . . . . . . . . . . 48

4.3. Getbruik van voorzieningen door ouderen: samenvatting en ramingen .... 52

4.4. Omvang van clientenstromen en potentie van substitutie ........... 54

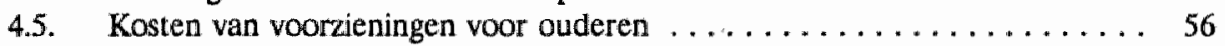

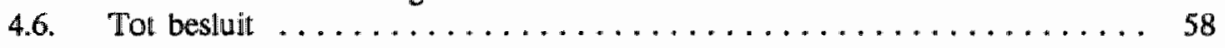

5. Introductie op de beschrijving van voorzieningen voor ouderen in Maastricht . . 63

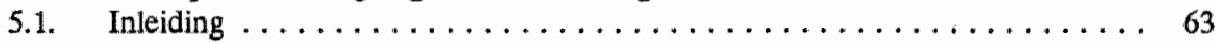

5.2. Wijze van aanpak: de instellingsenquete $\ldots \ldots \ldots \ldots \ldots \ldots \ldots \ldots$

5.3. Functionele indeling van ouderenzorg: afbakening van functies . . . . . . 64

5.4. Afwijkingen van het centrale stramien ..................... 68

5.5. Opzet van deel B . . . . . . . . . . . . . . . . . . . . . . . . 69 


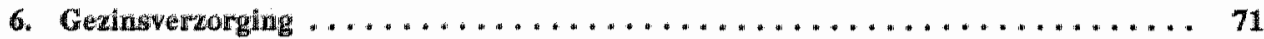

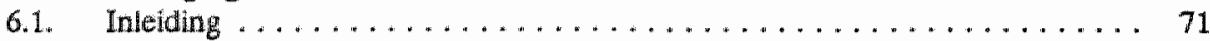

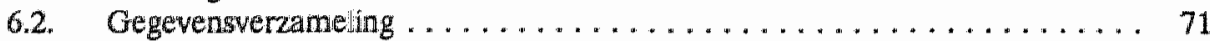

6.3. Trendmatige ontwikkelingen in het gebruik van gezinswerzorging $\ldots \ldots \ldots 72$

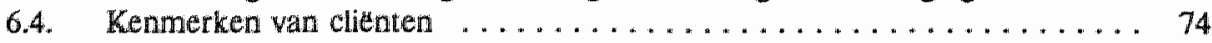

6.5. Bexindiging van hulp van de gezinsverzorging in $1988 \ldots \ldots \ldots \ldots \ldots$

6.6. Analyse van activitelten gezinsverzorging en relatie met hulpomvang . . . . 80

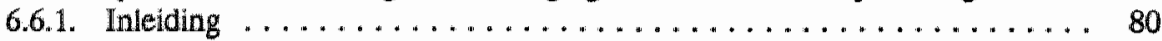

6.6.2. Dimensies van hulpverlening, afzonderlijk bezien ........... 81

6.6.3. Dimensies van hulp en de invloed op aard en omvang van hulp . . . . 82

6.6.4. Verklaring van de verstrekte hulp .................. 83

6.7. De kosten van gezinswerzorging ...................... 84

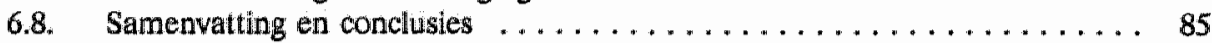

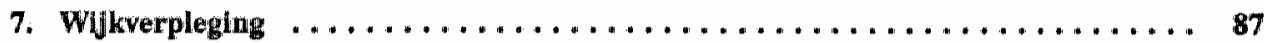

7.1. Inleiding en dataverzameling $\ldots \ldots \ldots \ldots \ldots \ldots \ldots \ldots \ldots \ldots \ldots$

7.2. Nadere toelichting op rapportagesysteem in Maastricht . . . . . . . . . 87

7.3. Analyse van kenmerken van clienten van wijkverpleging $\ldots \ldots \ldots \ldots \ldots$

7.3.1. Leeftijdswerdeling van clienten $\ldots \ldots \ldots \ldots \ldots \ldots \ldots \ldots$

7.3.2. Contacten. aantallen naar leeftijasgroepen . . . . . . . . . . . . . 89

7.3.3. Contacten: aard en doelen ........................ 90

7.3.4. Contacten tijd en plats . . . . . . . . . . . . . . . . . . . 92

7.3.5. Bereik van wijkverpleging . . . . . . . . . . . . . . . . 93

7.3.6. Personeelsinzet en aard wan contacten . . . . . . . . . . . . . . . . 94

7.4. Duur van hulpverlening en invloed op verdeling van contacten . . . . . . . 95

7.5. Personeelsformatie van kruiswerk in Maastricht . . . . . . . . . . . . . 99

7.6. Kosten en financiering van het kruiswerk in Maastricht . . . . . . . . 100

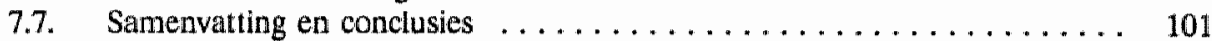

8. Gecoürdineerd ouderenwerk en het gebruik van dienstencentra . . . . . . . . 103

8.1. De ontwikkeling van het GOW in Maastricht $\ldots \ldots \ldots \ldots \ldots \ldots \ldots$

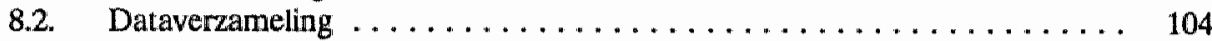

8.3. Analyse van kenmerken van bezoekers dienstencentra . . . . . . . 105

8.3.1. Leeftijdsituatie van bezoekers dienstencentra . . . . . . . . . . 105

8.3.2. Bereik van dienstencentra . . . . . . . . . . . . . . . . . . 106

8.3.3. Bezoek aan dienstencentra: frequentie en aard $\ldots \ldots \ldots \ldots \ldots$. . . 107

8.3.4. Vervoer naar en wijze van kennismaking met GOW . . . . . . . . 108

8.3.5. Gebruik van andere voorzieningen . . . . . . . . . . . . . . 109

8.4. Kosten en financiering van het gecoobdineerd ouderenwerk . . . . . . . 110

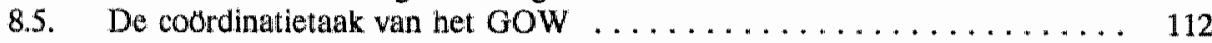

8.6. Samenvatting en conclusies . . . . . . . . . . . . . . 113

9. Indicatiecommissie en bejaardenoorden:

globaal overzicht periode 1985-1988 ... . . . . . . . . . . . . 115

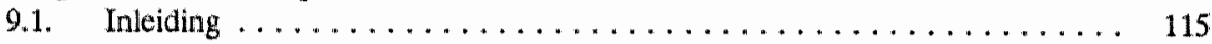

9.2. Indicatieconmissie bejaardenoorden (oude stijl) $\ldots \ldots \ldots \ldots \ldots \ldots \ldots$

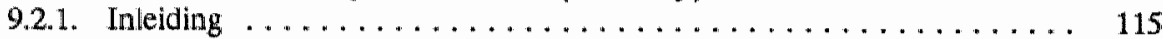

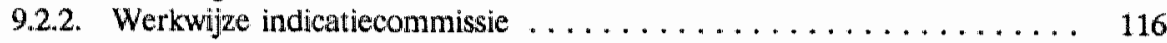

9.2.3. Beslissingscriteria bij de adviesbepaling $\ldots \ldots \ldots \ldots \ldots \ldots \ldots \ldots \ldots$

9.2.4. Aantal aanvragen en verstrekte adviezen in de periode $1980-1987 \ldots \ldots 118$

9.2.5. Indicatiecommissie Ouderenvoorzieningen nieuwe stij! $\ldots \ldots \ldots \ldots 121$ 
9.3. Overzicht van de bejaardenoorden in de periode $1985.1988 \ldots \ldots \ldots 122$

9.3.1. Capaciteitsontwikkelingen in bejaardenoorden te Maastricht . . . . . . 122

9.3.2. Opbouw van het bewonersbestand sinds $1985 \ldots \ldots \ldots \ldots \ldots$. . . . . . . 123

9.3.3. In- en uitstroom bejaardenoorden . . . . . . . . . . . . . . . 125

9.3.4. Wijkfuncties bejaardenoorden . . . . . . . . . . . . . . . . 127

9.3.5. Personeel in algemene bejaardenoorden ................ 128

9.3.6. Kosten en financiering van de bejaardenoorden . . . . . . . . . . . . . 130

9.4. Samenvatting van de belangrijkste bevindingen $\ldots \ldots \ldots \ldots \ldots \ldots$

10. Analyse van bewonerskenmerken in de Mastrichtse bejaardenoorden .... . 1135

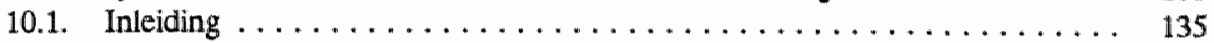

10.2. Gebruikte onderzoeksinstrumenten en gegevensverzameling . . . . . 135

10.2.1. Registratiesystemen voor meerzorg in bejaardienoorden ........ 135

10.2.2. Beoordelingsschaal Psychische en Sociale problemen (BPS) . . . . . 137

10.2.3. Gegevensverzameling in Maastrichtse bejaardenoorden . . . . . . . 138

10.3. Individuele meerzorg in Maastrichtse bejaardenoorden . . . . . . . . 138

10.3.1. Algemene bewonerskenmerken . . . . . . . . . . . . . . . . . . 139

10.3.2. Totale en gemiddelde meerzorg . . . . . . . . . . . . . . . . 140

10.3.3. Verschillen in meerzorg naar sexe, leeftijd en burgerlijke staat . . . . 141

10.4. Resultaten van de BPS-metingen in Maastrichtse bejaardenoorden . . . . . 144

10.4.1. Aanwezigheid van psycho-sociale problemen . . . . . . . . . . . . . 144

10.4.2. Samenhang met bewonerskenmerken ............... 146

10.4.3. De onderlinge samenhang tussen de BPS-schalen $\ldots \ldots \ldots \ldots \ldots, 147$

10.4.4. De samenhang tussen meerzorg en BPS-scores $\ldots \ldots \ldots \ldots \ldots$

10.5. Verschillen tussen bejaardenoorden? . . . . . . . . . . . 150

10.5. 1. Instellingsverschillen bij kenmerken van bewoners $\ldots \ldots \ldots \ldots \ldots$

10.5.2. Instellingsverschillen met betrekking tot uitkomsten van

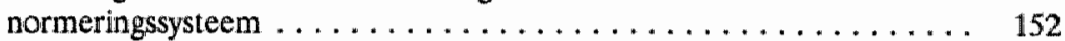

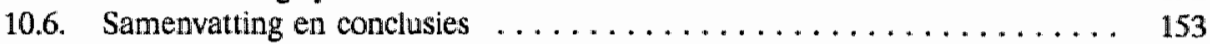

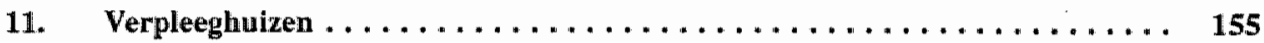

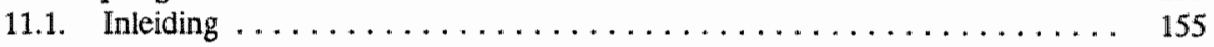

11.2. Gebruik verpleeghuiszorg in de periode $1980-1988 \ldots \ldots \ldots \ldots \ldots \ldots \ldots$

11.3. Patientenstromen naar, door en uit het verpleeghuis $\ldots \ldots \ldots \ldots \ldots \ldots$

11.4. Dagbehandeling in het verpleeghuis $\ldots \ldots \ldots \ldots \ldots \ldots 1$

11.5. Personeel en kosten verpleeghuiszorg in Maastricht . ........... 163

11.6. Samenvatting: vergelijking van lokale met nationale ontwikkelingen ..... 164

12. Samenvatting aanbodbeschrijving $\ldots \ldots \ldots \ldots \ldots \ldots \ldots \ldots \ldots \ldots \ldots \ldots \ldots$

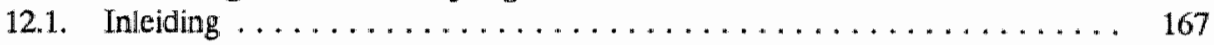

12.2. Bereik van voorzieningen $\ldots \ldots \ldots \ldots \ldots \ldots \ldots \ldots \ldots \ldots \ldots \ldots \ldots$

12.3. De kosten van ouderenzorg .......................... 169

12.4. Functionele benadering van personeelslasten $\ldots \ldots \ldots \ldots \ldots \ldots \ldots \ldots$

12.5. Kanttekening . . . . . . . . . . . . . . . . . . . . . . . 172

13. Begrippen, methoden en datamaterial $\ldots \ldots \ldots \ldots \ldots \ldots \ldots \ldots \ldots \ldots$

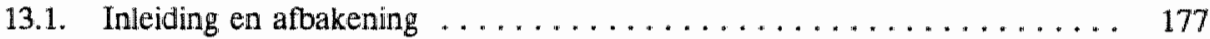

13.2. Gehanteerde behoefte'-begrippen ................. 177

13.3. Verklaringsmodellen voor voorzieningengebruik . . . . . . . . . . 179

13.3.1. Het model van Andersen . . . . . . . . . . . . . . . . . . . . . . . 179

13.3.2. Het begrip 'afhankelijkheid' van zorg . . . . . . . . . . . . . 181

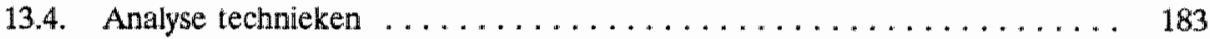

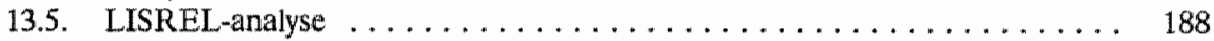

13.6. Datamateriaal . . . . . . . . . . . . . . . . . . . . . . . . 189 


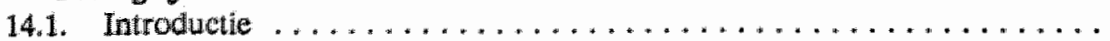

14.2. Demografische kenmerken . . . . . . . . . . . . . . . . . . . . 198

142.1 . Inleiding . . . . . . . . . . . . . . . . . . . . . . . 198

14.2.2. Onderlinge samenhang bij demografische kenmerken . . . . . . . . 198

14.2.3. Samenhang tussen demografische en andere variabelen . . . . . . . 199

14.3. (Instrumentele) Activiteiten van het Dagelijks Leven . . . . . . . . . . . . 200

14.3.1. Inleiding . . . . . . . . . . . . . . . . . . . . . . . . 200

14.3.2. Constructie (I)ADL-schalen ....................... 202

14.3.3. Relaties met andere aspecten uit de leefsituatie $\ldots \ldots \ldots \ldots \ldots \ldots$

14.4. Andere indicatoren voor lichamelijk functioneren $\ldots \ldots \ldots \ldots \ldots \ldots$

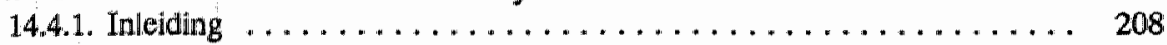

14.4.2. Constructie van en onderlinge samenhangen tussen gezondheidsindicatoren . . . . . . . . . . . . . . . . . 208

14.4.3. Relaties met andere variabelen ................... 210

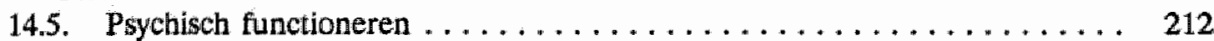

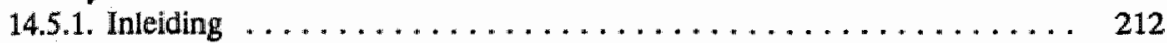

14.5.2. Schaalconstructie psychisch functioneren $\ldots \ldots \ldots \ldots \ldots \ldots \ldots$

14.5.3. Samenhang tussen psychisch functioneren en andere variabelen .... 217

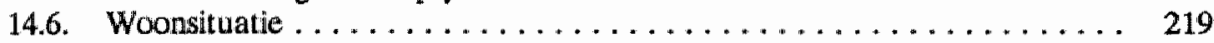

14.6.1. Inleiding . . . . . . . . . . . . . . . . . . . . . . . . . 219

14.6.2. Constructie van en onderlinge relaties tussen woon-variabelen . . . . . 221

14.6.3. Relaties tussen kernvariabelen woonsituatie en andere variabelen . . . 223

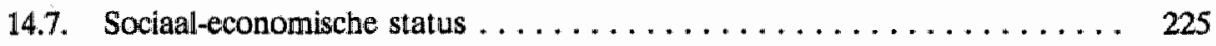

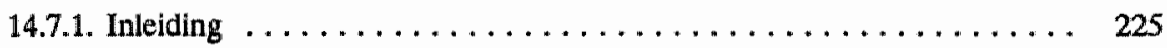

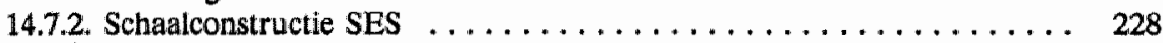

14.7.3. Samenhang tussen SES en andere variabelen . . . . . . . . . . 229

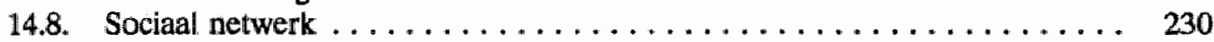

14.8.1. Inleiding . . . . . . . . . . . . . . . . . . . . . 230

14.8.2. Constructie van sociaal netwerk variabelen . . . . . . . . . . . 232

14.8.3. Relaties tussen sociaal netwerk en andere variabelen . . . . . . . 235

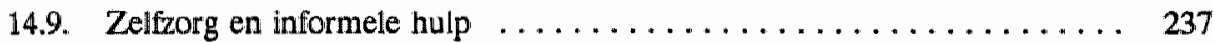

14.9.1. Inleiding . . . . . . . . . . . . . . . . . . . . . 237

14.9.2. Zelfzorg en informele hulp: patronen en constructie van variabelen .. 238

14.9.3. Samenhang lussen informele hulpverlening en andere variabelen . . . . 242

14.10. Samenvatting ............................ 243

15. Vooraieningengebruik door ouderen $\ldots \ldots \ldots \ldots \ldots \ldots \ldots \ldots \ldots \ldots \ldots \ldots$

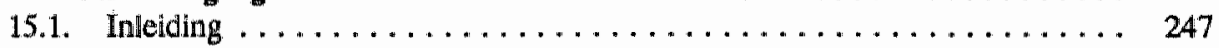

15.2. Voorzieningengebruik en determinanten daarvoor: een globale verkenning 248

15.3. Regressie-modellen ter verklaring van het gebruik ............ 253

15.4. Constructie van een kostenvariabele ..................... . . . 259

15.5. Een MIMIC-model voor afhankelijkheid . . . . . . . . . . . . . . . 264

15.6. Effect-simulatie met betrekking tot voorzieningen-gebruik . . . . . . . 271

15.7. Samenwatting en discussie ..................... 275

16. Algemene samenvatting en conclusies $\ldots \ldots \ldots \ldots \ldots \ldots \ldots \ldots \ldots \ldots \ldots$

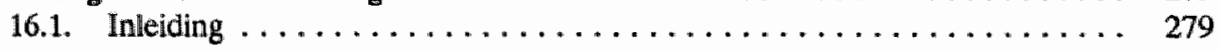

16.2. Onderzoekslijn 1: de aanbodzijde van de ouderenzorg . . . . . . . . . 281

16.3. Onderzokekslijn 2 : de vraagzijde van de ouderenzorg $\ldots \ldots \ldots \ldots \ldots \ldots . \ldots 283$

16.4. Een verbijzondering: de individuele kostenvariabele $\ldots \ldots \ldots \ldots \ldots \ldots \ldots$

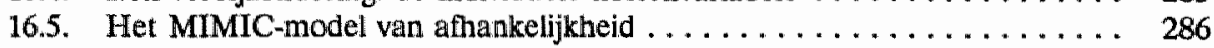

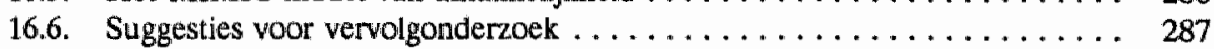

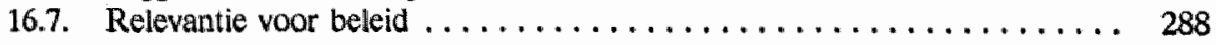




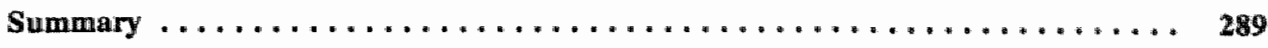

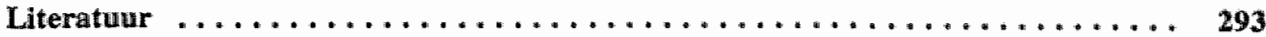

Bijlage 1. Tijdbalk ouderenzorg $\ldots \ldots \ldots \ldots \ldots \ldots \ldots \ldots \ldots \ldots \ldots \ldots$

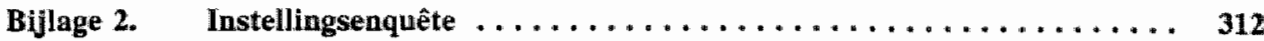

Bijlage 3. Berekening van de kosten van indicatie-stelling $\ldots \ldots \ldots \ldots \ldots \ldots$

Bijlage 4. Ruwe tellingen uit de peilingen van individuele meerzorg $\ldots \ldots \ldots \ldots$

Bijlage 5. Ruwe scores bij beoordeling psycho-sociale problematiek in

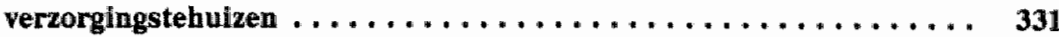

Bijlage 6. Correlatie-matrix tussen de verschillende (I)ADL-items $\ldots \ldots \ldots \ldots$

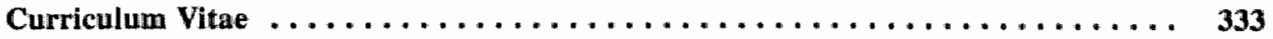





\section{Voorwoord}

Alle promovendi bebben én ding gemeen: zij zijn in het finale stadium van hun dissertatie zo onuitsprekellijk opgelucht dat 'de klus. gekdaard is dat zij de hele wereld zouden willen bedanken. Deze onbedwingbare wens omzetten in een leesbaar woorwoord moet worden beschouwd als de laatste hindernis voordat het manuscript naar de drukker kan gaan. Het is twijfelachtig of deze hindlernis de eenvoudigste is in de reeks van hindernissen die onlosmakelijk verbonden is aan het doen van onderzoek en het schrijven van een proefischrift.

Op 1 mei 1986 is met mijn aanstelling bij de vakgroep Economie van de Gezondheidszorg van de Rijksuniversiteit Limburg te Maastricht het project Model van Voorzieningen voor Ouderen van start gegaan. Het project, gefinancieerd door de (voormalige) Stuurgroep Onderzoek Ouder wordende Mens (SOOM) was het resultaat van een voorstudie die al in 1984 vericht was. Het project werd in 1985 goedgekeurd, maar het duurde tot 1 mei 1986 tot een onderzoeker gevonden was om het ten uitvoer te brengen. De aanvankelijk vastgestelde looptijd was op 1 mei 1989 verstreken, maar werd verlengd tot 1 mei 1990 en later nog eens tot 1 december 1990 . Ik ben de opdrachtgever, het Ministerie van WVC, zeer erkentelijk woor het gestelde vertrouwen (als een tot twee mal toe verieende werlenging zo uitgelegd mag worden). Gedurende de gehele looptijd van het project heeft een deskundige begeleidingscommissie bestaan om te waken over de voortgang van het project. Naast deze officielle taak was de meedenk- en klankbordfunctie, waarop altijd een beroep gedaan kon worden, vele malen belangrijker, zodat de samenwerking altijd prettig en vruchtbaar vertiep. In de begeleidingscommissie hadden de volgende leden zitting: mw. drs. M. Duynstee (Nationale Kruisvereniging; lid vanaf april 1989), mw. drs. P.S.A. Gho (thans werkzaam bij het Nationaal Instituut voor Zorg en Welzijn; lid tot april 1989), drs. F.G.W. Goudriaan (Directie Onderzoek en Ontwikkeling van het Directoraat Welzijn van het Ministerie van WVC; sinds 1 mei 1989 tevens secretaris begeleidingscommissie), drs. J.R. Kraan (plaatsvervangend directeur van de Directie Onderzoek en Ontwikkeling van het Directoraat Welzijn van het Ministerie van WVC; voorzitter begeleidingscommissie), drs. R. de Laat (thans werkzaam bij het NIZW), mw. drs. S.A.G. van der Linde, (Directie Ouderenbeleid van WVC; tot 1 mei 1989 secretaris begeleidingscommissie), drs. G. Rutten (Centrale Raad Gezinsverzorging), drs. J. Timmermans (Sociaal Cultureel Planbureau) en drs. T.F.W. Wehkamp (voorzitter van het Centraal Orgaan Samemwerkende Bonden van Ouderen). lk wil van deze gelegenheid gebruik maken deze commissie te bedanken voor de prettige samenwerking en de leden tevens te complimenteren met het feit dat zij het zo lang hebben kunnen volhouden hun waardevolle en gewaardeerde bijdrage te leveren.

Het is een goed universitair gebruik om voor een project een onderzoeksteam te formeren. Immers, 'alleen is maar alleen' en ik kon het ook niet alleen. De leiding was in handen van prof.dr. Frans Rutten die vanaf het begin bevorderde dat het project werd 'omgebouwd" tot een promovabel onderzoek. De vrijheid die hij mij in (en buiten) het onderzoek en bij dit proefschrift gaf was groot en bleef absoluut niet beperkt tot de zakelijke aspecten. Mijn waardering voor Frans is daarmee evenredig, zodat ik mij verheug op het blijven voortbestaan van onze samenwerking, zij het op een andere lokatie.

In een begeleidende rol maakte dr. Adriaan Visser mij op een prettige en luchtige wijze deelgenoot van zijn grote onderzoekservaring en leerde mij de betekenis van de stelling 'publish or perish'. Daarnaast hebben wij bij diverse projecten binnen het Deelproject Voorzieningen voor Ouderen (eveneens gefinancierd door de voormalige SOOM), waarvan Adriaan Visser de voortvarende leider was, op aangename wijze samengewerkt.

Voor het ontwikkelen van het onderzoeksplan, het uitvoeren van de voorstudie en het wegwijs maken op het onderzoeksterrein bij mijn start in 1986 ben ik drs. Frits Harmsze veel dank verschuldigd. Hij verschafte mij ook de broodnodige toegang tot 'het veld'. 
Tot 1 julf 1989 had ik bij het onderzoek een student-assistent als 'maatje': Eric Dolmans. Omdat ik zelf student-assistent geweest ben, weet ik wat het is om je voor het eerst op een vreemd studieterrein te begeven, zeker als je datarbij bowendien 'in het diepe gegooid wordt. Neem echter van mij aan dat je dat goed is afgegaan (het bewijs staat in de literatuurlijst). Wat echter wellicht belangrijker is dan het resultaat is de weg waarlangs dat wordt bereikt; die was in mijn ogen zo prettig dat ik het bepaald niet leuk vond dat je in 1989 besloot af te gaan studeren en daarvoor je assistentschap op te geven.

Nu kan je nog zo graag onderzoek willen doen, maar mensen die al dat geschrijf kunnen en willen omzetten in leesbaar drukwerk zijn daarbij onmisbaar. Ik heb het geluk gehad in de afgelopen jaren twee dames te treffen die dat zowel goed als snel als (meestal) goedgemutst deden. Totdat zij in eind 1988 bij de universiteit een andere baan aanvaardde was dat mw. Yvonne Lemmen-Lagarde en sindsdien mw. Maria Korbmacher-Kalivas. Beide 'meisjes' (echt, het is hun eigen jargon) verdienen hun gewicht in goud. Technische assistentie werd met grote inzet gegeven door ir. Jan van Emmerik. Deze man heeft 'gouden handjes' en is het levende bewijs dat de intelligentie niet onder maar boven het toetsenbord zit. Hij maakte in een paar jaar tijd vijf of zes proefschriften, waar anderen er maar én in hun leven doen. Hij blijft daarbij -in tegenstelling tot de promovendus- bovendien stressbestendig. Dit laatste gaat ook op voor mw. Jacqueline Micheels en mw. Ellen BreevoortZeguers die onder vaak grote tijdsuruk een onbetaalbare bijdrage hebben geleverd aan de verzameling en accurate verwerking van grote hoeveelheden gegevens.

In de slatfase van het onderzoek heeft mw. drs. Mirjam de Klerk een grote rol gespeeld. Hoewel zjj nog geen drie jaar op het onderzoeksterrein werkzaam is, heeft zij al mijn concepten dermate kritisch doorgelicht dat je je geen betere collega en paranimf kan wensen. Dit vol te houden tot de laatste versie van het proefschrift moet een bezoeking zijn geweest. Zij heeft dat echter nimmer laten merken. Of soms toch? Promoveer je zelf nog? Inhoudelijke steun met betrekking tot de 'ins en outs' van het ouderenbeleid van de overheid kreeg ik steeds van drs. Marcelis Boereboom, hoofd van de Hoofdafdeling Ontwikkeling en Afstemming van de Directie Ouderenbeleid van het Ministerie van WVC. Hij vormt het bewijs dat werk samen kan gaan met vriendschap en ik ben daarom blij dat hij bereid is mij als paranimfij bij te staan.

Het in dit boek beschreven onderzoek zou onmogelijk geweest zijn zonder de medewerking wan vele mensen in 'het veld" en aan de universiteit. Allerlei organisaties zijn in de afgelopen jaren door mij 'bestookt' met vragen om en over gegevens. Ondanks het feit dat woor hen de relevantie van het onderzoek -in ieder geval in eerste instantie- niet attijd duidelijk was en de instellingen er ook niet direct baat bij hadden, hebben toch vrijwel alle organisaties op een goede en prettige wijze meegewerkt. Ik ben de gezinsverzorging, de lokale en provinciale kruisverenigingen, alle bejaardenoorden, het verpleeghuis, het gecourdineerd ouderenwerk, de gemeente en de provincie hierwoor zeer erkentelijk. Met name het gezamenlijk besprekken van resultaten, het doordenken van de mogelijkheden en het -in enkele gevallengezamenlijk ontwikkelen van instrumentarium heb ik boeiend gevonden en op prijs gesteld. Dat ik daarbij -zeker in het begin- soms als een 'olifant door de porseleinen kast' ging, moet u maar toeschrijven aan mijn enthousiasme, jeugdigheid, ambities, onervarenheid, gebrek aan tact of aan een combinatie van voorgaande factoren. Bij het leerproces heeft $u$ echter in alle opzichten een verdienstelijke rol gespeeld.

Een speciaal dankwoord wil ik richten tot mw. dr. Carla Frederiks en mw. drs. Margreet te Wierik. Zij hebben mij de gegevens beschikbaar gesteld die zij voor hun eigen onderzoek verzameld hebben bij ruim 900 ouderen in de gemeente Maastricht. Let wel: dit betreffen gegevens die zij zelf nog maar net gereed hadden voor analyse en waarop zij zelf (gaan) promoveren. Begin oktober heeft Carla dat reeds volbracht en Margreet zal snel volgen. 
Dat je in zo'n situatie gegevens beschikbaar steit aan een derde, is in de universitaire onderzoekswereld een zelden aangetroffen fenomeen. Dat je vervolgens tussen de bedrijven door ook nog kans ziet om concepten van commentaar te voorzien, is helemaal ongelofelijk. Carla en vooral Margreet ben ik daarvoor zeer dankbaar. Als jullie soms hel gevoel bekroop dat i $\mathrm{k}$ wat al te voortvarend construeerde en concludeerde, dan biedt ik daarvoor mijn excuses aan; dat is nooit mijn opzet geweest. De op bet betreffende datamateriaal gebaseerde analyse en conclussies vallen natuurlijk onder mijn verantwoordelijkheid.

Het bevorderen van de zelfstandigheid en zelfredzaamheid van ouderen staat in het luwidige overheidsbeleid centraal, zoals ook in deze studie zal blijken. Er wordt echter vaak vergeten dat ouders hieraan een belangrijke bijdrage kunnen leveren door de wijze waarop zij hun kinderen opvoeden. Ik ben mijn ouders dankbaar voor de kansen die zij mij gaven bij het ontwikkelen van die zelfstandigheid, waarvoor opleiding, doorzettingsvermogen, werklust en een beschutte thuisbasis van kind tot jong-volwassene, belangrijke bouwstenen zijn. De eerlijkheid (die zij mij eveneens bijbrachten) gebiedt echter te zeggen (ook dat moet je leren) dat je dit alles pas echt gaat waarderen als je zelf komt te staan voor de "ouderrol".

Terugkijkend op een periode van ruim vier jaar sinds ik in Maastricht aan de slag ging, bekruipt mij het gevoel dat een skierr moet krijgen als hij een lawine op zich af ziet komen. Dit geldt te meer omdat ook in de prive-sfeer veel gebeurd is: Anne en ik zijn verhuisd en getrouwd; Aniek en Mark hebben hun opwachting gemaakt en in december verhuizen wij. Dat ik naast dit alles bij mijn werk en het schrijven van het proefschrift de voortdurende en liefdevolle steun van Anne kreeg is voor haar geheel vanzelfsprekend en daarom in haar ogen niet vermeldenswaardig. Ik zie dat volstrekt anders! 



\section{Inleiding}

\subsection{Het onderzoeksproject}

Begin 1986 startte aan de Rijksuniversiteit Limburg te Maastricht bij de vakgroep Economie van de Gezondheidszorg het project 'Model van Voorzieningen voor Ouderen' met de vraagstelling: 'Is het mogelijk een simulatiemodel van voorzieningen voor ouderen te ontwikkelen dat kan dienen als instrument voor de voorbereiding en de evaluatie van maatregelen op het terrein van het ouderenbeleid?' Het onderzoek is mogelijk gemaakt door een projectsubsidie van de Stuurgroep Onderzoek Ouder Wordende Mens (SOOM) ${ }^{1}$ en maakte onderdeel uit van een eveneens door de (voormalige) SOOM gefinancierd onderzoeksprogramma 'Voorzieningen voor ouderen' (Jolles en Visser, 1989; Visser, 1990). Aan het onderzoeksproject gingen twee voorstudies vooraf, een bij het Sociaal en Cultureel Planbureau in de periode 1979-1981 en een aan de Rijksuniversiteit Limburg in de periode 1984-1985 (zie de achtergronden in paragraaf 1.2). Met dit boek komt een (voorlopig) einde aan het onderzoeksproject 'Model van Voorzieningen voor Ouderen'.

In dit hoofdstuk worden de achtergronden van de studie toegelicht (paragraaf 1.2) en de probleemstellingen die daaraan ten grondslag liggen verder uitgewerkt (paragraaf 1.3). Wij besluiten met de opzet van deze studie, die in drie delen uiteenvalt, namelijk:

(a) een inventarisatie op nationaal niveau van demografische ontwikkelingen, het ouderenbeleid van de overheid en het gebruik van voorzieningen door ouderen;

(b) een analyse van de 'aanbodzijde' van de ouderenzorg in de gemeente Maastricht;

(c) een analyse van de 'vraagzijde' van de ouderenzorg op basis van individuele gegevens van diverse groepen ouderen in Maastricht

In het derde deel wordt tevens een koppeling tussen de vraag- en aanbodzijde tot stand gebracht, uitgaande van de individu-gebonden kosten van de ouderenzorg op lokaal niveau. De probleemstellingen van het onderzoek worden besproken in paragraaf 1.3 en de opzet van de gehele studie komt in paragraaf 1.4 aan de orde.

\subsection{Achtergronden van de studie}

Aan het project gaat een geschiedenis vooraf die terug te voeren is tot juli 1979 . Toen kreeg het Sociaal en Cultureel Planbureau van het Ministerie van CRM de opdracht een vooronderzoek te doen naar een modelmatige analyse van de samenhangen tussen voorzieningen in de gezondheidszorg en de maatschappelijke dienstverlening, waarbij tevens de mogelijkheden om deze samenhangen te kwantificeren onderzocht dienden te worden. In tweede instantie werd deze opdracht verbijzonderd tot de samenhangen in de ouderenzorg. Dit onderzoek (De Groot e.a., 1981) werd uitgevoerd op basis van geaggregeerde regionale gegevens, doch kon op basis van interregionale vergelijkingen geen substitutie tussen het professionele voorzieningen vaststellen. Dit werd met name toegeschreven aan het hoge aggregatieniveau van de studie, zodat het SCP tot de aanbeveling kwam eerst case-studies

1. De SOOM is bij besthikking van de Statusecretaris van CRM op 22 april 1982 ingesteld met de opdracht om gedurende een: periode van vijf jaar een samenhangesd onderzoeksprogramma op thet terrein wam de ouder wordilende mens te laten uitwoeren, te evalueren en bij te sturen. Eind 1987 heeft de SOOM harar werkzamineden betindigd, doch in 1998 kreeg alj een opwollger in de worm wan NESTOR (NEdertands STimuteringstonds Ouderen Research); deze zal tol 1995 onderzoek verder gaan itimuleren. 
van het beleid en het functioneren van instellingen op regionaal niveau te doen uitvoeren alvorens tot voortzeting van het modelmatig onderzoek te besluiten (Directeur drs. A.J. van der Stajy in her Ten geleide bij Groot e.a.., 1981).

Eind 1983 werd atan de Vakgroep Economie van de Gezondheidszorg gevraagd een onderzoeksvoorstel op te stellen voor de ontwikkeling van ten simulatiemodel. Het corspronkelijke onderzoksvoorstel dateert van 1985 (Denis, 1985; Subsidieaanvraag SOOM, no. SOO/SO-U-6423, 1985) en wordit in deze paragraaf beknopt samengevat. Na enkele aanpassingen werd eind 1985 door de SOOM de opdracht verleend om het project uit te voeren.

Het oorspronkelijke onderzoekswoorstel beoogde de ontwikkeling van een model van voorzieningen voor ouderen dat kan dienen als basis voor de voorbereiding en evaluatie van alternatieve beleidsmatregelen. Een betere afstemming van het zorgaanbod op de zorgbehoefte van ouderen en oplossing van problemen binnen het voorzieningensysteem staan centraal in deze beleidsalternatieven. Het onderzoek wordt benaderd vanuil een economische invalshoek, de vraag voor de toekomst is daarbij hoe binnen een bepaald financieel kader 20 goed mogelijk kan worden aangesloten op de wensen en behoefte van ouderen. Voor de analyse zijn dan drie onderwerpen relevant. Allereerst dient onderzocht te worden door welke factoren de mate van afhankelijkheid van zorgverlening bij ouderen wordt belnvioed of -anders gezegd-welke determinanten het gebruik van voorzieningen bepalen. Ten tweede dient onderzocht te worden op welke wijze voorzieningen aansluiten op de afhankelijkheid van ouderen of hoe met andere woordlen het aanbod van ouderenzorg gestructureerd is. Tenslotte wordt bezien met welke inzet van personeel en/of andere middelen en tegen welke kosten de zorgverlening aan ouderen met een bepaalde mate van afhankelijkheid tot stand komt. In eerste instantie werd in het oorspronkelijke onderzoeksvoorstel een model toegezegd dat statisch en beschrijvend van aard zou zijn.

Het onderhavige onderzoek gaat uit van drie categorieen van ouderen in relatie tot het wel of niet gebruiken van een bepaalde voorziening. Deze drie categorieén zijn:

1. Ouderen die geen gebruik maken van voorzieningen (later verder afgebakend tot die niet-gebruikers die well beperkingen hebben of hulp wensen);

2. Ouderen die gebruik maken van intramurale voorzieningen voor verpleging of werzorging (bejaardenoord of verpleeghuis);

3. Ouderen die gebruik maken wan voorzieningen in de thuissituatie.

De onderzochte voorzieningen in de thuiszorg (ad 3) betreffen met name gezinsverzorging, wijkverpleging en gecoordineerd ouderenwerk. Via mondelinge interviews bij ouderen zijn ook (meer globale) vragen opgenomen over andere soorten voorzieningen, namelijk: informele hulp, huisarts, specialist, fysiotherapeut, pedicure, maaltijdvoorziening, maatschappelijk werk (AMW), sociaal-geriatrische dienst (SGD), dagbehandeling in verpleeghuis, dagopvang in bejaardenoord en het ziekenhuis.

Deze gegevens zijn complementair aan het onderhavige onderzoek verzameld aan de hand van gesloten schriftelijke en mondelinge interviews bij verschillende groepen ouderen (Frederiks en Te Wierik, 1988; Te Wierik en Frederiks, 1989; Frederiks, 1990). Deze enquetegegevens geven aan welke voorzieningen ouderen gebruiken en welke ze zouden willen gebruiken ${ }^{2}$. Heronder wordt ook de informele hulp begrepen. Daarnaast werd intormatie verzameld over verschillende aspecten die relevant zijn bij de beoordeling van de leefsituatie van ouderen. Hierbij gaat het met name on het voorkomen van beperkingen in de dagelijkse activiteiten, gegevens over het sociale netwerk, de aard en mate van gebruik van informele hulp, de woonsituatie, de financiele situatie en de geestelijke toestand.

2. In de literwur over de beboefte an en de wasag naar woorzieningen worden aan decie begrippen verschiflende betekenissen

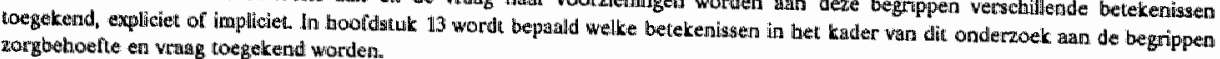


Binnen de zorgverlening aan ouderen kunnen verschillende functies worden onderscheiden. Een zorgfunctie kan door én of meerdere soorten van voorzeningen geleverd worden. $Z 0$ kan bijvoorbeeld persoonlijk lichamelijke verzorging geboden worden door geainsverzorging; wijkverpleging, bejaardenoorden en verpleeghuizen. Uitgaande van de behoeftebenadering wordt in deze studie in principe beoogd het gehele veld van ouderenzorg te beschrijven met behulp van een functionele indeling. Op deze wijze is het mogelijk de zorgbehoefte via de functies te koppelen aan het bestaande aanbod van de zorgvoorzleningen. Bij een beschrijving van deze voorzieningen ontkomt men echter niet aan een institutionele indeling, omdalt dat mu eenmaal het gangbare ordeningsprincipe is.

Ook in deze studie gaan wij uit van een institutionele indeling van het bestaande aanbod, maar wordt tevens een eerste aanzel gegeven tot een functionele indeling wan de werkzaam heden van personeel in de ouderenzorg. Deze beschrijving van voorzieningen voor ouderen of de 'aanbodzijde' van de ouderenzorg in de gemeente Maastricht vindt plaats in deel $\mathbf{B}$ van deze studie (zie paragraaf 1.4 voor de opbouw van de gehele studie) en geschiedt op grond van bedrijfsmatige kenmerken zoals kosten, technische middelen en voorzieningen, personeelsformatie, enzovoorts. De structuurbeschrijving behoeft niet voor iedere soort voorziening even gedetailleerd te zijn. Voorzieningen die speciaal of voor een groot deel ten behoeve van ouderen functioneren en waarbij de kosten dus (bijna) helemaal voor rekening van de ouderen komen, vereisen een meer gedetailleerde beschrijving. Bij voorzieningen die in principe voor iedereen toegankelijk zijn en waarbij het aandeel van de kosten voor rekening van de ouderen niet het hoofabestanddeel hoeft te vormen, kan worden volstaan met een minder gedetailleerde structuurbeschrijving. Voor het verzamelen wan de gegevens over de 'aanbodzijde' van de ouderenzorg is een instellingsenquete ontwikkeld, die in verschillende fasen werd uitgevoerd (zie hoofdstuk 5).

Het geheel van voorzieningen voor ouderen wordt beschouwd als een systeem. Binnen dit systeem spelen de relaties tussen de verschillende onderdellen een belangrijke rol. Welke samenhangen bestaan er in de aanbodzijde van de ouderenzorg en in het voorzieningenbeleid? Deze samenhangen kunnen worden omschrijven door middel van verschillende begrippen (Coolen, 1986), zoals 'integratie' (vormen van samenwerking tussen de verschillende voorzieningen), 'complementariteit' (dit treedt op als voorzieningen elkaar aanvullen), de mate waarin er sprake is van 'overlap' (als dezelfde functies door verschillende organisaties aangeboden worden) of juist van 'blinde vlekken' (al geen hulp ontvangen wordt omdat de gevraagde functie in het grensgebied tussen twee voorzieningen valt) en tenslotte 'substitutie'. Voor de laatste begrip zijn in de literatuur wele omschrijvingen gegeven (Stikker, 1985; NRV, 1989; Goudriaan, 1989), maar centraal staat het verleggen van clientstromen naar en tussen voorzieningen, met behoud van de zorgfuncties en de kwaliteit van zorg (Huijsman en De Klerk, 1989; NVR, 1989). Het substitutiebeleid van de overheid geefi ook aan in welke richting de verschuiving van clienten dient te verlopen, veronderstellend dat thuiszorg goedkoper is dan intramurale zorg (Goudriaan, 1989).

Bovenstaande begrippen hangen nauw met elkaar samen of zijn zelfs een voorwaarde voor elkaar: substitutie is slechis mogelijk als verschillende voorzieningen (gedeeltelijk) dezelfde functies aanbieden (overlap). Door het functie-onderscheid aan te brengen, krijgt het substitutiebegrip inhoud (NRV, 1989). Dit wordt in deel $\mathbf{B}$ van deze studie nader uitgewerkt.

\subsection{Probleemstellingen van het onderzoek}

Een beknopte schets van de ontwikkelingen in het ouderenbeleid tot op heden (zie hoofdstuk 3) wordt hier benut om de relevantie van het onderzoek nader aan te duiden en om te komen tot de formulering van de verschillende probleemstellingen van deze studie. 
Het uitgangspunt bij de opdrachtverllening van het onderzokk (zie paragraaf 1.1) betrof de wens om een beter inzicht te krijgen in de mogelijke gevolgen en effecten van beleidsalternatieven. De overheid wordt immers geconfronteerd met een aantal belangrijke en complexe problemen, warbij geleidelijk duidelijk is geworden dat de kennis ower de aard en invloed wan deze problemen onwoldoende is. Daarbij kunnen, zoals in de vorige paragraaf uiteengezer werd, drie thema's onderscheiden worden: aan de vraagzijde van de ouderenzorg worden ten eerste de demografische ontwikkelingen en de invloed daarvan op het gebruik van voorzieningen onderzocht en ten tweede worden andere individu-gebonden factoren die van invloed zijn op het gebruik van woorzieningen bestudeerd; als derde thema wordt de structuur van de aanbodzijde van de ouderenzorg bestudeerd in termen van personeel, kostprijzen en kosten. Deze globale aanduiding van de drie thema's wordt hierna voor elk afzonderlijk thema verder uitgewerkt. Daarbij wordt niet alleen het belang van het thme gellustreerd, maar worden tevens voor elk thema steeds de probleemstellingen geformuleerd; deze kunnen betrekking hebben op ontwikkelingen op nationaal niveau en/of ontwikkelingen op het niveau van het lokale onderzoek in de gemeente Maastricht.

Het eerste thema betreft de demografische ontwikkelingen en de invloed daarvan op het gebruik van voorzieningen door ouderen. De Nederlandse samenleving kenmerkt zich onder andere door cen toenemend aantal ouderen, zowel in absolute als in relatieve termen. Er wordt gesproken over 'vergrijzing' en zelfs over 'dubbele vergrijzing' omdat binnen de populatie het aantal hoogbejaarden nog eens extra toeneemt. Voor de komende decennia wordt een voortschrijdende vergrijzing verwacht die tot ver in de rwintigste eeuw zal aanhouden. Waarom vormt dit een belangrijk thema in het ouderenbeleid en waarom is de overheid zelfs bevreesd voor de mogelijke gevolgen van (dubbele) vergrijzing? De belangrijkste reden ligt in het feit dat ouderen relatief vaker en langduriger gebruik maken van voorzieningen en dat dat gebruik bovendien toeneemt naarmate de leeftijd stijgt. Dit laatste kan worden uitgedrukt in cijfers omtrent het leeftijdsspecifieke 'bereik' van voorzieningen, dat wil zeggen het aantal gebruikers in procenten van de bevolking naar leeftijdsgroep. Een verdergaande vergrijzing zal daardoor, ondler de veronderstelling dat andere relevante factoren niet veranderen, een belangrijke autonome invloed hebben op de kosten van de gezondheids- en welzijnszorg. Deze demografische bepaalde invloed op het voorzieningengebruik is onder de veronderstelling dat de huidige bereikcijfers constant blijven, echter een redelijk inzichtelijk te maken probleem. Immers, de volgende generatie ouderen bestaat reeds, zodat de vergrijzing van de Nederlandse bevolking relatief gemakkelijk te ramen is. Dat deze ramingen toch niet zo zeker zijn als op het eerste gezicht verwacht zou kunnen worden, wordt eveneens in het betreffende hoofdstuk gelluustreerd (zie boofdstuk 2).

Voor dit eerste thema kunnen op nationaal en lokaal niveau de volgende probleemstellingen worden geformuleerd:

(1) Welke demografische trends ten aanzien van ouderen hebben zich tot op heden afgetekend (dubbele' vergrijzing) en zullen zich in de nabije toekomst voordoen?

Hoe groot is, gegeven de demografische ontwikkelingen, het bereik van de belangrijkste voorzieningen in de ouderenzorg op nationaal en lokal niveau?

Het tweede thema betreft de individu-gebonden factoren die van invloed zijn op de vraag naar en het gebruik van voorzieningen. Dit thema valt uiteen in twee onderdelen, namelijk (a) de kennis over de gezondheidstoestand en behoeften van ouderen aan hulpwerlening en (b) de invloed daarvan op het gebruik door ouderen van professionele voorzieningen en informele hulp. In wezen is dit een -zij het uiterst relevante en noodzakelijkeverbijzondering van het demografische model dat zojuist aan de orde kwam (Klaassen-van den Berg Jeths, 1989; zie ook hoofdstuk 13); naast de demogratische kenmerken zoals leeftijd, sexe en burgerlijke staat, worden ook andere aspecten van de leefsituatie betrokken in de analyse van het gebruik van voorzieningen. 
Het belangrijkste uitgangspunt in het ouderenbeleid van de overheid betreft het beworderen van de zelfstandigheid en zelfredzaamheid van ouderen. De afhankelijkheid van ouderen met betrekking tot professionele zorg dient met andere woorden verminderd te worden. In de literatuur vormt het begrip "afhankelijkheid" (in de Anglosaksische literatuur aangeduid als 'dependency") dan ook een belangrijk concept (2ie bijwoorbeeld Munnichs en Van den Heuvel, 1976; Phillipson e.a., 1986). Ook in deze studie (en met name in deel C) staat de afhankelijkheid van ouderen centraal. Onderzoeksvragen die daarbij bestudeerd worden betreffen de factoren die gerelateerd zjjn aan de determinanten van afhankelijkheid, de belangrijkste afhankelijkheidsdimensies en de relatie tussen (de mate van) afhankelijkheid enerzijds en het voorzieningengebruik en de daaraan verbonden kosten anderzijds.

Het voorgaandle samenvattend kunnen met betrekking tot het tweede thema de volgende probleemstellingen worden geformuleerd:

(3) Welke aspecten van de leefsituatie van ouderen kunnen worden aangemerkt als determinanten van het gebruik van voorzieningen door ouderen en welke operationalisering kan hiervoor worden gebruikt?

(4) Welke verbanden bestaan er tussen deze determinanten of hoe groot is de verwevenheid tussen de verschillende aspecten van de leefsituatie?

(5) Welke van deze determinanten leveren een daadwerkelijke bijdrage als indicatoren voor de afhankelijkheid van ouderen in de verklaring van het voorzieningengebruik?

(6) Spelen naast deze determinanten ook nog andere factoren een rol, zoals venwijspatronen tussen de voorzieningen?

Deze probleemstellingen worden voornamelijk op lokaal miveau bestudeerd en uitgewerkt.

Het derde thema in deze studie betreft de structuur van de aanbodzijde van de ouderenzorg; het zorgsysteem en haar 'output' wormen een belangrijk studie-object. Er bestaat een gebrek aan kennis over het huidige zorgpatroon: door welke structuur wordt het huidige zorgsysteem gekenmerkt, hoeveel en welk soorten clienten gebruiken welke diensten, hoe verlopen de clientstromen tussen de voorzieningen en met welke inzet van middelen en kosten gaat het gebruik van voorzieningen, gedifferentieerd naar clientcategoriesn, gepaard? Bij dit derde thema worden vraagstukken op het geaggregeerde niveau van de aanbodzijde van de ouderenzorg centraal gesteld. Vragen die daarbij bestudeerd worden betreffen: welke voorzieningen zijn (in belangrijke mate) voor ouderen werkzaam, welke omvang van dienstverlening aan ouderen wordt er gerealiseerd, met welke kosten gaat dat gepaard on welke groepen ouderen, verbijzonderd naar mate van afhankelijkheid, worden daarmee bereikt? Ook gaan wij in op de functies van de ouderenzorg. Sinds enige jaren is er een discussie gaande met betrekking tot de toekomstige structuur van de Nederlandse ouderenzorg en de eventuele aanpassingen die daarvoor nodig zijn met betrekking tot het aanbod, de wet-en regelgeving en de financiering van de voorzieningen. De discussie richt zich met name op de samenstelling van het functie- en takenpakket van de verschillende voorzieningen. Er bestaat echter nog niet veel consensus over het begrip functie van zorgverlening, over de vraag welke functies kunnen worden onderscheiden in de ouderenzorg en over de omschrijving van voorzieningen in termen van deze functies. 
Voor het derde thema worden de volgende probleemstellingen opgesteld:

(7) Wal zijn de belangrijkste kemmerken van de verschillende clientgroepen in de ouderenzorg (zowel in termen van persoonskenmerken als in termen van omvang en duur van de hulpwerlening)?

(8) Hoe verlopen de clientstromen naar, door en uit de verschillende voorzieningen?

(9) Wat zijn op voorzieningenniweau de 'inputs' in termen van personeel en andere middelen en de 'outputs' in termen van 'produktie' en kosten?

(10) Hoe groot zijn de huidige kosten van de ouderenzorg en welke toename kan daarin op grond van demografische ramingen worden verwacht?

(11) Welke zorgfuncties leveren de woorzieningen en zijn deze te kwantificeren?

Probleemsteling 11 wordi alleen op lokaal niveau belicht; de andere vraagstellingen worden -zij het in wisselende mate-zowel op nationaal als lokaal niveau bestudeerd.

Wuj komen tot het hoofddoel wan het onderzoek. Het (individuele) gebruik van voorzieningen voor ouderen wordt nader geanalyseerd, waarbij verondersteld wordt dat dit in belangrijke mate bepaald wordt door de mate van afhankelijkheid van ouderen. Deze analyse mondt uit in een simulatiemodel dat dienst zou kunnen doen als een van de instrumenten om (beoogde) beleidsmatregelen op hun gevolgen te evalueren. De belangrijkste beleidswarianten die in deze studie worden bezien met behulp van het simulatiemodel betreffen: verdergaande vergrijzing, verbetering van de inkomenspositie van ouderen, versterking van hun sociale netwerk en uitbreiding van particuliere betaalde hulp.

De probleemstellingen ten aanzien van het beoogde model betreffen de volgende:

(12) Is het mogelijk een simulatiemodel van voorzieningen voor ouderen te ontwikkelen?

(13) Welke tendenties in het zorggebruik kunnen op basis van dit model 'voorspeld' worden voor (bij wijze van illustratie) een verbetering in de inkomenspositie van ouderen, een verbetering in hun sociaal netwerk en een uitbreiding van bet gebruik van particuliere (betaalde) hulp?

\subsection{Opzet van de studie}

Deze studie is als volgt gestructureerd (zie figuur 1.1).

Deel A geeft een inventarisatie op nationaal niveau en bestaat uit de hoofdstukken 2,3 en 4. Hoofdstuk 2 richt zich op de demografische ontwikkelingen in Nederland en het gebied waar de onderhavige studie is uitgevoerd, de gemeente Maastricht. Hoofdstuk 3 geeft in vogelvlucht een overzicht van de belangrijkste ontwikkelingen in het ouderenbeleid en de ouderenzorg. Daarbij wordit van de relevante (ouderen-)woorzieningen een historische schets gegeven, waarbij met name het owerheidsbeleid ten aanzien van die voorzieningen aan de orde komt. In hoofdstuk 4 wordt vervolgens een kwantitatieve analyse gemaakt van de verschillende voorzieningen in termen van cliënten, personeel en kosten. Dit hoofdstuk besluit onder andere met een analyse van de instroom van patienten c.q. clienten in de voorzieningen en wan de doorstroon tussen de voorzieningen onderling in Nederland. Tevens wordt op nationaale niveau een demografisch bepaalde raming van het gebruik van woorzieningen door ouderen gemaakt voor het jaar 2000 .

Deel $B$, bestaande uit de hoofdstukken $5 \mathrm{t} / \mathrm{m} 12$, geeft een vergelijkbaar overzicht van de lokale voorzieningenstructuur in de gemeente Maastricht, maar gaat op veel facetten dieper in dan mogelijk was bij het nationale deel. Met name wordt een statistische analyse gegeven van de verschillende clientbestanden van een vijftal voorzieningen, namelijk dienstencentra van het gecoördineerd ouderenwerk, gezinswerzorging, wijkverpleging, bejaardenoorden en verpleeghuizen. Ook wordt de indicatiecommissie (oude stijl) besproken. Ook op lokaal niveau wordt in het laatste hoofdstuk van deel $\mathrm{B}$ een demografische raming gemaakt van 
het gebruik in het jaar 2000 . Tevens wordt een empirische uitwerking van een functionele indelling van de ouderenzorg gepresenteerd.

In deel $\mathrm{C}$, dat bestaat uit de hoofdstukken $13 \mathrm{t} / \mathrm{m} 15$, wordt ingegaan op de determinanten van voorzieningengebruik op individueel niveau. Wij ontwikkelen en toetsen een model, waarin het gebruik van voorzieningen door ouderen verklaard wordt met een aantal indicatoren voor en oorzaken van lichamelijke en psychische afhankelijkheid. Dit gebeurt in hoofdstuk 15 , dat daarmee de kern van het onderzoek vormt en waarin het simulatiemodel van voorzieningen voor ouderen wordt beschreven. Op basis van dit model wordt tenslotte een aantal beleidsalternatieven geanalyseerd en geevalueerd. Daarbij zal rekening worden gehouden met een aantal voorspellingen over de demografische ontwikkelingen (CBS, 1990), de inkomenspositie van ouderen (Pommer, 1990) en over de ontwikkelingen betreffende de sociale netwerken van ouderen (STG, 1985; Klaassen-wan den Berg Jeths, 1989; Klaassen-van den Berg Jeths en Kraan-Jetten, 1985).

Wij besluiten met een samenwatting van de gehele studie. Daarbij worden enkele kanttekeningen geplaatst bij de mogelijkheden voor verder onderzoek en verfijning van het simulatiemodel (hoofdstuk 16). Tenslotte worden enkele beleidsaanbevelingen gedaan.

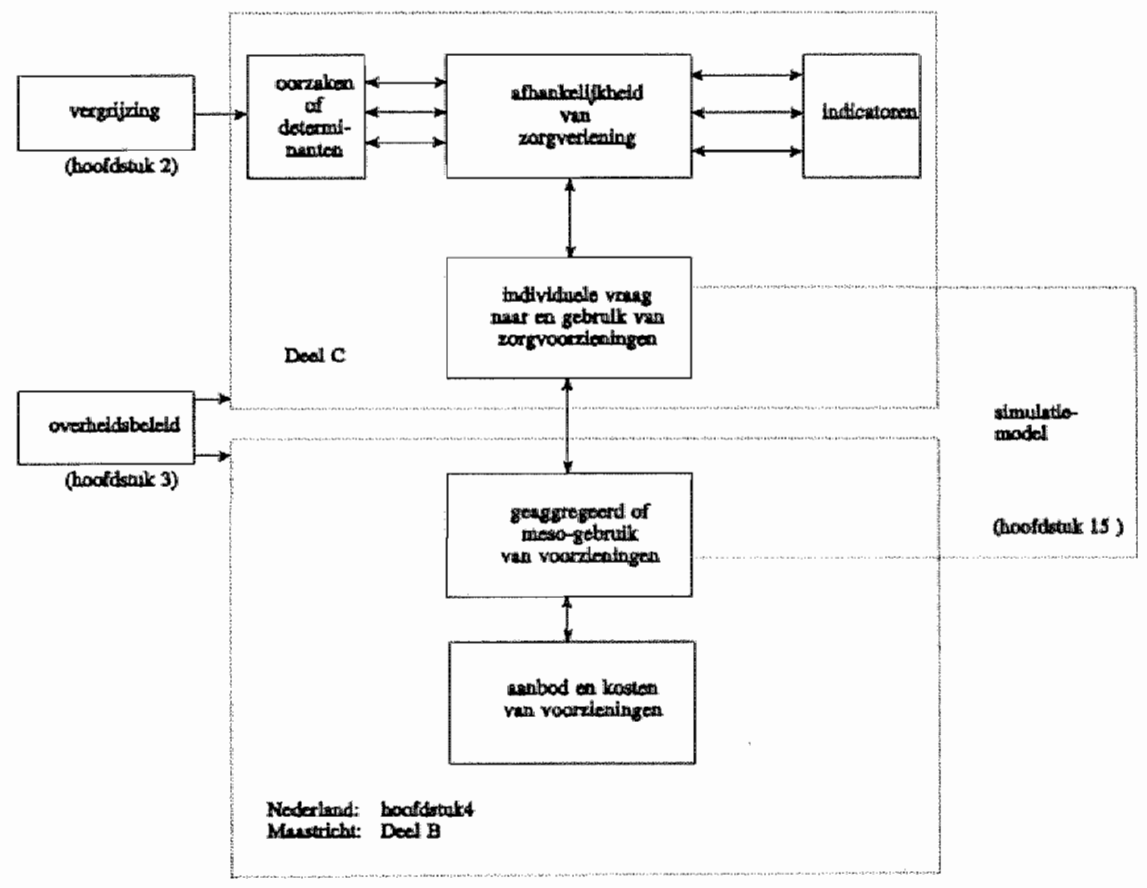

Figuur 1.1. Schematische weergave van de belangrijkste onderdelen wan deze studie 


\section{Deel A}

\section{Nationale inventarisatie van voorzieningen voor ouderen}

Dit deel beoogt inzicht te verschaffen in enkele Nederlandse ontwikkelingen die het lokale niveau overschrijden, maar daarop wel van invloed zijn en daarom voor een globaal inzicht in de ouderenzorg van belang worden geacht. In drie hoofdstukken komen achtereenvolgens aan de orde: demografische trends (hoofdstuk 2), het owerheidsbeleid ten aanzien van (de zorgverlening aan) ouderen, waarbij ook de beleidsmatige ontwikkelingen met betrekking tot de belangrijkste voorzieningen aangestipt worden (hoofdstuk 3) en tot stot een kwantitatief overzicht van de voor ouderen belangrijkste voorzieningen (hoofdstuk 4). 



\section{Demografische trends in Maastricht en Nederland}

\subsection{Inleiding}

In dit hoofdstuk wordt ingegaan op de (dubbele) vergrijzing, zowel in Maastricht als in Nederland, waarbij ook de lange termijn ontwikkelingen in het verleden en hedne worden belicht. Voor nationale gegevens gaan wij uit van publikaties van het CBS. De gegevens voor Maastricht zijn afkomstig van de gemeentelijke afdeling Onderzoek en Statistiek.

In deze inleiding past een kanttekening bij de omschrijving van de onderzoekspopulatie. De termen 'bejaarde' en 'oudere' bebben in het verleden elk een eigen (bij-)klank gekregen. In het vervolg zal zo veel mogelijk de neutrale benaming van ' 65 -plus' of '65-plusser(s)' worden gehanteerd, alls weergave van het feit dat een bepaalde leeftijdsgrens overschreden is. Voor andere leeftijdscategorieen worden vergelijkbare benamingen gehanteerd (bijvoorbeeld 85 plussers). De leeftijdscategorieesn zijn ingedeeld in intervallen van vijf jaar.

In dit hoofdstuk worden de volgende onderwerpen besproken: de (dubbele) vergrijzing van de Nederlandse bevolking sinds de Tweede Wereldoorlog en een vergelijking daarvan met de situatie in de gemeente Maastricht (de gemeente waarin het gehele onderzoek zich heeft afgespeeld) sinds 1980 in paragraaf 2.2; de samenstelling van de bevolking vanaf 65 jaar naar burgerlijke staat en omvang van het huishouden in paragraaf 2.3 (ook hier weer de nationale ontwikkelingen sinds 1950 en een vergelijking met lokale gegevens sinds 1980 ); de verwachtingen betreffende toekomstige ontwikkelingen in de omvang en de samenstelling van de oudere bevolking, de daarmee gepaard gaande onzekerheden van demografische prognoses in paragraaf 2.4 ; de invloed van vergrijzing op het voorzieningengebruik door ouderen in paragraaf 2.5 en tenslotte een samenvatting van de bevindingen in paragraaf 26.

\section{2. (Dubbele) vergrijzing in cijfers}

Met het begrip 'vergrijzing' wordt gedoeld op een toename van het aantal 65-plussers, niet alleen in absolute omvang, maar ook in relatieve termen, uitgedrukt in procenten van de totale bevolking. Vergrijzing wordt vaak afgesehilderd als een grote en niet te vermijden ramp, die bijvoorbeeld voor de gezondheidszorg onoverkomelijke financiele consequenties zou hebben (zie paragraaf 1.3). Deze onafwendbaar geachte problematiek zou door de zogeheten 'dubbele vergrijzing' nog pregnanter zijn. Dubbele vergrijzing treedt op als niet alleen het aantal 65 -plussers toeneemt, maar als binnen deze populatie bovendien het aandeel van de 85 -plussers (bij sommige auteurs 80-plussers) eveneens toeneemt. Dubbele vergrijzing hangt samen met een steeds verdergaande vermindering van het sterfterisico als gevolg wan een zich geleidelijk aan verbeterende algemene leefsituatie en gezondheidstoestand, waardoor men langer kan bljiven leven (CBS, 1989). Deze toegenomen levensverwachting is echter te kenschetsen als een zeer geleidelijk proces, dat slechts een bescheiden bijdrage levert aan de vergrijzing (Van der Maas, 1989). Veel belangrijker is de enorme geboortegolf na de Tweede Wereldoorlog en andere veranderingen in geboortecijfers. Bij dit laatste spelen culturele veranderingen een belangrijke rol; deze vinden onder andere hun weerslag de algemene acceptatie van contraceptie, de verdeling naar burgerlijke staat en veranderende keuzen met betrekking tot het aantal kinderen en het moment van hun geboorte. Omdat de nacorlogse geboortegolf in Nederland veel groter en langduriger was 


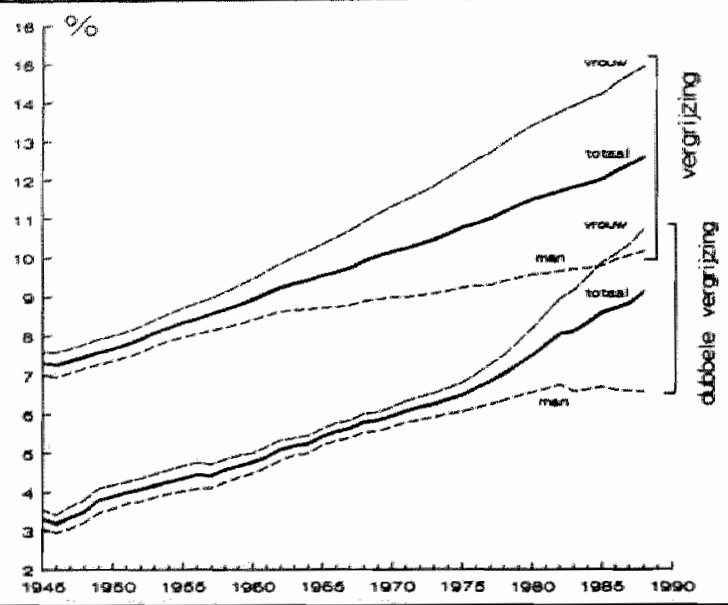

Figuur 2.1. Grafische illustratie van dubbele vergrijzing in Nederland

dan in de ons omringende landen, zal de top van de vergrijzing (rond 2040; zie vervolg) pas optreden als andere landen al weer aan een 'verjongingskuur' begonnen zijn. Vergrijzing is derhalve vooral een kwestie van geboortecijfers en veel minder van toegenomen levensverwachting; dit laatste is wel relevanter voor de dubbele vergrijzing. Daarbij wordt vaak vergeten dat de Nederlandse vergrijzing pas na de eeuwwisseling op een niveau komt dat vergelijkbaar is met thans al bestaande situaties in een aantal andere Europese landen (Nijkamp e.a., 1990), zoals Denemarken en West-Duitsland (beide een vergrijzingspercentage van $15,4 \%$ in 1988) of Belgie (14,4\% in 1988).

In de periode 1945-1988 is in Nederland het percentage 65-plus geleidelijk gestegen van $7,3 \%$ tot thans $12,5 \%$ (zie figuur 2.1 ). Ook wordt zichtbaar dat de vergrijzing bij vrouwen sterker is dan bij mannen: bij vrouwen is het percentage 65-plus toegenomen van 7,6\% in 1945 naar $15 \%$ in 1989 (gemiddelde stijging $2 \%$ per jaar); bij mannen is het percentage gestegen van $7,0 \%$ tot $10,2 \%$ (gemiddelde toename $1,1 \%$ per jaar). Dubbele vergrijzing is nog pregnanter bij de vrouwen geconcentreerd en treedt de laatste jaren bij mannen zelfs niet meer op. In de periode 1945-1989 is het aandeel 85-plus binnen de categorie 65plussers gestegen van $3,3 \%$ tot $9,2 \%$ (mannen en vrouwen). Bij vrouwen en mannen afzonderlijk ligt dit in 1989 op $11 \%$ respectievelijk $6,7 \%$.

Tabel 2.1. Vergrijzing naar sexe in Nederland en Maastricht, 1980-1989 (per 1 januari; aandeel 65 -plus in \% van totale bevolking)

\begin{tabular}{|c|c|c|c|c|c|c|}
\hline \multirow[b]{2}{*}{ jaar } & \multicolumn{3}{|c|}{ Meder 1 and } & \multicolumn{3}{|c|}{ Mastricht } \\
\hline & $\operatorname{man}$ & vrouw & totaal & man & vrouw & totanl \\
\hline $\begin{array}{l}1980 \\
1981 \\
1982 \\
1983 \\
1984 \\
1985 \\
1986 \\
1987 \\
1988 \\
1989\end{array}$ & $\begin{array}{r}9,53 \\
9,56 \\
9,61 \\
9,65 \\
9,68 \\
9,73 \\
9,88 \\
9,99 \\
10,10 \\
10,24\end{array}$ & $\begin{array}{l}13,37 \\
13,53 \\
13,71 \\
13,86 \\
14,01 \\
14,16 \\
14,12 \\
14,64 \\
14,85 \\
15,01\end{array}$ & $\begin{array}{l}11,46 \\
11,56 \\
11,68 \\
11,77 \\
11,87 \\
11,97 \\
12,18 \\
12,34 \\
12,51 \\
12,68\end{array}$ & $\begin{array}{l}10,38 \\
10,45 \\
10,41 \\
10,51 \\
10,48 \\
10,62 \\
10,80 \\
11,05 \\
11,26 \\
11,46\end{array}$ & $\begin{array}{l}15,09 \\
15,30 \\
15,37 \\
15,47 \\
15,52 \\
15,64 \\
16,06 \\
16,37 \\
16,62 \\
16,99\end{array}$ & $\begin{array}{l}12,79 \\
12,94 \\
12,96 \\
13,06 \\
13,07 \\
13,21 \\
13,52 \\
13,80 \\
14,05 \\
14,34\end{array}$ \\
\hline
\end{tabular}


Tabel 2.2. Dubbele vergrijzing in Nederland en Maastricht, 1980-1989

(per 1 januari; aandeel wan 85 -plus als \% van 65-plussers)

\begin{tabular}{|c|c|c|c|c|c|c|}
\hline \multirow[b]{2}{*}{ jaar } & \multicolumn{3}{|c|}{ Mederland } & \multicolumn{3}{|c|}{ Hatatch } \\
\hline & man & vrouw & total 1 & $\operatorname{man}$ & vrout & totar \\
\hline $\begin{array}{l}19810 \\
1981 \\
1982 \\
19813 \\
1984 \\
1985 \\
1986 \\
1987 \\
1980 \\
1989\end{array}$ & $\begin{array}{l}6.53 \\
6.63 \\
6.73 \\
6.56 \\
6.60 \\
6.66 \\
6.58 \\
6.55 \\
5.53 \\
6.68\end{array}$ & $\begin{array}{r}8.17 \\
8.54 \\
8.92 \\
9.12 \\
9.46 \\
9.82 \\
10.04 \\
10.28 \\
10.68 \\
10.99\end{array}$ & $\begin{array}{l}7.49 \\
7.75 \\
9.02 \\
9.08 \\
8.30 \\
8.55 \\
9.65 \\
9.75 \\
9.07 \\
9.24\end{array}$ & $\begin{array}{l}5.53 \\
5.69 \\
5.61 \\
5.79 \\
6.01 \\
5.99 \\
5.84 \\
5.64 \\
5.54 \\
5.52\end{array}$ & $\begin{array}{r}6.95 \\
7.51 \\
8.25 \\
8.90 \\
9.35 \\
9.61 \\
9.79 \\
9.72 \\
10.38 \\
10.78\end{array}$ & $\begin{array}{l}6.39 \\
6.79 \\
7.25 \\
7.58 \\
5.05 \\
8.21 \\
8.27 \\
8.15 \\
8.52 \\
8.77\end{array}$ \\
\hline
\end{tabular}

De gemeente Maastricht telt relatief meer 65-plussers dan geheel Nederland en is derhalve sterker vergrijsd (zie tabel 2.1). Hiervoor bleek al dat de vergrijzing vooral aan vrouwen is toe te wijzen. Het tempo van vergrijzing was in Maastricht vergelijkbaar met de nationale trend, maar de laatste jaren lijkt een versnelling op te treden.

De dubbele vergrijzing wordt in tabel 2.2 weergegeven door het aandeel van 85 -plus in de populatie 65-plussers, onderscheiden naar geslacht. Enerzijds blijkt dat de dubbele vergrijzing op de door ons gedefinieerde wijze in Maastricht in mindere mate aanwezig is dan in geheel Nederland, hetgeen betekent dat het aandeel van 85-plus in de populatie 65plussers lager is. Anderzijds echter wordt dit verschil zeer snel ingelopen, met name door vrouwen.

Ook in Maastricht vindt de dubbele vergrijzing vooral plaats bij het vrouwelijk deel van de bevolking. Bij mannen neemt weliswaar het aandeel van 65 -plussers in de totale bevolking toe (tabel 2.1), maar het aandeel van 85-plus binnen de populatie 65-plus neemt thans weer af. Het omslagpunt in de dubbele vergrijzing bij mannen blijkt te liggen in de jaren 1985 (Maastricht) en 1986 (Nederland). Samenvattend kan geconcludeerd worden dat de Maastrichtse bevolking in sterkere mate vergrijst dan de totale Nederlandse bevolking (waarbij het vergrijzingstempo vergelijkbaar is), dat de dubbele vergrijzing in Maastricht in mindere mate optreedt dan in Nederland (verschil wordt echter snel ingelopen) en dat de dubbele vergrijzing is geconcentreerd op het vrouwelijke deel van de 65-plussers (bij mannen treedt dubbele vergrijzing niet meer op).

\subsection{De 65-plussers naar burgerlijke staat en huishoudsamenstelling}

In diverse studies is naar voren gebracht dat met name alleenstaanden en nog specifieker alleenstaande vrouwen bij toenemende leeftijd een relatief groot beroep doen op voorzieningen (zie o.a. SCP, 1988). De verklaring hiervoor is dat bij alleenstaanden vaak de mogelijkheid ontbreekt om problemen en optredende gebreken in gezinsverband op te vangen (de zogenaarnde informele zorg of mantelzorg door partner, kinderen en dergelijke). Bovendien hebben vrouwen door een gemiddeld hogere leeftijdswerwachting een grotere kans de laatste levensjaren zonder partner door te brengen. Inzicht in de (ontwikkelingen in de) samenstelling van de populatie 65-plussers naar de burgerlijke staat is derhalve van belang. In tabel 2.3 wordt met betrekking tot geheel Nederland de procentuele verdeling van 65 -plussers gegeven naar de categorieen ongehuwd, gehuwd, verweduwd en gescheiden 
Tabel 2.3. Verdeling van 65-plussers in Nederland naar burgerlijke staat*

\begin{tabular}{|c|c|c|c|c|}
\hline Jar & ongehuwd & gehurd & weduwstat & ge schelden \\
\hline $\begin{array}{l}1950 \\
1955 \\
1960 \\
1965 \\
1970 \\
1975 \\
1980 \\
1985 \\
1989\end{array}$ & $\begin{array}{r}11,2 \\
11,1 \\
10,7 \\
10,0 \\
9,9 \\
9,7 \\
9,3 \\
8,6 \\
8,1\end{array}$ & $\begin{array}{l}52,5 \\
53,7 \\
55,0 \\
55,9 \\
55,5 \\
54,5 \\
53,9 \\
53,1 \\
53,\end{array}$ & $\begin{array}{l}35,3 \\
34,0 \\
33,0 \\
32,7 \\
33,1 \\
33,9 \\
34,2 \\
35,1 \\
34,9\end{array}$ & $\begin{array}{l}1,0 \\
1,2 \\
1,3 \\
1,4 \\
1,5 \\
1,5 \\
2,5 \\
3,2 \\
3,7\end{array}$ \\
\hline
\end{tabular}

* Exon: CBS, 2970; CBS, statitioch zakboek, divera jaren

voor de periode 1950-1989. Uit de gegevens komen verschillende trends naar voren. Allereerst is er een voortdurend dalende trend in het aandeel van ongehuwde 65-plussers en een voortdurend en sinds 1970 zelfs wrij scherp stijgende trend in het aandeel van gescheiden 65-plussers. Voor de andere twee categorieen zijn de trends minder eenduidig. Het aandieel van gehuwde 65-plussers steeg in de onderhavige periode eerst van $52,5 \%$ in 1950 tot een top wan bijna $56 \%$ in 1965 en daalde daarna tot circa $53 \%$ in 1985 . Sindsdien is er echter weer sprake van een geleidelijke toename (zje ook tabel 2.4). Een tegengestelde ontwikkeling kan worden teruggevonden in het aandeel van verweduwde 65-plussers: dat daalde eerst van ruim $35 \%$ in 1950 tot $33 \%$ in 1970 , steeg daarna weer tot iets boven de $35 \%$ in 1985 en sindsdien lijkt zich weer een bescheiden daling af te tekenen. Samenvattend blijkt zich derhalve een verandering in de samenstelling van de bevolking van 65 -plussers naar burgerlijke staat af te tekenen die in de tweede helft van de jarentachig gestart is.

In tabel 2.4 wordt darom de analyse van de verdeling naar burgerlijke staat verbijzonderd naar de periode vanaf 1984 , waarbij tevens een vergelijking gemaakt wordt tussen de gegevens over zowel 65- als 85-plussers op zowel nationaal als lokaal niveau. Nederlandse gegevens zijn ontleend aan Statistisch Zakboeken en Maandstatistieken Bevolking van het CBS; Maastrichtse gegevens zijn verstrekt door de gemeentelijke afdeling Onderzoek en Statistiek. De 65-plussers in Maastricht zijn relatief vaker verweduwd of ongehuwd (deels te verklaren door de aanwezigheid wan kloosteroorden) en relatief minder vaak gehuwd. Grosso modo

Tabel 2.4 De 65-plussers en 85-plussers naar burgerlijke staat

(verdeling in $\%$ totale bevolking per leeftijdsgroep)

\begin{tabular}{|c|c|c|c|c|c|c|c|c|c|}
\hline \multirow{2}{*}{$\begin{array}{l}\text { beyal- } \\
\text { kinge- } \\
\text { groep }\end{array}$} & \multirow{2}{*}{$\begin{array}{l}\text { Jatar } \\
(p a r \\
1-1)\end{array}$} & \multicolumn{2}{|c|}{ ongehuwd } & \multicolumn{2}{|c|}{ gehwwd } & \multicolumn{2}{|c|}{ weduws tal } & \multicolumn{2}{|c|}{ gotheiden } \\
\hline & & $\begin{array}{l}\text { Neder } \\
\text { land }\end{array}$ & $\begin{array}{l}\text { MaAa- } \\
\text { triobt }\end{array}$ & $\begin{array}{l}\text { Neder } \\
\text { land }\end{array}$ & $\begin{array}{l}\text { Mala - } \\
\text { tricht }\end{array}$ & $\begin{array}{l}\text { Neder } \\
\text { land }\end{array}$ & $\begin{array}{l}\text { Maag- } \\
\text { trioht }\end{array}$ & $\begin{array}{l}\text { Neder } \\
\text { land }\end{array}$ & $\begin{array}{r}\text { Maas- } \\
\text { tricht }\end{array}$ \\
\hline 65-p14a & $\begin{array}{l}1981 \\
1985 \\
1986 \\
1987 \\
1988 \\
1989\end{array}$ & $\begin{array}{l}8,8 \\
9,6 \\
8,5 \\
8,3 \\
8,2 \\
8,1\end{array}$ & $\begin{array}{l}10,7 \\
10,9 \\
10,8 \\
10,6 \\
10,3 \\
10,2\end{array}$ & $\begin{array}{l}53,2 \\
53,1 \\
53,1 \\
53,3 \\
53,4 \\
53,4\end{array}$ & $\begin{array}{l}49,7 \\
49,6 \\
49,5 \\
49,5 \\
49,8 \\
50,0\end{array}$ & $\begin{array}{l}35,0 \\
35,1 \\
35,0 \\
35,0 \\
34,9 \\
34,9\end{array}$ & $\begin{array}{l}36,9 \\
36,7 \\
36,7 \\
316,7 \\
316,5 \\
36,2\end{array}$ & $\begin{array}{l}3,1 \\
3,2 \\
3,4 \\
3,4 \\
3,5 \\
3,7\end{array}$ & $\begin{array}{l}2,7 \\
2,8 \\
3,0 \\
3,3 \\
3,4 \\
3,6\end{array}$ \\
\hline 85 mplus & $\begin{array}{l}1984 \\
1985 \\
1986 \\
1987 \\
1986 \\
1989\end{array}$ & $\begin{array}{l}10,1 \\
10,3 \\
10,3 \\
10,4 \\
10,4 \\
10,5\end{array}$ & $\begin{array}{l}13,8 \\
12,8 \\
12,8 \\
12,8 \\
12,2 \\
12,8\end{array}$ & $\begin{array}{l}17,8 \\
17,8 \\
17,5 \\
17,5 \\
17,5 \\
17,5\end{array}$ & $\begin{array}{l}16,9 \\
16,6 \\
15,6 \\
15,9 \\
14,4 \\
14,8\end{array}$ & $\begin{array}{l}70,0 \\
69,0 \\
69,9 \\
69,9 \\
69,8 \\
69,7\end{array}$ & $\begin{array}{l}61,3 \\
69,3 \\
70,0 \\
69,5 \\
71,5 \\
70,3\end{array}$ & $\begin{array}{l}2,0 \\
2,1 \\
2,3 \\
2,2 \\
2,3 \\
2,3\end{array}$ & $\begin{array}{l}1,0 \\
1,3 \\
1,6 \\
1,6 \\
1,9 \\
2,1\end{array}$ \\
\hline
\end{tabular}




\begin{tabular}{|c|c|c|c|c|}
\hline & & 1979 & 1983 & 1987 \\
\hline $\begin{array}{l}65-79 j \\
60 \text { jag }\end{array}$ & jas on ouder & $\begin{array}{r}12,7 \\
9,6\end{array}$ & $\begin{array}{l}11,0 \\
12,1\end{array}$ & $\begin{array}{r}6.1 \\
15,2\end{array}$ \\
\hline totaa 1 & 65-plus & 12,2 & 11,2 & 8,2 \\
\hline
\end{tabular}

geldt het zelfde voor 85 -plussers, met uitzondering van de verweduwde populatie die in relatieve omvang thans vergelijkbaar is met het Nederlandse gemiddelde.

Recent is een interessante ontwikkeling zichtbaar geworden (SCP, 1988, p. 36 37). Het aantal. ouderen dat bij of met hun kinderen woont is sedert 1979 geleidelijk afgenomen, maar bij hoogbejaarden (80-plus) is het tegendeel het geval (zie tabel 2.5). Dit betreft in veel gevallen bovendien dusdanig ernstig hulpbehoevende ouderen dat zil stellig in aanmerking zouden komen voor een bejaardenoord of verpleeghuis. De toename van het aantal hoogbejaarden dat bij of met hun kinderen woont kan samenhangen met verschillende factoren, zoals een toenemende bereidheid bij kinderen om hulp te bieden, een toename van de mogelijkheden en de kwaliteit van thuiszorg of een relatief geringer worden van het aanbod van bejaardenoorden en verpleeghuizen en een toename van de wachtlijsten daarvoor. Door een gebrek aan relevante gegevens kan hierover geen uitsluitsel gegeven worden; ook kan niet worden aangegeven hoe de ontwikkeling in het aantal meergeneratiehuishoudens was vóor 1979.

\subsection{Verwachtingen ten aanzien van de toekomst}

Demografische prognoses moeten $n_{\sharp}$ net als vele andere voorspellingen, met de nodige voorzichtigheid gehanteerd worden, omdat er rekening gehouden moet worden met een grote verscheidenheid aan factoren die op het bevolkingsverloop van invloed zijn. Variabelen die een rol spelen zijn onder andere vruchtbaarheid, huwelijk en scheiding,

Tabel 2.6. Prognose voor Nederlandse bevolking, aandeel van 65-plussers en verdeling van 65-plussers naar burgerlijke staat (middenvariant)*

\begin{tabular}{|c|c|c|c|c|c|c|}
\hline \multirow[b]{2}{*}{ ja } & \multirow{2}{*}{$\begin{array}{l}\text { totale } \\
\text { bevalking } \\
(x 1000)\end{array}$} & \multirow{2}{*}{ 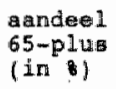 } & \multicolumn{2}{|c|}{ verdeling } & \multirow{2}{*}{$\frac{\text { natar bing : }}{\text { weduwetat }}$} & \multirow{2}{*}{$\frac{\text { gat (in b) }}{\text { gechediden }}$} \\
\hline & & & ongehuwd & gehuwd & & \\
\hline $\begin{array}{l}1990 \\
1995 \\
2000 \\
2005 \\
2010 \\
2020 \\
2030 \\
2040 \\
2050\end{array}$ & $\begin{array}{l}1489 \\
15316 \\
15717 \\
16002 \\
16142 \\
16219 \\
16092 \\
15566 \\
14857\end{array}$ & $\begin{array}{l}12,84 \\
13,37 \\
13,80 \\
14,25 \\
15,16 \\
18,90 \\
22,28 \\
24,07 \\
22,117\end{array}$ & $\begin{array}{r}7,9 \\
7,4 \\
7,0 \\
6,4 \\
7,6 \\
14,2 \\
22,0 \\
26,1\end{array}$ & $\begin{array}{l}53,3 \\
53,1 \\
52,6 \\
52,1 \\
51,6 \\
50,5 \\
43,6 \\
37,5 \\
31,2\end{array}$ & $\begin{array}{l}34,9 \\
34,9 \\
34,5 \\
33,8 \\
32,5 \\
21,9 \\
27,4 \\
26,1 \\
25,9\end{array}$ & $\begin{array}{r}3,9 \\
4,7 \\
5,9 \\
7,6 \\
9,7 \\
13,6 \\
14,9 \\
14,6 \\
13,6\end{array}$ \\
\hline
\end{tabular}

* Bron: CBS, 1989 
arantal en samenstelling van huishoudens, sterfte-risico's, maar by , ook sociaal-economische ontwikkelingen zouls werkgelegenheid en inkomen zijn van invloed op allerlei demografische werschijnselen (SER, 1987). In de huidige prognosemodellen voor demografische ontwikkelingen kunnen voornoemde vormen van onzekerheid slechts kwalitatief verwerkt worden door verschillende varianten te onderscheiden, waarbij de afstand tussen warianten de mate van onzekerheid weergeef. Zo hanteert het CBS een lage, midden en hoge variant van het toekomstige bevolkingsverloop, waarbij de middenvariant als meest plausibele beschouwd wordt. Door de eerder geschetste onzekerheid kunnen echter, zelfs op korte termijn, misrekeningen ontstaan. Men spreekt dan ook liever van onzekerheidsvarianten dan van alternatieve toekomstbeelden (SER, 1987). Op basis van de midden-variant uit de CBSbevolkingsprognose tot het jaar 2050 (CBS, 1989), wordt in tabel 2.6 de ontwikkeling van het aantal 65-plussers in Nederland geschetst.

De Nederlandse bevolking zal volgens de middenvariant tot 2020 stijgen tot 16,2 miljoen en daarna afnemen tot bijna 14,9 miljoen mensen. Het aandeel 65-plus in de totale bevolking zal volgens de middenvariant van de CBS-prognose uit 1989 toenemen van $12,5 \%$ in 1988 tot $24,1 \%$ in 2040 . Daarna treedt er echter een daling in tot $22,5 \%$ in het jaar 2050 . De conclusie lijkt gewettigd dat de vergrijzing de komende 25 jaar niet sneller zal verlopen dan de afgelopen 25 jaar, zodat de alom heersende vrees voor de vergrijzing enigszins gerelativeerd moet worden (Van de Maas, 1989). In figuur 2.2 wordt de vergrijzingstrend volgens de drie CBS-varianten weergegeven.

Naar verwachting zal het aandeel 85-plus onder 65-plussers de komende 20 jaar oplopen van $9 \%$ naar circa $12 \%$. Voorspellingen voor de periode na de eeuwwisseling moeten echter met omzichtigheid gehanteerd worden.

De verdeling naar burgerlijke staat binnen de populatie 65-plus zal in de toekomst aanzienlijk verschuiven. In toenemende mate zullen 65-plussers scheiden, omdat verwacht wordt dat de eerder geschetste historische trend zich woort zal zetten. Het aandeel van de gescheiden 65 -plussers neemt toe tot $9,7 \%$ in het jaar 2010. De eveneens gellustreerde dalende trend in het aandeel van ongehuwde 65 -plussers zal zich echter na de eeuwwisseling omkeren. Ondanks de gesignaleerde (bescheiden) toename in het aandeel van gehuwde ouderen in de periode 1985-1989 (zie tabel 2.3), wordt door het CBS verwacht dat dit een zeer tijdelijk verschijnsel was en dat het aandeel na 1990 verder zal dalen. Voorgaande verwachtingen

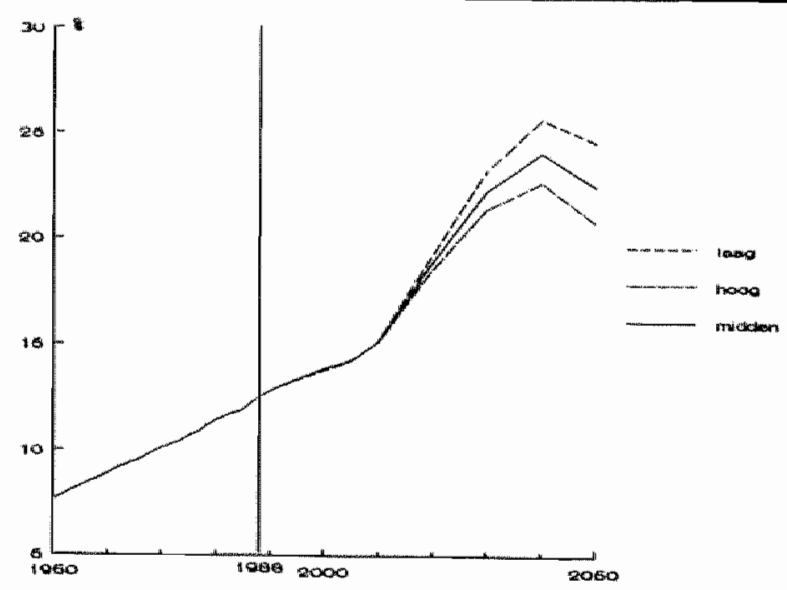

Figuur 2.2. Vergrijzingstrend tot 2050 volgens drie varianten (CBS, 1989) 
zullen ertoe leiden dat émpersoonshuishoudens bij 65 -plussers een steeds vaker optredend verschijnsel zullen worden. De voorspellingen daarna reflecteren de eerder besproken onzekerheidsnarges in de prognoses op een bijzonder dramatische wijze: indien deze prognose realiteit wordt, dan zou het aandeel van ongehuwde 65-plussers toenemen tot ruim $25 \%$ in het midden van de volgende eeuw en is een op de zeven ouderen gescheiden.

In vergelijking met eerdere prognoses (1985-1989), die door het CBS jaarlijks gemaakt worden, zijn frappante verschuivingen te signaleren, die in het licht van de modelonzekerheden niet onverwacht, maar toch nog verrassend groot zijn als bedacht wordit dat het gaat om woorspellingen die in een betrekkelijk korte periode gemaakt zjjn (Huijsman, 1989 b; Pennekamp en Goemans, 1989). De prognose voor 1985-2035 ging het verst met een vergrijzingspercentage van $26,9 \%$ in 2035 . In de daarop volgende prognoses (1986-2035 en 1987-2050) werd dit percentage neerwaarts bijgesteld tot $24,4 \%$ in de prognose 1986 en $22,8 \%$ in de prognose 1987 . De recentste prognose (1988-2050) verwacht echter een iets hoger percentage in 2035 , namelijk $23,65 \%$. De thans geldende middenprognose is ongeveer gelijk aan de hoge variant wit 1985 .

In tabel 2.7 is de prognose tot 2010 voor de Maastrichtse bevolking naar leeftijd in beeld gebracht (bron: gemeente Maastricht). Ook na de eeuwwisseling zal de vergrijzing voortgaan, zij het in minder sterke mate dan daarvoor $(17,8 \%$ in 2010). In het jaar 2000 behoort $16,3 \%$ van de Maastrichtse bevolking tot de oudere populatie; landelijk zal dat waarschijnlijk 13,8\% zijn (CBS, 1989). Bij vrouwen treedt, net als in het verleden, de vergrijzing het sterkst op. In 2000 ligt het vergrijzingspercentage bij hen in de gemeente Maastricht op 18,9\% en in geheel Nederland op 16,3\%. Bij mannen liggen de percentages op $13,4 \%$ respectievelijk $11,3 \%$.

\subsection{Vergrijzing en de invloed op voorzieningengebruik}

Op grond van tal van studies zijn enkele trends te benoemen die een op $z^{\prime} n$ minst gelijkblijvend, doch zeer waarschijnlijk toenemend gebruik van allerlei voorzieningen door ouderen aannemelijk maken. Sleutelbegrip in het maken van ramingen over toekomstig voorzieningengebruik betreft het 'bereik" van voorzieningen. Dit brengt tot uitdrukking hoeveel clienten gebruik maken van voorzieningen en wordt in deze studie gedefinieerd als het aantal clienten uitgedrukt in procenten van de bevolking. Als bet bereik wordt verbijzonderd naar leeftijdsgroepen in de bevolking, wordt in het vervolg van deze studie steeds gesproken wan 'leeftijdsspecifiek(e) bereik(cijfers)'. De (dubbele) vergrijzing van de bevolking zal om verschillende redenen een aanzienlijke druk op de voorzieningen teweeg brengen.

Tabel 2.7. Bevolkingsprognose voor Maastricht, 1990-2010

\begin{tabular}{|c|c|c|c|c|c|c|c|c|c|}
\hline \multirow{2}{*}{$\begin{array}{l}\text { leeftidg } \\
\text { oateigords }\end{array}$} & \multicolumn{3}{|c|}{1990} & \multicolumn{3}{|c|}{2000} & \multicolumn{3}{|c|}{2020} \\
\hline & mannen & vrour & tot wa & mannes & Wrouw & totan & mannen & vrour & tota:il \\
\hline $\begin{array}{l}554 \\
55-59 \\
60-64 \\
65-69 \\
70-74 \\
75-79 \\
60-04 \\
285 \\
\text { Totand }\end{array}$ & $\begin{array}{r}4.585 \\
3.159 \\
2.780 \\
2.647 \\
1.701 \\
1.220 \\
690 \\
372 \\
56.154\end{array}$ & $\begin{array}{r}4.923 \\
3.260 \\
3.349 \\
3.221 \\
2.441 \\
2.137 \\
1.507 \\
1.156 \\
60.994\end{array}$ & $\begin{array}{r}87.508 \\
6.419 \\
6.129 \\
5.568 \\
4.142 \\
3.357 \\
2.197 \\
1.529 \\
117.14\end{array}$ & $\begin{array}{r}2.82 \\
3.331 \\
2.973 \\
2.643 \\
2.061 \\
1.60 .6 \\
78.5 \\
530 \\
56.21\end{array}$ & $\begin{array}{r}3.1871 \\
3.399 \\
3.1514 \\
3.068 \\
2.9813 \\
2.5812 \\
1.607 \\
1.516 \\
1.180\end{array}$ & $\begin{array}{r}96.736 \\
6.730 \\
6.127 \\
5.711 \\
5.044 \\
4.188 \\
2.392 \\
2.046 \\
119.001\end{array}$ & $\begin{array}{r}37+42 \\
4+272 \\
4.029 \\
2.760 \\
2+200 \\
1.592 \\
944 \\
669 \\
54.328\end{array}$ & $\begin{array}{r}39.172 \\
4.411 \\
4.057 \\
3.182 \\
2.01 \\
2.448 \\
1.961 \\
1.757 \\
59.769\end{array}$ & $\begin{array}{r}77.014 \\
8.683 \\
8.066 \\
5.962 \\
5.001 \\
1.040 \\
2.905 \\
2.426 \\
124.117\end{array}$ \\
\hline
\end{tabular}

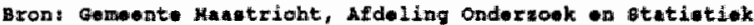


Ten eerste neemt door de vergrijzing de absolute omvang van 65 -plussers toe, zodat zelfs bij gelijkblijvende bereikcijfers het aantal oudere clienten van voorzieningen zal toenemen. Daarbij is het feit van belang dat ouderen vaak een groot beslag leggen op de 'produktiecapaciteit' van woorzieningen in de gezondheidszorg" niet alleen is hun aandeel in het totale clientenbestand vaak vele malen groter dan hun aandeel in de bevolking, maar tevens is het bereik van voorzieningen vaak groot genoeg om er voor te zorgen dat het om grote groepen gebruikers gaat (Goudriaan, 1989 en 1990; Huijsman, 1989b; Nijkamp e.a., 1990).

Ten tweede zijn er ontwikkelingen die het mogelijk maken dat de bereikcijfers zelf gaan stijgen, niet alleen door het dubbele karakter van de vergrijzing, maar ook door maatschappelijke trends zoals verdere individualisering en verkleining van buishoudens en sociaal-economische ontwikkelingen (zie bijvoorbeeld STG, 1985, 1987 en 1988).

Ten derde doet de overheid via het substitutiebeleid pogingen de clientenstromen naar en tussen voorzieningen (zie hoofdstuk 4) dusdanig te beînvloeden dat het accent meer komt te liggen op de thuiszorg in plaats van op de relatief duur geachte intramurale zorg, zoals die van het bejaardenoord en het verpleeghuis (Nota Ouderenbeleid, TK, 1987/1988). Dit heeft als consequentie dat de bereikcijfers van thuiszorgvoorzieningen zullen oplopen ten koste van die van intramurale voorzieningen.

Tenslotte worden door verschillende auteurs ontwikkelingen aan de vraagzijde gesignaleerd, waar de ouderen steeds meer en steeds duidelijker aangeven dat zij zo lang en zo zelfstandig mogelijk in de eigen omgeving willen blijven wonen en functioneren, eventueel met aanvullende hulp van thuiszorgorganisaties. Een van de consequenties van deze wensen over en behoeften aan extramurale dienstverlening is echter dat in de thuiszorg de intensiteit en de duur van hulpverlening per, gemiddeld steeds ouder wordende, client toe zal nemen. Bij de wijkverpleging wordt bijvoorbeeld geconstateerd dat het gemiddeld aantal contacten per 65-plusser door de jaren heen stijgt en een steeds intensiever en een steeds meer curatief gericht karakter krijgt (NK, 1988). In de volgende hoofdstukken worden deze ontwikkelingen uitgebreid aan de orde gesteld.

\subsection{Samenvatting en conclusies}

In deze paragraaf is stilgestaan bij de eerste probleemstelling van deze studie (zie paragraaf 1.3) en is ingegaan op cle vraag welke demografische trends zich ten aanzien van ouderen aftekenen op nationaal en lokaal niveau. De stelling is verdedigd dat de alom heersende vrees voor de zogeheten (dubbele) vergrijzing gedeeltelijk ongegrond is omdat deze in de komende decennia geen wezenlijk ander trendmatig verloop zal kennen dan in de afgelopen decennia. Pas na 2010 zal de trendbreuk die ten gevolge van de geboortegolf na de Tweede Wereldcorlog is opgetreden zich doen gelden in een versnelling van de vergrijzing, maar ook hierbij is een relativering op zijn plaats omdat pas dan een vergrijzingsniveau ontstaat die nu al in andere Europese landen wordt aangetroffen. Wel zal Nederland in vergelijking tot deze landen op een later moment de top in het vergrijzingsproces beleven (rond 2040), omdat de naoorlogse geboortegolf hier omvangrijker was en langer voortduurde dan in de ons omringende landen. Vergrijzing en veranderende cultuurpatronen doen zich ook gelden in de samenstelling van de oudere bevolking, zodat een absolute en relatieve toename wordt verwacht van het aantal eénspersoonshuishoudens bij 65-plussers. In hoeverre de gesignaleerde toename van meergeneratiehuishoudens bij 80-plussers zich zal doorzetten is moeilijk te voorzien. 


\section{De ontwikkeling van ouderenbeleid in vogelvlucht}

\subsection{Inleiding en afbakening}

In dit hoofdstuk worden in grote lijnen de historische ontwikkelingen geschetst die hebben geleid tot het buidige overheidsbeleid met betrekking tot de ouderen in Nederland. Deze ontwikkelingen worden gekenmerkt door wisselende accenten op toch telkenmalen terugkerende thema"s, namelijk 'inkomen en sociale zekerheid', 'huisvesting', 'vergrijzing", 'zorg(behoefte)' en 'substitutie'. Vele van deze thema's zijn niet alleen thans actueel, maar vormen al decennia lang onderwerp van discussie (Timmermans, 1989). Naast de beperking tot het terrein van de overheid en de zojuist genoemde thema's, wordt een afbakening in tijdvakken aangebracht. De bespreking concentreert zich op de periode 1945-1989 maar enkele ontwikkelingen voór die tijd zijn eveneens van belang. In dit hoofdstuk zijn de verschillende tijdvakken als volgt gekozen: het tijdwak tot aan het einde van de Tweede Wereldoorlog in 1945 (paragraaf 3.2), de periode 1945-1970 die aangemerkt kan worden als een periode van heropbouw en het ontstaan van de 'welvaartsstaat' (paragraaf 3.3) en de periode 1970-1990 die start met de eerste overheidsnota die specifiek op ouderen toegespitst was (paragraaf 3.4). Voor het overzicht van het ouderenbeleid zjin naast de daarop toe geschreven nota"s ook andere overheidsnota's van belang, mel name die waarin de structuur van de gezondheidszorg ter discussie staat. Dergelijke structuurmaatregelen blijken ook relevant te zijn bij de beschrijving van de meest belangrijke historische ontwikkelingen per voorziening (zie paragraaf 3.5 ). In bijlage 1 is een chronologisch overzicht opgenomen van de belangrijkste wetten en regelingen van overheidswege, de verschillende overheidsnota's (die in deze studie steeds bij naam genoemd worden om ze te kunnen blijven onderscheiden) en andere belangrijke gebeurtenissen (zoals oprichting van nationale organisaties) die van invloed zijn geweest op de ontwikkelingen in de ouderenzorg.

\subsection{Belangrijkste ontwikkelingen in de gezondheidszorg v66r 1945}

Hoewel met name de periode na 1945 bezien wordt, is daarvoor reeds een aantal belangrijke zaken gerealiseerd, die kort aandacht verdienen. De vier geneeskundige wetten van Thorbecke (Stb. 1865, no. 60) regelden voor het eerst de uitoefening van de geneeskunst, zowel met betrekking tot opleiding, bevoegdheden en beroepsuitoefening als wat betreft het toezicht. Hiermee was nog niet bereikt dat de geneeskundige zorg voor ledereen toegankelijk werd. Wel was sedert het midden van de negentiende eeuw hierin enige verbetering bereikt door de Gemeentewet (Stb. 1851, no. 85) en de Armenwet (Stb. 1854, no. 165). Ouderenzorg was rond de eeuwwisseling met name armenzorg, door de overheid verstrekt aan arme ouden van dagen die geen familie (meer) hadden om voor hen te zorgen. Hieraan kwam geleidlelijk een einde door het totstandkomen van het stelsel van sociale zekerheid, waarvan de Ongevallenwet (Stb. 1901, no. 157) en de Invaliditeitswet (Stb. 1913, no. 205) de eerste voorlopers waren. De particuliere aanpak van gezondheidszorg kreeg na 1875 vorm door de oprichting en groei van Kruisverenigingen (Nota Volksgezondheid, TK, 1965/1966; Boot en Knapen, 1988). Richtten de kruisverenigingen zich eerst op de bestrijding van besmettelijke ziekten, al snel (1880) kwam de wijkverpleging als hulp aan thuisverblijvende zieken centraal te staan (Nota Volksgezondheid, TK, 1965/1966, p. 21). In de periode 1900-1940 kwamen vervolgens de Gezondheidswetten (Stb. 1901, no. 157; Stb. 
1919, no. 784) en de Ziektewet (Stb. 1929, no. 374) tot tand, waardoor de ziekenfondsen (corspronkelijk aan het begin van de 19 e eeuw ontstaan uit de gildenkassen) een belangrijke rol in de gezondheidszorg gingen spelen. De curatieve gezondheidszorg, met name het ziekenbuiswezen, nam een grote vlucht (Nota Volksgezondheid, 'TK, 1965/1966).

\subsection{Ouderenbeleid in de periode 1945-1970}

Ouderenbeleid tijdens de eerste deccennia na de Tweede Wereldoorlog kan met name getypeerd worden als een inkomens- en huisvestingsbeleid. Rond $1960 \mathrm{kwam}$ daarbij voor het eerst en op meer expliciete wijze een extramuraal ouderenbeleid bij. Deze drie thema"s uit de periode $1945-1970$ worden in deze paragraaf beknopt belicht.

Het inkomensbeleid als onderdeel van het ouderenbeleid is vormgegeven in het sociale zekerheidsstelsel en het systeem van volksgezondheidsverzekeringen. Tijdens de ontwikkeling van het stelsel van soclale zekerheid werd voor ouderen in 1957 een belangrijke stap gezet in de vorm van de Algemene Ouderdomswet (Stb. 1956, no. 281), waarin als opvolger van de Noodwet Drees (Stb. 1947, no. 155) het pensioen als algemeen recht werd vastgelegd. Naast deze inkomensgarantie kwam tevens een financieel fundament onder de gezondheidsen welzljnszorg via de Algemene Bijstandswet (Stb. 1964, no. 312) en de Algemene Wet Bijzondere Ziektekosten (AWBZ; Stb. 1967, no.645). Bovendien werden voorzieningen voor 'ouden van dagen' gerealiseerd die zorg en vervangende woonruimte boden. Hoewel reeds in 1941 (na jaren van voorbereiding) het Ziekenfondsbesluit (Stb. 1941, no. 809) tot stand was gekomen, duurde het nog twintig jaar voordat de discussie over de wettelijk verplichte ziekenfondswerzekering in het sociale-zekerbeidsstelsel was uitgemond in een wet (Ziekenfondswet; Stb. 1964, no. 392). De unkomenspositie van ouderen had in de tussentijd well tot het inzicht geleid dat een verzekering voor hen sneller tot stand moest komen (Wet Ziekenfondsverzekering voor bejaarden; Stb. 1956, no. 634). De bejaardenverzekering gaf recht op dezelfde verstrekkingen als de verplichte verzekering, maar tegen aanmerkelijk gereduceerde premies.

Huisvestingsbeleid als onderdeel van het ouderenbeleid werd ingegeven door de woning nood na de Tweede Wereldoorlog. Tengevolge van deze woningnood nam het aantal bejaardenoorden een grote vlucht hetgeen leidde tot de noodzaak van toezicht op de instellingen en bescherming van hun bewoners. Dit resulteerde in de eerste Wet op de Bejaardenoorden (Stb. 1963, no. 18). Eind jaren zestig rees echter de vraag naar de financiele haalbaarheid en naar de afstemming op de behoeften en wensen van ouderen zelf. Niet alleen de aard en omvang van de intramurale zorg voor ouderen stond toen al ter discussie, maar tevens werden kanttekeningen geplaatst bij de wijze van organisatie en samenwerking in de totale zorg voor ouderen.

Het extramurale onderdeel in het ouderenbeleid staat weliswaar in de huidige discussie centraal, maar de fundamenten hiervoor werden gelegd in de periode 1955-1965. In 1956 had de rijksoverbeid al besloten om het extramurale ouderenwerk financieel te ondersteunen. Zo ontstonden bijvoorbeeld de Wet Ziekenfondsverzekering Bejaarden (Stb. 1956, no. 634) en laat zich ook de totstandkoming van subsidieregelingen voor onder andere de gezinswerzorging (Stb. 1957, no. 250) verklaren.

\subsection{Ouderenbeleid in de periode $1970-1990$}

In 1970 verscheen de eerste Nota Bejaardenbeleid waarin het vermoeden werd uitgesproken dat gedurende de periode na de Tweede Wereldoorlog de verbetering van de 
leefsituatie van ouderen in zowel materieel als immaterieel opzicht achter was gebleven bij die van andere bevolkingsgroepen. De noodzaak tot een speciaal op de oudere bevolking gericht welzijnsbeleid werd sterk gevoeld. De Nota Bejaardenbeleid 1970 gaf woor het eerst de hoofdlijnen voor een dergelijk beleid aan. Een belangrijke hinderpael betrof echter het ontbreken van voldoende (in zowel kwantitatief als kwalitatief opzicht) informatie over de leefsituatie van ouderen. Bij het verschijnen van de tweede Nota Bejaardenbeleld in 1975 was deze situatie nog weinig veranderd. Om in deze behoefte te voorzien ondernamen het CBS en het NIMAWO een onderzoek naar de leefsituatie van de Nederlandse bevolking van 55 jaar en ouder. Het CBS beeft in 1982 opnieuw een vergelijkbaar onderzoek onder ouderen gedaan (een derde onderzoek zou in 1988 worden uitgevoerd, maar is - na voorbereidende activiteiten - nimmer van start gegaan).

Naast de hierboven beschreven noodzaak voor het genereren van beleidsrelevante informatie ter ondersteuning van het ouderenbeleid, rees in de zeventiger jaren een tweede probleem. Het werd steeds duidelijker zichtbaar dat de Nederlandse bevolking sinds de Tweede Wereldoorlog in sterke mate aan het vergrijzen was. Was in 1945 nog slechts $7,3 \%$ van de gehele bevolking ouder dan 65 jaar, in 1970 lag dat al op 10,1\% (zie hoofdstuk 2). Bovendien nam de gemiddelde leeftijd van ouderen zelf eveneens steeds verder toe, zodat sprake is van dubbele vergrijzing.

Tot 1970 was het overheidbeleid met name gericht op de intramurale sector, waarbij wooral de bouw van bejaardenoorden grote prioriteit kreeg om de tengevolge van de oorlog ontstane woningnood te bestrijden. In de Nota Bejaardenbeleid 1970 (TK, 1970/1971) werd de aanzet gegeven tot ombuiging van dit beleid en werden voor het eerst uitgangspunten voor een integraal ouderenbeleid geformuleerd, waarvan de belangrijkste zijn (men sprak nog van "bejaarden'): 'bejaarden en niet-bejaarden zijn in de samenleving gelijkwaardig; de gezondheid en de in de voorgaande levensperiode verworven zelfstandigheid dienen zo lang mogelijk in stand te blijwen; de maatschappij kan hiervoor de helpende hand bieden door toekomstige bejaarden de kans te geven zich voor te bereiden op het bejaard zijn en bejaarden in hun behoeften tegemoet te komen; ouder worden is een proces waardoor de behoefte aan geschikte woonvormen, leefmilieu's en aan dienstverlening groter kan worden; onder de 'dienstwerlening' wordt een breed scala van 'handreikingen en voorzieningen' begrepen, zoals bron van inkomsten, bevorderen van intermenselijk contact, huishoudelijke hulp, aangepaste huiswesting, medisch advies en behandeling, lichaamsverzorging, verpleegkundige hulp en voorlichting" (Nota Bejaardenbeleid 1970, TK, 1970/1971, p. 4).

Het beleid is in deze eerste Nota Bejaardenbeleild (p. 16) als volgt saformuleerd: 'Het witgaande van het grondbeginsel van optimale integratie in de samenleving en vermijding van isolement - bevorderen, dat een in onderdelen aaneensluitend geintegreerd samenstel van activiteiten en voorzieningen tot stand komt en in stand gehouden wordt, waarin of waardoor bejaarden - al naar hun behoefte - kunnen blijven participeren in de samenleving, hun zelfstandige woon-en leefsituatie kunnen handhaven middels - aangepaste - dienstverlening, dan wel de subjectief gewenste verzorging en/of verpleging kunnen ontvangen, die op grond van objectieve criteria noodzakelijk worden (wordt) geacht'. De demografische ontwikkelingen zouden er voor zorgen 'dat er een grote behoefte zal blijven bestaan aan intramurale voorzieningen, voor zover deze althans niet vervangen kunnen worden door voorzieningen die slechts een gedeelte van een etmaal bestrijken. Duidelijk is evenzeer de nog weel groter behoefte aan voorzieningen voor zelfstandigen, mede gelet op de achterstand die hierbij aanwerig is'. Met als uitgangspunt (langere) zelfstandigheid van ouderen te bevorderen, werden in de nota van 1970 voorstellen gedaan voor onder meer verbetering van de inkomenspositie, uitbreiding van extramurale voorzieningen en dienstencentra en de bouw van bejaardenwoningen (minimaal 12.000 per jaar!).

Een algemene nota die ook woor het ouderenbeleid van belang geacht wordt, is de Structuurnota Gezondheidszorg 1974 (TK, 1973/1974). Hierin werd onder meer het 
uilgangspunt geformuleerd dat substitutie tussen de verschillende voorzieningen tot op zekere hoogte mogelijk moet zijn en dat in het bellang van de client voorkomen moet worden dat hil in een hoger echelon terecht komt dan strikt noodzakelijk is. Door het uitdrukkelijk streven de hulp- en zorgverlening in het eerste echelon te versterken en gelijktijdig die in het tweede echelon af te remmen, wordt in deze nota aan het begrip substitutie inhoud gegeven. Voorts is volgens de nota een onderdeel van het beleid gericht op het streven de voorzieningen zo dicht mogelijk bij de client te brengen. Dit zou moeten worden bereikt via spreiding van voorzieningen; het opzetten van kleinschalige voorzieningen, voorzieningen in de wijk en het bevorderen van thuiszorg en mantelzorg.

De tweede Nota Bejaardenbeleid 1975 (TK, 1974/1975) onderstreepte nog eens het in de eerste nota genoemde uitgangspunt van gelijkwaardigheid van ouderen en accentueerde het beleid gericht op de zo lang mogelijke zelfstandigheid, participatie en integratie van ouderen in de samenleving. De doelgroep wordt ten opzichte van de eerste nota verbreed van de meest kwetsbare bejaarden tot de gehele categorie ouderen vanaf 65 jaar. Duidelijk komt het probleem van de onderlinge afstemming tussen de sterk in aantal gegroeide voorzieningen naar voren en wordt tot eén van de kernpunten in het ouderenbeleid verheven. De terugdringing van de capaciteit in bejaardenoorden werd neergelegd in de zogenaamde $7 \%$ norm (in 1975 lag het feitelijk percentage op 9,5\%). Ook werd voor het eerst specifieke aandacht besteed aan de kwaliteit van de zorgverlening, naast andere indicatoren zoals de kwantiteit en vormgeving van organisaties. Een van de doelstellingen in de tweede Nota Bejaardenbeleid betreft het 'gesloten circuit": "een systeem van woorzieningen waarvan de elementen zodanig logisch en organisatorisch met elkaar zijn verbonden, dat het geheel in staat is de welkijns- en gezondheidsbehoeften van ouderen, althans voor zover dat redelijkerwijs vanuit instellingen en voorzieningen kan geschieden, integraal te behartigen'. Mede uit oogpunt van integratie van ouderen in de samenleving wordt het scheppen van afzonderlijke voorzieningen voor ouderen (categoraal voorzieningenbeleid) afgewezen. Een van de voorwaarden voor het functioneren van een gesloten circuit behelst de goede afbakening van functies en taken van instellingen. Waar dit onduidelijk blijft, ontstaan overlappingen in het zorgaanbod (WRR, 1982).

In de (algemene) Schets van de eerstelijnsgezondheidszorg uit 1980 (TK, 1979/1980) kreeg substitutie inhoud door de nadruk die in deze nota gelegd werd op een wijkgerichte opzet van kleinschalige voorzieningen en decentralisatie. Voorwaarde voor de realisatie van dit beleid is de versterking van eerstelijns gezondheidszorg en de terugdringing van de tweedelij $n$, die bovendien duurder is. Ook wordt aandacht gevraagd voor de mantelzorg en thuiszorg en de verschuiving van curatieve naar preventieve zorg. De schets wijst erop dat de veranderingen in de behoefte aan gezondheidszorg een betere aansluiting van het zorgaanbod daarop noodzakelijk maken.

In april 1982 verscheen een derde nota met betrekking tot het ouderenbeleid, Bouwstenen voor een ouderenbeleid (TK, 1981/1982). Het accent blijft liggen op het aanbieden van hulp die de zelfstandigheid en de zelfredzaamheid van ouderen bevordert. Daarbij wordt meer dan voorheen de nadruk gelegd op de eigen verantwoordelijkheid en de onderlinge hulpverlening, waarop de professionele hulp aanvullend moet functioneren. Net als in de algemene gezondheids- en welzijnszorg (zie Schets van de eerstelijnsgezondheidszorg; TK, 1979/1980), verschuift het accent bovendien naar preventieve zorg, mantelzorg en vrijwilligerswerk.

Het nieuwe kabinet kwam met een nadere standpuntbepaling en publiceerde in 1983 de Beleidsbrief Ouderenbeleid (TK, 1983/1984a). Ten opzichte van de oorspronkelijke Bouwstenen-nota (TK, 1981/1982), uitgebracht door het voorgaande kabinet, zijn verschuivingen in beleidsprioriteiten waar te nemen, die deels ingegeven zijn door nieuwe demogra- 
fische prognoses waarin dubbele vergrijzing nog verder gaat dan werd verwacht: De financiering van de ouderenzorg dreigde bij gelijkblijwend beleid onbetaalbaar te worden. Anderzijds noopte de sociaal-economische situatie tot bezuinigingen, waaraan ook de ouderenzorg niet zou kunnen ontkomen. Daarom worden maatregelen voorgesteld die onder meer moeten leiden tot een grotere doelmatigheid in de dienstverlening, een grotere samenhang tussen de vijf (basis-)woorzieningen voor ouderen en vermindering van overlappingen in hev zorgsysteem. Voorts wordt (verdere) verscherping van capaciteitsnormen en indicatiecriteria voorgestaan ten behoeve van de verdere terugdringing van intramurale ouderenzorg en wordt een nog grotere nadruk gelegd op zelfzorg, mantelzorg en vrijwilligerswerk. Capaciteitsnormen werden noodzakelijk geacht, omdat de beoogde verschuiving van de intra- naar extramurale zorg niet spontaan plaatsgevonden bleek te bebben. Het normeringsbeleid heeft soms het karakter van restricties, bijwoorbeeld de $7 \%$-norm voor bejaardenoorden; in andere gevallen worden groeipercentages voor de komende jaren aangegeven, bijvoorbeeld bij het kruiswerk. De overheid beoogt een accentverlegging van 'de anonieme, collectief gefinancierde solidariteit' naar 'de individueel en in de gemeenschap gevoelde en persoonlijk tot uitvoering gebrachte, op intermenselijke relaties gebaseerde solidariteit'. De 'zorgzame samenleving' doet haar intrede.

De nota Flankerend Ouderenbeleid (Ministerie van WVC, 1983) wordt in november 1983 als discussiestuk toegestuurd aan alle organisaties die betrokken zijn bij het bejaardenwerk en de bejaardenzorg, 'om daarmee het flankerend beleid verder tot leven te brengen'. Er wordt een globale afbakening gegeven: 'Flankerend beleid is overigens niet gericht op het in leven roepen van enigerlei nieuw soort voorziening voor bejaarden. Het beoogt een betere benutting van de taken en functies van de relevante voorzieningen voor bejaarden (gezinsverzorging, kruiswerk, gecoordineerd bejaardenwerk, bejaardenoorden, verpleeghuizen), waarbij het accent ligt op het ondersteunen van het eigen initiatief van ouderen en hun directe omgeving en initiatieven van vrijwilligers'. Flankerend beleid in enge zin beoogt dit voor de voorzieningen te bereiken; flankerend beleid in brede zin richt(te) zich op vernieuwende activiteiten op het gebied van technologische innovatie (strikt genomen buiten de grenzen van de ouderenzorg), maar is nooit goed van de grond gekomen (NFB, 1987 en 1988). Ter bevordering van het streven de zelfstandigheid van de in de wijk wonende ouderen te vergroten en om de bestaande leemtes in het aanbod (deels) aan te vullen, worden de wijkfuncties van bejaardenoorden gelintroduceerd, waardoor zelfstandig wonende ouderen de mogelijkheid kregen gebruik te maken van faciliteiten van bet verzorgingstehuis, zoals onder andere de warme maaltijdvoorziening, alarmering, bad en douche, pedicure, tijdelijke verzorging en sociaal-recreatieve activiteiten.

Naast de hierboven beschreven categorale nota's verschenen in 1983 ook enkele algemene nota's, zoals de Nota Volksgezondheid bij beperkte middelen (TK, 1983/1984b), Beleidsnota inzake wetgeving WVC (TK, 1983/1984c) en de Nota Eerstelijnszorg (TK, 1983/1984c). Het jaar 1983 brengt daarmee een omslag in het beleid (Goudriaan, 1989), waarbij de eerste lijn een substituerende in plaats van een verwijzende functie krijgt toebedacht en de term 'eerstelijnsgezondheidszorg' vervangen wordt door 'thuiszorg" (Van den Bos, 1989). In het zelfde jaar werd overigens het huidige Ministerie van Welzijn, Volksgezondheid en Cultuur tot stand gebracht (voorheen: Ministerie van Cultuur, Recreatie en Maatschappelijk Werk).

In de Nota volksgezondheid bij beperkte middelen (TK, 1983/1984b) staat bij de beoogde accentverschuivingen de doelstelling 'zelfstandigheidsbevordering' centraal. De nota presenteert een zorgmodel dat bestaat uit elkaar aanvullende en opvolgende functies met een onvermijdelijke afnemende mate van zelfstandigheid en mogelijkheid voor de client om in het eigen milieu te blijven. De in de nota bepleite verschuivingen worden in dit zorgmodel weergegeven. Genoemd wordt de verschuiving van curatieve naar preventieve zorg, van klinische naar poliklinische zorg en van tweede naar eerstelijns zorg. Deze accentver- 
schuivingen acht de nota noodzakelijk, onafhankelik van de vraag naar kostenbeheersing en de noodraak om tot ombuigingen te komen. Men maakt onderscheid tussen kwantitatieve substitutie (capaciteitsaanpassingen) en kwalitatieve substitutie (overheveling van functies). De maatregelen die daartoe doorgevoerd moeten worden, zoekt de nota in de sfeer van de regelgeving. De omvang en het tijdpad wan de substitutievoomemens worden in deze nota niet nader geconcretiseerd.

In de Belleidsmota inzake wetgeving WVC (TK, 1983/1984c) lijkt het kostenbeheersingsvraagstuk meer benadrukt te worden. Deze nota wijst op de noodzaak van overheveling van middetern: "Uit oogpunt van beheersing alsmede met het oog op het stimuleren van het eigen verantwoordelijkheidsgevoel van mensen dient ernaar gestreefd te worden, de zorg dicht bij huis zoveel mogelijk te versterken, door een gerichte werschuiving van middelen uit veel duurdere intra- naar extramurale zorg."

In de Nota eerstelijnszorg (1983) (TK, 1983/1984d) wordt de versterking van de eerste lijn centraal gesteld: 'Kwalitatieve en kwantitatieve versterking van de eerste lijn kan een beperking van het beroep op de doorgaans duurdere tweedelijnszorg mogelijk maken.' Deze nota is geschreven om te komen tot 'een begin van zodanige verschuivingen van de financiele middelen dat er sprake is van een totaalbeleid en versterking van de eerstelijns hulpverlening". In eerdere nota's waren reeds belangrijke beleidswoornemens voor eerstelijnszorg neergelegd. Als aanvulling op eerdere nota's wordt betoogd dat versterking van de thuiszorg. behalve door gerichte overheveling van financiele middelen uit de intra- naar extramurale zorg, ook kan worden nagestreefd door het aambrengen van een betere samenhang in beleid en planning.

De Algemene Rekenkamer evalueerde in 1985 de Basisvoorzieningen voor bejaarden (TK, 1985/1986) en kwam tot vernietigende conciusies: 'De harmonisatie van de instrumenten financiering, planning en wetgeving in het bejaardenbeleid heeft nauwelijks gestalte gekregen. Het streven van de rijksoverheid naar meer samenhang tussen de voor bejaarden relewante intra- en extramurale voorzieningen wordt ernstig belemmerd doordat de voorzieningen vanuit verschillende bronnen worden gefinancierd, ze grotendeels onafhankelijk van elkaar worden gepland en doordat samenhang ontbreekt tussen de van belang zijnde wettelijke regelingen' (p. 30). In 1985 wordt -mede naar aanleiding van dit rapport- de 7\%norm voor verzorgingstehuizen, "die niet gebaseerd is op inzicht in het werkelijk benodigde aantal bedden voor verzorgingsbehoevende bejaarden" (p. 29), losgelaten als streefcifer. Dergelijke normen passen overigens ook niet bij het substitutiebegrip, dat uitgaat van een zekere mate van overlap in taken en functies tussen voorzleningen, maar komen voort uit de idee met betrekking tot het zogenaamde "gesloten circuit", of uit de idee van geplande substitutie ten behoeve van kostenbeheersing (Stikker, 1985; NRV, 1989). In de plaats van een norm van $7 \%$ werd in 1985 het budgetsysteem voor bejaardenoorden als sturingsinstrument gehtroduceerd. Er worden sindsdien gelimiteerde budgetten (afgeleid uit de exploitaties van 1984) gedecentraliseerd naar de provincies, waarvoor in 1984 aanpassingen werden aangebracht in de Wet op de Bejaardenoorden (WBO; Stb. 1984, no. 656).

In 1986 wordt in de Nota zorg voor ouderen (TK, 1985/1986), bij wijze van voortzetting van het beleid uit zowel de eerdere bejaardennota's als de Nota volksgezondheid bij beperkte middelen (TK, 1983/1984b), naast de verschuivingen van de intramurale zorg naar extramurale zorg de verschuiving van professionele hulpverlening naar zelfzorg en mantelzorg en de verschuiving van curatieve naar preventieve zorg centraal gesteld. De versterking van de eerstelijn wordt tevens noodzakelijk geacht on de veranderende vraag te kunnen opvangen: 'Het is noodzakelijk zodanige randvoonwaarden te creesen dat zij de extramurale voorzieningen in stat stellen zowel in kwalitatief als in kwantitatief opzicht te voldoen aan de zich wijzigende vraag naar hulp'. Een nadere aanduiding van de gevolgen van dit 
voornemen voor de verschillende sectoren van de gezondheldszorg wordi in deze nota niet gegeven. Wel wordt ingegaan op met name de relatie tussen het bejaardenoord en het verpleeghuis, waarover in de Beleidsbrief van 1983 al een adviesaanvraag werd aangekondigd. De discussie concentreert zich rondom de onderwerpen indicatiestelling (per 1 januari 1989 gerealiseerd in Besluit Advisering hulpverlening ouderen; Stb. 1988 , po. 456), de groepswerzorging in bejaardenoorden, de geleidelijke afbouw wan de zogenaamde 1-oktoberbedden (later weer deels ongedaan gemaakt), de verpleeghuisarts als adviseur voor bet verzorgingshuis (Stcrt. 1986, no. 103) en de aanpassing van de normen voor verpleeghuizen (zie ook Nota Ouderenbeleid; TK 1987/1988). De eerder door de Algemene Rekenkamer aangegev. en knelpunten voor grotere samenhang op het terrein van financiering en wet-en regelgeving blijven voortdurende aandacht vragen, doch worden gedeeltelijk omzeild door een accentverschuiving van het aanbod naar de op individuele behoeften toegesneden 'zorg op maat'. De ideeen hierover zijn nog zo in ontwikkeling dat door de inhoudelijke discussies, de aandacht voor harmonisatie enigszins verslapt en tenminste tot enig respijt voor beleidsontwikkeling leidt.

De nota 'Over de ontwikkeling van gezondheidsbeleid: feiten, beschouwingen en beleidsvoornemens", de zogeheten Nota 2000 (TK, 1985/1986) pleit voor een betere afstemming van het zorgsysteem met het oog op veranderende behoeften aan zorg. Ontwikkelingen op het gebied van zelf- en mantelzorg, alternatieve geneeswijzen en het vrijwilligerswerk moeten hiervoor worden gestimuleerd. In de Nota 2000 worden de voornemens uil de Structuurnota 1974 en de Nota volksgezondheid bij beperkte middelen met betrekking tot zelfverantwoordelijkheid van de client verder uitgewerkt uitgaande van een hierrarchie van zorgrelaties: primair staat hierin de zelfzorg, secundair is mantelzorg (gezin, vrienden, famille) en als laatste komen pas de geprofessionaliseerde, door de staat gegarandeerde en collectief betaalde wormen van zorg. Deze hierarchie van zorgrelaties functioneert ook als een schuif- of substitutiemechanisme.

De Nota 2000 (TK, 1985/1986) meent dat de accentverschuivingen gevolgen moeten hebben voor de capaciteiten (p. 244). De overheveling van middelen wordt in deze nota voor het eerst voor het bele veld van gezondheidszorg financieel uitgewerkt en naar de diverse sectoren gedifferentieerd. Daarenboven moet het zorgsysteem veranderd worden. De capaciteit van de intramurale sectoren dient teruggebracht te worden en als compensatie kan het volume van een aantal andere sectoren extra toenemen. Het belangrijkste is een extra toename van extramuraje zorg $(1,2 \%)$. In totaal is er gemiddeld per jaar voor deze zorgsysteenverandering een volumetoename van $0,1 \%$ voorzien. Hieruil zou geconcludeerd kunnen worden dat de Nota 2000 wel substitutie bepleit, maar niet verwacht dat deze tot absolute kostenbesparingen zal leiden.

In de Nota kosten van vergrijaing voor WVC (Ministerie van WVC, 1986) werd onderzochi of het financiele meerjarenkader voldoende zou zijn om de gevolgen van de vergrijzing tot 1990 op te vangen. Het financiele gat tussen de meerjarenramingen en de demografische ramingen bedraagt ruim $f 1,5 \mathrm{mld}$. In de nota wordt een substitutievoorstel gepresenteerd waardoor de kosten van de intramurale voorzieningen mel ruim $f 800 \mathrm{~m} / \mathrm{n}$. verlaagd kunnen worden. Daartegenover staat extra ruimte van ongeveer $f 300 \mathrm{mhn}$. voor extramurale voorzieningen. In deze nota lijkt substitutie te zijn verworden tot een middel on kosten te besparen zonder dat nog aandacht wordt besteed aan de zorginhoudelijke gevolgen (NRV, 1989). Ook deze nota erkent echter dat de toename wan kosten slechts kan wordien afgeremd, niet omgebogen (Ministerie van WVC, 1986, p. 29).

De meest recente categorale nota die binnen het besproken tijdsvak vall, is de Nota Ouderenbeleid, Voortgangsrapportage 1982-1988 (TK, 1987/1988), de eerste in een reeks tweejaarlijkse rapportages aan de Tweede Kamer met betrekking tot bet vanaf 1982 gevoerde en verder te voeren ouderenbeleid (medio oktober 1990 is de tweede voortgangs- 
rapportage openbaar gemaakt). Tal van min of meer spontaan ontstane zorgvernieuwingen, zoals kleinschallige werpleeg- of verzorgingshuizen, dagverpleging in het ziekenhuis, 24-uurs bereikbaarheid, thuiszorg voor verpleeghuis-geindliceerden en de functie geriatrie in algemene ziekenhuizen, krijgen hun (bescheiden en bewaakte) plaats in het ouderenbeleidl. Daarbij is het interessant te vermelden dat ook de overheid erkent dat in het tot nu toe gevoerde interdepartementale ouderenbeleid de aandacht te zeer gericht is geweest op de meest zorgbehoevende ouderen'. 'In het toekomstige ouderenbeleid zal rekening gehouden worden met het feit dat ouderen niet eén homogene groep vormen'. 'Hiermee kan op den diur tevens het zelfbeeld wan en de beeldvorming over ouderen in het algemeen in meer positieve zin worden omgebogen ${ }^{2}\left(\mathrm{TK}_{,}, 1987 / 1988\right.$, p. 47).

Begin januari 1988 zijn tenslotte ook alle zogenaamde demonstratieprojecten in het kader van substitutie in de ouderenzorg van start gegaan. 'Het streven is om de resultaten van deze projecten nog in de lopende kabinetsperiode in het reguliere beleid te verwerken' ( $p$. 46)! Deze projecten worden duidelijke voorbeelden genoemd wan door de overheid gestimuleerde experimenten die een stapsgewijze invoering van de voorgestelde veranderingen voor een nieuw zorgbestel zullen bevorderen (Nota Verandering Verzekerd). De demonstratie-projecten worden noodzakelijk geacht omdat alle tot dan uitgevoerde, veelal zeer kleinschalige en lokale projecten sectorgericht waren en meer algemene conclusies over de (on-)mogelijkheden van substitutie moeilijk te toetsen zijn op grond van de resultaten tot dan toe (Nota Ouderenbeleid; TK, 1987/1988, p. 124). Tenslotte zullen de projecten informatie moeten leveren met betrekking tot de vraag of, en in hoeverre, door middel van substitutie een daadwerkelijke bijdrage aan de opvang van de demografische druk kan worden geleverd (TK, 1987/1988, p. 130).

\subsection{Ontwikkeling van voorzieningen in vogelvlucht}

In deze paragraaf worden de meest belangrijke ontwikkelingen belicht ten aanzien van gezinsverzorging, wijkverpleging, gecoordineerd ouderenwerk, bejaardenoorden en verpleeghuizen. Hiermee ontstaat een referentiekader voor de beschrijving van het gebruik van deze voorzieningen door ouderen in het vervolg van deze studie.

\subsubsection{Korte beschrijving van de gezinsverzorging}

De eerste vereniging voor huilsverzorging, zoals dat destijds heette, werd in 1895 opgericht in Deventer. Vlak na de 'Tweede Wereldoorlog werd de naam 'gezinswerzorging' gekozen, omdat men bij de wederopbouw het gezin als hoeksteen zag (Daal, 1987). Aan langdurige hulp aan bejaarden, gehandicapten of chronisch zieken in het kader van gezinsverzorging werd tot het eind van de jaren ' 50 niet of nauwelijks gedacht. De kwaliteitsbewaking stond bij de eerste subsidieregeling van 1948 voorop. Eind jaren vijftig brak het besef door dat vooral bejaarden en eerder genoemde groepen veel ambulante verzorgende hulp nodig hebben die vaak van langdurige aard is, maar tevens bleek dat de bestaande regelingen daarvoor geen mogelijkheden boden (gezinsverzorging was een tijdelijke voorziening, hoogstens voor enkele weken); dit leidde tot de invoering van de tweede subsidieregeling in 1958 (Maessen, 1989). Omdat bij hen niet noodzakelijkerwijs ook altijd hoog gekwalificeerd personeel ingezet hoeft te worden, ontstond het fenomeen 'helpster'. Vanaf het begin van de jaren zestig ging de overheid zich steeds meer bezig houden met planning, spreiding en doelmatigheid van voorzieningen. Schaalvergroting heeft sindsdien geleid tot enerzijds een afnemend aantal instellingen en anderzijds een toename van de gemiddelde grootte per instelling. In de eerste helft van de jaren zeventig ontstond de idee van 'welzijnsbeleid', waarbinnen gezinsverzorging een belangrijke plaats kreeg. De gezinsverzorging werd vanaf 
dat moment grotendeels gesubsidieerd door de rijksoverheid en nam in omvang sterk toe. Pas in 1976 werd voor het eerst op grote schaal getracht die groei enigszins te beheersen, onder meer door de invoering van landelijke richtlijnen voor indicatiestelling en retributieheffing naar draagkracht. De indirecte (open eind-)financiering via de bijstandswet werd teruggedraaid. Sinds 1978 staan de ontwikkelingen in de gezinsverzorging vrijwel witsluitend in het teken van de bezuinigings- en beheersingsmaatregelen, zoals vacaturestops, invoering alpha-hulp, kortingen op formatie-uren en retributieverhogingen (Maessen, 1989).

De taken van de gezinsverzorging zijn te omschrijven als huishoudelijke, verzorgende en begeleidende activiteiten, alsmede huishoudelijke ziekenverzorging, welke steeds aanvullend zijn op de tekorten in het huishouden. Om deze taken uit te voeren, maakt $85 \%$ van de instellingen onderscheid tussen traditionele en alpha-hulp. Alpha-hulp is sinds 1978 landelijk erkend en betreft puur huishoudelijke hulpverlening gedurende maximaal 12 uur per week en ten hoogste 2 werkdagen. Bij de alpha-hulp heeft de instelling een bemiddelende functie waarbij de alpha-hulpen in dienst treden van de clienten. Alle hulp die meer dan 2 dagdelen per week betreft of van een andere aard is dan puur huishoudelijk, behoort tot de "traditionele' hulp. Onder dit koepelbegrip vallen echter vele nieuwe vormen van hulpaanbod, die sinds begin tachtiger jaren in ontwikkeling zijn. Te noemen zijin de wijkbejaardenzorg, 24uurs-bereikbaarheid en -beschikbaarheid en (terminale) thuiszorg. Het in 1985 ingevoerde budgetteringssysteem, dat onder andere een maximum stelt aan de overheadkosten binnen het totale budget, zou de instellingen meer ruimte bieden om de toenemende en zich wijzigende hulpvraag op effectieve wijze op te vangen.

De financiering van de gezinsverzorging geschiedt uit twee inkomstenbronnen. De belangrijkste is de overheidssubsidie op grond van de Rijkssubsidieregeling Gezinsverzorging, die sinds 1 januari 1989 als tijdelijke subsidieregeling integraal is overgenomen in de AWBZ (Stcrt. 1989, no. 16). Dit wordt beschouwd als overgangsmaatregel naar volledige opname in het AWBZ-verstrekkingenpakket en is een van de gevolgen van het werk van de Commissie Dekker (1987). De tweede financieringsbron betreft de eigen bijdrage van de clienten, die afhankelijk is van het inkomen en de samenstelling van het huishouden. De gemiddelde eigen bijdrage beslaat slechts een klein deel (ongeveer $8,5 \%$ ) van de totale kosten.

\subsubsection{Korte beschrijving van de wijkverpleging}

De basis van het huidige kruiswerk werd gelegd in de 19 e eeuw met de oprichting van de eerste verenigingen ter bevordering van de volksgezondheid en het weren van epidemieen in 1895 (Boot en Knapen, 1988). Na de oprichting van een opleiding voor verpleegsters, dijde rond 1900 het kruiswerk sterk uit en vormde vanaf 1911 landelijke koepelorganisaties. De groel van het kruiswerk komt tot uitdrukking in het aantal gezinnen dat lid is van een van de regionale op plaatselijke kruisverenigingen. Rekening houdend met de gemiddelde gezinsgrootte is in 1940 ruim 1/3 wan de bevolking lid, in 1957 circa $60 \%$ en in 1987 bij benadering $70 \%$, hetgeen neerkomt op ongeveer 3,3 miljoen huishoudens (Boot en Knapen, 1988; Nationale Kruisvereniging, 1988).

De drie op levensbeschouwelijke grondslag georganiseerde kruisverenigingen het Algemene Groene Kruis (1911), het Wit-Gele Kruis (1923) en het Oranje-Groene Kruis (1938) gingen in de jaren zestig samenwerken, hetgeen uiteindelijk resulteerde in volledige fusie in de Nationale Kruisvereniging in 1977. De samenwerking wordt nog versneld door schaalvergroting, de vorming van Erkende KruisOrganisaties (EKO's) en de financiering van het kruiswerk krachtens de AWBZ (per 1-1-1980; Stb. 1980, no. 655). Thans is een tweede proces van schaalvergroting bijna voltooid, waarbij het aantal EKO's teruggebracht wordt tot circa 60 (super-)regionale werkverbanden. Doel van deze operatie in het kader van de Herstrukturering Landelijke Organisaties is te komen tot een oplossing van de problematiek van de zware bestuurlijk-organisatorische structuur van het kruiswerk en het ontbreken van 
krachtige erkende kruisorganisaties met een doelmatige schaalgrootte op districtsniveau (FOZ 1989: TK, 1988/1989, p. 109).

Het zorgaanbod van het kruiswerk wordt in acht zorgterreinen of zorgfuncties ingedeeld (NK, 1988): zwangerschapszorg, kraamzorg, jeugdgezondheidszorg (JGZ), zorg voor zieken en gehandicapten, de preventieve ouderenzorg, voedingsvoorlichting en dieetadvisering, gezondheidsvoorlichting en opvoeding (GVO) en tenslotte de verplegingsartikelen en hulpmiddelen. Hoewel het totale zorgaanbod van de kruisverenigingen zeer divers is, concentreren wij ons hier volledig op de voor ouderen belangrijkste zorgfunctie, de wijkverpleging.

\subsubsection{Korte beschrijving van het gecoürdineerd ouderenwerk en dienstencentra}

Het gecodrdineerd ouderenwerk als woorziening en als coordinerende instantie in de ouderenzorg is in de loop der tijden onderhevig geweest aan tairijke veranderingen die vrijwel parallel lopen aan de ontwikkelingen in het ouderenbeleid van de overheid. Hierdoor is het in deze paragraaf niet altijd mogelijk een strikt onderscheid te handhaven tussen enerzijds het gecoordineerd ouderenwerk als voorziening en anderzijds het gecoordineerd ouderenwerk als cen van de instrumenten van owerheidsbeleid.

In 1962 werd door de minister van CRM woor het eerst een pleidooi gehouden voor het dienstencentrum naar Scandinavisch model. In 1963 werd het eerste dienstencentrum geopend. Het aanvankelijk experimentele karakter werd benadrukt in de Voorlopige Rijksbijdrageregeling Dienstencentra woor Bejaarden (Stcrt. 1967, no. 199). Het dienstencentrum werd daarbij gedefinieerd als 'een instituut waarin of waaruit samenhangende diensten worden verleend". Het accent lag in deze beginfase op het aanbieden en organiseren van activiteiten voor ouderen, met name op sociaal-cultureel terrein, maar ook in de vorm van kleine hand-en spandiensten (pedicure, wasbeurt, de was doen), met de nadruk op de ruimtelijke accommodatie waarin een en ander geschiedde. De aanvankelijke doelstelling om in ledere wijk een dienstencentrum te realiseren is echter nooit verwezenlijkt.

De tweede ontwikkelingsfase laat een verschuiving zien van het organiseren van activiteiten naar de coördinatie en startte in 1970 met de eerste Nota Bejaardenbeleid (TK, 1970/1971). Het bevorderen en stimuleren van zelfstandig functioneren van ouderen in de eigen omgeving komt als hoofddoelstelling van het gecoordineerd bejaardenwerk (afgekort tot GBW of, sinds de term 'ouderen" geprevaleerd wordt boven 'bejaarden', GOW) naar woren. Daarbij stat niet langer de accommodatie zelf centraal, maar de functies die wervuld worden. Hiervoor ontstond de benaming 'project gecoordineerd bejaardenwerk" en verdween steeds meer de benaming 'dienstencentra' wit stichtingsnamen en dergelijke.

De volgende fase wordt gemarkeerd door de tweede Nota Bejaardenbeleid (TK, 1974/1975) en de (discussie over de) ontwerp-Rijksbijdrageregeling Gecoobrdineerd Bejaardenwerk in 1977. In de Tijdelijke Rijksbijdrageregeling (Stcrt. 1980, no. 91) werd verwoord dat het gecoordineerd bejaardenwerk zich ten doel stelt de zelfstandigheid en maatschappelijke integratie van de ouderen te bevorderen, met inspraak van de ouderen zelf, door het coördineren van de in de gemeente werkzaam zijnde organisaties en instellingen, door aandacht te vragen voor de positie van bejaarden, te signaleren welke voorzieningen niet of onvoldoende ontwikkeld zijn en tenslotte door het organiseren van activiteiten. Deze regeling was tijdelijk, ondat zij gold in afwachting van een bredere Rijksbijdrageregeling Maatschappelijke Dienstverlening, die in 1980 weliswaar in eerste fase werd ingevoerd maar later (1986) is teruggetrokken. Bovendien werd een aparte regeling voor het GOW ongewenst geacht vanwege de in gang gezette decentralisatie en de opvatting dat een breder draagvlak noodzakelijk is voor de realisering van de coơrdinatie-functie. Twee andere, deels parallel lopende, ontwikkelingen speelden aan het eind van de jaren zeventig eveneens een 
belangrijke rol. Ten eerste werd in 1977 bij de invoering wain het Besluit Opneming Bejaardenoorden (Stb. 1976, no. 619) de taak van het gecoordineerd bejaardenwerk voor personen die een advies van de (indicatie-) commissie ex artikel $6 \mathrm{j}$ van de WBO ontwangen hebben, benadrukt en vastgelegd. Deze taak richt zich op de coordinatie van de hulpuerlening en de procedurele afwikkelingen, zodat de hulpverleners ontlast worden en de ouderen doelmatiger geholpen worden. Ten tweede kwam ook bij ouderen een emancipatiebeweging op gang, waarbij het gecoordineerd bejaardenwerk een ondersteunende en stimulerende rol werd toegeschreven (Nota Bejaardenbeleid 1975).

Langzamerhand ontstond de behoefte aan een meer planmatig en gehtegreerd ouderenbeleid, waarvoor de nota Bouwstenen voor een ouderenbeleid (TK, 1981/1982) een eerste aanzet poogde te geven. Het gecoordineerd ouderenwerk werd in deze structuur een belangrijke coordinerende rol toebedacht. Bij de behoefte aan een meer doordacht ouderenbeleid speelden naast idesle ook demografische en financieel-economische overwegingen een zeer belangrijke rol. De bedoelde integratie werd echter gefrustreerd door een versnipperde wet- en regelgeving, waarin bevoegdheden bij verschillende overheidsniveau's lagen (en nog liggen) en de financieringssystemen stringent gescheiden waren. Als oplossing werd gedacht aan een zeer brede Wet op de Bejaarclenoorden of een algemeen (en niet categoraal) geldende Welzijnswet, zodat de integratie van ouderen in de samenleving verbeterd kan worden. Gelijktijdig met deze ontwikkelingen loopt de wens tot versterking van het informele circuit, zoals verwoord in de Beleidsbrief Ouderenbeleid (TK, 1983/1984a) en de discussienota Flankerend Ouderenbeleid (Ministerie van WVC, 1983). Het Reikwijdtebesluit van de nieuwe WBO (Stb. 1984, no. 678) bracht in 1985 zowel het flankerend beleid en de wijkfuncties van bejaardenoorden als het gecoordineerd ouderenwerk (eerst voor én, later voor twee jaar) binnen éen kader, waarvoor alle bevoegdheden zijn gedecentraliseerd naar de provinciale overheden. Per 1 januari 1985 is de officiele benaming veranderd in het Gecoordineerd OuderenWerk (GOW).

Vanaf 1985 vormde de wet op de bejaardenoorden (tijdelijk) het belangrijkste kader voor het ouderenbeleid en leek het met de cőrdinatie, in ieder geval op overheidsniveau, de goede kant uit te gaan. Het tijdelijke karakter werd aanvankelijk geacht tot 1990 te gelden: de bejaardenoorden zouden dan onder de Kaderwet Specifiek Welzijn (Stb. 1982, no. 539) worden gebracht en zodoende deel gaan uitmaken van én geintegreerd gemeentelijk welzijnsplan. De gezondheidszorg zou hierbij ingekaderd worden door de Wet Voorzieningen Gezondheidszorg (WVG; Stb. 1982, no. 497). In 1983 werd uiteindelijk duidelijk dat de WVG nooit gerealiseerd zou worden. De gedachten met betrekking tot weleijnsplannen op gemeentelijk niveau hebben echter stand gehouden en er toe geleid dai per 1 januari 1987 de bevoegdheden rondom het GOW verder zijn gedecentraliseerd van de provincies naar de gemeenten; dit gebeurde via de Welijnswet (Stb. 1987, no. 73). Ook onderdelen van het flankerend beleid en de wijkfuncties behoren nu tot de gemeentelijke taken, uitgezonderd capaciteitsgebonden voorzieningen (tijdelijk wonen, dag- cq. nacht-opvang).

Tot slot van deze paragraaf worden de gevolgen van de Welzijnswet (Stb. 1987, no. 73) voor het GOW kort besproken (zie ook Werkboek GOW, 1978). Het GOW is als een van de 19 werksoorten in dit juridisch kader opgenomen en ressorteert thans onder de gemeentelijke welzijnsplanning, evenals bet grootste deel van het flankerend ouderenbeleid en de woontussenvoorzieningen. Dit heeft voor het GOW de volgende consequenties. Ten eerste blijkt de rijksoverheid afgestapt te zijn van het idee van integrale planning en afstemming in het ouderenbeleid, zoals dat eerst was vastgelegd in het Reikwijdtebesluit WBO (Stb. 1984, no. 678). Hierdoor dreigt een tweedeling te ontstaan in welzijns- en gezondheidszorgbeleid voor ouderen, waardoor de (bestuurlijke) samenwerking en coordinatie tussen de basisvoorzieningen voor ouderen nadelig beinvloed wordt. Het onderbrengen wan het GOW in etn (administratie van een) gemeentelijke welzijnstichting wordt als een belemmering voor 
het functioneren beschouwd. Aan de andere kant wordt 'decategoralisering' juist toegejuilcht. De integratie wan ouderen in de gehele matschappij zou hiermee gediend zijn. Het belangrijkste gevolg is dat de beleidswerantwoordelijkheid voor het GOW verder gedecentraliscerd is naar het gemeentelijke niveau. De gemeentellike overheid beslist of (1) en zo ja tot welk bedrag (vaak via budgetsysteem) het gecourdineerd ouderenwerk gesubsidieerd wordt.

\subsubsection{Korte beschrifving wan de bejaardenoorden}

De geschiedenis van het fenomeen bejaardenoord gaat terug tot de middeleeuwen (Burger en Van Otterloo, 1983), toen nonnenkloosters een hospitium voor arme vrouwen stichtten (Synode van Aken, 816). Ook hadden kloosters waak hospittalen (inrichtingen van gastwrijheid) en gasthuizen om reizigers onderdak en werzorging te geven. Deze band tussen kioosters en gasthuizen werd door het Concilie van Vienne (1311) ongedaan gemaakt. Plaatselijke notabelen namen het bestuur over en richtten in de opkomende steden godshuizen voor arme en oude mensen op (16e en $17 \mathrm{e}$ eeuw). Toenemende verstedelijking, nijverheid en handel deden het aantal gebrekkigen en hulpbehoevenden toenemen, waardoor ook de vraag naar gast- en godshuizen toenam. Men ging toelatingscriteria hanteren (in de $17 \mathrm{e}$ eeuw!). Armen- en bejaardenzorg waren aanvankelijk charitatief werk van kerken en notabelen, doch het humanisme rond de $17 \mathrm{e}$ eeuw zorgde ervoor dat de zorg voor ouderen tot overheidstaak werd gemaakt. Aan het eind van de $18 \mathrm{e}$ eeuw veranderden de gasthuizen in tehuizen voor ouden van dagen met een vrij uniform verzorgingspakket. In de $17 \mathrm{e}$ en $18 \mathrm{e}$ eeuw ontstonden andere huisvestingsvormen voor ouderen, zoals 'hofjes' en pensiontehuizen met huisvesting en maaltijden. Na de Tweede Wereldoorlog krijgen deze pensiontehuizen een nieuwe impuls als een oplossing voor de woningnood. In de periode 1945-1969 kwamen er 56.500 bedden bij in 546 nieuwe, met rijkssteun gebouwde, bejaardentehuizen en nog eens 15.000 bedden in andere nieuwe of al bestaande tehuizen (Nota Bejaardenbeleid 1970, TK, 1970/1971). Langzaam ontstond het inzicht dat de bewoners naast huisvesting en maaltijden ook persoonlijke en lichamelijke verzorging nodig hebben. Aan het eind van de vijftiger jaren werd echter steeds duidelijker dat het peil van verzorging in de tehuizen niet altijd voldoende hoog is en dat soms zelfs sprake is van wantoestanden. De eerste Wet op de Bejaardenoorden (Stb. 1963, no. 18) is dan ook vooral een toezichtswet ter bewaking van de kwaliteit van de huisvesting en de verzorging in tehuizen die voor het eerst 'bejaardenoord' werden genoemd, namelijk inrichtingen waarin aan tenminste vijf personen van 65 jaar of ouder duurzame huisvesting, gepaard met gehele of gedeeltelijke verzorging, wordt verschaft (deze definitie geldt nog steeds). De provincies kregen een belangrijke rol bij het opstellen van en toezicht houden op regels voor bejaardenoorden. De toename in het aantal bejaardenoorden sinds 1963 werd deels veroorzaakt door de wetgeving, waarin het wrij uniforme verzorgingspakket omschreven is, en deels door het tot stand komen van een aantal sociale verzekeringswetten, waarbij met name de indirecte financiering van opname in het bejaardenoord via de Algemene Bijstandswet (Stb. 1964, no. 312) grote gevolgen heeft gekregen; in $1984 \mathrm{kreeg}$ ongeveer $80 \%$ van alle bewoners een ABW-uitkering. (Algemene Rekenkamer, 1985).

Tot 1970 was het overheidsbeleid met betrekking tot ouderen hoofdzakelijk gericht op de intramurale zorg, waarbij met name de bouw van bejaardenoorden grote aandacht had. In de eerste Nota Bejaardenbeleid van 1970 werd de aanzet gegeven tot ombuiging van dit beleid en komt de zelfstandigheid van ouderen voor het eerst in beeld (zie paragraaf 3.4). In de tweede nota Bejaardenbeleid van 1975 (TK, 1974/1975) werd uitgesproken dat de capaciteit van bejaardenoorden niet meer zou mogen bedragen dan $7 \%$ van de bevolking van 65 jaar en ouder. Deze veranderende beleidsopvattingen weerspiegelden zich in de wijziging van de WBO in 1972 (Stb. 1972, no. 344). Nieuwe elementen in de wet betreffen de planning en de indicatiestelling. Ook werd al gesproken over decentralisatie van de plan- 
ningsbevoegdheid naar de provincies, maar dit werd pas in 1985 gerealiseerd. Wel dient de provincie vanaf 1972 een "verklaring van geen berwaar" the geven alvorens een nieuw bejaardenoord gebouwd kan worden. De eis tot indicatiestelling door een onafhankelijke commissie waarbij de te volgen procedures en later ook de te stellen criteria wettelijk vastgelegd waren in het Besiuit Opneming Bejaardenoorden (Stb. 1976, no. 619), betekende een wezenlijke breuk met het verleden, toen iedere instelling volledig autonoom was in thaar opnamebeleid. Deze autonomie leidde echter tot grote wachtlijsten, ongelijke behandeling van ouderen en bovendien tot opnames van ouderen die wellicht langer thuis hadden kunnen blijwen. Ook de onafhankelijkheid van de in de gewijzigde WBO van 1972 (Stb. 1972, no. 344) genoemde nieuwe commissie voor de advisering over de aard en de mate van zorgbehoefte wordt belangrijk geacht. De criteria die bij de beoordeling van een aanvraag gehanteerd moeten worden, werden echter pas enige jaren later vastgelegd in her eerder genoemde Besluit Opneming Bejaardenoorden.

Op 1 januari 1985 is de Wet op de Bejaardenoorden (Stb. 1984, no. 656) opnieuw ingrijpend veranderd, met name op het punt van het beleidsregime. Bevoegdheden en middelen werden vanaf die datum vrijwel volledig toebedeeld aan de provincies en de vier grote gemeenten. Slechts de instellingen met een bijzondere functie (kicosterbejaardenoorden, tehuizen voor blinden en slechtzienden, etcetera; Stcrt. 1985, no. 14) bleven onder de competentie van de rijksoverheid vallen (met uitzondering van het kwaliteitstoezicht, dat bij de WBO-wijziging in 1988 (Stb. 1988, no. 77) echter alsnog naar de rijksoverheid is overgeheveld). In 1984 was een overgangsregeling van kracht, omdat de wijziging van de WBO langer duurde dan voorzien (Interimwet bejaardenoorden, Stb. 1983, no. 687), op grond waarvan het ministerie de nodige maatregelen (o.a. in verband met prijsstelling) heeft genomen. Vanaf 1 januari 1985 geldt via de nieuwe WBO (Stb. 1984, no. 562) een systeem van directe financiering, op grond waarvan de provincies een doel- (ook wel specifieke) uitkering krijgen waarmee de bejaardenoorden bekostigd worden voorzover de eigen bijdragen ontoereikend zijn. Voor de vaststelling, inning en afdracht van de eigen bijdragen zijn de gemeenten verantwoordelijk. De Gedeputeerde Staten stellen de begroting en tarieven vast en bepalen de hoogte van de provinciale bijdragen. De nieuwe financieringsmethodjek verliep niet bepaald vlekkeloos, omdat de hoogte van de rijksuitkeringen en de eigen bijdragen lang onzeker bleef en er bovendien tegelijkertijd structurele bezuinigingen op de budgetten van de instellingen $(4 \%)$ werden doorgevoerd. Ook de middelen in het kader wan het Flankerend Beleid werden in 1985 gedecentraliseerd. De berekening van de doeluitkeringen is bij de laatste wijziging van de WBO in 1989 voortaan gebaseerd op het aantal 75-plussers. Om de financiele gevolgen van deze wijziging op te vangen is een vereveningspad tot 1994 uitgestippeld (FOZ 1990, TK, 1989/1990).

Het bejaandenoord beeft zich ontwikkeld tot een verzorgingstehuis woor intensief verzorgingsbehoevenden. Deze karakterwijziging laat zich vertalen in een behoefte aan accommodatie $_{\mu}$ toegesneden op de zorgbehoefte van de bewonerspopulatie en een beboefte aan gekwalificeerd personeel (Nota Ouderenbeleid, TK, 1987/1988, p. 31). Geconstateerd wordt ook dat de grenzen tussen verzorgingstehuizen en verpleegtehuizen steeds verder vervagen. Om de functies scherper te kunnen onderscheiden is een Algemene Maatregel van Bestuur afgekondigd inzake de indicatiestelling van bejaardenoorden en verpleeghuizen (Stb. 1988, no. 456), die per 1 januari 1989 van kracht is en leidt tot én centrale indicatiecommissie voor beide voorzieningen. Verdere harmonisatie is doorgevoerd in de eigen bijdrageregeling voor verpleeghuizen die per 1 juli 1988 is verhoogd van $f 1350$ naar $f 2200$ per maand en daarmee vergelijkbaar is geworden met het tarief voor verzorgingstehuizen. Ook de consultatiefunctie van verpleeghuisartsen ten behoeve van het verzorgingstehuis en dagbehandeling worden genoemd als middel om de samenhang tussen beide voorzieningen te verbeteren. De zo groot mogelijke zelfstandigheid van ouderen, ook 
in de intramurale sectoren van bejaardenoorden en verpleeghuizen, blift centraal gedachtengoed.

\subsubsection{Korte beschrifving van de verpleeghuizen}

Het verpleeghuis is een instelling van gezondheidszorg waar verpleegkundige en (para-) medische hulp geboden wordt aan mensen die thuis of in het verzorgingstehuis niet meer voldoende kunnen worden geholpen. De verpleeghuiszorg wordt omschreven als een continue, gystematische en vaak langdurige multidisciplinaire zorg, de zogenaamde CSLMzorg, en wordt 'geleverd" in drie soorten verpleeghuizen: voor somatische zieken en voor psychogeriatrische patienten of in gecombineerde verpleeghuizen waar beide groepen aan bod komen. Thans zijn er ongeveer 50.000 bedden, verdeeld over 120 verpleeghuizen voor somatisch zieken, 78 psycho-geriatrische en 123 gecombineerde verpleeghuizen. In het kader van de Wet Ziekenhuis Voorzieningen (WZV; Stb. 1970, no. 268) gejden expliciete normen voor de toegestane capaciteit in verpleeghulizen. Deze normen drukken het aantal bedden uit in procenten van de bevolking en zijn voor somatisch zieken $1,2 \%$ van de 65 -plussers plus 0,35 promille van de totale bevolking en voor psycho-geriatrische patienten $1,25 \%$ (in de vier grote steden tijdelijk , $11,25 \%$ ). Voor psycho-geriatrische patienten bestaat al gedurende enige tijd een tekort aan bedden en wordt de thans geldende norm te laag geacht. Bovendien blijkt het onderscheid tussen somatisch zieken en psycho-geriatrische patienten lang niet altijd scherp te maken (Nota Ouderenbelleid, TK, 1987/1988). Een aantal somatische bedden is 'omgeruild' ten behoeve van psycho-geriatrische patienten, hoewel de capaciteit daarvan nog steeds onder de norm ligt (FOZ 1990). Het voornemen om de norm aan te passen en uit te gaan van én planningsnorm is nog nïet gerealiseerd.

Circa $90 \%$ van de capaciteil van verpleeghuizen komt ten goede aan ouderen $(65+)$, van wie een ruime meerderheid bovendien ouder is dan 80 jaar. De kosten, die ongeveer $f 200$ per dag bedragen, worden betaald krachtens de AWBZ. De patienten betalen een bijdrage in de verblijfskosten, waarmee $2,5 \%$ van alle verpleegkosten gedekt wordt (Algemene Rekenkamer, 1985). De grenzen tussen bejaardenoorden en verpleeghuizen lijken steeds verder te vervagen (Nota Ouderenbeleid, TK, 1987/1988; FOZ, 1990), hetgeen voor het Ministerie van WVC aanleiding vormde de indicering en toewijzing van beide voorzieningen, alsmede van dagbehandeling in het verpleeghuis, in een hand te brengen en de bevoegdheden vari de voormalige indicatiecommissle voor bejaardenoorden in die zin per 1 januari 1989 wit te breiden (zie vorige paragraaf). Voorheen was de procedure voor opneming in een verpleeghuis vastgelegd in het Besluit Verpleging in verpleeginrichtingen Bijzondere Ziektekostenverzekering (Stcrt. 1968, no. 103), doch daarin waren ten aanzien van de indicatiestelling geen regels gesteld (zoals in het Besluit Opneming Bejaardenoorden wel het geval was).

\subsection{Samenvatting}

Uit de verschillende overheidspublikaties blijkt dat substitutie binnen en tussen zorgsectoren vanaf het midden van de jaren zeventig consequent en consistent als beleidsvoornemen, maar soms ook niet meer dan een voornemen, wordt gepresenteerd. In deze publikaties worden zorgverschuivingen voorgestaan om de zorgverlening zo dicht mogelijk bij de client te realiseren: binnen de intramurale sector van klinische naar poliklinische hulp, van intramurale naar semi- en extramurale hulpverlening, van professionele hulpverlening naar zelfzorg en mantelzorg en van curatieve naar preventieve zorg.

De overheid verwacht met deze zorgverschuivingen een verbeterde afstemming van de zorg op de behoefte van de client (zorg op maat) te bewerkstelligen en stelt hierbij als voor- 
waarde dat versterkingen ten behoeve van semi- en extramurale sector, respectievelijke zelfzorg en mantelzorg, slechts tot stand worden gebracht bij overeenkomstige vermindering van de intramurale capaciteit, respectievelijk van professionele bulpverlening. Met name de herverdeling van de financiele middelen krijgt blijkens de verschillende beleidsnota's in de loop der tijd een steeds belangrijker plaats. In slechts een klein aantal nota's is concreet ingevuld op welke manier de voorgestane verschwivingen gerealiseerd dienen te worden en welke gevolgen hieraan verbonden worden voor de capaciteiten en de financiele middelen. De harmonisatie en integratie van wet- en regelgeving en planningsnormen is daarbij wel steeds als beleidswoornemen een telkenmale terugkerend onderwerp, doch in de praktijk is deze materie -op z’n minst gezegd- weerbarstig gebleken (Algemene Rekenkamer, 1985).

Uit de verschillende publikaties blijkt dat de overbeid hoge verwachtingen van substitutie heeft. Veelal wordt echter in de overheidsnota's een concretisering van financiele gevolgen achterwege gelaten. Gedeeltelijk is de overheid daartoe tot op heden ook niet in staat gebleken, omdat zij onvoldoende kennis heeft van de mogelijke invloed van een aantal hoofdproblemen in het ouderenbeleid, zoals vergrijzing, gezondheidstoestand en maatschappelijke positie op het voorzieningengebruik van ouderen. Wanneer de financiele gevolgen wel worden uitgewerkt, worden de veronderstellingen meestal niet expliciet atangegeven. Het is dan ook onduidelijk, hoe nauwkeurig en betrouwbaar de berekende besparingen zijn die als gevolg van de voorgestane substitutievoorstellen zouden kunnen worden bereikt (Goudriaan, 1989 en 1990; Huijsman en de Klerk, 1989).

Tenslotte speelt de complexiteit van de materie het ouderenbeleid parten, omdat een veelheid van facetten steeds integraal benaderd moet worden. De belangrijkste facetten in het ouderenbeleid betreffen naast een zorg- of voorzieningenbeleid (inclusief indicatiestelling, retributie, samenhang en dergelijke), het huisvestingsbeleid en het inkomens- of sociale zekerheidsbeleid. Zonder een adequaat huisvestingsbeleid voor ouderen is een substitutiebeleid zoals door het kabinet beoogd, onmogelijk (Brinkman bij start Stuurgroep Experimenten Volkshuiswesting, Staatscourant 7 maart 1988). Zulks lijkt ook te gelden voor een inkomensbeleid en een technologiebeleid (Klaassen-van den Berg Jeths en KraanJetten, 1985; Goudriaan, 1990). Er is in Nederland tot op heden nog nauwelijks integraal onderzoek gedaan naar de leefsituatie van en het voorzieningengebruik door ouderen. Dat onderzoek werd bovendien nimmer gekoppeld aan onderzoek bij instellingen naar de zorgintensiteit van de clienten en de daarmee gemoeide kosten. 


\section{Het gebruik van voorzieningen door ouderen in Nederland}

\subsection{Inleiding}

In dit hoofdstuk wordt het gebruik van voorzieningen door ouderen in Nederiand in beeld gebracht, daarmee een eerder gepubliceerd en uitgebreider overzicht (Huijsman, 1989b) samenvattend. Daarbij staat een tweetal thema's centraal. Het eerste thema behelst het op nationaal niveau in beeld brengen van het gebruik van voorzieningen door ouderen, waarbij de speciale interesse uitgaat naar het 'bereik' van een voorzlening (te berekenen als het percentage inwoners dat op jaarbasis gebruik maakt van de betreffende voorziening) en de kenmerken van de clienten. Ook wordt nagegaan met welke kosten de verschillende vormen van ouderenzorg gepaard gaan om zo kostprijzen voor zorgverlening te berekenen. Dit gebeurt voor elke basisvoorziening (gezinsverzorging, wijkverpleging, gecoordineerd ouderenwerk, bejaardenoorden en verpleeghuizen) apart in de paragrafen 4.2.1 tot en met 4.2.5. Het tweede thema brengt de bereikcijfers en kostprijzen tesamen om op die wijze te totale kosten van de ouderenzorg in Nederland te berekenen. Bij constant veronderstelde bereikcijfers voor de basisvoorzieningen is het vervolgens mogelijk voor de eeuwwisseling een raming te maken wan het aantal ouderen dat daarvan gebruik zal maken, uitgaande van de demografische prognoses die voor het jaar 2000 gepresenteerd zijn in hoofdstuk 2. Deze raming bij ongewijzigd beleid wordt gepresenteerd in paragraaf 4.3 en resulteert door de dubbele vergrijzing in een kostenstijging van circa $40 \%$ ten opzichte van de huidige uitgaven voor de genoemde basisvoorzieningen plus ziekenhuizen en huisartsen. Het substitutiebeleid beoogt deze bij ongewijzigd beleid te verwachten kostenontwikkelingen om te buigen, maar het merendeel van de onderzoeksresultaten tot nu toe wijst niet op grote mogelijkheden tot kostenreductie (Huijsman en de Klerk, 1989). In paragraaf 4.4 zal worden ingegaan op de mogelijkheden die het substitutiebeleid -bij de huidige kennis- heeft om de clientenstromen in de ouderenzorg en daarmee de kostenontwikkelingen te belinvloeden. De huidige kosten van de Nederlandse ouderenzorg worden gepresenteerd in paragraaf 4.5 . Het hoofdstuk wordt afgesloten met enkele kanttekeningen bij de beperkingen dio kleven aan de in gevolgde aanpak (paragraaf 4.6).

\subsection{Overzicht van gebruik per voorziening}

In deze paragraaf wordt een zeer beknopte schets gegeven van nationale gebruikscijfers met betrekking tot de belangrijkste voorzieningen voor ouderen. Aan de orde komen achtereenvolgens gezinsverzorging, wijkverpleging, gecoordineerd ouderenwerk (slechts summier bekend), bejaardenoorden en verpleeghuizen. De aanpak is daarbij steecis hetzelfde: per voorziening wordt ingegaan op (a) het gebruik door ouderen in termen van 'bereik', de kenmerken van gebruikers en de hulpintensiteit; (b) de personeelsformatie in de betreffende sector en (c) de totale kosten van de voorziening. In paragraaf 4.3. wordt het lavatste onderwerp toegespitst op ouderen. Beleidsmatige ontwikkelingen die hebben geleid tot de huidige opzet van de voorzieningen kwamen reeds in het vorige hoofdstuk aan bod. 


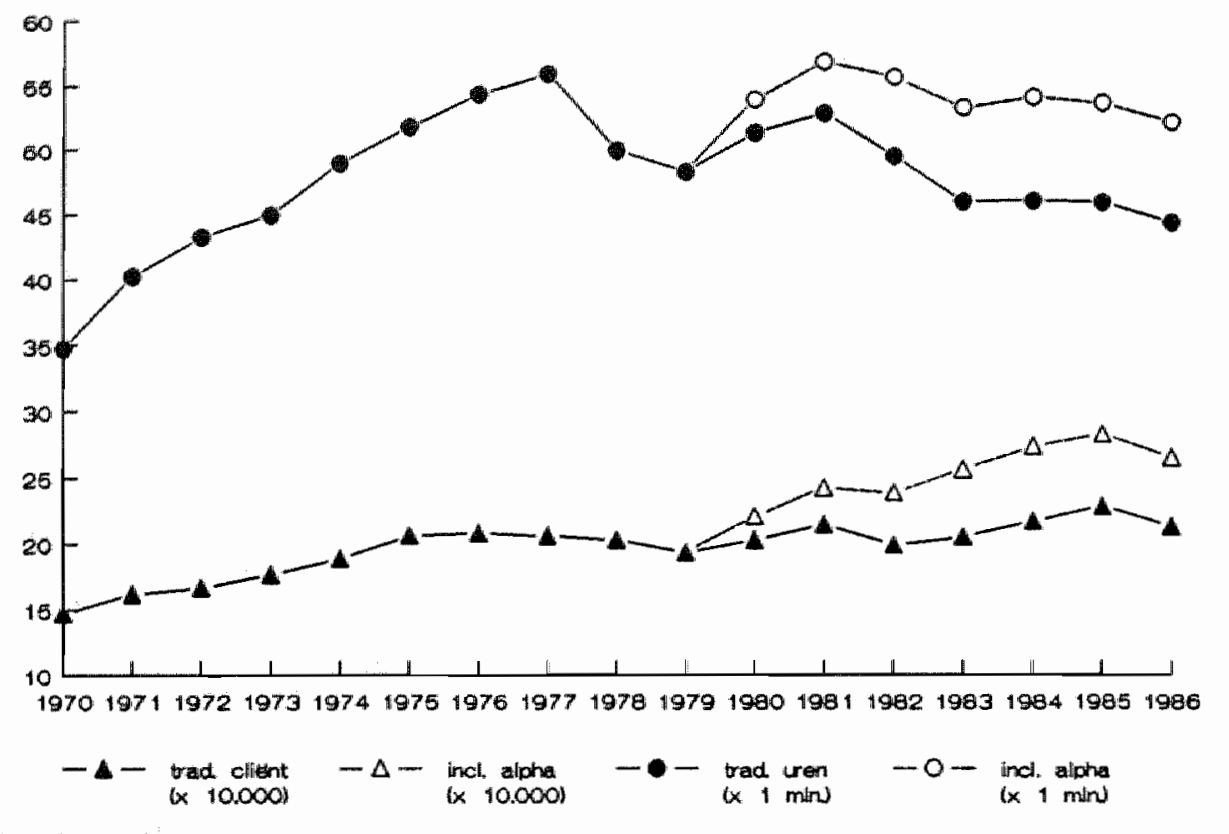

Figuur 4.1. Cliënten (x 10.000) en hulpuren ( $x 1$ mln.) gezinsverzorging in Nederland

\subsubsection{Gezinsverzorging in Nederland}

Figuur 4.1 laat de ontwikkeling van het totaal aantal clienten en het totaal aantal feitelijk verleende hulpuren zien (Huijsman en Dolmans, 1990). Sinds 1980 is naast de traditionele gezinsverzorging tevens de alpha-hulp in figuur 4.1 opgenomen. Tot 1978 komt een sterke uitbreiding van de gezinsverzorging naar voren. In de periode 1970-1977 nam het aantal clienten met circa $40 \%$ toe van 147.000 naar 206.000 personen en steeg het aantal hulpuren met $60 \%$ van bijna 35 naar 56 miljoen uur op jaarbasis. In 1978 trad echter een kentering op in deze historisch trend. Deze verandering heeft tot en met 1985 geen invloed gehad op het aantal cliénten dat op jaarbasis geholpen wordt, maar veel meer op de hulpomvang in uren, zodat het bereik (zie vervolg) niet is gedaald maar de hulpintensiteit per client wel.

Het beslag dat ouderen leggen op de capaciteit is in het verleden sterk toegenomen. In 1969 was $36 \%$ van de clienten 65 jaar of ouder. In 1986 was dit al ruim $61 \%$. Vanaf 1970 is hiervoor een bewust beleid gevoerd (Nota's Bejaardenbeleid 1970 en 1975). Ook in het aantal hulpuren ten behoeve van 65-plussers is een soortgelijke ontwikkeling te zien: $42,7 \%$ in 1974 en $59,6 \%$ in 1986. In figuur 4.2 is voor de periode 1974-1986 de verdeling van traditionele uren weergegeven voor de belangrijkste clieentcategorieenn. Daarbij is de indeling die in de sector zelf gehanteerd wordt, aangehouden zodat drie groepen onderscheiden worden, namelijk ouderen, chronisch zieken (in deze indeling per definitie jonger dan 65 jaar zodat bij de gezinsverzorging geen overlap met de categorie ouderen bestaat) en de overige groepen. Tevens is het verschil tussen (produktieve) hulpuren en de betaaluren van het personeel aangegeven. Dit verschil wordt veroorzaakt door de 'improduktieve' uren, die naast vakantie en verlof bestaan uit ziekteverzuim, cursus, werkoverleg e.d. De aldus gedefinieerde 'improduktiviteit' is in de loop der jaren geleidelijk gestegen van ruim $22 \%$ in 1974 tot bijna $34 \%$ in 1986. 


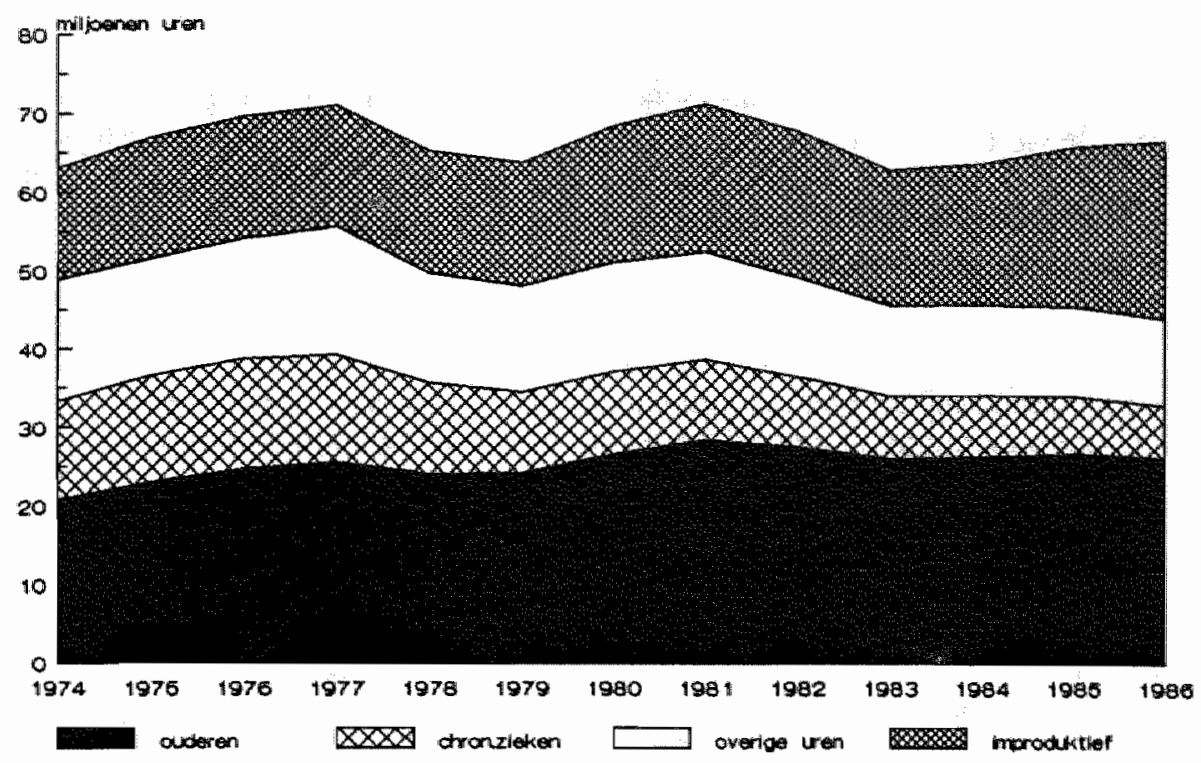

Figuur 4.2. Improduktieve uren en produktieve uren naar doelgroep bif de traditionele gezinsverzorging in Nederland (in miljoenen uren)

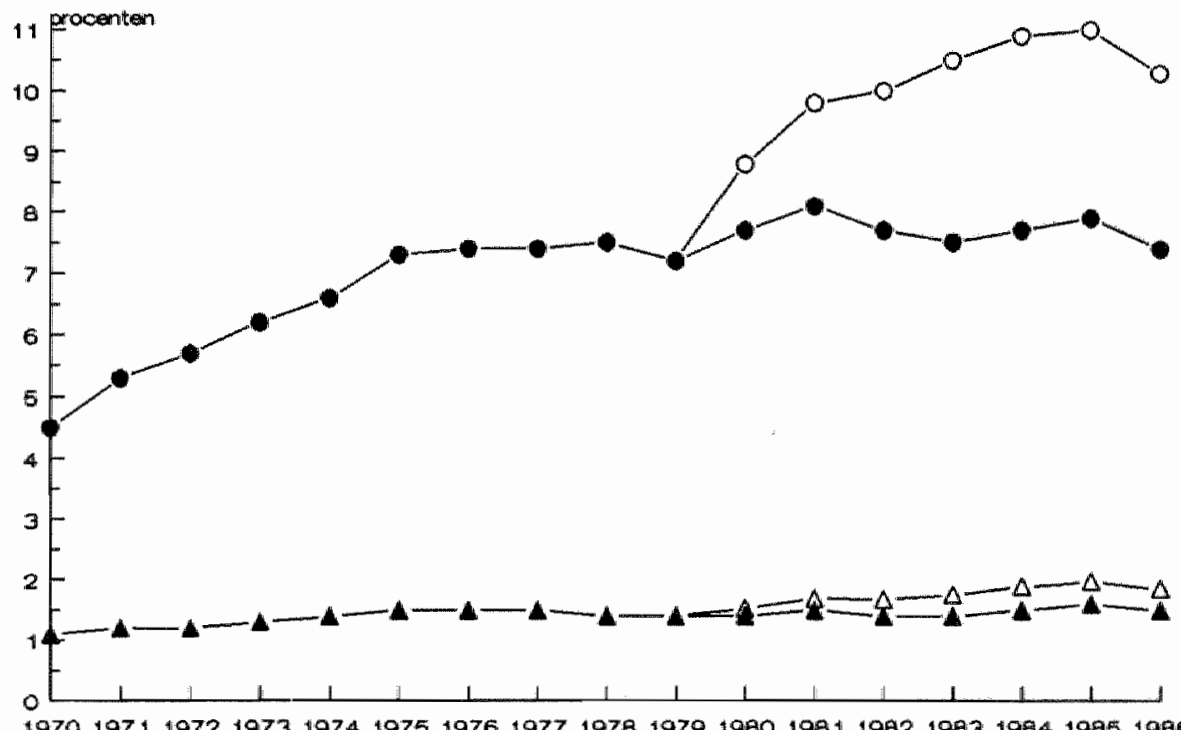

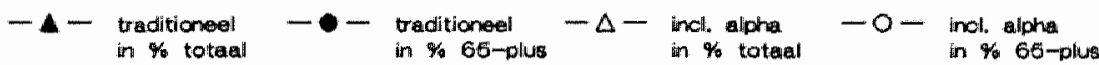

Figuur 4.3. Bereik van gezinsverzorging in Nederland in procenten van totale bevolking en van de bevolking van 65 jaar en ouder (sinds 1980 inclusief alpha-hulp) 
Met cen bereik ten opzichte van alle 65 -plussers in Nederland in 1986 van $7,4 \%$ bij traditionele hulp en $10,3 \%$ inclusief alpha-hulp is gezinsverzorging een belangrijize voorziening voor ouderen (2ie figuur 4.3). Gezinswerzorging wordt dan ook beschouwd als een essentile voorziening, waardoor ouderen langer zelfstandig kunnen blijven wonen (Nota Zorg voor Ouderen, 1986). Het aandeel van 65-plussers in de alpha-hulp was in 1986/1987 volgens een raming van het Ministerie van WVC circa $75 \%$ (Nota Zorg woor Ouderen, TK, 1985/1986). Medio 1988 ligt dat aandeel op circa $80 \%$, gebaseerd op een steekproef van $178(77 \%)$ instelingen (Centrale Raad Gezinswerzorging, 1988). Landelijk wordt voor traditionele hulp een constant bereik gesignaleerd, in procenten van zowel de totale als de oudere bevolking. Het bereik van alpha-hulp is gestegen.

De totale beschikbare formatie (zie tabel 4.1 ) is in de beschouwde periode nagenoeg constant. Vergelijking tussen het aantal arbeidsplaatsen en het aantal werkzame personen laat zien dat part-time arbeid in de gezinsverzorging veel voorkomt. Waar eerder werd geconstateerd dat de omvang van de hulpverlening is bljwen stijgen, blijkt hier dat de toenemende werklast bij een vijuwel constante personeelsformatie is opgevangen (FOZ 1989, TK, $1988 / 1989$, p. 105). Ondanks het feit dat een verschuiving in de verhouding tussen het uitwoerend en overig personeel (het aandeel van overig personeel daalde van $12,8 \%$ in 1980 tot $11,8 \%$ in 1985) heeft plaatsgevonden, leidt het een en ander tot toenemende wachtlijsten en minder hulpuren per client (FOGM 1988, TK, 1987/1988, p. 229).

De totale kosten van de sector gezinsverzorging zijn tot en met 1987 gestegen, met uitzondering van 1983 toen als gevolg van een overschrijding in 1982 een reductie van het uitgavenniveau met ruim 1\% heeft plaatsgevonden (FOGM 1987, TK, 1986/1987). De stijgingen in 1984 en 1985 zijn het gevolg van herbezetting van arbeidsduurverkorting en een wijziging in de Ziektewet en zijn derhalwe nominale ontwikkelingen, niet gerelateerd aan veranderingen in de hulpomvang. In 1984 is voorts het subsidiesysteem, gebaseerd op exploitatiebegrotingen, ingrijpend veranderd en overgegaan in een budgetteringssysteem voor alle kosten, waarbinnen aan de overheadkosten een maximum is gesteld (Rijkssubsidieregeling Gezinsverzorging, Stcrt. 1985, no. 29). Als gevolg van gewijzigd beleid zijn in 1986 de eigen bijdragen teruggelopen, doch door het toenemend aantal clienten is deze daling een jaar later geheel gecompenseerd en zet de stijgende tendens zich verder door. Het aandeel van retributies in de totale kosten blijf echter gering. In 1988 is het retributiesysteem opnieuw gewijzigd, waarbij een maximum uurtarief van $f 8,25$ geldt tot het zogenaamde individuele draagkrachtmaximum (op basis wan jaarinkomen van het gehele gezin) is bereikt. In 1988 werd door het Kabinet tevens het voorstel gedaan om de gesubsidieerde kortdurende hulpverlening (korter dan drie maanden) voor mensen jonger

Tabel 4.1. Personeel in de gezinsverzorging (omgerekend in f.t.e.)*

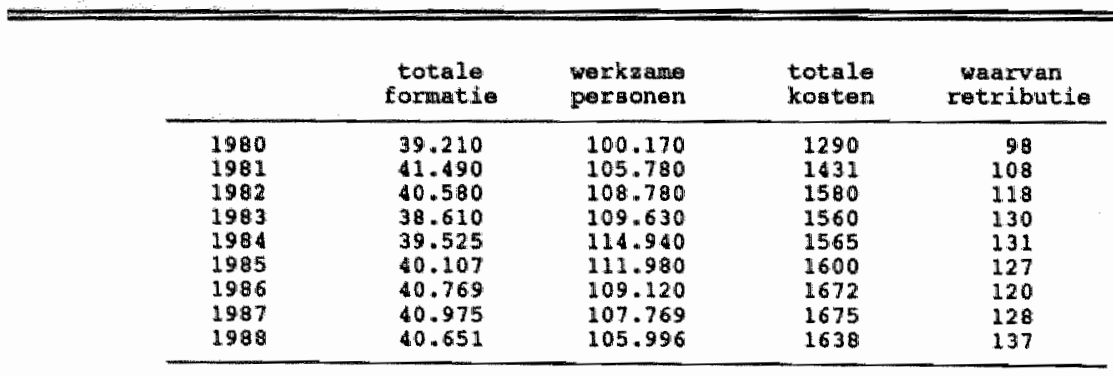

- Bron FOGM/FOz 
dan 65 jaar te beeindigen (uitgezonderd gehandicapten en terminale patienten). Dit plan is wegens heftig verzet gewijzigd in een bezuiniging van $3,5 \%$ die deels algemeen en deels selectlef is opgelegd. Deze bezuinigingen blijken opgevangen te zjn uit risicovoorzieningen (FOZ 1989, TK, 1988/1989) en zouden niet hebben geleld tot veranderingen in het wolume vain de hulpverlening.

Het aandeel van ouderen in de totale kosten van de sector gezinsverzorging laat zich als wolgt benaderen. In de hulpverlening, gemeten in uren, is het aandeel van de 65-plussers bij de traditionele hulp ongeveer $60 \%$ en bij de alpha-hulpverlening circa $80 \%$. Gemiddeld betekent dit dat het aandeel van ouderen in de totale hulpvertening, waarvan $85 \%$ traditionele hulp betreft, bij benadering op $65 \%$ ligt. In financiele termen betekent dat het beslag dat ouderen leggen op de gezinswerzorging in 1988 ruim 1 miljard gulden bedraagt (1.065 miljoen, gebaseard op $65 \%$ ten behoeve van 65 -plus).

\subsubsection{Wijkwerpleging in Nederland}

Het zorgaanbod van het kruiswerk wordt in acht zorgterreinen of zorgfuncties ingedeeld (zie paragraaf 3.5.2). Hier concentreren wij ons volledig op de voor ouderen meest belangrijke zorgfunctie, de wijkverpleging. Het wijkadministratiesysteem (WAS) is de belangrijkste gegevensbron en wordt door de wijkwerpleegkundigen en ziekenverzorgenden gebruikt als administratief hulpmiddel bij het vastleggen van het zorgverleningsproces (individu-gerichte zorgcontacten). Helaas gaan de beschikbare gegevens uit het WAS niet verder terug dan tot 1984, omdat zij voor die datum niet betrouwbaar worden geacht. In het WAS wordt de tijdsduur per contact niet geregistreerd; tot op heden zijn er ook geen bronnen beschikbarar met voldoende representatieve gegevens op dit punt. Wel zijn in enige provincies op basis van onder andere interviews, tijdschattingen met betrekking tot de contactduur gemaakt, die in gemiddeld 30 minuten per thuiscontact resulteren. Per gewerkt uur wordt \pm 40 minuten aan contacten besteed inclusief tijd aan voorbereiding, reizen en administratie. Daarbuiten worden voorts andere taken vervuld (zoals consultatie-bureau, cursusaanbod en scholing). Gegevens uit de Peilstations Kruiswerk lijken op een toename van de gemiddelde contactduur te wijzen, hetgeen samenhangt met een toenemend aantal zorgintensieve patienten.

De belangrijkste tendens in recente ontwikkelingen is een door de Nationale Kruiswereniging (NK, 1988) schrikbarend genoemde teruggang van preventie en cen enorme toename van curatieve zorg. Een andere conclusie is dat de verleende zorg steeds intensiever wordt en steeds meer verschuift naar het bewerkelijke verpleegdoel lichamelijke bygienische verzorging (zie tabellen 4.2 en 4.3 ). Uit de vergelijking tussen de ontwikkelingen tussen enerzijds bet aantal contacten per 100 inwoners (stabiel of enigszins dalend) en anderzijds het gemid-

Tabel 4.2. Wijkverpleging in Nederland naar leefijd, 1985-1988."

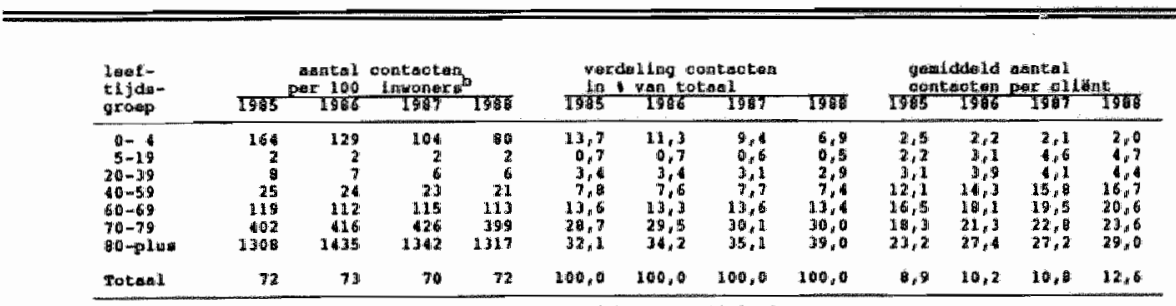

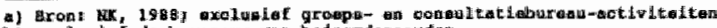

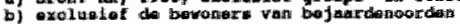


Tabel 4.3. Verplegudoelen bij individuele contacten met de wikverpleging"

\begin{tabular}{|c|c|c|c|c|c|}
\hline verpleogdoelen (In van & 1984 & 1985 & 1986 & 1987 & $19 \mathrm{gs}$ \\
\hline 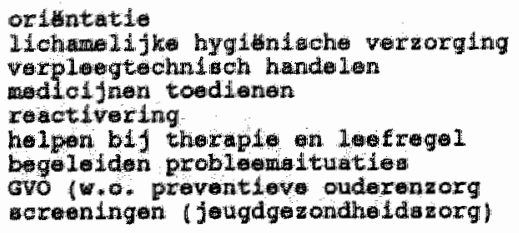 & $\begin{array}{r}1,2 \\
33,0 \\
16,0 \\
16,0 \\
1,0 \\
1,8 \\
5,11 \\
20,1 \\
0,8\end{array}$ & $\begin{array}{r}1,3 \\
36,4 \\
16,9 \\
16,6 \\
1,1 \\
4,4 \\
5,1 \\
15,4 \\
1,0\end{array}$ & $\begin{array}{r}1,6 \\
39,5 \\
18,6 \\
17,3 \\
1,4 \\
4,5 \\
4,7 \\
11,2 \\
0,8\end{array}$ & $\begin{array}{r}1,4 \\
39,9 \\
24,3 \\
15,0 \\
1,6 \\
5,7 \\
4,7 \\
7,1 \\
0,5\end{array}$ & $\begin{array}{r}1,4 \\
40,5 \\
23,6 \\
1,9 \\
1,6 \\
5,6 \\
4,4 \\
7,4 \\
0,6\end{array}$ \\
\hline Totad & 100,0 & 100,0 & 100.0 & 100,0 & 100,0 \\
\hline
\end{tabular}

- Bront M, 1986 en 1986; excl. groeps-on conaltetibureau-activiteiten

deld aantal contacten per client (sterk toenemend), blijkt dat het bereik van de wijkverpleging geleidelijk daalt.

De intensievere zorg blijkt in de eerste plaats uit de toename van het gemiddeld aantal contacten per client van 8,9 in 1985 tot 12,6 in 1988 . Dit komt neer op een stijging van ruim $40 \%$ in twee jaar tijd. Het karakter van de wijkverpleging verschuift daarbij steeds verder naar de bewerkelijke verpleegdoelen lichamelijke hygienische verzorging en verpleegtechnische handelingen. Werd in 1984 (FOGM 1986, TK, 1985/1986) nog 33\% van de contacten hieraan besteed (bijvoorbeeld wassen, hulp bij aan- en uitkleden of in en uit bed gaan), in 1988 was dat $40,5 \%$. Ook de verpleegtechnische handelingen nemen toe van $16 \%$ in 1984 tot $23,6 \%$ in 1988 . Zoals eerder gezegd, gaan de ontwikkelingen in de curatieve zorg ten koste van preventieve werkzaamheden. Illustratief hiervoor is de afname in de contactdoelen 'begeleiding' en GVO. Ook is er minder tijd voor contacten met derden, zoals personeel van het zieken- of verpleeghuis, die geraadpleegd kunnen worden ter bevordering van dienstwerlening aan de client.

In het kruiswerk waren in 19703.368 verpleegkundigen (inclusief toen nog slechts 14 ziekenverzorgenden) werkzaam voor de verplegimg en verzorging van hulpbehoevenden, voor preventieve huisbezoeken (bij zelfstaivug wonende ouderen), voorlichting en consultatiebureaus. In 1979 is dit aantal 4.468 (Boot en Knapen, 1988). Tegenwoordig worden met name de in het kadler van het AWBZ-basispakket toegestane formatieplaatsen geregistreerd (zle tabel 4.4). De toename van het direct verzorgend personeel weerspiegelt de in de afgelopen jaren toegekende volumegroei. De verhouding tussen direct verzorgend en indirect personeel ligt nu op $82,9 \%$ direct en $17,1 \%$ indirect (NK, 1988). Toch blijft er vooralsnog een discrepantie met de in 1983 in de Nota Eerstelijnszorg (TK, 1983/1984) geformuleerde streefnormen voor de verschillende personeelscategorieen, die in 1990 gerealiseerd zouden moeten zijn. De oude normering (1 wijkverpleegkundige op 3450 inwoners) zou

Tabel 4.4. Direct personeel bij kruisverenigingen (toegestane formatie)

\begin{tabular}{|c|c|c|c|c|c|c|c|}
\hline & 1983 & 1984 & 1985 & 1986 & 1987 & 1989 & noth \\
\hline 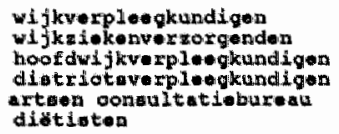 & $\begin{array}{r}4641 \\
1134 \\
471 \\
236 \\
233 \\
115\end{array}$ & $\begin{array}{r}774 \\
1202 \\
499 \\
238 \\
242 \\
139\end{array}$ & $\begin{array}{r}1933 \\
1253 \\
519 \\
240 \\
251 \\
163\end{array}$ & $\begin{array}{r}5009 \\
1270 \\
526 \\
241 \\
260 \\
167\end{array}$ & $\begin{array}{r}5119 \\
1278 \\
520 \\
242 \\
262 \\
169\end{array}$ & $\begin{array}{r}5172 \\
1321 \\
528 \\
248 \\
266 \\
171\end{array}$ & $\begin{array}{r}6396 \\
2232 \\
941 \\
319 \\
36.3 \\
319\end{array}$ \\
\hline
\end{tabular}


yervangen worden door een norm van 1 wijkverpleegkundige op 2500 inwoners, 1 wijkziekenwerzorgende op 6000 a 7500 inwoners (of 1 wijkziekenverzorgende op 3 wijkverpleegkundigen) en 1 dietiste op 50.000 inwoners. De norm voor hoofdwijkverpleegkundigen ten opzichte van het totaal van wijkziekenverzorgenden en wijkverpleegkundigen ligt op 1:9. In de toekomst zullen de normen komen te vervallen. Overigens zijn naast de genoemde formatie nog eens circa 200 naar fulltime omgerekende verpleegkundigen en ziekenvertorgenden werkzaam in de aanvullende thuiszorg, die (vooralsnog?) niet in het basispakket is opgenomen (NK, 1988).

Onder de kosten van bet kruiswerk worden gerekend de kosten van alle instellingen van plaatselijk, provinciaal en landelijk kruiswerk. De kosten wan de kruisorganisaties zijn slechts summier bekend. Bovendien wordt aanvankelijk slechts een onderscheid gemaakt tussen de personele en overige kosten (tabel 4.5). In de periode 1980-1988 bedraagt de jaarlijkse toename in de kosten van het kruiswerk gemiddeld ongeveer $5 \%$ en ligt darmee aanzienlijk lager dan vo6r 1980, toen percentages van 10 of meer gerealiseerd werden (FOZ 1989, TK, 1988/1989). De personele kosten beslaan circa 77,5\% van de totale kosten (bron: CBS, gegevens 1986). Kruiswerk in Beeld (NK, 1986) gaf een (onderbouwde) raming voor de benodigde gelden tot 1990 en kwam op een (resle) volumegroei van $4 \%$ per jaar. Enerzijds wordt de volumegroeĩ noodzakelijk geachi door de toenemende (dubbele) vergrijzing en anderzijds door de voorgenomen versterking van de eerstelijnszorg. De overheid heeft uit bezuinigingsoverwegingen deze groei tot twee keer toe gehalveerd en beoogde een vollumegroei (totale kostenstijging minus loon-en prijsstijgingen) van $2 \%$ in 1987 en $1 \%$ in de jaren 1988 en 1989 (FOZ 1989, TK, 1988/1989). Door de kortingen in verband met de Herstrukturering landelijke organisaties zullen de middelen per saldo slechts met 4 miljoen toenemen, doch de verwachting is dat dit niet ten koste van de hulpwerlening zal plaats vinden. Inclusief vaccinatiekosten (circa 36 miljoen in 1987) komt de totale raming van de kosten van het kruiswerk uit op 841 miljoen in $1987,864 \mathrm{~min}$ in 1988 en $868 \mathrm{mln}$ in 1989.

Het basispakket kruiswerk, waaronder circa driekwart van de taken van het kruiswerk vallen, wordt sinds 1 januari 1980 gefinancierd via de Algemene Wet Bijzondere Ziektekosten (AWBZ) en lidmaatschapsgelden. In de periode 1980-1985 vond de bekostiging van het basispakket plaats via het systeem van begrotingsfinanciering. In 1986 werden de materiele kosten gebudgetteerd en sinds januari 1987 tevens de personele kosten. Slechts de som wan deze twee deelbudgetten wordt vastgesteld, zodat daarbinnen volledige substitutievrijheid aanwezig is. Het budgetteringssysteem is steeds gebaseerd geweest op de historische kostenontwikkelingen, maar in augustus 1987 is tussen de Nationale Kruisvereniging, de financiers en het Centraal Orgaan Tarieven Gezondheidszorg (COTG) overeenstemming

Tabel 4.5. Kosten en financiering van het kruiswerk (in mln. guldens)*

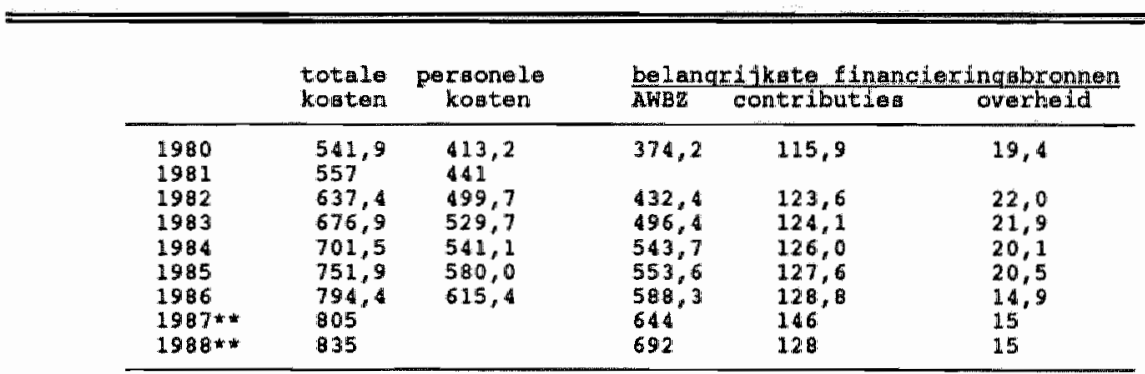

* Bron: CBS en EOGM/POZ

* Bron: FOZ 1990; contributiea incl. overige opbrengaten 


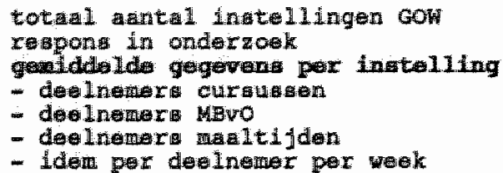

bereikt over de ontwikkeling van een integraal budgetteringssysteem dat per 1 januari 1990 effectief moet zijn. Vanaf deze datum is eveneens een wijziging van financieringsstromen voorzien. Voorheen werden de provinciale en nationale kruisorganisaties rechtstreeks gefinancierd; per 1990 wordt het totale macrobudget direct doorgesluisd naar de (dan nog 60) erkende kruisorganisaties, die vervolgens middelen ter beschikking (kunnen) stellen aan provinciale en landelijke organisaties.

Om een raming te maken van het aandeel van de ouderen in de kosten dient een benadering gemaakt te worden. Uitgaande van een aandeel van $75 \%$ in het totaal aantal contacten (zie tabel 4.2) bedragen de kosten voor ouderenzorg vanwege het kruiswerk in 1988 circa 626 miljoen gulden (inclusief aandeel van provinciale en landelijke organisaties, bureaukosten en dergelijke).

\subsubsection{Gecoördineerd ouderenwerk in Nederland}

Landelijke gegevens over het gecoordineerd ouderenwerk zijn zeer schaars en weinig gedetailleerd. Van het Centraal Bureau voor de Statistiek zijn de volgende gegevens over 1985 afkomstig (voorlopige cijfers).

Gegevens over activiteiten naar frequentie, aard en omvang ontbreken te enen malen, laat staan dat over de bezoekers en hun kenmerken iets bekend is. Dit ontbreken van landelijke data bracht ons tot de noodzaak van eigen onderzoek in Maastricht (zie hoofdstuk 8).

Tabel 4.7. Personele en financiëlle gegevens 1986-1987

\begin{tabular}{|c|c|c|c|c|}
\hline & \multicolumn{2}{|c|}{$\frac{\text { gemiddeld per ingtel1. }}{19861}$} & \multicolumn{2}{|c|}{ per formatleplaate 1987} \\
\hline 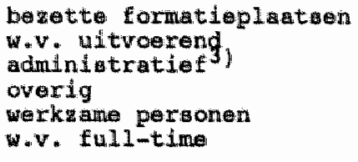 & $\begin{array}{l}4,4 \\
3,0 \\
1,1 \\
0,3 \\
6,5 \\
2,6\end{array}$ & $\begin{array}{l}4,3 \\
3,1 \\
1,0 \\
0,2 \\
7,0 \\
2,6\end{array}$ & $\begin{array}{l}1,0 \\
0,7 \\
0,2 \\
0,1 \\
1,6 \\
0,6\end{array}$ & $\begin{array}{l}1,4 \\
1,0 \\
0,3 \\
0,1 \\
2,3 \\
0,0\end{array}$ \\
\hline $\begin{array}{l}\text { totale lasten (f } 1000,- \text { ) } \\
\text { w. loonkosten } \\
\text { activiteiten } \\
\text { totale baten }(f \text { 1000 } \\
\text { w. vigen bijdragen }\end{array}$ & $\begin{array}{r}540 \\
238 \\
104 \\
538 \\
70\end{array}$ & $\begin{array}{r}548 \\
245 \\
110 \\
545 \\
80\end{array}$ & $\begin{array}{r}127,4 \\
57,0 \\
25,6 \\
126,9 \\
18,6\end{array}$ & $\begin{array}{r}176,8 \\
79,0 \\
35,5 \\
176,2 \\
25,8\end{array}$ \\
\hline
\end{tabular}

1) gebareerd op 250 imetellingen

2 voorlopig, 0.b.v. 147 instelingen

$3)$ incl. huis. personeel

4 excl. saldi 
Tot nu toe ongepubliceerde gegevens (met dank aan het CBS) over een deel van de instellingen (circa $80 \%$ in 1986 en $50 \%$ in 1987), laten de volgende personeels- en kostengegevens per instelling en formatieplaats zien (tabel 4.7).

Om een totaalbeeld van Nederland te krijgen gaan we uit van het aantal instellingen in 1985 (325) en de gemiddelde cijfes per instelling in 1986. In het gecoordineerd ouderenwerk zijn dan (bij benadering) 2100 personen werkzaam, die circa 1430 formatieplatsen bezetten, waarvan $70 \%$ uitvoerend. Circa $40 \%$ werkt full-time. Deze benadering blijkt echter te grof te zijn als hij toegepast zou worden op de kosten van het GOW. Er resulteert dan een kostenplaatje voor de sector van in totaal 175,5 miljoen gulden. Uit financiele overzichten van de overheid blijkt dat de totale kosten echter circa 100 miljoen bedragen (zie tabel 4.8). Dit betekent derhalve dat de eerder gepresenteerde CBS-cijfers gebaseerd zijn op de grotere instellingen in Nederland en dat kleinere instellingen met minder financiele middelen geen respons gaven.

De totale lasten van de GOW-sector bestaan voor $44 \%$ uit loonkosten en woor $21 \%$ uit materißle activiteitenkosten (exclusief koepelorganisaties). De overige lasten betreffen huur $(16 \%)$, interest en afschrijvingen $(3,5 \%)$ en overige, niet gespecificeerde lasten $(15,5 \%)$. Van de totale lasten wordt $13 \%$ gedekt door eigen bijdragen van ouderen zelf. Verrassend is dat bij gezinsverzorging het aandeel van de retributies in de totale kosten een vergelijkbare omwang heeft. De lasten voor de rijksoverheid bedragen ruim $80 \mathrm{~min}$, dat wil zeggen $80 \%$ a $81 \%$ van de totale lasten.

\subsubsection{Bejaardenoorden in Nederland}

Het Besluit Gegevensverstrekking Bejaardenoorden (Stb. 1969, no. 505) bevat de verplichting van houders van bejaardenoorden om bepaalde, nader omschreven gegevens jaarlijks aan het Centraal Bureau voor de Statistiek te verstrekken naar de toestand op 31 december. De deelname is dan ook, na enige jaren van startproblemen, vrijwel volledig. In tabel 4.9 zijn algemene gegevens over het aantal bejaardenoorden en de verzorgingscapaciteil opgenomen voor de periode 1965-1985 (Huijsman, 1988b). Tengevolge van de wijziging van de Wet op de Bejaardenoorden met ingang van 1 januari 1985 zijn de kloosterbejaardenoorden in dat jaar voor het eerst meegenomen. Het totaal aantal instellingen kwam daarmee op 1575 (31 december 1985). Ondanks de afname van het aantal oorden is het aantal verzorgden sterk toegenomen, zodat gesproken kan worden van schaalvergroting. Het gemiddeld aantal bewoners per oord is vrijwel verdubbeld van 48 tot bijna 90 personen. In bejaardenoorden worden drie soorten plaatsen gehanteerd, namelijk voor verzorgden, zieken en verpleegden. De laatste worden sinds 1971 de zogenalamde 1-oktober bedden (Stb. 1971, no. 505) genoemd en betreffen voornamelijk niet-erkende verpleegafdelingen of dependances van verpleeghuizen in bejaardenoorden. Het bestaan van deze bedden, waarvan er nog 300 resteren (FOZ 1989, TK, 1988/1989), is niet zonder discussie

Tabel 4.8. Totale kosten (in mln.) wan het GOW in Nederland (1981-1987)

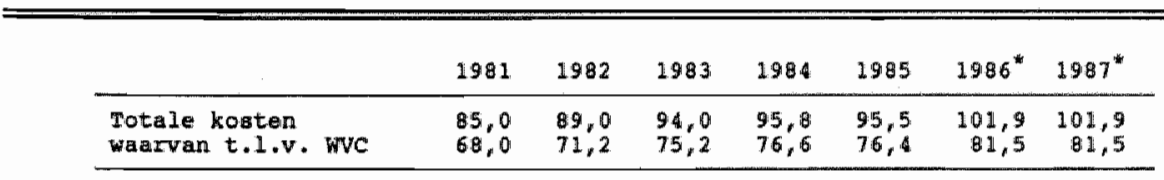

* 1 aming 


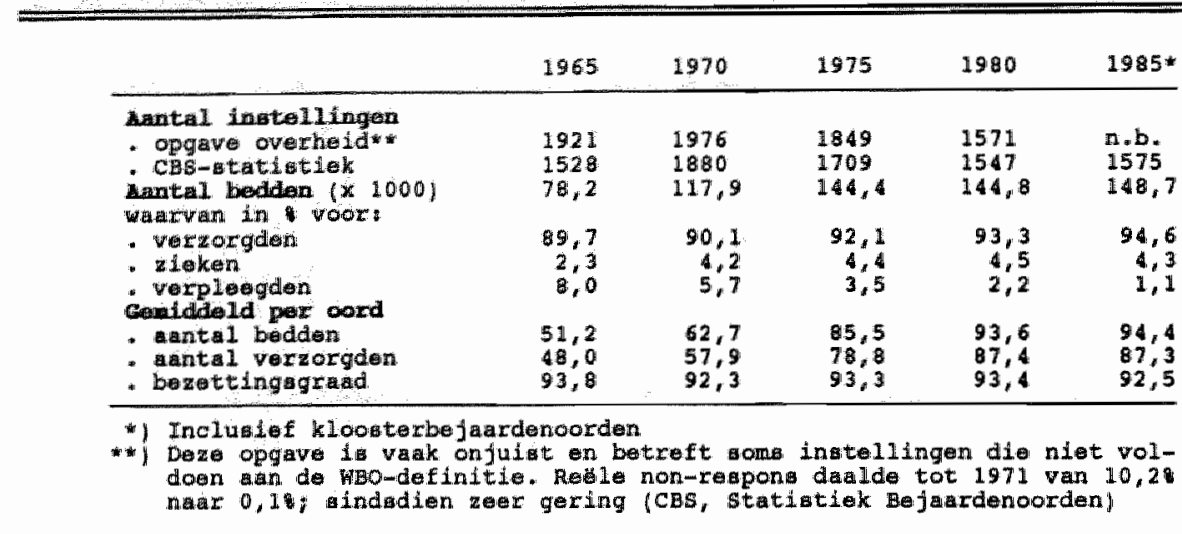

gebleven. Feit is echter dat de betekenis ervan zowel in absolute als in relatieve omvang sterk is werminderd. Eind jaren zestig ging het om circa $8 \%$ van het totaal aantal plaatsen; thans om nog geen $1 \%$. Het aantal bedden voor verzorgden en zieken (de 'ziekenboeg") is sterk toegenomen. Het lijkt minder juist de ziekenbedden, die in tegenstelling tot de bedden op de verpleegafdeling vooral bedoeld zijn voor tijdelijke zieke eigen bewoners, mee te tellen bij het totale bestand aan bedden. Gebleken is echter dat in een aantal bejeardenoorden de ziekenbedden -wegens plaatsgebrek- in gebruik zijn als verzorgingsplaatsen. Het totaal aantal plaatsen in bejaardenoorden is van 1965 tot 1976 bijna verdubbeld tot ruim 146.000 en is sindsdien geleidelijk afgenomen tot 143.700 in 1984 . In 1985 werden er circa 148.700 bedden geteld, doch in dat jaar werden voor het eerst ook de kloosterbejaardenoorden meegeteld. Indien de verschillen in capaciteit tussen 1984 en 1985 geheel worden toegerekend aan deze uitbreiding van de statistiek, dan zou het bij benadering gaan om 90 kloosterbejaardenoorden met circa 5000 plaatsen (gemiddeld 60 per instelling). Tenslotte dient te worden aangetekend, dat het aantal bedden in afzonderlijke woningen hierin niet is begrepen. Het aantal bedden in deze woningen is niet bekend. Van de totale capaciteit waren ultimo 1985 bijna 138.000 bedden $(92,5 \%)$ bezet.

Voor de bespreking van het aantal verzorgden in bejaardenoorden en hun kenmerken, wordt gebruik gemaakt wan de gegevens in tabel 4.10 . Het aantal ouderen dat in bejaardenoorden verzorgd wordt, is gestegen van ruim 73.000 in 1965 tot 136.200 in 1985 en 133.500 in 1988 (FOZ 1990, TK, 1989/1990). Bekijken wij de sexeverdeling dan is de verhouding tussen vrouwen en mannen toegenomen van 2:1 in 1965 tot 3:1 in 1988. In procenten van de bevolking is het aantal opgenomen mannen gestegen van $5 \%$ in 1965 tot $6,6 \%$ in de beginjaren "70 om vervolgens te dalen tot $4,3 \%$ eind 1988 . Bij de vrouwen is sprake van een gelijksoortige ontwikkeling, zij het op een hoger niveau, namelijk van $8 \%$ in 1965 via $10,9 \%$ in de beginjaren zeventig tot $8,9 \%$ eind 1988 . Deze cijfers betreffen de totale bevolking vanaf 65 jaar. In de figuren 4.4 en 4.5 wordt de leeftijdsverdeling naar gestacht gepresenteerd in procenten van de desbetreffende bevolkingsgroepen. Voor de leeftijdsgroepen tot 90 jaar komt het beeld overeen met het hiervoor geschetste totaalbeeld. De oudste bewoners vanaf 90 jaar vertonen echter een vrijwel continue toename. In 1984 is $40 \%$ van alle mannen, respectievelijk $47 \%$ van alle vrouwen ouder dan 90 jaar opgenomen in bejaardenoorden. De leeftijd is dan ook sinds 1965 sterk toegenomen. De mediane leeftijd is thans ruim $831 / 2$ jaar ( 80 jaar in 1965). Voor veel mensen is het bejaardenoord hierdoor de laatste woonomgeving. Voor $78 \%$ van het totaal aantal personen dat jaarlijks 
wordt uitgeschreven (circa 23.500), is overlijden hiervan de oorzak. Circa $87 \%$ van het jaarliks aantal opgenomen mensen is afkomstig uit de eigen omgeving.

Tot slat van deze schets van bewonerskenmerken wordt een enkele kanttekening geplaatsi bij de validiteit van bejaardenoordbewoners. Jaarlijks wordt in de enquête van het CBS aan de instellingen gevraagd de bewoners per 31 december in te delen naar vier validiteitscategorieen (zie tabel 4.10): (1) praktisch voortdurend bedlegerig; (2) niet bedlegerig, doch wel volledig hulpbehoevend; (3) niet bedlegerig, doch gedeeltelijk hulpbehoevend en (4) niet lichamelijk hulpbehoevend. Het aantal bewoners dat niet lichamelijk hulpbehoevend is en alleen huishoudelijke hulp behoeft, is sterk afgenomen van $69 \%$ in 1965 tot $39 \%$ in 1988 . Het percentage bewoners dat volledig hulpbehoevend en bedlegerig is, bleef sinds 1972 vrij stabiel, namelijk 2,6\%. De laatste jaren wordt deze groep echter iets groter; zij vormde in $19883 \%$ van het totaal (FOZ 1990, TK, 1989/1990). Overigens is dit percentage nog steeds lager dan in de beginjaren van de statistiek (meer dan $4,5 \%$ ). De bewoners die het minst of het meest valide zijn, worden in de discussie over substitutie aangeduid als groepen, waarvoor een andere voorziening of combinatie wan voorzieningen relevant zou kunnen zijn (Remmen, 1985; Ouderenbeleid, TK, 1988/1989).

Tabel 4.10. Kenmerken van bewoners bejaardenoorden (per 31 december)

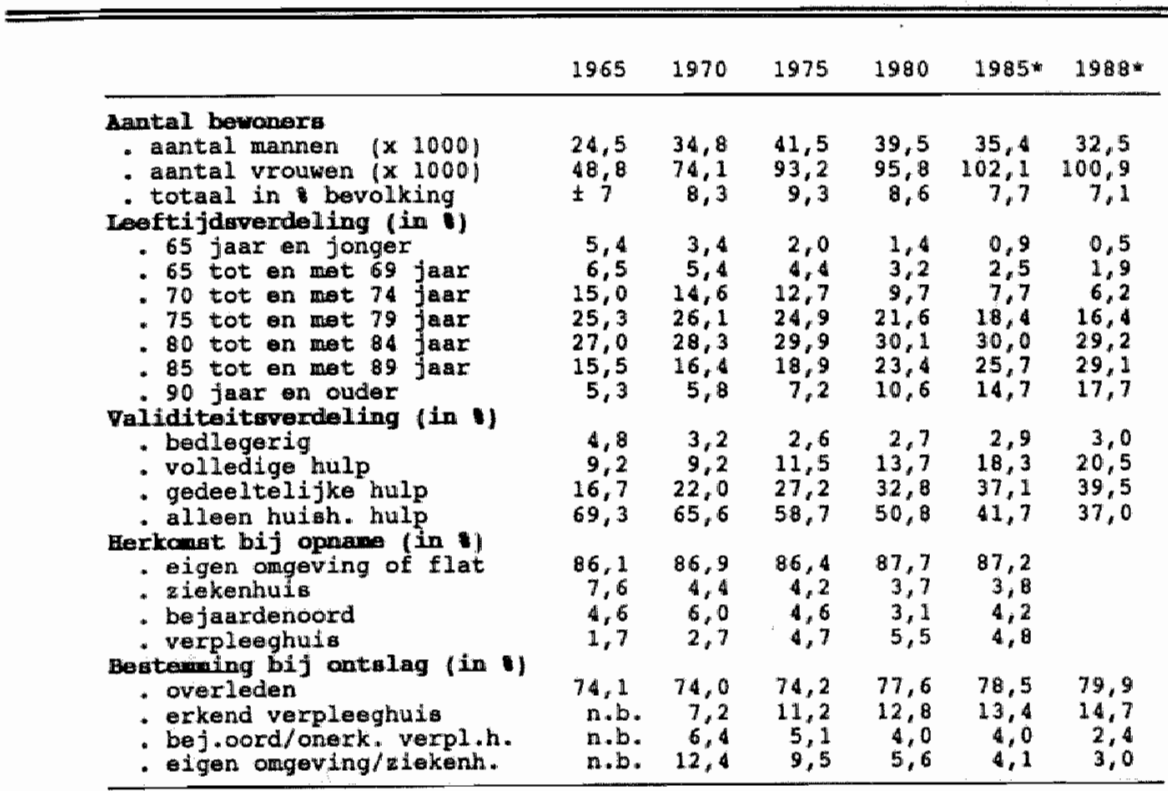

- Inclusiaf klooaterbejarardenoorden 


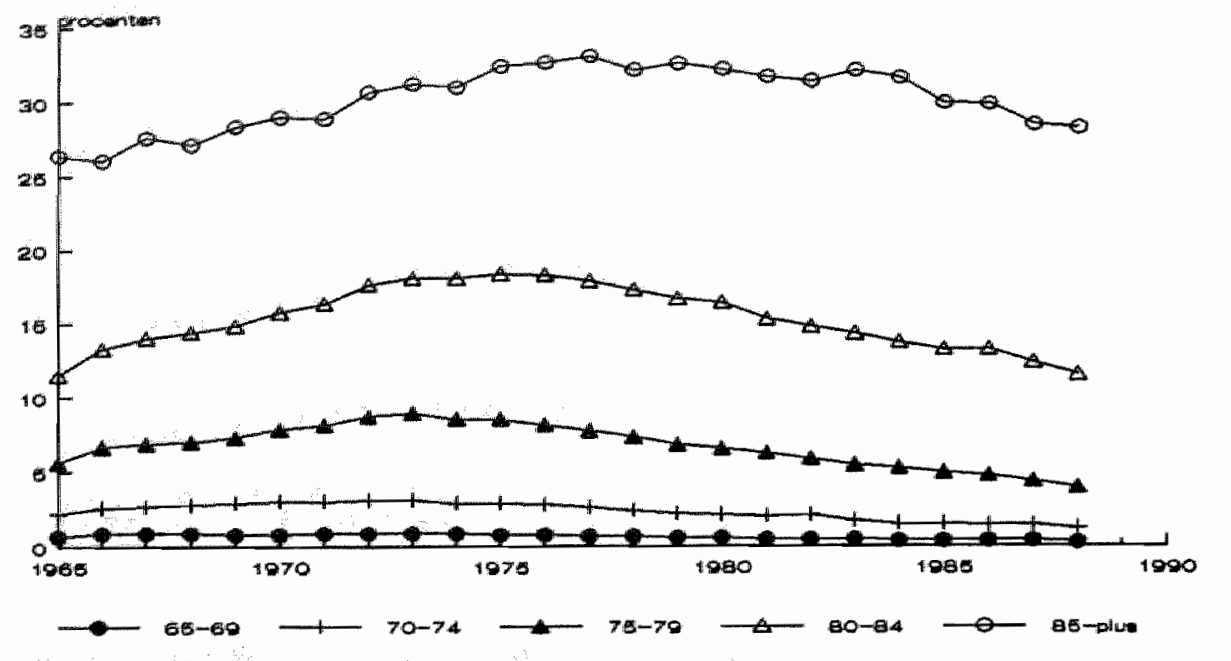

Figuur 4.4. Mannen in bejaardenoorden, in procenten van bevolking maar leeftijd

De invloed van de afnemende validiteit van de bewoners op deze personeelsformatie blijkt zeer belangrijk te zijn (Huijsman, 1988b). Voor deze analyse is uit de verdeling naar mate van validiteit een index geconstrueerd, die vervolgens met behulp van lineaire regressie mede gebruikt werd om de gemiddelde personeelsinzet per oord te verklaren. Uit deze analyse blijkt dat de invloed van de validiteitsindex toeneemt naarmate het gaat om functies die directer betrokken zijn bij de verzorging en verpleging van de bewoners. De grootste coefficient werd gevonden voor het verplegend personeel, gevolgd door verzorgend personeel. De conclusie dat de afnemende validiteit in de tijd gezien is samengegaan met een toenemende personeelsinzet is niet verrassend. Door middel van de statistische analyse is echter wel aangetoond dat de toenemend mate van invaliditeit inderdaad heeft doorgewerkt naar de toekenning van extra middelen aan de bejaardenoorden (zoals ingebed in formatiemodellen als van Twijnstra en Gudde, 1978).

Het aantal arbeidsplaatsen in de bejaardenoorden is sterk toegenomen (zie tabel 4.11). Betrof het in 1965 nog slechts 22.500 arbeidsplaatsen, in 1984 gaat het om 70.700 plaatsen. Omgerekend naar volledige banen is de ontwikkeling iets bescheidener, omdat het aantal deellijdbanen sterk toenam. Overigens moet hierbij opgemerkt worden dat het CBS vanaf 1974 alle deeltijdbanen als halve full-time banen beschouwt. Met ingang van 1985 verstrekken de instellingen zelf de juiste gegevens. In de totale personeelsformatie is het aandeel van verzorgende en verplegende functies relatief sterk toegenomen. De personeelssterkte per 100 verzorgden is gestegen van 28,3 in 1965 tot 38,7 in 1984 (steeds in voltijdse equivalenten). Hierboven werd gelllustreerd, dat de toenemende invaliditeit van de bewoners hierbij een belangrijke rol heeft gespeeld. Het tempo van de stijging is echter sinds 1980 afgezwakt, doch het personeel blijft ook na 1984 geleidelijk toenemen; het totale verzorgende en verplegende personeel telt eind 198628.700 voltijdse arbeidsplaatsen, waarvan bij benadering 21.000 formatieplaatsen voor de eerste categorie (CBS, 1989).

In 1969 werden voor het eerst ook financiele gegevens gepresenteerd. De eerste jaren nà 1969 moeten ze met enige terughoudendheid beschouwd worden, omdat aanvankelijk lang niet alle oorden dit soort gegevens wilden verstrekken. Sinds 1974 verstrekt ruim $90 \%$ van de oorden een exploitatie-overzicht (95\% van capaciteit). Met name de kleinere oorden blijven dus in gebreke. 


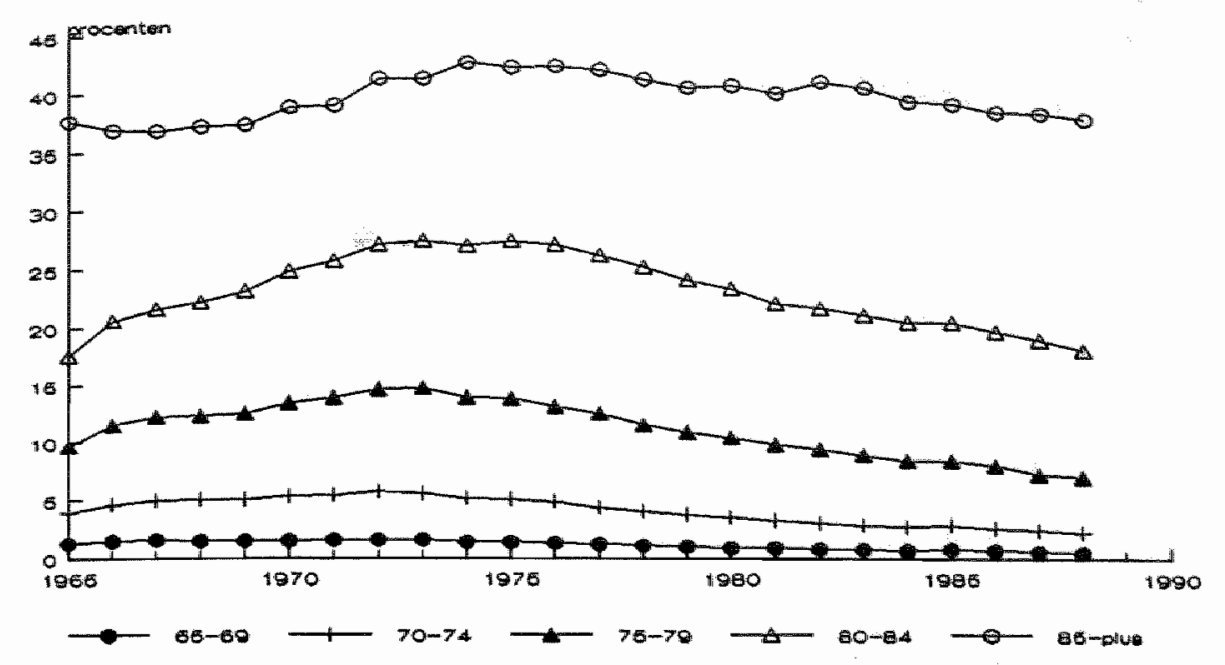

Figuur 4.5. Vrouwen in bejaardenoorden, in procenten van bevolking naar leeftijd

Ingevolge de verdelingssytematiek van de nieuwe Wet op de Bejaardenoorden wordt sinds 1985 jaarlijks voor de provincies en grote gemeenten een budget vastgesteld op basis van door het Parlement beschikbaar gestelde middelen. De provincies en grote gemeenten verdelen vervolgens dit budget over de instellingen in hun werkgebied. Voorts worden eigen bijdragen geheven bij de bewoners, die in 1987 in totaal ongeveer 1,8 miljard gulden bedroegen (FOZ 1989, TK, 1988/1989), ongeveer $41 \%$ van de totale kosten. Omdat de verslaglegging door het CBS sinds 1985 is gewijzigd en omdat sinds dat jaar tevens de kloosterbejaardenoorden zijn toegevoegd, wordt het kostenoverzicht beperkt tot de periode 1970-1984.

Tabel 4.11. Personeel in bejaardenoorden (in personen en formatie), 1965-1984

\begin{tabular}{|c|c|c|c|c|c|}
\hline & 1965 & 1970 & 1975 & 1900 & $1985^{1)}$ \\
\hline 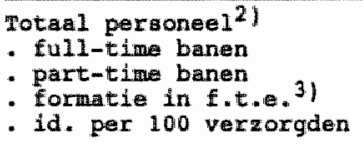 & $\begin{array}{r}10.460 \\
4.015 \\
20.737 \\
28,3\end{array}$ & $\begin{array}{r}27.381 \\
9.887 \\
32.781 \\
30,1\end{array}$ & $\begin{array}{r}35.772 \\
19.010 \\
45.277 \\
33,6\end{array}$ & $\begin{array}{r}35.977 \\
26.850 \\
49.402 \\
36.5\end{array}$ & $\begin{array}{r}32.399 \\
41.263 \\
52.649 \\
38,3\end{array}$ \\
\hline $\begin{array}{l}\text { Verzorgend personee }{ }^{2}, 41 \\
\text { - full-time banen } \\
\text { - part-time banen } \\
\left.\text { - formatio in } f . t .3^{3}\right)\end{array}$ & $\begin{array}{r}5.648 \\
484 \\
5.922\end{array}$ & $\begin{array}{r}9.554 \\
1.386 \\
10.311\end{array}$ & $\begin{array}{r}13.858 \\
3.655 \\
15.686\end{array}$ & $\begin{array}{r}14.755 \\
6.046 \\
17.770\end{array}$ & $\begin{array}{l}11.608 \\
13.281 \\
20.752\end{array}$ \\
\hline $\begin{array}{l}\left.\text { Verplegend peraonee } 1^{2}, 5\right) \\
\text { : full-time banen } \\
\text { - part-time banen } \\
\text {. formatie in } f . t . e .31\end{array}$ & $\begin{array}{r}1.857 \\
317 \\
2.037\end{array}$ & $\begin{array}{l}2.644 \\
1.197 \\
3.298\end{array}$ & $\begin{array}{l}3.525 \\
2.733 \\
4.892\end{array}$ & $\begin{array}{l}4.379 \\
4.544 \\
6.651\end{array}$ & $\begin{array}{l}4.193 \\
7.143 \\
7.728\end{array}$ \\
\hline $\begin{array}{l}\text { 1) Incluaief kloosterbeja } \\
\text { 2) Persomen met diploma } \\
\text { 3) Full Time Equivalenten } \\
\text { 4) Eejaardenverzorgenden } \\
\text { 5) Verpleegkundigen en zi }\end{array}$ & $\begin{array}{l}\text { perione } \\
\text { i fifgeror } \\
\text { en -helpe } \\
\text { ekenverzc }\end{array}$ & $\begin{array}{l}\text { in ople } \\
\text { op hele } \\
\text { en, ver } \\
\text { enden }\end{array}$ & $\begin{array}{l}\text { thg teza } \\
\text { tallen } \\
\text { gingsas }\end{array}$ & nten & \\
\hline
\end{tabular}




\begin{tabular}{|c|c|c|c|c|}
\hline & 1970 & 1975 & 1980 & 1984 \\
\hline 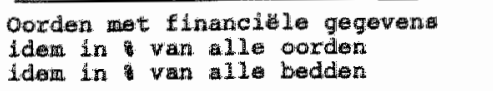 & $\begin{array}{l}1292 \\
63,2 \\
77,2\end{array}$ & $\begin{array}{l}25,66 \\
91,6 \\
94,4\end{array}$ & $\begin{array}{l}1412 \\
91,3 \\
95,0\end{array}$ & $\begin{array}{l}1325 \\
90,0 \\
90,0\end{array}$ \\
\hline 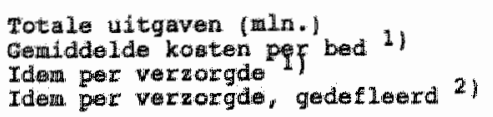 & $\begin{array}{r}590,0 \\
6350 \\
6870 \\
6870\end{array}$ & $\begin{array}{r}2064,8 \\
1440 \\
15480 \\
14200\end{array}$ & $\begin{array}{r}3271,1 \\
21410 \\
22970 \\
15520\end{array}$ & $\begin{array}{r}3957,1 \\
27540 \\
29570 \\
17500\end{array}$ \\
\hline 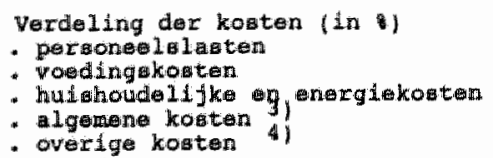 & $\begin{array}{r}47,2 \\
15,0 \\
7,1 \\
4,8 \\
25,9\end{array}$ & $\begin{array}{r}53,7 \\
10,2 \\
6,9 \\
4,2 \\
25,0\end{array}$ & $\begin{array}{r}56,3 \\
8,7 \\
8,6 \\
21,6 \\
21,8\end{array}$ & $\begin{array}{r}54,0 \\
8,1 \\
9,3 \\
4,5 \\
24,1\end{array}$ \\
\hline
\end{tabular}

1) fierond op tientallen quiden

2) o.b.w. prijoindex national frikomen (1970=100; statiotibch zakboek, cos:

3) inclubief verzorgingmiddelen

4) watronder huse, onderhoud, fachrifuingen e.d.

De totale kosten zijn in de periode 1969-1984 bijna vertienvoudigd. Tot 1980 zijn de personeelslasten relatief sterk toegenomen. In de jaren tachtig zijn deze kosten in zowel de volume- als de prijssfeer (lonen) enigszins teruggedrongen. De gemiddelde kosten per plaats per jaar zijn toegenomen met een factor 5 , dat wil zeggen met gemiddeld $11 \%$ per jaar, tot $f 27.540$,- in 1984. De gemiddelde kosten per verzorgde bedragen dan $f 29.570,-$. Na 1984 zijn de kosten blijwen stijgen met gemiddeld ruim $1 \%$ per jaar (FOZ 1989, TK, 1988/1989). Tenslotte wordt een gemiddelde kostprijs van $f$ 84,- per verzorgingsdag gemeld (FOZ 1990, TK, 1989/1990). De totale kosten liggen in 1985 op 4,25 miljard gulden en zijn sindsdien geleidelijk gestegen tot 4,5 miljard in 1989 (FOZ 1990, TK, 1989/1990). Naast de opneming van kloosterbejaardenoorden in 1985 speelt bij deze kostenstijging ook een andere toerekeningsmethodiek een rol en mogen de provincies en grote steden, die sinds 1985 als gevolg van decentralisatie de rol van financiers dragen, maximaal $5 \%$ van het budget van de in een bepaald jaar toegekende specifieke uitkering reserveren. In 1986 was dat omstreeks 69 miljoen (FOZ 1989, TK, 1988/1989). Deze reservering komt pas een jaar later tot uitdrukking in het kostenoverzicht. Daarnaast hebben de zogegheten bejaardenoorden met een bijzondere functie (bijvoorbeeld voor blinden en slechtzlenden of voor culturele minderheden) nog een budget van zo'n 200 miljoen ten behoeve van circa 6300 bedden (in 1988).

\subsubsection{Verpleeghuizen in Nederland}

Bij een licht dalend aantal verpleeghuizen ( $\operatorname{van} 327$ in 1981 tot 321 in 1987) en een stijgend aantal bedden ( $\operatorname{van} 47.400$ in 1981 tot 50.000 in 1987), vindt een verschuiving plaats naar gecombineerde verpleeghuizen (van 87 in 1981 naar 123 in 1987). Het aantal somatisch zieken is door verschuiving slechts in geringere mate afgenomen van 28.123 in 1981 naar 27.265 in 1987 , een daling met $3,2 \%$ in zes jaar. Van alle bedden is thans ongeveer $54,6 \%$ ten behoeve van somatisch zieken. In 1975 was dat nog 67,4\% (Heroverweging Bejaardenbeleid, TK, 1981/1982). In vergelijking met de normcapaciteit is er nog een, zij het steeds kleiner wordend, overschot aan somatische bedden en een immer voortdurend tekort aan psycho-geriatrische bedden. Het totaal aantal patienten bedraagt thans 50.000 personen die 17,8 miljoen verpleegdagen gebruiken. 
In tabel 4.13 zijn enkele gegevens opgenomen met betrekking tot de patienten in alle verpleeghuizen (somatisch, psycho-geriatrisch en gecombineerd). De leeftijdswerdeling van alle patiënten tezamen laat een steeds verdergaande verschuiving naar (zeer bejaarde) ouderen zien. De leeftijd is eind 1987 gemiddeld 80 jaar, met variatie naar geslacht (76 jaar bij mannen) en verpleegworm ( 82 jaar bij psycho-geriatrie). Geconstateerd wordt dat de sexe-verschillen bij de leeftijd voor somatisch zieken steeds verder uiteen lopen: in 1982 was de leeftijd woor vrouwen nog twee jaar hoger dan die voor mannen; in 1987 bijna 4 jaar (SIVIS Jaarboek 1987). De gemiddelde verbliffsduur vertoont een enigsains grillig verloop in de afgelopen jaren. Na een aanwankelijk dalende tendens in de begin jaren tachtig, lijkt de gemiddelde verpleegduur thans weer op te lopen. Dit laat onverlet dat de gemiddelde verpleegtijd voor psycho-geriatrische patienten twee a drie mal zo lang is als voor somatisch zieken. De gemiddelde verpleegduur verschilt niet alleen naar patientencategorie, maar tevens naar geslacht. Bij ontslagen patienten (exclusief overledenen) bestaat in de somatiek geen sexeverschil, in de psycho-geriatrie daarentegen is de verpleegduur voor vrouwen bijna 1,5 maal langer.

Van de in 1987 opgenomen personen is rum de helft afkomstig uit het ziekenhuis, $5 \%$ uit dagbehandeling, $11 \%$ uit het verzorgingstehuis en $24 \%$ uit de thuissituatie (zonder dagbehandeling). De reden van ontslag betreft bij ruim $57 \%$ overlijden (psycho-geriatrie: $79 \%$ ), ruim $7 \%$ gaat naar het ziekenhuis, $21 \%$ naar huis (slechts $5,6 \%$ bij psycho-geriatrie), ruim $8 \%$ naar een verzorgingstehuis en nog eens $37 \%$ naar de dagbehandeling. De stromen tussen verpleeghuizen zouden nog aanzienlijk groter zijn dan uit de cijfers ( $3 \%$ a $4 \%$ ) blijkt, omdat er ook nog andere routes bestaan om van het ene in het andere verpleeghuis te geraken. Geschat wordt dat uiteindelijk meer dan $10 \%$ van de psycho-geriatrische patienten in twree of meer verpleeghuizen verblijven gedurende hun totale verpleegtijd (SIVIS Jaarboek 1987).

Tot slot van deze schets van het gebruik van verpleeghuizen is in figuur 4.6 het bereik van deze voorziening, waarbij het aantal patienten per leeftijdsgroep is uitgedrukt in percentages ten opzichte wan het inwonertal in Nederland. Voor de leeftijdscategorieen tot 90 jaar laat de figuur een vrijwel constant bereik zien dat oploopt met de leeftijd, varierend van $0,4 \%$ en $1 \%$ in de twee jongste groepen tot 75 jaar, respectievelijk $5 \%$ voor patienten van $80 \mathrm{t} / \mathrm{m}$ 84 jaar en $9 \%$ voor $85-89$ jarigen. De bereikcijfers voor de oudste leeftijdsgroepen zijn bet hoogst, doch vertonen een dalende tendens: in de leeftijdsgroep $90 \mathrm{t} / \mathrm{m}$ 94 jaar was in 1982 $14 \%$ opgenomen in verpleeghuizen en in 1987 nog maar $12,6 \%$. Bij de oudste patienten trad van 1981 tot 1983 een stijging op van $14,2 \%$ tot $18,1 \%$, waarna een daling optrad tot $16,2 \%$ in 1987.

Vanuit het verpleeghuis wordt ook de mogelijkheid tot dagbehandeling aangeboden, waarmee beoogd wordt mensen die wel een verpleeghuisindicatie hebben, maar die de avond-, nacht- en weekendverzorging nog gewoon thuis kunnen krijgen, te reactiveren en te resocialiseren teneinde opneming in het verpleeghuis uit te stellen of te woorkomen. Ook voor dagbehandeling gelden normen, te weten 0,72 promille van de bevolking van 65 jaar en ouder plus 0,02 plaats per 1000 van de totale bevolking voor somatisch zieken en 0,75 promille van de 65-plussers voor psychogeriatrische dagbehandeling. Dagbehandeling is eveneens een AWBZ-verstrekking (Stb. 1977, no. 544). Per 1-1-1988 waren er in Nederland 2788 erkende plaatsen. In vergelijking tot andere voorzieningen is het aandeel van de mannen in de dagbehandeling vrij groot (ongeveer $46 \%$ ), met name bij somatische dagbehandeling ( $52 \%$ in 1987) De normatieve ruimte volgens de Wet Zuekenhuis Voorzieningen (Stb. 1979, no. 466) is de laatste jaren vrijwel opgevuld. Mede daarom hebben de verpleeghuizen, die in principe allemaal de mogelijkheid tot dagbehandeling hebben, gebruik gemaakt van de mogelijkheid om bedden om te wisselen voor dagbehandelingsplaatsen. Voor deze worm van substitutie binnen werpleeghuizen geldt de regel dat voor een bed twee dagbehandelingsplaatsen kunnen worden geschapen (FOZ 1989, TK, 1988/1989). Voorts 


\begin{tabular}{|c|c|c|c|c|c|c|c|}
\hline & 1981 & 1982 & 1993 & 1984 & 1985 & 1986 & 1987 \\
\hline 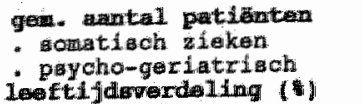 & $\begin{array}{l}46060 \\
27123 \\
18937\end{array}$ & $\begin{array}{l}46859 \\
27264 \\
19615\end{array}$ & $\begin{array}{l}48154 \\
27964 \\
20190\end{array}$ & $\begin{array}{l}47686 \\
26793 \\
20893\end{array}$ & $\begin{array}{l}48229 \\
26686 \\
21543\end{array}$ & $\begin{array}{l}48683 \\
26525 \\
22158\end{array}$ & $\begin{array}{l}49974 \\
26434 \\
22593\end{array}$ \\
\hline 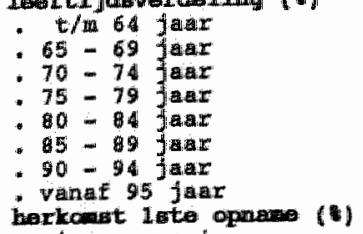 & $\begin{array}{r}10,13 \\
6,10 \\
11,40 \\
18,87 \\
22,65 \\
10,61 \\
9,08 \\
2,12\end{array}$ & $\begin{array}{r}10,88 \\
5,76 \\
10,92 \\
18,46 \\
23,27 \\
19,00 \\
9,33 \\
2,31\end{array}$ & $\begin{array}{r}10,37 \\
5,61 \\
10,73 \\
18,70 \\
23,45 \\
19,34 \\
9,33 \\
2,48\end{array}$ & $\begin{array}{r}9,90 \\
5,39 \\
10,46 \\
18,61 \\
23,79 \\
19,82 \\
9,62 \\
2,42\end{array}$ & $\begin{array}{r}9,61 \\
5,40 \\
10,00 \\
18,54 \\
23,92 \\
20,30 \\
9,69 \\
2,54\end{array}$ & $\begin{array}{r}9,14 \\
5,33 \\
10,05 \\
18,54 \\
24,03 \\
20,38 \\
9,86 \\
2,67\end{array}$ & $\begin{array}{r}8,80 \\
5,24 \\
9,56 \\
17,93 \\
24,31 \\
21,12 \\
10,19 \\
2,85\end{array}$ \\
\hline 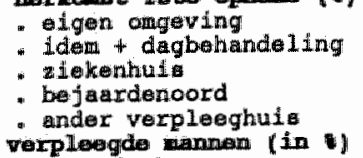 & $\begin{array}{r}30,5 \\
2,0 \\
56,6 \\
6,0 \\
4,1\end{array}$ & $\begin{array}{r}30,2 \\
2,3 \\
56,1 \\
7,1 \\
4,3\end{array}$ & $\begin{array}{r}29,6 \\
2,2 \\
55,9 \\
8,4 \\
3,9\end{array}$ & $\begin{array}{r}26,6 \\
4,2 \\
55,3 \\
9,9 \\
3,8\end{array}$ & $\begin{array}{r}25,9 \\
4,8 \\
56,5 \\
9,7 \\
2,9\end{array}$ & $\begin{array}{r}24,2 \\
5,2 \\
56,9 \\
10,9 \\
2,7\end{array}$ & $\begin{array}{r}24,0 \\
5,3 \\
55,4 \\
11,2 \\
3,8\end{array}$ \\
\hline - gomatioch & $\begin{array}{l}35,9 \\
28,8\end{array}$ & $\begin{array}{l}35,5 \\
28,2\end{array}$ & $\begin{array}{l}35,1 \\
27,5\end{array}$ & $\begin{array}{l}34,1 \\
27,1\end{array}$ & $\begin{array}{l}34,2 \\
26,8\end{array}$ & $\begin{array}{l}33,7 \\
26,6\end{array}$ & $\begin{array}{l}33,1 \\
26,1\end{array}$ \\
\hline
\end{tabular}

* Bronnen: SIVIS en WII

wordt bij de planning uitgegaan van een plafond, gelijk aan 6\% van de te plannen klinische bedden. In 1987 hadden 199 instellingen (62\%) dagbehandeling in hun pakket en bedroeg de totale 'produktie' 644.000 verpleegdagen, waarvan $45 \%$ psycho-geriatrisch. Gemiddeld komt een patient ongeveer 2 maal per week naar de dagbehandeling.

Van de in 1987 in behandeling genomen patienten (bijna 5500) is ruim 2\% afkomstig uit het ziekenhuis, bijna $8 \%$ uit een andere vorm van dagbehandeling, $17 \%$ uit het bejaardenoord (bij psycho-geriatrie 21\%) en $68 \%$ uit de thuissituatie (zonder dagbehandeling). De reden van ontslag uit de dagbehandeling (5900 ontslagen in 1987) is bij $4 \%$ het overlijden, bijna $15 \%$ gaat naar het ziekenhuis, $37 \%$ naar huis (psycho-geriatrie: $20 \%$ ), 15\% naar een bejaardenoord en nog eens $5 \%$ naar een andere vorm van dagbehandeling. Naar het verpleeghuis gaat tenslotte $1 / 4$ van de patienten (bij psycho-geriatrische dagbehandeling zelfs $43 \%$ ), zodat dagbehandeling als een 'tussenstation' voor uiteindelijke opname fungeert.

Het aantal personeelsleden (zie tabel 4.14) leat in de loop der jaren een stijgende tendens zien, die bovendien sneller verloopt dan de toename in capaciteit. Er treedt met andere woorden personeelsintensivering op, die echter enigszins is vertekend, omdat ook het personeel ten behoeve van dagbehandeling in de personeelsgegevens per 100 bedden is meegenomen. Voorts wordt niet gecorrigeerd voor de effecten van arbeidstijdverkorting (ATV) en wijzigingen in het leerlingenplan. Door de ATV-effecten zou nauwelijks sprake zijn van een toename in mensuren per bed, zodat de intensivering feitelijk niet plaats gevonden heeft (NZI, 1988). Men dient derhalve de gegevens met de nodige voorzichtigheid te bezien, ook al omdat de hulpbehoevendheid van patienten in verpleeghuizen stijgt (FOZ 1989, TK, 1988/1989). De budgetteringssystematiek heeft het mogelijk gemaakt de toenemende zorgbehoefte binnen het totale, stabiel gebleven, budget op te vangen door verschuivingen tussen personele en materiele kosten (FOZ 1989, p. 86).

Uit de statistieken van het NZI blijkt dat zich grote verschillen tussen de drie soorten verpleeghuizen voordoen: sinds 1981 is het aantal arbeidsplaatsen (full-time equivalenten) in gecombineerde verpleeghuizen met $50 \%$ (sic!) toegenomen, in psycho-geriatrische verpleeghuizen met $15 \%$ en in somatische verpleeghuizen is een daling met $16 \%$ opgetreden door wijzigingen in de erkenningen van somatisch naar gecombineerd. Opvallend is de toename van deeltijdarbeid in verpleeghuizen van $30 \%$ in 1980 nar $51 \%$ in 1987 en de toenemende 


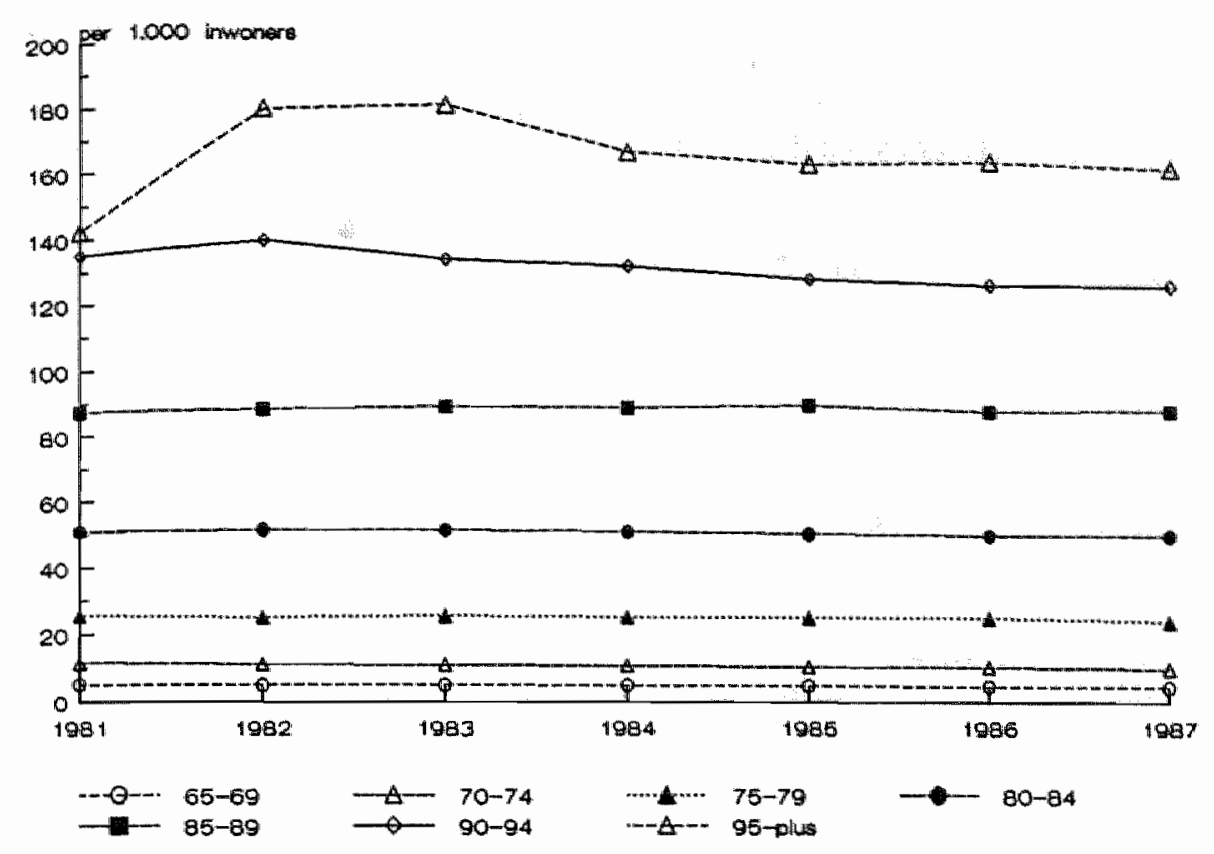

\section{Figuur 4.6. Patiënten in verpleeghuizen naar leeftijd per 1000 inwoners}

professionalisering: van het totale verpleegkundige personeel was in $198042 \%$ gediplomeerd en in $198758 \%$ (bron: CBS). In de verpleeghuizen bestaat circa $64 \%$ van de personeelssterkte uit verpleegkundig, verzorgend en opvoedkundig personeel. Hiervan zijn de ziekenverzorgendlen in de meerderheid $(80 \%)$.

De totale kosten zijn gestegen van $3 \mathrm{mrd}$. in 1981 tot $3,76 \mathrm{mrd}$. in 1987 en bestaan voor $69 \%$ uit personeelskosten, welk aandeel geleidelijk toegenomen is. De totale kosten per bed bedragen in 1987 ruim 74.000 gulden. De totale kosten stegen in de periode 1981-1987 met gemiddeld 3,7\% per jaar, de gemiddelde kosten per bed met 2,8\% en per verpleegdag met $2,5 \%$. De laatste tijd wordt de jaarlijkse kostenstijging bovendien steeds geringer.

Tabel 4.14. Personeel in verpleeghuizen naar functie*

\begin{tabular}{|c|c|c|c|c|c|c|c|}
\hline & 1981 & 1982 & 1983 & 1984 & 1985 & 1986 & 1987 \\
\hline $\begin{array}{l}\text { totale formatie } \\
\text { antal personeelsleden }\end{array}$ & $\begin{array}{l}47665 \\
59588\end{array}$ & $\begin{array}{l}48165 \\
61335\end{array}$ & $\begin{array}{l}50039 \\
62756\end{array}$ & $\begin{array}{l}52956 \\
65004\end{array}$ & $\begin{array}{l}52817 \\
68521\end{array}$ & $\begin{array}{l}54511 \\
71972\end{array}$ & $\begin{array}{l}55703 \\
75354\end{array}$ \\
\hline 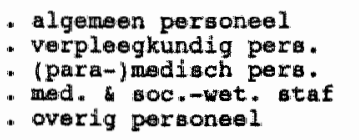 & $\begin{array}{r}12240 \\
29907 \\
3651 \\
507 \\
1350\end{array}$ & $\begin{array}{r}12.03 \\
31131 \\
3614 \\
479 \\
1329\end{array}$ & $\begin{array}{r}12454 \\
31894 \\
3772 \\
506 \\
1413\end{array}$ & $\begin{array}{r}12478 \\
32425 \\
3927 \\
506 \\
1619\end{array}$ & $\begin{array}{r}12900 \\
33324 \\
4043 \\
544 \\
2006\end{array}$ & $\begin{array}{r}13276 \\
34299 \\
4164 \\
619 \\
2163\end{array}$ & $\begin{array}{r}13192 \\
35077 \\
4310 \\
638 \\
2486\end{array}$ \\
\hline 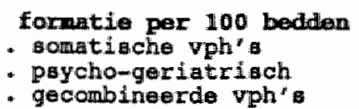 & $\begin{array}{r}106,5 \\
97,5 \\
105,7\end{array}$ & $\begin{array}{r}106,8 \\
96,8 \\
107,4\end{array}$ & $\begin{array}{l}108,8 \\
101,9 \\
108,2\end{array}$ & $\begin{array}{l}108,5 \\
103,6 \\
109,5\end{array}$ & $\begin{array}{l}110,7 \\
106,2 \\
111,3\end{array}$ & $\begin{array}{l}112,7 \\
107,5 \\
113,9\end{array}$ & $\begin{array}{l}113,7 \\
108,9 \\
116,0\end{array}$ \\
\hline
\end{tabular}

- Bron: NZI, uitgedrukt in full-time equivalenten, niet gecorrigeerd voor ATV 
De batten bestaan voor $98 \%$ uit verpleeg- en verzorgingsgelden en worden vergoed door de AWBZ De totale AWBZ-financiering is in de beschouwde periode sterk toegenomen tot thans ongeveer 3,8 miljard gulden. In 1968 , toen de verpleeghwizen net in opkomst waren, was dat nog slechts 196 miljoen gulden (ZFR, 1988). De overige baten bestaan woor ruim tweederde uit de inkomsten uit dagbehandeling en poliklinische behandelingen. De AWBZfinanciering met betrekking tot dagbehandeling is eveneens sterk toegenomen van 3,7 miljoen in 1977, toen de dagbehandeling als verstrekking erkend werd, tot 73,7 miljoen gulden in 1986. Voor de dagbehandeling bestaat een vast AWBZ-dagtarief van $f 122$ De totale kosten van de sector verpleeghuizen beslaan 3,8 miljard gulden. Bij een aandeel van 65 -plus van $91,2 \%$ in 1987 , worden de kosten van verpleeghuiszorg voor ouderen geraamd op 3,4 miljard, waarvan circa 67 miljoen voor dagbehandeling.

\subsection{Gebruik van voorzieningen door ouderen: samenvatting en ramingen}

In thet voorgaande is van de voorzieningen die voor ouderen als zeer belangrijk zijn aangemerkt een overzicht gegeven van het gebruik naar leeftijdsgroep. Deze getallen werden vervolgens uitgedrukt in procenten van de bevolking om het bereik van de betreffende voorziening te kwantificeren. In de inleiding werd dit een van de thema's van dit hoofdstuk genoemd. Bij wijze van samenvatting wordt in tabel 4.16 het leeftijdsspecifieke bereik van de in dit hoofdstuk besproken voorzieningen in beeld gebracht voor 1987, het meest recente jaar waarvoor bij het merendeel van de voorzieningen de benodigde gegevens beschikbaar zijn. Deze presentatie gaat echter verder dan een samenvatting van de bevindingen uit het voorgaande, omdat ook voor andere voorzieningen, zoals algemeen maatschappelijk werk (AMW), huisartsen of fysiotherapeuten, bekend is hoe het leeftijdsspecifieke gebruik bij ouderen verloopt. Per leeftijdscategorie is aangegeven hoeveel procent van de Nederlandse ouderen gebruik maakt van de opgenomen voorzieningen.

Tabel 4.15. Kosten verpleeghuizen (in mln. guldens)*

\begin{tabular}{|c|c|c|c|c|c|c|c|}
\hline Ko tenpot & 1981 & 1982 & 1903 & 1984 & 1905 & 2906 & 1907 \\
\hline 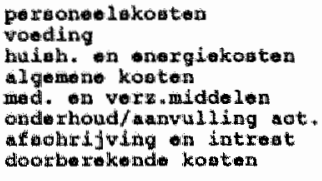 & $\begin{array}{r}2021,9 \\
124,9 \\
231,9 \\
110,7 \\
83,6 \\
84,0 \\
405,6 \\
-41,9\end{array}$ & $\begin{array}{r}2162,4 \\
134,2 \\
239,2 \\
135,1 \\
90,1 \\
92,1 \\
409,5 \\
-39,7\end{array}$ & $\begin{array}{r}227,2 \\
139,6 \\
244,3 \\
241,0 \\
94,0 \\
98,2 \\
429,4 \\
-40,4\end{array}$ & $\begin{array}{r}227,2 \\
144,5 \\
257,7 \\
149,7 \\
97,6 \\
105,3 \\
449,5 \\
=41,5\end{array}$ & $\begin{array}{l}2,35,9 \\
145,7 \\
264,4 \\
156,5 \\
101,0 \\
109,3 \\
142,5 \\
-40,8\end{array}$ & $\begin{array}{r}2501,1 \\
149,3 \\
236,3 \\
166,9 \\
107,6 \\
112,9 \\
456,8 \\
-44,8\end{array}$ & $\begin{array}{r}2579,4 \\
145,7 \\
225,0 \\
270,9 \\
109,3 \\
115,7 \\
459,4 \\
-43,3\end{array}$ \\
\hline totand kobten & 3021,4 & 3222,9 & $3.402,6$ & 3441,1 & 3536,5 & 3685,2 & 3762,2 \\
\hline $\begin{array}{l}\text { totad por bed }(f) \\
\text { do.por verploegdag }(f)\end{array}$ & $\begin{array}{r}63770,- \\
175,-\end{array}$ & $\begin{array}{r}673: 5,- \\
185,=\end{array}$ & $\begin{array}{r}70470_{1}- \\
192,-\end{array}$ & $\begin{array}{r}70690,- \\
191,-\end{array}$ & $\begin{array}{r}71780,- \\
195,-\end{array}$ & $\begin{array}{r}74120 \\
201^{\prime \prime}\end{array}$ & $\begin{array}{r}75285,- \\
203,-\end{array}$ \\
\hline
\end{tabular}

- Brom: Not 
Enkele gegevens behoeven nog enige nadere toelichting. Zo zijin voor wijkverpleging andere gegevens opgenomen dan eerder zijn gepresenteerd, omdat deze bereikciffers berekend zijn op basis van zelfstandig wonende ouderen en niet de totale bevolking, gebaseerd op een beperkte steekproef (geen grote steden). Voor de wijkverpleging zijn daarom twee andere soorten gegevens opgenomen, éen voor het aantal clienten en én voor het aantal contacten. Vanwege het relatief grote aantal cliènten dat slechts eén contact op jaarbasis heaft (47\% $50 \%$;K, 1988), lijkt het (gemiddelde) aantal contacten per inwoner voor beleidsdoeleinden relevanter te zijn.

Bij een aantal woorzieningen is weinig tot niets bekend over het gebruik dat ouderen daarvan maken, met name bij dagverzorging in bejaardenoorden en aanleunwoningen. Bij beide voorzieningen is slechts het totaal aantal gebruikers bekend, waarvan verondersteld is dat allen minimaal 65 jaar oud zjn.

Op basis van de leeftijdsspecifieke gebruikcijfers uit tabel 4.16 , is vervolgens een raming gemaakt van het absolute aantal gebruikers per voorziening in 1988 en 2000 , uitgaande van de veronderstelling dat de bereikcijfers voor de leeftijdsgroepen constant blijven. Deze demografische raming van zogenaamd ongewijzigd beleid (zje tabel 4.17 ), gebaseerd op de meest recente bevolkingsprognose (CBS, 1989), kan als basisraming gebruikt worden voor de beoordeling van allerlei maatregelen in het kader van het substitutiebeleid.

Bij het analyseren wan de demografische invloed op voorzieningengebruik blijken er drie typen voorzieningen te bestaan. Dit wordt duidelijk als de geraamde jaarlijkse toename voor een bepaalde voorziening wordt afgezet tegen de verwachte toename in het aantal 65 plussers in Nederland (die uitkomt op gemiddeld 1,4\% per jaar). Alle voorzieningen worden beïnvloed door vergrijzing, maar het relatief zware beslag dat hoogbejaarden leggen op voorzieningen zoals bejaardenoord en wijkwerpleging, zorgt ervoor dat bij deze voorzieningen de dubbele vergrijzing extra sterk doortelt, zodat de jaarlijkse stijging in het aantal gebruikers de toename van het aantal 65-plussers overtreft. Anderzijds zijn er ook voorzieningen waarvan hoogbejaarden relatief minder gebruik maken, zoals dagbehandeling in verpleeghuizen en dagverzorging in bejaardenoorden. Bij deze voorzieningen ligt de toename in het aantal gebruikers onder de vergrijzingstrend.

Tabel 4.16. Leeftijdsspecifiek voorzieningengebruik door ouderen in Nederland in 1987 (in \% per leeftijdsgroep in bevolking)*

\begin{tabular}{|c|c|c|c|c|c|c|}
\hline \multirow[b]{2}{*}{ voorzlening } & \multicolumn{5}{|c|}{ Leeftijdscategoriedn } & \multirow{2}{*}{$\underset{65+}{\text { Totad }}$} \\
\hline & $65-69$ & $70-7$ & $75-79$ & $9 p-8$ & 205 & \\
\hline $\begin{array}{l}\text { bejmardenoord } \\
\text { verpleeghui } \\
\text { ziekenhuid } \\
\text { dagbehandeling vph. } \\
\text { dacverzosing oord }\end{array}$ & $\begin{array}{r}0,5 \\
0,4 \\
11,2 \\
0,1 \\
\end{array}$ & $\begin{array}{r}2,0 \\
1,0 \\
12,6 \\
0,2\end{array}$ & $\begin{array}{r}6,3 \\
2,4 \\
15,0 \\
0,4 \\
0,6 .\end{array}$ & $\begin{array}{r}17,1 \\
5,0 \\
13,6 \\
0,5\end{array}$ & $\begin{array}{r}37,1 \\
10,5 \\
9,2 \\
9,5\end{array}$ & $\begin{array}{r}7,5 \\
2,5 \\
12,5 \\
0,3 \\
0,9\end{array}$ \\
\hline 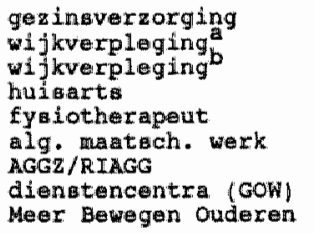 & $\begin{array}{r}2,1 \\
6,2 \\
1,5 \\
7,, 2 \\
12,2 \\
1,3 \\
1,3 \\
2,2 \\
6,8\end{array}$ & $\begin{array}{r}5,9 \\
10,2 \\
2,0 \\
79,2 \\
13,0 \\
2,1 \\
2,1 \\
3,2 \\
5,6\end{array}$ & $\begin{array}{r}11,8 \\
17,5 \\
5,1 \\
03,6 \\
11,9 \\
2,8 \\
2,8 \\
3,6 \\
4,4\end{array}$ & $\begin{array}{r}15,0 \\
27,5 \\
12,3 \\
83,7 \\
12,4 \\
4,4 \\
4,4 \\
2,0 \\
3,1\end{array}$ & $\begin{array}{r}12,5 \\
40,0 \\
15,6 \\
84,2 \\
7,7 \\
3,4 \\
3,4 \\
1,8 \\
1,2\end{array}$ & $\begin{array}{r}7,7 \\
15,0 \\
5,1 \\
90,7 \\
12,2 \\
2,3 \\
2,3 \\
2,8 \\
5,0\end{array}$ \\
\hline
\end{tabular}


Tabel 4.17. Ramilng var oudere gebruikers van voorzieningen in 1988 em 2000, ongewlyzigd beleid; constante leeftjdisspeciffeke bereikcijfers*

\begin{tabular}{|c|c|c|c|c|c|}
\hline & \multicolumn{2}{|c|}{ gebruix $\quad 988$ al } & \multicolumn{2}{|c|}{ gebrulk $2000 \mathrm{bj}$} & \multirow{2}{*}{$\begin{array}{l}\text { toename in } \\
\text { gebruiker } \\
\text { p. Jaar ol }\end{array}$} \\
\hline & $65+$ & antal & antial 1 & $65+$ & \\
\hline 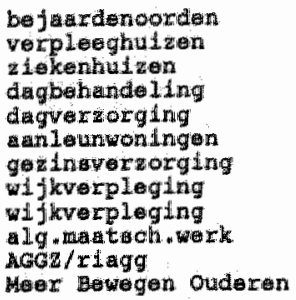 & $\begin{array}{r}7,5 \\
2,5 \\
12,5 \\
0,3 \\
0,9 \\
2,6 \\
7,7 \\
15,0 \\
5,1 \\
2,3 \\
1,5 \\
5,0\end{array}$ & $\begin{array}{r}136.100 \\
46.000 \\
230.100 \\
5.500 \\
16.000 \\
47.900 \\
141.000 \\
276.100 \\
93.900 \\
42.300 \\
27.600 \\
92.000\end{array}$ & $\begin{array}{r}180.200 \\
58.300 \\
269.000 \\
6.200 \\
19.500 \\
56.400 \\
176.200 \\
348.900 \\
120.200 \\
53.900 \\
34.500 \\
106.200\end{array}$ & $\begin{array}{r}8,3 \\
2,7 \\
12,4 \\
0,3 \\
0,9 \\
2,6 \\
0,1 \\
16,1 \\
5,5 \\
2,4 \\
1,4 \\
4,9\end{array}$ & $\begin{array}{l}2,20 \\
2,08 \\
1,38 \\
1,00 \\
1,48 \\
1,40 \\
1,88 \\
2,08 \\
2,18 \\
1,98 \\
1,98 \\
1,28\end{array}$ \\
\hline
\end{tabular}

* Bron: Ruj Jatan, 19896

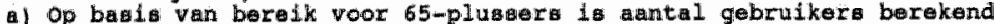

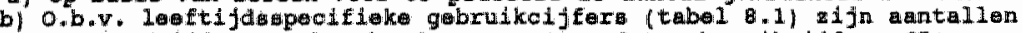

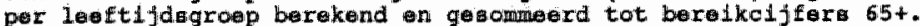

c) stijging van 1 , 4 is voldowde on gelijke tred te houden met vergrijang. Door dubbele vorgriffing en relatiof zwar gewicht van hoogbejaarden, 11 gt stijging blj $a, a$. bejaardenoordem boven dit gremiddelde.

\subsection{Omvang van cliëntenstromen en potentie van substitutie}

Het substitutiebeleid beoogt de door demografische ontwikkelingen bepaalde toename van de kosten van de ouderenzorg om te buigen door verschuivingen van clientenstromen tussen en binnen voorzieningen te bewerkstelligen, zodanig dat dit zal leiden tot een verminderd gebruik van relatief dure voorzieningen (Goudriaan, 1989).

In 1985 werd (WVC, 1986) een raming (vergelijkbaar met die die in de voorgaande paragraaf is gepresenteerd) gemaakt van de gevolgen van vergrijzing bij ongewijzigd beleid voor het voorzieningengebruik door ouderen en werd tevens een inschatting gemaakt van de substitutiemogelijkheden in het jaar 2000. Ongewijzigd beleid zou leiden tot een stijging van de collectieve uitgaven voor verzorgings-, verpleeg- en ziekenhuizen, kruiswerk, gezinswerzorging en huisartsen, van in totaal $40 \%$. De gelinwentariseerde substitutiemogelijkheden leiden tot een kostenreductie van $5 \%$ ten opzichte van de basisraming waardoor per saldo derhalve nog steeds een forse toename van de kosten van ouderenzorg zal blijven bestaan. In twee andere ramingen (SCP, 1986; Nota Zorg voor ouderen, TK, 1985/1986) worden vergelijkbare gegevens gepresenteerd (Goudriaan, 1989). De Commissie Dekker (1987) heeft tenslotte een substitutiepakket samengesteld op basis van de bestaande onderzoeken, waarin onder meer een reductie van de intramurale ouderenzorg mogelijk geacht wordt van $25 \%$ in zowel bejaardenoorden als verpleeghuizen en een afname van verpleegdagen in ziekenhuizen met 20 a $30 \%$. Het gehele pakket maatregelen zou op termijn een besparing van 1,5 a 1,8 miljard kunnen opleveren. Daarbij baseert men zich echter op onderzoeksresultaten uit vaak zeer lokale en kleinschalige projecten, zodat de onderlinge samenhang in en consistentie van het totale pakket niet bij voorbaat vaststaat en de resultaten niet zonder meer naar het macro-niveau kunnen worden vertaald (Nationale Raad Volksgezondheid, 1989). Het merendeel van de onderzoeksresultaten wijst niet op grote mogelijkheden tot kostenreductie (Huijsman en de Klerk, 1989). De totale kosten kunnen met maximaal 25\% teruggedrongen worden, maar als ook nog rekening gehouden wordt met door vergrijzing bepaalde basisramingen, resteert niet meer dan $5 \%$ tot $15 \%$ aan besparingen (Goudriaan, 1989 en 1990). In theorie is substitutie derhalve aardig, maar in de praktijk bestaan er tal 
wan belemmeringen en knelpunten (Commissie Dekker, 1987; Nota Ouderenbeleid, TK, 1988/1989; NRV, 1989).

Hel substitutiebeleid streeft vervanging van relatief dure door goedkopere zorg na door bet bewust verleggen van clientenstromen van intra- naar semi- en extramurale vooraieningen, van professionele naar vrijwilligers- en mantelzorg, kortom van 'zwaar' naar 'lichter' (Nota Ouderenbeleid, TK, 1988/1989). Substitutie richt zich derhalve op de clisntstromen tussen en binnen de voorzieningen. Het gaat daarbij om een zo adequaat en efficient mogelijke beinvloeding van de toestroom van (potentiele) cliênten naar voorzieningen door onder andere strengere indicatie- en toelatingscriteria te stellen, een betere analyse van de feitelijke behoefte te maken en een hechtere cooperatie tussen voorzieningen te bewerkstelligen via samenwerkingsverbanden en dergelijke. Het gat om clientenstromen, omdat het nauwelijks denkbaar is dat reeds opgenomen ouderen (bestanden) "verkast" worden naar andere voorzieningen (Coolen, 1989). In de ouderenzorg is echter op macroniveau nauwelijks materiaal aanwezig om clientenstromen in beeld te brengen. Waar wel gegevens over herkomst bij opname en bestemming bij ontslag voorhanden zijn, blijken zij bovendien tussen de sectoren niet op elkaar aan te sluiten. Voor extramurale zorg zijn in het geheel geen doorstroomgegevens bekend. Het substitutiebeleid heeft derhalve een belangrijk gegevensgebrek.

In figuur 4.5 is op basis van de beschikbare informatie een globale schatting gemaakt van het aantal ouderen dat op jaarbasis de voorzieningen in komt en/of verlaat. De enige voorzieningen waarvoor dit op een enigszins consistente manier mogelijk bleek te zijn, zijn bet bejaardenoord, de dagbehandeling van het verpleeghuis, het verpleeghuis en het ziekenhuis. Voor elk der genoemde voorzieningen is aangegeven hoeveel personen in 1987 direct uit de thuissituatie komen en hoeveel ouderen uit een van de andere voorzieningen afkomstig zijn. De onderste helft van de figuur geeft de uitstroom van de clienten c.q. patienten weer. Het merendeel van de ontslagredenen betreft het overlijden van de patient, uitgezonderd bij dagbehandeling en het ziekenhuis.

Het totaal aantal mutaties voor de voorzieningen (bejaardenoord, dagbehandeling, verpleegen ziekenhuis) en uitgezonderd overledenen, betreft ruim 460.000 ouderen, ofwel $25 \%$ van alle Nederlandse 65-plussers. Een op de vier ouderen beleefde in 1987 derhalve een verandering in leefomgeving ten gevolge van een opname in een (eventueel andere) intramuralè of semi-murale voorziening. Als alleen gekeken wordt naar opnames in een bejaardenoord of verpleeghuis, dan treedt op jaarbasis bij 3,5\% van alle 65 plussers cen verandering in de leefsituatie op. In deze berekeningen wordt echter, wederom door gebrek aan gegevens, geen rekening gehouden met de mogelijkheid dat dergelijke mutaties bij een en de zelfde persoon verschillende keren kunnen voorkomen. Zo is het traject van ziekenhuis (behandeling) naar verpleeghuis (revalidatie) naar dagbehandeling (resocialisering, behoud zelfstandigheid) en tenslotte naar extramurale zorg, geen ongebruikelijke route. Anderzijds is de gemiddelde verblijfsduur in het bejaardenoord dermate lang (circa 5 jaar), dat het aantal gevallen waarbij in een jaar tijd verschillende veranderingen bij dezelfde persoon voorkomen niet zo heel erg groot zal zijn. Het ziekenhuis vormt de uitzondering op deze regel. Tenslotte overlijdt $4,6 \%$ van alle 65 -plussers per jaar tijdens een verblijf in het bejaardenoord, de dagbehandeling, het verpleeg- of ziekenhuis (de helft van het overlijden).

Stroomgegevens naar, binnen en uit de extramurale sectoren zijn op het macro-niveau al helemaal niet voorhanden. Dit maakt de toetsing van de resultaten van het substifutiebeleid op het niveau van de rijksoverheid nauwelijks mogelijk. Er zijn ook andere aanwijzingen dat het substitutiestreven, dat toch al sinds de jaren zeventig, maar vooral in de jaren tachtig, hoge prioriteit heeft, tot op heden nog niet veel resultaat heeft opgeleverd. Zo blijkt er geen duidelijk verband te zijn tussen het bereik van bejaardenoorden versus die van gezinsverzorging (Huijsman, 1989b). Op grond van het substitutiestreven zou een negatief verband 


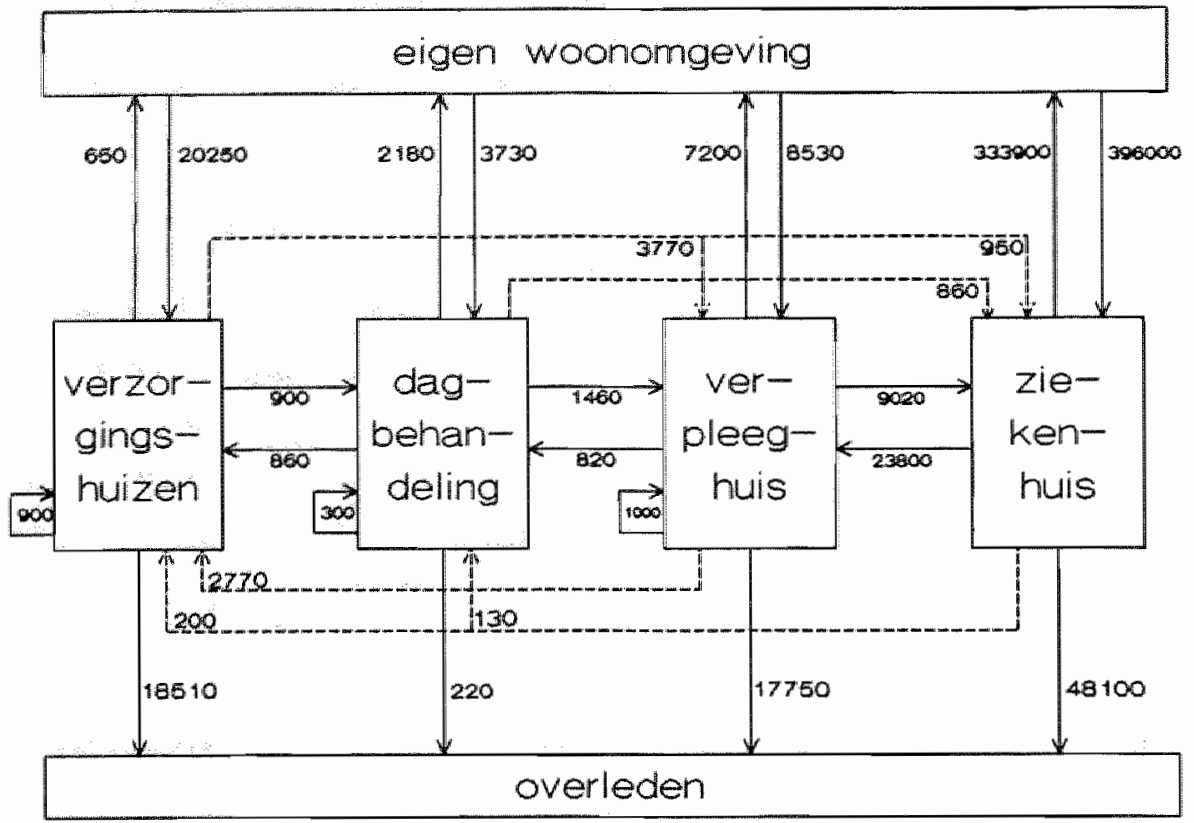

Figuur 4.7. Cliëntenstromen tussen de belangrijkste voorzieningen in 1987

tussen beide gepostuleerd moeten worden, dat echter op basis van macro-gegevens voor de periode 1969-1986 niet teruggevonden wordt. Deze conclusie wijkt niet af van die uit een in 1978 uitgevoerd onderzoek, eveneens gebaseerd op tijdreeksen (De Groot e.a., 1978). De conclusie verandert ook niet als regionale vergelijkingen worden gemaakt (De Groot e.an 1978; Coolen, 1980; Timmermans, 1983).

\subsection{Kosten van voorzieningen voor ouderen}

In tabel 4.18 wordt een overzicht gegeven van de kosten die aan het gebruik van gezondheidszorg- en welzijnswoorzieningen verbonden zijn. Waar dat mogelijk was zijn hier gegevens voor het meest recente jaar, meestal 1987, bijeen gebracht. Dat moest uit veel verschillende en nlet altiji met elkaar overeenstemmende bronnen gebeuren, zodat een aantal kostprijzen een meer tentatief karakter heeft. Waar alleen capaciteitgegevens en gemiddelde kosten op jaarbasis bekend waren, zijn de gemiddelde kosten per dag berekend en wice versa. Bij een aantal voorzieningen is alleen een uurtarief bekend. Berekening op jaarbasis is niet zinvol of onmogelijk omdat er dan meer gegevens nodig zijn of de opnameduur korter dan én jaar is.

Op basis van de kostenoverzichten is het zeer goed mogelijk om een prijskaartje te maken voor verschillende zogenaamde substitutie-pakketten (zie bijwoorbeeld ook Stikker, 1985 en Ouderenbeleid gewogen, 1987). Dit was ook de techniek die de commissie Dekker (1987) hanteerde bij het formuleren van haar voorstellen. Er zijn veel alternatieven denkbaar, die met behulp van de gepresenteerde gegevens op hun kosten beoordeeld kunnen worden (zie 
Tabel 4.18. Overzicht van de gemiddelde kasten in de gezomilheidszorg en maatschappelijke dienstwerlening in 1987 (per patiend/citeat)

\begin{tabular}{|c|c|c|c|}
\hline Voorziening/dienet & $\begin{array}{c}\text { gein kottan } \\
\text { pet dag } \\
\text { op } f 5,-1\end{array}$ & $\begin{array}{l}\text { mjwe } \\
\text { berekening } \\
<-a f->\end{array}$ & 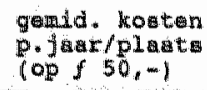 \\
\hline $\begin{array}{l}\text { giokenhuls } \\
\text { id bij } 65+ \\
\text { peych. ziekenhuis }\end{array}$ & 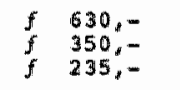 & $\underset{\infty-\infty}{\infty-\infty}$ & $\begin{array}{r}f 127.750,- \\
f 86.000,-\end{array}$ \\
\hline $\begin{array}{l}\text { werpleeghui } \\
\text { beachermi women vph } \\
\text { dagbehandeling vph }\end{array}$ & $\begin{array}{l}f \quad 205= \\
f \quad 120= \\
f \quad 125=\end{array}$ & $\underset{-\infty \rightarrow \infty}{-\infty \rightarrow \infty}$ & $\begin{array}{l}f \quad 75.300,= \\
f \quad 3.000,- \\
f \quad 4500,-6\end{array}$ \\
\hline $\begin{array}{l}\text { bejaardenoord } \\
\text { bejaardenoord-plua } \\
\text { dagverzorging } \\
\text { dagverz. -opvang } \\
\text { 24-unrs-zorg } \\
\text { anleminwoning bej.oord }\end{array}$ & $\begin{array}{lr}f & 85 . \\
f & 105,- \\
f & 30,- \\
f & 45,- \\
f & 175,-\end{array}$ & 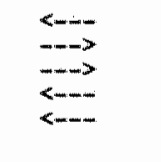 & $\begin{array}{rl}f & 31.000,- \\
f & 38.200,= \\
f & 11.000,= \\
f & 17.300,- \\
f & 63.200,- \\
f & 0.600,-\end{array}$ \\
\hline $\begin{array}{l}\text { RIAGG } \\
\text { A.g.Mat. Werk ( AMW) }\end{array}$ & & & $\begin{array}{lr}f & 3.650,- \\
f & 950,-\end{array}$ \\
\hline \multicolumn{4}{|l|}{ kostien per uur of per keex } \\
\hline $\begin{array}{l}\text { gezinszorg: trad. unr } \\
\text { gezinszorg: mipha unur } \\
\text { wijkverpleging: uur } \\
\text { idem per contact } 60+ \\
\text { nachtopvang per keer } \\
\text { warme maltijd per keer }\end{array}$ & $\begin{array}{l}30,- \\
20,- \\
80,- \\
50,- \\
44,- \\
10,-\end{array}$ & & \\
\hline
\end{tabular}

* Bron: Huijeman, $1989 \mathrm{~b}$

bijvoorbeeld ook Timmermans, 1983; Mootz e.a., 1986). Bij de beoordeling van de verschillende substitutie-alternatieven dient echter wel rekening gehouden te worden met het feit dat bij een eventueel intramuraal verblijf impliciet de huisvestingscomponent van verzorgingskosten is inbegrepen in de totale kosten. Bij een met intramurale opname te vergelijken en te substitueren alternatief in de thuiszorg dient derhalve met deze huisvestingscomponent rekening gehouden te worden. Coolen (1985) stelt deze component op $f 11.000$, dat wil zeggen ongeveer een derde van de kostprijs van opname in het bejaardenoord. Hoewel dergelijke berekeningen op macro-niveau slechts indicatief zijn, kunnen toch belangrijke conclusies getrokken worden. Voor opname in hel verpleeghuis bestaat een aantal alternatieven die veelal goedkoper zijn, zelfs indien zeer intensiewe zorg geboden moet worden. Bij substitutie van bet bejaardenoord zijn de calculaties niet altijd positief. Integendeel, afhankelijk van de zorgintensiviteit kan de thuiszorg zelfs (aanmerkelijk) duurder zijn. De baten van onder andere een betere afstemming op de behoeften van ouderen zelf, bijwoorbeeld tot uitdrukking komend in langer te handhaven zellstandigheid van een eventueel zelfs hogere kwaliteit, zijn echter moeilijk in geld te waarderen en worden dan ook vaak niet meegenomen. Bij pogingen tot kwantificering hiervan verschuiven de omslagpunten ten gunste van de thuiszorg (Van der Vlist, 1984).

De kosten wan de Nederlandse ouderenzorg zijn op grond van de in dit hoofdstuk gegeven overzichten te berekenen op ongeveer 15,5 miljard (zie tabel 4.19). Deze gegevens betreffen uitsluitend de belangrijkste vormen van gezondheids- en welzijnszorg voor ouderen. Op de terreinen van huisvesting (circa 1 miljard individuele huursubsidie aan 65-plussers) en socialle zekerheid (circa 23 miljard AOW-uitkeringen) zijn natuurlijk ook nog belangrijke uitgaven ten behoeve van ouderen gelokaliseerd. Tenslotte blijkt het niet mogelijk om de kosten op het gebied van genees- en hulpmiddelen zoals fysiotherapie aan ouderen te bere- 


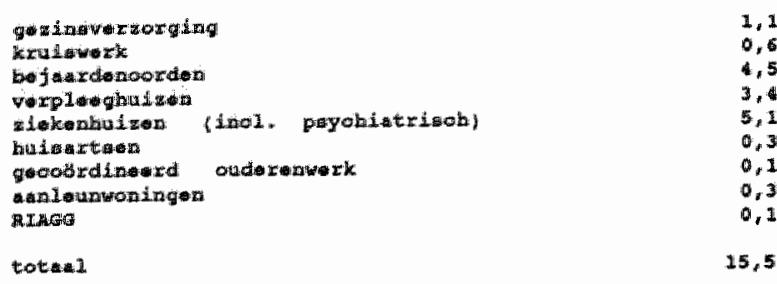

kenen. Over het algemeen zijn dit echter relatief kleinere posten, zodat de totale ouderenzorg met de gepresenteerde kasten ( 15 a 16 miljard) waarschijnlijk goed benaderd wordt.

\subsection{Tot besluit}

In dit deel is een overzicht gegeven van de beschikbare gegevens met betrekking tot de ouderenzorg in Nederland. Dit overzicht is geheel gebaseerd op ambtelijke beleidsstatistieken, statistieken van 'beroepsverzamelaars' zoals het CBS, het NZI of op statistieken van organisaties die een bepaalde sector bestrijken; dit is veelal de koepelorganisatie zoals de Nationale Kruisvereniging of de Centrale Raad van de Gezinsverzorging (deze zijn medio 1990 gefuseerd in de Nederlandse Vereniging voor Thuiszorg). Hoewel dergelijke statistieken veelal een goed globaal beeld van de eigen sector geven, kleven er bezwaren aan die een goed inzicht in de ouderenzorg bemoeilijken. Deze beperkingen wan ambtelijke statistieken worden beknopt aangeduid.

Ten eerste liggen aan de diverse statistieken zeer verschillende informatiesystemen ten grondslag die een eigen geschiedenis kennen, gebaseerd zijn op verschillende en vaak uiteenllopende informatiebehoeften en hoofdzakelijk bedoeld zijn als hulpmiddel bij de analyse van beleidsvraagstukken betreffende de eigen sector. Ten tweede zijn veel gegevens op macro-niveau vaak niet of onvoldoende specifiek en wordt bijvoorbeeld zelden een differentiatie van clientgroepen gehanteerd; wel lenen de gegevens zah goed woor een globaäl overzicht van de totale "produktie" van de verschillende sectoren. Dit gebrek aan specifiteit is onder andere ook de oorzalak voor het probleem dat er op nationaal niveau nauwelijks of geen inzicht te geven is in de clientstromen naar, tussen en uit de verschillende sectoren en voorzieningen; in deze studie is dat slechts met moeite en onder verschillende assumpties gerealiseerd voor slechts een beperkt aantal intramurale voorzieningen. Het voorgaande makkt een derde bezwaar duidelijk, namelijk dat de gegevens per sector vaak niet goed met elkaar in verband te brengen zijn om een sectoroverschrijdend overzicht te maken van bijwoorbeeld -zoals hier werd beoogd-de ouderenzorg. Daarvoor is de diversiteit in mate van detaillering en rubricering van clienten, produktie, personeel, kosten en dergelijke te groot. Een volgend bezwaar betreft het punt dat op macro-niveau niet voldoende recht kan worden gedaan aan de invloed wan individuele factoren op het gebruik en de kosten van voorzieningen, omdat noodzakelijkerwijze met geaggregeerde of gemiddelde gegevens gewerkt moet worden. Juist bij het analyseren van de mogelijkheden voor substitutie is het echter van wezenlijk belang onderscheid te maken naar probleemgroepen van gebruikers, bijvoorbeeld door een verbijzondering naar belemmeringen op het terrein van de dagelijkse en/of huishoudelijke activiteiten. Ook de kostprijzen voor de verschillende voorzieningen zouden in deze zin verder verfijnd moeten worden. Tenslotte kennen de verschillende informatiesystemen elk een eigen dynamiek, die er toe kan leiden dat van jaar tot jaar veranderingen optreden in de samenstelling, formulering en fasering van de vragenlijsten die 
ten grondslag liggen aan de ambielijke statistieken. Dit euvel vormt naast de woorgaande problemen een grote belemmering on een gedetailleerd, actueel en sectoroverschrijotende overzichten van de ouderenzorg in Nederland te maken.

Samenvattend wordt geconcludeerd dat een analyse van het gebruik van voorzleningen door ouderen in belangrijke mate bemoeilijkt wordt door twee hoofdproblemen: (a) het naast elkaar bestaan van verschillende informatiesystemen die sectorgebonden zijn en (b) het feit dat nawwelijks of geen specificatie van de client(situatie) is opgenomen in de bestaande systemen. In het vervolg van deze studie worden verschillende aanzetten gegeven om aan deze bezwaren tegemoet te komen. Daarbij wordt twee kanten belicht: de 'aanbodzijde' van de ouderenzorg, vertrekkend vanuit instellingsgegevens (Deel B van deze studie) en de 'vraagzijde' van de ouderenzorg, uitgaande van individuele gegevens van geselecteerde groepen ouderen. Een koppeling tussen beide mondt uit in een analyse van kostengegevens op individueel niveau in hoofdstuk 15 . 


\section{Deel B}

\section{De aanbodzijde van de ouderenzorg}

In dit deel staat de 'aanbodzijde' van de ouderenzorg in de gemeente Maastricht centraal. Zoveel mogelijk uitgaande van de eigen informatiesystemeni van de betreffende organisaties is een aanbod-enquete ontwikkeld om het gebruik van voorzieningen door ouderen in beeld te brengen en te analyseren. Hierdoor kunnen de thema's uit het voorgaande (nationale) deel, waarin ambtelijke statistieken benut werden die slechts globale gegevens bevatten, verdiept worden. De belangrijkste thema"s in dit deel betreffen (de veranderingen in) het bereik van de voorzieningen, de kenmerken van gebruikers, de gemiddelde hulpintensiteit per client, het ingezette personeel en de kosten van de ouderenzorg in Maastricht. In het afrondende hoofdstuk wordt onder meer ingegaan op de empirische bewindingen met betrekking tot de gehanteerde functionele indeling van de ouderenzorg. 


\section{Introductie op de beschrijving van voor- zieningen voor ouderen in Maastricht}

\subsection{Inleiding}

Dit hoofdstuk geeft het kader aan waarbinnen de geselecteerde voorzieningen te Maastricht beschreven en geanalyseerd worden. Er wordt hier uiteengezet op welke wijze de gegevensverzameling bij de instellingen in de gemeente Maastricht heeft plaatsgevonden. Eerst wordt het globale raamwerk besproken en wordt een toelichting gegeven op de in het onderzoek gehanteerde functionele indeling (paragraaf 5.2). Vervolgens wordt per voorziening besproken hoe en waarom er eventueel is afgeweken van het centrale stramien (paragraaf 5.3). Het hoofdstuk besluit met de opzet voor de rest van deell $\mathrm{B}$ van deze studie.

\subsection{Wijze van aanpak: de instellingsenquête}

Bij de aanvang van het onderzoeksproject in 1986 werd al snel duidelijk dat de gegevensverzameling bij alle verschillende organisaties in de ouderenzorg bemoelijkt wordt door het feit dat verschillende informatiesystemen gehanteerd worden. De belangrijkste landelijke 'verzamelaar' van gegevens is ongetwijfeld het Centraal Bureau voor de Statistiek, dat bijvoorbeeld enquêtes heeft ontwikkeld voor bejaardenoorden (een algemeen en een financieel deel), voor intramurale instellingen zoals ziekenhuizen en verpleeghuizen (afzonderlijk voor personeel, financien en produktiegegevens) en woor extramurale voorzieningen (gezinsverzorging, personeel en kosten kruiswerk en dergelijke). Ook andere organisaties verzamelen informatie, meestal voor specifieke sectoren. Zo kunnen genoemd worden" de woormalige organisatie Landelijk Samenwerkende Bejaardenoorden (LSB; thans Vereniging van Nederlandse Bejaardenoorden) woor uitgebreide financiele overzichten over haar eigen sector; WVC voor de gezinsverzorging (beeindigd bij de overgang naar de AWBZ per 1-1. 1989); het NZI voor bijvoorbeeld verpleeg- en ziekenhuizen en dergelijke. Het Centraal Bureau voor de Statistiek is wellicht de belangrijkste verzamelaar van gegevens (ook buiten de gezondheidszorg). Onderzoekers die voor verschillende typen voorzieningen gegevens willen verzamelen worden derhalve geconfronteerd met uiteenlopende systemen, die een varierende mate van cletaillering kennen en vaak van jaar tot jaar aangepast worden, zodat zelfs binnen een bepaalde sector problemen ontstaan bij het samenstellen van tijdreeksen. Een ander probleem behelst de verschillende fasen van automatisering waarin de organisaties verkeren. Bij de bejaardenoorden is dit bijvoorbeeld nog nauwelijks aan de orde zodat met kaartenbakken gewerkt moet worden. Wijkwerpleging (met het Wijk Administratie Systeem; afgekort tot WAS) en met name de gezinswerzorging (met het Landelijk Indicatie En Registratie systeem; in het vervolg: LIER-systeem) zijn veel verder.

In het onderhavige onderzoek werd aanvankelijk gedacht dat de probllemen bij gegevensverzameling ondervangen zouden kunnen worden door een enquete te ontwikkelen, die als het ware de grootste gemene deler van de gehanteerde informatiesystemen zou moeten vormen. Eigenlijk is het gehanteerde instrument geen enquete in de strikte zin van het woord, maar een instrument voor gestructureerde en uniforme dossier-vorming. Daarbij zijn verschillende fases onderscheiden. In de eerste stap werden alle beschikbare gegevens opgevraagd bij de instellingen zoals gezinswerzorging, kruiswerk, verzorgings. en verpleeghuizen. Deze gegevens worden veelal ontleend aan jaarverslagen en afschriften van 
landelijke vragenlijsten (zoals CBS- of NZI-enquetes) opgewraagd, aan de hand waarvan de enquetes zoveel mogelijk door de onderzoekers zelf worden ingevuid. In de tweede stap worden de al gedeeltelijk ingevulde enqueteformulieren aan de instellingen opgestuurd met het veraok om de enquetes zoveel mogelijk te completeren. Tijdens de derde fase wordt door middel van gesprekken met leden van directie of leidinggevend personeel getracht om eventuele leemiten op te vullen. Dit betrof met name de functionele indeling van werkzaamheden van het personeel (zie paragraaf 5.3). Omdat de enquette zoveel mogelijk wordi ingewuld door de onderzokers zelf, is de tijdsbesteding voor de instellingen zo beperkt mogelijk. De mondelinge eindstap verzekert dat eventuele onduidelijkheden opgehelderd kunnen worden, hetgeen bowendien de betrouwbaarbeid van die gegevens ten goedle komt.

In de instellingsenquete (zie bijlage 2) komen de volgende onderwerpen aan bod:

a. Algemene gegevens. Hier worden vragen gesteld over naam, adres, oprichtingsdatum, toelatingseisen en verzorgingsgebied van de instelling.

b. Organisatie-gegevens. Dit betreft vragen over de formele en de informele organisatiestructuur en over de aard en de frequentie van overleg tussen verschillende niveaus binnen de instelling en met andere instellingen.

c. Personeelsgegevens. Hier wordt gevraagd naar functies en taken op zowel uitvoerend als ondersteunend niveau, full-time of part-time banen, gemiddelde salarislast en inzet naar functies van zorgverlening (zie paragraaf 5.3 ).

d. Capaciteit. Dit żjn vragen omtrent capaciteit en gemiddeld gebruik van de verschillende faciliteiten wan de woorziening. Ook wordt naar patientgegevens zoals leeftijd, geslacht, contactfrequentie, herkomst bij opname en bestemming bij ontslag gevraagd.

e. Kosten. Dit betreft vragen over personeelslasten, kosten van zorgverlening en ondersteunende dienstverlening, investeringen, ${ }_{1}$ afschrijwingen en dergelijke.

f. Financiering. Hier wordt zowel naar financierende instanties als naar functies van zorgvertening gevraagd.

Uit dit overzicht blijkt dat de functionele indeling in deze studie (vooralsnog) is toegespitst op de personele hulpverlening. Dit neemt echter niet weg dat ook niet-personeelsgebonden middelen zijn toe te rekenen aan de verschillende functies (Van der Vlist, 1984; Centralle Commissie Bejaardenoorden, 1989).

\subsection{Functionele indeling van ouderenzorg: afbakening van functies}

Aan de behoeften van ouderen wordt tegemoet gekomen door een bepaalde functie van zorgverlening. Deze zorgfunctie kan door een of meerdere soorten van voorzieningen geleverd worden. Uitgaande van de behoeftebenadering proberen we het gehele veld van zorggebruk in eerste instantie te beschrijven op grond van een functionele indeling, waarmee nagestreefd wordt de zorgbehoefte via de functies te koppelen aan hel bestaande aanbod van de zorgvoorzieningen. Bij een beschrijving van deze voorzieningen ontkomt men echter niet aan een institutionele indeling, ondat dit aanbod nu eenmaal is georganiseerd in instellingen en beroepsbeoefenaren die vaak verschillende functies tegelijkertijd vervullen.

De indeling in functies kan twee 'uitersten' aannemen. Er is een indeling denkbaar in slechts enkele hoofdfuncties, maar een indeling kan ook zeer gedetailleerd zijn opgesplitst naar vele subfuncties. De eerste methode heeft het voordeel van de duidelijke structuur en de goede hanteerbaarheid. Het nadeel is echter dat binnen én functie zeer uiteenlopende activiteiten mogelijk zijn. Indien deze activiteiten of subfuncties worden weggelaten, zou belangrijke informatie over substitutiemogelijkheden tussen voorzieningen die eenzelfde functie uitoefenen, verloren kunnen gaan. Functies zijn meestal niet onderling substitueerbaar; voorzieningen die owereenkomstige functies in hun takenpakket hebben, zijn wel onderling substitueerbaar. De tweede methode, een zeer gedetailleerde uitsplitsing naar vele 
subfuncties, kan een beter inzicht in de substitutiemogelijkheden bieden. Het nadeel is echter dat het een zeer fragmentarische benadering van de zorgbehoefte van de oudere mens in de hand kan werken. Bovendien kunnen subfuncties zo met elkagr werweven zijn dat afbakening zowel theoretisch als praktisch nauwelijks mogelijk is.

ledere keuze tussen de twee uitersten is in meer of mindere mate arbitrair, maar de leidraad dient steeds te zijn dat de voor het onderzoek meest relevante informatie verkregen wordt. Na het opstellen van een concept-indeling is in gesprekken met de begeleidings commissie van het onderzoek (zie voorwoord voor de samenstelling daarvan) en met de Stedelijke Werkgroep Ouderenbeleid Maastricht uiteindelijk gekozen voor een indeling in tien functies. Deze indeling wordt zo aanstonds gepresenteerd, maar eerst wordt ingegaan op de toepassing van de functionele indeling.

Iedere voorziening kan per periode een bepaald aantal eenheden dienstverlening produceren, verdeeld over de verschillende soorten functies. In een matrix (zie figuur 5.1) kan dit worden verduidelijkt: elk kolomtotaal van de matrix geeft het aantal eenheden dienstveriening van de voorzieningen aan. Dit totaal wordt verdeeld per voorzieningensoort over de onderscheiden functies. Als teleenheid wordt gedefinieerd de eenheid van dienstverlening (geld, tijd, aantal contacten). De teleenheid moet homogeen zijn: de eenheden binnen eén functie zijn gelijk terwijl de eenheden binnen de voorzieningen optelbaar zijn. Ieder rijtotaal geeft het aantal eenheden dienstverlening dat ter beschikking komt van een functie. Element $(3, \mathrm{M}-2)$ geeft het aantal eenheden dienstverlening dat door de derde voorziening wordt geleverd aan de zorgfunctie $\mathrm{M}-2$.

In de instellingsenquête worden tien functies onderscheiden die voor de instellingen in de bij de enquete behorende toelichting geheel zijn gedefinieerd en afgebakend. Vooralsnog wordt de functie-indeling alleen gebruikt voor verdere detaillering van personeelsformatie. Deze beslaan echter circa $70 \%$ van alle kosten van de voorzieningen voor ouderen. Bowendien zijn andere zaken zoals apparatuur, voedingskosten en andere kostenposten vrij eenvoudig terug te voeren tot de verschillende functies. Voor de tien functies worden eerst de gehanteerde omschrijvingen gegeven (met steeds enige voorbeelden), waarna vervolgens wordt ingegaan op enkele aspecten van de functie-indeling.

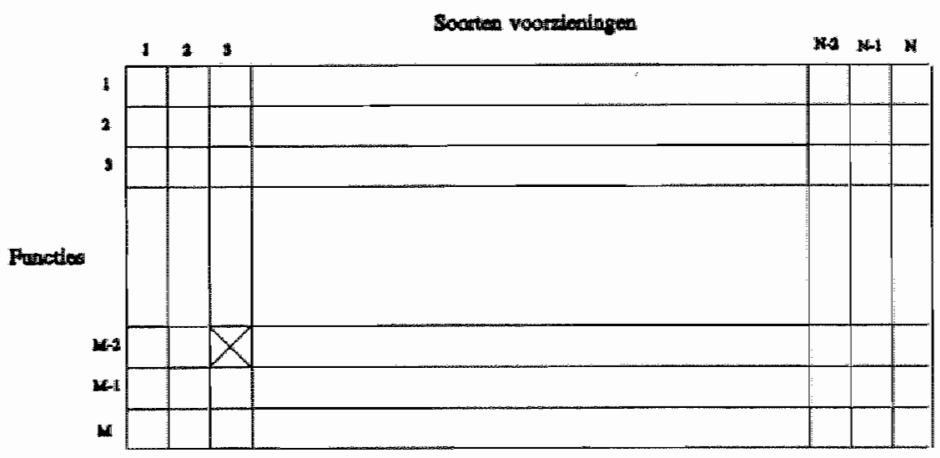


Functie 1:

Omschrijving:

Kanttekening:

Functie 2:

Omschrijving:

Voorbeelden:

Functie 3:

Omschrijving:

Voorbeeiden:

Functie 4:

Omschrijving:

Voorbeelden:

Functie 5:

Omschrijving:

Voorbeelden:

Functie 6:

Omschrijving

\section{Woon- en verblyfsfunctie}

bieden van een min of meer langdurige (vervangende) woon- en leefomgeving.

het wordt niet relevant geacht of de woon-en verblijfsfunctie een expliciete doelstelling is (bijvoorbeeld bij aanleunwoningen en bejaardenoorden), of een impliciet gevolg is van verzorging (zoals bij het verpleeghuis).

\section{Preventlefunctile}

het geheel wan activiteiten dat gericht is op het voorkomen van ongewenste situatles, met het doel het beroep op curatieve zorg te woorkomen of uil te stellen (ook wel: primaire preventie). Hieronder wordt tevens verstaan het opsporen van een zich ontwikkelende ongewenste situatie, die nog niet geleid heeft tot het afgeven wan signalen door de betrokken persoon (secundaire preventie), terwijl door tijdig ingrijpen verergering van de situatie voorkomen kan worden.

periodieke controles, bevolkingsonderzoek, Meer Bewegen voor Ouderen, Gezondheids Voorlichting en Opvoeding.

\section{Medische zorg}

alle activiteiten die gericht zijn op het diagnostiseren en behandelen van geconstateerde problemen op somatisch, tandheelkundig en psychisch gebied.

(deel van het) onderzoek van de indicatiecommissie, lichamelijk onderzoek, toedienen van injecties, transfusies en dergelijke.

\section{Verpleging}

alle activiteiten, die bestaan uit een min of meer langdurige lichamelijke en medische verzorging onder medische toezicht en controle van de arts. Deze activiteiten komen voort uit de aanwezigheid van niet (meer) te behandelen beperkingen van de patient, het volgen van een diagnostisch of therapeutisch regime of lichamelijke en mentale inactiviteit.

wondverzorging, ziekenverzorging, verpleegkundige handelingen zoals medicijntoediening, temperatuurmeting en dergelijke.

\section{Revalidatie/reactivering}

alle activiteiten, die vaak in een samenhangende groep van werkzatamheden gedaan worden met het doel een in zijn zelfstandigheid. beperkte persoon de kans te geven op optimale mogelijkheden van ontplooiing, zowel lichamelijk, geestelijk, sociaal, educatief als arbeidstechnisch. In die gevallen dat wolledig herstel niet mogelijk is, zal de behandeling erop gericht moeten zijn de patient in een toestand te brengen, waarin hij/zij zoveel mogelijk zelfstandig kan functioneren en owerblijvende capaciteiten zo goed mogelijk kan benutten.

revalidatie in verpleeghuis of ziekenhuis (bij vervroegd ontslag).

\section{Persoonlijke verzorging}

alle activiteiten die gericht zijn op het uitwoeren van de activiteiten van het dagelijks leven (ADL) en noodzakelijk zijn (geworden) op grond van diens gezondheidstoestand. Uitvoering van deze activiteiten geschiedt in principe door niet-verpleegkundigen (om het onderscheid met de betreffende functie zo scherp mogelijk te maken) en is gericht op het hulp bieden bij of (gedeeltelijk) overnemen van de activiteiten van het dagelijks leven, met als doel de zelfstandigheid van de betrokkene te bevorderen. 
Voorbeelden: lichamelijke hygiene en verzorging, hulp bij in en uit bed stappen, aan- en uitkleden of bij het gebruik van het toilet.

Functie 7:

Omschrijving:

Voorbeelden:

Functie 8:

Omschrijving:

Voorbeelden:

Functie 9:

Omschrijving:

Voorbeelden:

Functile 10:

Omschrijving:

Voorbeelden:

\section{Recreatie en socialle contacten}

alle activiteiten, die gericht zijn op enerajjds de ondersteuning wan de betrokkene bij zijn of haar zelfontplooilng en anderzijds het opheffen en/of vourkomen van isolement door middel van het bieden van de mogelijkheid van recreatie, gezelligheid, sociaal contact en dergelijke.

activiteiten dienstencentra/bejaardenoorden, Meer Bewegen voor Ouderen.

\section{Huishoudelijke verzorging}

alle activiteiten, die door middel van het verrichten van eenvoudige diensten het dagelijkse leven ondersteunen en gericht zijn op het zelfstandig of met hulp uitwoeren van dagelijkse huishoudelijke werkzaamheden.

koken, huishoudelijk werk, boodschappen of klusjes doen.

\section{Kunst- en hulpmiddelen (technische hulp)}

ondersteuning van de woonomgeving of de persoon zelf door middel van het beschikbaar stellen van de noodzakelijke hulpmiddelen, alsmede het verschaffen van de noodzakelijke gene 3 - en heelkundige instrumenten met het doel dat de betrokkene zo optimaal mogellik functioneert.

krukken, rolstoel, aanpassing van de woning, $A D L$-hulpmiddelen.

\section{Informatie- en adviesverstrekking}

alle activiteiten, die ontvanger-gericht gedaan worden en bestemd zijn ter verrijking van de kennis en het inzicht bij de ontvanger, zodat deze beter in staat is om beslissingen te nemen en/of handelingen te verrichten.

advies over wettelijke regels (bijvoorbeeld door sociale raadslieden), hulp bij administratie (o.a. belastingbiljet), voorlichting.

\section{Kanttekeningen bij een functionele indeling van ouderenzorg}

In het oorspronkelijke onderzoeksvoorstel (zie hoofdstuk 1) zijn enkele opmerkingen over de functionele indeling opgenomen. De belangrijkste punten zijn als volgt samen te vatten: (a) substitutie vindt alleen plaats binnen én functie en niet tussen verschillendle functies; (b) substitutie grijpt in op de aanbodzijde, niet op de vraagzijde; (c) voorzieningen worden gekenmerkt door de combinatie van functies die zij kunnen leveren; (d) functies kúnnen complementair zijn en ellkaar aanvullen.

Het formuleren van een goed hanteerbare functionele indeling stuit op een aantal problemen. Het eerste probleem betreft de mate waarin de opsplitsing in functies dient plaats te vinden. Een vergaande functionele indeling kan leiden tot een te fragmentarische indeling, waardoor het gevaar bestaat dat functies overeen gaan komen met de activiteiten wan individuele zorgverleners of afzonderlijke voorzieningen. Bovendien leidt het tot theoretische en praktische problemen (Timmermans, 1987; SCP, 1988). Een globale functieindeling kan echter leiden tot een te schematische weergave van vraag en aanbod. Een tweede probleem betreft de eenheden waarin functies worden weergegeven. Voor inzicht in de substitutiemogelijkheden dient deze per functie dezelfde te zijn; voor verschillende functies kunnen verschillende teleenheden gebruikt worden op grond van punt (a). In het onderzoek is een pragmatische oplossing nagestreefid door de functie-indeling te concentreren op (de werkzaamheden van) het personeel in de verschillende organisaties en andere vormen van dienstverlening te benaderen op basis van de daarmee gemoeide kosten. 
Het derde, maar misschien wel belangrijkste probleem betreft een technisch meetprobleem. Tydstudies byj werschillende personeelscategoriewn in verschillende typen wan woorzieningen en instellingen zouden een belangrijk onderdeel moeten vormen voor de concrete invulling van een functionele indeling; ondat daarvoor thans geen registratie-methoden bestaan. In het onderzoek is een minder intensieve oplossing nagestreefd, waarbij via vraaggesprekken met sleutelfiguren een benadering is gemaakt van de tijdsinzet van de verschillende personeelscategorietn voor de onderscheiden functies.

Voorzieningen laten zich beschrijwen door de mix van diensten of functies die zij aanbiedien. Voorzieningen werschillen van elkaar indien zij andere functies aanbieden of andere accenten op bepaalde functies leggen. Zo bieden zowel de wijkverpleging als de gezinsverzorging een combinatie van persoonlijke, huishoudelijke en verpleegkundige diensten aan, maar legt de wijkverpleging daarbij het accent op de verpleegfunctie en gezinsverzorging op persoonlijke en hüshoudelijke verzorging. Vanuit deze functionele benadering wordt thans ook van overheidswege de integratie tussen verpleeg- en verzorgingstehuizen woorgestaan, omdat de functie-pakketten van beide voorzieningen steeds minder verschillen vertonen. De functionele benadering kan ook dienen als instrument on voorgestane samenwerking tussen instellingen te kwantificeren. In de tabel 5.1. is aangegeven welke functies in principe door welke voorzieningen worden aangeboden. Daarbij beperken wij ons tot de 'basisvoorzieningen' voor ouderen (Algemene Rekenkamer, 1985), namelijk gezinsverzorging, wijkverpleging, gecoordineerd ouderenwerk, bejaardenoord en verpleeghuis. Andere auteurs hebben bijvoorbeeld voor gezondheidszorgvoorzieningen vergelijkbare functionele indelingen gepresenteerd (bijwoorbeeld Timmermans, 1987; SCP, 1988).

Bij de beschrijving van de voorzieningen in de hoofdstukken $6 \mathrm{t} / \mathrm{m} 11 \mathrm{komen}$ de onderscheiden functies vaak slechts impliciet terug. In de samenvatting (hoofdstuk 12) wordt echter een poging gedaan om op basis van de gepresenteerde gegevens een benadering te geven wan het gewicht dat de verschillende functies hebben in de werkzaamheden van het personeel en in de kosten van de onderzochte woorzieningen.

\subsection{Afwijkingen van het centrale stramien}

Hoewel in de volgende hoofdstukken per voorziening meer in detail wordt aangegeven watrom en hoe er is afgeweken van het centrale stramien zijn enkele algemene kanttekeningen hier op hun plaats. Algemeen kan gesteld worden dat de inventarisatie een zeer arbeidsintensieve aangelegenheid is die ook veel vergt van de instellingen omdat niet alle gevraagde gegevens standaard worden vastgelegd, de informatiesystemen vaak niet geauto-

Tabel 5.1. Typering van voorzleningen agar functies

\begin{tabular}{|c|c|c|c|c|c|}
\hline funot in a & $\begin{array}{l}\text { goingwer- } \\
\text { zorgling }\end{array}$ & $\begin{array}{l}\text { wijkwer- } \\
\text { pleging }\end{array}$ & GOW & $\begin{array}{l}\text { bejacr- } \\
\text { denoord }\end{array}$ & $\begin{array}{c}\text { verpleag: } \\
\text { huil }\end{array}$ \\
\hline 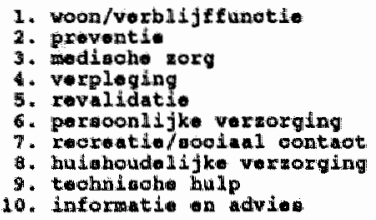 & $\begin{array}{l}\mathbf{x} \\
\mathbf{x} \\
\mathbf{x} \\
\mathbf{x}\end{array}$ & $\begin{array}{l}x \\
x \\
x \\
x\end{array}$ & $\begin{array}{l}x \\
x\end{array}$ & $\begin{array}{l}x \\
x \\
x \\
x \\
x\end{array}$ & $\begin{array}{l}\mathbf{y} \\
\mathbf{y} \\
\mathbf{z} \\
\mathbf{x} \\
\mathbf{x}\end{array}$ \\
\hline
\end{tabular}


matiseerd zijn, jaarverslagen vaak globaal zijn en sommige gegevens 'gevoelig" liggen (met name kostengegevens). Bovendien zijn voor verschillende enquete-onderdelen vaak verschillende informanten binnen een organisatie vereist, waardoor een extra vertragende factor ontstaat (ondanks het feit dat vaak een sleutelfiguur binnen de instelling aangewezen werd). Een ander algemeen probleem betreft het feit dat bij een langlopend onderzoek als het onderhavige de interesse bij instellingen, die op basis van vrijwilligheid (zonder sancties, maar voor de instellingen ook zonder direct profijt) hun medewerking hebben verleend, kan verslappen. Tussentijdse personeelswisselingen versterken dit verder. De derde algemene kanttekening die voor bijna alle voorzieningen opgaat betreft het feit dat de kostengegevens vaak pas na enig aandringen en bij bejaardenoorden (via de provincie) onder de voorwaarde dat slechts sectorgemiddelden worden gepresenteerd, verkregen zijn. Tenslotte kan gemeld worden dat ondanks de (theoretische) aantrekkelijkheid van een functionele indeling, de praktijk leert dat deze slechts bij benadering en onder veel veronderstellingen geconcretiseerd kan worden.

De belangrijkste aanpassing op het centrale stramien vindt plaats vanwege het feit dat in de meeste gevallen de gebruikelijke schriftelijke verslaglegging door organisaties in de ouderenzorg onvoldoende informatie over de bereikte clienten biedt. Bij de dienstencentra van het gecoördineerd ouderenwerk is daarom in 1988 een enquête onder de bezoekers gehouden (hoofdstuk 8) en bij de bejaardenoordbewoners een registratie (eind 1989/begin 1990) van de kenmerken van alle individuele bewoners uitgevoerd (hoofidstuk 10). Bij de gezinsverzorging (hoofdstuk 6) en bij de wijkverpleging (hoofdstuk 7) zijn secundaire analyses uitgevoerd op de door de betreffende instellingen ter beschikking gestelde clientinformatiesystemen. Bij het werpleeghuis tenslotte is geen eigen (veld-)onderzoek uitgevoerd, omdat deze in het complementaire project van het totale onderzoek (zie hoofdstuk 1) is ingebed (Te Wierik, 1990); de extra belasting die van de organisatie gevergd zou worden om mee te werken aan de instellingsenquête werd daardoor volgens de directeur te groot, mede omdat de resterende onderzoekstijd te krap was geworden.

\subsection{Opzet van deel B}

Hoofdstuksgewijs worden in dit deel van deze studie de volgende voorzieningen beschreven: gezinsverzorging, wijkverpleging, gecoordineerd ouderenwerk, bejaardenoorden en verpleeghuis. De aanpak is daarbij steeds hetzelfde. Eerst wordt een korte toelichting gegeven op de doelstelling en organisatiestructuur, vervolgens word de gegevensverzameling toegelicht en worden enkele kenmerken van de gebruikers beschreven (beknopt over de periode tot en met 1988 en meer in detail op basis van eigen onderzoek of secundaire analyse). Tenslotte komen de personeelsformatie, personeelskosten en andere kosten aan de orde. In de samenvatting in hoofdstuk 12 worden niet alleen de belangrijkste bevindingen nog eens bondig samen gevat, maar wordt ook een (eerste aanzet voor) kwantificering van een functionele indeling van ouderenzorg gepresenteerd. 



\section{Gezinsverzorging}

\subsection{Inleiding}

De Stichting Gezinszorg Maastricht werd in 1942 opgericht op initiatief van enkele particulieren, die als vrijwilliger het bestuur vormden. Benodigde middelen werden aanvankelijk uit liefdadigheid verkregen. Thans is er een vrijwel volledige subsidiering via de Rijkssubsidieregeling Gezinsverzorging (Stb. 1985, no. 29), waarbij de Stichting te Maastricht haar karakter van particuliere stichting zonder winstoogmerk behouden heeft. De doelstelling van de Stichting is als volgt omschreven: 'Huishoudens, die thet betrekking tot de binnen deze huishoudens te verrichten taken tekorten hebben of dreigen te krijgen en hierin niet zelf kunnen voorzien, hulp te bieden bij de noodzakelijke verzorging van hun huishouding teneinde een zo zelfstandig mogelijk functioneren van die huishoudens te bereiken of te behouden'. Deze doelstelling is algemeen gangbaar in heel Nederland en heeft z'n oorsprong in de invoering van de landelijke richtlijnen voor indicatiestelling in 1976. Uit te voeren taken van de gezinsverzorging, die steeds aanvullend zijn op de tekorten in het huishouden, betreffen huishoudelijke, verzorgende en begeleidende activiteiten alsmede huishoudelijke ziekenverzorging en zijn steeds aanvullend op de tekorten in het huishouden. De hulpverlening van de gezinszorg is globaal te splitsen in traditionele hulp en alpha-hulp. Voor de alpha-hulp, die sinds 1978 landelijk erkend is als werksoort, heeft de Stichting slechts een bemiddelende functie. Alpha-hulp wordt omschreven als huishoudelijke hulpverlening gedurende maximaal 12 uur per week over ten hoogste 2 werkdagen. Problemen bij het sociaal functioneren dienen nadrukkelijk afwezig te zijn. Alle hulp die meer tijd neemt dan 2 dagdelen per week of van een andere aard is dan puur huishoudelijke hulp, behoort tot traditionele hulp, waarvoor circa 550 hulpverleners in loondienst van de Stichting zijn (bejaardenverzorgenden, bejaardenhulpen, gezinshelpenden bij bejaarden, (gespecialiseerde) gezinsverzorgenden en gezinshelpenden). Van de drie functies bij de hulpverlening aan bejaarden vereisen alleen de eerste twee functies een diploma. Gemiddeld over alle Nederlandse instellingen wordt $90 \%$ van de hulp aan ouderen uitgevoerd door gezinshelpenden bij bejaarden. De bejaardenverzorgenden en -helpenden vervullen respectievelijk $4 \%$ en $6 \%$ van de hulp (FOGM 1987, TK, 1986/1987).

\subsection{Gegevensverzameling}

De Stichting Gezinszorg Maastricht was tot 1986 niet geautomatiseerd, waardoor gedetailleerde gegevens over de achterliggende jaren moeilijk te achterhalen waren. Voor de periode 1975-1986 is vrijwel uitsluitend gebruik gemaakt van het jaarverslag dat over de zelfde periode is uitgebracht en meer globale gegevens bevat (zie paragraaf 6.3). In de eerste onderzoeksfase (Huijsman en Dolmans, 1988) werden aanvullende gegewens verstrekt: in 1987 was het clientenbestand van de Stichting volledig geautomatiseerd, zodat sindsdien de meest relevante gegevens voor onderzoek beschikbaar kwamen (Huijsman en Dolmans, 1990). In 1987 ontbraken de geslachtgegevens echter nog, omdat deze niet in de officiele registratie opgenomen zijn. Ook het aantal produktieve uren dat een client gekregen heeft na correctie voor ziekte, verlof en dergelijke van het personeel, werd aanvankelijk niet in de clientregistratie opgenomen, maar afzonderlijk verwerkt bij de financiele administratie in verband met de afrekening van de eigen bijdragen van de cliênten. Vanaf begin 1988 zijn beide soorten gegevens (sexe en produktieve hulp) op 
verzok van de onderzoeker opgenomen in de geautomatiseerde registratie. In dit hoofdstuk wordt, na en meer globaal owerzicht over de periode 1975-1987, een analyse van de (oudere) chienten wan de gezinswerzorging gegeven. Deze analyse is gebaseerd op gegevens uit hel (geautomatiseerde) Landellike Indicatie En Registratie systeem (kortweg het LIERsysteem) per medio december 1988 (einde 13de periode).

\subsection{Trendmatige ontwikkelingen in het gebruik van gezinsver- zorging}

In deze paragraaf worden de trendmatige ontwikkelingen in de periode 1975-1987 besproken. Ter inleiding op de dienstverlening door de gezinsverzorging te Maastricht wordt kort ingegaan op enkele nieuwe ontwikkelingen. In 1979 werd gestart met de bemiddeling voor alpha-hulp. In 1981 is gestart met een centrale intake voor alle hulpverlening. Voordelen van deze behandelingswijze met betrekking tot nieuwe clienten, die voorheen per wijkteam plaats vond, zjn samen te vatten onder de noemers van efficiẻntie, uniformiteit en objectiviteit (minder belnvloeding door eventuele beschikbaarheid van hulp). In juni 1983 startte de instelling met een project Tijdelijke Slaapwacht, een voorziening voor ten hoogste vier weken om tijdelijke ondersteuning te kunnen geven met het doel de zelfstandigheid van het huishouden mogelijk te maken of te laten blijven. Deze voorziening biedt in feite niet meer dan aanwezigheid, in Maastricht van daartoe geselecteerde werkstudenten, die alleen bij nood hulp verlenen. Na een aanvangsperiode worden thans per jaar 35 a 40 personen geholpen met gemiddeld 17 a 18 nachten slaapwacht. Ook in 1983 werd gestart met groepshulpverlening aan ouderen, ook well de wilkbejaardenverzorging genoemd. Kenmerkend voor deze differentiatie is de wijksgewijze aanpak, waarbij een team hulpverleners met een grote mate van organisatorische vrijheid verantwoordelijk is voor de hulpverlening aan een groep ouderen. De verleende hulp is een op de vraag toegesneden combinatie van huishoudelijke en persoonlijke verzorging, ook buiten de kantooruren. Ruim de helft van alle instellingen in Nederland heeft deze hulpvorm in het pakket. In december 1983 is gestart met acute hulpwerlening of hulp op afroep die altijd van korte duur is (maximaal drie weken) en bestemd is voor plotseling in nood komende hulpverleningscategorieen (nieuwe of oude clienten), maar ook gebruikt wordt om in minder acute situaties de continulteit te waarborgen. In Maastricht zijn hiervoor vijf krachten beschikbaar met elk 30 uur per week. In Nederland biedt $25 \%$ van ce instellingen deze hulp aan. In 1986 is op bescheiden schaal de avond-en weekend-hulp ingevoerd, die in eerste instantie alleen gericht was op assistentie bij ADL-activiteiten, toezicht op medicijngebruik en huiselijke ziekenverzorging. Met ingang van 1 september 1986 heeft de instelling bij wijze van experiment de hulp rondom terminale patiénten (terminale thwiszorg) verruimd tot buiten de kantooruren (avond, nacht en weekend). Daartoe is een groep van zes gekwalificeerde hulpwerleners aangesteld, die zeer uiteenlopende werkzaambeden kunnen verrichten, varierend van huishoudelijk werk tot lichamelijke verzorging en psychische steun en begeleiding. Omvang en lijdstip is mede afhankelijk gesteld van de bereidheid en aanwezigheid van andere disciplines (vaak huisarts en wijkwerpleging), maar ook van informele hulp. Per jaar wordt in Maastricht aan circa 50 clienten terminale thuiszorg toegekend.

Tabel 6.1 geeft het verloop in de traditionele en alpha-hulpverlening weer, waarbij onderscheid gemaakt wordt tussen het aantal clienten per peildatum (einde van de 13de periode, rond 13 december) en het aantal hulpgevallen gedurende het gehele jaar (inclusief nieuwe clienten). De traditionele hulp kende per peildatum in 1975 nog 950 clienten en was geleidelijk teruggelopen tot bijna 900 clienten aan bet begin van 1980. In dat jaar kwam de alpha-hulp in Maastricht tot ontwikkeling, waarvan ook de traditionele hulp aanvankelijk 
Tabel 6.1. Verloop hulpverlening bij traditionele en alpha-hulp

\begin{tabular}{|c|c|c|c|c|c|c|c|c|c|}
\hline & $\$ 980$ & 1981 & 1922 & 1933 & 1904 & 1985 & 1906 & 1987 & 19 g. \\
\hline 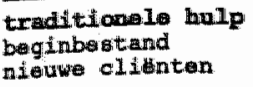 & $\begin{array}{l}895 \\
792\end{array}$ & $\begin{array}{r}1001 \\
578\end{array}$ & $\begin{array}{l}999 \\
565\end{array}$ & $\begin{array}{l}909 \\
594\end{array}$ & $\begin{array}{l}919 \\
547\end{array}$ & $\begin{array}{l}970 \\
484\end{array}$ & $\begin{array}{l}1.2 \\
594\end{array}$ & $\begin{array}{l}978 \\
461\end{array}$ & $\begin{array}{r}1076 \\
556\end{array}$ \\
\hline $\begin{array}{l}\text { bulpgewal lem } \\
\text { afger loten }\end{array}$ & $\begin{array}{r}1677 \\
676\end{array}$ & $\begin{array}{r}1579 \\
580\end{array}$ & $\begin{array}{r}1564 \\
655\end{array}$ & $\begin{array}{r}1503 \\
594\end{array}$ & $\begin{array}{r}1466 \\
487\end{array}$ & $\begin{array}{r}1484 \\
551\end{array}$ & $\begin{array}{r}196 \\
518\end{array}$ & $\begin{array}{r}1439 \\
363\end{array}$ & $\begin{array}{r}1632 \\
533\end{array}$ \\
\hline $\begin{array}{l}\text { eindbatand } \\
\text { \%. } 6 \text {. 65-plus (v) }\end{array}$ & $\begin{array}{l}1001 \\
75,9\end{array}$ & $\begin{array}{r}999 \\
76.4\end{array}$ & $\begin{array}{r}909 \\
77,1\end{array}$ & $\begin{array}{r}919 \\
75,1\end{array}$ & $\begin{array}{r}970 \\
76.4\end{array}$ & $\begin{array}{r}912 \\
79,9\end{array}$ & $\begin{array}{r}978 \\
79\end{array}$ & $\begin{array}{l}1076 \\
33,5\end{array}$ & $\begin{array}{l}1099 \\
85,4\end{array}$ \\
\hline 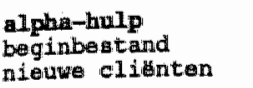 & $\begin{array}{r}32 \\
171\end{array}$ & $\begin{array}{r}180 \\
44\end{array}$ & $\begin{array}{l}179 \\
135\end{array}$ & $\begin{array}{l}277 \\
252\end{array}$ & $\begin{array}{r}466 \\
96\end{array}$ & $\begin{array}{r}490 \\
13\end{array}$ & $\begin{array}{l}379 \\
119\end{array}$ & $\begin{array}{r}426 \\
40\end{array}$ & $\begin{array}{r}0.9 \\
16\end{array}$ \\
\hline $\begin{array}{l}\text { hulpgera } 1 \text { lon } \\
\text { afgea lotan }\end{array}$ & $\begin{array}{r}203 \\
23\end{array}$ & $\begin{array}{r}224 \\
45\end{array}$ & $\begin{array}{r}314 \\
37\end{array}$ & $\begin{array}{r}529 \\
63\end{array}$ & $\begin{array}{r}562 \\
72\end{array}$ & $\begin{array}{l}503 \\
124\end{array}$ & $\begin{array}{l}98 \\
72\end{array}$ & $\begin{array}{r}466 \\
57\end{array}$ & $\begin{array}{r}425 \\
54\end{array}$ \\
\hline $\begin{array}{l}\text { aindbettand } \\
\text { w.w. 65-p1ua( ) }\end{array}$ & $\begin{array}{r}180 \\
89\end{array}$ & 967 & $\begin{array}{r}277 \\
97,1\end{array}$ & $\begin{array}{r}466 \\
78,1\end{array}$ & $\begin{array}{r}490 \\
80,8\end{array}$ & $\begin{array}{r}379 \\
96,3\end{array}$ & $\begin{array}{r}96 \\
97,7\end{array}$ & $\begin{array}{r}409 \\
98,3\end{array}$ & $\begin{array}{c}371 \\
100,0\end{array}$ \\
\hline
\end{tabular}

geprofiteerd lijkt te hebben, omdat er in dat jaar aanmerkelijk meer nieuwe cliênten bij kwamen (ruim 17\% meer dan het jaar daarvoor). Sindsdien loopt de omvang van de traditionele hulp echter weer geleidelijk terug tot thans circa 1500 hulpgevallen per jaar. In de traditionele hulp is het aandeel van ouderen sterk toegenomen: in 1975 nog $70 \%$, in $198076 \%$ en thans ruim $85 \%$. De alpha-hulp is sinds haar introductie in 1979 sterk toegenomen tot bijna 500 cliênten aan het eind van 1984. Sindsdien lijkt echter een zekere verzadiging in de vraag naar deze hulpvorm op te treden. Daarbij speelt sinds 1987 bovendien mee dat er door de wetgeving rond de tweeverdieners nauwelijks nieuwe alphahulpen beschikbaar komen, zodat in 1988 een daling (met 10\%) in de verleende hulp

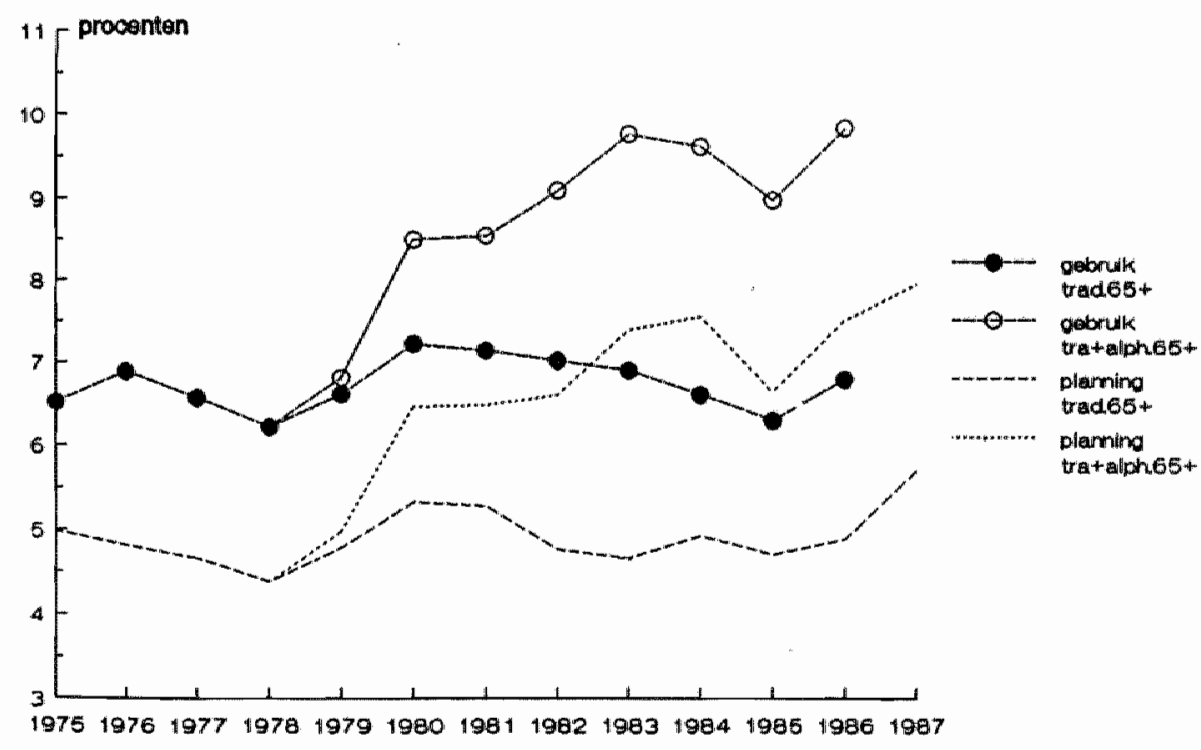

Figuur 6.1. Bereik gezinsverzorging bij ouderen wolgens plannings- en gebruiksdefinitie 
optrad. Door haar aard (puur huishoudelijk) is de alpha-hulp vooral geschikt voor ouderen. Dit blijkt ook uit het alandeel wan ouderen in het clientenbestand: thans zijn zelfs alle clienten van de alpha-hulp 65 jaar of ouder.

In figurir 6.1 wordt het bereik van gezinsverzorging voor ouderen in relatie tot de 65 plussers in de Maastrichtse bevolking sinds 1975 in beeld gebracht, vanaf 1979 inclusief alpha-hulp. Voor de berekening van het bereik zijn twee varianten denkbaar. Indien het aantal clienten per pelldatum (einde dertiende periode) wordt uitgedrukt in procenten van de bevolking (jaarultimo), dan kan gesproken worden van een 'planningsdefinitie' van bereik, die onder andere voor het personeelsbeleid gehanteerd kan worden. Indien men uitgaat van het aantal hulpgewallen per jaar dan is sprake wan een 'gebruiksdefinitie" van bereik (Huijsman en Dolmans, 1988). De verschillen cussen beide bereiksvarianten nemen af naarmate het verloop in her clientenbestand afneemt, met andere woorden als de gemiddelde duur van de hulpverlening toeneemt. Het bereik volgens de gebruiksdefinitie ligt thans op bijna $10 \%$ van alle 65 -plussers, waarvan bijna eenderde de alpha-hulp betreft.

De doorstroming in de gezinsverzorging neemt geleidelijk af (zie tabel 6.1). De hulpverlening per client gaat steeds langer duren, zodat er per jaar steeds minder hulpgevallen worden afgesloten. Er zijn daardoor steeds minder mogelijkheden om nieuwe clienten in zorg te nemen, hetgeen onder meer blijkt uil de oplopende wachttijden bij de traditionele hulp (zie tabel 6.2). Aanvankelijk werden in 1980 nog twee van de drie aanmeldingen binnen een week afgehandeld, maar in 1988 is dat nog maar éen op drie. Wachttijden van een maand of langer zijn dan ook bepaald geen uitzondering meer; zij komen thans bij bijna $30 \%$ van de nieuwe clïnten voor. Bij de ouderen is de wachttijd nog sterker opgelopen; bijna $40 \%$ moet thans een maand of langer wachten.

\subsection{Kenmerken van cliënten}

Als datamateriaal voor de beschrijving en analyse van de clientkenmerken is gebruik gemaakt van (anonieme) individuele clientgegevens wan de Maastrichtse instelling per peildlatum in 1988 (zie Huljsman en Dolmans (1990) voor een vergelijkbare analyse over 1987). Ten behoeve van de financiele afwikkeling met het Ministerie van WVC is deze peildatum een vast gegeven, namelijk het einde van de dertiende periode (van telkens vier weken) van ieder jaar (rond 14 december). Als gevolg van beeindiging van de hulpwerlening en nieuwe inschrijvingen gedurende het jaar, kunnen gegevens per peildatum niet dienen als

Tabel 6.2. Wachttijden bij de traditionele gezinsverzorging

\begin{tabular}{|c|c|c|c|c|c|c|c|}
\hline & 1980 & 1981 & 1982 & 1983 & 1984 & 1985 & 1986 \\
\hline 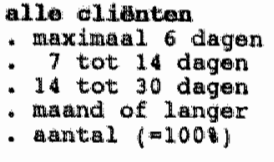 & $\begin{array}{r}64,6 \\
18,3 \\
9,7 \\
8,4 \\
782\end{array}$ & $\begin{array}{r}55,2 \\
23,7 \\
11,1 \\
10,0 \\
578\end{array}$ & $\begin{array}{r}51,7 \\
24,4 \\
12,6 \\
11,3 \\
565\end{array}$ & $\begin{array}{r}61,3 \\
23,1 \\
7,4 \\
8,2 \\
594\end{array}$ & $\begin{array}{r}46,8 \\
21,9 \\
15,2 \\
16,1 \\
547\end{array}$ & $\begin{array}{r}43,2 \\
18,2 \\
16,7 \\
21,9 \\
484\end{array}$ & $\begin{array}{l}35,1 \\
18,2 \\
17,5 \\
29,3 \\
584\end{array}$ \\
\hline 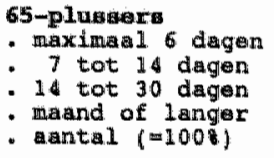 & $\begin{array}{r}49,3 \\
21,4 \\
14,5 \\
14,8 \\
35,1\end{array}$ & $\begin{array}{r}14,9 \\
23,8 \\
14,7 \\
16,6 \\
265\end{array}$ & $\begin{array}{r}36,5 \\
26,9 \\
16,5 \\
20,0 \\
260\end{array}$ & $\begin{array}{r}50,2 \\
28,7 \\
10,1 \\
11,0 \\
317\end{array}$ & $\begin{array}{r}34,5 \\
25,7 \\
17,9 \\
22,0 \\
296\end{array}$ & $\begin{array}{r}32,7 \\
13,6 \\
15,5 \\
38,2 \\
220\end{array}$ & $\begin{array}{r}25,3 \\
18,2 \\
18,5 \\
38,1 \\
336\end{array}$ \\
\hline
\end{tabular}


Tabel 6.3. Cliënten naar leeftijd en bereik in procenten wan de bevolküng onderscheiden naar hulpvorm en burgerlijke staat, december 1988

\begin{tabular}{|c|c|c|c|c|c|c|c|c|c|}
\hline \multirow{2}{*}{\multicolumn{2}{|c|}{$\begin{array}{l}\text { leef- } \\
\text { tijdis- } \\
\text { groep }\end{array}$}} & \multicolumn{3}{|c|}{ leeftifdeverdeling (*) } & \multicolumn{3}{|c|}{ berelk in bevolking (1) } & \multicolumn{2}{|c|}{ Ldem nar burg, btat } \\
\hline & & totand & tradi. & Apha & $\operatorname{totan} 1$ & trad 1. & alpho & gehumd & overigi \\
\hline $\begin{array}{l}55 \\
60 \\
65 \\
70 \\
75 \\
80\end{array}$ & $\begin{array}{l}\leq 54 \\
=59 \\
=64 \\
=89 \\
=74 \\
=79 \\
=84 \\
=85\end{array}$ & $\begin{array}{r}7,8 \\
1,5 \\
2,3 \\
8,8 \\
15,9 \\
25,6 \\
22,8 \\
14,9\end{array}$ & $\begin{array}{c}10,2 \\
1,7 \\
2,8 \\
9,4 \\
13,3 \\
22,3 \\
22,4 \\
17,4\end{array}$ & $\begin{array}{r}0,8 \\
0,8 \\
0,6 \\
7,0 \\
23,7 \\
35,2 \\
24,2 \\
7,5\end{array}$ & $\begin{array}{r}0,1 \\
0,3 \\
0,5 \\
2,4 \\
5,5 \\
11,5 \\
16,3 \\
15,7\end{array}$ & $\begin{array}{r}0,7 \\
0,3 \\
0,5 \\
1,9 \\
3,4 \\
7,5 \\
11,9 \\
19,7\end{array}$ & $\begin{array}{l}0,0 \\
0,0 \\
0,0 \\
0,5 \\
2,1 \\
4,0 \\
4,4 \\
2,0\end{array}$ & $\begin{array}{r}0,2 \\
0,2 \\
0,2 \\
1,0 \\
2,8 \\
7,9 \\
12,9 \\
14,0\end{array}$ & $\begin{array}{r}0,1 \\
0,8 \\
1,4 \\
4,9 \\
9,4 \\
1,3,8 \\
16,9 \\
14,9\end{array}$ \\
\hline \multicolumn{2}{|c|}{$65-p 1 u$} & 60,4 & 85,2 & 97,8 & 7,9 & 5,7 & 2,2 & 3,9 & 11,6 \\
\hline \multicolumn{2}{|c|}{ Tot.aantal } & $1 \quad 1462$ & 1090 & 372 & & & & 405 & 1057 \\
\hline
\end{tabular}

maatstaf woor de totale hulpverlening op jaarbasis. Voor inzicht in de situatie en kenmerken van clienten is het materiaal wel zeer goed bruikbaar. Afzonderlijk wordt tevens gekeken naar de kenmerken van clienten bij wie de hulp in de loop van het jaar is betindigd. In de analyse is ten eerste gekeken naar de achtergrondkenmerken van clienten, zoals de leeftijd, de samenstelling van het huishouden en het inkomen. Ten tweede worden de omvang, de reden(en) en de duur van de hulpverlening nader onderzocht.

\section{Leeftijdsverdeling en bereik in procenten van bevolking}

Tabel 6.3 geeft de leeftijdsverdeling van het clientenbestand en het leeftijdsspecifieke bereik in procenten van de Maastrichtse bevolking. Hieruit blijkt dat de leeftijdscategorieen $75 \mathrm{t} / \mathrm{m}$ 84 jaar (bij traditionele hulp) en $70 \mathrm{t} / \mathrm{m} 79$ jaar (bij alpha-hulp) de belangrijkste zijn. Veronderstellend dat veel redenen woor het aanvragen van hulp van gezinsverzorging (zie ook hierna) leeftijdsspecifiek zijn, zal de dubbele vergrijzing leiden tot een grotere hulpvraag. Het dubbele karakter van vergrijzing zal de gesuggereerde toename van de hulpvraag nog versterken. De bereikcijfers zijn immers het hoogst bij ouderen vanaf 80 jaar.

\section{Samenstelling huishouden}

Het merendeel der clienten is alleenstaand, dat wil zeggen ongehuwd, gescheiden of verweduwd. Bij de alpha-hulpwerlening is het aandeel van alleenstaanden met $75 \%$ het grootst. Bij traditionele hulp is het percentage alleenstaanden 'slechts' 65\%. In totaal is $67,8 \%$ van alle clienten alleenstaand. Bij alleenstaanden is de hulpvorm in belangrijke mate de alpha-hulp en liggen de bereikcijfers in procenten wan de bevollking (zie tabel 6.3) hoger dan bij de gehuwden of samenwonenden. Dit is onder andere te verklaren wit het feit dat een aanwezige partner vaak mantekorg verleent waardoor een beroep op de gezinsverzorging (vooralsnog) achterwege kan blijven (Belleidsbrief Ouderenbeleid, TK, 1983/1984). De maatschappelijke trend betreffende individualisering zou tot een afuame van de mantelzorg kunnen leiden en daarmee tot een grotere vraag naar professionele hulp (STG, 1985).

\section{Redenen van hulpvraag}

Tabel 6.4 is een weergave van de redenen voor de hulpwraag gesplitst naar leeftijd. De twee belangrijkste redenen voor bulpverlening zijn de aanwezigheid van respectievelijk lïchamelijke handicaps en langdurige ziekte. Het onderscheid tussen langdurige en kortstondige ziekte wordt door de gezinsverzorging gelegd bij 6 maanden. De aanwezigheid van een lichamelijke handicap onderscheidt zich van langdurige ziekte door het permanente en stabiele karakter van de handicap. Het proces bij langdurige ziekte daarentegen is veelal 
Tabel 6.4* Reden wan hulpverlening procentuele verdelling per leeftidscategorie wan de oudat geindliceerde in het huishouden

\begin{tabular}{|c|c|c|c|c|c|c|c|c|c|}
\hline aulpredenen & 354 & $5.5-59$ & $60-54$ & $65-69$ & $70-76$ & $75-79$ & $80-84$ & 285 & Totaal \\
\hline 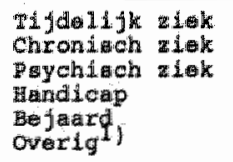 & $\begin{array}{l}22,8 \\
29,8 \\
14,9 \\
15,7 \\
15,8\end{array}$ & $\begin{array}{r}13,6 \\
27,3 \\
4,5 \\
40,9 \\
9,1\end{array}$ & $\begin{array}{r}20,6 \\
41,2 \\
17,6 \\
11,8 \\
4,5 \\
8,9\end{array}$ & $\begin{array}{r}1.4,0 \\
29,6 \\
4,7 \\
48,1 \\
3,1 \\
1,6\end{array}$ & $\begin{array}{r}3,4 \\
21,0 \\
6,4 \\
63,1 \\
2,1 \\
2,6\end{array}$ & $\begin{array}{r}5,3 \\
24, \frac{1}{3} \\
3,7 \\
6,6 \\
1,6\end{array}$ & $\begin{array}{r}5,1 \\
23,7 \\
3,3 \\
54,5 \\
12,3 \\
1,2\end{array}$ & $\begin{array}{r}2,8 \\
30,7 \\
4,1 \\
46,8 \\
13,8 \\
1,8\end{array}$ & $\begin{array}{r}7,2 \\
25,8 \\
5,4 \\
51,0 \\
7,5 \\
3,1\end{array}$ \\
\hline Ament libnten & 114 & 22 & 34 & 129 & 233 & 374 & 334 & 218 & 1462 \\
\hline
\end{tabular}

1) wamgerehap, wheiding, sterfgeval, overbelagting en opname

in beweging. Lichamelijke handicaps blijken de meest frequente reden bij ouderen te zijn, terwijl bij jongere clienten de reden langdurige ziekte het hoogste scoort (30\%). Ook bij de jongste clientengroep (tot 55 jaar) komt een lichamelijke handicap als hulpreden echter nog vrij vaak voor $(17 \%)$. Grofweg kan men stellen dat de hulpredenen bij 65-plus vallen onder de noemer handicaps en dat de hulpredenen voor de overige leeftijdsgroepen vallen onder de noemer ziekten (tijdelijk, chronisch of psychisch). Deze verschillen tussen clienten onder en boven de leeftijdsgrens van 65 jaar zijn bovendien significant $\left(\chi^{2}=98,8 ; \mathrm{p}<0,01\right)$.

\section{Inkomenswerdeling van gezinsverzorgingscliënten}

Het netto inkomen van de clienten van alpha-hulp (gezinnen $f$ 1741,- en alleenstaanden $f$ 1200,- per maand) ligt iets lager dan dat van de cliênten van traditionele hulp (gezinnen $f$ 1774,- en alleenstaanden $f 1233,-$, wellicht vanwege het feit dat de alpha-hulp bijna uitsluitend ouderen betreft, die relatief een enigszins lager inkomen hebben. De inkomenswerschillen tussen de beide hulpvormen zijn echter niet significant. Vergelijking met nationale gegevens met betrekking tot de inkomensverdeling van gezinsverzorgingsclienten in 1986 (FOGM 1988, TK, 1987/1988) laat zien dat de Maastrichtse inkomensverdeling voor gezinnen en alleenstaanden vrijwel parallel loopt met de nationale verdeling en derhalve representatief geacht mag worden (Huijsman en Dolmans, 1988). De draagkracht van de clienten van de gezinsverzorging is, zoals ook uit de hier gepresenteerde gegevens blijkt, in het algemeen laag (Kwekkeboom, 1985; Zijde, 1985). Bij 30\% van alle clienten ligt het inkomen beneden de ondergrens van de retributietabellen. Deze clienten betalen het mini-

Tabel 6.5. Duur van zorgverlening In procentuele verdeling per leeftijdsgroep van de oudst geindiceerde en gemiddeld

\begin{tabular}{|c|c|c|c|c|c|c|c|c|c|}
\hline & 95 & $55-5,9$ & $60-64$ & $65-69$ & $70-74$ & $75-79$ & $80-84$ & $z 85$ & totadil \\
\hline 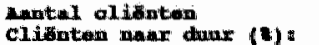 & 114 & 22 & 34 & 129 & 233 & 374 & 334 & 218 & 1462 \\
\hline 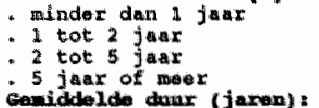 & $\begin{array}{l}43,9 \\
27,2 \\
14,9 \\
14,9\end{array}$ & $\begin{array}{r}36,4 \\
31,8 \\
9,1 \\
22,7\end{array}$ & $\begin{array}{r}29,4 \\
29,4 \\
29,4 \\
1.8\end{array}$ & $\begin{array}{l}31,8 \\
16,3 \\
34,1 \\
17,8\end{array}$ & $\begin{array}{l}16,7 \\
14,2 \\
38,2 \\
30,9\end{array}$ & $\begin{array}{l}16,3 \\
20,3 \\
3.1,6 \\
31,6\end{array}$ & $\begin{array}{l}18,0 \\
19,2 \\
29,3 \\
33,5\end{array}$ & $\begin{array}{l}27,4 \\
29,7 \\
28,0 \\
34,9\end{array}$ & $\begin{array}{l}21,0 \\
191,7 \\
30,0 \\
29,3\end{array}$ \\
\hline 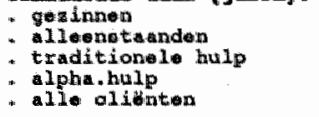 & $\begin{array}{l}1,8 \\
3,6 \\
2,1 \\
3,5 \\
2,2\end{array}$ & $\begin{array}{l}1,4 \\
4,2 \\
3,0 \\
2,0 \\
2,9\end{array}$ & $\begin{array}{l}3,7 \\
2,2 \\
2,7 \\
2,7\end{array}$ & $\begin{array}{l}2,7 \\
2,9 \\
2,5 \\
4,3 \\
2,9\end{array}$ & $\begin{array}{l}3,3 \\
3,5 \\
3,2 \\
4,6 \\
3,7\end{array}$ & $\begin{array}{l}3,4 \\
4,1 \\
3,4 \\
4,6 \\
3 ;, 9\end{array}$ & $\begin{array}{l}3,2 \\
4,4 \\
3,9 \\
4,9 \\
4,2\end{array}$ & $\begin{array}{l}2,7 \\
4,7 \\
4,3 \\
5,5 \\
4,5\end{array}$ & $\begin{array}{l}2,8 \\
4,1 \\
3: 7 \\
4,7 \\
3: 7\end{array}$ \\
\hline
\end{tabular}

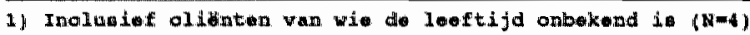


mumtarief van $f 3$-per week, ongeacht de hulpomvang. Ter verdere illustratie kan vermeld worden dat $65 \%$ van de oudere clienten (65-plus) de AOW als maximum inkomen heef. Aangezien het inkomen de grondslag is voor de eigen bijdragen in de kosten van hulpverlening, zal de vergrijzing en verdere individualisering van de bevolking kunnen leiden tot wen grotere bulpvraag bij een gemiddeld lager inkomen (bij constant blijvende andere factoren).

\section{Duur van hulprerlening}

Het ligt voor de hand te veronderstellen dat naarmate de leeftijd stijgt de hulpduur toeneemt. De reden lichamelijke handicap is immers de meest voorkomende reden bij ouderen. Idealiter moet de hulpduur gemeten worden bij de afgesloten gevallen, maar door de recente datum van automatisering is hun aantal nog te gering om betrouwbare analyses uit te woeren. Dit betekent dat de gepresenteerde cijfers met betrekking tot hulpduur (tabel 6.5) te laag berekend zijn en dat de werkelijke hulpduur langer is. Slechts $21 \%$ is korter dan éen jaar in zorg (de gemiddelde hulpduur is 3,7 jaar). De bulpduur stijgt naarmate de leeftijd toeneemt ( 2,2 jaar bij jonger dan 55 jaar en 4,5 jaar bij 85 -plus). Deze significante positieve samenhang met leeftijd $\left(\chi^{2}=2362,2 ; p<0,001\right)$ komt ook bij traditionele en alpha-hulp afzonderlijk naar voren. De hulpduur bij alleenstaanden $(4,1$ jaar) is anderhalf keer zo lang als bij gezinnen $(2,8$ jaar $)$ en cok dit verschil is significani $\left(x^{2}=66,8\right.$; $\mathrm{p}<0,01)$. Dit is wellicht te verklaren uit het feit dat de partners elkảar tot op zekere hoogte kunnen verzorgen (mantelzorg). Hierdoor kan de vraag naar professionele hulp uitgesteld worden, of kan weer eerder worden teruggevallen op de informele zorg waardoor de hulpduur van professionele hulpverlening verkort kan worden (Zorg voor Ouderen, TK, 1985/1986; Beleidsbrief Ouderenbeleid, TK, 1983/1984; STG, 1985).

\section{Omvang van de hulpverlening in uren per week}

Voor het aantal uren hulp per week hanteert de gezinsverzorging drie kengetallen, namelijk de geindiceerde uren, de toegewezen uren en werkelijke verleende (produktieve) uren (zie figuur 6.2). De gelindiceerde uren komen tot stand door tijdens de 'intake' de clientsituatie zo objectief mogelijk te analyseren met behulp van het landelijke indicatie- en registratiesysteem (LIER-systeem). Vervolgens wordt gekeken of de geindiceerde uren feitelijk gegeven kunnen worden en of de client dat ook wenst. Het is immers goed voor te stellen dat de client maar eén keer per week een "vreemde" in huis wil hebben in plaats van drie keer. Daarnaast zal de instelling rekening moeten houden met personele en financiele restricties. Ook kan de werkmethodiek van invloed zijn (groeps/wijkbejaardenzorg of zorg-op-maat). Deze afwegingen tezamen resulteren in de toegewezen uren. Het feitelijk aantal uren verleende hulp wijkt hier echter sterk van af. De redenen hiervoor zijn samen te vatten met

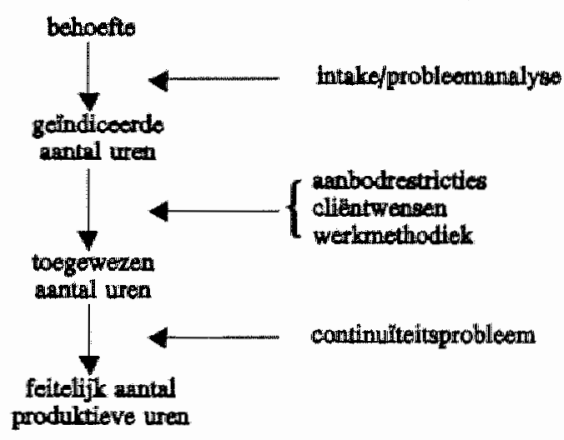

Figuur 6.2. De totstandkoming van uren hulpverlening 
Tabil 6.6. Verloop wan de geindiceerde, toegewezen en produktieve uren naar leeftjd (gemiddeld wantal uren per cliént per week)

\begin{tabular}{|c|c|c|c|}
\hline Letedja & gelndicend & toegewezen & produktief \\
\hline $\begin{array}{r}\leq 54 \\
55-64 \\
65=74 \\
75=79 \\
80=84 \\
85-69 \\
=90\end{array}$ & $\begin{array}{r}13,5 \\
7,2 \\
6,3 \\
6,0 \\
6,4 \\
6,8 \\
10,6\end{array}$ & $\begin{array}{r}12,6 \\
7,0 \\
6,0 \\
5,9 \\
6,2 \\
6,9 \\
9,9\end{array}$ & $\begin{array}{r}7,3 \\
4,9 \\
4,4 \\
4,6 \\
4,9 \\
5,5 \\
7,4\end{array}$ \\
\hline Totand & 7,0 & 15,8 & 5,0 \\
\hline
\end{tabular}

het begrip 'continuiteitsprobleem'. Hieronder verstaat men het wegvallen van beschikbare urencapaciteit door wrije tijd, arbeidstijdverkorting, bijzonder verlof en ziekteverzuim van het personeel. Dit probleem wordt ten dele opgevangen met vakantie- en oproepkrachten.

In tabel 6.6 wordt het verloop van geindiceerde, toegewezen en produktieve uren weergegeven voor de verschillende leeftijdscategoriedn. De produktieve uren blijken gemiddeld $27,1 \%$ lager dan de gelndiceerde uren. De hierboven geformuleerde hypothese met betrekking tot de relatie tussen leeftijd en aantal hulpuren blijkt maar gedeeltelijk juist te zijn. Clienten jonger dan 55 jaar ontvangen, na 90 -jarigen, de meeste uren hulp per week, terwijl bij deze groep de duur van de hullp het kortst is $(2,2$ jaar). Blijkbaar is hier sprake van veel hulp in een relatief korte periode aan een relatief kleine groep met de laagste bereikcijfers. Uit tabel 6.6 blijkt wel dat 80 -plussers meer uren hulp per week ontvangen dan de leeftijdscategorie $65 \mathrm{t} / \mathrm{m} 79$ jaar. Binnen de categorie 65 -plussers blijkt de gemaakte veronderstelling ten aanzien van het positieve verband tussen leeftijd en omvang van de hulp wel van toepassing te zijn (Pearson's $r=0,12 ; p<0,001$ ).

De toegewezen uren omvatten $96,5 \%$ van de gelindiceerde uren. Bij de allerjongste en alleroudste cliënten is dit enigszins lager. Waarschijnlijk spelen in de hoogste leeftijdscategorie problemen aan clientzijde of heeft intussen intramurale opname plaatsgevonden. Het gemiddeld aantal toegewezen uren bedraagt 6,8 uur. Naar hulpworm is dat gemiddeld 7,9 uur voor traditionele hulp en 3,7 uur voor alpha-hulp. Dit verschil is significant $(t=20,0$; $\mathrm{p}<0,001)$. Het verschil tussen de toegewezen en produktieve uren hulp is gemiddeld $26,5 \%$. Dit continufteitsprobleem blijkt in de praktijk met name ten laste te komen van de jongste leeftijdsgroepen en bedraagt daar $42 \%$. Bij alpha-hulp zijn de verschillen aanzienlijk kleiner. Het verschil tussen feitelijk verleende en toegewezen uren (die gelijk zijn aan geindiceerde uren) bedraagt gemiddeld slechts $13,5 \%$. Ook hier zijn de verschillen het grootst bill de allerjongsten ( $40 \%$ ) en de alleroudste clienten ( $25 \%$ ).

\subsection{Beëindiging van hulp van de gezinsverzorging in 1988}

Dankzij de automatisering bestaat voor het eerst de gelegenheid om de hulpverlening en kenmerken van clienten bij wie de hulp van de gezinsverzorging beeindigd is, nader te analyseren. De gegevens voor 1987 waren niet in voldoende aantal en mate van betrouwbaarheid voorhanden. In 1988 is bij 614 clienten de hulp afgesloten. Analoog aan het voorgaande wordt een analyse gemaakt van hun kenmerken en de aard en omvang van de hulp die zij gekregen hebben en over welke termijn. Daarbij gaat de interesse met name uit naar verschillen met clienten bij wie hulp aen het eind van 1988 nog voortduurde $(N=1462)$. 
Tabell 6.7. Leeftijd en sexe van afgesloten en nog lopende cliènten

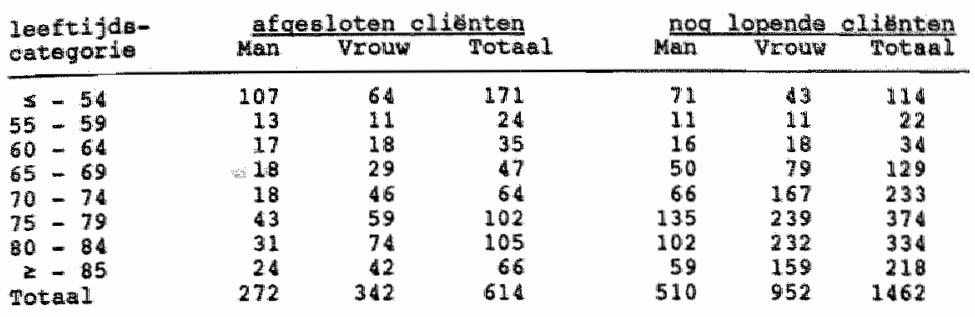

\section{Leeftidd en sexe}

Tabel 6.7 geeft de leeftijds- en geslachtswerdeling weer voor afgesloten en lopende clienten. Tussen beide groepen treden de volgende verschillen op. Bij de afgesloten hulpgevallen komen relatief veel mannen voor $(44,3 \%$ versus $34,9 \%)$ en relatief veel jonge clienten: $27,9 \%$ van de afgesloten en $7,8 \%$ van de nog lopende gevallen is jonger dan 55 jaar. Ook binnen de categorie vanaf 65 jaar gaat dit op: afgesloten clienten zijn gemiddeld jonger dan nog voortdurende hulpgevallen. De uitzondering hierop betreft de groep 85 -plussers: hun aandeel bij de afgesloten 65-plussers $(17,1 \%)$ is groter dan bij de nog lopende 65-plussers $(16,9 \%)$. Voor een belangrijk deel zijn de geschetste verschillen te verklaren uit de samenstelling wan het huishouden. Alleenstaanden komen relatief vaak voor bij lopende situaties $(70,9 \%)$ en gezinnen daarentegen bij afgesloten hulpgevallen $(44,3 \%)$. De hulpduur is derhalve bij gezinnen (relatief jongere clienten waaronder ook meer mannen zijn) korter dan bij alleenstaanden. De volgende paragraaf gaat dieper in op de verschillen in gezinssamenstelling.

\section{Samenstelling van het huishouden}

De afgesloten en nog lopende hulpgevallen vertonen saillante verschillen naar burgerlijke staat en samenstelling van het huishouden. Deze zijn in tabel 6.8 in beeld gebracht, tussen haakjes is vermeld hoeveel procent van de betreffende clientgroep 65 jaar of ouder is. Het aandeel van gezinnen is bij de afgesloten cases met $45,4 \%$ aanzienlijk groter dan bij de nog aanwezige clienten. Bij de gezinnen is de leeftijd ook aanzienlijk lager: $35,1 \%$ is blf afsluiting minstens 65 jaar en bij voortdurende hulpsituaties is dit ruim twee maal zo veel $(73,9 \%)$. Voortdurende hulpgevallen zijn vaker verweduwd $(45,6 \%$ versus $34,4 \%)$ of ongehuwd $(20,9 \%$ versus $17,4 \%)$ en minder vaak gehuwd of samenwonend $(27,7 \%$ versus $38,4 \%)$ of

Tabel 6.8. Huishoudsamenstelling van afgesloten en nog lopende cliếnten (tussen haakjes aandeel $65+$ )

\begin{tabular}{|c|c|c|c|c|}
\hline & \multicolumn{2}{|c|}{ afgesloten $(\mathbb{N}=61 \mathbb{1})$} & \multicolumn{2}{|c|}{ nog lopend $(N=1462)$} \\
\hline $\begin{array}{l}\text { gezimnen } \\
\text { lleenstaand }\end{array}$ & $\begin{array}{l}279 \\
335\end{array}$ & $\begin{array}{l}(35,1) \\
(85,7)\end{array}$ & $\begin{array}{r}425 \\
1037\end{array}$ & $\begin{array}{l}(73,9) \\
(94,3)\end{array}$ \\
\hline $\begin{array}{l}\text { gehuwd/samenw. } \\
\text { ongehuwd } \\
\text { gescheiden } \\
\text { verweduwd }\end{array}$ & $\begin{array}{r}236 \\
107 \\
60 \\
211\end{array}$ & $\begin{array}{l}(41,1) \\
(78,5) \\
(26,7) \\
(89,1)\end{array}$ & $\begin{array}{r}405 \\
305 \\
86 \\
666\end{array}$ & $\begin{array}{l}(79,6) \\
(87,9) \\
(69,8) \\
(96,2)\end{array}$ \\
\hline
\end{tabular}




\begin{tabular}{|c|c|c|}
\hline & afgesoten $(\mathrm{N}=64)$ & 1opend $(N=1462)$ \\
\hline 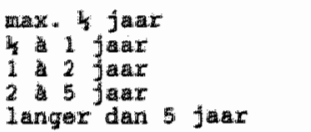 & $\begin{array}{l}43,00 \\
16,18 \\
15,58 \\
14,28 \\
11,20\end{array}$ & $\begin{array}{r}11,5 \\
9,51 \\
19,7 \% \\
39,0 \\
29,3\end{array}$ \\
\hline 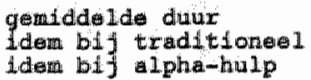 & $\begin{array}{l}1,8 \text { jaar } \\
1,5 \text { jaar }(N=553) \\
4,5 \text { jaar }(k=61)\end{array}$ & $\begin{array}{l}3,8 \text { jaar } \\
3,5 \text { jaar }(w=1090) \\
4,7 \text { jaar }(w=372)\end{array}$ \\
\hline
\end{tabular}

gescheiden $(5,9 \%$ versus $9,8 \%)$. Het aandeel van 65 -plus is over de gehele linie bij de afgesloten gevallen lager dan bij de lopende situaties. Vooral bij gehuwde en gescheiden clienten zijn de verschillen aanzienlijk.

\section{Duur wan de hulpverlening}

Indien de duur van de hulpverlening gemeten wordt bij per peildatum aanwezige clienten zoals in de vorige paragraaf gebeurd is, blijft de kortdurende hulpverlening door gezinsverzorging buiten beeld. Om een beter inzicht te krijgen in de hulpduur, dienen zowel de afgesloten als de nog lopende clientgevallen afzonderlijk geanalyseerd te worden. Tabel 6.9 laat zien dat de afgesloten hulpsituaties beduidend korter in zorg waren dan de nog voortdurende gevallen. Het verschil bedraagt gemiddeld 2 jaar en wordt met name veroorzaakt door de kortdurende hulpverlening. Bij de afsluitingen duurden 6 op de 10 gevallen maximaal een jaar ( $43 \%$ slechts maximaal een half jaar), terwijl bij de nog lopende gevallen 6 op de 10 cliênten al twee jaar of langer in zorg zijn. De verdere onderverdeling van de gemiddelde hulpduur naar hulpvorm laat zien dat de verschillen met name gelokaliseerd zijn bij de traditionele gezinsverzorging. Bij alpha-hulp, die gemiddeld langer duurt dan traditionele zorg, zijn de verschillen verwaarloosbaar.

\subsection{Analyse van activiteiten gezinsverzorging en relatie met hulpomvang}

\subsubsection{Inleiding}

Tijdens het intake-gesprek met de client wordt een uitvoerige inventarisatie gemaakt van de uit te voeren taken. Hiervoor wordt de standaardlijst van het LIER-systeem gebruikt (zie bijlage), dat drie categoriestn activiteiten onderscheidt. Ten eerste is er de categorie huishoudelijke verzorgende taken, waaronder de organisatie en uitvoering van huishoudelijke werkzaamheden (licht en zwaar), maaltijdverzorging, verzorging van kleding en linnengoed en boodschappen doen. In totaal betreft deze categorie 15 taken. De tweede groep activiteiten betreft hulp bij of zorg voor algemeen dagelijkse levensverrichtingen, zoals aan- en uitkleden, wassen, eten, medicijngebruik en ziekenverzorging. Er worden in totaall 7 taken onderscheiden. De derde categorie vitvoerende taken ligt op het terrein van de (sociale) begeleiding, bijvoorbeeld in de vorm van het besturen van het totale huishouden, het bezighouden, begeleiden of zelfs opvoeden van de kinderen, het verlenen van psychische steun en dergelijke. Deze categorie telt in totaal 20 activiteiten. De leidsterstaken (bijvoorbeeld instructie, verwijzing, ondersteuning en dergelijke) zijn hierbij inbegrepen. 
De hulp kan twee vormen aennemen: of er wordt bij de activiteliten ondersteunende hulp gegeven waarbij de client en zijn/haar eventuele gezin zoveel mogelijk zelistandig blift, of de betreffende ta(a)k(en) wordt geheel overgenomen door de gezinsverzorging. Bij een aantal begeleidende of sociale taken is alleen het laatste mogelijk.

In deze paragraaf wordt langs statistische weg de samenhang tussen de aitvoerende taken geanalyseerd. Daarbij wordt zowel per categorie als voor het totaal bekeken of het mogelijk is de veelheid van in het LIER-systeem onderscheiden taken terug te brengen tot een beperkt aantal dimensies van hulpverlening. In principe kan de hypothese geformuleerd worden dat de bovenbeschreven drie categoriedn ook langs statistische weg (hier via factoranalyse) teruggevonden dienen te worden. Vervollgens wordt onderzocht of de drie categorieen ook afzonderlijke dimensies van hulpverlening vertegenwoordigen of dat zij meer in elkaars verlengde liggen. Tenslotte wordt beoogd om hiermee de omvang van hulpverlening door de gezinsverzorging te verklaren.

\subsubsection{Dimensies van hulpverlening, afzonderlijk bezien}

In deze subparagraaf gaan wij in op de eerste vraag: zijn de verschillende taken uit het LIER-systeem samen te voegen tot een beperkt aantal dimensies van hulpverlening? Ter beantwoording van deze vraag worden eerst de drie taakcategoriebn afzonderlijk bezien en wordt via factoranalyse de samenhang tussen de mogelijke activiteiten onderzocht. Vervolgens wordt de validiteit van eventuele scha(a)li(en) onderzocht en wordt een keuze gemaakt voor het aantal uiteindelijke schalen (aspecten) per onderscheiden categorie. Tenslotte worden deze schalen bijeengebracht om het aantal dimensies van hulpverlening te bepalen. In de hierna volgende analyses heeft bij de 35 (uitgezonderd de 7 leidsterstaken) mogelijke taken een hercodering plaatsgevonden. Indien de gezinsverzorging bij een activiteit niets ondersteunt of overneemt, is de score nul; wordt er geholpen dan is de score een half en wordt de betreffende activiteit geheel door de gezinsverzorging overgenomen dan is de score een. In de analyse wordt het totale bestand betrokken (inclusief afgesioten hulpsituaties; $N=2076$ ).

Bij de huishoudelijke verzorgende taken (oorspronkelijk 15 activiteiten) worden via factoranalyse vijf verschillende aspecten gevonden met een totale verklaarde variantie van $69,7 \%$. Deze factoren bestaan uit:

1. organisatie huishoudelijke werkzaamheden en alle werkzaamheden maaltijdverzorging (totaal 6);

2. wassen en strijken;

3. verzorging kleding, verstelwerk en planten/huisdieren;

4. dagelijkse en periodieke boodschappen;

5. licht en zwaar huishowdelijk werk.

Globaal wordt derhallve dezelfde indeling teruggevonden zoals die in thet LIER-systeem wordt gehanteerd in de zes subcategorieen voor huishoudelijk verzorgende taken. Daarop zijn twee uitzonderingen: (a) organisatie en (b) maaltijdverzorging worden samengevoegd in ến aspect (factor 1), maar (c) de verzorging van kleding en linnengoed wordt juist uiteengelegd in twee factoren (2 en 3). Factoranalyse op de zes oorspronkelijke subcategoriežn laat zien dat deze onderdeel wan éen en dezelfde factor zijn, maar de verklaarde variantie is dan aanzienlijk lager $(43,3 \%)$. De schaalbaarheid is alleszins goed: de alpha-coefficient bedraagt 0,86 voor de 15 afzonderlijke items of 0,73 voor de zes subcategorieen. Eventuele verbeteringen zijn slechts zeer marginaal (tweede decimaal van alpha-coefficient).

De verzorgende hulp ten aanzien van kinderen en/of volwassenen is de tweede categorie die door de gezinsverzorging wordt onderscheiden en betreft hulp of zorg bij algemeen dagelijkse activiteiten (ADL). De factor-analyse leidt tot twee factoren die precies de 
corspronkelijke indeling volgen: hulp voor kinderen als een factor en alle ADL-ittems voor volwassenen als tweede factor. De verklaarde variantie bestaat $56,4 \%$ van de totale variantie tussen de dienten. Gezien hel feit dat de eerste factor (kinderen) voor onze onderzoekspopulatie niet of nauwelijks relevant is, wordt deze categorie in $z^{x} n$ geheel ais een dimensie beschouwd. Weglaten van de eerste factor leidt tot verbetering van de alphacoefficient van 0,72 naar 0,78 . Hiermee resteert de ADL-schaal, die vooral voor ouderen relevant is.

De derde categorie betreft de begeleidende, sociale activiteiten. Via factoranalyse worden wit de 13 mogelijke taken vijf factoren gedestilleerd, die de oorspronkelijke onderverdeling a t/m I (zie bijlage) vrijwel exact volgen. De enige uitzondering betreft het feit dat de sfeerscheppende taken (c) en eventuele werkbezoeken aan buitenshuis verpleegden (d) worden samengevoegd tot een factor. De totale verklaarde variantie is $67 \%$. Indien de factoranalyse wordt uitgevoerd met de oorspronkelijke zes subcategorieen dan worden twee factoren gevonden, waarbij de tweede factor bestaat uit het werkbezoek aan een buitenshuis verpleegd lid van het clienthuishouden en de subcategorie met betrekking tot de kinderen. Omdat beilde taken voor ouderen minder relevant zijn (vaak alleenstaand en geen thuiswonende kinderen), wordt de sociale begelliding in het vervolg als een dimensie beschouwd. De schaalbaarheid is goed ( $\alpha=0,67$ voor alle 13 items).

Naast de hierbowen beschreven categorieln voor de direct uütvoerende werkzaamheden, wordt via het LIER ook gefnventariseerd welke leid(st)erstaken eventueel in de begeleidende sfeer nodig zijn. Via factoranalyse wordt duidelijk dat dit zeer uiteenlopende taken zijn. Er worden drie factoren berekend:

1. instrueren van direct uitwoerenden, het probleembewust maken van de gezinsverzorgenden en het helpen veranderen van de clientsituatie;

2. toezicht op de hulpverlening en ondersteunen of helpen verwerken van de problematiek ten gunste van het uitvoerend personeel;

3. het verwijzen naar en samenwerken met andere disciplines.

De verkJaarde variantie op clientniveau is met $55,5 \%$ ten opzichte van de eerder beschreven analyses vrij laag. De schaalbaarheid is volgens Cronbach's alpha van 0,46 eveneens laag, maar niet verder te verbeteren.

Uit het voorgaande kan geconcludeerd worden dat de in het LIER opgenomen taken ook in de (statistische) praktijk consistent in te delen zijn in drie categorie ${ }^{n}$. Binnen elk der categorieen wordt ook de verdere rubricering middels factoranalyse gereproduceerd. Slechts op enkele punten voldoet het datamateriaal niet aan de LIER-categorieen, doch dit betreffen slechts kleine afwijkingen. Belangrijke uitzondering hierop betreft de grote diversiteit in de niet direct-uitvoerende taken van de leid(st)ers gezinsverzorging. De analyse lakat zien dat de zeven taken maar liefst drie verschillende terreinen lijken te bestrijken en derhalve niet tot een noemer zijn terug te voeren. De reden hiervoor is gelegen in het feit dat de leid(st)erstaken de begeleiding betreffen van zowel het uitvoerend personeel als van de (meer gecompliceerde) clientsituaties (sociale begeleiding).

\subsubsection{Dimensies van hulp en de invloed op aard en omvang van hulp}

Aansluitend op voorgaande analyses van mogelijke dimensies in de hulpverlening wordt de facioranalyse toegepast op de drie hoofdcategorieen, waarbij cok de afzonderlijke taken betrokken worden ( 6 mal huishoudelijk, 2 maal verzorgend en 6 maal begeleidend) en de leid(st)erstaken. Er worden vier factoren afgeleid (zie tabel 6.10):

1. alle huishoudelijke taken, uitgezonderd de eerste (organisatie);

2. organisatie van het huishouden plus ADL-taken volwassenen plus de derde (sfeerscheppende) begeleidingstaak;

3. de totale zorg voor en begeleiding, opvoeding e.d. van kinderen, aangevuld met. werkbezoek buitenshuis (de verpleegde moeder!); 
Tabel 6.10. Dimensles van hulpverleaing $(\mathrm{N}=2110)^{*}$

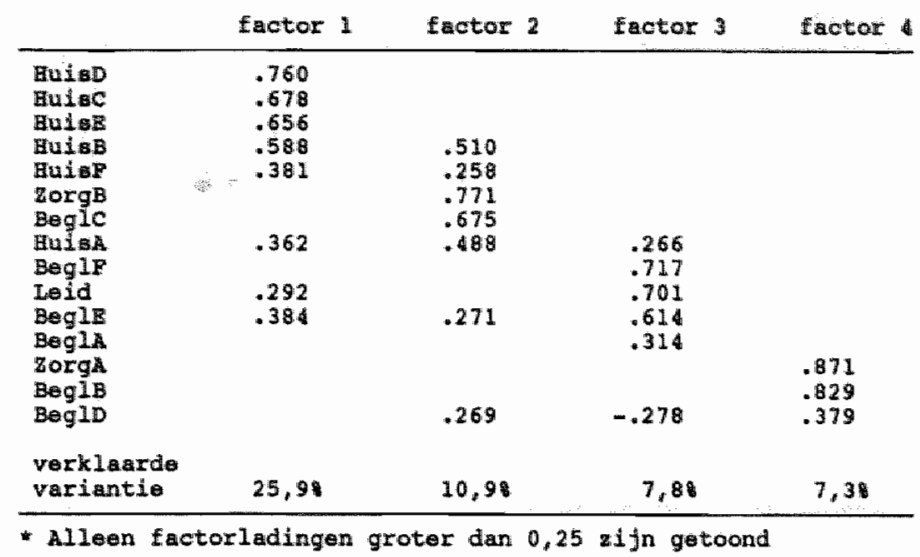

4. de resterende begeleidende taken (besturen van huishouden, psychische steun en helpen veranderen van clientsituatie) en de leid(st)erstaken.

Grosso modo worden de volgende dimensies teruggevonden: (a) huishoudelijke hulp; (b) ADL-hulp voor volwassenen; (c) hulp ten behoeve van kinderen en (d) sociale begeleiding en leiding. De totaal verklaarde variantie bedraagt $52 \%$ en Cronbach's alpha is 0,77 .

\subsubsection{Verklaring van de verstrekte hulp}

De volgende onderzoeksvraag die thans uitgewerkt wordt betreft de vraag of de aard, omvang en duur van de hulpverlening verklaard kunnen worden uit de scores op de hierboven afgeleide dimensies van hulpverlening. Deze dimensies onderscheiden wij in twee vormen, namelijk de oorspronkelijke categorietn uit het LIER-systeem en de (eveneens vier) statistische factoren uit het voorgaande. Voor elke dimensie wordt de somscore van de samenstellende items gebruikt als schaalscore. De hulpdimensies zijn vervolgens via multiple regressie gebruikt ter verklaring wan de hulpomvang in uren, waarbij drie verschillende te

Tabel 6.11. Hulpomvang (uren) bij nog in zorg zijnde cliënten (totaal en 65-plus) verklaard door hulpdimensies*

\begin{tabular}{|c|c|c|c|c|c|c|}
\hline & \multicolumn{2}{|c|}{ Golindicomed antal wren } & \multicolumn{2}{|c|}{ 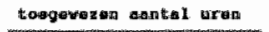 } & \multicolumn{2}{|c|}{ foltelljk } \\
\hline & alle allonten & $65-p 10 s$ & allo olibaten & $65-p l u g$ & allo ollewintan & 65-plon: \\
\hline 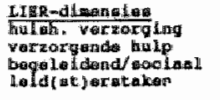 & 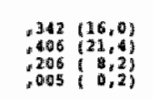 & 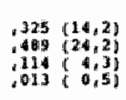 & 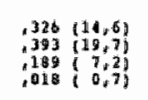 & 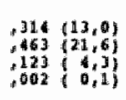 & 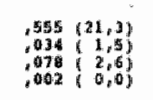 & 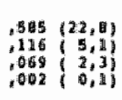 \\
\hline varkl varlaxthe $\left(\bar{R}^{2}\right)$ & "3il & "5: & "sic & 32 & $30:$ &, 67 \\
\hline 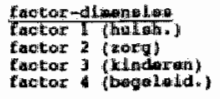 & 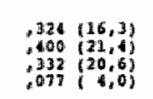 & 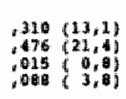 & $\begin{array}{l}314(14,3) \\
377(18,2) \\
259(14,6) \\
.098(4,7)\end{array}$ & $\begin{array}{l}305(12,2) \\
4442(19,8) \\
0000(0,2) \\
0006(3,6)\end{array}$ & $\begin{aligned} 5272 & (20,0) \\
0078 & 3,2) \\
0013 & (1,6) \\
0072 & (2,9)\end{aligned}$ & 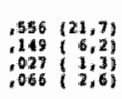 \\
\hline 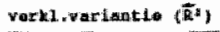 & in 64 & ,54 & .56 & . 49 & .30 & .46 \\
\hline
\end{tabular}

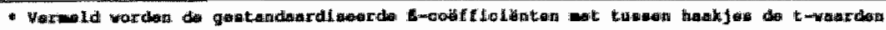


verklaren variabelen mogelijk zijo, namelijk de gelndiceerde uren, de toegewezen uren en de produktieve uren per chent per week. De resultaten (zie tabel 6.11) laten enkele opmerkelifk zaken ziex. Duidelijk wordt dat de hulpdimensies met name bij de indicatíestelling een goede verklaring voor de hulpomwang bieden en circa $60 \%$ van de variantie verklaren. Bij de feticlijke hulpvertening spelen kennelijk echter nog andere factoren een rol, omdat alleen de huithoudelijke hulpdimensie nog een significante bijdrage levert aan de verklaring van de hulpomvang en de totale verklaarde wariantie aanmerketijk lager is. De tweede concusie is dat de in de vorige paragraaf afgeleide factor-dimensies een aanzienlijk betere verklaring bieden dan de oorspronikelijke LIER-dinensies. Ook de factor "(sociale) begeleiding/leid(st)erstaken' draagt nu significant bij aan de verklaring van de hulpomvang.

Ten derde kan op basis van de resultaten inzicht gegeven worden in het relatieve belang van de vier onderscheiden hulpdimensies. Bij de indicatiestelling heeft de zorgdimensie waaraan de ADL-items de belangrijkste bijdrage leveren, het grootste gewicht. Vervolgens zijn bij de factor-dimensies de huishoudelijke hulp en hulp ten beboeve van kinderen ongeveer even belangrijk. Het belang van de sociale begeleiding/eid(st)erstaken is aanzjenlijk lager dan bij de overige dimensies. De leid(st)erstaken (oorspronkelljke LIER-indeling) leveren gén bijdrage aan de verklaring van de hulpomvang, maar zijn wel van belang als zij in combinatie met begeleidende taken worden meegenomen (de vierde factor).

Samenvattend wordt geconcludeerd dat de LIER-systematiek bij de indicatiestelling vrij consistent blijkt te worden aangehouden. In het traject vanaf indicatie tot feitelijke (produktieve) hulpverlening gaan echter meer en meer andere factoren een rol spelen, zodat uiteindelijk de verklaringsgraad op basis van de hulpdimensies aanzienlijk afneemt tot nog geen $40 \%$. De tweede belangrijke bevinding is dat de rubricering in het oorspronkelijke LIER-systeem op basis van de statistische analyses enigszins anders vormgegeven zou moeten worden. De huishoudelijke en verzorgende componenten blijven min of meer intact, maar het lijkt zinvol de totale hulp en zorg voor kinderen apart te onderscheiden en de begeleidende en leid(st)erstaken meer in onderlinge samenhang te bezien.

\subsection{De kosten van gezinsverzorging}

In het hierboven samengevatte onderzoek is ook de kostprijs van een uur alpha- en traditionele hulp berekend. Hierbij zijn de indirecte kosten zoals indirecte salarissen (administratie, directie, enz.), reis-en verblijfkosten etc. verdeeld over de alpha- en traditionele hulpverlening met het aantal (produktieve) hulpverleningsuren als verdeelsleutel. Dit leidt bij alphahulp overigens tot een kostprijs die in de praktijk enkele procenten lager zal liggen omdat er te veel indirecte kosten aan de alpha-hulp toegerekend worden. Zo blijkt bijwoorbeeld de benodigde tijd voor de intake bij alpha-hulp circa $20 \%$ lager te zijn dan bij traditionele hulp (Centrale Raad Gezinswerzorging, 1988). Een betere toerekeningssystematiek (op basis van kostenplaatsen en kostendragers) is thans bij de Centrale Raad voor Gezinsverzorging in ontwikkeling. De in tabel 6.12 gepresenteerde kostprijzen moeten dan ook als benaderingen beschouwd worden. Ook vergelijking met nationale gegevens is niet goed mogelijk, omdat daar, in tegenstelling tot hier gepresenteerde gegevens, de materiele en huisvestingskosten buiten beschouwing blijven. Deze posten vormen tezamen bij benadering 6 a $7 \%$ van de totale kosten. Een produktief uur alpha-hulp kost bijna 19 gulden, de traditionele hulp ruim 31 gulden. De gemiddelde eigen bijdrage beslaat slechts een klein deel van de totale kostprijs per produktief uur (inclusief 'overhead') en bedraagt $14,7 \%$ wan de kostprijs per uur bij alpha-hulp en $7,6 \%$ bij de traditionele hulp. Substitutie van traditionele naar alphahulp kan, indien mogelijk gegeven de individuele clientsituatie, leiden tor goedkopere dienstverlening. In de praktijk blijkt het echter, als gevolg van onder andere de tweeverdienerswetgeving, een steeds groter probleem te worden om alpha-hulpwerleners aan te trekken. 
Tabel 6.12. Integrale kostprijs per produktief uur naar hulpworim, onderschetden naar directe en indirecte kosten

\begin{tabular}{|c|c|c|c|}
\hline & alpha-hulp & traditioned 1 & $\cot n-1$ \\
\hline $\begin{array}{l}\text { Integralo kostorly } \\
\text { wararan in }\end{array}$ & $f 10,70$ & $f 31,155$ & $f 27.85$ \\
\hline $\begin{array}{l}\left.\text { - directe kosten }{ }^{2}\right) \\
\text { - indirecte kosten } \\
\text { - opbrengat retributio }\end{array}$ & $\begin{array}{l}61,2 \\
38,8 \\
14,7\end{array}$ & $\begin{array}{r}77,0 \\
23,0 \\
7,6\end{array}$ & $\begin{array}{r}76,0 \\
26.0 \\
9.0\end{array}$ \\
\hline
\end{tabular}

De totale kosten en de financiering van de gezinsverzorging te Maastricht sinds 1981 zijn opgenomen in tabel 6.13. De jaarlijkse mutaties in de kosten, die in 198712,4 miljoen bedroegen, lopen ongeveer parallel aan de landelijke ontwikkelingen (zie hoofdstuk 4). De salariskosten zijn met een aandeel van $94 \%$ verreweg thet belangrijkste, terwijl daarbinnen het aandeel van ondersteunend personeel (administratie en dergelijke) enigszins is gestegen van $18,3 \%$ in 1981 tot $19,5 \%$ in 1987 .

\subsection{Samenvatting en conclusies}

De gezinsverzorging heeft zich ontwikkeld tot een belangrijke extramurale voorziening voor ouderen met een bereik van $10 \%$ van de 65 -plussers; ruim $85 \%$ van alle clienten (bij alphahulp zelfs bijna $100 \%$ ) blijkt ouder dan 65 jaar te zijn. Bij de analyse van de individuele kenmerken wan de clienten van de gezinsverzorging is geconstateerd dat alleenstaande ouderen relatief meer gebruik maken van gezinsverzorging, met name de alpha-hulp. Als mogelijke reden daarvoor is het ontbreken van mantelzorg gegeven. De hulpreden lichamelijke handicap komt bij de mensen ouder dan 65 jaar het meest frequent voor. Dit in tegenstelling tot de jongere clienten waar de reden langdurige ziekte het belangrijkste is. Ouderen vragen daarom gedurende een relatief lange periode hulp, terwijl bij de jongere clienten de hulpduur korter maar intensiever is. Binnen de groep ouderen $(65+)$ is een positieve samenhang tussen de leeftijd en totale hulpwraag (duur en uren per week) aangetroffen. Voortgaande (dubbele) vergrijzing en individualisering zal in de toekomst een grotere hulpvraag met zich meebrengen waar meer personele en financiele middelen tegenover zulten moeten staan. Daarnaast wordt er veel verwacht wan verdere flexibilisering van het aanbod zoals zorg-op-maat, een op de individuele behoefte aangepaste combinatie van alpha-hulp en traditionele hulp en wormen van groepsverzorging in de wijk.

Tabel 6.13. Kosten van gezinswerzorging ( $x$ f 1000,-)

\begin{tabular}{|c|c|c|c|c|c|c|c|}
\hline Kostemposten & 1981 & 1982 & 1983 & 1984 & 1925 & 1986 & 1987 \\
\hline $\begin{array}{l}\text { galarisen traditioneel } \\
\text { olariasen indir. pero. } \\
\text { loonbedrag alpha-hulp } \\
\text { roi en verblijfkosten } \\
\text { overige lasten }\end{array}$ & $\begin{array}{r}7823 \\
1854 \\
431 \\
86 \\
851\end{array}$ & $\begin{array}{r}7047 \\
1984 \\
390 \\
85 \\
1074\end{array}$ & $\begin{array}{r}7408 \\
1989 \\
883 \\
78 \\
807\end{array}$ & $\begin{array}{r}7921 \\
1996 \\
1111 \\
75 \\
910\end{array}$ & $\begin{array}{r}7341 \\
1936 \\
913 \\
67 \\
919\end{array}$ & $\begin{array}{r}7474 \\
1949 \\
609 \\
61 \\
1016\end{array}$ & $\begin{array}{r}8482 \\
2265 \\
858 \\
74 \\
731\end{array}$ \\
\hline total koaten & 11045 & 10580 & 11165 & 12013 & 11179 & 11309 & 12409 \\
\hline
\end{tabular}





\section{Wijkverpleging}

\subsection{Inleiding en dataverzameling}

In dit hoofdstuk concentreren wij ons op de Regionale Vereniging het Groene Kruis in Maastricht en omgeving, die ook Eijsden tot haar werkgebied rekent. De gegevens zjjn dusdanig bewerkt dat de hier gepresenteerde analyses slechts betrekking hebben op Maastricht. De gegevens zijn voor het eerst beschikbaar voor 1983, doch in dit eerste jaar nog niet geheel valide (zie paragraaf 3.3 ). In de rest van het hoofdstuk wordt als startjaar uitgegaan van 1984. In paragraaf 7.2 wordt een nadere toelichting gegeven op het door de regionale vereniging te Maastricht gehanteerde rapportagesysteem. Vervolgens worden in paragraaf 7.3 de belangrijkste kenmerken van clienten van de wijkverpleging geanalyseerd. Aan de orde komen ondermeer de leeftijdsverdeling van clienten, de verdeling van het aantal contacten over de verschillende leeftijdscategorieckn, alsmede de aard van deze contacten. Vervolgens worden bereikcijfers gepresenteerd, waarbij zowel het aantal clienten als het aantal contacten wordt uitgedrukt in procenten van de bevolking naar leeftijd. De duur van de hulpverlening bij de wijkverpleging en de invloed daarvan op de verdeling van clienten en contacten komen aan de orde in paragraaf 7.4. In paragraaf 7.5 wordt ingegaan op de personeelsformatie kruiswereniging en de ontwikkelingen daarin gedurende de laatste jaren (tevens afgezet tegen norm-formaties). Tenslotte worden de kosten en financiering van het kruiswerk in Maastricht besproken, waarbij tevens een gemiddelde kostprijsberekening per gerealiseerd contact wordt gepresenteerd. Het hoofdstuk sluit af met een samenvatting van de belangrijkste bevindingen.

\subsection{Nadere toelichting op rapportagesysteem in Maastricht}

In het kruiswerk fungeert het Wijk Administratie Systeem (in het vervolg: het WAS) als instrument voor de verslaglegging van individuele contacten met clienten. Groepsactiviteiten zoals worden op deze wijze niet geregistreerd. In Maastricht hanteert men de handleiding van WAS-codes die binnen het gehele kruiswerk in Limburg gebruikt wordt. Het facultatieve deel, waarin onder andere de huisarts, GVO-taken en diagnosecategorieen geregistreerd kunnen worden, is in Maastricht niet in gebruik. Naast het nummer voor de basiseenheid, wijk en basisfunctionaris worden per client de maand en het jaar van hulpverlening genoteerd, het gezinsnummer uit de ledenadministratie, het gezinslidnummer en de geboortemaand en geboortejaar. Per contact wordt genoteerd of dat binnen of buiten 'kantoortijd" plaatsvindt. Ook de plaats waar het contact tot stand komt wordt genoteerd, bijvoorbeeld bij patient thuis of tijdens spreekuur. Een volgend belangrijk registratie-item betreft het doel van het contact. Onderscheiden worden:

- lichamelijk/hygiennische verzorging; waaronder ook hulp bij ADL-functies, (preventie van) decubitus en hulp bij prothesen;

- verpleegtechnisch handelen, wondverzorging, contrôle van lichaamsfuncties, catheteriseren en elastische kousen aantrekken;

- medicijnen toedienen, varierend van injecties tot druppelen;

- reactiveren: het bevorderen van zelfstandigheid van de patient, assisteren bij het herstel van lichaamsfuncties, gebruik van hulpmiddelen en dergelijke;

- helpen bij therapie of leefregel, zoals advisering en stimulering bij medicijngebruik, voeding/dieet, medische controle, zuurstofapparatuur; 
- begeleiden in probleenisituaties, waarbij assisteren bij analyse, oplossing of aanvaarding van problemen van psychosociale of andere arard, stervensbegeleiding, intramurale opname, verlies van partner en dergelijke;

- gezondheldsvoorlichting en -bevordering: het verstrekken van informatie en advies inzake mogelijkheden yoor het beworderen van gezond gedrag of woorzover gewenst begeleiding gewen bij het realiseren daarvan;

- sereeningsprojecten: het enige wat hier geregistreerd wordt is onderzoek in kader van gehoorscrening (niet-patientgerichte deel van formulier);

- contacten met derden ten behoeve van de client worden eveneens geregistreerd, waarbij een uitsplitsing plaatsvindt naar groepen warmee contact gelegd wordt (zieken-, verpleeghuis, andere disciplines, vrijwilligers en functionarissen eigen organisatie);

- orientatie huisbezoeken, hetgeen altijd een nieuwe client betref, gekoppeld aan een feitelijke hulpvraag (huisbezoeken op initiatief van de organisatie worden onder GVO. doelen geregistreend).

Het bovenstaande maakt duidelijk dat het WAS een registratie van handelingen van hulpverleners is en geen systeem voor clientregistratie, zoals bijvoorbeeld het LIER-systeem bij de gezinsverzorging.

\subsection{Analyse van kenmerken van cliënten van wijkverpleging}

Zoals eerder reeds vermeld is, staan in principe gegevens ter beschikking vanaf 1983, het eerste jaar waarin bet geautomatiseerde registratiesysteem gehanteerd is. In eerdere analyses werd echter duidelijk dat dit eerste jaar niet goed bruikbaar is, omdat niet alle gegevens ingewoerd zijn. De zorgintensiteit wordt daardoor overschat (Huijsman, 1989c). In de rest van dit hoofdstuk wordt daarom de periode 1984-1988 (5 jaren) nader bestudeerd.

\subsubsection{Leeftijdsverdeling van cllënten}

De oorspronkelijke databestanden (op basis van contacten) zijn dusdanig geaggregeerd (op gezinsnummer en daarbinnen op gezinslidnummer) dat de clienten zichtbaar worden. Registratieproblemen met betrekking tot het geboortejaar (dat in sommige gevallen geschat wordt binnen de in het WAS gebruikelijke intervallen van tien jaar) zijn min of meer ondervangen door de hoogst opgegeven leeftijd te nemen. Gevoeligheidlsanalyses met betrekking tot de invloed van deze veronderstelling hebben niet plaats gevonden.

Tabel 7.1. Aantal cliènten per leeftijidscategorie

\begin{tabular}{|c|c|c|c|c|c|c|}
\hline \multicolumn{2}{|c|}{ leatijo } & 1984 & 1985 & 1986 & 1987 & 1988 \\
\hline $\begin{array}{l}55 \\
60 \\
65 \\
70 \\
75 \\
80 \\
85\end{array}$ & $\begin{array}{l}=54 \\
=59 \\
=64 \\
=69 \\
=74 \\
=79 \\
=84 \\
=89 \\
=90\end{array}$ & $\begin{array}{r}516 \\
220 \\
348 \\
341 \\
494 \\
640 \\
641 \\
236 \\
137\end{array}$ & $\begin{array}{r}5.034 \\
195 \\
295 \\
354 \\
464 \\
615 \\
701 \\
275 \\
144\end{array}$ & $\begin{array}{r}.247 \\
141 \\
260 \\
349 \\
451 \\
592 \\
627 \\
300 \\
156\end{array}$ & $\begin{array}{r}421 \\
139 \\
244 \\
323 \\
428 \\
557 \\
559 \\
336 \\
180\end{array}$ & $\begin{array}{r}418 \\
120 \\
191 \\
307 \\
354 \\
493 \\
603 \\
393 \\
205\end{array}$ \\
\hline Tot & tagl & 8.381 & 8.077 & 7.123 & 7.189 & 7.084 \\
\hline
\end{tabular}


In de periode 1984-1988 treedt een daling in thet totaal antal clienten op van 8.381 in 1984 tot 7.084 clienten in 1988. De laatste jaren lijkt een zekere stabilisatie op te treden rond in total 7.100 clienten in de gemeente Maastricht. Duidelijk is echter dat in het clientenbestand het aandeel van ouderen niet zo groot is (zie tabel 7.1). Het aandeel van 65-plus schommelt gemiddeld rond $1 / 3$. Met name de alleroudste clienten blijwen echter tot en met 1988 in relatieve onvang toenemen. In 1984 was nog $4,5 \%$ ouder dan 85 jaar; in 1988 is dat $8,4 \%$. Dalende proporties over de gehele periode treffen wij vooral aan bij de "jongbejaarden' van 55 tot 75 jaar.

\subsubsection{Contactem: aantallen naar leeftudsgroepen}

Het totaal aantal geregistreerde contacten, dat wil zeggen de som van eventuele eerste, tweede en/of derde contacten op een en dezelfde dag, neemt in de gehele periode vrijwel continu toe. In 1984 werden nog ruim 95.700 contacten geregistreerd; in 1988 zijn dat er circa 107.600. Dat betekent een totale toename van $12,4 \%$ in 5 jaar of gemiddeld $3 \%$ per jaar. De enige uitzondering hierop betreft het jaar 1985 met een dalling van 3,5\%. Over de precieze oorzak hiervan is niets bekend. Het aandeel wan 65 -plus in het aantal contacten neemt steeds verder toe van $69,8 \%$ in 1984 tot $78,3 \%$ in 1988 . Binnen de groep ouderen treedt bovendien een verschuiving op naar oudere leeftijdsgroepen. In 1984 was $48 \%$ van de contacten met 65 -plus ten behoeve van 80-plus; in 1988 is dat bijna $61 \%$.

Er wordt veelal gewerkt met het gemiddeld aantal contacten per client als indicatie voor de zorgintensiteit van de wijkwerpleging. Theoretisch zijn gemiddelden als maatstaf echter alleen betrouwbaar, als de verdeling wan mogelijke waarden die van de normale verdeling benadert. Figuur 7.1 laat duidelijk zien dat dat ten aanzien van de verdeling van contacten in geen geval opgaat. De verdeling voor alle clienten is zelfs zeér scheef: hoewel het aandeel van mensen met slechts én contact op jaarbasis gedaald is, vormt zij $45 \%$ van het totaal $(50 \%$ in 1984). Nog eens $17 \%$ heeft twee contacten. Bij 65-plussers is de verdeling minder scheef. In 1988 heeft $20 \%$ van hen eén contact en $8 \%$ twee contacten. Duidelijk komt de bij ouderen hogere zorgintensiteit naar voren: $44 \%$ heeft meer dan 10 contacten. Uit de verdeling voor alle clienten blijkt dat de mediaan bij én contact ligt, doch door afronding komt zij op twee uit. Het gemiddelde (15,2 in 1988) is door de langgerekte staart van de verdeling aanzienlik hoger. In het vervolg wordt toch in de meeste gevallen met gemiddelden gewerkt, omdat dit de maatstaf is die in publikaties van de Nationale Kruisvereniging gebruikt wordt (zie hoofdstuk 4). De vergelijkbaarheid met nationale gegevens is op deze wijze gewaarborgd.

Tabel 7.2. Aantal contacten per leeftijdscategorie

\begin{tabular}{|c|c|c|c|c|c|c|}
\hline lee & eftud & 1984 & 1995 & 1986 & 1987 & 1988 \\
\hline $\begin{array}{l}55 \\
60 \\
65 \\
70 \\
75 \\
80 \\
85\end{array}$ & $\begin{array}{l}\leq 54 \\
=59 \\
=64 \\
=69 \\
=74 \\
=79 \\
=84 \\
=89 \\
=90\end{array}$ & $\begin{array}{r}16.792 \\
4.726 \\
7.475 \\
7.396 \\
10.428 \\
17.118 \\
22.117 \\
5.958 \\
3.785\end{array}$ & $\begin{array}{r}14.930 \\
3.942 \\
7.264 \\
5.416 \\
3.430 \\
17.228 \\
23.053 \\
7.091 \\
4.039\end{array}$ & $\begin{array}{r}14.6114 \\
2.738 \\
5.674 \\
0.727 \\
10.313 \\
16.529 \\
21.750 \\
12.668 \\
4.999\end{array}$ & $\begin{array}{r}16.755 \\
2.558 \\
4.025 \\
7.098 \\
11.747 \\
16.138 \\
24.904 \\
12.999 \\
6.221\end{array}$ & $\begin{array}{r}15.130 \\
3.021 \\
5.163 \\
0.623 \\
9.200 \\
15.106 \\
25.846 \\
18.187 \\
7.131\end{array}$ \\
\hline \multicolumn{2}{|c|}{ Totaa: } & 95.705 & 92.393 & 96.134 & 105.045 & 107.609 \\
\hline
\end{tabular}



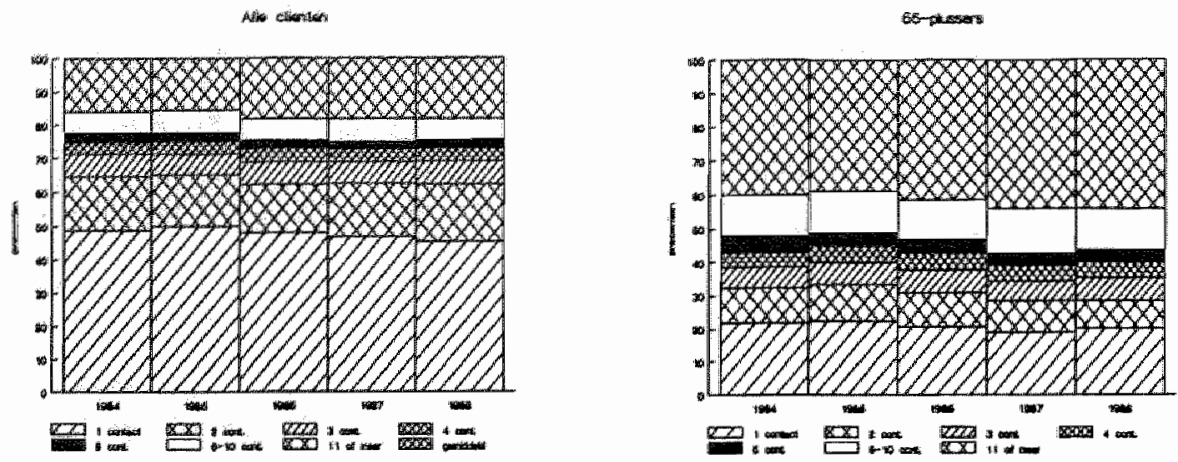

Figuur 7.1. Contactverdeling (in \%) voor alle clienten en voor 65-plus

Binnen de groep oudere clienten (zie tabel 7.3) loopt de zorgintensiteit op vanaf gemiddeld ruim 25 contacten bij de jongsten tot ruim 46 bij de $85-89$ jarigen (gegevens 1988). Bij de alleroudste clienten is het aantal contacten met 34,8 weer iets lager. Over de gehele periode bezien, is er sprake van een stijgende zorgintensiteit zowel over leeftijdsgroepen als in totaal. Van jaar tot jaar bestaan echter belangrijke afwijkingen van de gesignaleerde trend. Vooral bij 85 tot 90 jarigen is de stijging zeer sterk (bijna een verdubbeling ten opzichte van 1984). Beknopt wordt ingegaan op verschillen binnen de onderscheiden leeftijdscategorieèn. In tabel 7.3 is voor het meest recente jaar de marge rondom het gemiddeld aantal contacten per leefitjdsgroep weergegeven door middel van de standaardfout. Deze neemt in absolute omvang toe met de leeftijd, net als het gemiddelde, doch in procenten van dat gemiddelde neemt de standaardfout tot 85 jaar af om daarna iets groter te worden.

\subsubsection{Contacten: aard en doelen}

In tabell 7.4 is de procentuele verdeling weergegeven van de tien mogelijke doelen voor contact met de wijkverpleging (zie paragraaf 7.2 voor een omschrijving). Er treden sterke verschuivingen op in de richting van meer curatieve zorg van een steeds meer bewerkelijke

Tabel 7.3. Gemiddeld aantal contacten per cliênt

\begin{tabular}{|c|c|c|c|c|c|}
\hline leetijd & 1984 & 1985 & 1986 & 1987 & $1988 *$ \\
\hline $\begin{array}{r}554 \\
55-59 \\
60=64 \\
65=69 \\
70-74 \\
75=79 \\
80-64 \\
85=89 \\
=90\end{array}$ & $\begin{array}{l}3,11 \\
20,73 \\
21,48 \\
21,69 \\
21,11 \\
26,75 \\
34,50 \\
25,25 \\
27,63\end{array}$ & $\begin{array}{r}2,97 \\
20,22 \\
24,62 \\
15,30 \\
20,72 \\
28,01 \\
32,09 \\
25,79 \\
28,05\end{array}$ & $\begin{array}{r}3,49 \\
19,42 \\
21,82 \\
25,01 \\
22,92 \\
27,92 \\
34,69 \\
42,23 \\
31,40\end{array}$ & $\begin{array}{r}3,79 \\
18,40 \\
19,77 \\
24,45 \\
27,45 \\
28,97 \\
4,55 \\
41,42 \\
34,65\end{array}$ & $\begin{aligned} 3,42 & (0,35) \\
25,18 & (5,42) \\
27,03 & (4,69) \\
28,74 & (4,38) \\
25,99 & (2,69) \\
30,65 & (3,08) \\
42,86 & (3,68) \\
46,28 & (4,99) \\
34,79 & (4,02)\end{aligned}$ \\
\hline Potal & 11,42 & 11,44 & 13,78 & 14,61 & $15,19(0,63)$ \\
\hline
\end{tabular}

* Tusen hakje日 de standarafout 


\begin{tabular}{|c|c|c|c|c|c|}
\hline Contactdoel & 1984 & 1985 & 1986 & 1987 & 198 \\
\hline $\begin{array}{l}\text { oribntatie } \\
\text { lich, verzorging } \\
\text { verplegk. handelen } \\
\text { medicijutoediening } \\
\text { reactiveren } \\
\text { therapie, leefregels } \\
\text { begeleiding probl. } \\
\text { gwo, bevordering } \\
\text { creening } \\
\text { contact met derden }\end{array}$ & $\begin{array}{r}0,63 \\
41,19 \\
14,39 \\
7,87 \\
2,90 \\
9,27 \\
7,47 \\
9,02 \\
0,16 \\
6,99\end{array}$ & $\begin{array}{r}0,79 \\
4,06 \\
16,64 \\
7,76 \\
1,99 \\
7,30 \\
6,98 \\
8,43 \\
0,03 \\
6,01\end{array}$ & $\begin{array}{r}0,74 \\
47,24 \\
15,65 \\
9,52 \\
1,8.5 \\
6,315 \\
6,62 \\
6,98 \\
0,02 \\
6,03\end{array}$ & $\begin{array}{r}0,64 \\
49,87 \\
15,04 \\
8,60 \\
1,70 \\
5,62 \\
5,70 \\
6,81 \\
0,02 \\
5,92\end{array}$ & $\begin{array}{r}0,57 \\
52,18 \\
16,14 \\
9,12 \\
1,13 \\
3,197 \\
4,24 \\
6,96 \\
0,03 \\
5,11\end{array}$ \\
\hline rotal antal $(=1008)$ & 95.705 & 92.393 & 98.134 & 105.045 & 107.609 \\
\hline
\end{tabular}

aard. Lichamelijke hygienische verzorging neemt toe van $41,2 \%$ in 1984 naar $52,6 \%$ in 1988. Het absolute aantal contacten met dit doel stijgt dan met $44 \%$ in 5 jaar tijd, terwijl de stijging in alle contacten $12 \%$ bedraagt. Ook het belang van het contactdoel verpleegtechnisch handelen loopt op van $14,4 \%$ in 1984 naar $16,1 \%$ in 1988 . In absolute termen betekent dit een toename met $25 \%$.

De toenemende curatieve zorg in de vorm van lichamelijke verzorging en verpleging is ten koste gegaan van het helpen bij therapie en leefregel, begeleiden bij probleemsituaties en contacten met derden. Bij andere contactdoelen zijn de ontwikkelingen in de tijd niet zo geprononceerd als bij de hiervoor genoemde. Interessant is vervolgens of het bovenstaande en meer algemene beeld nog specifieke ontwikkelingen naar leeftijdsgroepen heeft gekend. De diverse verpleegdoelen die bij de wijkverpleging geregistreerd worden, blijken een belangrijke relatie met de leeftijd van de client te hebben. Met name bij lichamelijk hygienische verzorging springt dat positieve verband met leeftijd in het oog: bij de clienten jonger dan 55 jaar is slechts $21 \%$ van alle contacten ten behoeve van dit doel, terwijl dat bij de alleroudsten ruim $75 \%$ is. Bij gezondheidsvoorlichting en -opvoeding is de relatie met leeftijd juist andersom. Vervolgens is er een aantal doelen dat een piek heeft bij een bepaalde leeftijdscategorie. Zo'n piek treffen wij aan bij jong-bejaarden met betrekking tot verpleegkundige handelingen, therapie, begeleiding en reactivering. Een piek bij hoogbejaarden wordt daarentegen gevonden bij het doel medicijnen toedienen, uitgezonderd bij de 90-plussers, waar lichamelijke verzorging de overhand heeft.

Tabel 7.5. Leeftijdsspecifieke verdeling contactdoelen in 1988

\begin{tabular}{|c|c|c|c|c|c|c|c|c|c|c|}
\hline contiactdoel & $\leq 54$ & $55-59$ & $60-64$ & $65-69$ & $70-74$ & $75-79$ & $60-64$ & $85-89$ & 290 & total \\
\hline $\begin{array}{l}\text { oridntatie } \\
\text { werzorging } \\
\text { verpl. hand. } \\
\text { medicijnen } \\
\text { reactiver. } \\
\text { therapie } \\
\text { begiliden } \\
\text { Gwo, beword. } \\
\text { BCreening } \\
\text { cont.derden }\end{array}$ & $\begin{array}{r}1,1 \\
20,8 \\
15,0 \\
5,8 \\
0,3 \\
2,7 \\
6,4 \\
41,1 \\
0,2 \\
6,5\end{array}$ & $\begin{array}{r}0,8 \\
51,9 \\
24,4 \\
2,5 \\
2,7 \\
4,0 \\
5,4 \\
1,9 \\
6,4\end{array}$ & $\begin{array}{r}0,7 \\
50,6 \\
23,1 \\
1,9 \\
2,0 \\
6,6 \\
7,7 \\
2,3 \\
5,1\end{array}$ & $\begin{array}{r}0,8 \\
52,2 \\
19,7 \\
9,1 \\
1,1 \\
4,1 \\
6,4 \\
1,5 \\
5,2\end{array}$ & $\begin{array}{r}0,9 \\
45,9 \\
23,4 \\
11,7 \\
1,3 \\
3,5 \\
5,9 \\
2,1 \\
5,3\end{array}$ & $\begin{array}{r}0,7 \\
57,2 \\
1 \%, 5 \\
5,0 \\
1,1 \\
5,6 \\
1,5 \\
1,8 \\
0,0 \\
5,7\end{array}$ & $\begin{array}{r}0,5 \\
57,3 \\
14,0 \\
15,5 \\
1,0 \\
4,0 \\
2,4 \\
1,0 \\
4,3\end{array}$ & $\begin{array}{r}0,4 \\
64,0 \\
12,4 \\
10,3 \\
1,4 \\
3,3 \\
2,8 \\
0,9 \\
4,6\end{array}$ & $\begin{array}{r}0,3 \\
75,7 \\
8,7 \\
3,4 \\
1,4 \\
3,4 \\
1,5 \\
1,0 \\
4,5\end{array}$ & $\begin{array}{r}0,7 \\
5.2,6 \\
1.6,1 \\
9,1 \\
1,1 \\
4,0 \\
4,2 \\
7,0 \\
0,03 \\
5,1\end{array}$ \\
\hline Totan 1 & 1513.0 & 3021 & 5163 & 1823 & 9200 & 15100 & 25846 & 18187 & 7131 & 107609 \\
\hline
\end{tabular}


Leefijdsspecifieke ontwikkelingen in de aard wan de contacten sinds 1984 (niet in tabellen weergegeven) blikkn vrijwel parallel te lopen aan algemene trends in de verdeling van conLacten natr verpleegdoelen (tabel 7.4 ) en aan de eveneens algemene verschuiving van contacten naar oudere clienten. Uitzonderingen op deze regel zien wij mel name bij de alleroudsten, voor wie voor 1988 het aandeel van lichamelijke verzorging circa 10 procentpunten lager ligk ten gunste van verpleegkuadig handelen en medicijntoediening. Bij dat laatste doel was van alle contacten in 1984 circa $10 \%$ en in 1988 rum $21 \%$ ten behoeve van 85 -plus. Bij verpleegkundige handelingen is het aandeel van 85 -plus meer dan verdubbeld van $6,8 \%$ naar $16,5 \%$. De algemene afname in contacten met derden is bij hoogbejaarde clienten niet opgetreden, zodat deze contacten stecds meer ten gunste van ouderen komen.

\subsubsection{Contacten: tijd en plaats}

Naast het doel van het betreffende contact wordt ook geregistreerd waar en op welk tijdstip (naar dagdeel en werkdag) het contact plaats vindt. Tabel 7.6 geeft een overzicht van de contacten naar tijd en plaats in de periode 1985-1988. Het jaar 1984 wordt hier buiten beschouwing gelaten, omdat de gegevens voor dit jaar onvolledig zijn. De contacten tijdens de zater-, zon- en feestdagen zijn bijvoorbeeld niet afzonderlijk geregistreerd. Er treedt een verschuiving op van contacten tijdens kantooruren naar "s awonds en in het weekend of tijdens feest- of vrije dagen. Toch betreft het een geleidelijke verschuiving: tijdens kantooruren ontstond in $198586 \%$ en in $198879 \%$ van de contacten.

De 24-uursbereikbaarheid heeft in Maastricht sinds 1986 gestalte gekregen. De registratie van de bereikbaarheidsdienst wordt los van het WAS gevoerd. De mate van detail van de gegevens is dan ook beperkt en kent bijwoorbeeld geen leeftijdsverdeling. Aan de andere kant zijn toch enkele relevante gegevens beschikbaar die inzicht geven in deze betrekkelijk nieuwe vorm van dienstverlening door het kruiswerk (Huijsman, 1989c). In de jaren 19861988 is het aantal contacten via de bereikbaarheidsdienst verdrievoudigd (van 321 naar 931), waarbij gegevens over de eerste helft van 1989 (653 contacten) doen vermoeden dat deze groel onverminderd doorgat. De belangrijkste initiatiefnemer is de client zelf of een huisgenoot $(80$ a $85 \%)$. De huisarts of andere extramurale voorzieningen spelen een bescheiden ( $3 \%$ in 1986-1988) doch lets toenemende rol (5\% in eerste helft 1989), ook bij eventuele doorverwijzing nà het contact. Via de bereikbaarheidsdienst wordi $40 \%$ naar de dagdienst verwezen, $25 \%$ naar de avonddienst ${ }_{\text {, en }}$ klein deel naar de huisarts $(3 \%)$ en $18 \%$ wordt direct algehandeld.

Tabel 7.6. Tudstip en plats van de contacten, 1985-1988

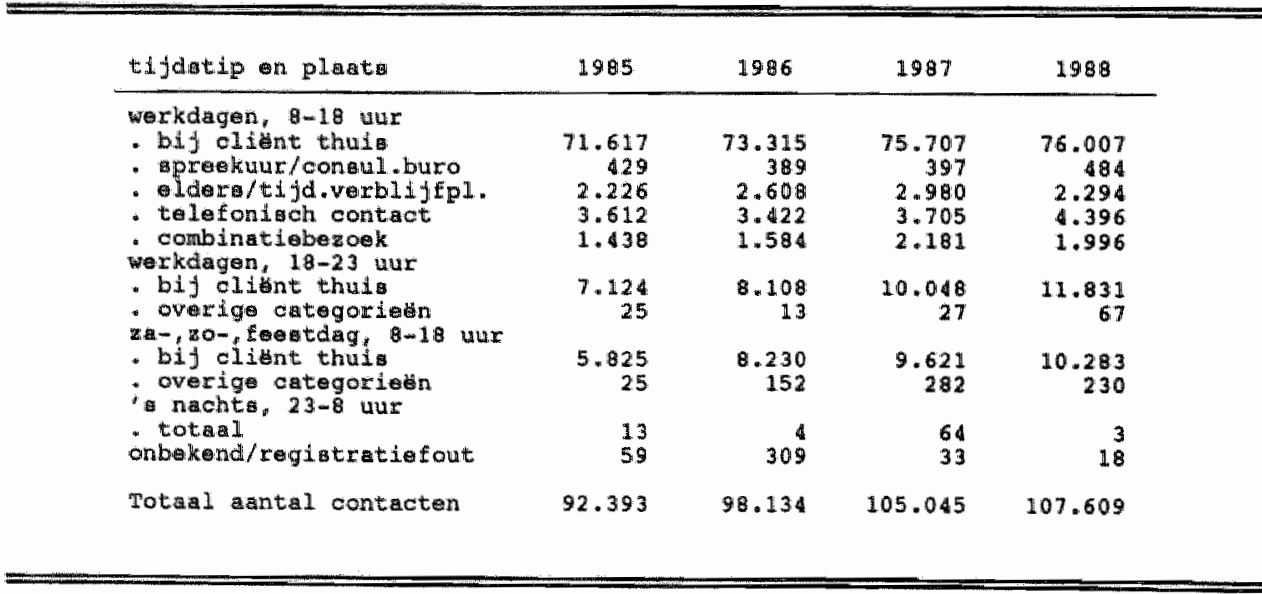




\subsubsection{Bereik van wijkverpleging}

Er zijn twee gangbare methoden om het bereik van wijkwerpleging tot uitdrukking te laten komen: tên door het aantal clienten uit te drukken in procenten van de bevolking en een door het aantal contacten uit te drukken per 100 inwoners. De Nationale Kruisvereniging gebruikt in haar rapporten de zelfstandig wonende bevolking als basis. Deze aanpak wordi hier niet gevolgd om twee redenen. Ten eerste richt het onderzoek zich op alle voorzieningen voor ouderen en dienen deze herleid te worden tot een en dezelfo noemer. Ten tweede kan met de NK-methode ook niet goed ingespeeld worden op de (beoogde) resultaten van het substitutiebeleid en wordt zelfs een onjuist beeld gegeven in die gevallen waarin veranderingen in aantallen clienten en/of contacten niet precies gelijke tred houden met veranderingen in het aandeel van zelfstandig wonende ouderen. In het vervolg worden beide methoden om de bereikcijfers te berekenen gevolgd, maar uitgedrukt in procenten van de totale populatie, gespecificeerd naar leeftijdsgroepen en het total der 65-plussers.

In tabel 7.7. wordt een overzicht gegeven van het aantal clienten ten opzichte van de bevolking per 1 januari van elk jaar (eerste methode).

Het bereik ten opzichte van 65 -plussers is 2 a $21 / 2$ keer zo groot als het totale bereik van de wijkverpleging, dat nu schommelt rond de $6 \%$. Overigens zijn dergelijke bereikcijfers voor de wijkwerpleging door het grote aandeel van énnalige clienten (45\%) enigszins. geflatteerd. Net als eerder in hoofdstuk 4 werd geconcludeerd voor de nationale gegevens, zien wij ook hier in de gehele periode een dalend bereikcijfer (tot $6,1 \%$ in 1988). Tenslotte wordt een zeer hoog bereikcijfer gevonden voor de hoogste leeftijdscategorieën: bijna $30 \%$ voor $80-84$ jaar en ruim $40 \%$ voor 85 -plus, bij welke groep de stijging in bereik opvallend is.

In tabel 7.8 is de tweede methodiek gevolgd, waarbij het aantal contacten is uitgedrukt per inwoner. Nu uit het woorgaande bekend is, dat zowel het (relatieve) aantal clienten als het gemiddeld aantal contacten per client sterk toeneemt met de leeftijd van de client, zal het niet verbazen dat deze twee factoren, elkaar versterkend, leiden tot een scherp leeftijdspaw troon voor het aantal contacten per inwoner. Met uitzondering van 1985 treedt een vrijwel voortdurende stijging in het aantal contacten per inwoner op gedurende de periode 19841988, met name in de oudere leeftijdsgroepen. De stijgende zorgintensiteit (aantal contacten per client) compenseert derhalve de dalende bereikciffers volgens de eerste methode en leidt zo tot stijgende bereikcijfers volgens de tweede methode. Deze laatste lijkt te prefereren boven de eerste, omdlat de eenmalige contacten, die $3 \%$ van de contacten en $45 \%$ van de clienten betreffen, nu niet zo'n zwaar gewicht krijgen.

Tabel 7.7. Cliènten in procenten van de bevolking (per 1-1)

\begin{tabular}{|c|c|c|c|c|c|c|c|}
\hline \multicolumn{3}{|c|}{$1 \in f t i d d g g r o e p$} & \multirow{2}{*}{$\begin{array}{r}1984 \\
6,19 \\
3,55 \\
5,66 \\
7,21 \\
12,19 \\
21,64 \\
34,50 \\
31,29\end{array}$} & \multirow[b]{2}{*}{$\begin{array}{r}1985 \\
5,04 \\
3,04 \\
4,68 \\
7,50 \\
11,20 \\
20,13 \\
36,78 \\
33,90\end{array}$} & \multirow[b]{2}{*}{$\begin{array}{r}1986 \\
4,92 \\
2,18 \\
4,10 \\
7,05 \\
10,80 \\
18,90 \\
32,02 \\
35,60\end{array}$} & \multirow{2}{*}{$\begin{array}{r}1987 \\
5,10 \\
2,13 \\
3,90 \\
6,20 \\
10,22 \\
17,50 \\
27,54 \\
39,97\end{array}$} & \multirow[b]{2}{*}{$\begin{array}{r}1988 \\
5,09 \\
1,84 \\
3,09 \\
5,72 \\
8,39 \\
15,20 \\
29,40 \\
43,18\end{array}$} \\
\hline $\begin{array}{l}55 \\
60 \\
65 \\
70 \\
75 \\
80\end{array}$ & $\begin{array}{l}=54 \\
=59 \\
=64 \\
=69 \\
=74 \\
=79 \\
=84 \\
=85\end{array}$ & 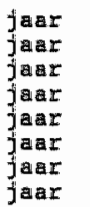 & & & & & \\
\hline \multicolumn{3}{|c|}{$\begin{array}{l}\text { Totaal } \\
65-\text { plus }\end{array}$} & $\begin{array}{r}7.40 \\
16.00\end{array}$ & $\begin{array}{r}7,08 \\
16,95\end{array}$ & $\begin{array}{r}6,22 \\
15,97\end{array}$ & $\begin{array}{r}6,23 \\
14,99\end{array}$ & $\begin{array}{r}6,12 \\
14,48\end{array}$ \\
\hline
\end{tabular}




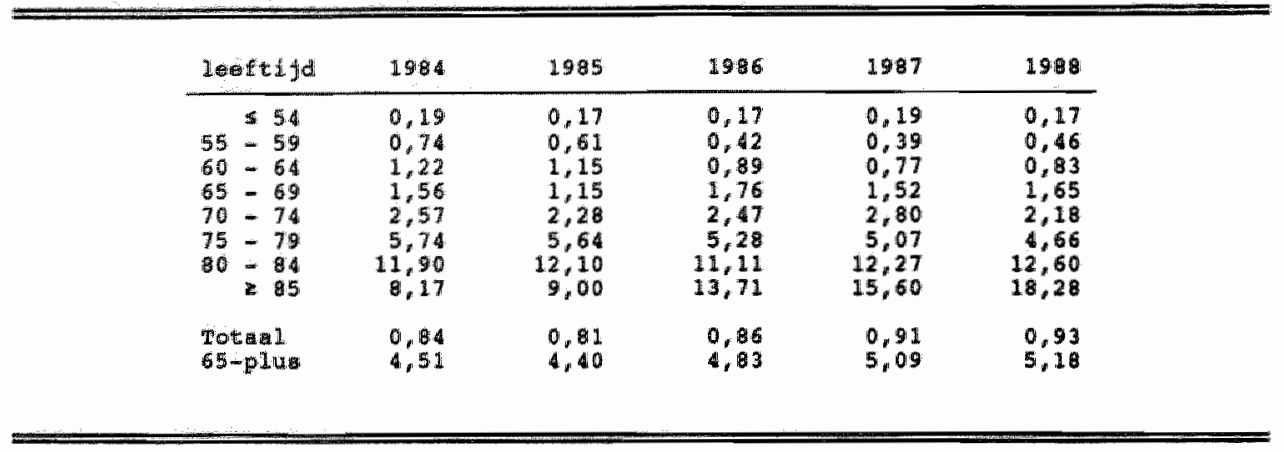

\subsubsection{Personeelsinzet en aard wan contacten}

Het is interessant te bezien welke personeelscategorieen ingezet worden bij welke soort activiteilten en bij welke clientgroepen (naar leeftijd). De verdeling van contacten over wijkwerpleegkundigen, wijkziekenverzorgenden, de vervang(st)ers van beide en de verpleeg. kundigen in de wijk staat vermeld in tabel 7.9 .

De verhouding tussen het personeel in de wijkwerpleging en wijkziekenverzorging (inclusief vervanging) is in de periode 1984-1988 wrijwel constant. Opvallend is daarbij dat vervanging ten behoeve van wijkverpleegkundigen steeds meer voorkomt en zeer omvangrijk is in 1988. Hier doet zich kennelijk de groeiende krapte op de arbeidsmarkt voor deze categorie gelden (Boot en Knapen, 1988). Vervanging wordt vooral ingezet in de avond-en weekenddienst, die in omvang sterk toeneemt, maar waarvoor in afwachting van een reorganisatie nog geen structurele plaatsen zijn gecreeerd. Tenslotte wordt wellicht de vaste formatie tot een minimum beperkt, zodat in piekperiodes een flexibele inzet van op ad hoc basis aangetrokken personeel (uit pool) bereikt kan worden.

Voor het meest recente jaar analyseren wij vervolgens de besteding van de contacten per personeelscategorie aan de verschillende verpleegdoelen. Hierdoor kunnen verschillen in het werk van de diverse personeelscategorieen beter aan het licht gebracht worden (zie tabel 7.10). Van alle contacten wordt in 1988 gemiddeld $52,6 \%$ door wijkverpleegkundigen gedaan, $19 \%$ door vervanging van hen, $22,2 \%$ door wijkziekenverzorgenden of hun vervanging $(4,9 \%)$ en $1,3 \%$ door verpleegkundigen in de wijk.

De wijkverpleegkundigen houden zich retatief weinig bezig met het verpleegdoel lichamelijke verzorging, maar relatief meer met verpleegkundig handelen, het bijstaan bij therapie en leefregels, het begeleiden bij probleemsituaties en de screening (alle contacten met dit doel). Ook contacten met derden worden veelal door wijkverpleegkundigen

Tabel 7.9. Procentuele verdeling van contacten naar personeelscategorieên

\begin{tabular}{|c|c|c|c|c|c|}
\hline personea licategorio & 1984 & 1985 & 1986 & 1987 & 1988 \\
\hline $\begin{array}{l}\text { wi jkverpleegkundigen } \\
\text { vervanging wijkwerpl. } \\
\text { wifkz lekenverzorgenden } \\
\text { vervanging wijkzikenv. } \\
\text { verp.kundigen in wijk }\end{array}$ & $\begin{array}{r}60,0 \\
10,6 \\
24,8 \\
1,7 \\
2,9\end{array}$ & $\begin{array}{r}58,0 \\
16,2 \\
20,7 \\
4,0 \\
1,1\end{array}$ & $\begin{array}{r}50,5 \\
15,7 \\
19,3 \\
5,3 \\
1,2\end{array}$ & $\begin{array}{r}57,9 \\
16,9 \\
19,3 \\
5,0 \\
1,0\end{array}$ & $\begin{array}{r}52,6 \\
19,0 \\
22,2 \\
4,9 \\
1,3\end{array}$ \\
\hline Totaal contacten $(=100)$ & 95.705 & 92.393 & 98.134 & 105.045 & 107.609 \\
\hline
\end{tabular}


Tabel 7.10. Verdeling van contacten naar aard per personeelscategorle in 1988

\begin{tabular}{|c|c|c|c|c|c|c|}
\hline contactdosion & $\operatorname{wpp}^{1}$ & verwp ${ }^{2}$ & $\mathrm{wr}^{3}$ & warkt & $v+w^{5}$ & Totanl \\
\hline $\begin{array}{l}\text { oridatatie } \\
\text { lich. verzorging } \\
\text { verpleegk hande len } \\
\text { medicijntoediening } \\
\text { reactivering } \\
\text { therapie, leefregel } \\
\text { begeleiden probl. } \\
\text { gvo, bevordering } \\
\text { creening } \\
\text { contact met derden }\end{array}$ & $\begin{array}{r}1,0 \\
41,7 \\
18,1 \\
9,7 \\
1,1 \\
4,5 \\
5,7 \\
11,3 \\
0,1 \\
6,8\end{array}$ & $\begin{array}{r}0,2 \\
69,0 \\
14,6 \\
8,0 \\
0,6 \\
1,7 \\
1,6 \\
3,5 \\
0,8\end{array}$ & $\begin{array}{r}0,4 \\
59,8 \\
13,5 \\
8,6 \\
2,0 \\
5,5 \\
3,2 \\
1,4 \\
= \\
5,5\end{array}$ & $\begin{array}{r}0,1 \\
71,8 \\
12,7 \\
11,0 \\
0,1 \\
1,0 \\
1,1 \\
0,1 \\
-\overline{2}, 1\end{array}$ & $\begin{array}{r}0,8 \\
61,4 \\
17,2 \\
1,9 \\
1,0 \\
0,1 \\
11,3 \\
1,3 \\
- \\
5,0\end{array}$ & $\begin{array}{r}0,7 \\
52,6 \\
16,1 \\
9,1 \\
1,1 \\
4,0 \\
4,2 \\
7,0 \\
5,03\end{array}$ \\
\hline Totaal $(=1008)$ & 56655 & 20456 & 23900 & 5248 & 1350 & 10760 \\
\hline
\end{tabular}

1. wjkverpleegkundige (wwp)

2. vervang (at) er van wijkverpleagkundige (vervp)

3. Wijkziekenverzorgende (wzv)

4. vervang(t) er van wijkziekenvergorgende (verwz)

5. verpleogkundige in de wijk (viw)

onderhouden. Bij vervanging komt het accent met name op lichamelijke verzorging te liggen. Contacten met derden zijn dan bijvoorbeeld veel minder in vergelijking met de te vervangen categorie. Ook meer secundaire verpleegdoelen, zoals begeleiding bij problemen, therapie en leefregel, zijn relatief gering. Dergelijke verschuivingen bevreemden echter niet, indien bedacht wordt dat vervanging maar tot $70 \%$ mag worden ingezet.

De personeelsinzet is tot besluit van deze paragraaf in de tabel 7.11 gespecificeerd naar de leeftijd van de client waarmee de hulpverlener contact heeft. Deze tabel is op basis van het clienten- en niet het contactenbestand gegenereerd, om in beeld te brengen welke hulpverleners de client ontmoet. Voor bijvoorbeeld 20 contacten met én wijkziekenwerzorgende en én contact met een wijkverpleegkundige betekent dat op clientniveau dat de relatieve komst voor beide hulpverleners gelijk is. $\mathbb{E r}$ komt een duidelijk verband met leeftijd naar woren, dat in relatie staat met het hiervoor beschreven patroon van contacten en de aard daarvan, onderscheiden naar de leeftijd van de cliènten en personeelscategorieen.

\subsection{Duur van hulpverlening en invloed op verdeling van contacten}

De jaarbestanden van het wijkadministratiesysteem zijn zodanig gekoppeld, dat getraceerd kan worden hoe lang de clienten in zorg zijn bij de wijkverpleging. Bij deze analyse van de duur van de hulpwerlening kan niet verder teruggekeken worden dan tot 1984.

Tabel 7.11. Contact met personeelscategorieën (in \%) op cliëntmiveau in 1988

\begin{tabular}{|c|c|c|c|c|c|c|c|c|c|c|}
\hline & & $5=$ & $9-64$ & -69 & $70-74$ & $5-79$ & $80-84$ & $85-1$ & 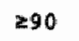 & \\
\hline $\begin{array}{l}\text { Ne } \\
\text { ervanging wop } \\
\text { iv } \\
\text { iw }\end{array}$ & $\begin{array}{r}10,7 \\
0,7 \\
0,2 \\
0,2\end{array}$ & $\begin{array}{r}16,3 \\
16,0 \\
2,7 \\
1,7\end{array}$ & $\begin{array}{r}13,7 \\
14,6 \\
1,9 \\
0,9\end{array}$ & $\begin{array}{r}15,3 \\
17,5 \\
1,9 \\
1,7\end{array}$ & $\begin{array}{r}16,3 \\
23,9 \\
2,6\end{array}$ & $\begin{array}{r}14,5 \\
23,10 \\
3,9 \\
0,9\end{array}$ & $\begin{array}{r}46,9 \\
15,5 \\
31,6 \\
4,6 \\
1,1\end{array}$ & $\begin{array}{l}5 \\
4 \\
0 \\
6\end{array}$ & $\begin{array}{r}38,4 \\
19,9 \\
36,3 \\
5,2\end{array}$ & $\begin{array}{r}74,8 \\
12,7 \\
10,3 \\
1,6 \\
0,6\end{array}$ \\
\hline cotalal & 4418 & 120 & 191 & 307 & 354 & 493 & 603 & 393 & 205 & 7084 \\
\hline
\end{tabular}




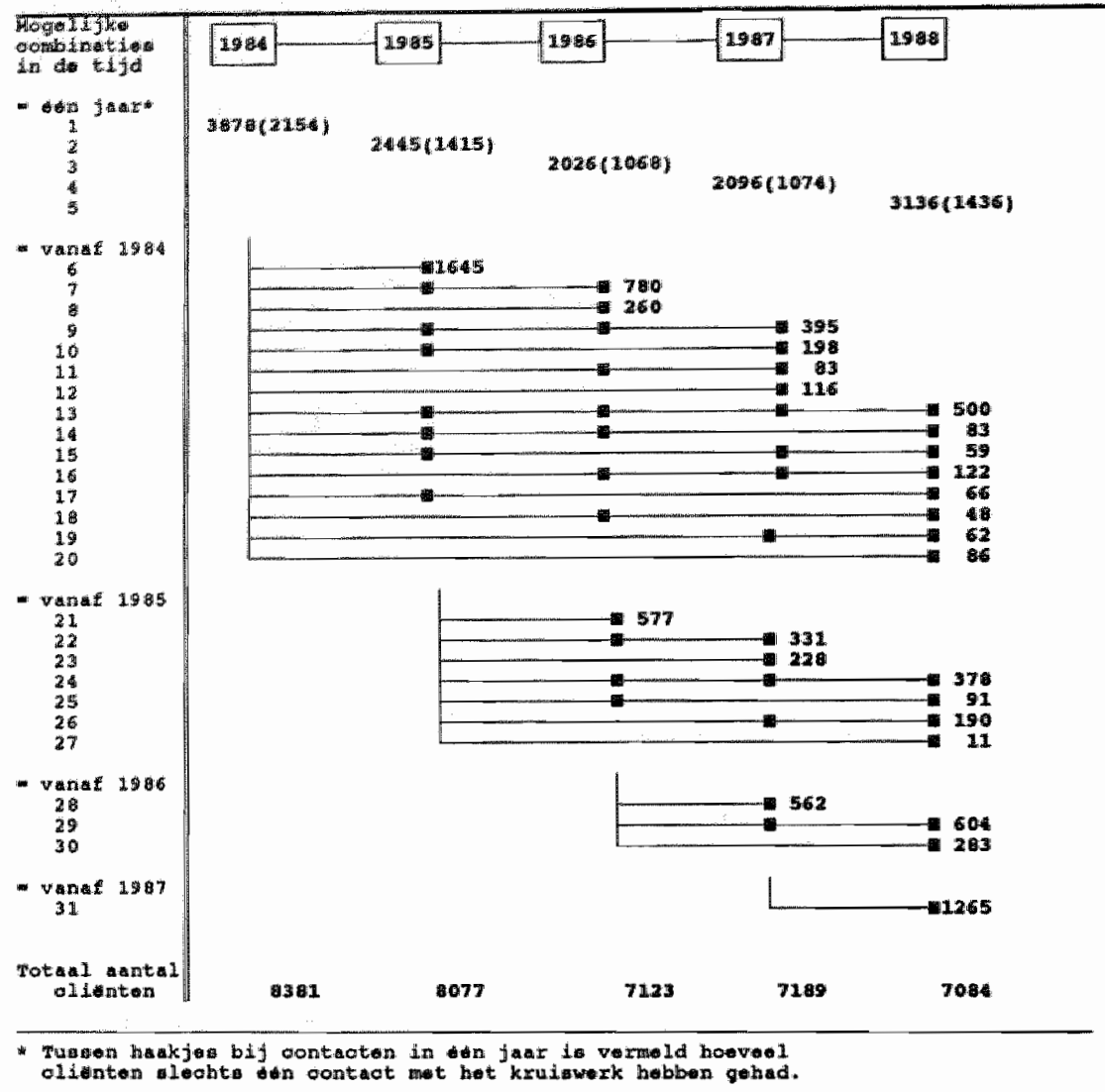

Figuur 7.2. Duur van de hulpverlening door de wijkverpleging: mogelijke combinaties in de periode 1984-1988 en het aantal clitinten

Vanwege verwerkingsproblemen kon slechts een klein aantal variabelen voor de analyse geselecteerd worden: het gezinsnummer en gezinslidnummer (de zoeksleutels in de koppeling van de jaarbestanden), het geboortejaar, het totaal aantal contacten in cen jaar en tenslotte het begin- en eindpunt van bulpverlening binnen eén jaar (op kwartaalbasis).

In figuur 7.2 ajn alle mogelijke combinaties in de periode $1984-1988$ (in totaal $2^{5}-1=31$ ) in beeld gebracht. De eerste vijf mogelijkheden betreffen clienten die slechts in eén jaar contact hebben gehad, waarbij tussen haakjes vermeld is hoeveel van deze personen slechts eén contact hadden. Vervolgens wordt in beeld gebracht hoeveel clienten in een bepaald jaar, beginnend met 1984, ook in een volgend jaar of nog langer in zorg zijn. Het optreden van een contact in een bepaald jaar wordt in de figuur steeds aangegeven door een blokje. Als laatste mogelijkheid zijn tenslotte de clienten in beeld gebracht die in 1987 voor het eerst in zorg kwamen en ook in 1988 gebruik gemaakt hebben van de wijkverpleging.

Een groot deel van de clienten blijkt in slechts ến van de jaren contact te hebben gehad: genjiddeld gaat het om bijna $36 \%$ wan alle cliënten op jaarbasis. Dit cijfer wordt echter om twee redenen enigszins vertekend. Enerzijds is het mogelijk dat er al clienten van vór 1984 aanwezig waren en voor wie 1984 het laatste jaar van wijkverpleging was. Anderzijds zullen er clienten zijn die in 1988 voor het eerst in zorg kwamen en in 1989 terugkeren. In 1985 1987 is het percentage clienten dat slechts contact had in een van deze drie jaren dan ook lager (circa 29\%). Van deze clienten had bovendien ongeveer de helft slechts één contact. 
Tabel 7.12. Verdeling van cliénten en contacten naar hulpduur (in \%)

\begin{tabular}{|c|c|c|c|c|c|c|c|c|}
\hline \multirow[b]{2}{*}{ hulpduar } & \multicolumn{4}{|c|}{ clienten } & \multicolumn{4}{|c|}{ contacten } \\
\hline & 1985 & 1986 & 1987 & 1988 & 1985 & 1986 & 1987 & 198 \\
\hline $\begin{array}{l}\text { navar } \\
1 \text { jaar } \\
2 \text { jaar } \\
3 \text { jaar } \\
4 \text { jaar }\end{array}$ & $\begin{array}{l}53,9 \\
46,1\end{array}$ & $\begin{array}{l}18,0 \\
19,3 \\
31,9\end{array}$ & $\begin{array}{l}46,8 \\
16,2 \\
15,7 \\
21,\end{array}$ & $\begin{array}{l}44,3 \\
17,9 \\
12,5 \\
10,9 \\
14,5\end{array}$ & $\begin{array}{l}31,8 \\
68,2\end{array}$ & $\begin{array}{l}26,0 \\
23,6 \\
46,1\end{array}$ & $\begin{array}{l}26,0 \\
17,3 \\
16,7 \\
40,3\end{array}$ & $\begin{array}{l}23,6 \\
17,5 \\
10,3 \\
15,6 \\
33,0\end{array}$ \\
\hline Totaal $(=1000)$ & 8077 & 7123 & 7189 & 7084 & 92393 & 98134 & 105045 & 107609 \\
\hline
\end{tabular}

Om de gemiddelde duur van de hulpverlening te benaderen, is in tabell 7.12 berekend hoe lang de cliënten in een bepaald jaar al in zorg waren en hoe de verdeling van contacten over de verschillende cohorten is. Gebruik makend van de epidemiologische vuistregel dat de incidentie (de nieuwe clienten) maal de duur gelijk is aan de prevalentie (het totaal aantal clienten), kan de gemiddelde duur van de wijkverpleging benaderd worden op $2 V_{4}$ jaar in 1988 (de reciproke van de fractie nieuwe clienten).

Er blijkt sprake te zijn van een geleidelijke toename van de hulpduur, waarbij het aandeel van nieuwe clienten steeds kleiner wordt. Deze nieuwe clienten krijgen bovendien gemiddeld minder contacten (in 1988 gemiddeld 8,1 contacten tegenover een overall gemiddelde van 15,2 , terwijl de zorgintensiteit van de al aanwezige clienten stijgt, zodat het aandeel van de contacten met nieuwe clienten in het totaal nog scherper daalt (van 32\% naar iets minder dan 23,6\%). Tenslotte blijkt het gemiddeld aantal contacten (zie tabel 7.13) toe te nemen met de duur van de hulpverlening, zodat met name de zorgintensiteit van clienten die 3 jaar of langer in zorg zijn, hoog is ( $11 / 2$ a 2 maal boven thet gemiddelde).

Uit het voorgaande blijkt welk beslag langdurige hulpverlening legt op de beschikbare capaciteit. Dit is het mooist te illustreren met de clienten die in 1988 al (minstens) vier jaar onafgebroken in zorg zijn geweest bij de wijkverpleging. Uit figuur 7.2 (mogelijkheid 13) blijkt dat het een relatief kleine groep betreft (500 clienten). Met een aandeel van 7,1\% in het totale clientenbestand van 1988 gebruikt deze groep langdurig verzorgden circa 29.500 contacten, dat is $27,4 \%$ van het total aantal contacten in 1988 (zie tabel 7.14). Dit aandeel in het totaal aantal contacten is bovendien geleidelijk gestegen gedurende de periode 19841987 om in het laatste jaar weer enigszins te dalen, maar is altijd vrij hoog geweest. De gemiddelde zorgintensiteit voor deze 'zware" clientencategorie binnen de wijkverpleging is het hoogst van alle clienten en stijgt gedurende de gehele periode in snel tempo, met uitzondering van het laatste jaar. Tenslotte kan vermeld worden dat deze groep clienten ook het grootste aantal ouderen telt: $60 \%$ van deze clienten is 65 jaar of ouder tegenover een ge-

Tabel 7.13. Gemiddeld aantal contacten voor diverse cohorten

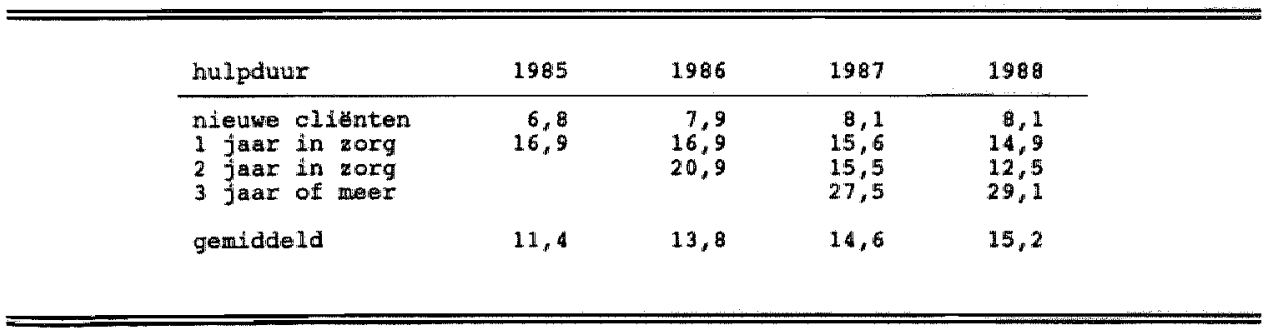


Tabel 7.14. Kernclffers woor cliênten met onafgebroken hulp $(\mathrm{N}=500)$

\begin{tabular}{|c|c|c|c|c|c|}
\hline & 1984 & 1985 & $19: 86$ & 1987 & 1980 \\
\hline 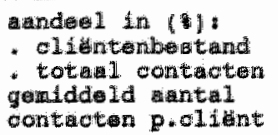 & $\begin{array}{r}6,6 \\
23,1 \\
4,3\end{array}$ & $\begin{array}{r}6,2 \\
26,6 \\
9,2\end{array}$ & $\begin{array}{r}7,0 \\
28,0 \\
54,9\end{array}$ & $\begin{array}{r}7,0 \\
30,2 \\
63,4\end{array}$ & $\begin{array}{r}7, \\
27, \\
59,1\end{array}$ \\
\hline
\end{tabular}

middelde over de gehele periode van ruim $30 \%$. Van alle contacten met deze intensief zorgbehoevende clienten in 1988 is $88 \%$ ten behoeve van 65 -plus.

Het voorgaande kan de vraag doen rijzen, of het gemiddeld aantal contacten niet hoger zou moeten zijn. Uit de frequentieverdeling wan het aantal contacten (zie tabel 7.15) blijkt dat ook bij cle clienten die al langer in zorg zijn, het nog vaak voorkomt dat dit niet meer dan ten contact per jaar betreft. Weliswaar daalt dit aandeel naarmate deze clienten langer in zorg zijn, maar dat gaat zeer geleidelijk tot het moment dat men drie jaar in zorg is. Pas bij de categorie die sinds 1984 onafgebroken in zorg is, neemt het aandeel van clienten met slechts én contact significant af tot $26,4 \%$. Het feit dat men all langer in zorg is, doet zich met name gelden in de staart van de verdeling. Twee of meer contacten per week (meer dan 100 per jaar) komt voor bij 14,6\% van de sinds 1984 aanwezige clienten en bij slechts $1,2 \%$ van de nieuwe clienten.

Bij de ouderen (tabel 7.16) komt een min of meer vergelijkbaar patroon naar voren, maar is het aandeel van mensen met eén contact aanzienlijk lager, met name bij langdurige hulp. Toch heeft nog $9 \%$ van de clienten die sinds 1984 aanwezig zijn jaarlijks maar én contact. Aan de andere kant heeft éen op de tien van hen minstens elke werkdag in het jaar contact met de wijkverpleging $(6,3 \%$ zelfs 365 dagen per jaar).

Door terugkoppeling van de hulpduur naar het oorspronkelijke clientenbestand voor 1988 kan tot slot van dit hoofdstuk de verdeling van contacten naar verpleegdoelen geanalyseerd worden voor de verschillende categoriën elienten. Daarbij gaan wij weer uit van de clienten die sinds zij in zorg kwamen onafgebroken gebruik zijn blijven maken van de wijkverpleging.

Naarmate de hulpduur toeneemt verschuift de aard van de hulp door wijkverpleging in de richting van steeds meer lichamelijke hygienische verzorging, verpleegkundige handelingen

Tabel 7.15. Contactfrequentie voor enkele belangrijke groepen in 1988

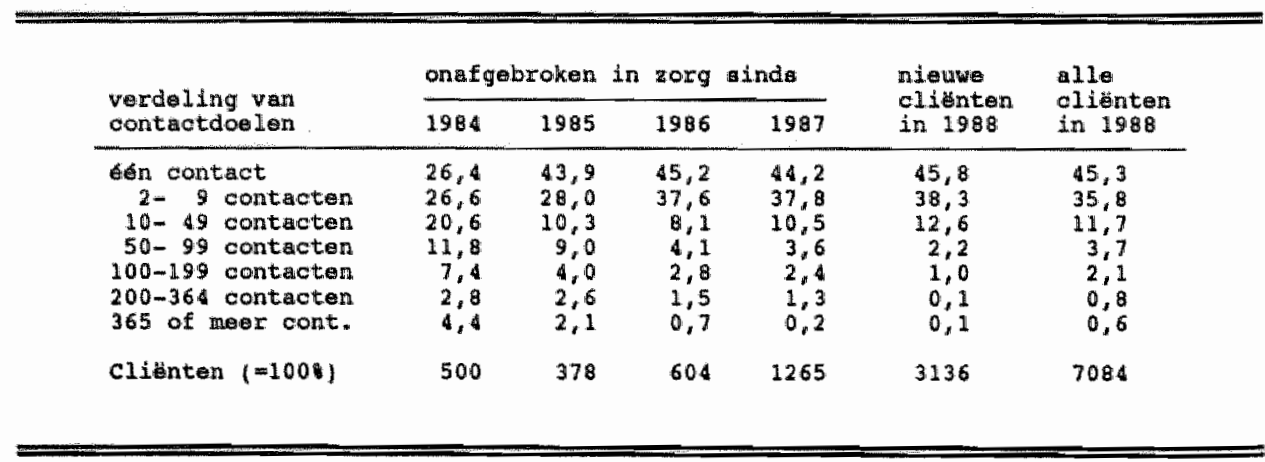


Tabel 7.16. Contactrequentie voor enkele groepen 65-plussers In 1988

\begin{tabular}{|c|c|c|c|c|c|c|}
\hline \multirow{2}{*}{$\begin{array}{l}\text { rerdeling van } \\
\text { contactdoelen }\end{array}$} & \multicolumn{4}{|c|}{ onafgebroken in corg Inda } & \multirow{2}{*}{$\begin{array}{l}\text { nifouwe } \\
\text { cilidnten } \\
\text { in } 1988 .\end{array}$} & \multirow{2}{*}{$\begin{array}{l}\text { alle } \\
\text { elifmen } \\
\text { in } 1988\end{array}$} \\
\hline & 1984 & 1985 & 1985 & 19187 & & \\
\hline $\begin{array}{l}\text { en contact } \\
2-9 \text { cantacten } \\
10-49 \text { contacten } \\
50-99 \text { cantacten } \\
100-199 \text { contacten } \\
200-364 \text { contacten } \\
365 \text { of moer cont. }\end{array}$ & $\begin{array}{r}9,9 \\
22,2 \\
30,5 \\
17,9 \\
10,6 \\
3,6 \\
6,3\end{array}$ & $\begin{array}{r}12,7 \\
25,4 \\
43,0 \\
20,4 \\
9,9 \\
5,6 \\
3,5\end{array}$ & $\begin{array}{l}19,9 \\
33,7 \\
32,0 \\
12,2 \\
7,2 \\
5,0 \\
2,2\end{array}$ & $\begin{array}{l}16,7 \\
27,6 \\
42,0 \\
12, \\
6,5 \\
4,0 \\
0,6\end{array}$ & $\begin{array}{r}22,7 \\
0, \\
28,4 \\
5,1 \\
2,5 \\
0,3 \\
0,3\end{array}$ & $\begin{array}{r}20,1 \\
33,18 \\
27,6 \\
9,5 \\
5,4 \\
2,1 \\
1,4\end{array}$ \\
\hline clisinten $(=1.000)$ & 302 & 142 & 181 & 348 & 1040 & 2355 \\
\hline
\end{tabular}

en medicijnen toedienen (zie tabe』 7.17). Deze verschuiving gaat ten koste van begeleiding in probleemsituaties, gezondheidsvoorlichting en -opvoeding en de contacten met derden. Dit soort contactdoelen is kennelijk minder noodzakelijk of minder relevant naarmate men langer in zorg is bij de wijkverpleging. Het aandeel van ouderen neemt eveneens toe naarmate men langer in zorg is. Bij nieuwe clienten in 1987 is $27,5 \%$ ouder dan 65 en $14 \%$ ouder dan 80 jaar. Dit loopt op tot $60,4 \%$ en $33,2 \%$ voor clienten die sinds 1984 onafgebroken in zorg zijn. Gemidoeld is van alle clienten in $198833,2 \% 65$-plus en $17 \%$ 80-plus.

\subsection{Personeelsformatie van kruiswerk in Maastricht}

Uitgaande van de Kernbeleidsstatistiek voor de provincie Limburg (periode 1979-1984) en de jaarverslagen van de regionale vereniging zelf, zijn in tabel 7.18 de ontwikkelingen in de personeelsformatie uitgezet naar personeelscategoriesn en in totaal (in full-time equivalenten, afgekort tot f.t.e.).

Sinds 1980 blijkt met name het direct uitvoerend personeel (inclusief hoofdwijkverpleegkundigen) sterk uitgebreid te zijn van 55 naar 79,5 formatieplaatsen, een gemiddelde jaarlijkse toename van $5,4 \%$. Het ondersteunende personeel is in omvang nagenoeg constant gebleven, na een aanvankelijke uitbreiding in 1984 . De totale formatie is thans 91,4 arbeidsplaatsen (f.t.e.). Ten opzichte van 1980 betekent dat een gemiddelde groei met 4,5\% per jaar.

Door het stabiel gebleven formatiepeil van indirect personeel, is de verhouding direct versus indirect personeel sterk verbeterd ten gunste van de hulpverlening. Deze ontwikkeling heeft ook nationaal plaatsgewonden. Thans is $87 \%$ van al het personeel direct bij de hulpverlening betrokken, waarbij ook de bijna 7 f.t.e. voor hoofdwijkverpleegkundigen meegerekend is. In 1980 lag dit percentage nog op $82 \%$.

Tabel 7.17. Verdeling contacten voor enkele belangrijke groepen in 1988

\begin{tabular}{|c|c|c|c|c|c|c|}
\hline \multirow{2}{*}{$\begin{array}{l}\text { verdeling van } \\
\text { contactdoelen }\end{array}$} & \multicolumn{4}{|c|}{ anafgebroken in zorg ainds } & \multirow{2}{*}{$\begin{array}{l}\text { nieuwe } \\
\text { elienten } \\
\text { in } 1988\end{array}$} & \multirow{2}{*}{$\begin{array}{l}\operatorname{tot} a \\
\ln \\
1908\end{array}$} \\
\hline & 1984 & 1985 & 1986 & 1987 & & \\
\hline $\begin{array}{l}\text { Hich verzorging } \\
\text { werpleegk handelen } \\
\text { medicljntoodiening } \\
\text { contact met dexden } \\
\text { overige doelen }\end{array}$ & $\begin{array}{r}63,1 \\
13,2 \\
12,2 \\
3,3 \\
8,2\end{array}$ & $\begin{array}{r}55,1 \\
14,8 \\
14,4 \\
4,6 \\
11,1\end{array}$ & $\begin{array}{r}56,6 \\
10,7 \\
11,0 \\
4,7 \\
17,0\end{array}$ & $\begin{array}{r}55,0 \\
14,2 \\
6,6 \\
5,5 \\
10,7\end{array}$ & $\begin{array}{r}39,3 \\
23,7 \\
5,7 \\
6,3 \\
25,0\end{array}$ & $\begin{array}{r}52,6 \\
16,1 \\
9,1 \\
5,1 \\
17,1\end{array}$ \\
\hline Totaal (-1008) & 29531 & 13590 & 10177 & 18814 & $2538: 5$ & 107609 \\
\hline
\end{tabular}


Tabel 7.18. Personeelsformatie wan reglonale kruisvereniging Maastricht en omgeving*

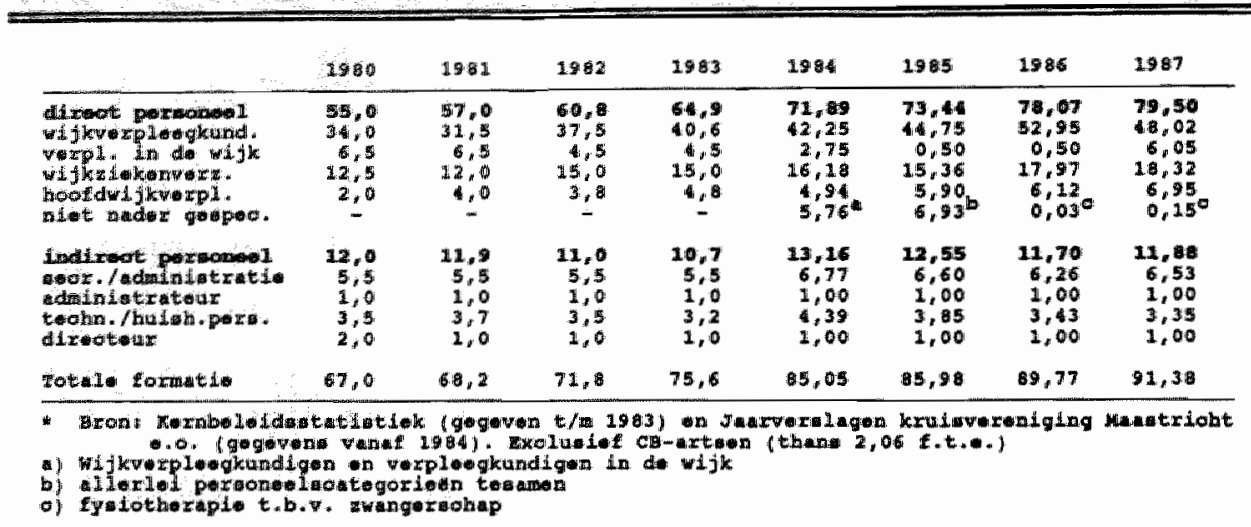

De jaarlijkse uitbreidingen zijn een uitvloeisel van de vanaf 1980 aan het Kruiswerk toegekende volumegroei en wordt op basis van provinciale volumeplannen verdeeld over de regionale verenigingen. Naast volumegroei is in 1983 en 1984 tevens sprake van uitbreiding als gevolg van de herbezetting in het kader van de arbeidsduurverkorting. Deze herbezetting mocht echter niet voor $100 \%$ benut worden. Tenslotte geldt specifiek voor Limburg nog een uitbreiding in de toegestane formatie ten gevolge van de in 1981 aan de provincie toegekende Structurele ArbeidsPlaatsen (SAP): Maastricht kreeg in 1981 drie SAP-plaatsen; ến wijkverpleegkundige en twee wijkziekenverzorgenden.

\subsection{Kosten en financiering van het kruiswerk in Maastricht}

Bij de bespreking van de kosten en financiering van de regionale kruisvereniging te Maastricht beperken wij ons tot het basispakket in het kader van de AWBZ. De kosten die buiten het basispakket vallen, zijn zeer gering (in 1987 nog geen $f 30.000$,-) en worden bovendien meer dan gecompenseerd door extra-contributies (het gedeelte dat boven op de standaardrontributie gelegd kan worden; in Maastricht 50 cent) en door de overige kosten. De basiseesheden dragen de standaardcontributie af aan de vereniging en kunnen zelf de bestemming van de extra-contributie bepallen.

In tabel 7.19 is de exploitatierekening van het basispakket voor de periode 1983-1987 in kaart gebracht. De totale lasten zijn in deze vijf jaar met $9,5 \%$ gestegen tot 6,16 miljoen in 1987 (gemiddeld 2,3\% per jaar). De belangrijkste stijging trad echter op in $1986(6,7 \%)$. Van de totale lasten wordt het grootste deel in beslag genomen door de personeelskosten van het directe en indirecte personeel tezamen. Het aandeel van de personeelslasten in de totale lasten bedraagt in $198787,1 \%$ en is sinds $1983(86,2 \%)$ derhalve licht gestegen. Het aandeel van de bureau-, administratie- en algemene kosten is daarentegen licht gedaald van $4,7 \%$ tot $4,4 \%$ in 1987 . De kosten worden voor een groot deel gedragen door de AWBZ $(82,6 \%$ van alle kosten in 1987). Gebruikers van de diensten van het kruiswerk dragen door middel van de contributies (in $1987 f 40,-$ per lid) circa $16 \%$ van de totale kosten.

Op basis van dit overzicht, gecombineerd met de gegevens over contacten, kan een benadering van de kostprijs van de wijkverpleging gemaakt worden. Hiertoe moet nog een veronderstelling gemaakt worden, ondat bij de cliëntanalyses alleen naar de gemeente Maastricht gekeken is en niet naar het totale werkgebied van de regionale kruisvereniging, 


\begin{tabular}{|c|c|c|c|c|c|}
\hline & 1983 & 1984 & 1985 & 1986 & 1987 \\
\hline 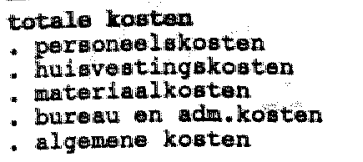 & $\begin{array}{r}5.632,2 \\
.857,4 \\
383,4 \\
127,5 \\
177,2 \\
86,7\end{array}$ & $\begin{array}{r}5.739,2 \\
+888,7 \\
369,4 \\
106,9 \\
180,0 \\
194,2\end{array}$ & $\begin{array}{r}5.804,7 \\
5.051,1 \\
368,5 \\
120,7 \\
188,9 \\
75,5\end{array}$ & $\begin{array}{r}6.191,8 \\
5,359,2 \\
390,5 \\
142,8 \\
166,1 \\
125,2\end{array}$ & $\begin{array}{r}6.164,9 \\
5.370,3 \\
379, \\
147, \\
145,0 \\
123,9\end{array}$ \\
\hline $\begin{array}{l}\text { totale baten } \\
\text { * ABE } \\
\text { * bijaragen cont.besluit } \\
\text { - huren } \\
\text { - baten woorgande jaren } \\
\text { - rente } \\
\text { - overige baten } \\
\text { - contributies }\end{array}$ & $\begin{array}{r}5.632,2 \\
4.420,5 \\
13,5 \\
41,4 \\
36,2 \\
35,9 \\
169,3 \\
915,4\end{array}$ & $\begin{array}{r}5.739,2 \\
4.514,3 \\
18,5 \\
39,8 \\
- \\
58,7 \\
167,5 \\
940,4\end{array}$ & $\begin{array}{r}5.804,7 \\
4.573,2 \\
19,2 \\
41,3 \\
4,9 \\
40,2 \\
166,4 \\
959,5\end{array}$ & $\begin{array}{r}6.191,8 \\
4.996,8 \\
19,6 \\
48,5 \\
1,1 \\
11,3 \\
145,7 \\
968,8\end{array}$ & $\begin{array}{r}6.164,9 \\
5.094,4 \\
19,6 \\
52,7 \\
1,1 \\
3,9 \\
9,2 \\
984,1\end{array}$ \\
\hline
\end{tabular}

* Herberekend wegens enigazins gewijzigde rubricering $v$ am de kostenposten

dat ook Eysden omvat. In 1988 was $5,72 \%$ van alle contacten ten behoeve van de inwoners van Eysden. Veronderstellend dat dit aandeel ook in 1987 opgaat, zijn er in het totale werkgebied in 1987111.400 contacten gerealiseerd. Bij een exploitatie van 6,16 miljoen resulteert dat in een gemiddelde kostprijs van $f 55$,- per contact.

Bij dit generale gemiddelde kan een aantal kanttekeningen geplaatst worden. Allereerst dienen om een zuiver beeld van de kostprijs per contact te krijgen, uit de totale kosten die posten afgezonderd te worden die geen betrekking hebben op individuele contacten. Het gaat dan bijvoorbeeld om de kosten van pre- en postnatale cursussen. Vervolgens zou een onderscheid gemaakt kunnen worden naar de personeelscategorieen die de contacten realiseren. Per voltijdse arbeidsplaats in 1987 blijkt dit te leiden tot een verschil in het gemiddeld aantal contacten. Verpleegkundigen (wijkverpleegkundigen, verpleegkundigen in de wijk en vervanging) realiseerden in 1987 ongeveer 85.000 contacten met 54,1 f.t.e., hetgeen gemiddeld ruim 1.570 contacten per arbeidsplaats betekent. Bij wijkziekenverzorgenden en hun vervanging worden in totaal circa 26.400 contacten geregistreerd (rekening houdend met Eysden) en zijn er in totaal 18,3 plaatsen. Gemiddeld betekent dat ruim 1.440 contacten per kracht. Geconstateerd kan worden dat verpleegkundigen derhalve $9 \%$ meer contacten verrichten. Daar staat echter tegenover dat de gemiddelde loonkosten voor de verpleegkundigen circa $f 53.000$,- per jaar bedragen en daarmee bijna $30 \%$ boven de loonkosten voor wijkziekenverzorgenden (circa $f 41.000,-$ ) liggen. Per contact resteert derhalve een werschil in kostprijs van circa $20 \%$ (ten gunste van wijkziekenverzorging). De laatste kanttekening betreft het onderscheid dat idealiter gemaakt zou moeten worden tussen directe en indirecte kosten. De rol van de hoofdwijkverpleegkundigen is in een dergelijke verdeling niet goed in beeld te brengen. In de statistieken van de kruisverenigingen worden hoofdwijkverpleegkundigen onder het directe personeel begrepen, doch hun rol ligt voor een belangrijk deel in de coördinatie en het management van de zorgverlening en is in die zin voor de feitelijke hulpverlening van meer indirecte aard.

\subsection{Samenvatting en conclusies}

Uit de analyse van clientkenmerken blijkt dat een daling in het totale clientbestand is opgetreden van ruim 8.000 in 1984 naar iets meer dan 7.000 personen in 1988. Het aandeel van ouderen (65-plus) schommelde in de periode 1984-1988 rond 1/3. De alleroudste clienten nemen absoluut $e n$ relatief in aantal toe: in 1988 is $8,4 \%$ van alle clienten 85 jaar of ouder. Het totaal aantal geregistreerde contacten nam met gemiddeld $3 \%$ per jaar toe 
tot 107.609 contacten in 1988 . Het aandeel van 65 -pius vertoont een onafgebroken stijging tot $78,3 \%$ in 1988 . De zorgintensiteil bij wijkverpleging in de periode 1984-1988 toegenomen tot thans 15,2 contacter. De ouderen vanaf 65 jaar consumeren 2 a 3 maal zoveel contacten als dit overall genviddelde. De verklaring hierwoor kan weeledig zijn: met de leeftijd neent enerzijds de kans op een intramurale opname toe en anderzijos stijgt cok de kans op gecombineerde hulpwerlening door zowel het kruiswerk als de gezinswerzorging, waardoor minder contacten nodig zijn dan in de situatie dat alleen het kruiswerk de benodigde zorg zou leveren.

Het aandeel van lichamelijke bygienische verzorging is toegenomen tot ruim $52 \%$ in 1988 . Ook verpleegtechnische handelingen worden steeds belangrijker en beslaan thans ruim $16 \%$ van alle contacten. De toename in curatieve zorg is ten koste gegaan van meer preventief geaarde activiteiten, maar ook de contacten met andere hulpverleners laten een daling zien. Bij de alleroudste cilenten wordt deze trend echter niet teruggevonden, waaruit geconcludeerd wordt dat afstemming in de zorg belangrijker wordt naarmate de zorg intensiever wordt.

Het bereik van de wijkverpleging, uitgedrukt in het percentage clienten ten oprichte van de totale bevolking, is gedaald van $7,4 \%$ tot $6,1 \%$. Bij 65 -plussers is eveneens een daling tot $14,5 \%$ in 1988 waar te nemen. Binnen de oudere populatie stijgt het bereik sterk met de leeftijd tot $43,2 \%$ voor 85 -plussers (gegevens 1988). Bovenstaande cijfers worden echter in niet onbetekenencle mate vertekend door het feit dat een aanzienlijk deel van de clienten slechts eén contact op jaarbasis heeft (in $198845 \%$ van alle clienten). De tweede methode die uilgaat van het aantal contacten per inwoner is veel minder gevoelig voor het aantal eenmalige clienten, omdat dat slechts $3 \%$ van alle contacten beslaat. De stijgende zorgintensiteit compenseert de afname in het aantal clienten meer dan volledig, zodat het bereik van wijkverpleging, uitgedrukt in het aantal contacten per inwoner, in de periode 1984-1988 is opgelopen.

Vervolgens is een analyse gemaakt van de duur van de hulpverlening. Enerzijds blijkt het aantal clienten dat slechts énmalig contact heeft gehad gedurende de gehele periode erg groot $(30 \%)$. Anderzijds bestaat er een groep clienten die langdurig in zorg is en in aantal welliswaar klein is, maar een groot beslag op het aantal contacten legt. De gemiddelde duur van de hulpverlening is bij benadering $2 \frac{1}{4}$ jaar. Personen die onafgebroken wijkverpleging hebben gebruikt gedurende de gehele periode 1984-1988 zijn nader bestudeerd. Deze groep vormt $7,1 \%$ wan het clientenbestand in 1988 , maar gebruikt $27,4 \%$ van alle contacten, hetgeen neerkomt op gemiddeld 59 contacten per client op jaarbasis. Zelfs bij deze intensieve groep clienten komt het echter nog vrij vaak (26\%) voor dat slechts eén contact wordt geconsumeerd. Deze langdurig in zorg verblijwende categorie clienten heeft niet alleen in omvang meer zorg, maar ook een intensievere zorg dan alle andere clienten. Tenslotte betreft het voor een groot deel $(60 \%)$ oudere clienten (vanaf 65 jaar). Samenvattend kan gesteld worden dat naarmate men langer in zorg is bij de wijkverpleging, de omvang wan de zorg toeneemt en deze zorg relatief steeds intensiever wordt door een verschuiving van de verpleegdoelen naar de lichamelijke en hyglenische verzorging.

De totale kosten (voor bijna $90 \%$ personeelslasten) bedragen thans 6,16 miljoen en worden voor ruim $80 \%$ vergoed door de AWBZ. Nog eens $16 \%$ van de kosten wordi gedekt door de heffing van contributies bij de leden van de kruisvereniging. In Maastricht en omstreken betreft dat circa 25.000 huishoudens. Per contact is om diverse redenen slechts een benadering van de kosten mogelijk, die resulteert in $f 55$, per contact. Het zou, ook in het kader van de Dekker-plannen, zeer wenselijk zijn een differentiatie in de kostprijsberekening te ontwikkelen, zowel naar de directe en indirecte kosten, als naar de personeelscategorieen en de verschillende zorgfuncties die in het kruiswerk worden onderscheiden (Meijer, 1990; Hujjsman en Janssen, 1990). 


\section{Gecoördineerd ouderenwerk en het gebruik van dienstencentra}

\subsection{De ontwikkeling van het GOW in Maastricht}

Het gecoördineerd ouderenwerk (in het vervolg: GOW) is in Maastricht van oudsher een werkvorm geweest van een overkoepelende gemeentelijke welzijnsstichting. Het aanvankelijk zo genoemde 'open bejaardenwerk' kreeg tot eind zeventiger jaren woornamelijk gestalte in hel werk van de dienstencentra. Het eerste dateert uit 1969 (in de binnenstad). Er kwamen in korte tijd drie nieuwe dienstencentra bij:" Maastricht Oost, Mariaberg/Brusselse Poort (1973) en in een complex van 248 bejaardenwoningen in Daalhof (1974). In $1975 \mathrm{kreeg}$ DC Mariaberg een dependance. Bij de start van elk dienstencentrum werd tevens een functionaris benoemd (toen 'leider dienstencentrum"), in Oost ondersteund door een medewerker (1976). In het project Binnenstad-West is bovendien nog een half-time medewerker aangesteld. Begin jaren zeventig begint de stedelijke coordinatie langzaam gestalte te krijgen. Het in 1968 opgerichte Maatschappelijk Overleg Maastricht start in 1970 een sectie Bejaardenbeleid, waarin stedelijk overleg gevoerd wordt over meer algemene (beleids-)zaken op het terrein van het welaijn voor bejaarden. Participanten waren de gemeente (dienst sociale zaken), gezinsverzorging, kruiswerk, bejaardenoorden, verpleeghuis, geestelijke gezondheidszorg en bejaardenorganisaties. Vanaf 1971 participeert het open bejaardenwerk in de Registratiecommissie Opname Verzorgingstehuizen, de voorloper van de indicatiecommissie voor bejaardenoorden. Reeds begin 1975 is de aanstelling van een stedelijk projectleider (nu 'hoofdfunctionaris') aanhangig gemaakt, doch hieraan werd pas medio 1980 door het Ministerie van CRM gehoor gegeven in het kader van het zogenaamde arbeidsplaatsenplan gecoordineerd bejaardenwerk. Per 1 januar 1981 is de hoofdfunctionaris in dienst getreden. Na voorgaande fasen van opbouw van het dienstencentrumwerk startte eind 1977 een fase van herstructurering, die door allerlei oorzaken (Huijsman, 1989d) bijna vijf jaar duurde. Eind maart 1981 verscheen het eindrapport van de commissie, waarbij de richtlijnen en voorschriften van de Tijdelijke Rijksbijdrageregeling (Stcrt. 1980, no. 91) bijna letterlijk gevolgd worden naar doelstelling, bestuurssamenstelling en dergelijke. In 1983 werd het nieuwe sectorbestuur, samengesteld volgens de voorschriften van de rijksbijdrageregeling (onder andere $30 \%$ van zetels voor vertegenwoordigers van ouderen), gelnstalleerd door de wethouder van Sociale Zaken, Welzijn en Volksgezondheid. De instelling voor het Gecoordineerd OuderenWerk (GOW) in Maastricht was hiermee een feit. Sinds 1983 gaat de aandacht vooral wit naar het realiseren van feitelijke coordinatie en samenwerking tussen instellingen op uitvoerend niveau (met name op wijkniveau) en op beleidsniveau (directie en besturen). Dit kreeg gestalte in eerstelijnsoverleg in het merendeel der Maastrichtse wijken, maar ook in concrete samenwerkingsprojecten zoals rondom dagopvang (1984), maaltijdvoorziening en alarmering (1985) en het project Integrale Hulpverlening Daalhof (1986). Een ander concreet voorbeeld van afstemming tussen instellingen is de herindeling van werkgebieden in Maastricht (1984). Ook aanvragen in het kader van het Flankerend Beleid zijn op uitdrukkelijk verzoek van de instellingen onder coördinatie van het GOW tot stand gekomen en bij de provincie ingediend. Dit heeft begin 1988 verder gestalte gekregen middels de aanstelling van een functionaris Flankerend Belleid. 


\subsection{Dataverzameling}

Alle activiteiten van het GoW zijn gebundeld in vier zogenaamde projecten, namelik Project Binnenstad-West, Project Mariaberg-Daalhof, Project Brusselse Poort en Project Maastricht-Oost. Iedere functionaris is wel op de hoogte van de aard, lokatie en frequentie van de activiteiten die onder zijn verantwoordelijkheid vallen, maar weet sllechits bij benadering hoeveel mensen deze activiteiten bezoeken of hoeveel ouderen slechts komen voor de gezelligheid, zonder structureel aan activiteiten mee te doen. Kenmerken van de gebruikers van dienstencentra en van de deelnemers aan GOW-activiteiten, zoals hun leeftijd of samenlevingsvorm, zijn onbekend.

Het bovenstaande en het feit dat ook via andere wegen geen inzicht te verkrijgen is over de gebrukkers en hun kenmerken, is in 1988 aanleiding geweest om een enquete te houden onder alle regelmatige bezoekers en deelnemers aan structurele activiteiten, die vallen onder de verantwoordelijkheid van het GOW. Door middel van de enquête (Huijsman, 1989d), die in overleg met de (hoofd)functionarissen van het GOW werd opgesteld, is gepoogd meer inzicht te krijgen in het gebruik van dienstencentra en de deelname aan activiteitten. Daarbij moest aan een aantal voorwaarden worden voldaan. Ten eerste mocht de enquete niet te lang duren om medewerking zo makkelijk mogelijk te maken. Derhalve moest een keuze worden gemaakt ten aanzien van relevante vragen. Zo zijn vragen naar het gebruik van andere voorzieningen summier gebleven en ontbreken vragen over hoe lang men al komt. De aandacht werd met name gelegd op bezoekfrequentie en redenen daarvoor. Men kon aangeven naar welke andere lokaties men $\delta \delta k$ gaat voor GOW-activiteiten, welke activiteiten dat dan zijn en hoe vaak men dárheen gaat. Gekozen werd voor een periode van cén week om zoveel mogelijk ouderen te bereiken (de week van maandag 25 aprill $t / m$ zondag 1 mei 1988). In deze week is op iedere lokatie door een functionaris of vrijwilliger van het GOW aan de bezoekers gevraagd om de enquête in te vullen. In de praktijk bleek dat gezamenlijk invullen met de oudere het beste werkte en dan vlug plaats kon vinden.

Op éen lokatie (Dienstencentrum Daalhof) werd het veldwerk gedurende de gehele week door de onderzcekers zelf uitgevoerd vanwege praktische en organisatorische redenen. Waar nodig werd door de onderzoekers ook op andere plaatsen ingesprongen, doch dit was incidenteel. Nergens werden problemen met de enquête gesignaleerd, mede door het feit dat de opzet daarvan steeds met de functionarissen was voorbereid. Een belangrijke groep activiteiten, namelijk het Meer Bewegen voor Ouderen, is niet op deze wijze onderzocht, omdat het gaat om ruim 50 groepen met gemiddeld 20 deelnemers. Daarnaast bestaan er nog ruim 15 groepen die zwemmen of bewegen in warm water, eveneens in het kader van MBvO. Overigens zal blijken dat bij dienstencentra slechts sporadisch aangegeven werd dat men cok naar MBvO-activiteiten gat (circa 8\%). Deze voorzieningen lijken derhalve min of meer gescheiden van elkaar gebruilkt te worden en zich op verschillende doelgroepen te richten (Huijsman, 1989d). Voor de start van het veldwerk was afgesproken bij te houden hoeveel mensen weigerden mee te werken aan de enquete. Desondanks is het uiteindelijke aantal niet-geênqueteerde personen niet exact bekend. Veiligheidshalve kan de totale nonrespons op circa $10 \%$ gesteld worden. Overigens bleken veel bezoekers, die aanvankelijk weigerden, in de loop van de week alsnog mee te willen werken, ofwel op de zelfde lokatie, ofwel elders, zodat de non-respons nog iets lager is. In totaal zijn 639 enquetes verwerkt en bleken daarnaast nog 8 formulieren niet goed ingevuld te zijn. Het feitelijk aantal bezoekers, rekening houdend met de non-respons, wordt geschat op circa 700 mensen. 


\subsection{Analyse van kenmerken van bezoekers dienstencentra}

Gemakshalve wordt steeds over de "bezoekers van dienstencentra" gesproken, makr er zijn ook andere lokaties in Maastricht waar activiteiten in het kader en onder verantwoordelijkheid van het GOW georganiseerd worden, bijwoorbeeld in een buurthuis of wijkgebouw. Al deze lokaties zijn in het onderzoek betrokken. Incidentele activiteiten, zoals cursussen en vieringen, worden door deze onderzoeksmethode niel bestreken.

Achtereenvolgens komen aan de orde: leeftijds- en geslachtsverdeling van bezoekers dienstencentra, leefsituatie van respondenten (alleen of samen), bezoekfrequentie en bezoekredenen, vervoer en wijze van contact met GOW en het gebruik van andere voorzieningen (gezinsverzorging, wijkverpleging).

\subsubsection{Leeftijdsituatie van bezoekers dienstencentra}

De leeftijds- en geslachtsverdeling van alle bezoekers van dienstencentra en andere gebouwen waar activiteiten plaats vinden onder verantwoordelijkheid van het GOW te Maastricht, is samengevat in tabel 8.1. Er is een aantal vragen gesteld over de leefsituatie van de bezokers van dienstencentra. Gevraagd is naar de buurt of wijk waar men woont en of men alleen of samen met iemand anders woont. Bewust is niet gevraagd naar de straat en huisnummer (privacyl) of burgerlijke staat, omdat deze zaken gevoelig kunnen zijn of net geworden zijn (overlijden partner!). Uit de literatuur is overigens bekend dat niet zozeer burgerlijke staat als wel de omvang van het huishouden, hier onderscheiden in alleenstaand of samenwonend, van belang is voor eventueel gebruik van woorzieningen (zie onder andere STG, 1985). Zoals bij veel voorzieningen in de welzijns- en gezondheidszorg zijn ook bij de dienstencentra de vrouwen in de meerderheid. Van alle bezoekers is meer dan $2 / 3_{\text {, namelijk }}$ $69,4 \%$, vrouw. Uit de leeftijdsverdeling blijkt dat bij mannen én vrouwen een niet onaanzienlijk deel $(32,3 \%$ respectievelijk $28,7 \%)$ van de bezoekers jonger is dan 65 jaar. De belangrijkste leeftijdscategorieen betreffen mensen van 65 tot 80 jaar (circa $57 \%$ ). Van een klein deel van de respondenten is overigens geen leeftijd $(2,3 \%)$ of geslacht $(0,3 \%)$ bekend. Van de respondenten warvan de leefsituatie bekend is $(N=628)$ blijkt $47,3 \%$ alleen te wonen. Ruim $80 \%$ biervan betreft alleenwonende vrouwen. Van diegenen die samenwonen $(52,7 \%)$ met partner, kinderen of anderen is $42 \%$ manlijk. Uit de leeftijdsverdeling blijkt dat samenwonende personen (mannen en vrouwen) gemiddeld jonger zijn dan alleenwonen-

Tabel 8.1. Bezoekers dienstencentra naar leeftild, samenlevingsworm en geslacht

\begin{tabular}{|c|c|c|c|c|c|c|c|c|c|c|c|}
\hline \multirow{2}{*}{\multicolumn{2}{|c|}{ Leeftijd }} & & \multicolumn{3}{|c|}{ Alleenwonend } & \multicolumn{3}{|c|}{ s menwonend/giehuwd } & \multicolumn{3}{|c|}{ Totaral } \\
\hline & & & $\mathbf{M}$ & $\mathbf{v}$ & Tot. & 4 & $\mathbf{v}$ & mot. & $\mathbf{M}$ & $\mathrm{v}$ & wat. \\
\hline $\begin{array}{l}55 \\
60 \\
65 \\
70 \\
75 \\
80 \\
85\end{array}$ & $\begin{array}{l}\leq 54 \\
-59 \\
-64 \\
-69 \\
=74 \\
=79 \\
-84 \\
-89 \\
290 \\
\text { zekend }\end{array}$ & $\begin{array}{l}\text { jaar } \\
\text { jaar } \\
\text { jaar } \\
\text { jaar } \\
\text { jaar } \\
\text { jaar } \\
\text { jaar } \\
\text { jaar } \\
\text { jaar }\end{array}$ & $\begin{array}{r}1 \\
1 \\
7 \\
5 \\
9 \\
17 \\
5 \\
6 \\
1 \\
2\end{array}$ & $\begin{array}{c}5 \\
6 \\
25 \\
38 \\
64 \\
65 \\
23 \\
11 \\
3 \\
3\end{array}$ & $\begin{array}{c}6 \\
7 \\
32 \\
43 \\
73 \\
82 \\
28 \\
17 \\
4 \\
5\end{array}$ & $\begin{array}{r}16 \\
13 \\
24 \\
35 \\
28 \\
14 \\
4 \\
3 \\
1\end{array}$ & $\begin{array}{r}23 \\
28 \\
40 \\
38 \\
31 \\
16 \\
9 \\
1 \\
6\end{array}$ & $\begin{array}{c}39 \\
41 \\
64 \\
73 \\
59 \\
31 \text { * } \\
13 \\
4 \\
7\end{array}$ & $\begin{array}{c}17 \\
14 \\
32 \\
40 \\
37 \\
32 \\
10 \\
9 \\
1 \\
3\end{array}$ & $\begin{array}{c}28 \\
34 \\
65 \\
77 \\
96 \\
83 \\
32 \\
12 \\
3 \\
12\end{array}$ & $\begin{array}{r}45 \\
48 \\
97 \\
117 \\
133 \\
117 \\
42 \\
21 \\
4 \\
1.5\end{array}$ \\
\hline Fot & :ad 1 & & 54 & 243 & 297 & 138 & 192 & 331 & 195 & 142 & 635 \\
\hline
\end{tabular}

- Inclubief gealacht en leefituatie onbekend ( $N=2)$ 
den. De gemiddelde leeftid wan 65 -plussers is bij alleenstaanden 77 jaar voor mannen en 75 Jar voor vrouwen; bij samenwonenden is dat 71 respectievelijk 72 jaar. Het bereik (in procenten van bevolking) naar de leeftijd, het geslacht en de samenlevingsvorm van de respondenten wordt in tabel 8.2 gepresenteerd.

Het GOW beeft de gemeente Maastricht onderverdeeld in vier projecten die elk een eigen stadsdeel tot werkgebied hebben. De respondenten werd gevraagd hun woonwijk aan te geven volgens een indeling naar 41 wijken en buurten, die samengevoegd zijn conform de GOW-indeling (Hujjsman, 1989d). Gebleken is dat dienstencentra en andere lokaties een belangrijke (wijk)functie hebben voor het stadsdeel waar zij gelokaliseerd zjjn (met name in Oost) omdat er slechts weinig mensen uit andere stadsdelen komen. De afstand tot een dienstencentrum en de vervoersmogelijkheden daar naar toe spelen met andere woorden cok een rol bij het gebruik van dienstencentra. Het aandeel van 65-plus in het totale bezoekersaantal varieert naar lokatie en stadsdeel. Relatief veel 65-plussers worden aangetroffen in de dienstencentra. Daalhof (77\%), Lambertus (96\%) en Providentia (94\%).

\subsubsection{Dereik van dienstencentra}

Tabel 8.2 geeft het bereik van dienstencentra naar leeftijd en geslacht (op basis van bevolkingsgegevens per 1 januari 1988). Mensen jonger dan 55 jaar of van wie de leeftijd onbekend is, zujn buiten de leeftjjdsverdeling gelaten. Mensen, van wie geen leeftijd bekend is, zijn onder de aanname dat zij allen ouder zijn dan 65 , opgenomen in het totale bereik ten opzichte van alle 65-plussers in Maastricht (zie tabel 8.2 , laatste regel). Het bereik neemt toe met de leeftijd tot een maximum voor de leeftijdscategorie van $75 \mathrm{t} / \mathrm{m} 79$ jaar, om daarna weer te dalen. Bij vrouwen ligt het bereik gemiddeld een vol procentpunt hoger, uitgezonderd de oudste leeftijdsgroep van 85 -plus, waar het bereik voor mannen bijna twee maal zo groot is. Gemiddeld komt $2,8 \%$ van alle 65 -plussers in een der Maastrichtse dienstencentra. De gemiddelde leeftijd van deze 65 -plussers is ruim 73 jaar. Ter correctie van de non-respons kunnen bovenstaande gegevens met maximaal $10 \%$ opgehoogd worden, waardoor het totale bereik uitkomt op circa $3 \%$.

Naar stadsdeel gedifferentieerd valt met name het hoge bereik in de wijken wan het project Mariaberg-Daalhof op, waar in totaal 7,5\% van de 65 -plussers bereikt wordt. Overigens moet daarbij opgemerkt worden dat het dienstencentrum Daalhof gelokaliseerd is binnen een complex bejaardenwoningen en voor bewoners daarvan een belangrijke rol kan vervullen. Het bereik is her laagst voor Binnenstad West met slechts $2 \%$ van alle 65 plussers, doch hier zijn relatief veel ouderen intramuraal gehuisvest.

Tabel 8.2. Berelk van dienstencentra in Mastricht naar leefsituatie van bezoekers

\begin{tabular}{|c|c|c|c|c|c|c|c|c|c|c|c|}
\hline & & & \multicolumn{3}{|c|}{ Alleentionend } & \multicolumn{3}{|c|}{ Samenwomend } & \multicolumn{3}{|c|}{ Totaal } \\
\hline & & & $M$ & $\mathrm{v}$ & Totm & W & $\mathrm{V}$ & Tot. & $M$ & $v$ & Tot. \\
\hline $\begin{array}{l}55 \\
60 \\
65 \\
70 \\
75 \\
80\end{array}$ & $\begin{array}{l}-59 \\
-64 \\
=69 \\
-74 \\
-79 \\
-84 \\
=85\end{array}$ & $\begin{array}{l}\text { jaar } \\
\text { jaar } \\
\text { jaar } \\
\text { jaar } \\
\text { jaar } \\
\text { jaar } \\
\text { jaar } \\
\text { Jaar. }\end{array}$ & $\begin{array}{l}0,2 \\
1,4 \\
1,1 \\
2,5 \\
4,5 \\
2,0 \\
3,3\end{array}$ & $\begin{array}{l}0,7 \\
2,2 \\
2,9 \\
4,3 \\
4,3 \\
1,9 \\
1,4\end{array}$ & $\begin{array}{l}0,5 \\
1,9 \\
2,4 \\
3,9 \\
4,4 \\
1,9 \\
1,9\end{array}$ & $\begin{array}{l}0,5 \\
1,0 \\
1,0 \\
2,1 \\
1,8 \\
1,1 \\
2,2\end{array}$ & $\begin{array}{l}1,1 \\
1,8 \\
2,3 \\
3,0 \\
2,8 \\
4,2 \\
1,6\end{array}$ & $\begin{array}{l}0,8 \\
1,4 \\
2,1 \\
2,5 \\
2,4 \\
2,3 \\
1,9\end{array}$ & $\begin{array}{l}0,4 \\
1,1 \\
11,6 \\
2,2 \\
2,7 \\
1,6 \\
2,9\end{array}$ & $\begin{array}{l}1,0 \\
1,9 \\
2,6 \\
3,8 \\
4,0 \\
2,2 \\
1,4\end{array}$ & $\begin{array}{l}0,7 \\
1,6 \\
2,2 \\
3,2 \\
3,6 \\
2,0 \\
1,8\end{array}$ \\
\hline Tot & $\tan 1$ & plus & 2,9 & 3,2 & 3,2 & 1,9 & 3,0 & 2,4 & 2,1 & 3,1 & 2,8 \\
\hline
\end{tabular}




\subsection{Bezoek aan dienstencentra: frequentie en aard}

In deze subparagraaf wordi ingegaan op de vraag hoe vak men gemiddeld per week naar het dienstencentrum of de lokatie gaat waar de enquete is ingevuld; tevens wordt de aard van het bezoek onderzocht, waarbij meer dan eén antwoord kon worden gegeven. Ook voor het bezoek aan andere GOW-lokaties dan die warar de vragenlijst werd ingewuld, is (apart) gevraagd naar bezoekredenen en -frequentie. In tabel 8.3 wordt de verdeling van de ant* woorden naar de bezoekfrequentie en het geslacht van de respondenten gegeven (exclusief ontbrekende antwoorden en personen van wie het geslacht onbekend is).

De frequentie van bezoek aan het dienstencentrum of een andere GOW-lokatie is hoog. Van de mannen komt bijna $67,7 \%$ twee maal of vaker per week op de lokatie waar men ondervragad is. Bif vrouwen is dat minder, namelijk $41,6 \%$. Opmerkelijk is het aantal vrouwen dat zegt slechts een maal per week te komen. Wellicht speelt de aard of reden van bezoek hierbij een rol. Ook is wellicht sprake van een waste groep deelnemers. Gemiddeld komen mannen 2,6 en vrouwen 1,9 keer per week naar de betreffende lokatie. Overigens btijkt niet alleen het bereik, maar ook de bezoekfrequentie een positief verband met de leeftijd te hebben. Bij vrouwen is dit verband het sterkst en loopt op van gemiddeld 1,3 bezoeken per week in de leeftijdscategorie $56 \mathrm{t} / \mathrm{m} 69$ jaar tot 2,2 maal per week bij $75 \mathrm{t} / \mathrm{m}$ 84 jaar. Bij nog hogere leeftijd neemt de bezoekfrequentie weer af.

De redenen voor het bezoek kunnen zeer uiteen lopen en variëren van het nuttigen van een warme maaltijd tot recreatieve en sociaal-culturele activiteiten (tabel 8.4). Ook kan men, met name bij de twee traditionele centra, alleen 'voor de gezelligheid' komen, zonder deel te nemen aan een activiteit. Gemiddeld worden er per persoon twee redenen voor een bezoek aran een dienstencentrum aangegeven. De helft van de mensen geeft aan twee of meer redenen te hebben. De bellangrijkste daarvan zijn gezelligheid $(56 \%)$, recreatie zoals kienen $(39 \%)$, handwerken ( $26 \%$ ) of andere zaken, zoals zingen, biljarten, schaken etcetera. $(23,5 \%)$, waarbij zingen het meest voorkomt (bijna 11\%). Een deel van de mensen komt voor het nuttigen van een warme maaltijd $(8 \%)$ en een vergelijkbaar aantal mensen komt voor Meer Bewegen voor Ouderen ( $9 \%)$. Maar weinig mensen $(2,8 \%)$ geven zélf aan te komen voor hulp bij bijvoorbeeld het invullen van formulieren of voor voorlichting en andere informatie en dan meestal ook nog in combinatie met andere bezoekredenen. Een aantal redenen wordt bijna geheel of in belangrijke mate sámen met andere redenen genoemd, waarbij het gaat om gezelligheid en recreatie, maar ook on Meer Bewegen voor Ouderen. De mensen die slechts eên bezoekreden aangeven komen relatief vaak $(61 \%)$ cén keer per week (alle respondenten tezamen is dat $47 \%$ ). Het gaat dan met name om groeps-

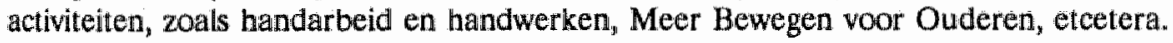

Tabel 8.3. Bezoekfrequentie naar het geslacht van de bezoekers van dienstencentra.

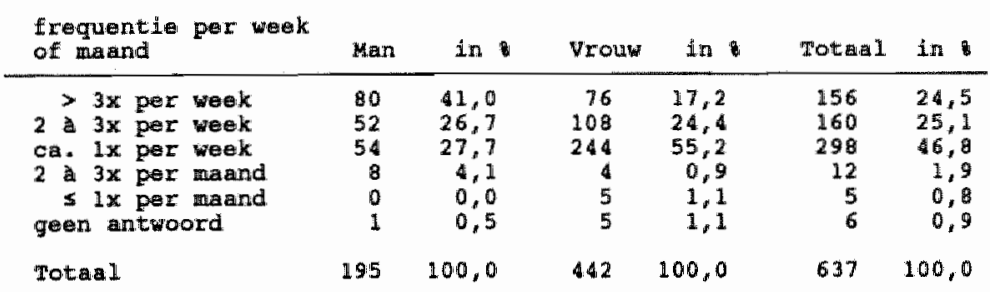


Tabel 8.4. Hezoek an dienstencentrum: redenen en frequentie (meer dan 6en antwoord per persoon mogelijk)

\begin{tabular}{|c|c|c|c|c|c|}
\hline & \multicolumn{4}{|c|}{ dantal redonen voor honst } & \multirow{2}{*}{$\begin{array}{l}\text { potan } \\
\text { keor ge- } \\
\text { ntwoord }\end{array}$} \\
\hline & 1 & 2 & 3 & 4 of 5 & \\
\hline 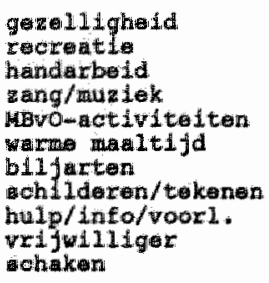 & $\begin{array}{r}61 \\
96 \\
64 \\
18 \\
8 \\
16 \\
3 \\
16 \\
2 \\
6 \\
9\end{array}$ & $\begin{array}{r}196 \\
96 \\
69 \\
26 \\
19 \\
16 \\
16 \\
6 \\
6 \\
8\end{array}$ & $\begin{array}{l}76 \\
51 \\
28 \\
19 \\
27 \\
11 \\
12 \\
1 \\
6 \\
2 \\
1\end{array}$ & $\begin{array}{l}9 \\
7 \\
4 \\
6 \\
4 \\
4\end{array}$ & $\begin{array}{r}362 \\
252 \\
165 \\
69 \\
58 \\
50 \\
31 \\
23 \\
18 \\
16 \\
10\end{array}$ \\
\hline hamtal peroonon & 319 & 230 & 79 & 9 & 637 \\
\hline
\end{tabular}

\subsubsection{Vervoer naar en wijze van kennismaking met GOW}

De respondenten konden ook bij de vraag naar de wijze waarop zij naar activiteiten van het Gecoordineerd Ouderenwerk komen, meer dan eén antwoord geven, variërend van te voet tot openbaar vervoer. Dit geldt ook woor de manier waarop zij voor het eerst in contact kwamen met het GOW.

Circa $90 \%$ van de mensen die de vervoersvraag beantwoorden $(\mathrm{N}=627)$, komt op maar eén wijze naar het dienstencentrum of een andere lokatie waar een activiteit van het GOW plaats vindt (zie tabel 8.5). Ruim de helft komt te voet. Dat lijkt een tweede aanwijzing te zijn dat de afstand tot een dienstencentrum een belangrijke bepalende factor is voor gebruik van het GOW. Dit geldt ook als meer dan eén antwoord kan worden gegeven, omdat het antwoord "te voet" dan eveneens het belangrijkste is. Op de tweede plaats komt het openbaar vervoer (per bus) dat bij $20 \%$ van de respondenten het enige vervoermiddel is. Met de eigen auto komt bijna $16 \%$ van de bezoekers. Minder belangrijk zijn de fiets $(10,2 \%)$, taxi $(2,8 \%)$ of de mogelijkheid dat de desbetreffende oudere door anderen (bijvoorbeeld partner) gebracht wordt $(3,6 \%)$.

Beknopt wordt ingegaan op de wijze waarop men voor het eerst in aanraking kwam met het gecourdineerd ouderenwerk, dat wil zeggen door wie of wit welke bron de ouderen

Tabel 8.5. Vervoer bij bezoek aan dienstencentra of andere GoW-activiteiten

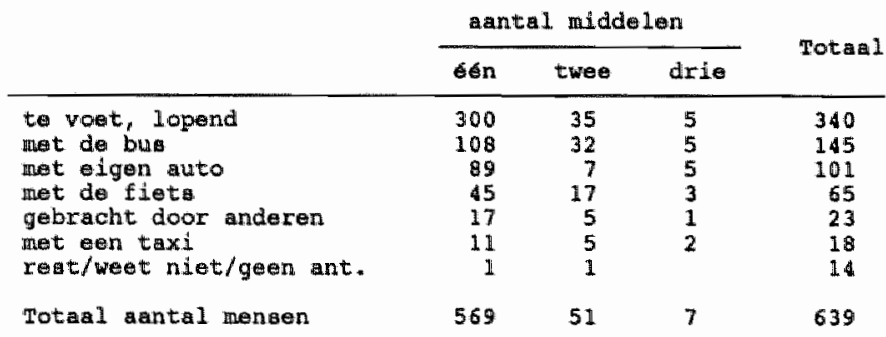


geinformeerd werden over het bestaan van dergelijke activiteiten. Hierbij moet opgemerkt dat de informatie soms gedateerd is, omdat zij de dienstencentra al langere tijd bezoeken. Antwoorden kunnen hierdoor enigszins onbetrouwbaar zijn, ondat men niet goed neer weet wanneer en hoe men voor het eerst in aanraking kwam met het GOW. Vrienden en kennissen blijken de belangrijkste informatiebron te zijn. Van alle respondenten heeft tweederde de informatie van deze mensen gekregen. In de praktijk blijkt dat men de eerste keer bijwoorbeeld door de buturman of -vrouw meegenomen is naar een activiteit in het dienstencentrum of andere GOW-activiteit. De rest van de bezoekers heeft de informatie uit zeer uiteenlopende, vaak enkelvoudige bronnen verkregen, varierend van professionele hulpverleners zoals huisarts of GGZ $(4,9 \%)$ en maatschappelijk werk $(3,3 \%)$, tot eigen initiatief $(4,1 \%)$ of het feit dat men er woont $(6,6 \%$; betreft uitsluitend Daalhof). Opvallend weinig wordt in dit verband gezinsverzorging of wijkverpleging genoemd (1\%) of gedrukte informatie (krant/folder: 1,7\%). Door GOW-functionarissen wordt echter gesteld dat informatie via krant/folder met name gericht is op niet-structurele activiteiten zoals een vakantiereis, kerstviering en dergelijke en daardoor bij andere mensen terecht komt dan de hier onderzochte groep van regelmatige bezokers. De restpost 'anderzins" varieert zeer, maar betreft kleine aantallen van maximaal 3 a 4 mensen per antwoord (GOW, ouderenbond, zonnebloem, toeval). Achteraf moet wellicht gesteld worden dat de atangeboden antwoorden in sommige gevallen niet specifiek genoeg zijn geweest, zodat veel door de respondent zelf moest worden ingevuld. In nieuw onderzoek zou het belangrijk kunnen zijn om onder andere een verbijzondering te maken naar buren, nu begrepen onder kennissen.

\subsubsection{Gebruik van andere voorzieningen}

Een apart aandachtspunt in de enquete onder de bezoekers van dienstencentra vormde het gebruik van andere voorzieningen, met name in de extramurale sector en ten aanzien van de wijkfuncties van bejaardenoorden, waaronder met name de warme maaltijdvoorziening en sociaal-culturele activiteiten. In tabel 8.6 wordt het voorzieningengebruik naar leeftijd uitgesplitst.

Het gebruik van voorzieningen is opvallend hoog: gemiddeld heeft $25 \%$ van alle respondenten hulp via eén $(20,8 \%)$ of een combinatie $(3,3 \%)$ van de opgenomen diensten. Bij een

Tabel 8.6. Gebruik van voorzieningen naar leeftijd van de bezoeker

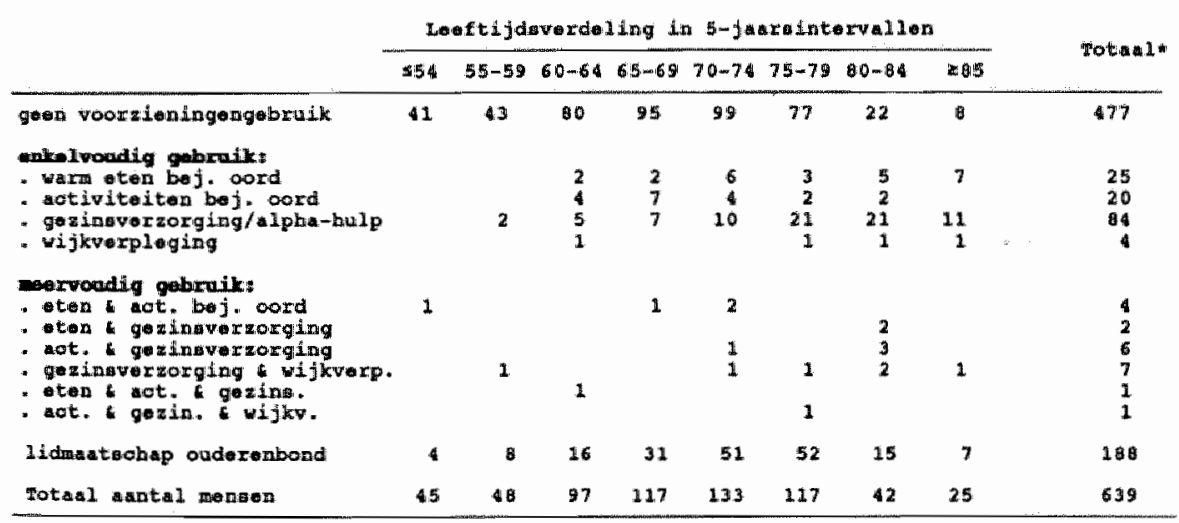

- Inelusief laeftijd ombekend ( $k=15$ ) 
klein deel $(1,3 \%)$ is het getbruk onbekend. Het voorzieningengebruik neemt sterk toe met de leeftuj. Van bezoekers jonger dan 60 jaar heef slechts $10 \%$ hulp maar bij de respondenten wan 80 jaar of ouder is dat meer dan $55 \%$. Het belangrijkste is de gezinsverzorging, die bij $65 \%$ van diegenen die een van de voorzieningen gebruiken, genoemd wordt. Wikkerpleging komt bij bezoekers van dienstencentra nauwelijks voor $(8 \%)$ en dan yooral in combinatie met gezinswerzorging. Het percentage respondenten dat lid is van een ouderenbond ligt op $29,4 \%$ en heeft met het toenemen van de leeftijd aanvankelijk zelf ook een stiggend verloop, maar daalt daarna. Van bezoekers onder de 60 jaar is bijna $13 \%$ lid van een ouderenbond; hel maximum ligt bij de leeftijdscategorie 75.79 jaar (40\%).

Het geslacht van de respondent blijkt geen rol te spelen in het (globale) onderscheid tussen wel of geen gebruik Van de wrouwen heeft $74,4 \%$ geen hulp; bij mannen $75,4 \%$. Per voorziening kan het geslacht echter wel wan belang zijn. Bij de vrouwen van wie het voorzieningengebruik bekend is, gebruikt $15,9 \%$ een warme maaltijo in een bejaardenoord en gaat $18,6 \%$ naar de activiteiten aldaar, heeft $67,3 \%$ gezinswerzorging en $9,7 \%$ wijkverpleging. Bij mannelijke gebruikers zijn deze percentages achtereenvolgens: $29,2 \%$ (eten), $22,9 \%$ (activiteiten bejaardenoord), $52,1 \%$ (gezinswerzorging) en $2,1 \%$ (wijkverpleging). Belangrijk is de samenstelling van het huishouden. Bij de alleenstaanden heeft $35 \%$ hulp, vooral bestaande uit maaltijdvoorziening en gezinsverzorging; bij samenwonende personen gebruikt slechts $14,5 \%$ professionele hulp en dat betreft vaak slechts éen voorziening (uitgezonderd warm eten).

De bezoekfrequentie heeft een opwallend verjoop met voorzieningengebruik: mensen met alleen gezinsverzorging komen vaker (gemiddeld 2,6 keer per week) dan personen zonder hulp $(2,1$ keer per week) en de mensen met alleen wijkverpleging komen her minst $(1,4$ keer). Naarmate meer voorzieningen in beeld komen, neemt de bezoekfrequentie weer af van 2,4 bij ến voorziening tot 1,7 bij drie voorzieningen (gemiddelden).

Tenslotte blijkt er ook verband te bestaan met de reden waarvoor men naar dienstencentra gaat. Van de mensen die komen om warm te eten $(\mathrm{N}=50$ ), heeft slechts $56 \%$ geen hulp, krijgt $26 \%$ gezinsverzorging en gaat $16 \%$ ook warm eten in een bejaardenoord. $\mathrm{MBvO}$ deelnemers $(\mathrm{N}=58)$ maken relatief weinig gebruik van voorzieningen $(15,5 \%)$ en dan vrijwel alleetu van gezinsverzorging.

\subsection{Kosten en financiering van het gecoördineerd ouderenwerk}

Bij de inwoering van de Tijdelijke rijksbijdrageregeling gecoördineerd bejaardenwerk werd de gemeenteraad verplicht om een subsidieverordening voor het GOW wast te stellen, welke verordening voor $\mathbb{1}$ juli 1980 ingevoerd moest zijn. Met de invoering van de Welzijnswet gaan de gemeenten de subsidieverordening. GOW inpassen in een bredere verordening voor de gehele welzijnssector, doch de praktische invulling en de daaruit volgende herkenbarheid van de werksoort staat vrij.

Een belangrijk deel van de financiering betreft de personeelslasten en de daarbij geldende salarisregeling. Deze was voorheen speciaal voor het GOW toegespitst (de Salarisregeling Oecoordineerd Bejaardenwerk 1979), doch is thans een (integraal) onderdeel van de algemene CAO voor het welzijnswerk.

Voór de Welzijnswet bedroeg de rijksbijdrage per jaar $80 \%$ van de exploitatiekosten. Voor de eigen bijdragen was voor alle mogelijke activiteiten van het GOW een lijst opgesteld, waarin vermeld stond of er een bijdrage geheven moest worden en zo ja of deze de directe kosten van de betreffende activiteit wel of niet volledig moet dekken (Circulaire d.d. 8-10-74). Voorts golden allerlei aanwijzingen voor bijwoorbeeld vervoerskosten, functie- 
Tabel 8.7. Totale exploitatie GOW Maastricht 1980-1988 $(\mathrm{x} f 1000,-)$

\begin{tabular}{|c|c|c|c|c|c|c|c|c|c|}
\hline & 1980 & 198.1 & 198 & 1. & 198 & 1985 & 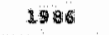 & 1987 & In \\
\hline 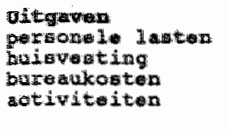 & $\begin{array}{r}1812,0 \\
463,0 \\
191,3 \\
24,6 \\
229,5\end{array}$ & $\begin{array}{r}1141,4 \\
577,3 \\
200,1 \\
34,0 \\
232,2\end{array}$ & $\begin{array}{r}1107,6 \\
6018,6 \\
197,0 \\
31,8 \\
119,3\end{array}$ & $\begin{array}{r}112,5 \\
617,7 \\
3,4,9 \\
35,5 \\
115,5\end{array}$ & 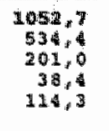 & $\begin{array}{r}1121,7 \\
577,9 \\
214,2 \\
12,6 \\
100,9\end{array}$ & $\begin{array}{r}1075 \\
602,2 \\
1.0 \% \\
467 \\
187\end{array}$ & 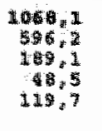 & 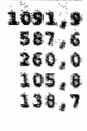 \\
\hline 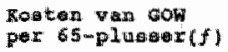 & 72,40 & 80,00 & 76.65 & 76,00 & 71,10 & 7445 & $69 \cdot 0$ & 67,15 & 65,40 \\
\hline
\end{tabular}

omschrijvingen, investeringskosten (bijwoorbeeld bij maaltijdvoorziening), het arbeidsplaatsenplan (1980) en dergelijke. Met de Welzijnswet zijn de GOW-gelden die naar de gemeenten vloeien niet langer geoormerkt en heeft de gemeentelijke overheid de mogelijkbeid te schuiven met haar middelen. Hiermee wordt nagestreefd dat de gemeente duidelijker dan tot nu toe een eigen ouderenbeleid kan ontwikkelen dat beter is toegesneden op de plaatselijke omstandigheden en mogelijkheden. Tevens betekent dat echter dat de bezuinigingen op de doeluitkering.Welzijnswet (1989 en 1990), ook (deels) op het GOW afgewenteld kunnen worden. Er was voor de jaren 1987 en 1988 echter wel een overgangsregeling voor de ouderenzorg van kracht.

Aan de hand van Jaarrekeningen van de Stichting Trajekt (voorheen Stedelijk Instituut voor Sociaal Werk Maastricht) is voor het Gecoordineerd Ouderenwerk, dat een sectie binnen de welzijnsstichting vormt, een overzicht van de totale exploitatie sinds 1980 samengesteld.

De totale kosten van het Maastrichtse GOW bedragen ruim 1 miljoen gulden. Na een aanvankelijke lastenstijging in de begin jaren tachtig, nemen de totale kosten de laatste jaren weer af onder druk van 's lands overheidsbezuinigingen. Binnen de totale kosten nemen de personeelslasten een belangrijke plaats in. In 1980 was het aandeel van personeelskosten $46 \%$ en nam toe to $55 \%$ in 1982 en 1983 , waarna in 1984 een abrupte daling volgde tot $51 \%$ (personele herschikkingen tussen projecten). Thans ligt het aandeel van personeelslasten op $54 \%$. Deels door de overheidsbezuinigingen, deels door andere prioriteitsstelling binnen het GOW, is het aandeel ten behoeve van activiteiten in de periode 1980-1985 drastisch gedaald van ruim $20 \%$ in het begin tot $9 \%$ in 1985 . De laatste drie jaar neemt het activiteitenaandeel weer toe. Er blijkt echter een (administratieve) verschuiving plaats gevonden te hebben tussen de posten 'activiteiten' en 'diversen'. Worden beide posten samengenomen dan is het aandeel daarvan in de totale kosten gedurende de periode 1980 . 1987 continu gedaald van $33 \%$ in 1980 tot $23 \%$ in 1987 . Bureaukosten zijn gedurende de gehele periode geleidelijk aan toegenomen tot $4,5 \%$ in 1987. Aangezien in 1988 een iets afwijkende begrotingsmethodiek is gehanteerd, is vergelijking met voorgaande jaarrekeningen niet goed mogelijk. In 1988 is ook bet flankerend beleid ( $f 102.155,-)$ geheel in de exploitatierekening verwerkt. De vier projecten hebben geen evenredig deel in de totale kosten. Het relatief grootste project is Binnenstad West (35\%), gevolgd door Maastricht Oost $(31 \%)$ en Daalhof/Mariaberg (17\%). Het relatief kleinste project, gemeten in het aandeel in de totale kosten, is Brusselse Poort (16\%).

De financiering van het gecoðrdineerd ouderenwerk valt bijna geheel onder de verantwoordelijkheid van de overheid (nu de gemeente), zoals eerder aan de orde kwam. Het aandeel van overheidssubsidies in de totale kosten is in de periode 1980-1988 gestabiliseerd op 80\%, zoals van overheidswege ook beoogd werd. Het aandeel van eigen bijdragen van deelnemers an activiteiten is geleidelijk toegenomen tot $6 \%$ van de totale kosten.

Als de kosten gerelateerd worden aan het aantal inwoners van 65 en ouder, ontstaat het volgende beeld (zie tabel 8.8): in 1981 werd nog $f$ 80,- per 65-plusser besteed, in 1987 nog 


\begin{tabular}{|c|c|c|c|c|c|}
\hline & $\begin{array}{l}\text { totale } \\
\text { komten }\end{array}$ & $\begin{array}{l}\text { Fubuidie } \\
\text { owerberd }\end{array}$ & $\begin{array}{l}\text { eigan } \\
\text { bijdat. }\end{array}$ & $\begin{array}{l}\text { kogtien } \\
\text { Mowow }\end{array}$ & $\begin{array}{l}\text { koaten } \\
\text { maltija }\end{array}$ \\
\hline $\begin{array}{l}1960 \\
1981 \\
1982 \\
1983 \\
1984 \\
1985 \\
1986 \\
1987\end{array}$ & $\begin{array}{l}72,39 \\
90,02 \\
76,66 \\
76,38 \\
71,07 \\
76,47 \\
69,39 \\
67,15\end{array}$ & $\begin{array}{l}52,64 \\
50,98 \\
61,45 \\
59,73 \\
58,17 \\
57,47 \\
55,52 \\
54,77\end{array}$ & $\begin{array}{l}n . b . \\
3,64 \\
4,21 \\
4,27 \\
4,14 \\
4,07 \\
4,16 \\
4,48\end{array}$ & $\begin{array}{l}2,81 \\
3,37 \\
3,85 \\
3,62 \\
3,78 \\
3,73 \\
3,54 \\
3,74\end{array}$ & $\begin{array}{l}6,57 \\
6,27 \\
7,98 \\
7,29 \\
7,06 \\
6,65 \\
5,87 \\
\text { n.b. }\end{array}$ \\
\hline
\end{tabular}

*) Total 1 van MBwO, volkadangien on zwemian

slechts $f 67$. Voor 1988 wordt een nog lager bedrag begroot, namelijk $f 65,40$. Dat is in vergelijking met andere grote steden, waar het bedrag 2 a 3 keer hoger is, vrij mager (Esselink, 1988). Hiertegenover staat een gemiddelde eigen bijdrage van $f$ 4,50 per 65 plusser in 1987. Dat was nog $f 3,64$ in 1981 .

\subsection{De coördinatietaak van het GOW}

Coordinatie (gedefinieerd als het geheel van sociale interacties tussen dienstverlenende organisaties, waarin bewust en doelgericht een zekere afstemming wordt nagestreefd via communicatie en cooperatie; Coolen, 1986) is steeds meer de hoofdtaak van het gecoordineerd ouderenwerk geworden en krijgt als een van de GOW-functies de meeste aandacht. De noodzaak van coordinatie wordt alom onderschreven en is hoofdprioriteit in het overheidsbeleid ten aanzien van de ouderenzorg (Algemene Rekenkamer, 1985; Nota Ouderenbeleid, "TK, 1987/1988; Nota 2000, TK, 1985/1986; Werkboek GOW, 1978). In de praktijk blijkt coördinatie echter een moeizame zaak te zijn. In Maastricht wijken de ervaringen met coordinatie niet sterk af van landelijk gesignaleerde punten (Algemene Rekenkamer, 1985; Godfroij, 1979 en 1981; Bekkers, 1986; Strootman, 1987; Emonts, 1988; Hujjsman, 1989d). Coordinatie vergt een langdurig en moeizaam proces dat zich afspeett langs de lijn van behoedzame toenadering, informatie-uitwisseling en (pogingen tot) afstemming in werkwijze, tot concrete afbakening van werkgebieden, doelgroepen en taken. Op deze plats beperken wij ons tot de belangrijkste conclusies uit dit deel van het onderzoek (zie verder: Huijsman, 1989d). Zeker in vergelijking met het verleden kan gesteld worden dat er veel tot stand is gekomen. Dit laat onverlet dat het tempo waarin dat gebeurt niet erg hoog is en het proces van coordinatie moeizaam verloopt. Het vergt tijd om voorheen autonoom opererende organisaties bijeen te brengen, met name daar waar tradities en aandachtsvelden verschillen en sanctiemogelijkheden bij de uitvoering van de coordinatie-functie ontbreken. De verschillende vormen van wijk- of eerstelijnsoverleg, waaraan bijna alle hulpverleners (inclusief bejaardenoorden) meewerken, voorzien in een behoefte. Door de hulpverleners zelf wordt afstemming en coordinatie in het uitvoerend vlak, direct ten behoeve van (gezamenlijke) clienten, ervaren als zeer zinvol en bovendien goed verlopend. Voor een gezamenlijk ouderenbeleid is samenwerking op uitvoerend niveau onontbeerlijk. Duidelijk komt naar voren dat de coordinatie op bestuurlijk niveau veel minder gemakkelijk verloopt. Op bestuursniveau lijken de marges om coördinatie in het ouderenbeleid daadwerkellik te bereiken veel geringer en vereisen pogingen on afstemming te bereiken een langdurig proces en een behoedzame aanpak. Tradities en vrees voor eventueel verlies van autonomie en beslissingsbevoegdheden zijn de belangrijkste belemmerende factoren. 
Individuele project-functionarissen van het GOW in Maastricht besteden $20 \%$ a $25 \%$ wan hun werkijd aan allerlei vormen van wijkoverleg met wisselende organisaties en personen, zoals kruiswerk, gezinsverzorging, bejaardenoorden, vrijwilligers, pastoratat, wijkagent on ouderen(-bonden). De stedelijke coördinatie beslaat meer dan $50 \%$ van een produktief mensjaar, waarvan in Maastricht circa $80 \%$ ten laste van de hoofdfunctionaris, bij enkele stedelijke groepen bijgestaan door een projectfunctionaris. Bij het merendeel van allerlei overleg-en samenwerkingsvornen fungeert een functionaris als voorzitter en/of secretaris.

\subsection{Samenvatting en conclusies}

Uit de leeftijds- en sexeverdeling van de respondenten bleek dat ruim $69 \%$ vrouwen betreft. Een niet onaanzienlijk deel van de mensen is echter jonger dan 65 jaar: bij mannen ruim $32 \%$, bij vrouwen bijna $29 \%$. De belangrijkste leeftijdscategorie is de groep van 65 tot 80 jaar (ruim 57\%). Het bereik, berekend als het percentage dat het aantal bezoekers aan dienstencentra uitmaakt van de Maastrichtse bevolking (per leeftijdscategorie), is gemiddeld $3 \%$ van alle 65 -plussers (inclusief non-respons) en neemt toe met de leeftijd tot een maximum voor de categorie 75-79 jaar. De gemiddelde leeftijd van de bezoekers ouder dan 65 jaar, is bij alleenstaanden (voor $80 \%$ vrouwen) 77 jaar voor mannen en 75 jaar voor vrouwen. Bij samenwonende bezoekers ( $53 \%$ van alle bezoekers) is dat 71 en 72 jaar. Het bereik is groter voor alleenstaanden $(3,2 \%)$ dan samenwonenden $(2,4 \%)$.

Bij de mannen geeft $68 \%$ van de respondenten aan minimaal twee keer per week een bezoek te brengen aan het dienstencentrum of een andere GOW-lokatie. Gemiddeld komen mannen 2,6 keer per week. Bij vrouwen is dat veel lager $(1,9)$, wellicht vanwege de aard van het bezoek (én maal per week naar de handwerkgroep). De bezoekfrequentie vertoont een zelfde verband met de leeftijd als de eerder besproken bereikpercentages. Voor vrouwen is de samenhang met leeftijd sterker dan voor mannen. De respondenten geven gemiddeld twee redenen voor hun bezoek. Het belangrijkste is gezelligheid en ontspanning of recreatie, maar opvallend is ook het gebruik van warme maaltijden $(8 \%)$ en Meer Bewegen voor Ouderen $(9 \%)$. Ten aanzien van het vervoer naar het dienstencentrum blijkt dat ruim de helft te voet komt. De afstand tot een dienstencentrum is met andere woorden een belangrijke factor naast de aanwezigheid van openbaar vervoer, waarwan $20 \%$ gebruik maakt.

Tevens is aandacht besteed aan het gebruik van andere voorzieningen, namelijk warm eten of activiteiten un bejaardenoord, gezinsverzorging en wijkverpleging. Gemiddeld heeft $20,8 \%$ hulp van eén voorziening en $3,3 \%$ van een combinatie van woorzieningen. Het voorzlieningengebruilk neemt sterk toe met de leeftijd, tot $55 \%$ bij 80 -plus. Het belangrijkste is gezinsverzorging ( $65 \%$ van de 'gebruikers'). Wijkverpleging komt bij bezoekers van dienstencentra nauwelijks voor $(8 \%)$ en vaak in combinatie met gezinsverzorging. Van de respondenten is $29,4 \%$ lid van een ouderenbond. Het voorzieningengebruik is bij alleenstaanden drie maal zo groot als bij samenwonenden.

De totale lasten varieerden in de periode 1980-1988 tussen 1,0 en 1,1 miljoen. De personeelskosten vormen verreweg het grootste aandeel in de kosten (nu circa 54\%). Deels door overheidsbezuinigingen, deels door andere prioriteitstelling, is het aandeel van activiteiten en andere directe kosten geleidelijk aan gedaald van ruim $1 / 3$ tot lets minder dan $1 / 4$ van de totale kosten. De overheid (thans de gemeente, voorheen het rijk) draagt $80 \%$ wan de kosten, terwijl de deelnemers aan activiteiten nog eens $6 \%$ voor hun rekening nemen. Tot slot werden enkele gemiddelde kostengegevens per 65-plusser in de gemeente Maastricht berekend. De totale kosten wan het GOW blijken in de periode 1981-1988 sterk gedaald te zijn van $f$ 80, naar circa $f$ 65,- per 65 -plusser. De overheid neemt daarwan zoals 
gezegd $80 \%$ voor haar rekening. Het gemiddelde bedrag per 65-plusser in Maastricht ligt aanzienlijk onder het gemiddelde bedrag in vergelijkbare andere (middel-)grote steden. 


\section{Indicatiecommissie en bejaardenoorden: globaal overzicht periode 1985-1988}

\subsection{Inleiding}

In dit hoofdstuk wordt een globaal overzicht gegeven van de meest belangrijke trends in de bejaardenoorden en de "toegangspoort' daartoe, de indicatiecommissie. Omdat de onderzoeksperiode de jaren $1985 \mathrm{t} / \mathrm{m} 1988$ betreft, wordt in feite de indicatiecommissie 'oude stijl' beschreven. Dit gebeurt in paragraaf 9.2 , waarbij de werkwijze van de indicatiecommissie en de gehanteerde criteria aan bod komen en onder andere het aantal verstrekte adviezen naar urgentie alsmede de omvang van de wachtlijst besproken worden. In paragraaf 9.3 gaan we in op de bejaardenoorden, waarbij achtereenvolgens besproken worden: de capaciteitsontwikkelingen, de opbouw van het bewonersbestand, de in- en uitstroom in de sector, de wijkfuncties en tot slot (voor de algemene bejaardenoorden) de totale personeelsformatie en de kosten. In paragraaf 9.4 worden de belangrijkste bevindingen beknopt samengevat.

\subsection{Indicatiecommissie bejaardenoorden (oude stijl)}

\subsubsection{Inleiding}

De Wet op de Bejaardenoorden bevat onder meer de regeling van de opname van ouderen in bejaardenoorden. De artikelen $6 \mathrm{~h}$ tot en met 61 van de WBO waren echter dermate globaal, dat in 1976 een speciale Algemene Maatregel van Bestuur (AMvB) werd uitgevaardigd, het Besluit Opneming Bejaardenoorden (Stb. 1976, no. 619), waarin de opname verder werd geregeld (zie vervolg). In 1988 is de taak van de indicatiecommissie via het Besluit Indicatie-advisering bejaardenoorden en verpleeginrichtingen (Stcrt. 1988, no. 456) echter verbreed tot verpleeghuizen, dagbehandeling en dagverzorging. Omdat de nieuwe werkwijze in de praktijk op veel moeilijkheden stuitte, is de invoeringsdatum door het ministerie van WVC met een jaar vertraagd. Een van de problemen betreft de ontwikkeling van een nieuw indicatiesysteem, warin nu ook meer aandacht aan de psycho-sociale problematiek gegeven zou moeten worden. Dit nieuwe indicatiesysteem is, in tegenstelling tot het oorspronkelijk systeem voor de bejaardenoorden, nfet vastgelegd in een wettelijk besluit en moet door de indicatiecommissies zelf ontworpen worden. Enerzijds wordt hiermee recht gedaan aan de onderzoeksbevinding (Overbeek, 1983) dat de indicatiestelling niet los gezien wordt en kan worden van het lokale voorzieningenaanbod, anderzijds bestaat het gevaar dat de verschillende lokale indicatiesystemen sterk zullen galan divergeren, zodat het wellicht efficienter ware geweest toch een landelijk systeem te ontwikkelen. Omdat het nieuwe indicatiesysteem ook in Maastricht pas op 1 september 1989 is ingevoerd, wordt in het vervolg van deze paragraaf de oude (in feite achterhaalde) situatie beschreven. Aan het eind van het hoofdstuk zal beknopt worden ingegaan op de nieuwe wijze van indiceren en de daarbij te haniteren criteria. 


\subsubsection{Werkwijze indicatiecommisisüe}

Het (voormallge) Besluit Opneming Bejaardenoorden (Stb. 1976, no. 619) gaf de minimale voorwararden aan, waaraan de commissie dient te voldoen. De leden zijn onafhankelijk en er diende ténminste een arts en maatschappelijk werkende lid te zijn. Maastricht kende tot 1 januari 1990 twee wan deze functionarissen en voorts een secretaris. Een vertegenwoordiger van het Gecoordineerd Ouderenwerk was voorzitter. De commissie brengt aan de ouderen die daarom vragen advies uit ower de wenselijkheid wan een opname in een bejaardenoord. Daartoe wordt een onderzoek ingesteld naar de zorgbehoefte van de aanvrager, uitgaande van de eveniens in het Besluit vastgelegde indicatiecriteria (zie paragraaf 9.2.3). De stappen in het indicatiesysteem zijn weergegeven in de figuur 9.1 en gelden nog steeds. Er kan tevens informatie worden ingewonnen bij de betreffende huisarts en/of bij de eventueel al aanwexige thuiszorgorganisaties zoals de gezinsverzorging. De maatschappeilik werkende stelt op grond van de verzamelde informatie en na een huisbezoek bij de aanvrager een rapport op over de situatie naar aanleiding waarvan de commissie tot haar advies komt. Dit wordt in eerste instantie aan de betrokken oudere(n) uitgebracht en indien deze geen bezwaar daartegen heeft (hebben), doorgestuurd aan het bejaardenoord naar voorkeur van de aanvrager(s). Deze(n) wordt(en) op de wachtlijst geplaatst. Een advies dat negatief luidt voor opname, maar positief voor extramurale hulp, kan onder de zelfde condities aan thuiszorgorganisaties worden toegezonden. De commissie stelt zich tevens op de hoogte of de geadviseerde hulp ook feitelijk wordt verleend (artikel 25). De totale procedure tot aan het uitbrengen van het advies aan alle betrokkenen kent een wettelijke maximum-termijn van zes weken. Indlien de situatie van de betreffende oudere drastisch verandert of als de wachtlijstsituatie erg lang heeft geduurd, wordt ewentueel een herindicatie verricht.

Na het uitbrengen wan het advies is de rol van de indicatiecommissie in wezen uitgespeeld, maar in Maastricht ging men verder dan strikt genomen vereist wordt. De indicatiecommissie fungeerde sinds 1 maart 1985 tevens als plaatsingscommissie en 'bewaakte' onder

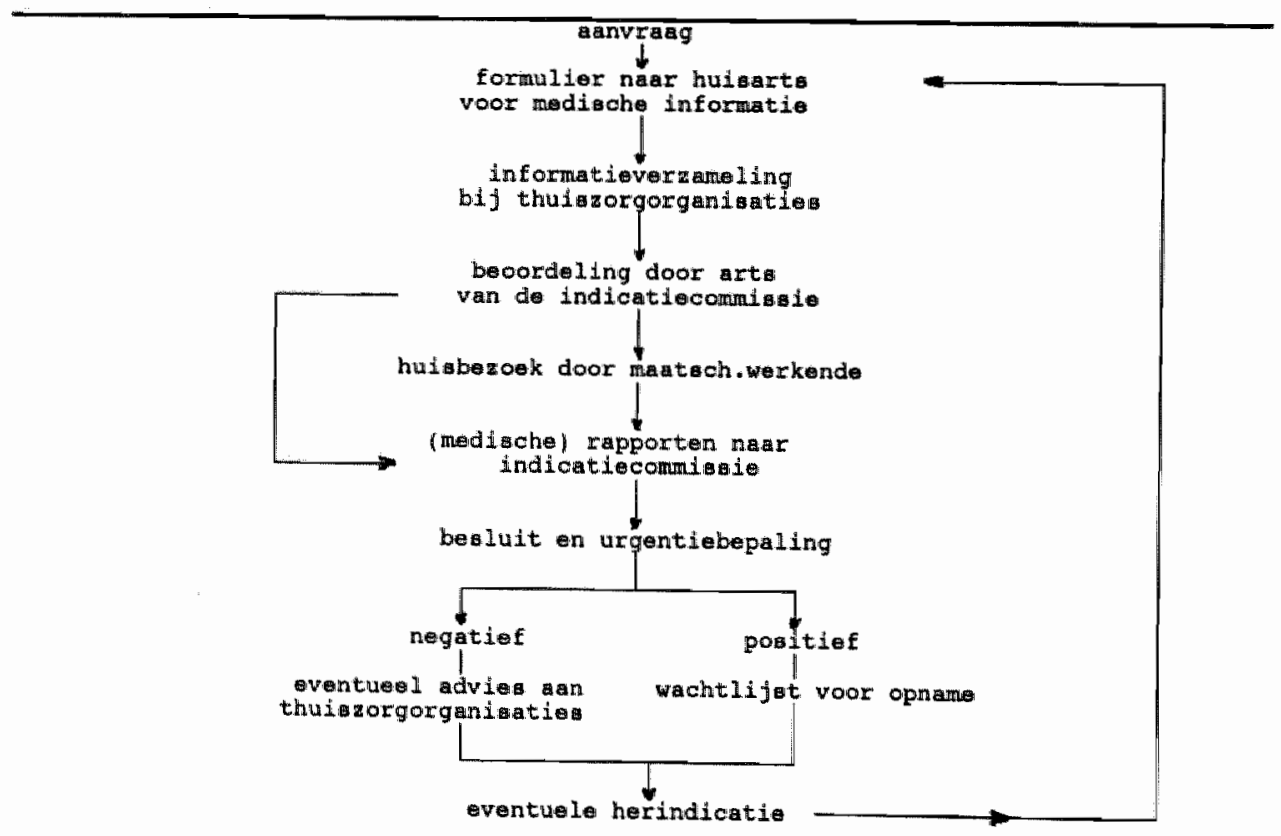

Figuur 9.1. Stappen in het (voormalige) indicatiesysteem van bejaardenoorden 
andere expliciet de situatie van ouderen op de wachtlijst. Telkens als er een plaats vrijkwam, stelde de commissie een lijst met de meest urgente vijf alleenstaande ouderen of drie

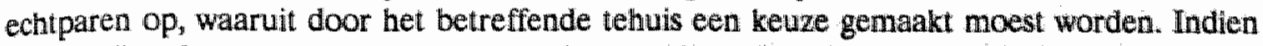
de instelling de voorgedragen personen niet geschikt achtte, bijvoorbeeld in het licht van het niveau van de zorgbehoefte van de al aanwezige bewoners, moest dit met redenen onkleed kenbaar gemaakt worden aan de commissie, die vervolgens een andere lijst opstelde. Aan de plaatsingstaak van de commissie is op 1 april 1990 een einde gekomen door de bezuinjgingen die door de gemeente werden opgelegd. De commissie heeft ten gevolge hiervan moeten besluiten deze, strikt naar de letter als extra te beschouwen, taak af te stoten.

De commissie te Maastricht heeft nog andere (extra) taken, namelijk sinds eind oktober 1986 het indiceren, verwijzen, bemiddelen en coordineren naar aanleiding van verzoeken om tijdelijke opname in bejaardenoorden (mogelijk bij vijf daarvan). In 1988 werden 85 aanvragen voor tijdelijke opname ingediend, waarvan $68 \%$ feitelijk tot stand kwam. De commissie beoordeelt sinds 1985 tevens de noodzaak voor aansluiting op het centraal alarmeringssysteem (waarbij het bieden van 'zekerheid' belangrijk is) aan de hand van een beperkt aantal criteria betreffende de gezondheid en met name valproblematiek, de huishoudvorm (er is slechts 1 echtpaar aangesloten) en de omvang van het sociale netwerk. Per jaar komen er circa 140 aanvragen binnen, waarvan 80 tot $85 \%$ wordt gehonoreerd. Sinds begin 1989 verricht de commissie tenslotte ook de indicering voor aanleunwoningen bij bejaardenoorden en verpleeghuizen. Op basis van een benadering van personeels- en overige lasten kunnen de kosten per advies berekend worden op ongeveer $f$ 350,- (zie bijlage 3).

\subsubsection{Beslissingscriteria bij de adviesbepaling}

Het Besluit Opneming Bejaardenoorden stelde dat het onderzoek zich moet richten op zes aspecten die de zelfstandigheid van ouderen kunnen bedreigen, namelijk: (a) het gezichtsvermogen (eventueel met bril of contactlenzen); (b) de lichamelijke toestand via zes zogenaamde ADL-activiteiten betreffende zich binnenshuis verplaatsen, aan- en uitkleden, in en uit bed stappen, gaan zitten en liggen, gebruik maken van toilet en eten; (c) problemen bij acht huishoudelijke activiteiten, met name het koken van een warme maaltijd, de verzorging van de andere maaltijden, lichte en zware schoonmaakwerkzaamheden, bed opmaken, dagelijkse boodschappen doen, verzorgen van kleding en linnengoed en de verwarming; (d) de sociale onstandigheden, verbijzonderd naar de mate van sociaal contact; (e) de psychische omstandigheden, omschreven als eventuele contactstoornissen, eenzaamheid, storend gedrag, zwaarmoedigheid en geheugenstoornissen; en tenslotte (f) de woonsituatie, met name al of niet inwonend, aantal vertrekken, trappen, wijze van verwarming, onderhoud, nabijheid van openbaar vervoer, -groen en bank- of postkantoor. Na inventarisatie op de genoemde terreinen van het functioneren van de aanvrager, dient de noodzaak tot een opname beoordeeld te worden. Een positief advies wordt altijd voorzien van een urgentiebepaling, die gebaseerd is op een 'puntensysteem', waarbij voor ledere beperking bij de bovengenoemde aspecten a $\mathrm{t} / \mathrm{m}$ e (nfet bij ( $f$ ) woonsituatie; zie vervolg) een punt wordt toegekend. De urgentiebepaling geschiedde in het oude systeem op de volgende wijze: urgentie 6 (hoogste) problemen met handelingen
(a) gezichtsvermogen of
(b) de ADL-

urgentie 5

urgentie 4

: tenminste vier punten bij (c) huishoudelijke activiteiten, zonder dat er (in-)formele bulp is

urgentie 4

: tenminste drie problemen bij (c) huishoudelijke activiteiten en tegelijkertijd eên probleem bij (d) sociale of (e) psychische toestand, zonder dat er (in-)formele hulp aanwezig is

urgentie 3

urgentie 2 (laagste)

: als bij urgentie 5, maar mét aanwezigheid hulp

: als bij urgentie 4 , maar mét aanwezigheid hulp 
Overigens kan nog een urgentleciffer 7 worden afgegewen aan die ouderen die al in een bejaardenoord verblijven, maar door sluiting of renovatie daarvan moeten verhuizen naar een ander tehuis (artikel: 16).

Het onderzoekstormulier bleek in de praktijk op een aantal bezwaren te stuiten (Overbeek, 1983). Ten eerste kan alleen met ja of nee geantwoord worden, zonder dat enige verdere nuancering mogelijk is. Ten tweede staan de gehanteerde criteria en de intepretatie daarvan ter discussie. Direct na inwoering bleek in 1978 dat ruim de helft (56\%) van de indicatiecommissies problemen met het onderzoeksformulier en de wijze van vraagstelling daarin heeft (NIMAWO, 1978). Ten derde bestaan er bezwaren tegen de beperkte mate waarop de psycho-sociale problematiek in beeld gebracht word: het meten van de frequentie van social contact zegt nog niets over de kwaliteit en de ondervonden steun daarvan. Voor de beoordeling van psychische problemen is bovendien speciale deskundigheid vereist. Ten vierde ontstaat een summier beeld van de alanwezige zorg van informele of professionele aard. Ook hier zijn slechts ja/nee antwoorden mogelijk op de vraag of zij aanwezig is, zonder dat ingegaan wordt op omvang en kwaliteit van deze hulp en de vraag of de draagkracht van informele hulp (met name partner) voldoende is.

Bij de adviesbepaling, die uitgaat van een 'puntensysteem' voor de verschillende aspecten, wegen vooral de ADL-problematiek, waarbij er minstens eén beperking moet zijn, en de huishoudeli.jke problemen, waarvan er minstens drie moeten bestaan, zwaar mee in de uiteindelijke beslissing. De woonsituatie mag niet worden meegeteld in de adviesbepaling en aan de psycho-sociale problematiek wordt volgens de critici onvoldoende gewicht toegekend. Met name dit aspect van de leefsituatie van ouderen zou echter vaak een belangrijke reden zijn voor het doen van een aanvraag voor het bejaardenoord. Veelvuldig gebruik van artikel 14.2 van het Besluit (urgentie 1), gemaakt voor uitzonderingsgevallen met het doel om de ouderen die noch ADL- noch huishoudelijke beperkingen, maar wel aanzienlijke psychosociale problemen kennen, toch een positief advies te kunnen geven, illustreert dat ook.

\subsubsection{Aantal ganvragen en verstrekte adviezen in de periode 1980-1987}

In deze paragraaf wordt aan de hand van jaarverslagen van de commissie te Maastricht een overzicht gegeven van het aantal aanvragen voor opname in de periode 1980-1987 en de aard van de verstrekte adviezen. Tevens worden enkele belangrijke kenmerken van de aanvragers en positief geadviseerden besproken, zoals de leeftijd en burgerlijke staat.

In tabel 9.1 is het aantal aanvragen en de negatieve of positieve beslissing daarover in de periode 1980-1987 gesplitst naar alleenstaanden en echtparen. Er is niet in beeld gebracht dat een aantal aanvragen niet tot een adviesbepaling komt, omdat men zich tussentijds heeft teruggetrokken of is overleden. Ook bij de positief gelndiceerden treedt deze "uitval' op (ongeveer $10 \%$ a $15 \%$ ). Van het totaal aantal aanvragen van alleenstaanden resulteert geniddeld $65 \%$ a $70 \%$ in een positief advies. Dit percentage daalde aanvankelijk eerst tot $53 \%$ in 1984 , maar stijgt sindsdien weer geleidelijk tot thans $75 \%$. Bij echtparen zijn de cijfers vergelijkbaar.

Het totaal aantal aanvragende personen (alleenstaanden of partners) neemt in relatieve termen, uitgedrukt als percentage van de Maastrichtse bevolking van 65 jaar en ouder, geleidelijk af. In 1980 diende nog $3 \%$ van de oudere bevolking een aanvraag in voor opname; nu is dat 2,5\%. De uitschieter in 1986 betreft wellicht inhaalvraag na de verscherping van het opnamebeleid in het jaar daarvoor. Uiteindelijk krijgt jaarijiks bijna $2 \%$ van alle ouderen een positief advies. Indien dat gebeurd is, wordt men op wachtlijst 


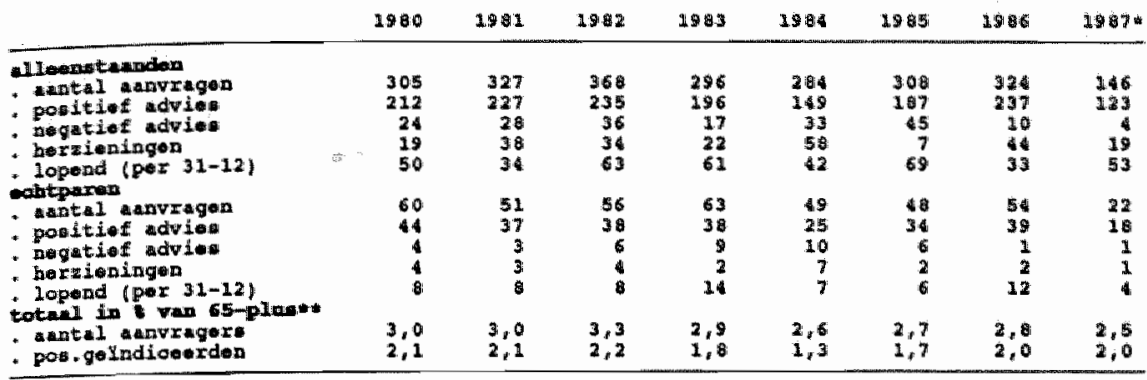

* Allen gagevera over de oerste holft ran dat faur

* Davolkingigeqevens voor Mabtricht por 1 jansari vain ledar jaar

geplaatst, die in Maastricht door dezelfde commissie wordt beheerd (zie paragraaf 9.2.2). In het begin van de onderzochte periode liep de wachttijd dermate hoog op (tot ruim een jaar), dat de hiervoor beschreven plaatsingsprocedure door alle tehuizen noodzakelijk geacht werd, om zo de meest urgente gevallen adequaat te kunnen helpen. Er werd afgesproken dat voortaan nog slechts die ouderen zouden worden opgenomen die als urgentiecijfer een 1,5 of 6 kregen. Bovendien werd de wijze van beoordeling zelf aangescherpt. Aan de hand van onderstaande tabellen kan het verloop van de wachtlijsten in de onderzochte periode bestudeerd worden.

Allereerst valt op dat de omvang van de wachtlijst in 1984 inderdaad is afgenomen en wel met ruim een kwart ten opzichte van de jaren daarvoor. In 1986 neemt de omvang echter enigszins toe. Het strikter beoordelen van de situatie van de aanvrager en het gezamenlijke opnamebeleid op basis van de hoogste urgenties lijkt effectief te zija, omdat naast de inkrimping van de wachtlijst zowel het aantal vervallen aanvragen (van ouderen met toch een positief advies) afneemt, als het aantal opgenomen ouderen stijgt (bij een gelijkblijvende capaciteit), zodat de doorstroming in de sector derhalve groter wordt. Ook de gemiddelde wachttijd is korter geworden. Naast de omvang van de wachtlijst, is de samenstelling van die wachtlijst van belang (zie tabel 9.3). Bij alleenstaanden neemt het aandeel van positief geindiceerden met een lage urgentie (cijfers $2 \mathrm{t} / \mathrm{m}$ 4) af van ruim $40 \%$ tot $35 \%$ alan het eind wan de beschouwde periode. Urgentie 1 , vaak toegekend aan mensen met alleen psychosociale problematiek, wordt in het striktere opnamebeleid vanaf 1984 nauwelijks meer

Tabel 9.2. Mutaties in wachtlijsten (1981-1986): alle ouderen tesamen (alleenstaanden + echtparen)

\begin{tabular}{|c|c|c|c|c|c|c|c|}
\hline & & 2981 & 1982 & 2983 & 1984 & 1985 & 1986 \\
\hline wachtlijot & $2 / 1$ & $33 y$ & 337 & $3: 51$ & 327 & 230 & 237 \\
\hline pou - advíned & & 301 & 311 & 272 & 199 & 215.5 & $3 \times 5$ \\
\hline to plabtan & & $\overline{633}^{+}$ & $\overline{648}^{+}$ & 623 & $\underset{526}{+}$ & $m_{43}^{+}$ & $\overline{5.5}_{5}+$ \\
\hline opgenarien & & $202-$ & 212:- & 212 & $201-$ & $215-$ & $249-$ \\
\hline vervallan & & $94-$ & $85-$ & $85-$ & 67- & $41-$ & $46-$ \\
\hline wachtIijot & $31 / 12$ & 337 & 351 & 327 & 238 & 237 & 255 \\
\hline
\end{tabular}




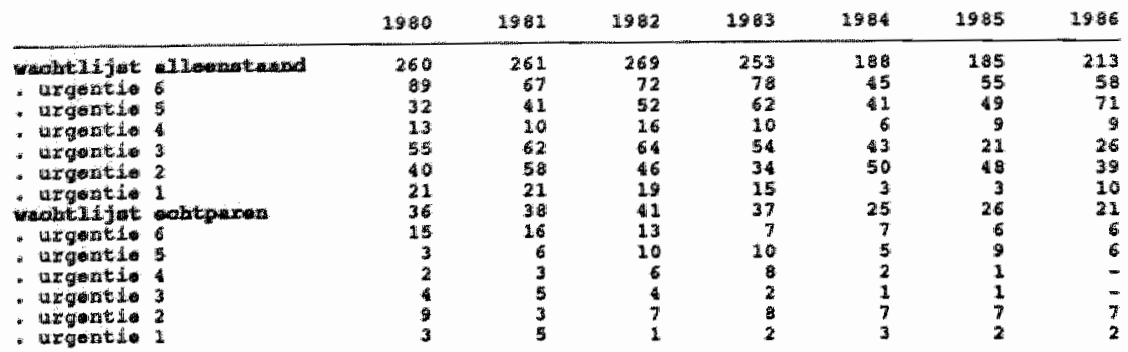

gegeven. Hoge urgenties komen na de trendbreuk in 1984 meer en meer voor; thans bij ruim $60 \%$ van de alleenstaande wachtenden. Bij echtparen wijkt het beeld enigszins af van het voorgaande. De urgenties 3 en 4 worden vrijwel niet meer afgegeven, waaruit blijkt dat echtparen die kunnen terugvallen op enige vorm van hulp steeds moeilijker een positief advies krijgen. Toch krijgt nog bijna een derde de laagste urgentie. Hoge urgenties zijn verstrekt aan circa $57 \%$ van de echtparen.

Het uiteindelijke doel van indicatiestelling betreft de regulering van de instroom in bejaardenoorden, op een zodanige wijze dat dat enerzijds op een uniforme en gevalideerde wijze plaats vindt en er anderzijds toe leidt dat de meest urgente gevallen het eerst worden opgenomen. In Maastricht wás daarom de taak van de indicatiecommissie zo verbreed dat zij tevens fungeert als plaatsingscommissie, waardoor zij bij het vrijkomen van een plaats invloed heeft op de keuze uit de wachtlijst (keuze van tehuizen is beperkt tot door de commissie voorgedragen personen).

Tabel 9.4. heeft inzicht in de urgentie-graad die de ouderen hadden voordat zij werden opgenomen. In 1980 had circa $33 \%$ van de alleenstaanden en $44 \%$ van de echtparen een lage urgentie en werd nog eens $5 \%$ van de eerste groep en $25 \%$ van de tweede groep opge-

Tabel 9.4. Aantal opnamen naar urgentie (exclusief ouderen van buiten de gemeente)

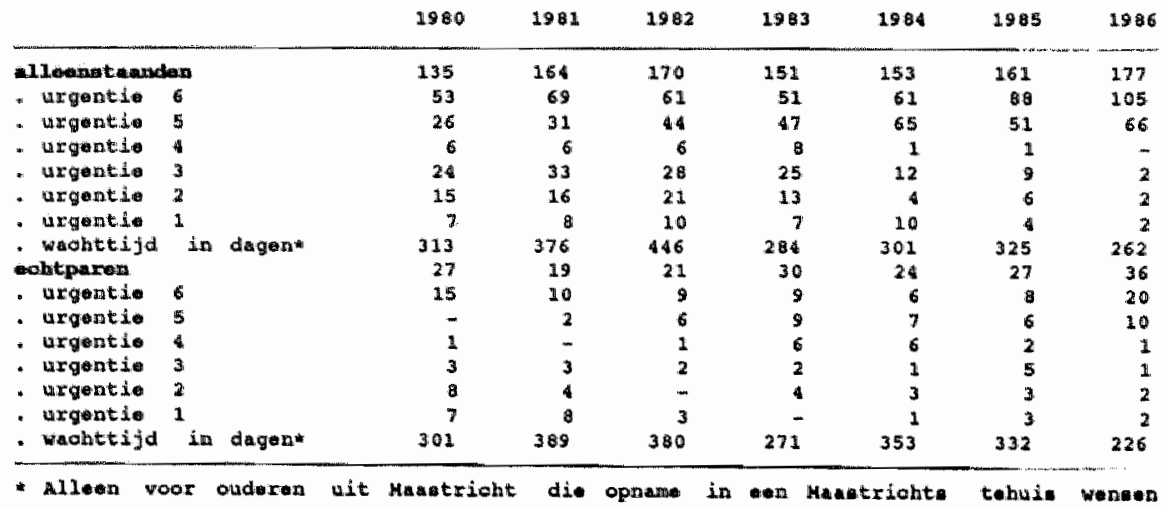


nomen op basis van een positief besiuit krachtens het artikel 14 lid 2 (voor uitzonderingsgevallen!). Had van de opgenomen alleenstaanden in 1980 slechts $59 \%$ een urgentieciffer 5 of 6 , in 1986 is dat $97 \%$. De hoogste urgentie had eerst $39 \%$ en in $198659 \%$. Bij echtparen is de zelfde ontwikkeling opgetreden, zij het iets minder geprononceerd: in 1980 bad $56 \%$ de hoogste urgentie en werd $26 \%$ toegelaten via het inmiddels bekende artikel 14 lid 2 , nu heeft $83 \%$ de hoogste urgentie en nog slechts $6 \%$ urgentie 1.

\subsubsection{Indicatiecommissie Ouderenwooraieningen nieuwe stijl}

Per 1 september 1989 is de nieuwe commissie zoals bedoeld in het Besluit Indicatieadvisering bejaardenoorden en verpleeginrichtingen (Stb. 1988, no. 456) van start gegaan, hoewel een aantal zaken met betrekking tot procedures, urgentie-systematiek, automatisering en afhandeling werkzaamheden van de oude commissie, nog niet geregeld was. Per 1 november 1989 heeft de gemeente Eysden de indicatiestelling voor de bejaardenoorden en werpleeghuizen overgedragen aan de Maastrichtse commissie, die daarmee een regionaal karakter krijgt. Voor het werkgebied Eysden is het terrein van de te bestrijken voonieningen echter beperkt tot de zojuist genoemde voorzieningen, terwijl in de gemeente Maastricht tevens gelndiceerd wordt voor tijdelijke opname, dagverzorging, woontussenwoorzieningen en centrale alarmering. De commissie heeft harar spreekuur in ere hersteld en is elke werkdag 's morgens telefonisch te bereiken of woensdagmiddag te bezoeken.

In tegenstelling tot het oude Besluit Opneming Bejaardenoorden is thans geen puntensysteem voor de urgentiebepaling voorgeschreven, doch staat het de individuele commissies in den lande vrij om zelf de mate van urgentie en de wijze waarop die wordt alangegeven te bepalen. In Maastricht gaat men vooralsnog uit van de oude systematiek, maar zijn diverse urgenties samengevoegd, zodat er van de aanvankelijk zeven categorieen er nu nog vier over zijn. Thans hanteert men voor de beoordeling van een eventuele opname in een van de bejaardenoorden de volgende criteria:

urgentie 1: opname wenselijk (oude urgentie 2 en 3); huishoudelijke beperkingen, hulp aanwezig

urgentie 2: urgent (oude urgentie 4); hüishoudelijke hulp ontoereikend; geestelijke toestand goed

urgentie 3: zeer urgent (oude urgentie 5); ADL-beperkingen of lichte geestelijke problematiek

urgentie 4: opname met spoed (oude urgentie 1 en 6); evenals 3, maar in crisissituatie; thuissituatie niet te handhaven door psychische, sociale of somatische problematiek.

Zoals eerder bleek, vervult de commissie sinds 1 april 1990 helaas geén plaatsingsrol meer. Voor alle andere voorzieningen waarvoor de commissie nieuwe stijl de indicatiestelling werricht, worden eveneens maximaal vier verschillende urgenties toegekend, maar de inhoud varieert per voorziening. Voor bijvoorbeeld verpleeghuiszorg (opname of dagbehandeling) wordt urgentie 2 gegeven als opname urgent is en op korte termijn gerealiseerd moet worden en betreft urgentie 4 een spoedopname, waarbij de toekenning van de urgentie achteraf plaats vindt. Voor de woontussenvoorzieningen (aanleunwoningen) bestaan wel plannen om tot urgentiebepaling te komen, maar deze zijn nog niet gerealiseerd. De commissie benadrukt het voorlopige karakter van het een en ander; in 1990 zal het indicatie- en urgentiesysteem verder worden verfijnd en aangescherpt. 


\subsection{Overzicht van de bejaardenoorden in de periode 1985-1988}

In deze paragraa wordt een globaal owerzicht gepresenteerd ten aanzien van de bejaardencorden in de gemeente Maastricht. Aan de orde komen achtereenvollgens de capaciteitsontwikkefingen, het aantal opgenomen bewoners naar leeftijd en sexe, het bereik van de voorziening, de in en uitstroom in de sector, de ontwikkeling van wijkfuncties, de personeetsformatie en de totale kosten van de gehele sector.

\subsubsection{Capaciteitsontwikkellingen in bejaardenoorden te Maastricht}

In Maastricht functioneren thans 9 gewone bejaardenoorden met een totale capaciteit van circa 1000 plaatsen (zie tabel 9.5). Medio 1987 is een klein oord gesloten en in maart 1988 begon de sloop van het bejaardenoord met een bijzondere functie voor blinde ouderen, dat echter weer nieuwbouw krijgt (gereed in maart 1990). Er zijn ook nog drie kloosterbejaardenoorden met een totale capaciteit van 138 plaatsen. Zij vallen, gelijk het blindenbejaardenoord, direct onder WVC als oorden met een bijzondere functie (in het vervolg: categorale bejaardenoorden).

In 1987 werd door Gedeputeerde Staten een verklaring van geen bezwaar als bedoeld in artikel 6d van de WBO verleend aan de Stichting Burgerlijk Armenbestuur voor de bouw van een nieuw bejaardenoord in Maastricht-Oost met een capaciteit van 70 plaatsen. Dit bejaardienoord dient tevens ter vervanging van Huize in den Drinck (30 plaatsen), zodat per saldo de capaciteit in Maastricht met 40 plaatsen zal toenemen (Jaarverslag ingevolge de WBO 1987, GS Limburg). De investeringskosten bedragen ongeveer 9,5 miljoen gulden (Jaarrekening Burgerlijk Armenbestuur 1988). Tezamen met het verzorgingstehuis worden 32 aanleunwoningen, een wijksteunpunt en een huisartsenpraktijk gebouwd. De bejaardenoorden staan voor een groot deel geconcentreerd in de Binnenstad, waar ook het verpleeghuis ligt: in dit stadsdeel (16\% van alle ouderen in de gemeente) ligt $47 \%$ van de totale capaciteit, waaronder die van alle oorden met een bijzondere functie.

Het was bij de start van het onderzoek in 1986 de bedoeling een inventarisatie en analyse te maken van alle bejaardenoorden over de periode 1980-1988. Het duurde echter tot decem-

Tabel 9.5. Goedgekeurde capaciteit van de Maastrichtse bejaardenoorden (per 31-12)

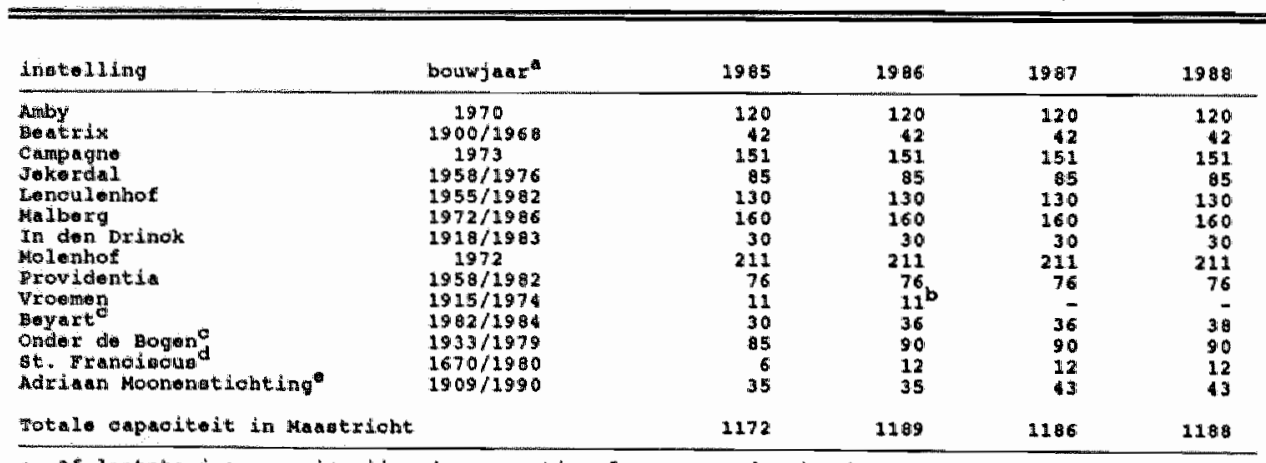

a. Of lastate jar ran ingrijpende renovatie of vervangende aieawbouv

4. Opgoheven per 31 juli 1987

c. Rloogterbej a relenoord

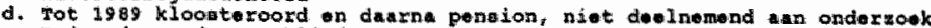

- Bejaardenoord voer blinden on loohtrienden (ook wel: ilicht hivede) 
ber 1989 tot alle instellingen medewerking verleenden, waarbij het verschijnen van een rapport over psycho-sociale problematiek in een van de tehuizen (Huijsman, 1989e) uileindelijk de doorslag gaf. Naast het medio 1987 gesloten bejaardenoord, weigerde een andere kleine instelling alle medewerking. Via bet Bureau Onderzoek en Statistiek van de Gemeente Maastricht is van dit oord wel bekend hoeveel mensen (naar sexe en leeftijd) er verblijven per 31 december 1987 en 1988. Een ander oord werkte weliswaar mee, maar men kon door nieuwbouw niet alle gevraagde gegevens terugvinden. Hoewel het naar de corzaken voor aanvankelijke of totale weigering gissen blijft, lijkt het aannemelijk dat het onderzoek voor deze tehuizen, die tot de kleinste gerekend kunnen worden, als te bedreigend ervaren werd.

\subsubsection{Opbouw van het bewonersbestand sinds 1985}

In deze paragraaf baseren wij ons op de CBS-enquete voor bejaardenoorden, die sinds 1965 jaarlijks moet worden ingevuld. De speciale aandacht gaat uit naar de leeftijds- en validiteitsverdeling, de instroom naar herkomst en de uitstroom naar bestemming. De gegevens betreffen de periode $1985-1989$ (ultimo elk jaar). In tabel 9.6 wordt het totale bewonersbestand van alle tehuizen tezamen uitgesplitst naar leeftijdsgroepen. De gemiddelde leeftijd ligt net onder de 83 jaar. In de betreffende leeftijdscategorie van $80 \mathrm{t} / \mathrm{m}$ 84 jaar bevindt zich ruim $30 \%$ van alle bewoners. Ruim $40 \%$ van alle bewoners is echter ouder dan 85 jaar en dit aandeel is de laatste jaren stijgende, door een toename van met name zeer-hoogbejaarde bewoners (90-plus).

Het bereik van de algemene bejaardenoorden ligt in de gemeente Maastricht onder de zogenaamde 7\%-norm (die nooit in het overheidsbeleid is geformaliseerd): in 1983 was $6,6 \%$ van de 65 -plussers opgenomen in een algemeen verzorgingstehuis, eind 1988 was dat door het toenemend aantal ouderen bij gelijkblijvende, zelfs afnemende capaciteit nog maar $5,8 \%$. Van alle in algemene corden opgenomen ouderen is in 1989 ongeveer driekwart vrouw (zie figuur 9.2). Dit aandeel is iets lager in de jongere groepen en het hoogst bij 90plus (in 1989 is van ben $80 \%$ een vrouw).

Naar geslacht en leeftijd gespecificeerd zijn in figuur 9.3 de bereikcijfers (dat wil zeggen het aantal bejaardenoordbewoners naar geslachts- en leeftijdsgroep uitgedrukt in procenten van de Maastrichtse bevolking) voor de algemene bejaardenoorden gedurende de periode 19831988 (per 31 december wan ieder jaar) in beeld gebracht. In alle leeftijdsgroepen ligt het bereik voor vrouwen boven dat voor mannen. Gemiddeld is per 31 december 1988 3,7\%

Tabel 9.6. Leeftijdsverdeling (in \%) in bejaardenoorden" (per 31 december)

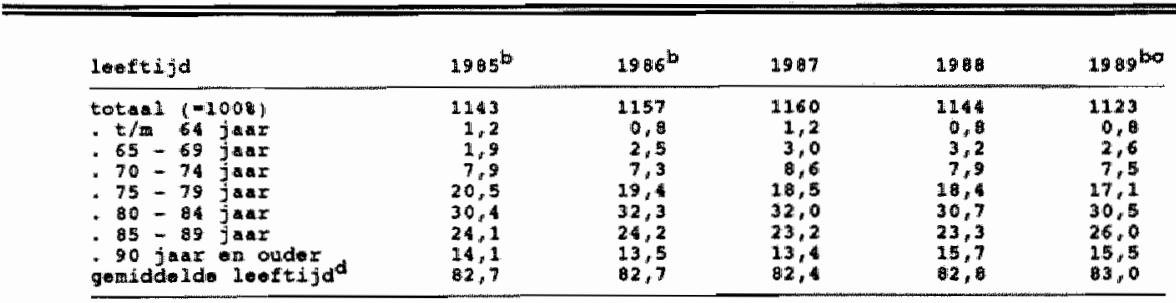

a. Inolua ief oorden bijzondere fumetto

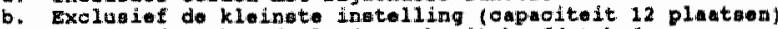

c. Gebaewerd op het delonderroek lit hoofdatulk 6

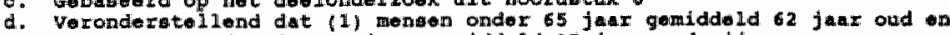

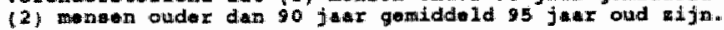




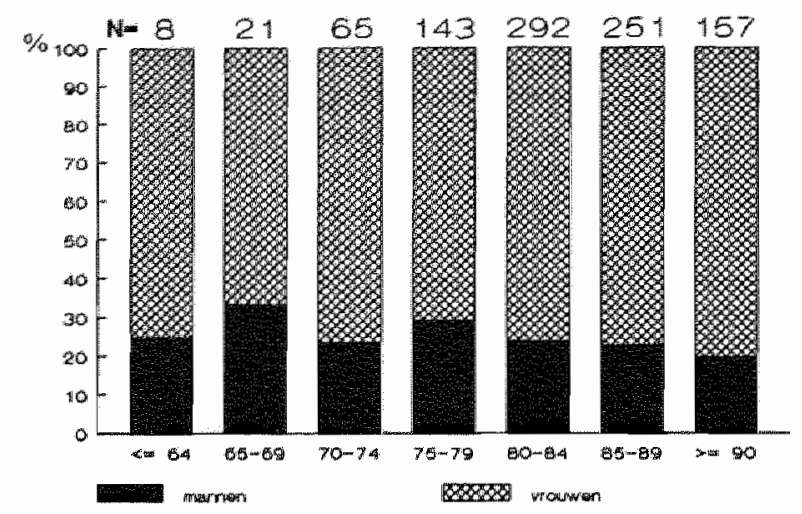

Figuur 9.2. Aandeel van sexen in algemene oorden (in \%; per kolom aantal bewoners)

van alle mannen en 7,0\% van alle vrouwen van 65 jaar en ouder in een van de algemene bejaardenoorden te Maastricht opgenomen. Voor de categorale bejaardenoorden komt daar nog eens $0,9 \%$ voor de mannen en $1,1 \%$ woor de vrouwen bij, genniddeld $1,1 \%$ van alle 65 . plussers in de gemeente Maastricht, zodat het totale bereik van alle bejaardenoorden uitkomt op 6,9\%. Dit bereik (1988) loopt sterk op met de leeftijd van $0,5 \%$ tot 70 jaar, $1,6 \%$ bij $70-74$ jaar, $4,9 \%$ bij $75-79$ jaar en $14,4 \%$ bij $80-84$ jaar tot $26,9 \%$ bij 85 -plussers.

Begin jaren ' 80 kampte men met zulke lange wachtlijsten, dat een wachttijd van twee jaar geen uitzondering was. Om de doorstroming te bevorderen is een gezamenlijk opnamebeleid ontwikkeld, waarbij mensen met slechts huishoudelijke bulpbehoefte niet meer worden opgenomen (zie voorgaande paragraaf). De hier gehanteerde CBS-registratie leent zich voor de vraag of dit opnamebeleid $z^{\prime} n$ weerslag heeft gehad op de validiteitsverdeling van de bewoners. Er worden wier groepen onderscheiden (zie ook paragraaf 4.2.4), namelijk (a) volledig bedlegerig, (b) niet bedlegerig maar wel volledig hulpbehoevend, (c) gedeeltelijk

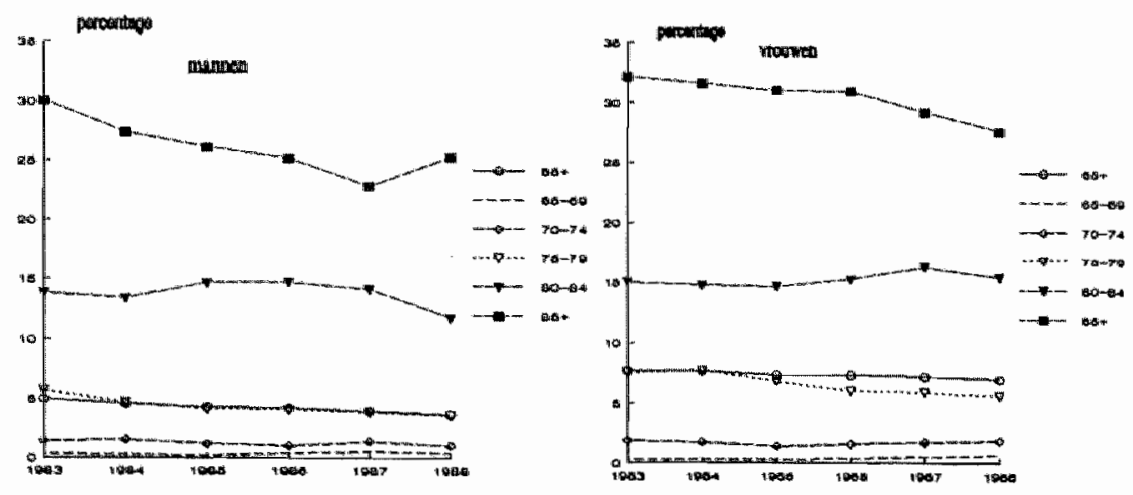

Figuur 9.3. Bereik van de algemene oorden naar sexe en leeftijdsgroep 


\begin{tabular}{|c|c|c|c|c|}
\hline & $1985^{b}$ & $1986^{6}$ & 1987 & 196 \\
\hline 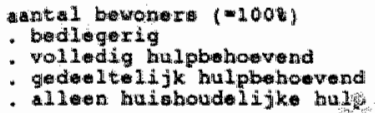 & $\begin{array}{r}953 \\
3,9 \\
23,4 \\
46,3 \\
24,8\end{array}$ & $\begin{array}{r}95 \\
2,4 \\
23,9 \\
12,9 \\
30,8\end{array}$ & $\begin{array}{r}467 \\
3,2 \\
2,4 \\
36,5 \\
36,9\end{array}$ & $\begin{array}{r}956 \\
3 ; 0 \\
31 ; 2 \\
40 ; \\
20\end{array}$ \\
\hline
\end{tabular}

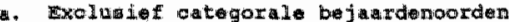

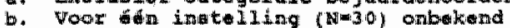

hulpbehoevend op ADL-gebied en (d) niet lichamelijk hulpbehoevend maar zich reddend met enige huishoudelijke hulp. Tabel 9.7 laat niet meteen een duidelijke kentering in de validiteitswerdeling zien, maar in 1988 lijkt toch sprake te zijn van een afname van het aantal bewoners in de lichtste categorie en een toename in de zwaarste categorie, zodat de effecten van het gezamenlijke opnamebeleid met enige vertraging toch merkbaar zijn via de validiteitsverdeling van de bewoners.

De validiteitswerdeling in de instellingen met een bijzondere functie is niet helemaal bekend, maar analyse voor twee daarvan doet vermoeden dat deze vooral in kloosteroorden enigszins gunstiger is dan in algemene bejaardenoorden. In $1988(\mathrm{~N}=127)$ is die verdeling als volgt: $3,9 \%$ is bedlegerig; $18,9 \%$ is geheel hulpbehoevend; $41,7 \%$ partieel hulpbehoevend en $35,4 \%$ krijgt hoogstens huishoudelijke hulp.

\subsubsection{In- en uitstroom bejaardenoorden}

Een belangrijke doelstelling van het in 1985 ingevoerde gezamenlijke opnamebeleid betrof bespoediging van de doorstroming in de sector. Net als bij de voorgaande analyses is niet van alle tehuizen de relevante statistiek beschikbaar. Tabel 9.8 laat zien welke oorden in deze subparagraaf worden bestudeerd. In $1986 \mathrm{kwam}$ het instroompercentage aanzienlijk hoger uit dan in het jaar daarvoor, maar dit voordeel van het nieuwe opnamebeleid lijkt geleidelijk weg te ebben. In 1988 was het instroompercentage van de vermelde instellingen gemiddeld $20,4 \%$ (18,8\% inclusief oorden met bijzondere functie). De variatie tussen de

Tabel 9.8. Relatieve instroom in bejaardenoorden (in \% van capaciteit)

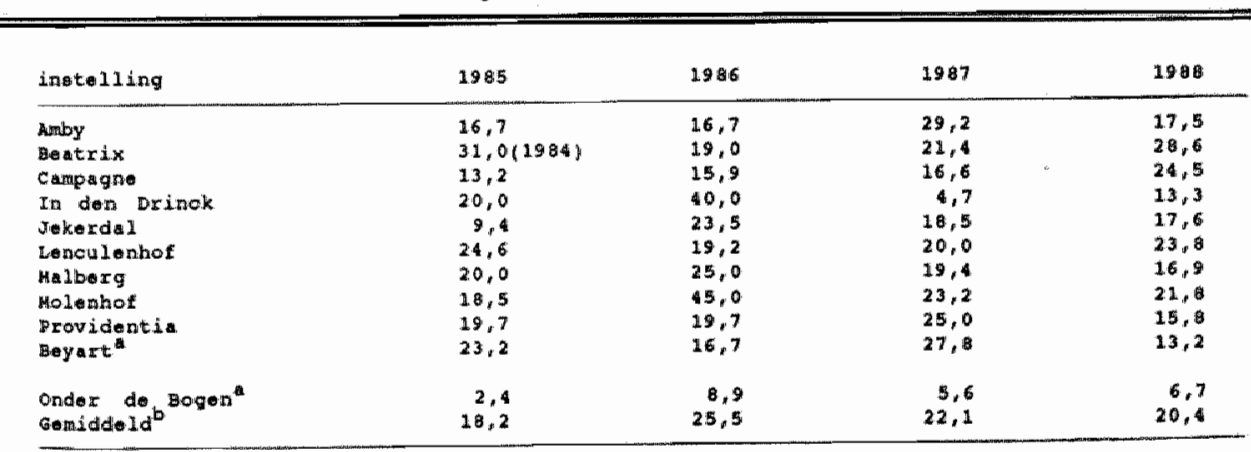

a. Koostexbejamdemord

b. Gemiddelde voor de algomeno betarramoorden 
instellingen is echter groot en loopt bij de algemene bejaardenoorden van minimaal $13,3 \%$ tot maximaai $28,6 \%$. De relatieve instroom in de kloosterbejaardenoorden was in 1988 aanzienlijk lager. Gegevens van de indicatiecommissie laten overigens zien dat het instroompercentage vớr de beschouwde periode nog iets lager was, namelijk rond $15 \%$ à $16 \%$ begin jaren tachtig. Uit het eigen deelonderzoek (zie volgende hoofdstuk) komt in 1989 een nog verdere daling van het instroompercentage tot $17 \%$ naar voren. Hoewel de meetprocedure kan leiden tot een geringe onderschatting van de instroom (die mensen betreffend die in de loop van 1989 ook weer zijn uitgeschreven), zet de daling van de doorstroming verder voort en komt in de burt van de situatie woor 1985.

Tabel 9.9 geeft de leeftijdsverdeling van de jaarlijkse instroom en de herkomst van deze nieuwe bewoners voordat zij werden opgenomen. Daarbij moet allereerst worden opgemerkt dat artikel la van de WBO de mogelijkheid biedt om personen jonger dan 65 jaar op te nemen, mits daartoe een verklaring door Gedeputeerde Staten wordt afgegeven. Daarvoor dienen er zodanige bijzondere omstandigheden te zijn dat de betrokkene niet meer thuis verzorgd kan worden, zulks ter beoordeling van de indicatiecommissie. Er wordt geconcludeerd dat de nieuwe bewoners steeds ouder worden, doch dit is een geleidelijke ontwikkeling en een trendbreuk die als gevolg van de wijziging in het opnamebeleid in 1985 verwacht zou kunnen worden, is niet opgetreden, hoewel de beschouwde periode kort is. In 1985 was nog $21 \%$ van de 'nieuwkomers' 85 -plus, in $198831 \%$. De gemiddelde leeftijd van de nieuwkomers ( 81 jaar in 1988) komt daarmee dichter bij die van de al aanwezige bewoners (ruim 82,5 jaar in 1988).

Verreweg de meeste bewoners komen uit de eigen omgeving (circa $87 \%$ ) en een klein deel uit het verpleeghuis. De stroom uit het verpleeghuis kan echter van jaar tot jaar aanzienlijk variëren. De stromen tussen de bejaardenoorden onderling (herplaatsingen van al eerder opgenomen ouderen) zijn gering. Sinds 1986, in tegenstelling tot 1985, komt een opname vanuit een (psychiatrisch) ziekenhuis haast niet meer voor. Opnamen na een verblijf in een aanleunwoning worden tenslotte bij uitzondering geconstateerd; alleen in 1987 kwam dit bij twee oorden voor en betrof toen slechts vier personen. Dit lijkt een aanwijzing te zijn voor ook elders gesignaleerde effecten van deze vorm van 'beschermd wonen' voor ouderen, waardoor een intramurale opname achterwege kan blijven (Coolen en Van Pelt, 1985).

Tabel 9.9. Leeftijdsverdeling en herkomst van instroom (in \% van totaal)

\begin{tabular}{|c|c|c|c|c|}
\hline & 19185 & 1986 & 1907 & 1988 \\
\hline 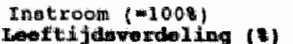 & 194 & 273 & 237 & 216 \\
\hline 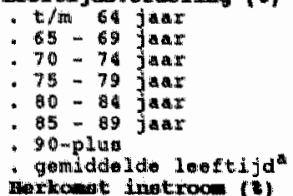 & $\begin{array}{r}2,1 \\
5,2 \\
10,3 \\
28,4 \\
33,0 \\
14,9 \\
6,2 \\
1,3\end{array}$ & $\begin{array}{r}1,1 \\
5,9 \\
13,6 \\
23,8 \\
31,9 \\
18,3 \\
5,5 \\
80,0\end{array}$ & $\begin{array}{r}3,4 \\
5,5 \\
12,2 \\
25,3 \\
30,8 \\
17,7 \\
5,1 \\
79,6\end{array}$ & $\begin{array}{r}0,9 \\
3,2 \\
15,7 \\
20,6 \\
28,2 \\
22,2 \\
0,0 \\
01,0\end{array}$ \\
\hline 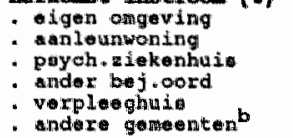 & $\begin{array}{r}4,5 \\
0,0 \\
5,7 \\
2,6 \\
7,2 \\
8,2\end{array}$ & $\begin{array}{r}8,7 \\
0,0 \\
1,1 \\
2,6 \\
8,4 \\
4,0\end{array}$ & $\begin{array}{r}80,6 \\
1,7 \\
0,0 \\
7,6 \\
10,1 \\
5,5\end{array}$ & $\begin{array}{r}87,0 \\
0,0 \\
2,3 \\
6,0 \\
4,6 \\
10,2\end{array}$ \\
\hline
\end{tabular}

4. Veronderatel I nd diat (1) monan onder 65 jas gomiddeld 62 jaur oud

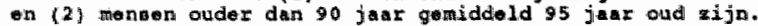

b. Overilappend the de andere oategorielon. 


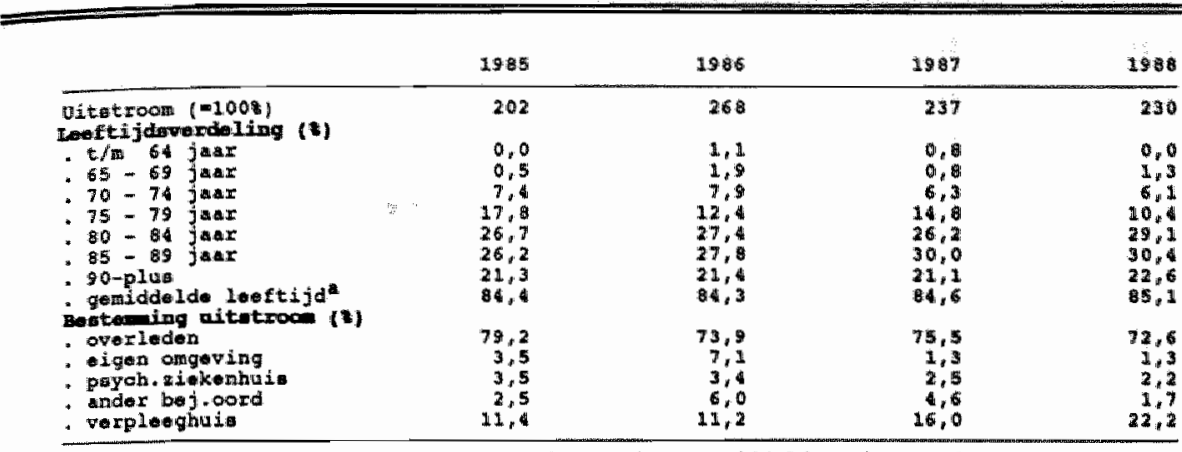

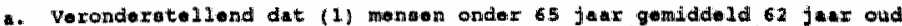

on (2) Eamoen ouder den 90 juar gonididild 95 jear oud zijn.

Tabel 9.10 laat de uitstroom uit de bejaardenoorden zien. Er is vast te steflen dat in 1986 aanmerkelijk meer ouderen werden uitgeschreven dan in het jaar daarvoor. Dit geldt met name voor de grotere tehuizen met meer dan 125 plaatsen. De voormalige bewoners worden steeds ouder, zodat nu meer dan 50\% ouder is dan 85 jaar, welke grens gelijk is aan de gemiddelde leeftijd van de uitgeschrevenen. Bij ongeveer driekwart betreft de reden van uitschrijving het overlijden van de bewoner. Steeds meer mensen worden echter overgeplaatst naar het verpleeghuis. Relatief wordt zelfs bijna een verdubbeling geconstateerd van $11,4 \%$ van de uitstroom in 1985 tot $22,2 \%$ in 1988. Er gaan slechts weinig personen voor een permanent verblijf over naar een (psychiatrisch) ziekenhuis en ook de stroom terug naar de eigen omgeving is minimaal. De uitschieter in $1986(7,3 \%$ naar huis) is geheel toe te schrijven aan ến (de grootste) instelling.

\subsubsection{Wijkfuncties bejaardenoorden}

De laatste jaren zijn bejaardenoorden zich steeds meer gaan richten op de bewoners van de wijk waarin zij gelokaliseerd zijn vila de zogenaamde wijkfunctie van bejaardenoorden, waardoor zelfstandig wonende ouderen gebruik kunnen maken vain dienstverlening van het verzorgingstehuis, zonder daarin te zijn opgenomen (Reikwijdtebesluit WBO; Stb. 1984, no. 678). Het gebruik van wijkfuncties wordit sinds 1985 (in dat jaar via een aparte viragenlijst) gehnventariseerd via de Statistiek Bejaardenoorden. Mogelijke functies zijn (tussen haakjes het percentage oorden in Nederland dat deze aan het eind van 1986 aanbood): kortdurende opname (51\%), dagverzorging (16\%), nachtopvang (9\%), maaltijdverstrekking ( $69 \%$; bijna geheel voor aanleunwoningen), bad- of douchevoorziening $(9 \%)$, voetverzorging (12\%), MBVO (39\%) en alarmsyteem (47\%). Met deze laatste mogelijkheid worden in Nederland 38.300 ouderen ( $2,1 \%$ van alle 65 -plussers) geholpen, waarvan $70 \%$ in een aanleunwoning bij het bejaardenoord woont.

In tabel 9.11 wordt een overzicht gegeven van de in Maastricht gerealiseerde wijkfuncties. Omdat de betreffende vragen het eerste jaar niet geintegreerd waren in de CBS-enquete zijn voor 1985 geen gegevens bekend. Voorbeelden die eind 1988 in Maastricht feitelijk gerealiseerd zijn, betreffen de kortdurende opname waarvan 80 mensen gebruik maakten, dagverzorging (41 personen), nachtopvang (waarvan geen gebruik is gemaakt), maaltijdwoorziening (gemiddeld bijna 80 maaltijden per dag), voetverzorging (55x) en Meer Bewegen voor Ouderen (85x). Aansluiting op een alarmeringssysteem hebben ruim 340 ouderen 
Tabel 9.11. Whlfuncties van bejaardenoorden: het gebruik op jaarbasis

\begin{tabular}{|c|c|c|c|c|}
\hline & 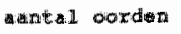 & 1986 & 1987 & 198 \\
\hline 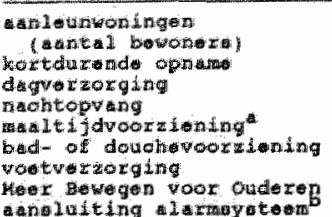 & $\begin{array}{l}3 \\
5 \\
2 \\
1 \\
5 \\
2 \\
3 \\
5 \\
5\end{array}$ & $\begin{array}{r}202 \\
236) \\
43 \\
33 \\
6 \\
72 \\
6 \\
32 \\
73 \\
300\end{array}$ & $\begin{array}{r}201 \\
237 \\
69 \\
26 \\
6 \\
74 \\
12 \\
58 \\
77 \\
3.2\end{array}$ & $\begin{array}{r}202 \\
239 \\
00 \\
41 \\
0 \\
79 \\
6 \\
55 \\
85 \\
341\end{array}$ \\
\hline
\end{tabular}

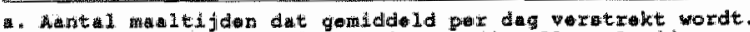

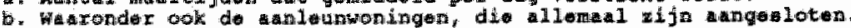

(2\% van alle 65 -plussers), waarbij opgemerkt wordt dat dat inclusief de aanieunwoningen is die allemaal zijn aangesloten. Opgemerkt wordt dat ook enkele andere wijkfuncties vooral worden ingezet bij de bewoners van aanleunwoningen, zoals de maaltijdservice (65\%). Sinds 1 november 1989 bestaat er wel een Stedelijke Maaltijdvoorziening (niet in tabel) met een bejaardenoord als producent, vier eetpunten in verschillende wijken en daarnaast thuisbezorging. In totaal worden per week circa 200 maaltijden gedistribueerd; de indicatiestelling gebeurt door de maaltijdvoorziening zelf.

De dagverzorging blijkt nationaal well, maar in Maastricht slechts bij uitzondering benut te worden door mensen uit een aanleunwoning. Dagverzorging bestaat slechts bij twee tehuizen, waarbif er een in het oog springt (29 ouderen in 1988). Kortdurende opname heeft een grote vlucht genomen ( 80 maal in 1988) en is bij zes instellingen mogelijk. Samenvattend kan geconcludeerd worden dat de mate waarin de wijkfuncties in Maastricht gestalte hebben gekregen, niet veel afwijkt van het eerder geschetste landelijke beeld.

\subsubsection{Personeel in algemene bejaardenoorden}

Voor de algemene oorden die aan het onderzoek deelnamen ( 9 instellingen, uitgezonderd het kleinste dat in 1987 gesloten is) wordt thans ingegaan op de omvang van de personeelsformatic. Daarbij wordt het onderscheid tussen indirect en direct personeel gehanteerd. Onder het directe personeel wordt het verzorgende personeel (bejaardenverzorgenden, -belpenden en verzorgingsassistenten) en thet verplegende personeel (verpleegkundigen en ziekenverzorgenden) begrepen. Vaak betreft dat gediplomeerd personeel, maar in bescheiden mate wordt ook personeel in opleiding binnen de instellingen aangetroffen, hetgeen afzonderlijk vermeld is. Daarbij wordt opgemerkt dat de afname in deze categorie deels een artefact is, omdat zij vroeger wel en thans niet meer in de formatie wordt meegeteld. Ook het indirecte personeel wordt naar functie verbijzonderd (directie, administratie en huishoudelijk, technisch, agrarisch of overig personeel). Tabel 9.12 geeft een overzicht van de formatie in algemene bejaardenoorden in de periode 1985-1988 en toont naast de absolute omvang in voltijdse equivalenten (f.t.e.) ook de formatie per 100 bewoners. De gemiddelde bezetting telt 39 a 40 voltijdse plaatsen, waarvan 61 a $62 \%$ direct personeel in de verzorgende of verplegende sector. Door meerhoofdige directies in een aantal oorden heeft een gemiddeld oord 1,4 directie-plaatsen; eenhoofdige directies komen slechts bij $1 / 3$ van de oorden voor.

Bínnen de categorie indirect personeel is het keukenpersoneel (30,2\% in 1988) en het huishoudelijk personeel $(27,5 \%)$ het belangrijkst, gevolgd door technisch, agrarisch en overig personeel $(22,5 \%)$. Tot en met 1987 is het aandeel van het indirecte personeel geleidelijk 
Tabel 9.12. Totale personeelsformatie in de algemene bejaardenoorden (in voltijdse banen of fit.e.)

\begin{tabular}{|c|c|c|c|c|}
\hline & 1985 & 1986 & 1987 & 19 \\
\hline totale personel 1 & 371,92 & 390,06 & $3: 47,03$ & 379,75 \\
\hline 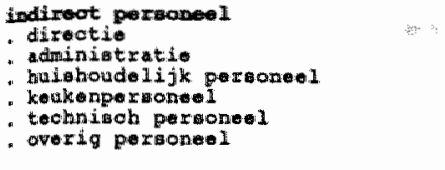 & $\begin{array}{r}141,59 \\
10,66 \\
17,52 \\
37,56 \\
45,56 \\
15,37 \\
14,62\end{array}$ & $\begin{array}{r}150,18.5 \\
10,+14 \\
18,23 \\
43,318 \\
43,9.9 \\
15 ; 17 \\
19,29\end{array}$ & $\begin{array}{r}151,89 \\
11,84 \\
16,41 \\
39,91 \\
45,94 \\
14,97 \\
22,81\end{array}$ & $\begin{array}{r}145,67 \\
12,50 \\
16,54 \\
39,59 \\
41,03 \\
19,09 \\
17,62\end{array}$ \\
\hline 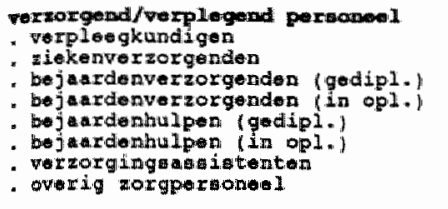 & $\begin{array}{r}230,33 \\
20,61 \\
28,17 \\
101,01 \\
11,80 \\
27,84 \\
0,00 \\
2,06 \\
38,84\end{array}$ & $\begin{array}{r}239,21 \\
20,1.3 \\
3,8,70 \\
101,36 \\
9,42 \\
27,07 \\
2,30 \\
3,47 \\
36,76\end{array}$ & $\begin{array}{r}235,15 \\
20,51 \\
10,95 \\
100,71 \\
15,52 \\
3,2,25 \\
0,80 \\
2,01 \\
32,40\end{array}$ & $\begin{array}{r}234,00 \\
22,38 \\
42,67 \\
107,20 \\
3,30 \\
31,00 \\
0,500 \\
1,000 \\
26,93\end{array}$ \\
\hline 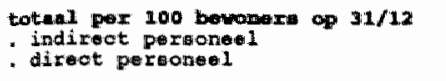 & $\begin{array}{l}38,26 \\
14,57 \\
23,70\end{array}$ & $\begin{array}{l}319,60 \\
13,31 \\
24,29\end{array}$ & $\begin{array}{l}319,53 \\
1.5,51 \\
24,0.2\end{array}$ & $\begin{array}{l}39,23 \\
19,05 \\
24,16\end{array}$ \\
\hline
\end{tabular}

opgelopen, maar in 1988 trad een kentering op. Dit wordt vooral veroorzaakt door uitbesteding van werkzaamheden aan derden, maar dit is moeilik in formatieplaatsen te kwantificeren (idealiter wel vereist voor het totaalbeeld). Per 100 bewoners zijn er eind 1988 15 personeelsleden in de indirecte sfeer in dienst.

Het directe personeel (inclusief afdelings- en andere hoofden) bestaat voor bijna de helft uit bejaardenverzorgenden ( $46 \%$ ), maar ziekenverzorgenden worden belangrijker (van $12 \%$ tot $18 \%$ in 1988). Opmerkelijk is voorts het dalend aantal personen dat in opleiding is voor bejaardenverzorgende. Verzorgingsassistenten treft men in de algemene oorden, in tegenstelling tot kloosteroorden, vrijwel niet aan. De personeelsformatie per 100 bewoners is sinds 1986 licht gedaald tot thans 39,2 voltijdse plaatsen, waarvan 24,2 in de directe sfeer. Landelijk is er een vergelijkbare ratio met het aantal verzorgden (zie hoofdstuk 4). Hoewel de financiele situatie de provincie noodzaakt een restrictief beleid te voeren inzake eventuele uitbreiding van personeelsformatie, wordt geconstateerd dat er een toenemende zorgbehoefte is, die zall leiden tot de vraag om in zowel kwantitatief als kwalitatief opzicht meer personeel toe te staan (Jaarverslag WBO, 1984/1985, GS Provincie Limburg). De beperktheid van middelen maakte volgens het provinciale bestuur een herziening op het normenstelsel voor de personele voorzieningen (voorheen het Twijnstra en Gudde systeem, 1978) noodzakelijk. Met name in de verzorgende sector is er een grote discrepantie tussen het berekende en het feiltelijke aantal formatieplaatsen. In 1985 bestonden er nog intenties om landelijk een nieuw formatiemodel te ontwikkelen, maar toen in 1986 bleek dat dat niet zou gebeuren, besloot de provincie een eigen Normeringssysteem voor Personele voorzieningen in Verzorgingstehuizen (NPV) te ontwikkelen dat in 1987 zou worden ingevoerd (Jaarverslag WBO, 1986). De feitelijke invoering is uiteindelijk uitgesteld tot 1 januari 1991. Wel wordt sinds oktober 1988 het registratie-gedeelte door de bejaardenoorden ingevuld.

Het voorgaande totaaloverzicht van de personeelsformatie laat onverlet dat er tussen de instellingen belangrijke verschillen kunnen bestaan. In 1988 varieert de personeelsratio van 33,8 tot 5. 5 per 100 bewoners. Indien de verzorgingscapaciteit wordt uitgezet tegen de personeelsformatie, blijkt echter toch sprake te zijn van een vrij sterk lineair verband met slechts enkele uitschieters (zie figuur 9.4 voor de absolute personeelsomvang en de relatieve omvang per 100 bewoners). Als vuistregel voor de benadering van de formatie bij een gege- 


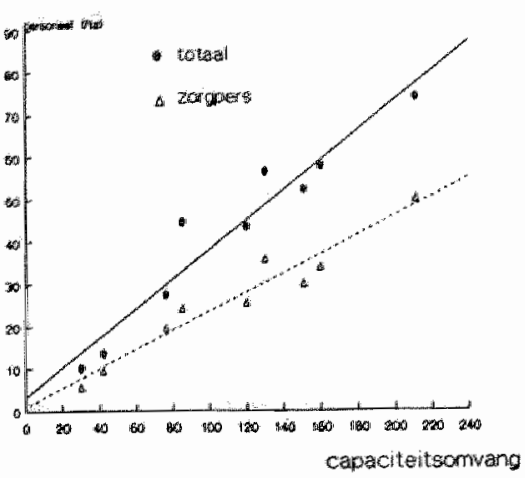

pensoned isfomatic in absolute omrang

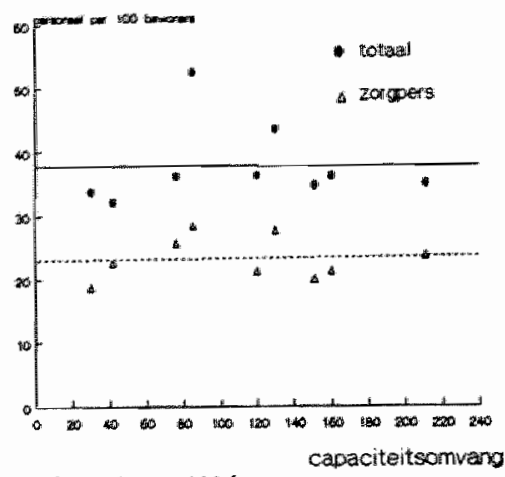

formatie per 100 bewones

\section{Figuur 9.4. Personeelsformatie naar grootte wan de instelling (algemene bejaardenoorden)}

ven capaciteit (in absolute aantal plaatsen) kan worden uitgegaan van de volgende formule

$$
\text { totale formatie }=0,348 *[\text { capaciteit }]+3,317 \quad\left(\bar{R}^{2}=0,963\right)
$$

Bij een dergelijke lineaire formule is er geen reden om te veronderstellen dat het mogelijk is een bepaalde optimale onvang voor het bejaardenoord te vinden waarbij de meest gunstige verhouding tussen personeel en verzorgden bereikt wordt: als beste benadering geldt een constante ratio van 24 directe en 15 indirecte personeelsleden per 100 bewoners (algemene oorden). De zogenaamde 'schaalvoordelen' zijn wel alangetroffen in onderzoek maar de kostenstructuur van bejaardenoorden in Nederland (Goudriaan e.a., 1989) en wijzen op een optimale capaciteil van circa 130 plaatsen per oord.

\subsubsection{Kosten en financiering van de bejaardenoorden}

Eind januari 1990 gaf het Bureau Bejaardenbeleid van de provincie Limburg toestemming om voor het onderzokk gebruik te maken van de bij de provincie aanwezige jaarrekeningen van de Maastrichtse bejaardenoorden. Bij deze toestemming werd de uitdrukkelijke voorwaarcle gesteld dat alleen getotaliseerde of gemiddelde gegevens zouden worden gepresenteerd, zodat afzonderlijke instellingen niet als zodanig herkenbaar zijn. In deze paragraaf wordt een overzicht gegeven van de gemiddelde en totale kosten van de algemene bejaardenoorden in de periode 1985-1988. Daarbij dienden er door onvolledigheid van gegevens enkele veronderstellingen gemaakt te worden. De reden daarvoor is het feit dat na het indienen van een door de accountant gecontroleerde jaarrekening in sommige gevallen door de provincie een correctie wordt toegepast als een kostenpost niet conform haar prijsregellen gecalculeerd werd (bijvoorbeeld een afwijkende afschrijvingstermijn); deze correcties waren niet altijd te traceren, maar leiden tot een wel altijd bekende subsidiebeschikking waarin steeds het totale goedgekeurde exploitatiebudget, de eigen bijdragen van bewoners en de uiteindelijke provinciale subsidie voor dat jaar vermeld zijn. As het totaal van subsidie en retributie niet gelijk was aan het goedgekeurde budget, dan is verondersteld dat het eventuele restant steeds verrekeningen met voorgaande jaren en oorspronkelijke subsidies betreft. Met name in 1985 en 1986 waren deze verrekeningen van belang, omdat er lange tijd onduidelijkheid bestond over de precieze omvang van de eigen bijdragen. Deze 
bleken ook lager uit te vallen dan door het Ministerie wan WVC geraamd was. Limburg besioot de lagere opbrengsten uit eigen bijuragen (in 1985 circa 4,5 op een totaalraning van 97,8 mitjoen) te compenseren door werhoging van de provinciale subsidie (die in 1985 circa 124 miljoen en in 1988 circa 129 miljoen bedroeg), waarwoor zij echter weer een eenmalige compensatie-uitkering van het Ministerie ontving. De problemen bij de nieuwe prowinciale financieringswijze werden verder gecompliceerd door kortingen op de dotatie aan onderhoudsfonds (naar $50 \%$ ) en op de variabele lasten in 1984 en een exploitatiekorting van $4 \%$ in 1985 . In 1986 en 1987 zijn geen budgettaire maatregelen genomen. In 1988 is de onderhoudsdotatie weer verhoogd tot $75 \%$ en $\mathrm{kreeg}$ het personeel een eenmalige extra uitkering. In twee gevallen moest worden uitgegaan van de aanvaarde begrotingen in plaats van de jaarrekeningen (een oord voor 1984 en een oord voor 1987 en 1988).

Om te voldoen aan de gestelde voorwaarde over de presentatie van gegevens, wordt een overzicht gegeven van de opbouw en samenstelling van de gemiddelde kosten per verzorgingsdag. Ook hiervoor moest een veronderstelling gemaakt worden. Er is zoveel mogelijk uitgegaan van feilelijk 'geproduceerde' verzorgingsdagen, maar indien deze niet bekend zijn worden zij benaderd door de capaciteit (tabel 9.5) te vermenigvuldigen met het aantal dagen in een jaar. De jaarrekeningen zijn geschoond voor de exploitatie van atanleunwoningen (bij drie oorden). Ook moet worden vermeld dat bestedingen in het kader van het flankerend beleid in de jaren 1985-1987 niet goed zijn af te zonderen, hetgeen dan ook achterwege is gebleven. In 1988 werd het flankerend beleid voor het eerst via een functionele benadering van de totale dienstverlening door bejaardenoorden een gelntegreerd onderdeel van de begrotingen en was het mogelijk het flankerend beleid uit de jaarrekening voor de betreffende oorden (vijf stuks) af te zonderen. De provinciale subsidie voor Maastricht (op basis van vaste richtlijnen) was in $1988 f 67.660$ voor tijdelijke opname en $f$ 44.170 voor dagverzorging. Nachtopvang wordt in Maastricht sinds 1988 niet meer aangeboden. Maaltijdvoorziening en andere wijkfuncties die voorheen via het flankerend beleid eveneens door de provincie (mede) werden gefinancierd, vallen in 1988 voor het eerst onder de verantwoordelijkheid van gemeenten (welzijnswet). De provincie houdt haar bevoegdheden voor tijdelijke opname, nachtopvang en dagverzorging. Als overgangsmaatregel werden in 1988 de (extra) organisatiekosten van maaltijdvoorziening door de provincie gesubsidieerd (ruim $f 3.100$ in Maastricht). Op basis van vier van de vijf exploitatieoverzichten voor tijdeiijke opname bedragen de gemiddelde kosten (produktie 1820 dagen) $f 46,20$ per dag, waarvan $68 \%$ personeelslasten betreft. De eigen bijdrage is $f 6$ en de provincie subsidieert $f 30$ per dag. Het saldo diende ten laste van de reserves te komen. In 1990 is een nieuwe werordening opgesteld die dit probleem gedeeltelijk ondervangt met hogere subsidies.

Tabel 9.13. Gemiddelde kosten (in f) per verzorgingsdag in algemene bejaardenoorden

\begin{tabular}{|c|c|c|c|c|}
\hline & 19195 & 19816 & $1.8 \mathrm{a}$ & 1980 \\
\hline 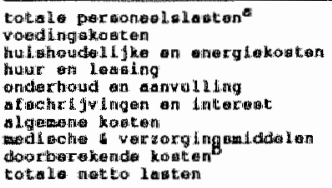 & $\begin{array}{r}6,35 \\
7,108 \\
0,180 \\
5,22 \\
2,184 \\
7,107 \\
2,182 \\
0,112 \\
=3,57 \\
77,33\end{array}$ & $\begin{array}{r}50,340 \\
7,21 \\
6,390 \\
5,340 \\
3,33 \\
7,39 \\
2,32 \\
0,12 \\
-2,77 \\
82,31\end{array}$ & $\begin{array}{r}50,22 \\
7,91 \\
7,92 \\
5,71 \\
3,98 \\
7,26 \\
3,1,25 \\
0,10 \\
-2,95 \\
01,64\end{array}$ & $\begin{array}{r}-1,20 \\
6,62 \\
7,11 \\
5,80 \\
2,515 \\
7,30 \\
3,14 \\
0,12 \\
-2,68 \\
01,61\end{array}$ \\
\hline 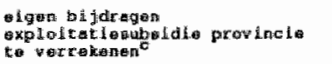 & $\begin{array}{r}32,90 \\
4,3,96 \\
1,07\end{array}$ & $\begin{array}{r}33,49 \\
47,59 \\
1,26\end{array}$ & $\begin{array}{l}30,27 \\
49,0,11 \\
-10,67\end{array}$ & $\begin{array}{r}32 \times 79 \\
19 \times 39 \\
0.47\end{array}$ \\
\hline
\end{tabular}


De netto lasten per dag bedragen gemiddeld $f 81,60$ (zie tabel 9.13). Het goedgekeurde budget voorziet in circa $f 82,80$. De verdeling van de netto lasten is in 1988 als volgt: $62,7 \%$ betreft personeelstaisten, $8,1 \%$ is voor voeding (met een gemiddelde prijs van $f 6,60$ per dag), de totale huisvesting (inclusief onderhoud, afschrijvingen en interest) vormt $28,4 \%$ van de dagprijs en $4 \%$ betreft algemene kosten (inclusief die van medische en verzorgingsmiddelen). Een deel $(3,3 \%)$ van de kosten wordt verrekend (0.a. met aanleunwoningen) of wordt gecompenseerd door de rijksbijdrage bejaardenhuisvesting van het ministerie van VROM of door opbrengsten uit "bedrijven" zoals een winkel in het tehuis. De eigen bijdragen dekken $40,2 \%$ van de gemiddelde netto lasten per verzorgingsdag in de lekenbejaardenoorden te Maastricht.

Financieel bestaan er grote verschillen tussen de oorden. Figuur 9.5 laat de minimale, gemiddelde en maximale kostprijzen per dag zien. Het laagste kostenniveau betreft steeds hetzelfde tehuis en het maximale tarief afwisselend twee dezelfden. In 1988 is de verdeling globaal als volgt: ến oord ligt iets onder $f 70$ per dag, drie instellingen hebben een dagprijs tussen $f 70$ en $f 80$, twee oorden liggen wlak bij het gemiddelde van $f 81,60$ en de rest tussen $f 90$ en $f 95$ per dag. De uitschieter in 1986 lijkt eenmalig.

De opbouw van de dagtarieven naar kostensoort laat eveneens belangrijke verschillen zien. Ter illustratie wordt een beknopt overzicht gegeven van de onderlinge variaties in de aandelen van de verschillende posten in de totale netto lasten per dag. Voor het merendeel van de instellingen ligt het aandeel van de personeelslasten tussen $59 \%$ en $63 \%$ (gemiddeid voor alle algemene oorden 62,7\%), maar er is én uitschieter naar boven (75\%). Bij de voedingskosten zijn de verschillen ook aanzienlijk: het aandeel in de totale lasten per dag varieert van $6 \%$ tot $14 \%$ (gemiddeld $8,1 \%$ ). De totale huisvestingskosten (inclusief afschrijvingen, interest en onderhoud) kennen een aandeel dat ligt tussen $14 \%$ en $39 \%$ (gemiddeld $28,4 \%$ ). Aan de financieringszijde bestaan eveneens grote variaties tussen de verschillende instellingen: het aandeel van de eigen bijdragen varieert tussen $32 \%$ en $56 \%$ (gemiddeld 40,2\%).

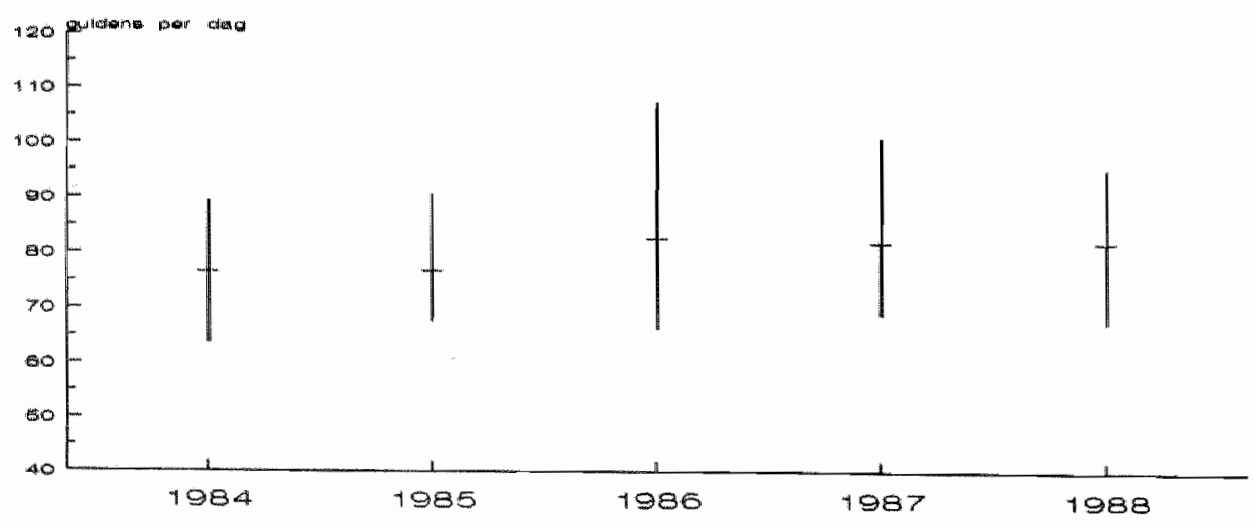

Figuur 9.5. Uiterste en gemiddelde dagtarieven per (algemeen) bejaardenoord in 19841988 


\subsection{Samenvatting van de belangrijkste bevindingen}

In dit hoofdstuk werd een globale schets gepresenteerd van de ontwikkelingen in de sector van bejaardenoorden in de gemeente Maastricht gedurende de afgelopen viff jaar. Deze schets dient als introductie op de analyse van de zorgbehoefte (op basis van individuele bewonersgegevens van alle tehuizen) in het volgende hoofdstuk. De totale capaciteit van algemene bejaardenoorden (negen instellingen) en bejaardenoorden met een bijzondere functie (een instelling voor blinde en slechtziende ouderen en drie kloosterbejaardenoorden) is bijna 1200 plaatsen.

Van de ingediende aanvragen voor opname in een bejaardenoord wordt jaarlijks circa driekwart goedgekeurd. Het strengere opnamebeleid heeft er sinds 1985 toe geleid dat de instroom in de bejaardenoorden (per jaar bijna $2 \%$ van alle 65 -plussers in de gemeente) gerealiseerd wordt bij een kortere wachtijd (toch nog acht à negen maanden) en alleen voor die ouderen plaats vindt die de hoogste urgentie hebben. Dit gezamenlijke opnamebeleid onder de coordinatie van de indicatie- tevens plaatsingscommissie heeft tevens tot gevolg gehad dat de verschillen in bewonerskenmerken tussen de Maastrichtse tehuizen haast niet meer bestaan (Frederiks en Te Wierik, 1988) en dat de aanvragers qua problematiek haast niet verschillen van de huidige gemiddelde bewoner, zodat in de toekomst de hulpbehoefte in de bejaardenoorden verder zal stijgen. In dit licht lijkt hechtere samenwerking tussen de bejaardenoorden onderling en met verpleeghuizen noodzakelijk, waarbij de start van het brede indicalie-systeem nieuwe stijl een nuttig instrument kan zijn. Verdere verscherping van opname-criteria als middel ter beteugeling van de benodigde capaciteit lijkt nog nauwelijks mogelijkheden te hebben, omdat nu al $95 \%$ van de alleenstaanden en $83 \%$ van de echtparen de hoogste urgentie ( 5 of 6 ) heeft. Per advies worden de kosten geraamd op $f 350$, (zie bijlage 3 ).

De gemiddelde leeftijd in de bejaardenoorden is thans ongeveer 83 jaar en stijgt zeer geleidelijk. Het aandeel van hoogbejaarden (85-plus) steeg van $38 \%$ in 1985 tot $41,5 \%$ in 1988. Van alle bewoners van gewone verzorgingstehuizen is ongeveer $75 \%$ vrouwelijk; dit aandeel neemt iets toe met de leeftijd ( $80 \%$ bij 90 -plus). Het bereik van alle bejaardenoorden tezamen komt in 1989 op 6,9\% van alle 65-plussers in Maastricht $(5,8 \%$ voor algemene oorden), ligt in alle leeftijdsgroepen voor vrouwen boven dat voor mannen en stijgt met de leeftijd wan $0,5 \%$ tot 70 jaar tot $27 \%$ bij 85 -plussers. De validiteitswerdeling, zoals die door het CBS wordt geregistreerd, vertoont in de periode 1985-1988 cen geleidelijke verslechtering.

De instroom in bejaardenoorden loopt de laatste twee jaar geleidelijk terug tot $20 \%$ in 1988 (en zelfs $17 \%$ in 1989; zie hoofdstuk 10), zodat eén van de beoogde effecten van het in 1985 ingevoerde opnamebeleid weer langzaam verdwijnt. De gemiddelde leeftijd bij opname is ongeveer 81 jaar en stijgt geleidelijk: in 1985 was $21 \%$ van de 'nieuwkomers' 85 jaar of ouder en in 1988 was dat $31 \%$. Verreweg het grootste deel $(87 \%)$ komt uit de thuissituatie, terwijl bijna driekwart in het verzorgingstehuis overlijdt, zodat dit woor veel ouderen de laatste woonomgeving is.

De gemiddelde kosten van de algemene bejaardenoorden in Maastricht bedragen ruim 81 gulden per dag, waarvan $63 \%$ personeelslasten (bij een intensiteit van 39,2 full-time plaatsen per 100 bewoners) betreft en $28 \%$ aan huisvesting (inclusief afschrijvingen, interest en dergelijke) wordt besteed. De eigen bijdragen van bewoners dekken gemiddeld $40 \%$ van de netto lasten. 


\section{Analyse van bewonerskenmerken in de Maastrichtse bejaardenoorden}

\subsection{Inleiding}

Het sinds medio 1988 voor algemene bejaardenoorden verplichte registratiesysteem voor individuele meerzorg van de provincie Limburg wordt in dit hoofdstuk gebruikt om inzicht te krijgen in de kenmerken van de bewoners van algemene en categorale Maastrichtse bejaardenoorden. Hoewel het meerzorgsysteem bedoeld is als middel voor de berekening. van personeelsformatie, kunnen de (individuele) gegevens zeer goed gebruikt worden om het inzicht in het bewonersbestand verder aan te scherpen. Hierdoor kunnen individuele veranderingen in de benodigde meerzorg naar functie gevolgd en geanalyseerd worden.

\subsection{Gebruikte onderzoeksinstrumenten en gegevensverzameling}

Naar aanleiding van het vooronderzoek dat in 1989 bij Molenhof werd uitgevoerd (Huijsman, 1989e), is in januari 1990 in alle Maastrichtse tehuizen een tweetal instrumenten gebruikt ter evaluatie wan de verzorgingsbehoefte en leefsituatie van de bewoners van de verzorgingstehuizen. Deze instrumenten, de Beoordelingsschaal voor Psychische en Sociale problemen (BPS) en het registratiesysteem van de individuele meerzorg dat ten grondslag lag aan het geplande, maar nimmer ingevoerde normeringssysteem personele voorzieningen van de provincie Limburg, worden in deze paragraaf beknopt besproken en toegelicht. De gegevens zijn in januari 1990 (in sommige gevallen uitlopend in februari) door de Maastrichtse tehuizen zelf verzameld en hebben betrekking op de toestand van bewoners rond de jaarwisseling. De feitelijke verzameling van gegevens wordt in paragraaf 10.2.3. toegelicht.

\subsubsection{Registratiesystemen voor meerzorg in bejaardenoorden}

In het oorspronkelijke formatiemodel van Twijnstra en Gudde (1978) worden onder basiszorg die verzorgende activiteiten verstaan die in gelijke mate aan nagenoeg alle, doch minimaal $80 \%$, van de bewoners ten goede komen. De standaardnorm voor basiszorg omvat het ronddelen van voedsel, dranken en medicijnen en het onderhouden van algemene sociale contacten en bedraagt in het oorspronkelijke model 6 minuten per dag per bewoner. De gewijzigde normen onderscheiden twee siluaties, een waarbij de bewoners zelfstandig en alleen eten ( 7 minuten) en eén waarin gezamenlijk gegeten wordt ( $16 \mathrm{~min}$.). De meerzorg omvat in het oorspronkelijke model $33 \mathrm{ADL}$-handelingen in 11 clusters. De personeelsformatie wordt berekend door sommering over bewoners van basis-, meer- en incidentele zorg, rekening houdend met onder andere werkoverleg en een omrekeningsfactor om van netto naar bruto formatieplaatsen te komen (1,2 a 2). Medio 1984 presenteerde Twijnstra en Gudde een aan psycho-sociale problematiek aangepaste versie van het formatiemodel, onder meer leidend tot uitbreiding van de algemene sociale contacten met ontspannende activiteiten al of niet onder speciale begeleiding van het personeel en met opname van enkele veelvuldig voorkomende verpleegkundige handelingen.

In 1988 ontwikkelde Gedeputeerde Staten van de Provincie Limburg ter vervanging van het systeem van Twijnstra en Gudde, dat in Limburg nooit is gehanteerd, een eigen normerings- 
systeem voor personele voorzieningen in bejaardenoorden. Het systeem, dat op experimentele basis sinds oktober 1988 door de bejaardenoorden in Limburg al met bewonersgegewens moet worden "gevoed", kent nog woorlopige tijdsnormen voor de ADL-handelingen. Overigens is de officiele imworing vertraggd tot 1 januari 1991 en zullen voor die tijd nog aanpassingen worden doorgevoerd. Qua systematiek is het Limburgse normeringsmodel gelijk aan dat van Twijnstra en Gudde. Het onderscheidt de sectoren verzorging, huishouding voedselvoorziening, algemeen beheer en overige (geestelijke) verzorging. Bij het bepalen van: de normen wordt rekening gehouden met de schaal van de instelling. De algemene basiszorg behoeft volgens de Limburgse methodiek 20,5 minuten per dag per bewoner en bestaat onder andere wit hulp bij baden en/of toilet maken, verzorgen van bed en opruimen van de kamer (11 min.) en sociale contacten. De individuele meerzorg gaat uit boven de algemene basiszorg en wordt geregistreerd met een periodieke peiling van een aantal in normtijden uitgedrukte zorghandelingen. Dat betreft hulp bij de volgende handelingen: eten/drinken, lopen/zitten/opstaan, aan-/uitkleden, incontinentie, behandeling/voorkoming van decubitus, extra aandacht en verpleegkundige handelingen. Voor leiding verzorging en huishouding wordt uitgegaan van 3,5 minuten per bewoner per dag $(0,013$ bruto formatieplaats per verzorgingsplaats). Activiteitenbegeleiding is afhankelijk van de grootte van de instelling en varieert van minimaal een halve tot maximaal én $\mathrm{kracht}$ per instelling. De overige sectoren, zoals voedselvoorziening, huishouding en beheer, kennen ook personeelsnormen, die gebaseerd zijn op het aantal verzorgingsplaatsen, wooneenheden of vierkante meters in het tehuis.

Omdat de registratie van individuele meerzorg volgens het Limburgse systeem gebruikt wordt in de beschrijuing en analyse van de Maastrichtse bejaardenoordbewoners, is het goed de handelingen die in de registratie zijn opgenomen nader te bezien. Bij onderstaande handelingen wordt per bewoner bekeken of zij het nog zelf kunnen, daarbij begeleiding nodig hebben of dat het helemaal voor de bewoner moet worden gedaan (zie ook bijlage 4):

- Hulp bij eten en/of drinken is onderverdeeld in een beetje hulp (brood smeren, vlees snijden, fruit schillen, tafel dekken), gedeeltelijke hulp bij het nuttigen wan de maaltijd en volledige hulp of continue toezicht bij het eten.

- Hulp bij lopen, zitten en/of opstaan vindt alleen binnen de instelling plaats. Hulp bij kleding onderscheidt enige hulp bij uitkleden, enige hulp bij aankleden en enige of volledige hulp bij aan- en uitkleden.

- Hulp of toezicht bij naar het toilet gaan kan regelmatig een beetje of volledig nodig zijn. In de hulp bij incontinentie is begrepen hel eventuele verzorgen van wasgoed of huidirritaties en het ledigen van de catheter.

- Decubitus kan in meer preventieve (voorkoming) of behandelende zin geregistreerd worden (wrijven met zalf is verpleegkundige handeling).

- Extra aandacht vindt plaats wegens factoren van psychische aard en zou - zij het op een enigszins onbeholpen en primitieve wijze - rekening kunnen houden met de psychosociale problematiek van individuele bewoners. De intensiteit van deze extra aandacht wordt mede bepaald door het gedrag van de bewoner. Veel extra aandacht vindt gedurende meerdere malen per dag, ongeacht de plaats in het tehuis, plaats.

Tenslotte wordt een aantal verpleegkundige handelingen genoemd die de bewoner niet meer zelfstandig kan doen. Hier (als enige plaats in het systeem) bestaat de mogelijkheid. om afwijkende verrichtingen die niet in de lijst van verpleegkundige handelingen zijn
opgenomen, in te vullen. 
De Beoordelingsschaal voor Psychische en Sociale problemen (Van Loveren-Huyben ea., 1988a) zou specifiek geschikt zijn voor het meten van de ernst van psycho-sociale problemen in verzorgingstehuizen. Uitgangspunt woor de BPS is de Nederlandse bewerking van de PAMIE (Physical And Mental Impairment of function Evaluation; Gurel e.a., 1972; Van Eekelen, 1978, 1981) geweest, waaruit de items voor cognitie, stemming en sociaal contact genomen zjn, aangevuld met items uit de Becordelingsschaal voor Oudere Patienten (BOP; Van der Kam e.a., 1971). Daarnaast zijn items toegevoegd die betrekking hebben op meer specifieke aspecten van het sociaal gedrag van bewoners van verzorgingshuizen en op agressief gedrag. Ook zijn de functies 'boren, zien en spreken' opgenomen. Het resultaat is een beoordelingsschaal die bestaat uit subschalen met in totaal 36 items (alle met 5 antwoordmogelijkheden; zie ook bijlage 5):

1. cognitie $[0, . .44]$; deze subschaal bestaat uit 11 items, waaronder die met betrekking tot geheugen, orientatie, verwardheid, taalvaardigheid en begrip. Een hogere score duidt op problemen, die echter deets door de beoordelaar vanuit zijn eigen gezichtspunt overschat kunnen worden of deels tijdelijk kunnen zijn (bijv. door verlies van een partner). Een hoge score mag daarom niet zondermeer gelnterpreteerd worden in de zin van psychogeriatrische problemen of stoornissen (Van der Kam e.a., 1971, p. 40).

2. Stemming $[0, \ldots, 28]$; deze subschaal bestaat enerzijds uit items die aangeven in hoeverre een bewoner voor zichzelf opkomt en aandacht van personeel trekt, en geeft anderzjds een beeld van de emotionele problemen. Ook hier is voorzichtigheid geboden omdat een hoge score niet bij voorbaat een slecht teken is, maar kan dujden op positieve assertiviteit ( 7 items).

3. Sociaal gedrag $[0, . ., 20]$; deze derde subschaal geeft aan of iemand zich terugtrekt op de kamer of deelneemt aan het maatschappelijk verkeer (activiteiten) in bet tehuis ( 5 items).

De discussie in de handleiding (Van Loveren-Huyben e.a., 1988a) gaat vrijwel niet in op de resterende 13 items die niet in een van de drie subschalen zijn ondergebracht.

De BPS lijkt op grond van statistische analyses betrouwbaar (intern consistent) en stabiel in samenstelling en in de tijd te zijn. Interbeoordelaarsbetrouwbaarheid is (nog) niet getest en ook de predictieve validiteit van de BPS is nog onbekend. Vergeleken met de BOP lijkt de BPS beter te discrimineren en bovendien psycho-sociale problematiek aan te kunnen geven: $27 \%$ heeft in meer of mindere mate cognitieve problemen, $38 \%$ stemmingsproblemen en $58 \%$ sociale problemen. De beoordeling van cognitieve problemen door het personeel met behulp van de BPS blijkt nauw samen te hangen met het oordeel van een arts (Van Loweren-Huyben e.a., 1988a).

Er zijn nog enkele belangrijke kanttekeningen te plaatsen. Het personeel lijkt aanvankelijk nog sterk wit te gaan van een eigen mening zo niet yooroordeel over de betreffende bewoners, dat pas na enige tijd verdwenen is. Geconcludeerd wordt dat het personeel moet leren kijken naar het gedrag van de bewoners. Omdat voorts de samenhang met testpsychologisch onderzoek niet groot is, blifft een deel van de sociale en psychische problemen onopgemerkt door het personeel. Eerder werd een onderschatting van ongeveer $25 \%$ gevonden. De problematiek op het gebied van Algemeen Dagelijkse Levensverrichtingen bleek echter overschat te worden, waarschijnlijk omdat de ADL een expliciete rol speelde in de personeelsformatie (Van Loveren-Huyben e.a., 1985). Overigens blijkt hoogstens $25 \%$ a $40 \%$ van de variantie in psychische en sociale problematiek verklaard te kunnen worden door de ADL-invaliditeit. Ook het omgekeerde is het geval, hetgeen aanpassing op de traditionele formatie-modellen op basis van uitsluitend ADL-items (Twijnstra en Gudde, 1978; Provincie Limburg, 1988) noodzakelijk maakt (Van Loveren-Huyben e.a., 1988a, p. 38). Tot slot zijn eerste voorzichtige 'normen' voor de scoren op de schalen voor cognitie (20, maar 
begin bij 10), stemming (12) en sociaal contact (12) gepresenteerd, doch nog niet verder uitgewerkt (Van Loweren-Huyben e.a., 1988a, p. 54-59).

\subsubsection{Gegevensverzameling in Maastrichtse bejaardenoorden}

Allereerst dienden de kwartaallijsten wan het prowinciale meerzorgsysteem ingevuld te worden naar de toestand van 31 december 1989. Deze gegevens moesten voorts aangevuld worden met enkele demografische gegewens over de bewoners betreffende de geboortedatum, het geslacht, de burgerlijke staat, de intrede- of opnamedatum, het door de instelling gevoerde registratienummer of 'stamnummer' en een eventweel verblijf in een ziekenhuis, verpleeghuis of psychiatrische inrichting (waarbij men ingeschreven blijft in het bejaardenoord). De meerzorgformulieren zijn ten behoeve van het onderzoek op dusdanige wijze gecopieerd, dat de namen van bewoners vervallen. In plaats daarvan is door de onderzoeker het 'stamnummer' als identificatiesleutel gehanteerd, zodat meerzorg- en BPS-gegevens aan elkaar te koppelen zijn.

De categorale tehuizen hanteren een ander registratiesysteem dat maandelijks op nationale schaal gebruikt wordt voor alle oorden met een bijzondere functie, maar goed vertaalbaar is in het provinciale systeem: er hoefde slechts een selectie van betreffende meerzorghandelingen plaats te vinden uit een registratiesysteem dat daarnaast ook nog andere zaken bevat. De normtijd per handeling wijkt in het categorale systeem ook enigszins af en houdt apart rekening met avonddienst; in dit onderzoek wordt de normtijd uit het provinciale systeem aangehouden om wille van de onderlinge vergelijkbaarheid.

Tabel 10.1 geeft aan hoe de ontvangst van de beide formulieren per tehuis verliep, welke aantallen bewoners dit betreft en op welke datum de gegevens betrekking hebben.

\subsection{Individuele meerzorg in Maastrichtse bejaardenoorden}

In deze paragraaf gaan wij eerst in op de meer algemene kenmerken van de bewoners, zoals leeftijds- en geslachtsverdeling, de gemiddelde verblijfsduur en burgerlijke staat van de bewoners. Verwolgens wordt in de tweede subparagraaf ingegaan op de gemiddelde individuele meerzorg per bewoner en bespreken wij verschillen naar demografische kenmerken zoals leeftijd, sexe, burgerlijke staat en dergelijke.

Tabell 10.1. Gegevensverzameling bij Maastrichtse bejaardenoorden

\begin{tabular}{|c|c|c|c|c|c|c|}
\hline \multirow[b]{2}{*}{ Hngtell tho } & \multicolumn{3}{|c|}{ 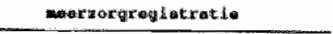 } & \multicolumn{3}{|c|}{ 幽s-1 l jotan } \\
\hline & abatal & dintiamin & contranget & antal & datevent" & ontryangiat \\
\hline 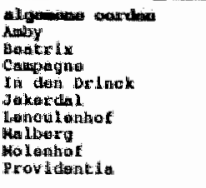 & $\begin{array}{r}119 \\
318 \\
145 \\
210 \\
82 \\
228 \\
127 \\
194 \\
76\end{array}$ & $\begin{array}{c}27 / 12 \\
32 / 12 \\
31 / 12-6 / 1 \\
31112 \\
30 / 12 \\
26 / 12 \\
10 / 41 \\
31 / 112 \\
22 / 12\end{array}$ & $\begin{array}{l}\$ / 1 \\
10 / 1 \\
10 / 2 \\
11 / 1 \\
0 / 1 \\
25 / 1 \\
10 / 1 \\
10 / 1 \\
7 / 2\end{array}$ & $\begin{array}{r}119 \\
39 \\
147 \\
20 \\
972 \\
127 \\
157 \\
190 \\
76\end{array}$ & $\begin{array}{c}31 / 12 \\
31 / 12 \\
0.1 \mathrm{nd}, j \mathrm{an} . \\
31 / 12 \\
31 / 12 \\
26-31 / 12 \\
14112-4 / 1 \\
31 / 12-4 / 1 \\
26-30 / 01\end{array}$ & $\begin{array}{r}9 / 2 \\
2 / 2 \\
14 / 2 \\
5 / 2 \\
22 / 1 \\
215 / 1 \\
0 / 2 \\
31 / 1 \\
\pi / 2\end{array}$ \\
\hline 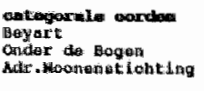 & $\begin{array}{l}10 \\
3.6\end{array}$ & $\begin{array}{l}10 / 1 \\
21 / 12 \\
\text { a.b. }\end{array}$ & $\begin{array}{l}17 / 2 \\
6 / 2 \\
7 / 2\end{array}$ & $\begin{array}{l}80 \\
80 \\
16\end{array}$ & $\begin{array}{c}10 / 1 \\
(j a n / 1) \\
23 / 1\end{array}$ & $\begin{array}{r}30 / 3 \\
6 / 2 \\
7 / 2\end{array}$ \\
\hline Tollean & 1123 & & & 1.120 & & \\
\hline
\end{tabular}

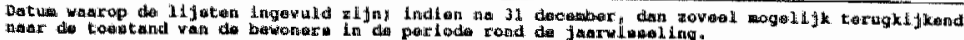




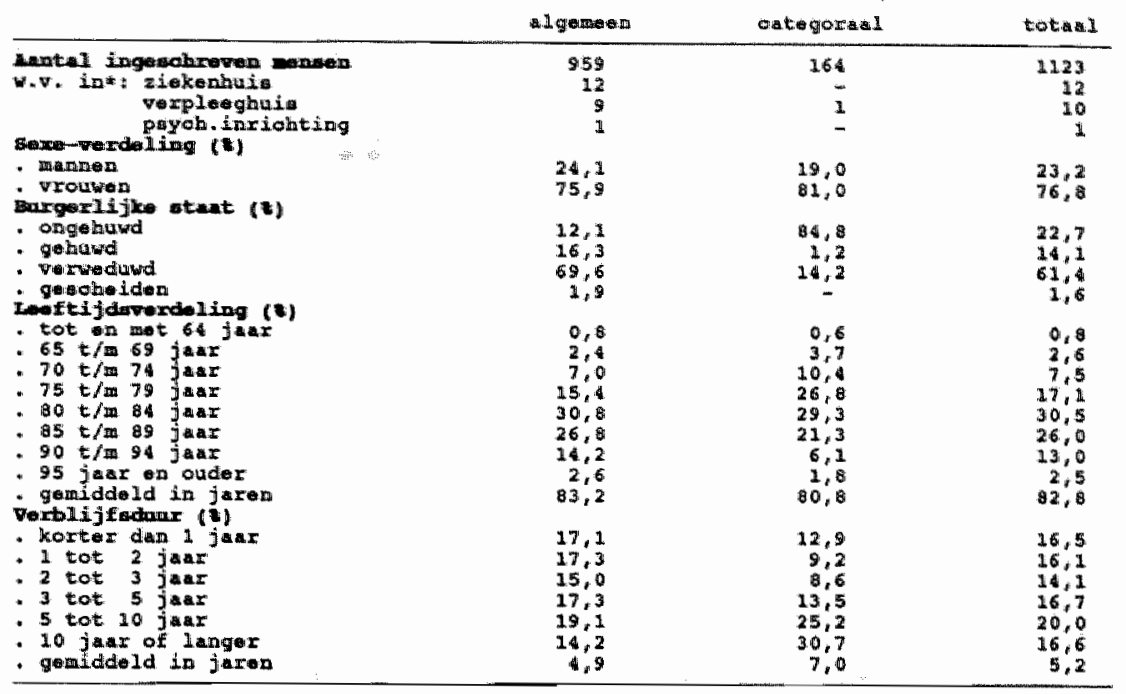

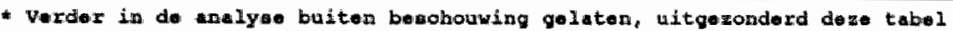

\subsubsection{Algemene bewonerskenmerken}

In tabel 10.2 zijn enige allgemene bewonerskenmerken bijeengebracht, waarbij naast het totaal aantal ook wordt aangegeven hoeveel bewoners op het moment van registratie elders verbleven, maar nog bij de betreffende instelling staan ingeschreven in de verwachting dat bet verblijf elders tijdelijk is. Deze worden verder niet in de analyses betrokken en betreffen 12 maal een ziekenhuisopname, 10 maal een verblijf in het verpleeghuis en een maal in een psychiatrische inrichting. Hierdoor is een van de twee registratie-instrumenten niet ingevuld, zodat de analyse in het vervolg van dit hoofdstuk betrekking zal hebben op 1100 personen.

Gemiddeld is in de algemene oorden $24,1 \%$ en in de categorale oorden $19 \%$ van de bewoners man. De verdeling naar burgerlijke staat laat duidelijk zien dat het aandeel van bewoners die verweduwd zijn in de algemene oorden groot is (70\%) en dat in categorate corden de meeste bewoners $(85 \%)$ ongehuwd zijn. De gemiddelde leeftijd ligt op bijna 83 jaar, maar is in bijzondere instellingen lager (bijna 81 jaar) dan elders (ruim 83 jaar). Het aandeel der zeer hoogbejaarden varieert per instelling en is met name in de categorale oorden laag ( $8 \%$ ). Gemiddeld is in de algemene corden bijna $17 \% 90$ jaar of ouder.

De werblijfsduur ligt gemiddeld op vijf jaar, maar is in de categorale tehuizen aanzienlijk hoger (gemiddeld zeven jaar). De nieuwe aanwas in 1989 bedraagt gemiddeld $17 \%$ in algemene en slechts $13 \%$ in de categorale oorden, waar bovendien ruim $30 \%$ al 10 jaar of langer aanwezig is.

De besproken bewonerskenmerken bangen onderling samen. Vooropgesteld moet worden dat de verdeling naar burgerlijke staat in de categorale tehuizen geheel afwijkt van die in gewone oorden: $84 \%$ van de 31 mannen en $85 \%$ van de 132 vrouwen in een van de drie categorale oorden is ongehuwd, terwijl men daar geen gescheiden en slechts twee gehuwde ouderen tegenkomt. In de algemene bejaardenoorden worden de volgende verdelingen aan- 
Tabell 10.3. Bewoners van algemene bejaardenoorden naar sexe, burgerlikke staat en (gemiddelde) lleefijd

\begin{tabular}{|c|c|c|c|c|c|c|c|c|c|}
\hline & \multirow{2}{*}{ 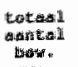 } & \multicolumn{7}{|c|}{ 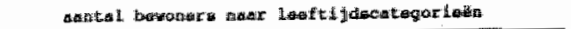 } & \multirow{2}{*}{$\begin{array}{l}\text { genth } \\
\text { teded } \\
\text { tifd }\end{array}$} \\
\hline & & 364 & $65-69$ & $701-74$ & $73-73$ & $20-9.4$ & $-5-89$ & 29ia & \\
\hline 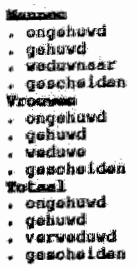 & 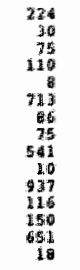 & $\begin{array}{l}4 \\
1 \\
1 \\
5 \\
5 \\
1 \\
1 \\
8 \\
5 \\
1 \\
2\end{array}$ & $\begin{array}{r}7 \\
7 \\
1 \\
1 \\
2 \\
14 \\
4 \\
1 \\
8 \\
1 \\
21 \\
7 \\
2 \\
9 \\
3\end{array}$ & 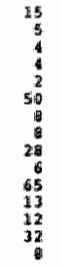 & $\begin{array}{r}42 \\
9 \\
17 \\
14 \\
2 \\
104 \\
4 \\
14 \\
75 \\
3 \\
143 \\
113 \\
31 \\
19 \\
15\end{array}$ & $\begin{array}{r}30 \\
7 \\
22 \\
1.4 \\
222 \\
23 \\
29 \\
170 \\
292 \\
30 \\
31 \\
241\end{array}$ & 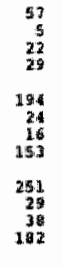 & $\begin{array}{r}31 \\
1 \\
3 \\
29 \\
7 \\
126 \\
43 \\
7 \\
106 \\
457 \\
14 \\
15 \\
176 \\
2\end{array}$ & 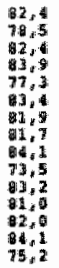 \\
\hline
\end{tabular}

getroffen (zie tabel 10.3). De leeftijd van vrouwen is gemiddeld 1 jaar hoger dan die van mannen en vertoont tevens verband met de burgerlijke staat: weduwen zijn het oudste ( 84 jaar) en gescheiden vrouwen het jongste (73,5 jaar). Hoewel vrouwen gemiddeld genomen ouder zijn dan mannen, is dit in de onderscheiden groepen toch zeer verschillend en zijn gehuwde mannen gemiddeld ouder en zijn met name gescheiden mannen aanzienlijk ouder (gemiddeld ruim 77 jaar) dan vrouwen in dezelfde situatie (gemiddeld 73,5 jaar), waarbij opgemerkt moet worden dat dit slechts kleine aantallen betreft.

Een deel van de leeftijdsverschillen, die per peildatum gemeten zijn, kan verklaard worden uit verschillen in verbliffscuur voor de onderscheiden groepen, omdat deze een enigszins ander verband met sexe en burgerlijke staat vertoont. De verblijfsduur is voor mannen lager $(4,3$ jaar $)$ dan voor vrouwen $(5,1)$ jaar. Dit verschil wordt in alle groepen van burgerlijke staat aangetroffen, maar is het grootst bij ongehuwden (mannen 5,1 en vrouwen 6,0 jaar) en gehuwden (man 3,0 en vrouw 3,6 jaar). Bij gescheiden bewoners treedt een afwijkend patroon op (man 5,3 en vrouw 2,4 jaar). De langste verblijfsduur wordt gevonden bij ongehuwde vrouwen ( 6 jaar) en de kortste bij gescheiden vrouwen $(2,4$ jaar), gevolgd door gehuwde mannen ( 3 jaar).

De instroomleeftijd kan ontleend worden aan de gegevens over de mensen die in $1989 \mathrm{zjjn}$ opgenomen ( $N=160$ in de algemene oorden en $N=21$ in de categorale oorden). De gegevens woor algemene oorden laten de volgende gemiddelde leeftijd zien:" de leeftijd bij opname is voor mannen ongeveer een half jaar lager $(80,8$ jaar) dan voor vrouwen $(81,4$ jaar) en het laagst bij gescheiden ouderen ( 75 jaar, uitsluitend vrouwen), gevolgd door de gehuwden ( 79 jara). Bij ongehuwden (voor $56 \%$ mannen) is de leeftijd voor mannen wederom lager (ruim 2 jaar) dan voor vrouwen. Verweduwde ouderen (17\% mannen) hebben bij opname de hoogste leeftijd (mannen 83,4 jaar en vrouwen 82,4 jaar). De geniddelde leeftijd bill opname in een bejaardenoord in 1989 bedroeg 81,25 jaar.

\subsubsection{Totalle en gemiddelde meerzorg}

In tabel 10.4 worden uit de registratie van individuele meerzorg de totalen en gemiddelden per bewoner gepresenteerd, zoals die gemeten zijn rond de jaarwisseling 1989/1990, onderscheiden naar" zorgfunctie en type instelling (algemeen of categoraal). Bijlage 4 geeft de ruwe telling voor het aantal bewoners per categorie. De totale meerzorg bedraagt ruim 53.000 minuten per dag, of ongeveer 48,4 minuten per bewoner. De zorgintensiteit ligt in de algemene bejaardenoorden ongeveer $70 \%$ boven die in de categorale oorden. Deze ver- 
Tabel 10.4. Individuele meerzorg in Mastrichtse bejaardenoorden: totalen en gemiddelden per persoon

\begin{tabular}{|c|c|c|c|c|c|c|}
\hline \multirow[b]{2}{*}{ 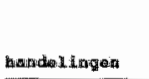 } & \multicolumn{2}{|c|}{ Algemana adran } & \multicolumn{2}{|c|}{ costegoralo: 0ordes } & \multicolumn{2}{|c|}{ 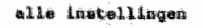 } \\
\hline & $\begin{array}{l}\text { potale } \\
\text { aryangl }\end{array}$ & (1) & $\begin{array}{l}\text { totale } \\
\text { ons and }\end{array}$ & 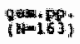 & $\begin{array}{l}\text { totals } \\
\text { tonang }\end{array}$ & 120 \\
\hline 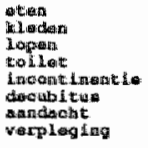 & $\begin{array}{r}1185,0 \\
3607,5 \\
4169,0 \\
445,0 \\
6317,5 \\
390,0 \\
9456,0 \\
459,0\end{array}$ & $\begin{array}{r}12,65 \\
3,85 \\
4: 45 \\
4,75 \\
6,74 \\
4,15 \\
10,05 \\
4,91\end{array}$ & $\begin{array}{l}020,0 \\
482,5 \\
714,0 \\
719,0 \\
563,0 \\
390,0 \\
704,0 \\
5.53,5\end{array}$ & $\begin{array}{l}5,01 \\
2,96 \\
4,38 \\
4,41 \\
3,45 \\
2,39 \\
4,32 \\
3,40\end{array}$ & 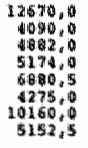 & 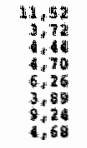 \\
\hline 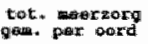 & $\begin{array}{l}48338,4 \\
5370,9\end{array}$ & $5.1,59$ & $\begin{array}{l}1946,0 \\
1540,7\end{array}$ & 30,34 & $\begin{array}{l}5324,0 \\
440,3\end{array}$ & 40.n \\
\hline
\end{tabular}

schillen tussen typen tehuizen zijn zo groot, dat zij in het vervolg afzonderlijk beschouwd worden (in paragraaf 10.5 worden verschillen tussen alle 12 bejaardenoorden besproken).

Het is van belang onderscheid aan te brengen tussen het aantal handelingen dat niet meer of niet meer geheel zelfstandig door een bewoner kan worden verricht en de intensiteit van hulp daarbij. Dit verband is exponentieel: de gemiddelde meerzorg neemt relatief sterker toe dan het aantal handelingen, zodat de gemiddeld hulp per handeling oploopt. Meerzorg gaat dus niet alleen een steeds breder pakket omvatten, maar wordt ook steeds intensiever. Er bestaat voorts een zekere hierarchie. Naarmate het meerzorgpakket omvangrijker wordt, gaan daartoe de volgende verrichtingen behoren (zie tabel 10.5): kleden, eten, lopen, incontinentie, toiletgang en tenslotte decubitus (dezelfde volgorde als op registratie-formulier).

In deze analyse is niets gezegd over de extra aandacht, omdat deze zich ten opzichte wan het hiervoor gesignaleerde hierarchische patroon enigszins afwijkend gedraagt en dwars door andere handelingen voor problemen kan zorgen. Extra aandacht is dus van een enigszins andere orde dan de overige items. Dit gaat, zij het in mindere mate, ook op voor de verpleegkundige handelingen.

\subsubsection{Verschillen in meerzorg naar sexe, leeftijd en burgerlijke staat}

In tabel 10.6. is aangegeven welke verschillen er bestaan in de gemiddelde zorgintensiteit tussen mannen en vrouwen. Als nfet gecorrigeerd wordt voor mogelijke leeftijdsinvloeden,

Tabel 10.5. Bewoners naar aantal en soort handelingen, waarbij zil hulp krijgem*

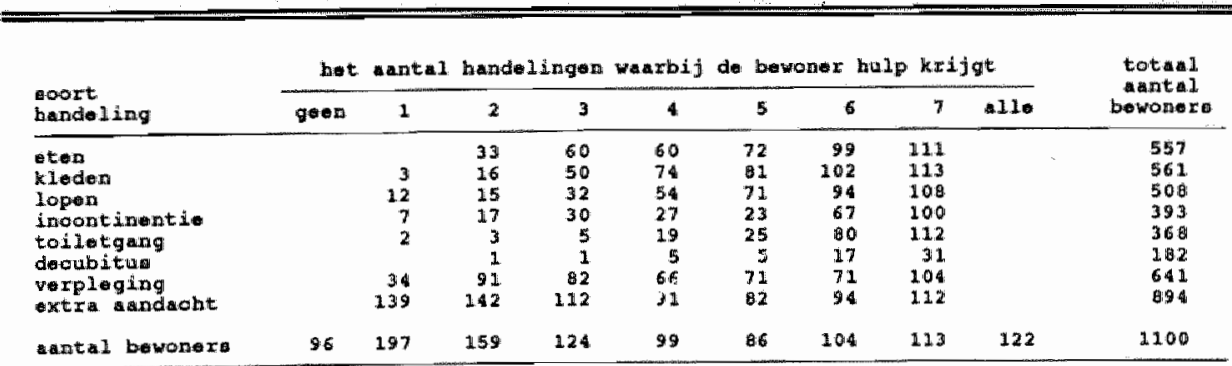

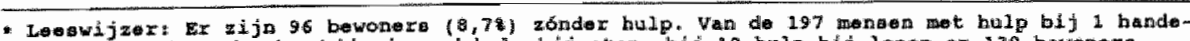

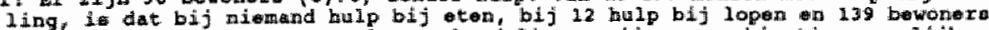

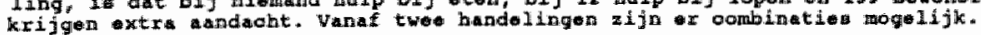


Tabel 10.6. Gescoorde ninuten meerzorg: gemiddelden naar geslacht

\begin{tabular}{|c|c|c|c|c|c|c|}
\hline & \multicolumn{2}{|c|}{ 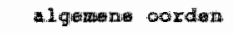 } & \multicolumn{2}{|c|}{ etegorale oorden } & \multicolumn{2}{|c|}{ al ingtel1ngan } \\
\hline 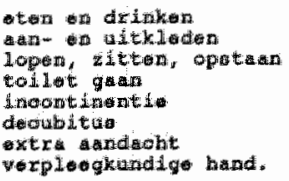 & $\begin{array}{r}12,14 \\
3,43 \\
3,73 \\
4,48 \\
5,23 \\
3,15 \\
5,76 \\
5,02\end{array}$ & $\begin{array}{r}12,62 \\
3,98 \\
4,67 \\
4,64 \\
6,30 \\
4,46 \\
10,20 \\
4,18\end{array}$ & $\begin{array}{l}5,48 \\
3,29 \\
3,29 \\
2,27 \\
3,85 \\
0,40 \\
2,81 \\
4,06\end{array}$ & $\begin{array}{l}4,92 \\
2,90 \\
4,64 \\
4,91 \\
3,36 \\
2,84 \\
4,67 \\
3,24\end{array}$ & $\begin{array}{r}11,33 \\
3,40 \\
3,68 \\
, 22 \\
5,94 \\
2,82 \\
9,91 \\
4,89\end{array}$ & $\begin{array}{r}13,57 \\
3,91 \\
4,57 \\
4,05 \\
6,35 \\
4,21 \\
9,33 \\
4,62\end{array}$ \\
\hline 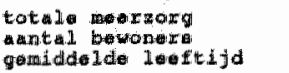 & $\begin{array}{l}47,93 \\
22,4 \\
82,4\end{array}$ & $\begin{array}{l}512.74 \\
713 \\
83.4\end{array}$ & $\begin{array}{l}25,40 \\
31 \\
78,4\end{array}$ & $\begin{array}{l}3 x, 4 \\
132,4 \\
814\end{array}$ & $\begin{array}{l}45,20 \\
255 \\
82,0\end{array}$ & $\begin{array}{l}49,42 \\
845,1 \\
83,1\end{array}$ \\
\hline
\end{tabular}

dan is geén wan de in de tabel weergegeven verschillen in gemiddelde meerzorg tussen mannen en vrouwen significant. Het is twijfelachtig of dit zou veranderen als wel rekening wordt gehouden met eventuele leeftijdsverschillen. Mannen hebben alleen bij verpleging gemiddeld meer hulp nodig. De gemiddelde meerzorg is in categorale oorden weliswaar voor vrouwen relatief nog hoger dan voor mannen ( $24 \%$ versus $10 \%$ verschil bij algemene oorden), maar de variaties per handeling zijn veel groter, zodat mannen bijvoorbeeld niet alleen bij verpleegkundige handelingen (zoals ook in de algemene oorden), maar ook bij eten/drinken, aan/witkleden en incontinentie hoger scoren.

Het zorgpatroon vertoont naar leeftijd een interessant verloop (tabel 10.7), dat te kenschetsen is als een 'dalparabool': vanaf de allerjongste bewoners tot in de categorie 70 74 jaar daalt de gemiddelde individuele meerzorg, om daarna te stijgen naarmate men ouder is, zodat de hoogste score gevonden wordt bij bewoners van 90 jaar en ouder. Het kan ook anders gezegd worden: jong-bejaarden worden alleen opgenomen als er sprake is van een grote zorgbehoefte of als de partner zeer hulpbehoevend is; verder geldt als algemene beeld dat naarmate de leeftijd stijgt, de zorgintensiteit over de gehele linie toeneemt. Dit leeftijdspatroon ('dalparabool') komt ook voor indien naar de afzonder lijke items van individuele meerzorg gekeken wordt.

Naar burgerlijke staat (tabel 10.7) is woor de twee typen oorden bezien hoe groot de gemiddelde meerzorg is bij de verschillende categorieen, waarbij het belangrijk is bij de burgerlijke staat ook het geslacht steeds te betrekken. Daardoor wordt duidelijk dat de echtparen vaak

Tabel 10.7. Gemiddelde totalle meerzorg naar leeftijd, burgerlijke staat en geslacht

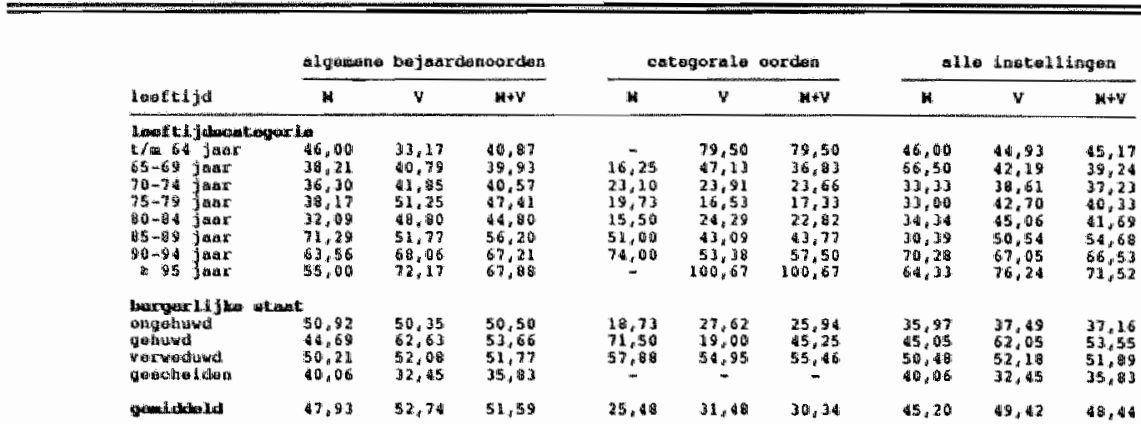


Tabel 10.8. Gemiddelde meerzorg per bewouer naar werbllfsduur

\begin{tabular}{|c|c|c|c|c|}
\hline \multicolumn{2}{|c|}{ 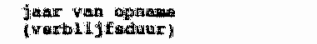 } & 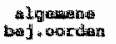 & 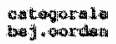 & 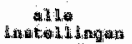 \\
\hline 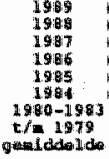 & 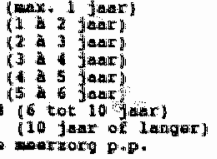 & 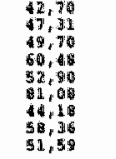 & 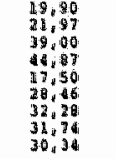 & 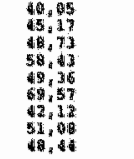 \\
\hline
\end{tabular}

worden opgenomen omdat het met de vrouw niet goed gaat; de gemiddelde meerzorg is bij gehuwde vrouwen $40 \%$ hoger dan bij gehuwde mannen, bij wie de zorgintensiteit tol een van de laagste behoort. Gescheiden bewoners hebben echter de minste meerzorg; bij hen speelden waarschijnlijk andere opname-redenen (bijvoorbeeld eenzaambeid; wordt besproken bij de BPS-analyse).

Tot slot bekijken wij de invloed van de verblijfsduur op de individuele meerzorg. In dit verband is interessant of de nieuwe bewoners (korter dan 1 jaar opgenomen) en langdurig aanwezige bewoners een afwijkende zorgintensiteit hebben ten opzichte van de andere bewoners. In tabel 10.8 is het verloop van de gemiddelde meerzorg naar verblijfsduur in beeld gebracht. Het beeld is niet geheel eenduidig* de zorgbehoefte stijgt met de verblijlsduur zolang deze lager is dan 4 jaar en bereikt dan een niveau van ongeveer een uur meerzorg per dag. Rond de gemiddelde verblijfsduur van 4 tot 6 jaar treedt dan een breuk op. Bij zeer langdurige bewoners (verblijfsduur groter dan 10 jaar) stijgt de gemiddelde meerzorg echter weer.

Een mogelijkheid om de gezamenlijke invloed van de hiervoor besproken factoren zoals sexe, leeftijd, burgerlijke staat en verblijfsduur te analyseren, betreft de zogenaamde multiple regressie waarbij rekening kan worden gehouden met de onderlinge samenhang tussen deze factoren. Omdat echter een goede theorie ontbreekt kan deze analysemethode slechts beperkte geldigheid gegeven worden (er worden immers geen hypothesen getoetst). Regressie kan (maar dan tentatief), goed gebruikt worden om de sterkte van mogelijke effecten nader te onderzoeken. In tabel 10.9 is dat gedaan voor de verschillende handelingen, waarbij alle variabelen gelijktijdig en gedwongen zijn opgenomen in de vergelijking. Het resultaat is over het algemeen niet goed. De verklaarde variantie is gemiddeld $47 \%$, maar vaak aanzienlijk lager (met name bij decubitus). Als de variabelen vrij kunnen worden

Tabel 10.9. Regressie gezamenlijke invloed van leeftijd, sexe, burgerlijke staat en verbliffisduur op de omvang wan meerzorg*

\begin{tabular}{|c|c|c|c|c|c|c|c|c|c|}
\hline \multirow{2}{*}{ 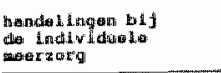 } & \multicolumn{2}{|c|}{$\operatorname{Hac} \mathbb{E} t \mathbf{j} d$} & \multicolumn{2}{|c|}{ gga:a linethat" } & \multicolumn{2}{|c|}{ burg. ataat } & \multicolumn{2}{|c|}{ verbLLfludaurer } & \multirow[b]{2}{*}{$\mathrm{R}^{2}$} \\
\hline & Heta & 4 & Eotsta & $\mathbf{t}$ & $\cos x$ & 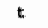 & Betiar & $k$ & \\
\hline 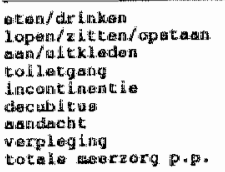 & $\begin{array}{l}0,55 \\
0,42 \\
0,57 \\
0,545 \\
0,5,55 \\
0,22 \\
0,45 \\
0,53 \\
0,57\end{array}$ & $\begin{array}{l}4,6 \\
3,6 \\
5,4 \\
4,3 \\
4,2 \\
1,6 \\
4,7 \\
4,5 \\
5,14\end{array}$ & $\begin{array}{r}-0,10 \\
0,13 \\
0,00 \\
0,01 \\
-0,12 \\
0,00 \\
-0,01 \\
-0,09 \\
=0,03\end{array}$ & $\begin{array}{l}1,0 \\
1,7 \\
0,0 \\
0,1 \\
1,1 \\
0,5 \\
0,0 \\
0,0 \\
0,4\end{array}$ & $\begin{array}{r}0,16 \\
0,03 \\
0,09 \\
0,02 \\
0,13 \\
0,02 \\
0,3,3 \\
0,16 \\
0,15\end{array}$ & $\begin{array}{l}2,1 \\
0,4 \\
1,3 \\
0,3 \\
1,7 \\
0,2 \\
5,6 \\
2,3 \\
2,2\end{array}$ & $\begin{array}{r}0,00 \\
0,07 \\
0,02 \\
0,02 \\
-0,00 \\
0,05 \\
0,02 \\
0,04 \\
0,02\end{array}$ & $\begin{array}{l}0,0 \\
2,0 \\
0,5 \\
0,0 \\
1,2 \\
0,2 \\
0,2 \\
0,0 \\
0,0 \\
0,0\end{array}$ & 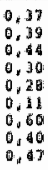 \\
\hline
\end{tabular}


gekozen, is leefijd de enige die (wolgens een aantal criteria) wordt geselecteerd. Alleen bij decubitus is het leeftidseffect niet significant. Geen van de sexe-verschillen is significant. De invloed wan burgerlijke staat op de meerzorg is significant en is toe te wijzen aan een beperkt aantal handelingen, namelijk eten/drinken (verweduwden $23 \%$ hoger dan de rest), extra aandacht (verweduwden $30 \%$ meer) en verpleging (gehuwden $22 \%$ meer dan anderen). Verweduwden scoren bovendien significant hoger dan anderen bij hulp bij aanen uitkleden en incontinentie. Tot slot heeft de verblijfsduur een positief, doch niet-significant effect op meerzorg. Alleen bij mobiliteit is sprake van een significant verblijfseffect ( $30 \%$ minder hulp dan al aanwexige bewoners). Frappant is het negatieve teken bij hulp bij incontinentie, een indicatie dat nieuwe bewoners hierop relatief veel beroep doen.

\subsection{Resultaten van de BPS-metingen in Maastrichtse bejaardenoorden}

De psycho-sociale problematiek in de bejaardenoorden staat de laatste jaren sterk in de belangstelling, zowel vanwege de gevolgen voor de individuele bewoners en het totale leefklimaat, als door de belasting die daarmee op het personeel van een instelling gelegd wordt. Algemeen leeft het idee dat de psycho-sociale problematiek onvoldoende onderkend wordt bij het bepalen van de benodigde personeelsformatie, hetgeen bijwoorbeeld aanleiding is geweesit om het Twijnstra en Gudde model bij te stellen en wellicht ook meespeelde toen de Maastrichtse instellingen hun goedkeuring aan het onderhavige onderzoek gaven. In het vooronderzoek bij Molenhof is getoond dat de Beoordelingsschaal voor Psychische en Sociale problemen in verzorgingstehuizen een goed instrument vormt ter bestudering van dit aspect van het menselijk functioneren. In deze paragraaf worden de resultaten besproken van de meting die rond de jaarwisseling 1989/1990 heeft plaatsgevonden in de 11 bejaardenoorden te Maastricht. Deze meting is verricht door hoofden verzorging en afdelingshoofden van de betreffende tehuizen, na instructie door het hoofd verzorging van Molenhof die reeds gewend was met dit instrument te werken. Bij de discussie aan bet eind van deze paragraaf zullen wij ingaan op de vraag of het zelf invullen door personeelsleden (hetgeen overigens de uitdrukkelijke bedoeling van het instrument is) gevolgen heeft gehad voor de betrouwbaarheid van de resultaten in dit onderzoek.

\subsubsection{Aanwezigheid van psycho-sociale problemen}

Gelijktijdig met de registratie van de individuele meerzorg aan het eind van het laatste kwartaal in 1990 heeft in alle bejaardenoorden te Maastricht een meting plaatsgevonden met behulp van de Beoordelingsschaal voor Psychische en Sociale problemen in verzorgings-

Tabel 10.10. Resultaten op de BPS-schalen in de algemene oorden $(N=937)$ en de categorale oorden $(\mathrm{N}=163)$

\begin{tabular}{|c|c|c|c|c|c|c|}
\hline & \multicolumn{2}{|c|}{ Dogeldelomeghan } & \multicolumn{2}{|c|}{ oteamiding onchwal } & \multicolumn{2}{|c|}{ eontmetructual } \\
\hline & $\begin{array}{l}\text { algameno } \\
\text { obinden. }\end{array}$ & $\begin{array}{l}\text { gis tegorale } \\
\text { gorden }\end{array}$ & $\begin{array}{l}\text { algemense } \\
\text { oprebant }\end{array}$ & $\begin{array}{l}\text { cateroralisi } \\
\text { torden. }\end{array}$ & $\begin{array}{l}\text { alvomone } \\
\text { otorthen }\end{array}$ & $\begin{array}{c}\text { caltegrorale } \\
\text { woridan }\end{array}$ \\
\hline 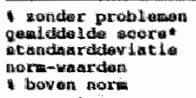 & $\begin{array}{l}21,9 \\
11,5 \\
12,8 \\
20.01 \\
21,1\end{array}$ & 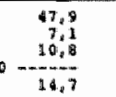 & 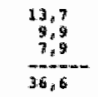 & $\begin{array}{r}29,4 \\
15,8 \\
7,3 \\
-19,6\end{array}$ & $\begin{array}{r}20,5 \\
9,50 \\
6,5 \\
-2,5,0\end{array}$ & $\begin{array}{r}8,5 \\
6,7 \\
6,0 \\
14,1\end{array}$ \\
\hline
\end{tabular}

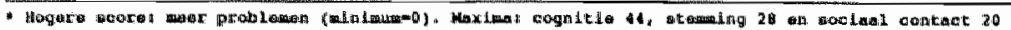


tebuizen (zie paragraaf 10.2 voor explicatie van BPS). De resultaten van de BPS-meting, die heeft plaatsgevonden bij 1120 bewoners waarvan er 1100 worden betrokken in de analyse (voor de resterende 20 zijn er geen registratiegegevens over de verstrekte individuele meerzorg omdat zij tijdelijk elders verblijven) staan vermeld in tabel 10.10. Daarbij is de uitsplitsing naar de drie subschalen aangehouden, zoals die door de oorspronkelijke auteurs (Van Loveren-Huyben e.a., 1988a) gebruikt worden. Dat betreffen de schalen voor cognitie, stemming en sociale contacten. De ruwe tellingen bij de 36 verschillende BPS-items zijn wermeld in bijlage 5 (afzonderlijk voor de leken-en andere bejaardenoorden).

Voorafgaande aan de analyses die inzicht in de psycho-sociale problematiek moeten verschaffen, is eerst bezien op het instrument zelf voldoende betrouwbaar is.

De oorspronkelijke BPS-schalen zijn door middel van factor-analyse op basis van de gegevens opnieuw beoordeeld op samenstelling en hun onderlinge samenhang. De drie schalen voor cognitie, stemming en contact worden inderdaad teruggevonden en werkJaren gezamenlijk $65,4 \%$ van de variantie tussen de bewoners. Ook de samenstelling van de subschalen wijkt in onze analyse niet veel af van de oorspronkelijke indeling: slechts én item valt in een andere schaal dan oorspronkelijk door Van Loveren-Huyben e.a. gevonden werd. Dat betreft het item 'negeert wat om hem/haar heen gebeurt', die nu in de contactschaal terecht komt. De betrouwbaarheid van de oorspronkelijke schalen is buitengewoon hoog en leidt tot betrouwbaarheidscoefficienten (Cronbach's alpha) die ver boven 0,8 liggen: bij cognitie is de coefficient 0,94 , bij stemming 0,90 en bij sociaal contact 0,87 .

De oorspronkelijke BPS-schalen komen wellicht in aanmerking voor een (bescheiden) revisie, die zich met name zou moeten richten op vier elementen (Huijsman, 1990): (a) herziening van de minst stabiele schaal voor stemming; (b) verschuiven van bet item over het negeren van de omgeving van de cognitie- naar de contactschaal (bleek ook in het corspronkeijike onderzoek een 'zwevend" item te zijn: Van Loveren-Huyben e.a., 1988a, p. 26); (c) het bezien van de mogelijkheid om schalen aan te vullen met belangrijke items (bijvoorbeeld de cognitieschaal met suffen overdag en 's nachts onrustig) en (d) tenslotte dient onderzocht te worden of daadwerkelijk sprake is van lineaire of additieve schalen (hetgeen voor een deel bereikt kan worden door de selectie van items, zoals hiervoor bleek bij de contactschaal). Ondanks deze mogelijke aanpassingen gaan wij in het vervolg uit van de oorspronkelijke schallen voor cognitie, stemming en contact.

Volgens de 'norm" (minimaal 20 punten) constateren wij dat in de acht algemene bejaardenoorden $24,1 \%$ en in de categorale oorden $14,7 \%$ van alle bewoners ernstige problemen heeft met het cognitief functioneren. Dit zijn personen waarvoor een indicatie lijkt te bestaan voor de aanwezigheid van psycho-sociale problematiek. Van LoverenHuyben e.a. wijzen in hun handleiding echter op de voorzichtigheid waarmee deze conclusie moet worden getrokken en raden aan al bij een cognitie-score groter dan 10 de situatie van de betreffende bewoner nader te bekijken, omdat eventueel actie van meer preventieve aard nodig kan zijn. Volgens dit minder zware selectie-criterium heeft $40 \%$ van de bewoners in de algemene oorden en $24,5 \%$ van de bewoners in de categorale tehuizen lichte tot ernstige problemen. De percentages voor de algemene bejaardenoorden komen overigens redelijk overeen met die uit het onderzoek van Te Wierik en Frederiks (1989). Zij vinden bij $40 \%$ van de onderzochte bewoners geheugenstoornissen (via de Abreviated Mental Test van Quereshi en Hodkinson, 1974) en bij $21 \%$ depressieve klachten (via de schaal van Zung, 1965). Bij de BPS-subschaal voor stemming blijkt het grootste percentage bewoners boven de betreffende norm (12) gevonden te worden: ruim eenderde $(36 \%)$ in de algemene corden en bijna eenvijfde $(19,6 \%)$ in de categorale oorden heeft ernstige stemmingsproblemen. In vergelijking met het onderzoek ten behoeve van de oorspronkelijke schaalconstructie lijkt dit een erg hoge uitkomst te zijn. Van Loveren-Huyben e.a. (1988b) vonden als hoogste percentage $13 \%$. Van Schijndel (1989) daarentegen vindt circa $20 \%$ (experiment Mirtehof). Voor sociaal contact wordt bij $28,3 \%$ en $14,1 \%$ van de bewoners van respec- 


\begin{tabular}{|c|c|c|c|c|c|c|}
\hline \multirow{4}{*}{ 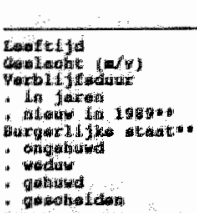 } & \multicolumn{2}{|c|}{$\log 1$ t 1 L } & \multicolumn{2}{|c|}{ Stennitids } & \multicolumn{2}{|l|}{ Conturet } \\
\hline & $\begin{array}{l}0,120 \\
0,012\end{array}$ & \{alla & $\begin{array}{l}0.014 \\
0.072\end{array}$ & (a) & $\begin{array}{r}0,142 \\
-0,022\end{array}$ & mand \\
\hline & $\begin{array}{l}-0,041 \\
-0,015\end{array}$ & 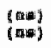 & $\begin{array}{r}0,05.2 \\
-0,1.66\end{array}$ & & $\begin{array}{r}0,028 \\
-0,034\end{array}$ & $\begin{array}{l}\text { (and } \\
\text { ras: }\end{array}$ \\
\hline & $\begin{array}{r}-0,1010 \\
0,117 \\
-0,016 \\
0,010\end{array}$ & 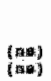 & $\begin{array}{r}-0,100 \\
0,100 \\
-0,010 \\
0,008\end{array}$ & (iAf) & $\begin{array}{r}-0.207 \\
0.101 \\
-0.692 \\
0.168\end{array}$ & (no) \\
\hline
\end{tabular}

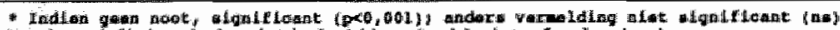

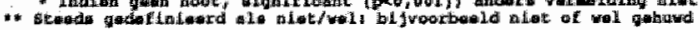

tievelijk de algemene en categorale corden ernstige problemen aangetroffen. Ook deze resultaten liggen boven die uit het authentieke onderzoek (varierend van $7 \%$ tot $17 \%$ ).

\subsubsection{Samenhang met bewonerskenmerken}

Om een indruk te krijgen van de samenhang tussen de scores op de BPS-schalen en de belangrijkste kenmerken van de bewoners, zoals leeftijd, geslacht, burgerlijke staat en verblijfsduur, is voor deze variabelen een correlatiematrix berekend (zie tabel 10.11). Er blijkt geen invloed uit te gaan van het geslacht van de bewoner op cognitic en sociaal contact, maar wel op stemming. Daar scoren mannen aanzienlijk beter (gemiddeld 8,4 punten) dan vrouwen (gemiddeld 9,7), waarbij in herinnering geroepen wordt dat een hogere score op meer problemen duidt; dit verschil is significant. Er bestaat een significante samenhang tussen de leeftijd en de scores op cognitie en social contact, maar niet op stemming. Van Loveren-Huyben e.a. (1988a, p. 38) melden hetzelfde resultaat. Over bet algemeen geldt dat naarmate een bewoner ouder is, hij of zij slechter functioneert, maar in de jongste leeftijdscategorieen bestaan enkele belangrijke uitzonderingen op deze regel (vooral bij 65-69 jaar). Het verband tussen verblijfsduur en het psycho-sociaal functioneren blijkt zeer gering te zijn en niet eenduidig: wij vinden een klein negatief effect (net niet significant) op het cognitief functioneren en een klein positief effect op stemming (wel significant), terwijl er geen significant effect is op sociaal contact. De nieuwkomers in 1989 scoren op alle schalen beter dan mensen die én jaar of langer aanwezig zijn, maar alleen op de stemmingsschaal is dat significant.

Het voorgaande betrof de correlaties voor alle tehuizen tezamen, maar op enkele punten bleek het belangrijk te zijn het onderscheid naar type instelling (algemene of categoraal) nog eens in aanmerking te nemen. Dit is niet van belang bij leeftijd en geslacht, maar wel bij burgerlijke staat. In de algemene bejaardenoorden zijn ongehuwden juist slechter af op de drie BPS-schalen en is dat verband bij sociaal contact zelfs significant. Bij gehuwden werden eerst niet-significante correlaties gevonden; bij de algemene oorden afzonderlijk worden deze verbanden bij cognitie $(-0,07)$ en contact $(-0,08)$ significant zodat gehuwden aanmerkelijk meer psycho-sociale problemen kennen dan de niet-gehuwden. Bij gescheiden bewoners treden geen veranderingen op als alleen naar de algemene bejaardenoorden gekeken wordt. De samenhang tussen verblijfsduur en sociaal contact wordt dan wel significant, maar voor de 'nieuwkomers' veranderen de correlaties niet. 
De samenhang tussen de drie BPS-schalen laat zich als volgt schetsen. Allereerst zijn de onderlinge correlaties hoog: contact en stemming hebben een correlatie van 0,65 en 0,40 met cognitie en onderling van 0,47 ( $P<0,001$ ), terwijl ook het overschrijden van "normen" sterk met ellkaar samenhangt, met name bij cognitie en sociaal contact $(0,46)$ en bij stemming en sociaal contact $(0,36)$. Overigens zijn de gevonden correlaties tussen de schalen geheel in overeenstemming met hetgeen Van Loveren-Huyben e.a. (1988a, p. 38) presenteren; dit geldt ook voor de samenhang tussen de drie BPS-schalen en de meerzorg- of ADL-schaal (zie vervolg). Uit deze congruentie van onze bevindingen met die van de oorspronkelijke auteurs kan wellicht geconcludeerd worden dat in het Maastrichtse onderzoek geen (onbedoelde) vertekening is ontstaan in de resultaten, dat wil zeggen dat de verschillende beoordelaars in de 11 tehuizen in voldoende mate de objectiviteit in acht hebben genomen bij het invullen van de vragenlijst.

Vervolgens is bekeken hoe vaak de 'normen' overschreden worden en in welke combinaties (zie tabel 10.12). De helft van de bewoners overschrijdt geen enkele norm $(50,7 \%)$; dit aandeel ligt in de gewone verzorgingstehuizen aanzienlijk lager $(47,7 \%)$ dan in de categorale tehuizen $(68,1 \%)$. Het overschrijden van slechts éen norm gebeurt door $5,3 \%$ van de bewoners bij cognitie, door $14,6 \%$ bij stemming en door $5,6 \%$ bij contact. Bij algemene oorden is dat $5,0 \%$ (cognitie), $15,6 \%$ (stemming) en $6,0 \%$ (contact).

Hieruit komt het opmerkelijke gegeven naar voren dat, gegeven de invalshoek van slechts. én overschreden norm, er in categorale oorden een grotere cognitieve problematiek bestaat dan bij de algemene oorden. Combinaties van normoverschrijdende waarden kennen de valgende frequenties (voor alle oorden en tussen haakjes apart voor algemene oorden): cognitie/stemming $2,7 \%(2,9 \%)$; cognitie/contact $4,3 \%(4,7 \%)$; stemming/contact $6,3 \%(6,6 \%)$ en alle subschalen tegelijkertijd nog eens $10,5 \%(11,5 \%)$. Bij dergelijke combinaties liggen de percentages voor de algemene oorden derhalve altijd boven die voor de categorale.

De voorgaande bespreking van correlaties tussen en combinaties van waarden op de diverse schalen laat een zekere rangorde zien in psycho-sociale problematiek. Allereerst is er een grote groep (ongeveer de helft) die in het geheel geen problemen kent en derhalve niet op gestelde criteria voor cognitie, stemming of sociaal contact overschrijdt. Als er psycho-sociale problemen optreden, dan betreft dat in eerste instantie stemmingsproblemen, waarbij wervolgens contactproblemen kunnen komen. Zodra er problemen op stemming en contact zijn, zal dat ook zeer snel bij cognitie het geval zjjn. Als er eenmaal psycho-sociale problemen zijn, dan is dat ook vrij snel op verschillende aspecten.

Tabel 10.12. Combinaties van normoverschrijding op de BPS-schalen (aantal bewoners)*

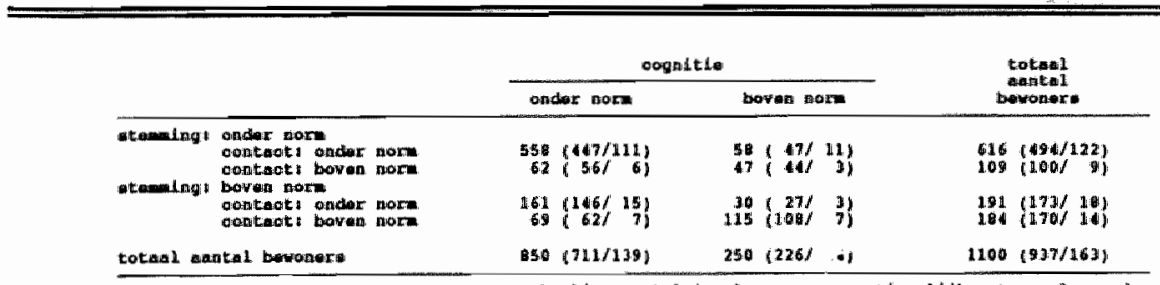

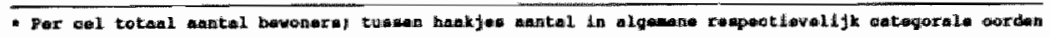


Interessant is vervolgens om te bezien of er samenhang bestaat tussen de scores uit het provinciale registratiesysteem voor individuele meerzorg en die uit de BPS-metingen. De eerste conclusie uit dit onderzoek naar de samenhang tussen BPS en meerzorg is gebaseerd op factor-analyse met de acht aftonderlijke meerzotg-items en de drie afzonderlijke BPSschalen. Dit levert twee factoren op met in de ene factor alle meerzorg-items zónder de aandachtsvirag (verklaarde variantie $51,5 \%$ ) en in de tweede alle BPS-schalen met de aandachtsvitagg (verklaarde wariantie $12,5 \%$ ). De vraag omtrent het geven van extra aandacht is derhalve wan een andere orde dan de andere vragen over individuele meerzorg. Het buiten beschouwing laten van dit item bij bet construeren van een meerzorg- of ADL-dimensie leidt ook to een sterkere schaal, die een groter deel van de variantie tussen de bewoners kan verklaren ( $60 \%$ voor alle items en $65 \%$ als aandacht eruit blijft). De tweede bevinding is dat er cen belangrijke mate van samenhang blijkt te bestaan tussen de totale meerzorg en de afzonderlijke meerzorgitems aan de ene kant en de drie BPS-schalen aan de andere kant. De aandachtsvraag correleert het sterkst met de drie BPS-schalen en deze samenhang is bovendien sterker dan voor de totale meerzorg. Dit is een tweede aanwijzing dat de vraag naar extra aandacht van de overige meerzorghandeligen moet worden afgezonderd.

Samenvattend blijkt het derhalve zinvol te zijn een aantal dimensies in de totale werzorging te onderscheiden. Er liggen twee dimensies erg voor de hand, die wij benoemen als respectievelijk een ADL-dimensie (meerzorghandelingen) en een psycho-sociale dimensie. Deze dimensies zijn als volgt tot stand gekomen. In paragraaf 10.22 zagen wij dat Van LoverenHuyben e.a. -zij het met enig woorbehoud- de subschaal voor cognitie aanduiden als instrument om de psycho-sociale problematiek het scherpst in beeld te brengen. In paragraaf 10.4.1 bleek dat $24 \%$ van de bewoners boven de 'norm' (dat will zeggen meer dan 20 punten) voor cognitie uitkomt. Hoewel dit percentage vrij hoog lijkt, wordt hier als vuistregell gehanteerd dat bewoners met een cognitie-score boven de 'norm' te kampen hebben met psycho-sociale problematiek. De psycho-sociale dimensie in dit onderzoek banteert de tweedeling onder of boven de cognitienorm. De ADL-dimensie kan op verschillende manieren worden ingevuld. Eerder werd geconcludeerd dat het geven van extra aandacht en in iets minder mate de verpleegkundige handelingen afwijken ten opzichte van het algemene patroon. Beide kunnen namelijk voorkomen ongeacht het feit of er problemen zijn bij de meer traditionele ADL-items zoals eten en kleden. Bij de analyse aan het begin van deze paragraaf zagen wij dat bij factoranalyse de aandachtsvraag wordt ondergebracht bij BPS, hetgeen een andere aanwijzing is voor het verschillende karakter van dit item.

$\mathrm{Er}$ is nog een enigszins andere aanpak denkbaar, die elders al eerder is toegepast (Kibbeling e.a., 1989y en in het vooronderzoek bevredigende resultaten bleek te geven. Daarbij wordt onderscheid gemaakt tussen twee soorten ADL-items: een lichte categorie met hulp bij kleden, eten, lopen of toiletgang, en een zware categorie met hulp vanwege incontinentie en behandeling of voorkoming van decubïtus. De rubricering maakt eigenlijk gebruik van de hierarchie in ADL-items. Deze is zodanig dat als er sprake is van incontinentie-problemen het waarschijnlijk is dat achtergelegen (gemakkelijker) verrichtingen, zoals eten en kleden, eveneens zijn uitgevallen of niet meer zelfstandig kunnen worden uitgevoerd. Conform de aanpak in het vooronderzoek ontstaat er dan een ADL-dimensie, waarbij als lichtste categorie geldt dat er geén ADL-problemen zijn op het traditionele vlak (zónder aandacht en verpleging), als zwaarste categorie geldt gelijktijdige aanwezigheid van incontinentie en decubitus, en als middencategorie alle andere mogelijkheden. Deze ADL-rubricering betreft het aantal traditionele ADL-handelingen, waarbij de gescoorde meerzorg voor aandacht en verpleegkundige handelingen wel wordt meegenomen in de meerzorgintensiteit.

Uit de hierboven toegelichte classificatie komt naar voren dat precies énderde van alle bewoners geen enkel probleem kent, noch in termen van ADL-belemmeringen (waarbi] 
Tabel 10.13. Classificatie van de bewoners (in aantal) nar ADL en psychasouelale problematiek*

\begin{tabular}{|c|c|c|c|c|c|}
\hline \multirow{2}{*}{ 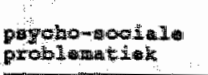 } & \multicolumn{3}{|c|}{ ADE- prob derom to th } & \multirow{2}{*}{\multicolumn{2}{|c|}{ 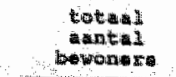 }} \\
\hline & gen & Hoht & Indax & & \\
\hline 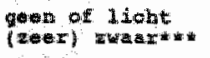 & $\begin{array}{l}320(269 / 59) \\
21(20 / 1)\end{array}$ & $\begin{array}{l}456(380 / 76) \\
146(131 / 15)\end{array}$ & $\begin{array}{llll}6 & 627 & 4 \\
3 & 157 & 0\end{array}$ & $\begin{array}{l}850 \\
250\end{array}$ & $\begin{array}{l}(711 / 139 \\
(326) 24)\end{array}$ \\
\hline terami antal & $349(299 / 60)$ & $602(511 / 91)$ & $163(13)(12)$ & 1100 & $(393163)$ \\
\hline
\end{tabular}

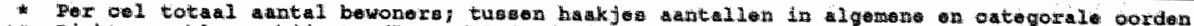

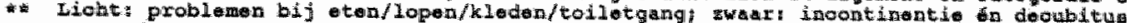

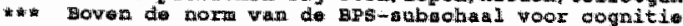

nogmaals vermeld wordt dat extra aandacht of verpleegkundige handelingen nfet ajn meegeteld), noch in termen van het psycho-sociaal functioneren. Het totaal aan psychosociale problematiek betreft $22,7 \%$ en ernstige ADL-problemen $13,5 \%$ van alle bewoners. Zeer zware problemen op beide dimensies treffen wij aan bij 7,5\% van de bewoners. Deze hebben hulp nodig bij alle handelingen uil de meerzorg-registratie en kampen met psychosociale problemen gezien het feit dat zij de BPS-norm voor cognitie hebben overschreden. Tussen de extremen bevindt zich een grote middengroep met ADL- en psycho-sociale problemen, waarbij de laatste relatief steeds meer voorkomen naarmate er bij meer items meerzorg geboden wordt: als er geen ADL-problemen zijn is er ook haast geen psychosociale problematiek; bij lichte ADL-problemen heeft $24 \%$ tevens psycho-sociale problemen en bij zware ADL-problemen is dat zelfs $56 \%$. In algemene oorden wordt de volgende verdeling aangetroffen: $31 \%$ heeft geen ADL-problemen en een klein deel van deze groep wel psycho-sociale problemen (7\%); de middencategorie betreft. $54,5 \%$ van de bewoners, van wie ruim een kwart psycho-sociale problemen heeft; de zwaarste ADL-categorie betreft $14,6 \%$ van de bewoners, waarvan lets meer dan de helft ook boven de cognitienorm uitgaat.

Met bovenstaande classificatie als leidraad bezien wij opnieuw de gemiddelde meerzorg in minuten per bewoner (tabel 10.14). Gezien het feit dat de ADL-dimensie uitgaat van zes van de acht items uit het meerzorgsysteem, kan er bij afwezigheid van ADL-problemen toch nog meerzorg gegeven worden, namelijk voor verpleging en/of extra aandacht. De meerzorg per bewoner loopt sterk op met de mate van ADL-problemen. Bij lichte ADL-stoornissen is circa 50 minuten meerzorg nodig en bij ernstige ADL-problemen bijna 2,5 uur. Mensen met psycho-sociale problemen, warbij de ADL-dimensie even buiten beschouwing blifft, hebben ruim 2,5 maal zoveel zorg nodig als bewoners zonder deze problemen, die gemiddeld 34 minuten individuele meerzorg per dag krijgen. Deze verschillen zijn significant $(t=19,0 ; P<0,001)$

Tabel 10.14. Gemiddelde meerzorg in minuten per bewoner volgens classificatie

\begin{tabular}{|c|c|c|c|c|c|c|c|}
\hline \multirow[b]{3}{*}{ ADw-probilanger } & \multicolumn{3}{|c|}{ 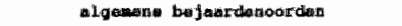 } & \multicolumn{4}{|c|}{ 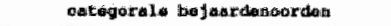 } \\
\hline & \multicolumn{2}{|c|}{ 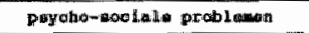 } & \multirow{2}{*}{ dold } & \multicolumn{3}{|c|}{ 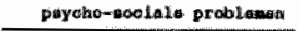 } & \multirow{2}{*}{ wastal } \\
\hline & genofluthe & (zasery zware & & quen/l L lahte & (mowr) & Dharie & \\
\hline 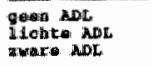 & $\begin{array}{r}5.9 \\
139 \\
1396\end{array}$ & $\begin{array}{r}11,4 \\
76 ; 0 \\
156,8\end{array}$ & $\begin{array}{r}6,2 \\
51,7 \\
167,0\end{array}$ & $\begin{array}{l}1,6 \\
11,0 \\
85,60\end{array}$ & 73 & & $\begin{array}{r}1,6 \\
10,61 \\
11.5 ;\end{array}$ \\
\hline quend dele Li: & $3 \pi_{n}$ & 37,4 & 51,6 & 20,1 & 19 & & 10,3 \\
\hline
\end{tabular}


Bekijken wij de combinatie wan ADL-en psycho-sociale problematiek, dan blijkt dat bij afwezigheid van beidle problemen minder zorg gegeven wordt dan in die situaties waarbij en geen ADL-maar wel psycho-sociale problemen zijn. Deze verschillen tussen al of geen psycho-sociale problematiek en afwezigheid van ADL-belemmeringen zijn significant en geheel toe te wijzen aran het gewen van extra aandacht. De verschillen concentreren zich op die bewoners die zich in de lichte ADL-categorie bevinden. Daar is de aanwezigheid van psycho-sociale problematiek van grote significante betekenis op de omvang van de verleende meerzorg: zonder psycho-sociale problemen circa 41 minuten en met dit soort problemen 76,5 minuten individuele meerzorg gemiddeld per dag per bewoner, met andere woorden ongeveer $87 \%$ meer (en bij categorale tehuizen zelfs meer dan het dubbele). Een opmerkelijke bevinding betreft het feit dat bij bewoners met gelijktijdig lichte of zware ADLproblemen en psycho-sociale problematiek de verschillen tussen de beide soorten instellingen niet significant zijn. Het kan ook anders gezegd worden: bij aanwezigheid van zowel lichamelijke als psycho-sociale problemen wijkt de gemiddelde zorgintensiteit per bewoner in de categorale bejaardenoorden niet af van die in de algemene bejaardenoorden; de frequentie van deze 'dubbele' problematiek is in de categorale tehuizen echter wel lager $(14,1 \%$ versus $22 \%)$. Tenslotte blijkt het bij zware ADL-problemen minder relevant te zijn of er tevens psycho-sociale problemen aanwezig zijn: weliswaar wordt er in het laatste geval lets meer zorg (gemiddeld $16,2 \%$ ) gegeven, maar dit verschil is veel minder dan bij andere ADL-groepen en maar net significant.

\subsection{Verschillen tussen bejaardenoorden?}

In deze paragraaf wordt (zeer beknopt) ingegaan op de eventuele verschillen tussen de algemene bejaardenoorden. Hierbij worden de categorale instellingen buiten beschouwing gelaten omdat enerzijds niet alle relevante gegevens beschikbaar zijn en anderzijds geen volledig beeld is gegeven van de aldaar gegeven meerzorg, die meer omvat dan de in deze studie besproken handelingen. Eerst worden de verschillen in de bewonerskenmerken besproken, waarbij drie deelterreinen aan de orde zijn, namelijk demografische kenmerken, individuele meerzorg en psycho-sociale problematiek. Bij deze analyse wordt waar mogelijk tevens een vergelijking gemaakt met het onderzoek van Frederiks e.a. (1988), die in 1987 al eerder onderzoek bij de Maastrichtse tehuizen hadden verricht. Daarbij bestaat er echter een cruciaal verschil in de wijze waarop de gegevens verzameld zijn: het eerder uitgevoerde onderzoek betrof interviews met de bewoners zelf; terwijl het onderhavige onderzoek geheel door het personeel van de instellingen is ingevuld. Dit kan tot een verschillende beoordeling over de bewoners leiden. Overigens zullen om begrijpelijke redenen geen gegevens over individuele oorden worden gepresenteerd, doch slechts de tendenties worden besproken in termen van verbanden en significantie.

\subsubsection{Instellingswerschillen bij kenmerken van bewoners}

Meli betrekking tot leeftijd bestaan er tussen de negen algemene oorden significante verschillen $\left(x^{2}=85,06 ; p=0,04\right)$. Deze verschillen zijn met name toe te wijzen aan enerzijds het aandeel van 90 -plussers (varierend van $5 \%$ tot maximaal $19 \%$ van alle bewoners) en anderzijds aan bewoners jonger dan 65 jaar. De laatste komen in een vijftal instellingen voor; het betreft slechts 8 bewoners. Indien deze jongste groep buiten beschouwing gelaten wordt en de leeftijdsverdeling ingedikt wordt tot tienjaarsintervallen van $65-74,75-84$ en 85 plus (zoals in het onderzoek van Frederiks e.a. gebeurde), dan zijn er geén significante verschillen tussen de instellingen meer (dit in tegenstelling tot de bevinding van Frederiks e.a.). De verschillen tussen de bejaardenoorden met betrekking tot de verdeling naar sexe en burgerlijke staat zjjn significant en daardoor wel in overeenstemming met de bevindingen 
wan Frederiks e.a. Het percentage verweduwde bewoners varieert van $62 \%$ tot maximaal $87 \%$ (gemiddeld 69,6\%).

Opmerkelijk is verder dat het relatieve aandeel per instelling van het aantal nieuwe bewoners (opgenomen in 1989) weliswaar grote fluctuaties laat zien van ruim $7 \%$ tot $20 \%$ (met als uitschieter bijna 29\%), maar niet significant verschillend tussen de instellingen bijjkt te zjjn $\left(\alpha^{2}=11,87 ; p=0,16\right)$. Met betrekking tot de verblijfsduur verschillen de instellingen wel significant varierend van 4 tot 6 jaar. Bij deze toetsing is wederom de indeling van Frederiks gebruikt om een vergelijking te kunnen maken: de resultaten van beide onderzoeken stemmen overeen. De verblijfsduur in de categorale bejaardenoorden is overigens aanzienlijk hoger (gemiddeld 7 jaar).

Eerder was al gelllustreerd dat de demografische kenmerken van bewoners onderling samenhangen. De toetsing van verschillen tussen de instellingen zou hiermee rekening moeten houden. Analyse van meerdimensionale kruistabellen tussen enerzijds instellingen en anderzijds leeftijd én geslacht ên burgerlijke staat laten gén significante verschillen meer zien, met uitzondering van het aandeel van gehuwde mannen. Dit alles leidt ons inziens tot het eindoordeel dat er geen grote verschillen zijn tussen de algemene bejaardenoorden met betrekking tot de samenstelling naar leeftijd, burgerlijke staat en geslacht. Wel maakt het uit of er mensen jonger dan 65 jaar zijn opgenomen en zijn de verschillen bij de gehuwde mannen groot genoeg om significant te zijn. Het voorgaande impliceert dat de betreffende resultaten uit het onderzoek van Frederiks e.a. (1988) niet gerepliceerd worden. Hiervoor bestaan wellicht twee redenen: enerzijds ligt er een periode van ongeweer tweeenhalf jaar tussen beide onderzoeken, waardoor verschillen mogelijk zijn; anderzijds is het mogelijk dat in het eerder uitgevoerde onderzoek enige vertekening door selectiviteit in de respons heeft plaatsgevonden (Frederiks e.a., p. 17 en 25), waarbij opgemerkt wordt dat het hier in principe toch om 'harde' gegevens over de sociaal-demografische kenmerken van bewoners gaat.

Vervolgens gaan wij beknopt in op eventuele verschillen tussen de instellingen met betrekking tot de zorgbehoefte van bewoners. Om de analyse niet nodeloos te bemoeilijken wordt afgezien van de interactie met de leeftijds- en geslachtsopbouw binnen de oorden, waarin overigens zoals net aan de orde kwam geen erg grote verschillen bestaan. Indien de meest belangrijke indicatoren voor zorgbehoefte bezien worden, zoals het percentage bewoners dat BPS-'normen' overschrijdt, het gemiddelde aantal ADL-beperkingen en de gemiddelde individuele meerzorg, dan blijkt dat de algemene bejaandenoorden op alle bowengenoemde bewonerskenmerken significant verschillen. Dit is ook het geval voor de mate waarin in een instelling eenzaamheid voorkomt. De verschillen in individuele meerzorg zijn niet alleen in zijn totaliteit significant, maar ook op het niveau van afzonderlijke items.

Afzonderlijke aandacht is besteed aan eventuele verschillen tussen bejaardenoorden betreffende de kenmerken van in 1989 nieuw opgenomen bewoners $(N=160)$. Het resultaat is frappant: er zijn geén significante verschillen op demografische kenmerken (leeftijd, sexe, burgerlijke staat) en ook geen significante verschillen in het aantal ADL-beperkingen, de individuele meerzorg én de BPS-scores, uitgezonderd die bij sociaal contact. Dit lijkt (naast de in het voorgaande hoofdstuk beschreven ontwikkelingen met betrekking tot de instroompercentages, de gemiddelde leeftijd en de urgentiegraad van de ouderen op de wachtlijst) een volgende aanwijzing te zijn dat het gezamenlijke opnamebeleid inderdaad 'werkt' en nageleefd wordt. In combinatie met de bevindingen over de al langer aanwezige bewoners wordt echter tevens geconcludeerd dat de wijze van zorgverlening tussen de algemene bejaardenoorden zodanig werschilt dat ondanks de nivellerende werking van het opnamebeleid er op termijn toch bewonerswerschillen ontstaan tussen de instellingen onderling. 
Tot slot van deze beknopte schets van verschillen tussen de algemene bejaardenoorden in de gemeente Maastricht wordt ingegaan op de mogelijke gevolgen van de inwoering van het Normeringssysteem Personele woorzieningen Verzorgingstehuizen voor de afzonderlijke instellingen. In het Limburgse nodel voor normering van de personeelsformatie in bejaardenoorden is een systematiek vitgewerkt om het benodigde personeel voor een instelling met een bepaalde capaciteit te berekenen. Daarbij worden verschillende sectoren onderscheiden, zoals huishouding, voeding, administratie, activiteitenbegeleiding, en directe zorgverlening (basiszorg en meerzorg). Per sector wordt een personeelsnorm (in "bruto full time' plaatsen) aangebouden met als meeteenheid helt aantal plaatsen (volgens capaciteilt, niet volgens werkelijke bezetting) of het aantal eén- en tweepersoonskamers (met name in sector huishouding) of het aantal vierkante meters (bw. schoonmaak openbare ruimtes). Naast een basispakket van 20,5 minuten zorg per dag die voor elke bewoner hetzelfde is, zal volgens het plan de individuele meerzorg aan het eind van ieder kwartaal in beeld gebracht moeten worden, op basis warvan berekend gaat worden hoe veel verzorgend en verplegend personeel gezien de zorgbehoefte binnen de instelling noodzakelijk is.

Om een eerste indruk te krijgen van de relatie tussen personeelsformatie en zorgbehoefte in een instelling, is in figuur 10.1 per instelling het aantal personeelsleden gedeeld door het aantal bewoners uitgezet tegen de gemiddelde meerzorg per bewoner. Dit is gedaan voor het totale personeel (bovenste lijn) en het verzorgend of verplegend personeel (onderste lijn). De onderste lijn zou in principe een rechte lijn moeten zijn: hoe meer meerzorg hoe meer verzorgend personeel. De bovenste lijn wekt enigszins verbazing: kennelijk is er een soort optimaal punt van gemiddelde meerzorg waarbij een optimale omvang van het totale personeel hoort (corrigerend voor de onderste lijn gaat het eigenlijk om het 'overhead' personeel). Bij zowel een lagere als een hogere gemiddelde zorgbehoefte is relatief veel (niet-verzorgend) personeel aanwezig. Opgemerkt wordt dat de getekende curven ('dalparabolen') in alle gevallen aanzienlijk beter passen (in termen van verklaarde variantie) dan een rechte lijn.

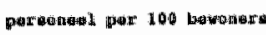

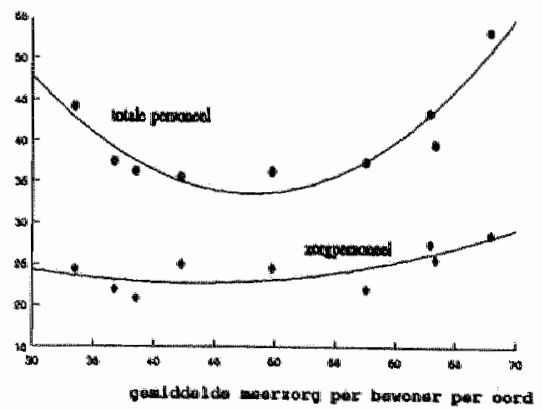

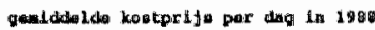

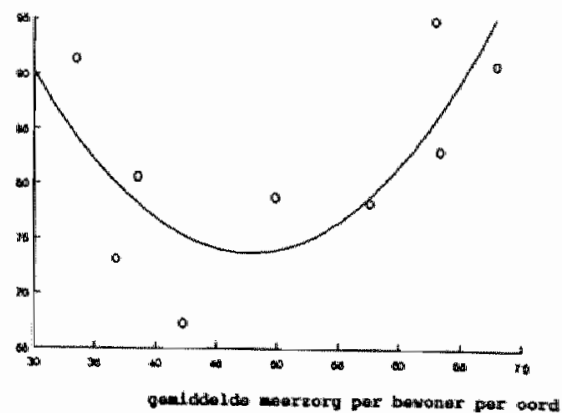

Figuur 10.1. Algemene oorden naar combinatie van gemiddelde meerzorg en personeel of kostprijs 
Op basis van de gepresenteerde gegewens is het mogelijk de gevolgan vam de invoering van het systeem te berekenen. Voor alle algemene corden tezamen in de gemeente Maastricht, die in totaal 825 énpersoonskamers en 90 tweepersoonskamers met in totaal 1005 capaciteitsplaatsen tellen, komt het personeelsmodel uit op de gegevens zoals vermeld in tabel 10.15 (zie ook paragraaf 9.3). De aanpak is daarbij als volgt: voor alle niet-direct verzorgende sectoren zijn de normen (inclusief die voor basiszorg) toegepast op het aantal bewoners of een- en tweepersoonskamers. Bij een tweetal sectoren zijin ramingen gemakkt omdat gegevens ontbreken (o.a. vierkante meters publieke ruimte). De posten zijn opgeteld tot het subtotaal. Het verschil met de feitelijke formatie eind 1988 (het recentste waarover in het onderzoek beschikt kon worden) resteert dan voor individuele meerzorg. Uit deze resterende formatie is berekend hoeveel minuten dat zou betekenen. Daartegenover staat de gescoorde meerzorg, zodat de verschillen ten gevolge van het NPV systeem berekend kunnen worden. Het zal niet verrassen dat alle algemene bejaardenoorden onder de gescoorde meerzorg komen (gemiddeld $-35 \%$ ), maar de verschillen daarbij zijn groot. Gemiddeld voor de gehele sector komt de berekening met het huidige normeringssysteem (dat nog niet officieel ingevoerd is) uit op een personeelstekort wan $18,5 \%$ ten opzichte van de totale formatie per ultimo 1988. Per instelling varieert dat van $7 \%$ tot maximaal $45 \%$. Indien rekening gehouden wordi met de toch enigszins dubieuze objectiviteit van het registratiesysteem, bijvoorbeeld door de aandachtsvraag niet mee te laten tellen, dan resteert nog een tekort ten opzichte van de totale personeelsformatie van $8,2 \%$.

\subsection{Samenvatting en conclusies}

De gemiddelde tijdsbesteding met betrekking tot individuele meerzorg is ruim 48 minuten per bewoner per dag en betreft al of niet intensieve huip bij acht handelingen (eten, kleden, lopen, toiletgang, incontinentie, decubitus, extra aandacht en verpleging). Aangetoond is dat er een exponentieel verband bestaat tussen het aantal handelingen waarbij meerzorg gegeven wordt en de intensiteit van deze zorg, gemeten in minuten. Voorts is gellustreerd dat de uitval van functies een hierarchisch patroon kent in dezelfde volgorde als net genoemd, die ook op het registratieformulier wordt gehanteerd. Dit geldt met name voor de eerste zes handelingen, terwijl verpleegkundige handelingen en extra aandacht zich minder mooi conformeren aan de geschetste hierarchie. Vrouwen blijken over het algemeen iets meer meerzorg te krijgen, maar de verschillen met mannen zijn gering en niet significant. Naarmate de leeftijd stijgt, neemt de zorgintensiteit over de gehele linie en op afzonderlijke items toe. Naar burgerlijke staat worden vrij grote verschillen gevonden, waarbij gehuwde vrouwen verweduwde vrouwen de meest zorgbehoevende bewoners blijken te zijn. Echtparen blijken opgenomen te worden omdat het met de vrouw slecht gaat: de gemiddelde meerzorg is bij gehuwde vrouwen $40 \%$ hoger dan bij mannen. De zorgbehoefte stijgt natmate men langer in het bejaardenoord verblijft tot een globaal maximum bij een verblijf van ongeveer 5 jaar (rond dit getal bevindt zich ook de gemiddelde verbliffsduur), waarna zij weer daalt. Bij langdurig verblijvende bewoners (10 jaar of meer; gemiddeld ruim $16 \%$ van alle bejaardenoordbewoners) siligt de gemiddelde meerzorg echter weer.

De resultaten van de meting met de Beoordelingsschaal voor Psychische en Sociale problemen (BPS) lijken er op te wijzen dat dit soort problematiek groot is, ondat het percentage bewoners dat boven de norm van de drie onderscheiden schalen ligt, steeds hoger is dan door de corspronkelijke auteurs wordt gemeld. Ernstige cognitieve problemen worden aangetroffen bij $24,1 \%$ van de bewoners van algemene verzorgingstehuizen en bij $14,7 \%$ van de bewoners van categorale oorden. Stemmingsproblemen vinden wij bij een $37 \%$ in de leken- en $20 \%$ in de categorale bejaardenoorden en de schaal woor sociaal contact registreert bij $29 \%$ respectievelijk $14 \%$ ernstige problemen. Van alle bewoners heeft de helft op geen van de BPS-schalen een score boven de norm. 
Tabel 10.15. Model vormering bejaardenoorden: gevolgen voor alle algemene corden tezamen

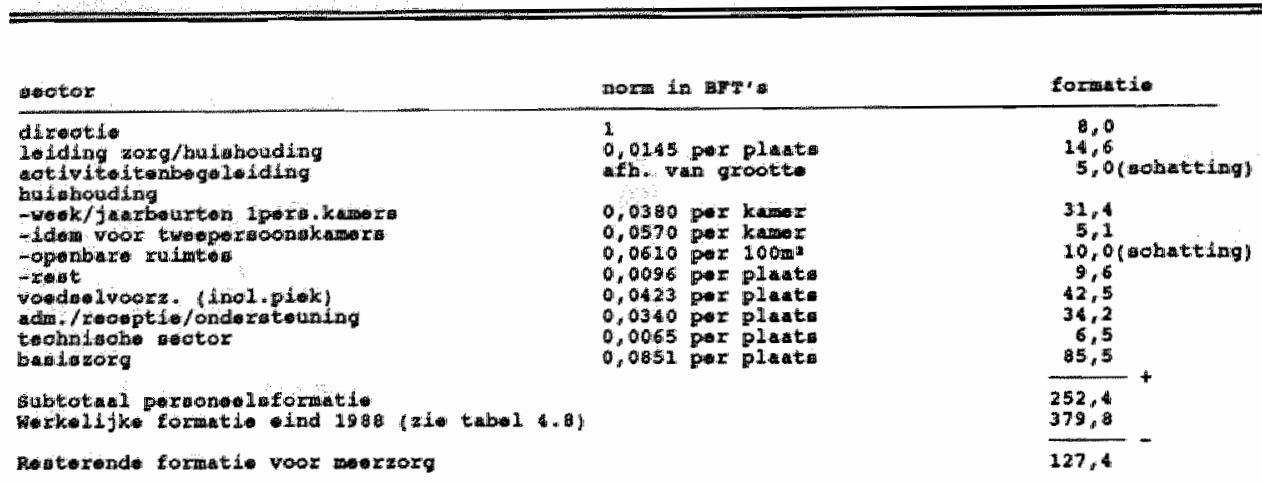

De laatste stap in dit hoofdstuk betreft de koppeling van individuele meerzorg met de psycho-sociale problematiek als gemeten via de BPS en leidt tot een tweedimensionale classificatie van bewoners. Bij lichte $\mathrm{ADL}$-stoornissen is circa 50 minuten meerzorg nodig en bij ernstige ADL-problemen bijna 2,5 uur. Mensen met psycho-sociale problemen hebben ruim 2,5 maal zoveel zorg nodig als bewoners zonder deze problemen. De verschillen concentreren zich op die bewoners die zich in de lichte ADL-categorie bevinden. Daar is de aanwezigheid van psycho-sociale problematiek wan grote significante betekenis op de omvang van de verleende meerzorg: zonder psycho-sociale problemen circa 41 minuten en met dit soort problemen 76,5 minuten individuele meerzorg gemiddeld per dag per bewoner. Bij aanwezigheid van zowel lichamelijke als psycho-sociale problemen wijkt de gemiddelde zorgintensiteit per bewoner in de categorale bejaardenoorden niet af van die in de algemene bejaardenoorden; de frequentie is in de categorale tehuizen echter wel lager.

De zogenaamde subsitutie-mogelijkheden voor de lichtste categorieern bewoners (geen meerzorg of slechts individuele meerzorg bij of verpleegkundige handelingen of extra aandacht) zijn op basis van de hier gepresenteerde gegevens te ramen op ongeveer $30 \%$ van de huidige bewoners. Dit cijfer ligt niet veel lager dan dat uit het veel geciteerde onderzoek van Remmen (1985). Anderzijds bestalat er ook een vrij grote groep bewoners die bij alle of op een na alle handelingen individuele meerzorg nodig hebben, die dan ook erg untensief is; dit betreft $13,5 \%$ van alle bejaardenoordbewoners of $14,6 \%$ als alleen gekeken wordt naar de algemene bejaardenoorden. Meer dan de helft van deze categorie (56\%) heeft niet alleen zware ADL-beperkingen, maar tevens ernstige cognitieve problemen. Deze laatste groep (ernstige problemen op beide dimensies), in total $7,5 \%$ van alle bewoners, heeft gemiddeld circa 2,5 uur meerzorg per persoon per dag nodig, legt daarmee beslag op een kwart van de totale meerzorg in een bejaardenoord en zou wellicht beter kunnen worden opgenomen in een verpleeghuis of komt in aanmerking voor dagbehandeling aldaar. Dit geldt waarschijnlijk ook voor de bewoners met zware ADL-problemen maar zonder psychosociale problematiek ( $6 \%$ van alle bewoners; gemiddelde meerzorg 132,5 minuten per persoon; ruim 16\% van de totale capaciteit), die dan in aanmerking komen voor de somatische afdeling van het verpleeghuis. Indien er echter voor gekozen wordt (of indien dat gezien de beperkte verpleeghuiscapaciteit niet anders kan) om deze bewoners te behouden, dan dienen er wellicht maatregelen genomen te worden in de sfeer van aan personeel te stellen kwaliteitseisen of moet gedacht worden aan een meer systematische vormgeving van de consultatiefunctie van verpleeghuisartsen. 


\section{Verpleeghuizen}

\subsection{Inleiding}

Het verpleeghuis is een instelling van gezondheidszorg waar verpleegkundige en (para-) medische hulp geboden wordt aan mensen die thuis of in het verzorgingstehuis niet meer voldoende geholpen kunnen worden. De verpleeghuiszorg wordt omschreven als een continue systematische, vaak langdurige en multidisciplinaire zorg, de zogenaamde CSLM-zorg, en wordt 'geleverd' in drie soorten verpleeghuizen: voor somatische zieken en voor psychogeriatrische patienten of in gecombineerde verpleeghuizen waar beide groepen aan bod komen. In Maastricht bestond tot eind 1987 een gecombineerd verpleeghuis, namelijk de verpleegkliniek Klevarie. Deze vervult een regionale functie en heeft een capaciteit van 396 bedden, waarvan er 231 bestemd zijn voor somatische patienten (58\%) en 165 voor psychogeriatrische patienten (42\%). Van de laatste categorie hebben er in 1984 twee bedden de functie van separeerbed voor psycho-geriatrische patienten gekregen. Sinds 15 oktober 1987 is er in Maastricht naast de reeds bestaande verpleegkliniek een nieuwe voorziening op dit gebied, verpleegkliniek De Zeven Bronnen, gelokaliseerd in het oostelijk stadsdeel Amby. Dit is eveneens een gecombineerd verpleeghuis voor somatisch zieken ( 60 plaatsen) en psycho-geriatrische patienten (ook 60 plaatsen). Op termijn (waarschijnlijk eind 1991) zal de capaciteit van De Zeven Bronnen worden uitgebreid van 120 naar 180 plaatsen.

Tot slot kan vermeld worden dat er eind 1980 door het ministerie van WVC aan Psychomedisch Streekcentrum Vijverdal een tijdelijke erkenning is verstrekt voor 65 psychogeriatrische bedden onder de voorwaarde dat deze na de realisering van het nieuwe verpleeghuis daarheen overgaan. Over het tijdstip van deze overheveling heeft geruime tijd onenigheid bestaan tussen Vijverdal en het Burgerlijk Armenbestuur, waaronder de verpleeghuizen resorteren. In 1988 besloot de Staatsecretaris om de tijdelijke erkenning van Vijwerdal te verlengen tot 1 januari 1990. Vanaf dat moment wordt een jaarlijks verlenging. van de erkenning verwacht tot het moment dat de volledige capaciteit van De Zeven Bronnen beschikbaar is. Hieraan is de voorwaarde verbonden dat de betreffende afdeling een dependance zou worden van De Zeven Bronnen; deze constructie komt echter waarschijnlijk niet tot stand. Bij voltooiing van de uiteindelijke capaciteit van dit verpleeghuis (180 plaatsen) zal Vijverdal haar erkenning verliezen omdat de resterende capaciteit dan overeen komt met de geldende normen (zie hoofdstuk 4). Om een aantal redenen is het niet mogelijk om voldoende betrouwbare gegevens te presenteren over de verpleegafdeling van Vijverdal. Ten eerste startte men in 1980 met 27 bedden, die aan het eind van het jaar pas uiltgebreid werden tot het erkende aantal van 65 plaatsen; de eerste gegevens die over de betreffende afdeling beschikbaar zijn dateren echter van 1982. Daarna is het wel mogelijk om over geaggregeerde gegevens te beschikken, maar deze worden door de afdeling Medische Registratie van Vijverdal niet voldoende betrouwbaar geachl (telefonische mededelingen) en zijn bovendien niet zo gedetailleerd als die van Klevarie, zodat een gemeenschappelijke basis voor vergelijking ontbreekt. Tot 1987 werd geen aparte regustratie gevoerd waarmee op afdelingsniveau (dus ook voor de verpleegafdeling) de personeelsinzet en kasten inzichtelijk gemaakt zouden kunnen worden. Tenstotte is pas in 1987/1988 een geautomatiseerd systeem ingevoerd. Dit alles maakt een analyse die ook de verpleegafdeling van Vijverdal omvat niet erg zinvoll.

De capaciteit van Klevarie en De Zeven Bronnen is thans 516 bedden, waarvan 291 (45\%) woor somatiek. Het werkgebied van beide beslaat geheel Zuidelijk Zuid-Limburg (ruím 150.000 inwoners). Omdat De Zeven Bronnen pas begin 1988 geleidelijk volledig in gebruik 
is genomen en de gegevens over de verpleeghuisdependance niet zijn af te zonderen van de gegevens over andere afdelingen in het Psycho-medische Sireekcentrum Vijverdal, beperken wij ons in het overzicht van verpleeghuiszorg in Maastricht in de periode 1980-1988 tot de verpleegklintek Klevarie. Voor inzicht in de verdeling van patienten naar sexe, leeftujd, herkomst bij opname en bestemming bij ontslag is deze aanpak toereikend; voor de berekening van het berreik wan verpleeghwizen wordt echter een minder juiste voorstelling van zaken gegeven. Enerzijds wordt de (psycho-geriatrische) capaciteit in Vijverdal en voor 1988 de toeloop op het nieuwe verpleeghuis ten onrechte niet meegerekend. Maar anderajds wordt in de berekening van de bereikejfers geen rekening gehouden met bet feit dat de verpleeghuizen een regionale functie vervullen (zie paragraaf 11.2). Per saldo zullen de bereikcijfers warschijnlijk toch een redelijk inzicht geven voor de gemeente Maastricht.

De opbouw van dit hoofdstuk is als volgt: in paragraaf 11.2 worden ontwikkeling in het gebruik en bereik sinds 1980 geschetst; in paragraaf 11.3 gaan wij in op de patientenstromen naar, door en uit het verpleeghuis; in paragraaf 11.4 komt de dagbehandeling aan bod en in paragraaf 11.5 de personeels- en kostenopbouw van het verpleeghuis Klevarie. In paragraaf 11.6 wordt niel alleen een samenvatting gegeven, maar wordt tevens een vergelijking gemaakt met de nationale gegevens over de verpleeghuiszorg vit hoofdstuk 4 .

\subsection{Gebruik verpleeghuiszorg in de periode 1980-1988}

Theoretisch kan met de beschikbare capaciteit van het gecombineerde verpleeghuis Klevarie een 'produktie' van circa 144.500 verpleegdagen gerealiseerd worden, waarvan 84.300 op de somatische afdelingen en 60.200 op de psycho-geriatrische afdelingen (waarbij verondersteld is dat ook de separeerbedden volledig bezel zijn). Uit de overzichten van het aantal verpleegdagen (tabel 11.1) en de in de kliniek aanwezige patienten aan het eind van ieder jaar (tabel 11.2) blijkt dat de aanwezige somatische capaciteit in het verleden niet ten volle gebruikt werd, maar dat de psycho-geriatrische wel steeds volledig of zelfs meer dan volledig benut werd. Dit bleek al eerder een nationaal optredend verschijnsel te zijn. Klevarie kende in de gehele periode 1980-1988 steeds een bezettingsgraad van gemiddeld ruim $99 \%$.

In de verdeling van de patienten naar geslacht heeft zich een geleidelijke verschuiving voorgedaan naar vrouwen; was in 1980 nog $30,1 \%$ van alle patienten man, in 1988 is dat $24,6 \%$. Vooral bij de somatische zorg is het aandeel van mannen afgenomen van $32,6 \%$ in 1980 tot $24,3 \%$. Deze verschuiving hangt samen met de dubbele vergrijzing, die zich met name op vrouwen concentreert (zie hoofdstuk 2).

Van alle verpleeghuispatienten die per 31 december aanwezig zijn, bestaat gemiddeld $92 \%$ a 93\% uit 65-plussers. Binnen de categorie ouderen treedt een geleidelijke verschuiving op

Tabel 11.1. Produktie van verpleeghuis in aantal verpleegdagen

\begin{tabular}{|c|c|c|c|}
\hline & $\begin{array}{l}\text { acrat d aiohe } \\
\text { putiontion }\end{array}$ & $\begin{array}{l}\text { paychoger. } \\
\text { patidnten }\end{array}$ & $\begin{array}{l}\text { totalin antal } \\
\text { veEpleagdagen }\end{array}$ \\
\hline $\begin{array}{l}1900 \\
1981 \\
1982 \\
1983 \\
1984 \\
1985 \\
1986 \\
1587 \\
1980\end{array}$ & $\begin{array}{l}83.990 \\
83.948 \\
83.917 \\
83.864 \\
83.980 \\
63.977 \\
83.871 \\
83.457 \\
83.571\end{array}$ & $\begin{array}{l}60.167 \\
60.019 \\
60.076 \\
60.078 \\
60.296 \\
59.970 \\
60.138 \\
60.034 \\
60.191\end{array}$ & $\begin{array}{l}144.157 \\
143.867 \\
143.953 \\
143.942 \\
144.276 \\
143.847 \\
144.009 \\
143.491 \\
143.762\end{array}$ \\
\hline
\end{tabular}


Tabel 11.2. Patienten naar verzorgingscategorie en sexe per 31 december

\begin{tabular}{|c|c|c|c|c|c|c|c|c|c|}
\hline & 1980 & 1981 & 19192 & I918 & 1984 & 196 & 19:86 & 19187 & 1 界 \\
\hline \multicolumn{10}{|l|}{ 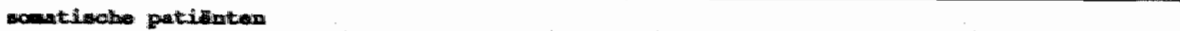 } \\
\hline 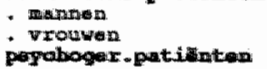 & $\begin{array}{r}75 \\
155\end{array}$ & $\begin{array}{r}74 \\
154\end{array}$ & $\begin{array}{r}78 \\
185\end{array}$ & $\begin{array}{r}71 \\
152\end{array}$ & $\begin{array}{r}72 \\
13\end{array}$ & $\begin{array}{r}5 \\
+51\end{array}$ & $\begin{array}{r}6 \\
459\end{array}$ & $\begin{array}{r}60 \\
469\end{array}$ & $\begin{aligned} 546 \\
174\end{aligned}$ \\
\hline 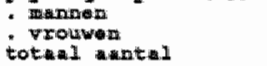 & $\begin{array}{l}44 \\
221 \\
395\end{array}$ & $\begin{array}{r}44 \\
121 \\
393\end{array}$ & $\begin{array}{l}6.6 \\
1.20 \\
3.89\end{array}$ & $\begin{array}{r}43 \\
121 \\
387\end{array}$ & $\begin{array}{r}38 \\
12: 5 \\
388\end{array}$ & $\begin{array}{r}37 \\
127 \\
390\end{array}$ & $\begin{array}{r}43 \\
121 \\
391\end{array}$ & $\begin{array}{r}13 \\
122 \\
394\end{array}$ & $\begin{array}{r}61 \\
72+2 \\
39\end{array}$ \\
\hline
\end{tabular}

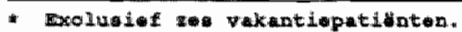

naar hoogbejaarden (85-plus); in 1980 was nog $27 \%$ van alle 65 -plussers hoogbejaard en in $198836,3 \%$. De laatste twee jaar is bovendien voor het eerst sprake van (aanzienlijk) meer dan 50 patienten van bowen de 90 jaar. De gemiddelde leeftijd van alle aanwezige patienten tezamen is gestegen tot ongeveer 80 jaar. Daarbij is het van belang onderscheid te maken tussen somatische en psycho-geriatrische patienten. Net als in de rest wan Nederland is een psycho-geriatrische patient thans gemiddeld 4 a 5 jaar ouder dan een somatische patient. Dit verschil is echter bepaald niet stabiel: in 1980 was het zelfs acht jaar, in 1986 maar twee jaar. Leeftijdsverschillen ten aanzien wan de sexen zijn stilaan groter geworden tot thans $4 \%$ jaar tussen mannen (gemiddeld 76 jaar) en vrouwen (bijna 81 jaar). De leeftijdswerdeling blijkt goed overeen te komen met de eerder gepresenteerde nationale verdeling; ook het historisch verloop in de leeftijdsopbouw stemt overeen. In de statistieken waarover ten behoewe van het onderzoek kon worden beschikt, wordt geen onderscheid gemaakt naar burgerlijke staat, zodat deze onbelicht blijft in deze studie.

Opname in een verpleeghuis geschiedt vaak voor lange tijd en leidt er vaak toe dat ook de laatste verblijfsplaats bereikt is. Dat neemt niet weg dat er nog een aanzienlijke groep patienten is die, veelal voor verder herstel na een ziekenhuisverblijf of revalidatie slechts kort in het verpleeghuis verblijft. Als illustratie worden de gegevens voor 1988 gebruikt: van de per 31 december aanwezige patienten verbleef $8,1 \%$ er korter dan én maand en $5,1 \%$ korter dan drie maanden; voor de ontslagen patienten ligt de verblijfsduur geheel anders en gaat het bij $26,8 \%$ om een opname korter dan eén maand en $16,1 \%$ korier dan drie maanden. De mediane verblijfsduur ligt bij de ontslagen patienten ongeveer rond de vijf à zes maanden. Tot slot kan vermeld worden dat sinds 1986 , toen het percentage patienten dat binnen een half jaar ontsiagen werd was gedaald tot een historisch dieptepunt van $47 \%$ (in 1980 nog $62 \%$ ), de doorstroming in de kliniek weer enigszins verbetert doordat er weer meer mensen op een kortere termijn het verpleeghuis verlaten.

Tabel 11.3. Leeftijdswerdeling van de aanwezige patiënten per $\mathbf{3 1}$ december

\begin{tabular}{|c|c|c|c|c|c|c|c|c|c|}
\hline & 1500 & 1984 & 1982 & 1903 & 294 & $15 \mathrm{gs}$ & 1906 & 1987 & 1988 \\
\hline 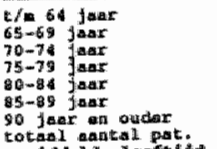 & $\begin{array}{r}3.7 \\
27 \\
5.5 \\
80 \\
92 \\
614 \\
39 \\
395\end{array}$ & $\begin{array}{r}33 \\
22 \\
41 \\
92 \\
63 \\
90 \\
99 \\
393\end{array}$ & $\begin{array}{r}25 \\
17 \\
14 \\
90 \\
68 \\
03 \\
42 \\
3109.4\end{array}$ & $\begin{array}{r}23 \\
20 \\
35 \\
93 \\
100 \\
76 \\
140 \\
910.7\end{array}$ & $\begin{array}{r}28 \\
1.5 \\
13 \\
77 \\
19 \\
42 \\
4.8\end{array}$ & $\begin{array}{r}24 \\
21 \\
47 \\
70 \\
100 \\
78 \\
42 \\
390\end{array}$ & $\begin{array}{l}211 \\
10 \\
45 \\
811 \\
94 \\
0.4 \\
491\end{array}$ & $\begin{array}{r}26 \\
19 \\
39 \\
911 \\
96 \\
73 \\
59 \\
394\end{array}$ & $\begin{array}{r}79 \\
16 \\
50 \\
699 \\
918 \\
79 \\
34 \\
395\end{array}$ \\
\hline 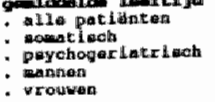 & $\begin{array}{l}78,5 \\
73,5 \\
81,5 \\
76,5 \\
70,5\end{array}$ & $\begin{array}{l}77,5 \\
73,5 \\
61,5 \\
78, \\
79\end{array}$ & $\begin{array}{l}76,5 \\
76,4 \\
71,7 \\
76,5 \\
100,5\end{array}$ & $\begin{array}{l}79,8 \\
77,9 \\
71,9, \\
76,9 \\
91,1\end{array}$ & $\begin{array}{l}180,4 \\
78,7 \\
192,7 \\
76,9 \\
81,8\end{array}$ & $\begin{array}{l}79,9 \\
78,4 \\
81,9 \\
75,7 \\
91,6\end{array}$ & $\begin{array}{l}80,3 \\
70,4 \\
81,5 \\
71,5,5 \\
81,4\end{array}$ & $\begin{array}{l}79,5 \\
77,7 \\
92,6 \\
76,1 \\
90,7\end{array}$ & $\begin{array}{l}75,6 \\
77,8 \\
52,4 \\
76,1 \\
00,7\end{array}$ \\
\hline
\end{tabular}

- Bxolumiof zoo vahantiapetiontea 
Tabel 11.4. Patiëntwerdellog (in \%) Klevarie maar verbliffsduur in jaren

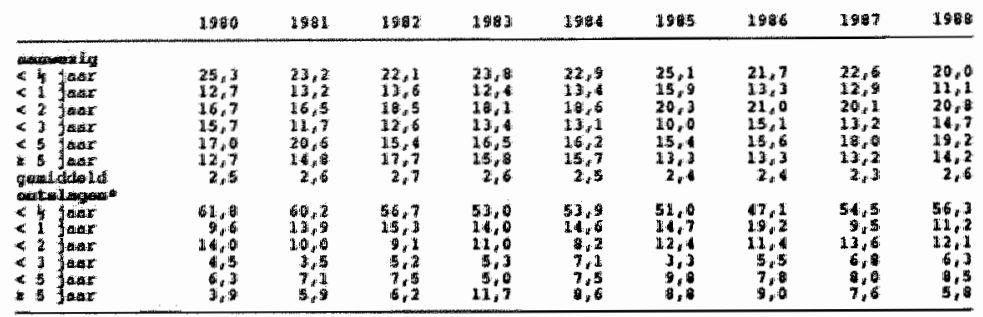

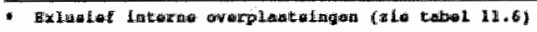

Bij de per 31-12 nog aanwezige patienten ligt de gemiddelde verblijfsduur rond $21 / 2$ jaar. Het aandeel van patienten die korter dan een half jaar geleden zijn opgenomen is gedaald van $25 \%$ tot $20 \%$ en het aandeel van de patienten die al tenminste drie jaar in de instelling verblijven, is gestegen tot $33,4 \%$ in 1988 . Ook hier is het van belang onderscheid te maken naar het soort patient. Somatische patietnten blijven aanzienlijk korter $(2,2$ jaar in 1988) in het verpleeghuis dan psycho-geriatrische patienten $(3,1$ jaar), hoewel bij hen de jaarlijkse fluctuaties groot zijn (zie figuur 11.1).

Het bereik is een belangrijk gegewen, dat in de Wet Ziekenhuis Voorzieningen (WZV) is vastgelegd. Omdat de verpleeghuizen in principe een regionale functie hebben, zou het bereik moeten worden berekend als het percentage patienten ten opzichte van de bevolking van dat werkgebied. Omdat echter verreweg het grootste deel van de patienten afkomstig is uit Maastricht zelf en voor het totale werkgebied niet alle bevolkingsgegevens in het bezit van de onderzoeker zijn, wordt het bereik hier ten opzichte van de Maastrichtse bevolking berekend (bijna $80 \%$ van de bevolking in het totale werkgebied). Omdat anderzijds de capaciteit van de tijdelijk erkende verpleegafdeling van Vijverdal niet is meegerekend (zie paragraaf 11.1), zal naar verwachting toch een redelijk inzicht in het bereik op gemeentelijk niveau gegeven kunnen worden. Het bereikpercentage voor 65-plus is (eind 1988) 1,33\%

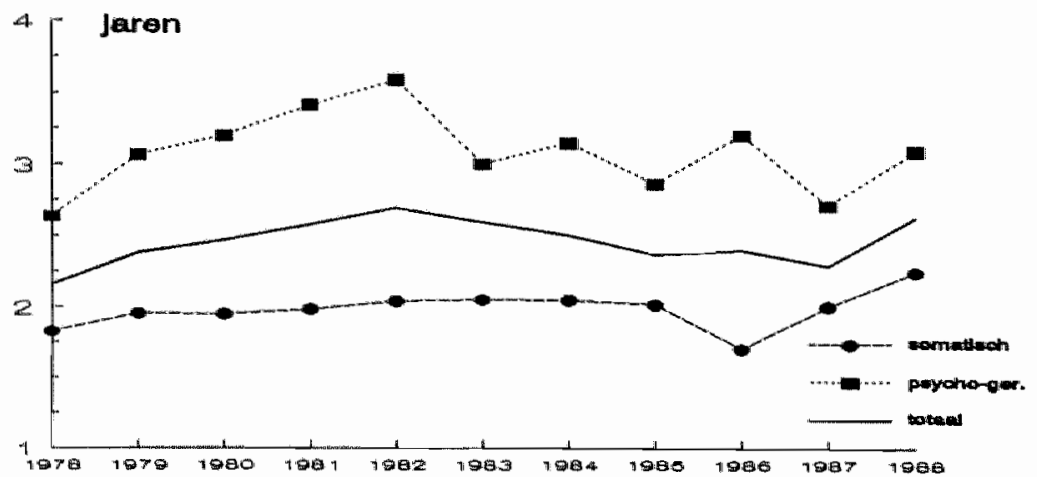

Figuur 11.1. Gemiddelde verblijfsduur bij per 31-12 aanwezige patiënten 


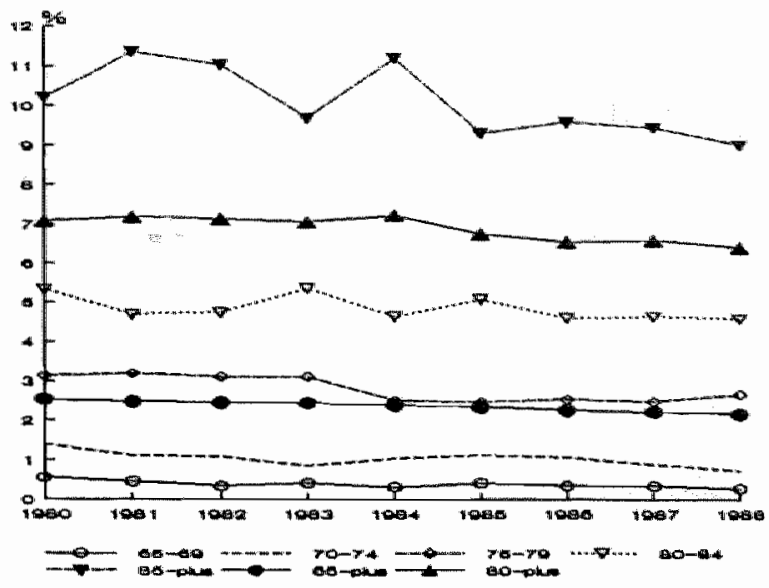

Figuur 11.2. Bereikpercentages verpleeghuils in periode 1980-1988

voor mannen en $2,73 \%$ voor vrouwen (gemiddeld $2,19 \%$ ). Voor de diverse leeftijdsgroepen beeft zich over de gehelle linie een daling in bereik voorgedaan (zie figuur 11.2). Thans is in de categorie $75-79$ jaar $2,7 \%$ opgenomen, $4,6 \%$ bij $80-84$ jaar en van 85 -plus $9,1 \%$. Vooral in de laatste groep zijn de verschillen naar sexe groot: $5,4 \%$ van de mannen en $10,3 \%$ van de vrouwen vanaf 85 jaar is opgenomen.

\subsection{Patiëntenstromen naar, door en uit het verpleeghuis}

De gesignaleerde toename in de verpleegduur impliceert enerzijds dat de instroom van nieuwe patienten in het verpleeghuis afneemt en anderzijds dat het verpleeghuis voor steeds meer patienten een 'eindstation' vormt. Tabel 11.5 illustreert dit: in 1980 werden 362 patienten opgenomen, waarvan 34,3\% vanwege een heropname; in 1988 was het aantal opnames teruggelopen tot 234 patienten, waarvan $20,1 \%$ vanwege een heropname, terwijl. de bezettinggraad onveranderd hoog bleef.

Tabel 11.5. Opgenomen patiënten naar herkomst

\begin{tabular}{|c|c|c|c|c|c|c|c|c|c|}
\hline & 1980 & 1961 & 1982 & 19 㬐 3 & 1984 & $100 \mathrm{~s}$ & 1986 & 1997 & A.9.20 \\
\hline 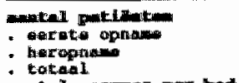 & $\begin{array}{l}230 \\
1.24 \\
36.2\end{array}$ & $\begin{array}{l}25,5 \\
12: 11 \\
379\end{array}$ & $\begin{array}{l}233 \\
126 \\
359\end{array}$ & $\begin{array}{l}224 \\
109 \\
\$ 131\end{array}$ & $\begin{array}{r}210 \\
95 \\
305\end{array}$ & $\begin{array}{r}120 \\
92 \\
912\end{array}$ & $\begin{array}{r}197 \\
69 \\
256\end{array}$ & $\begin{array}{r}269 \\
79 \\
275\end{array}$ & $\begin{array}{r}197 \\
237\end{array}$ \\
\hline 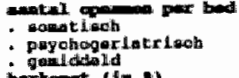 & $\begin{array}{l}1,32 \\
0,35 \\
0,91 \\
0,112\end{array}$ & $\begin{array}{l}1,34 \\
0,42 \\
0,96\end{array}$ & $\begin{array}{l}1,79 \\
0,36 \\
0,911\end{array}$ & $\begin{array}{l}1,13 \\
0,34 \\
0,94\end{array}$ & $\begin{array}{l}1,05 \\
0,30 \\
0,77\end{array}$ & $\begin{array}{l}0,97 \\
0,53 \\
0,78\end{array}$ & $\begin{array}{l}0,04 \\
0,3,316 \\
0,0,5\end{array}$ & $\begin{array}{l}0,73 \\
0,39 \\
0,70\end{array}$ & $\begin{array}{l}0,75 \\
0,38 \\
0,55\end{array}$ \\
\hline 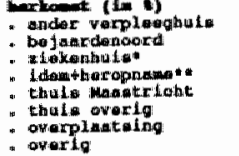 & $\begin{array}{r}0,0 \\
4,4 \\
12,0 \\
16,0 \\
3,9 \\
3,9 \\
7,2 \\
7,7\end{array}$ & 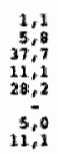 & $\begin{array}{r}1,7 \\
7,0 \\
34,8 \\
13,8 \\
15,0 \\
9,2 \\
4,7 \\
13,6\end{array}$ & $\begin{array}{r}2,1 \\
5,4 \\
32,1 \\
11,7 \\
22,8 \\
4,2 \\
4,8 \\
10,8\end{array}$ & $\begin{array}{r}6,2 \\
5,6 \\
3,0 \\
9, \\
21,6 \\
3,3 \\
1,6 \\
9,2\end{array}$ & $\begin{array}{r}3,2 \\
1,0,9 \\
12,3 \\
16,7 \\
39,6 \\
4,7 \\
1,3 \\
11,6\end{array}$ & $\begin{array}{r}0,8 \\
12,9 \\
30,7 \\
19,1 \\
18,9 \\
4,7 \\
2,3 \\
3,5\end{array}$ & $\begin{array}{r}1,6 \\
10,18 \\
31,18 \\
10,3 \\
21,1 \\
5,1 \\
4,3\end{array}$ & $\begin{array}{r}2,6 \\
11,1 \\
44,0 \\
12,0 \\
10,0 \\
7,7 \\
3,0\end{array}$ \\
\hline
\end{tabular}

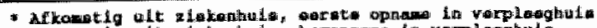

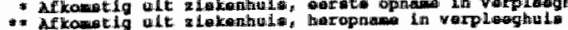


Het aantal opnemingen per bed is als gevolg van de verminderde doorstroming drastisch gedaald, met name op somatische afdelingen (van 1,32 in 1980 tot 0,75 in 1988). Bif de psycho-geriatrische afdelingen treedt stabilisering op rond 0,4 opnamen per bed. Van de in 1988 opgenomen personen $(N=234)$ is $44 \%$ afkomstig uit het ziekenhuis en komt nog eens 12\% uit het ziekenhuis, maar was daarvoor al opgenomen in het verpleeghuis. Zo'n (tijdelijk) verblijf in hel ziekenhuis duurde in het verleden gemiddeld 8 a 9 dagen, maar in 1988 is dalt toegenomen tot gemiddeld $11 \frac{112}{2}$ dag (betreft 28 patienten). Ongeveer een kwart komt uit de eigen thuissituatie, in ongeveer $70 \%$ van de gevallen binnen de gemeente Maastricht. Van hen maakte overigens al $30 \%$ gebruik van dagbehandeling in hetzelfde verpleeghuis (niet getegistreerd bij instroom in de kliniek, maar afgeleid uit ontslaggegevens van dagbehandeling; zie aldaar). In totaal komt in $19888,1 \%$ vanuit de dagbehandeling, maar in de periode daarvoor was dat aandeel enigszins hoger (10\% à 11\%). Bejaardenoorden worden bij de instroom in het verpleeghuis steeds belangrijker; in 1980 was slechts $4,4 \%$ afkomstig wit een tehuis, maar in 1988 is dat ruim $11 \%$. Dit is echter een relatieve toename, ondat het totaal aantal opnamen (de noemer) gedaald is. Echter, met name in de periode $1985-1987$ kwam toch een groot deel uit bet bejaardenoord.

Zowel in de herkomst bij instroom als in de bestemming bij ontslag worden in de tabellen steeds de interne overplaatsingen meegeteld. Hierop wordt thans kort ingegaan. Interne overplaatsingen kwamen met name in het begin van de onderzochte periode vrij veelvuldig voor en betroffen toen 20 a 25 patienten (circa $5 \%$ van de instroom). Thans zijn er op jaarbasis circa 10 overplaatsingen. Ongeveer $80 \%$ a $85 \%$ daarvan loopt van somatische naar psycho-geriatrische afdelingen en betreft patienten bij wie na verloop van tijd naast lichamelijke gebreken ook psycho-sociale problemen, zoals dementie, aan het licht komen. De afname van het aantal owerplaatsingen zou er wellicht op kunnen wijzen dat er ook op de somatische afdelingen steeds meer psycho-sociale problemen optreden, zodat alleen de allerzwaarste patienten nog worden overgeplaatst.

Tabel 11.6 geeft een overzicht van de bestemming van de patienten bij ontslag uit het verpleeghuis. Daarbij moet overigens worden opgemerkt dat de gegevens jaarlijks sterk kunnen varieren. In 1988 zijn de ontslagredenen als volgt verdeeld $(N=233)$ : bijna $60 \%$ wordt uitgeschreven ten gevolge wan overlijden, bijna $17 \%$ gaat naar het ziekenhuis, bijna $11 \%$ gaat terug naar huis, $7 \%$ naar een verzorgingstehuis en nog eens $3 \%$ naar een ander verpleeghuis. Dat laatste betreft vanaf 1987 vrijwel uitsluitend het nieuwe verpleeghuis De Zeven Bronnen, dat deel is van dezelfde stichting en in 1987 de deuren opende. Ook bij deze gegevens wordt de eventuele bestemming "naar huis plus dagbehandeling' niet geregistreerd, maar is afgeleid uit gegevens van de dagbehandeling zelf.

Samenvattend blijkt er een tendens te zijn dat steeds meer mensen in het verpleeghuis over\ijden, dat veel mensen niet alleen uit het ziekenhuis komen (meer dan de helfi), maar daar

Tabel 11.6. Ontslagen patiënten naar bestemming

\begin{tabular}{|c|c|c|c|c|c|c|c|c|c|}
\hline & 1960 & 1981 & 1982 & 1983 & 1984 & 1985 & 1986 & 1987 & 1988 \\
\hline $\begin{array}{l}\text { aratial ontglagen pat idinten } \\
\text { beatemming (in } \% \text { ) }\end{array}$ & 363 & 374 & 36.3 & 335 & 304 & 310 & 255 & 276 & 233 \\
\hline 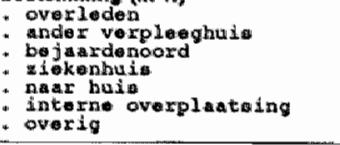 & 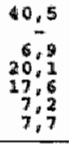 & $\begin{array}{r}44,1 \\
0,3 \\
7,0 \\
17,4 \\
16: 8 \\
9 ; \\
9,3\end{array}$ & $\begin{array}{r}40,8 \\
0,3 \\
16,3 \\
16: 6 \\
15: 7 \\
15: 7 \\
\end{array}$ & $\begin{array}{r}5,1 \\
0,3 \\
5,9 \\
17,9 \\
14,6 \\
4,8 \\
10,4\end{array}$ & $\begin{array}{r}53,3 \\
10,2 \\
12: \frac{1}{14} \\
14: \frac{1}{7}\end{array}$ & $\begin{array}{r}57, \frac{1}{3} \\
5,3 \\
21,6 \\
11 ; 9 \\
1,9 \\
1,3\end{array}$ & $\begin{array}{r}55,7 \\
7,7 \\
23,5 \\
21,9\end{array}$ & $\begin{array}{c}49,6 \\
5: 18 \\
5: 1 \\
22,1 \\
13,0 \\
4 ; 3\end{array}$ & $\begin{array}{r}59: 9 \\
3: 0 * \\
6: 9 \\
16: 7 \\
3: 9\end{array}$ \\
\hline
\end{tabular}

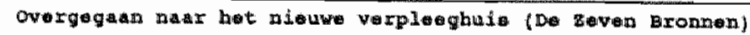


Tabel 11.7. Productie van de dagbehandeling in aantall verpleegdagen

\begin{tabular}{|c|c|c|c|c|c|c|}
\hline & man. & 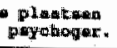 & $\begin{array}{l}\text { belbandol } \\
\text { abogyn }\end{array}$ & $\begin{array}{l}\text { vaurgriab } \\
\text { p. gi. }\end{array}$ & 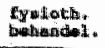 & 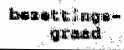 \\
\hline $\begin{array}{l}1901 \\
1981 \\
1.982 \\
1983 \\
1984 \\
1988 \\
1908 \\
1987 \\
1980\end{array}$ & $\begin{array}{l}15 \\
15 \\
15 \\
15 \\
15 \\
15 \\
15 \\
18 \\
18\end{array}$ & $\begin{array}{l}13 \\
13 \\
13 \\
13 \\
13 \\
13 \\
13 \\
14 \\
16\end{array}$ & $\begin{array}{l}8.936 \\
6.910 \\
6.940 \\
7.908 \\
7.090 \\
6.956 \\
6.961 \\
7.362 \\
7.713\end{array}$ & 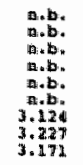 & 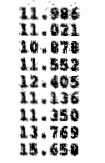 & 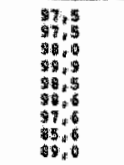 \\
\hline
\end{tabular}

ook weer naar terug gaan (circa een vijfde) en dat het aandeel van de mensen die weer naar huis gaan, in de loop van de jaren geleidelijk is afgenomen. Enerzijds vormt het verpleeghuis voor steeds meer mensen de laatste leefsituatie, anderzijds worden ook bij het verpleeghuis de patientstromen van en naar de andere voorzieningen steeds belangrijker.

\subsection{Dagbehandeling in het verpleeghuis}

Vanuit Klevarie (nfet in Vijverdal) wordt ook de mogelijkheid tot dagbehandeling aangeboden, waarmee beoogd wordt mensen die wel een verpleeghuisindicatie hebben, maar die de avond-, nacht- en weekendverzorging nog gewoon thuis kunnen krijgen, te reactiveren en te resocialiseren teneinde opneming in het verpleeghuis uit te stellen of te voorkomen. In Maastricht, waar de dagbehandeling sinds 1 mei 1977 als voorziening wordt aangeboden, startte men met 28 plaatsen (waarvan 15 voor psycho-geriatrie). Thans zjjn er 34 erkende plaatsen, waarvan 18 voor somatische patiënten en 16 voor psycho-geriatrische patienten (47\%). De tot eind 1986 bestaande capaciteit was steeds vrijwel volledig bezet en leverde een 'produktie' van ongeveer 7.000 behandeldagen per jaar en gemiddeld bijna 11.500 fysiotherapeutische behandelingen. Opmerkelijk is dat de in 1987 erkende extra plaatsen niet ten volle benut worden, vooral op de psycho-geriatrische afdeling, waar het bezettingspercentage net onder de $80 \%$ ligt, hetgeen betekent dat de drie extra plaatsen niet gebruikt worden. Wellicht verbetert dit in de toekomst als gevolg van verdergaande vergrijzing.

Naast de in tabel 11.7 opgenomen fysiotherapeutische behandelingen worden in het kader van de dagbehandeling nog andere verrichtingen gedaan, namelijk laboratoriumonderzoek (ongeveer 400 per jaar) en logopedische behandelingen (bijna 500 maal). Voorts wordt in ruim $90 \%$ van de gevallen een warme maaltijd genuttigd en krijgt nog eens 3 a $4 \%$ een broodmaaltijd, zodat slechts een op de twintig bezoekers geen maaltijd krijgt. Slechts weinigen komen met eigen vervoer of worden door anderen gebracht, zodat woor ruim $90 \%$ het vervoer door de instelling verzorgd wordt.

Tabel 11.8. Frequentie (in $\%$ van totaal) bij dagbehandeling (bij per 31-12 aanwezige patiënten)

\begin{tabular}{|c|c|c|c|c|c|c|c|c|}
\hline & & 19012 & $19: 8.9$ & 1906 & 1985 & 1966 & 1967 & 198 \\
\hline $\begin{array}{l}1 x \\
2 x \\
9 x \\
4 x \\
5 x\end{array}$ & 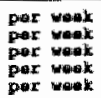 & $\begin{array}{r}7,1 \\
62,5 \\
23,2 \\
3,6 \\
33_{4}\end{array}$ & $\begin{array}{r}9,3 \\
70,0 \\
15,0 \\
3,3 \\
3,3\end{array}$ & $\begin{array}{r}18,0 \\
70,5 \\
6,6 \\
1,9\end{array}$ & $\begin{array}{r}12,5 \\
70,3 \\
1.2,5 \\
1,7\end{array}$ & $\begin{array}{r}7,5 \\
71,4 \\
115\end{array}$ & $\begin{array}{r}5,2 \\
69,0 \\
19,0 \\
5,9\end{array}$ & $\begin{array}{r}1.7 \\
68.6 \\
17.2 \\
7,6 \\
7.6\end{array}$ \\
\hline$g e:$ & athellold & 2,34 & 2,23 & 2,03 & 2,14 & 2,242 & 2,34 & 2,39 \\
\hline
\end{tabular}


Tabel 11.9. Leefijdsverdeling man de aamwezige patiênten per 31 december

\begin{tabular}{|c|c|c|c|c|c|c|c|c|c|}
\hline & L1:0 & 151 & $1 \$ 12$ & 1983 & $194+4$ & 19.85 & 1986 & 1987 & 1908 \\
\hline 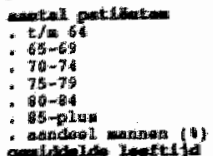 & $\begin{array}{r}51 \\
1.3 \\
6 \\
8 \\
1.3 \\
12 \\
5 \\
55,2\end{array}$ & $\begin{array}{r}6 . \\
1.4 \\
6 \\
9 \\
8 \\
1.7 \\
7 \\
41.4\end{array}$ & $\begin{array}{r}10 \\
7 \\
10 \\
110 \\
11.1 \\
11.1\end{array}$ & $\begin{array}{r}60 \\
18 \\
6 \\
14 \\
12 \\
0 \\
6 \\
10 \\
140\end{array}$ & $\begin{array}{l}6: 1 \\
14 \\
5 \\
10 \\
11 \\
14 \\
5.5\end{array}$ & 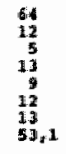 & $\begin{array}{c}67 \\
13 \\
7 \\
13 \\
13 \\
5 \\
6 \\
47,6\end{array}$ & $\begin{array}{l}58 \\
10 \\
11 \\
12 \\
11 \\
6: \\
51,4\end{array}$ & $\begin{array}{c}64 \\
11 \\
8 \\
11 \\
9 \\
16 \\
93,1\end{array}$ \\
\hline 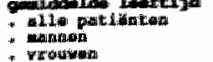 & $\begin{array}{l}74 \\
71 \\
77\end{array}$ & $\begin{array}{l}72,5 \\
70 \\
76\end{array}$ & $\begin{array}{l}71,5 \\
710 \\
76\end{array}$ & $\begin{array}{l}7,6 \\
70,6 \\
70,6\end{array}$ & $\begin{array}{l}73,4 \\
71,4 \\
76,5\end{array}$ & $\begin{array}{l}74 ; 4 \\
73: 2 \\
75,7\end{array}$ & $\begin{array}{l}72.3 \\
70.3 \\
74\end{array}$ & $\begin{array}{l}72,1 \\
70,5 \\
74,5\end{array}$ & $\begin{array}{l}7.3_{14} 9 \\
72 \\
76\end{array}$ \\
\hline
\end{tabular}

De meeste patienten (ongeveer 2/3) komen twee maal per week naar de dagbehandeling. Het gemiddeld aantal bezoeken, gemeten bij de aan het eind van het jaar aanwezige patienten, daalde aanwankelijk van ruim 2,3 tot 2,0 bezoeken per week, maar ligt thans weer jets boven het uitgangsniveau, namelijk op gemiddeld 2,39 bezoeken per patient (tabel 11.8).

Gezien het feit dat de behandelfrequentie per patiént varieert, maar zelden meer dan drie dagen per week is, kunnen met de capaciteit van 34 plaatsen veel meer mensen per week geholpen worden. Gemiddeld zijn er in de periode 1980-1988 per peildatum (31 december) ongeveer 60 patienten aanwezig. In het begin van deze periode was ruim $22 \%$ jonger dan 65 jaar, thans is dat enigszins teruggelopen tot ruim $17 \%$. De gemiddelde leeftijd bedraagt ruim 73 jaar en is 6 a 7 jaar lager dan bij in de kliniek opgenomen patienten. Bij dagbehandeling is het aandeel van mannen hoog (gemiddeld $50 \%$ ). Ook nationaal wordt een groot aandeel van mannen gezien (circa $47 \%$ ).

In vergelijking met de nationale gegevens over de herkomst van dagbehandelingspatienten zijn enkele verschillen te constateren, die kort aangestipt worden. Allereerst komt het ziekenhuis als plaats van herkomst in de rest van Nederland (2\%) haast niet voor, maar betreft dat in Maastricht ongeveer een vijfde van alle patienten. Het bejaardenoord en het verpleeghuis worden in Maastricht eveneens iets vaker genoemd. Rechtstreeks vanuit de eigen omgeving wordt in Maastricht echter veel minder vaak een patient opgenomen dan nationaal; in 1988 betreft het in Maastricht $49 \%$ en in de rest van Nederland $75 \%$ van alle patienten. Wellicht kan een deel van de verschillen verklaard worden uit het feit dat zij in Maastricht de aanwezige patienten betreffen en in Nederland geregistreerd zijn bij eerste opname van verpleegde patienten. De ontslaggegevens betreffende de bestemming wijken eveneens af van nationale gegevens. Ook hierbij wordt in Maastricht veel vaker het ziekenhuis opgegeven $(26,4 \%$ in 1988 versus $4 \%$ ), terwijl een ontslag naar de thuissituatie of naar een bejaardenoord minder vaak wordt genoemd.

Tabel 11.10. Herkomst bij opname en bestemming bij ontslag dagbehandeling

\begin{tabular}{|c|c|c|c|c|c|c|c|c|c|}
\hline & 1980 & 1981 & 1.902 & 1.983 & 1984 & 1085 & 1986 & 1967 & 19818 \\
\hline \multicolumn{10}{|l|}{ warlinguet (a) } \\
\hline 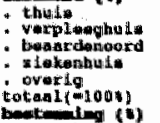 & $\begin{array}{r}1,9,5 \\
15,10 \\
14,2 \\
10,2 \\
2,4 \\
127\end{array}$ & $\begin{array}{l}11,7 \\
27,4 \\
20,0 \\
20,1 \\
140\end{array}$ & $\begin{array}{l}16,2 \\
1,2,5 \\
20,0 \\
10,6 \\
0,7 \\
1,8\end{array}$ & $\begin{array}{r}42,4 \\
12,4 \\
21,4 \\
19,2 \\
0.8 \\
1125\end{array}$ & $\begin{array}{r}53,7 \\
9,7 \\
25,4 \\
11,2 \\
134\end{array}$ & $\begin{array}{r}13+7 \\
13+3 \\
22+2 \\
20,7 \\
135\end{array}$ & $\begin{array}{r}50,3 \\
0,7 \\
18,2 \\
19,5 \\
3,8 \\
119\end{array}$ & $\begin{array}{r}10,0 \\
1.3,4 \\
1.15,9 \\
248,2 \\
3,5 \\
142\end{array}$ & $\begin{array}{r}48,8 \\
7,5 \\
24,4 \\
13,1 \\
9,9 \\
127\end{array}$ \\
\hline 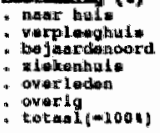 & $\begin{array}{l}30,0 \\
13,3 \\
15,5 \\
33,3 \\
2,5 \\
5, \\
120\end{array}$ & $\begin{array}{r}31,3 \\
21,3 \\
1.8,1 \\
21,3 \\
1,3 \\
1,4 \\
1.1\end{array}$ & $\begin{array}{r}31,3 \\
20,7 \\
21,3 \\
21,3 \\
1,0 \\
1,3 \\
1.50\end{array}$ & $\begin{array}{r}30,6 \\
21,5 \\
24,0 \\
19.8 \\
0,8 \\
3,3 \\
121\end{array}$ & $\begin{array}{r}31,8 \\
17,3 \\
24,8 \\
18,8 \\
2,3 \\
3,0 \\
1039\end{array}$ & $\begin{array}{l}31,41 \\
20,5 \\
25,0 \\
21,2 \\
0,8 \\
1,5 \\
132\end{array}$ & $\begin{array}{r}34,7 \\
19,3 \\
18,0 \\
24,0 \\
3,3 \\
0,7 \\
15,0\end{array}$ & $\begin{array}{r}22,8 \\
21,8 \\
12,6 \\
37,2 \\
4,8 \\
2,0 \\
1,9\end{array}$ & $\begin{array}{r}20,1 \\
22,3 \\
19,8 \\
26,8 \\
4,7 \\
0,8 \\
121\end{array}$ \\
\hline
\end{tabular}


Tenstotte wordt beknopt ingegaan op bet bereik van dagbehandeling, eveneens ten opzichte van de Maastrichtse in plaats van de regionale bevolking. Allereerst wordt opgemerkt dat bij vergelijking met de landelijk gellende normen het aantal beschikbare plaatsen (uitgedrukt in promillage van de 65-plussers en na aftrek van 0,02 plaatsen per 1000 inwoners voor de somatische plaatsen) uitkomt op 1,9 promille tegen een norm van in totaal 1,5 promille (gelijkelijk verdeeld over somatische en psycho-geriatrische plaatsen). De resterende 0,4 promille zou ten goede moeten komen aan patienten van butten de gemeentelijke, maar binnen de regionale grenzen. Het totale bereik ten opzichte van de Maastrichtse bevolking ligt thans op 3,2 promille; het sexeverschil is precies andersom dan bij veel voorzieningen gebruikelijk is ( 4,2 en 2,5 promille voor mannen respectievelijk vrouwen).

Samenvattend kan gesteld worden dat de dagbehandeling een niet meer weg te denken woorziening in de ouderenzorg betreft, die eigenlijk het karakter heeft van een "tussenstation". Bij instroom in de dagbehandeling komt de helft uit de eigen woonomgeving, waarheen slechts $25 \%$ tot $30 \%$ terugkeert. Twee andere belangrijke 'leveranciers', maar tevens 'afnemers' zijn respectievelijk het bejaarderoord en het ziekenhuis. Het karakter van 'tussenstation' wordt vooral gellustreerd met de uitstroom naar het verpleeghuis zelf (in $198822,3 \%$ ), waarvoor dagbehandeling derhalve niet als substituut optreedt, maar voor een gedeelte van de patienten eigenlijk een 'wachtkamer' is en slechts leidt tot uitstel van uiteindelijk een echte opname in het verpleeghuis (Nuy e.a., 1984).

\subsection{Personeel en kosten verpleeghuiszorg in Maastricht}

Voor een overzicht van het personeel in en de kosten van de verpleeghuiszorg in Maastricht beperken wij ons geheel tot Klevarie. De totale fulltime personeelsformatie betreft in 1988 440 plaatsen en is sinds 1981 gestegen met in totaal $13 \%$, ondanks een stabilisatie en zelfs inkrimping in 1984. Gediplomeerde ziekenverzorgenden vormen met $31 \%$ de grootste categorie, gevolgd door de categorie huishoudelijk en technisch personeel (23\%). Deze laatste personeelscategorie is in 1988 fors uitgebreid, waarmee bijna de gehele formatiegroei van dat jaar verklaard wordt. Verdere vermeldenswaardige trends betreffen (a) de afname van het aantal ziekenverzorgenden in opleiding van $25 \%$ aan het begin van de onderzochte periode tot $21 \%$ in 1988 , (b) de groel van de overigens op zich bescheiden groep overig algemeen personeel $(2,2 \%)$ en (c) het wisselvallige verloop bij het overige verzorgende personeel. Tenslotte kan vermeld worden dat de laatste twee jaar steeds meer personeel wordt ingezet dat niet in vaste loondienst is.

De kosten van de verpleeghuissector bedragen ruim 28 miljoen guldens op jaarbasis. In deze kosten, waarin ook de lasten van dagbehandeling werden opgenomen, zijn de perso-

Tabel 11.11. Personeel in verpleegkliniek Klevarie in de periode 1981-1988

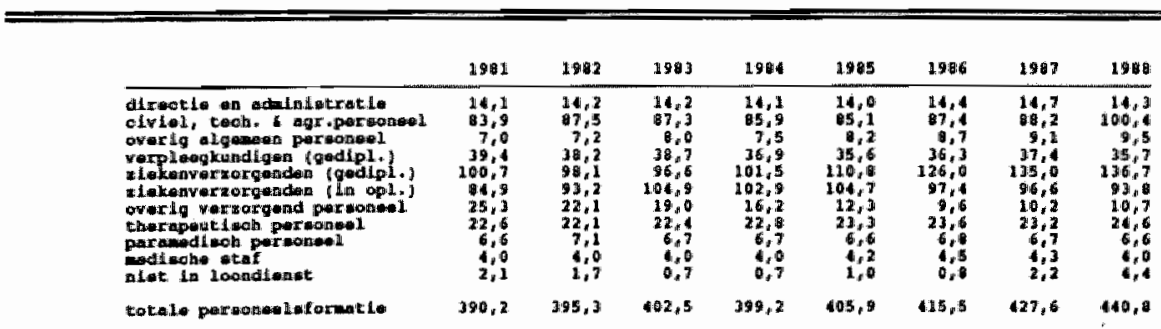


neelstasten (inclusief sociale lasten) verreweg het belangrijkste en dat gedurende de beschouwde periode bovendien in steeds grotere mate. In 1980 was het aandeel van de totale personeelslasten nog circa $63,5 \%$ en aan het eind is dat opgelopen to $69,9 \%$.

De op een na belangrijkste kostenpost vormt de post interest en afschrijvingen op gebou-

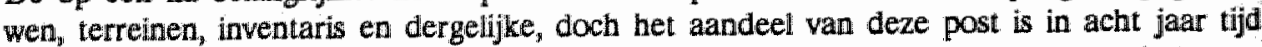
gehalveerd $\operatorname{van} 21,3 \%$ in 1980 tot $11,1 \%$ in 1988 . De in het begin van de periode nog voortdurende afschrijvingen op het oude gebouw van de kliniek zijn debet aan het toen nog grote aandeel van de afschijvingen in de totalle kosten. Relatief toegenomen zijn algemene kosten, voedingskosten, kosten van medische en andere verzorgingsmiddelen en de kosten van onderhoud. De negatieve kosten via doorberekeningen en bedrijwen (in feite dus meeropbrengsten van bijvoorbeeld maaltijden en verhuur van verpleegstersflats) zijn de laatste jaren aanzienlijk lager dan aan het begin van de jaren tachtig.

Voor de financiering ontvangt het verpleeghuis sinds 1985 een extern budget dat wordt vastgesteld door het Centraal Orgaan Tarieven Gezondheidszorg (COTG). Dit budget is afhankelijk van vooraf gemaakte produktieafspraken met het verbindingskantoor van de AWBZ. Voor Maastricht is dat het Ziekenfonds Zuidelijk Zuid-Limburg. De tarifering door het COTG leidt er toe dat er tussen Klevarie en andere verpleeghuizen in Nederland nauwelijks verschillen bestaan in de opbouw van de kosten per verpleegdag; deze bedragen iets meer dan $f 200$ per dag en bij dagbehandeling bestaat wordt een tarief van $f 122$ per dag.

\subsection{Samenvatting: vergelijking van lokale met nationale ontwikkelingen}

Als afronding van dit hoofdstuk wordt op hoofdijnen een beknopte vergelijking gemaakt tussen de gegevens voor Klevarie en de nationale gegevens over verpleeghuizen. (In paragraaf 11.1 is de beperking tot het genoemde verpleeghuis toegelicht.) Allereerst blijkt het bereik van de voorziening in procenten van de bevolking geen verschil te vertonen: er is weinig fluctuatie en het bereik loopt sterk op met de leeftijd van $1 \%$ tot 75 jaar tot $9 \%$ voor 85-plus. Ook de demografische kenmerken van patienten verschillen nauwelijks. De gemiddelde leeftjjd is ongeveer 80 jaar, maar bij psycho-geriatrische patienten ongeveer 4,5 jaar hoger dan bij somatische patienten (er is een zelfde verschil tussen mannen en vrouwen) en de gemiddelde verbliffscluur is 2,5 jaar (gemeten bij de per 31 december aanwezige patienten), maar bij psycho-geriatrische patienten ongeveer anderhalf maal langer dan bij somatisch zieken.

Tabel 11.12. Kosten verpleeghuis 1980-1981 (x $f$ 1000,-)

\begin{tabular}{|c|c|c|c|c|c|c|c|c|c|}
\hline & 1980 & 1018 & 1982 & 1903 & 1984 & 1905 & 1996 & 1987 & $198: 8$ \\
\hline 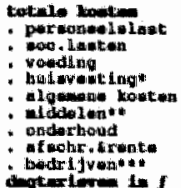 & $\begin{array}{r}27610 \\
1161.3 \\
5996 \\
1091 \\
1762 \\
675 \\
700 \\
6314 \\
5890 \\
-759\end{array}$ & $\begin{array}{r}20017 \\
11922 \\
5974 \\
2110 \\
2027 \\
753 \\
914 \\
7315 \\
5417 \\
-667\end{array}$ & $\begin{array}{r}29717 \\
12707 \\
5177 \\
1202 \\
2316 \\
920 \\
797 \\
723 \\
1265 \\
-830\end{array}$ & $\begin{array}{r}29220 \\
13019 \\
6221 \\
1164 \\
2274 \\
840 \\
762 \\
753 \\
5496 \\
-909\end{array}$ & 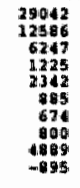 & $\begin{array}{r}28391 \\
13173 \\
5110 \\
1277 \\
2334 \\
871 \\
732 \\
853 \\
4230 \\
-500\end{array}$ & $\begin{array}{r}20626 \\
14297 \\
5096 \\
1259 \\
2070 \\
982 \\
750 \\
939 \\
3803 \\
-566\end{array}$ & $\begin{array}{r}20422 \\
14737 \\
5041 \\
1255 \\
2067 \\
914 \\
797 \\
957 \\
3150 \\
-523\end{array}$ & $\begin{array}{r}20156 \\
15069 \\
4610 \\
120 \\
2036 \\
958 \\
806 \\
995 \\
3121 \\
-543\end{array}$ \\
\hline 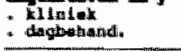 & 105,60 & $\begin{array}{l}192,75 \\
1,13,7\end{array}$ & $\begin{array}{l}202.200 \\
110^{2}=\end{array}$ & $\begin{array}{l}97,00 \\
119,-0\end{array}$ & $\begin{array}{l}201,90: \\
120 x^{-}\end{array}$ & $\begin{array}{l}201,000 \\
1120, \ldots\end{array}$ & $\begin{array}{l}2016,50 \\
122=\end{array}$ & & $\begin{array}{l}202,50 \\
122,=\end{array}$ \\
\hline
\end{tabular}

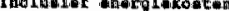

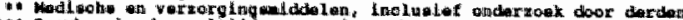

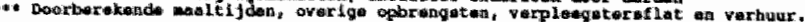


De herkomst van patienten kent wel geringe lokale afwijkingen: in Maastricht wordt het ziekenhuis iets minder vaak genoemd ( $44 \%$ versus $57 \%$ ), het bejaardenoord komt ongeveer even vaak voor (11\%) en de thuissituatie is in Maastricht een lets belangrijkere 'leverancier'. Overigens wordt in Maastricht een extra onderscheid gemaakt ten aanzien van patienten die na een ziekenhuis opnieuw in het verpleeghuis worden opgenomen (in $1988 \mathrm{gold}$ zo"n heropname voor $12 \%$ ). Bij de herkomst van dagbehandelingspatienten zijin de verschillen ten opzichte van de nationale gegevens veel groter: in Maastricht wordt het ziekenhuis als plaats van herkomst bij ongeveer een vijfde genoemd, maar komt in de rest van Nederland (2\%) haast niet voor; het bejaardenoord en het verpleeghuis worden in Maastricht eveneens iets vaker genoemd; vanuit de eigen omgeving komt in Maastricht $49 \%$ en landelijk $75 \%$ van alle patienten. Wellicht kan een deel van de verschillen verklaard worden uit het feil dat zij in Maastricht de aanwezige patienten betreffen en in Nederland geregistreerd zijn bij eerste opname van de verpleegde patiénten.

Bij dagbehandeling wijken de ontslaggegevens inzake de bestemming eveneens af van nationale gegevens. Ook hierbij wordt in Maastricht veel vaker het ziekenhuis opgegeven (26,4\% in 1988 versus $4 \%$ ), terwijl een ontslag naar de thuissituatie of naar een bejaardenoord minder vaak genoemd wordt. Net als nationall, is het aandeel van mannen in dagbehandeling relatief hoog ( $53 \%$ in Maastricht en $46 \%$ in de rest van Nederland). De frequentie voor dagbehandeling per patient is zowel nationaal als lokaal ongeveer 2,4 bezoeken per week.

Tot slot zijn er nauwelijks verschillen in de opbouw van de kosten per verpleegdag die iets meer dan $f 200$ per dag bedragen en bij dagbehandeling een vast tarief van $f 122$ kennen. 


\section{Samenvatting aanbodbeschrijving}

\subsection{Inleiding}

In dit hoofdstuk worden bij wijze van afronding enkele kernelementen uit de voorgaande hoofdstukken samengevat in de vorm van een leeftijdsspecifiek overzicht van het gebruik door ouderen van de basisvoorzieningen in de gemeente Maastricht en de daaraan verbonden totale kosten, die via het aandeel van ouderen in de 'produktie' toegerekend worden aan de ouderenzorg. Vervolgens wordt een tentatieve benadering gemaakt van het aandeel dat de verschillende zorgfuncties hebben in de kosten.

\subsection{Bereik van voorzieningen}

In de voorgaande hoofdstukken is een beschrijving gegeven wan de belangrijkste voorzieningen voor owderen, waarbij gegevens gepresenteerd zijn over de omvang van het gebruik, de kenmerken van gebruikers, het personeel en de kosten van dienstverlening. Achtereenvolgens gebeurde dat voor de gezinsverzorging, de wijkverpleging, het gecoordineerd ouderenwerk, de bejaardenoorden (inclusief indicatiecommissie en wijkfuncties) en het verpleeghuis (inclusief dagbehandeling). In tabel 12.1 wordt het leeftijdsspecifieke gebruik van deze voorzieningen in beeld gebracht voor 1988, het eindjaar van de in het onderhavige onderzoek bestudeerde periode. Per leeftijdscategorie van vijfjaars-intervallen is aangegeven hoeveel procent van de Maastrichtse ouderen gebruik maakt van de geselecteerde voorzieningen. Over het algemeen stijgt het bereik van de voorzieningen met de leeftijd, maar hierop bestaan enkele belangrijke uitzonderingen. Het bereik van de alpha-hulp neemt in de oudste leeftijdscategorie af en wel zo sterk dat ook het bereik van de totale gezinsverzorging, ondanks een lichte stijging bij de traditionele hulpverlening, eveneens afneemt bij 85-plus. De tweede uitzondering op het algemene patroon betreft het bereik van de

Tabel 121. Leeftijdsspecifiek bereik van voorzieningen in Maastricht in 1988

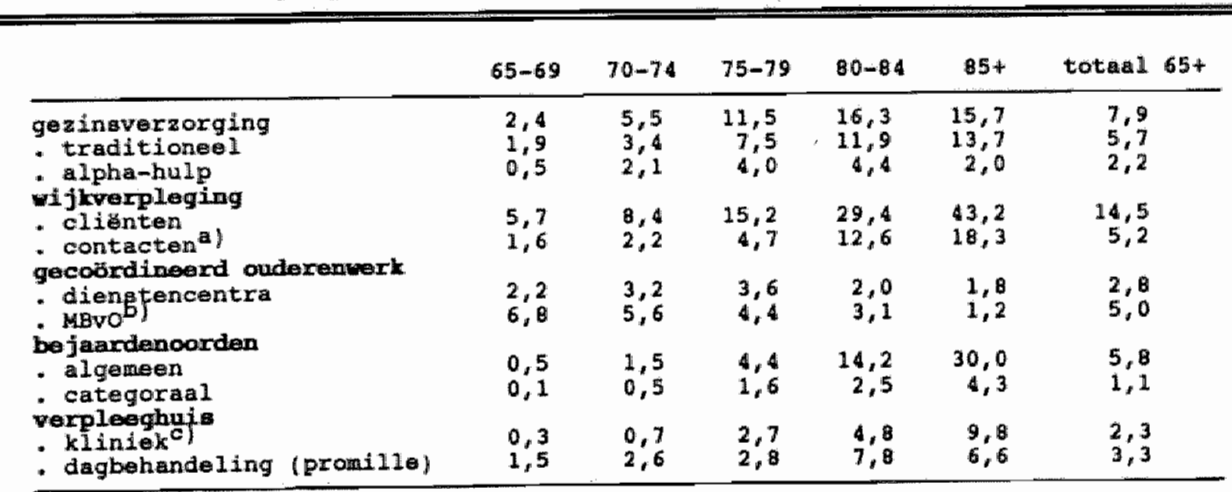

a) gemiddeld aantal contacten per inwoner

b) bron: Eujjeman, 1989 b

c) ook een regionale functie 
dienstencentra en het Meer Bewegen woor Ouderen (waarover elders gerapporteerd is; zie Huijsman, 1989d) dat daait met de oplopende leeftijdsgroepen. Tenslotte kan vermeld worden dat ook het bereik van dagbehandeling (in promillages) in de oudste categorie (85plus) afneemt. Ten opzichte van de in hoofdstuk 4 gepresenteerde landelijke gegevens (zie tabel 4.16) kunnen voor Maastricht de volgende vergelijkingen gemaakt worden. Het bereik van de gezinswerzorging en de wijkverpleging is in beide situaties ongeveer gelijk. Bij gezinsverzorging wordt voor 65 -plus op landelijk niveau een bereik van $7,7 \%$ en in Mrastricht van $7,9 \%$ gevonden. Ten opzichte van de landelijke gegevens is echter in het onderhavige onderzoek een minder scherpe teruggang voor 85 -plus gevonden $(15,7 \%$ versus $12,2 \%$ ). In dit onderzoek is het bovendien mogelijk een onderscheid te maken tussen de puur huishoudlelijke alpha-bulp en andere vormen van gezinsverzorging, betgeen landelijk niet mogelijk is. Met betrekking tot de wijkverpleging worden in het onderhavige onderzoek meer gedetailleerde gegevens beschikbaar dan landelijk mogelijk was (daar in 10-jaarsintervallen vanaf 60 jaar). Globaal zijn er geen verschillen in beide clientreeksen waar te nemen, uitgezonderd het in Maastricht enigszins lagere bereik in de cattegorieen van $70 \mathrm{t} / \mathrm{m}$ 79 jaar. Het gemiddeld aantal contacten per hoofd van de bevolking (de tweede methode van bereikmeting bij wijkverpleging) ligt in Maastricht echter wel op een enigszins hoger niveau, met name in de twee hoogste leeftijdscategorieen. Samenvattend lijkt geconcludeerd te kunnen worden dat bet bereik van de twee belangrijkste extramurale voorzieningen in Maastricht bij hoogbejaarden (85+) op een hoger niveau ligt dan het landelijk gemiddelde. Het bereik van bejaardenoorden in de groep van 85 -plussers in Maastricht $(34,3 \%$ inclusief categorale bejaardenoorden) is daarentegen lager dan nationaal (37,1\%). Hetzelfde, zij het in mindere mate, gat op voor het verpleeghuis $(9,8 \%$ versus $10,5 \%)$, waarbij bovendien aangetekend wordt dat het bereik in Maastricht enigszins overschat wordt, omdat niet gecorrigeerd werd voor de regionale functie van deze voorziening. De dagbehandeling kent in Maastricht een enigszins hoger bereik $(6,6 \%)$ dan landelijk vermeld werd (5\%o).

Op basis van de gegevens uit tabel 12.1 en de eerder gepresenteerde demografische raming (zie hoofdstuk 2) kan een raming gemaakt worden van het aantal (oudere) gebruikers van voorzieningen in de gemeente Maastricht. De raming bij ongewijzigd beleid is gebaseerd op leeftijdsspecifieke berekeningen, die vervolgens gesommeend zijn voor alle 65-plussers. Door dit aantal te delen op het voor het jaar 2000 verwachte aantal ouderen, wordt het nieuwe bereikcijfer voor 65-plus verkregen (derde kolom in tabel 12.2).

De gemiddelde jaarlijkse procentuele toename dient beschouwd te worden in relatie tot dezelfde toename in de bevolking, vanaf 65 jaar, welke geraamd wordt op 1,47\%. In het Jaar 2000 zullen er dan naar verwachting 19.380 ouderen in de gemeente Maastricht woonachtig zijn (was 16.273 in 1988). Uit vergelijking tussen de groei in voorzieningengebruik enerzijds en de bevolkingsgroep anderzijds wordt duidelijk welke invloed de dubbele vergrijzing heeft op de verschillende voorzieningen. Bijna alle voorzieningen bereiken relatief veel hoogbejaarden, zodat de stijging in voorzieningengebruik boven de verwachte toename van het aantal 65 -plussers uitkomt. De enige uitzondering hierop betreft het gebruik van dienstencentra en Meer Bewegen voor Ouderen. Met name bij de bejaardenoorden en het verpleeghuis laat zich de dubbele vergrijzing goed voelen. Op grond van deze demografische raming bij ongewijzigd beleid, dient de capaciteit van de algemene en categoralle bejaardenoorden tezamen toe te nemen met énderde. Bij het verpleeghuis zouden er 115 plaatsen bij moeten komen (ruim 30\%), hetgeen al gedeeltelijk gerealiseerd is met de opening in 1989 van het tweede verpleeghuis in de gemeente Maastricht. De capaciteit daarvan is thans 120 plaatsen, maar zal op termijn met nog eens 60 plaatsen worden uitgebreid om in de regionale behoefte te voorzien (zoals die in de normen thans is vastgelegd). De tijdelijke erkenning van 65 bedden voor psycho-geriatrische patien in Vijverdal (zie hoofdstuk 11) zou volgens deze demografische raming wellicht voor een bellangrijk deel vervangen moeten worden door een structurele oplossing. Bij het voor- 


\begin{tabular}{|c|c|c|c|c|c|}
\hline & \multicolumn{2}{|c|}{ gebruik 1988} & \multicolumn{2}{|c|}{ gebrulk 2000} & \multirow{2}{*}{$\begin{array}{l}\text { toename per } \\
\text { jaar (in ) }\end{array}$} \\
\hline & berelk & antal & bereik & ante 1 & \\
\hline $\begin{array}{l}\text { gezingveriorging } \\
\text { traditioneel } \\
\text { alphe-hulp } \\
\text { ijleverpleglng }\end{array}$ & $\begin{array}{l}5,7 \\
2,2\end{array}$ & $\begin{array}{l}926 \\
366\end{array}$ & $\begin{array}{l}6,0 \\
2,3\end{array}$ & $\begin{array}{r}1159 \\
448\end{array}$ & $\begin{array}{l}1,69 \\
1,70\end{array}$ \\
\hline $\begin{array}{l}\text { - Cibunten } \\
\text { contacten } \\
\text { gecodrdineerd ouderenmerk }\end{array}$ & $\begin{array}{r}14,5 \\
5,2\end{array}$ & $\begin{array}{r}2355 \\
4295\end{array}$ & $\begin{array}{r}15,3 \\
5,5\end{array}$ & $\begin{array}{r}2972 \\
107467\end{array}$ & $\begin{array}{l}1,96 \\
2,04\end{array}$ \\
\hline $\begin{array}{l}\text { - dienetencentra } \\
\text { Bbro } \\
\text { bejandencorden }\end{array}$ & $\begin{array}{l}2,8 \\
5,0\end{array}$ & $\begin{array}{l}449 \\
821\end{array}$ & $\begin{array}{l}2,7 \\
4,9\end{array}$ & $\begin{array}{l}523 \\
9153\end{array}$ & $\begin{array}{l}1,28 \\
1,25\end{array}$ \\
\hline $\begin{array}{l}\text { algemean } \\
\text { catiegoraal } \\
\text { verpleaghuis }\end{array}$ & $\begin{array}{l}5,8 \\
1,1\end{array}$ & $\begin{array}{l}951 \\
163\end{array}$ & $\begin{array}{l}5,4 \\
1,3\end{array}$ & $\begin{array}{r}1242 \\
245\end{array}$ & $\begin{array}{l}2,25 \\
3,4\end{array}$ \\
\hline $\begin{array}{l}\text { KIiniek } \\
\text {. dagbehandeling (匆) }\end{array}$ & $\begin{array}{l}2,3 \\
3,3\end{array}$ & $\begin{array}{r}366 \\
53\end{array}$ & $\begin{array}{l}2,5 \\
3,4\end{array}$ & $\begin{array}{r}481 \\
6.6\end{array}$ & $\begin{array}{l}2,30 \\
1,84\end{array}$ \\
\hline
\end{tabular}

gaande dient echter wel de kanttekening geplaatst te worden dat de ramingen gemaakt zijn onder de veronderstelling dat andere belangrijke factoren constant blijven. In dit verband wordt bijwoorbeeld onder meer verondersteld dat de validiteitsverdeling en de daarop gebaseerde zorgbehoeften constant blijven en dat ook het consumptiepatroon niet veranderd. Van een verder doorvoeren van substitutie-mogelijkheden wordt dan ook op deze plaats geabstraheerd; eerder zagen wij echter dat deze mogelijkheden bij bejaardenoorden wel degelijk voor handen zijn (zie paragraaf 10.6).

\subsection{De kosten van ouderenzorg}

De kosten van de ouderenzorg in de gemeente Maastricht kunnen, analoog aan de berekening in hoofdstuk 4 voor geheel Nederland, benaderd worden op basis van het aandeel dat de 65-plussers hebben in de hulpverlening. Deze aandelen worden uitgedrukt in procenten van de produktieve uren bij de gezinsverzorging ( $99 \%$ bij alpha-hulp en $85 \%$ bij traditionele hulp), het aantal contacten bij de wijkverpleging $(78,3 \%)$, het aantal patienten bij de dagbehandeling $(82,8 \%)$ of bij opname in het verpleeghuis $(92,7 \%)$ of gelijk gesteld aan $100 \%$ bij gecoördineerd ouderenwerk, flankerend beleid en bejaardenoorden). Weliswaar is bij het gecoördineerd ouderenwerk getoond dat het aandeel van 'jongeren' bij de bezoekers van dienstencentra niet onaanzienlijk is (30\%), maar dit soort werk betreft slechts een klein deel van de werkzaamheden van het gecoordineerd ouderenwerk. Omdat enige benadering van het feitelijke aandeel van ouderen in de totale kosten van het GOW arbitrair zou zijn, is deze (even arbitrair) op $100 \%$ gesteld. In tabel 12.3 zijn de totale kosten van de besproken voorzieningen overgenomen uit de voorgaande hoofdstukken.

De kosten van ouderenzorg in de gemeente Maastricht bedragen bij henadering 72,4 miljoen gulden. Het grootste deel hiervan wordt in beslag genomen door de intramurale sectoren van bejaardenoorden en verpleeghuis $(75,6 \%)$. Landelijk wordt een iets hoger percentage $(81,2 \%)$ gevonden (zie hoofdstuk 4 ). In de extramurale sector is de gezinsverzorging verreweg de grootste post (14,9\% van de totale ouderenzorg). 
Tabel 123. Kosten van Maastrichtse voorzieningen in de ouderenzorg (in min.)

\begin{tabular}{|c|c|c|c|}
\hline & totale kosten & ouderenzorg & idem in \\
\hline 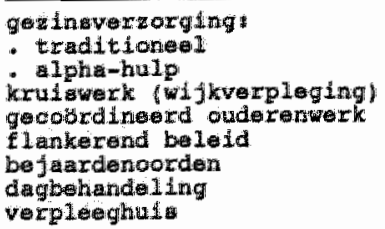 & $\begin{array}{r}11,0 \\
1,4 \\
6,2 \\
1,0 \\
0,2 \\
29,5 \\
0,9 \\
27,2\end{array}$ & $\begin{array}{r}9,4 \\
1,4 \\
4,9 \\
1,0 \\
0,2 \\
29,5 \\
0,0 \\
25,2\end{array}$ & $\begin{array}{l}85,3 \\
99,4 \\
78,3 \\
100 \\
100 \\
100 \\
82,8 \\
92,7\end{array}$ \\
\hline totad 1 & 77,4 & 72, & 93,5 \\
\hline
\end{tabular}

\subsection{Functionele benadering van personeelslasten}

In hoofdstuk 5 werd viteengezet welke functies onderscheiclen worden in de ouderenzorg. Deze functionele indeling is toegespitst op de werkzaamheden van functionarissen (zie vraag

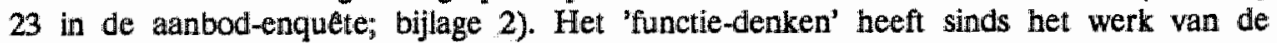
Commissie Structuur en Financiering in de Gezondheidszorg (Commissie Dekker, 1987) een belangrijke impuls gekregen, maar is voor een aantal voorzieningen tegelijkertijd nog nauwelijks empirisch onderzocht. Dit is wel gedaan voor een aantal voorzieningen zoals bejaardenoorden (Kibbeling e.a., 1988, 1989), of op basis van clientgegevens (SCP, 1988) of voor een bepaalde groep patienten, zoals terminale patiènten (Mejer, 1990). Ook (interne) budgetteringsmethoden zoals bij ziekenhuizen gehanteerd worden, kunnen als een functionele benadering van zorgverlening worden opgevat. Ondanks het aantrekkelijke perspectief van een functionele benadering van ouderenzorg bleken de instellingen nauwelijks in staat te zijn een goede benadering van de personeelsinzet per functie te geven. Wel bleek het mogelijk een globale aanduiding te geven van de gemiddelde tijdsbesteding over de tien functies in procenten van de totaal beschikbare tijd, zij het met marges van plus of min $5 \%$. De hier gepresenteerde gegevens dienen daarom voornamelijk als illustratie van de mogelijkheden van een gekwantificeerde functionele indeling van de ouderenzorg. Er kunnen derhalve slechts conclusies getrokken worden over de tendenties, zonder dat in dit stadium bijwoorbeeld op verantwoorde wijze kostprijzen voor een eenheid van een bepaalde functie tussen verschillende functies vergeleken kunnen worden.

Voor drie sectoren is het mogelijk gebleken de functionele indeling nader in te vullen, namelijk voor de gezinsverzorging, de wijkverpleging en de bejaardenoorden. De eerste twee zijn door de onderzoeker zelf geconcretiseerd op basis van de gepresenteerde gegevens over de aard van de hulpvertening (via de LIER-codes voor gezinsverzorging en de WAS-codes voor contactdoelen bij de wijkverpleging). Voor gezinsverzorging zijn additionele gegevens ontleend aan gegevens die door middel van dezelfde instellingsenquete verzamell zijn in de gemeente Venlo (De KJerk en Huijsman, 1990). Een viertal Maastrichtse bejaardenoorden is in de loop van de onderzoeksperiode bereid geweest (een poging te wagen om) de betreffende enquête-vraag te beantwoorden. Tabell 12.4. geeft een indruk van de verdeling van arbeidstijd per personeelscategorie over de verschillende functies. De onderscheiden functies (zie hoofdstuk 5) betreffen: (1) woon- en verblijfsfunctie, (2) preventiefunctie, (3) medische zorg, (4) verpleging, (5) revalidatie/reactivering, (6) persoonlijke verzorging, (7) recreatie en sociale contacten, (8) huishoudelijke verzorging, (9) technische hulp en tenslotte (10) informatie- en adviesverstrekking. Bij tabel 12.4 kunnen de volgende kanttekeningen worden geplaatst. Per definitie worden in de extramurale sectoren geen werkzaamheden verricht in het kader van functie 1 (wonen/ verblijf). Bij bejaardenoorden daarentegen is verondersteld dat het ondersteunend personeel well werkzaamheden voor deze functie ver- 
Tabel 124. Globale aanduiding functionele indeling per personeelscategorie (in $\%$ van beschikbare tijd) in Marastricht

\begin{tabular}{|c|c|c|c|c|c|c|c|c|c|c|c|c|}
\hline \multicolumn{3}{|l|}{ 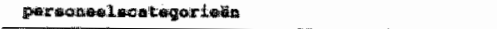 } & \multicolumn{10}{|c|}{ 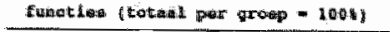 } \\
\hline griog & 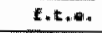 & 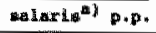 & 1 & 2 & 3 & 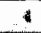 & 5 & 6 & 7 & in & $\$$ & 30 \\
\hline 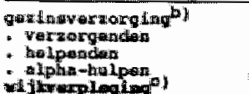 & $\begin{array}{r}65,2 \\
175,2 \\
41.0\end{array}$ & 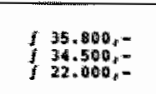 & $=$ & & $=$ & $=$ & $\begin{array}{l}1.5 \\
10 \\
5\end{array}$ & $\begin{array}{r}25 \\
15 \\
-\end{array}$ & $\begin{array}{r}10 \\
5 \\
5\end{array}$ & $\begin{array}{l}40 \\
\$ 5 \\
05\end{array}$ & $\bar{z}$ & 5 \\
\hline 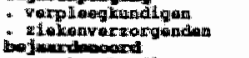 & $54: \frac{1}{18}$ & $\begin{array}{l}53.000,-2 \\
\text { if } 1.000 . n=\end{array}$ & - & 12 & $=$ & $\begin{array}{l}30 \\
21\end{array}$ & 7 & 68 & $\bar{z}$ & $\overline{-}$ & $=$ & 3 \\
\hline 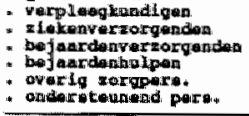 & $\begin{array}{r}22,4 \\
42,7 \\
109 ; \\
31,45 \\
27,89 \\
145,7\end{array}$ & 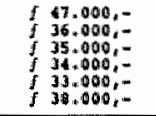 & $=$ & $\begin{array}{l}7 \\
7 \\
5 \\
2 \\
3 \\
1\end{array}$ & $\begin{array}{l}7 \\
z \\
z \\
3 \\
2\end{array}$ & $\begin{array}{r}30 \\
10 \\
3 \\
1 \\
5 \\
-\end{array}$ & $\begin{array}{r}15 \\
10 \\
10 \\
7 \\
6 \\
7\end{array}$ & $\begin{array}{r}20 \\
3.5 \\
4.5 \\
5 i 5 \\
50 \\
3\end{array}$ & $\begin{array}{l}70 \\
10 \\
10 \\
15 \\
6\end{array}$ & $\begin{array}{l}5 \\
30 \\
20 \\
25 \\
20 \\
10\end{array}$ & $\begin{array}{l}5 \\
5 \\
y \\
- \\
2\end{array}$ & $\begin{array}{l}3 \\
3 \\
-\end{array}$ \\
\hline
\end{tabular}

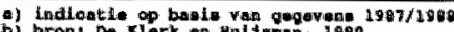

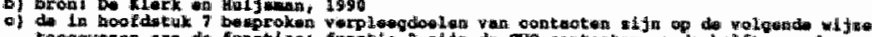

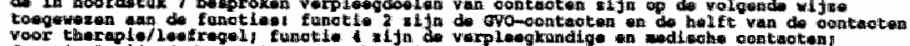

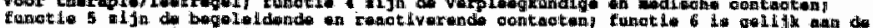

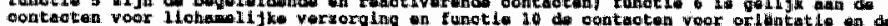

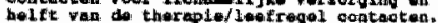

richt. Als bovendien geen verdere indicatie gegeven kan worden voor de verdeling over de resterende functies, zodanig dat het totaal sommeert tot $100 \%$, dan is verondersteld dat de rest van het werk in het kader staat van het in stand houden van de woonfunctie van het bejaardenoord in het algemeen. Op deze wijze is met name bij directie, administratic en technisch personeel 60 tot $90 \%$ van de beschikbare tijd toebedeeld aan de eerste functie. Net als in de extramurale sectoren is verondersteld dat het verzorgend personeel in de bejaardenoorden geen werkzaamheden verricht ten behoeve van de woonfunctie. Bij de extramurale voorzieningen is verondersteld dat het indirecte personeel qua functionele indeling synchroon loopt met bet directe personeel.

Uit tabel 12.4 zijn vervolgens de aandelen van de verschillende functies in de totale personeelslasten berekend door per personeelscategorie de kosten per functie te berekenen (bij verpleegkundigen in het bejaardenoord is dat bijvoorbeeld $7 \%$ van het produkt van 22,4 f.t.e. a $f 47.000,-)$ en deze vervolgens per functie te sommeren over de verschillende personeelscategorieèn. Het resultaat van deze exercitie staat vermeld in tabel 12.5 , waarbij tevens voor de drie sectoren de totale personele lasten (inclusief sociale lasten) zijn opgenomen. Er wordt nogmaals benadrukt dat de gepresenteerde verdeling over de diverse functies een illustratie vormt.

Bij gezinsverzorging houdt het grootste deel van de kosten verband met de huishoudelijke functie $(60,5 \%)$. Voorts komt $16 \%$ ten laste van de zesde functie (persoonlijke verzorging, ADL-ondersteuning) en bijna $11 \%$ van reactivering. Müder van belang is preventie (5\%), sociale begeleiding (6\%) en informatie- en adviesverstrekking (1\%). Bij de wijkverpleging komt ongeveer de helft van de personeelskosten ten laste van de functie voor persoonlijke verzorging, drietiende ten laste van de verplegende functie en eentiende heeft betrekking op de preventieve functie. De functies 1 (per definitie), 3 en 7 tot en met 9 worden in deze indeling niet door de wijkverpleging vervuld. In de bejaardenoorden worden wel personeelslasten doorberekend aan de woonfunctie $(15 \%)$ en zijn voorts de zesde functie (persoonlijke verzorging) en de achtste functie (huishoudelijk) procentueel gezien ongeveer even belangrijk (26 a 27\%). Hierbij spelen twee factoren een rol: enerzijds is vit de gesprekken met instellingen gebleken dat deze twee functies vaak gelijktijdig plaatsvinden als het personeel bij bewoners op de kamer komt en daardoor moeilijk scherp zijn af te bakenen; anderzijds 
Tabe1 12.5. Benadering voor functionele indeling van personeelslasten (in \%)

\begin{tabular}{|c|c|c|c|}
\hline Eunctios & gezinguerzorging & wijkverpleging & bejaardenoord \\
\hline 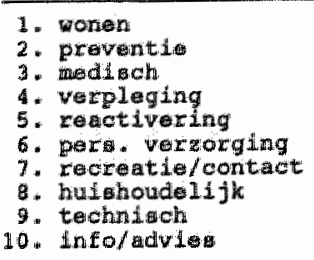 & $\begin{array}{c}5,0 \\
- \\
- \\
10,8 \\
16,1 \\
6,3 \\
60,5 \\
- \\
1,3\end{array}$ & $\begin{array}{c}- \\
10,5 \\
= \\
28,8 \\
5,4 \\
51,3 \\
= \\
= \\
3,0\end{array}$ & $\begin{array}{r}15,0 \\
3,4 \\
2,1 \\
5,3 \\
6,7 \\
26,4 \\
8,5 \\
27,1 \\
2,5 \\
3,0\end{array}$ \\
\hline 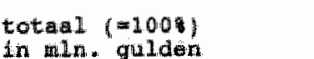 & 9,3 & 5,4 & 18,5 \\
\hline
\end{tabular}

leidt het verschil in salariering tot een zekere nivellering tussen beide functies ${ }^{1}$. In de bejaardenoorden worden voorts alle andere functies eveneens vervuld (in tegenstelling tot de gezinswerzorging en de wijkverpleging), maar zijn de aandelen in de totale personeelslasten bescheiden (varierrend van $2 \%$ tot $8 \%$ ). Bij deze sector is het van belang om de overige niet-personele kosten (circa $37 \%$ ) nog kort te bezien in relatie tot de functionele indeling. Verreweg de meeste kostenposten, zoals huishoudelijke kosten (5\%), energiekosten ( $4 \%$ ), onderhoud en afschrijvingen (7\%) kunnen mijns inziens begrepen worden alls facilitair ten behoeve van de woonfunctie van bejaardenoorden. Er zijn echter ook zeer gedetailleerde toerekeningsschema's denkbaar (Kjbbeling e.a., 1988). Onder de veronderstelling dat van alle niet-personele kosten bij benadering driekwart aan de woonfunctie kan worden toegerekend, resulteert een aandeel van deze functie in de totale kosten van de bejaardenoorden van 37 a $38 \%$. Elders wordt een vergelijkbaar cijfer gesuggereerd: Coolen (1985) rekent $f$ 11.000,- voor de wooncomponent in de totale kosten van circa $f 30.000^{4}$ voor een verzorgingsplaats in het bejaardenoord.

\subsection{Kanttekening}

Met dit hoofdstuk is de beschrijving wan het 'aanbodzijde' van de ouderenzorg in de gemeente Maastricht afgerond. Kernthema's in dit deel van deze studie waren het bereik van voorzleningen, de globale kenmerken van de client, maatstaven voor de gemiddelde hulpintensiteit per client, de personeelsformatie en de kosten van ouderenzorg.

Hoewel in het oorspronkelijke onderzoeksvoorstel (zie hoofdstuk 1; Denis, 1985) een centraal stramien als leidraad gekozen was, bleek dit in de praktijk moeilijk te handhaven.

Als instrument voor een meer uniforme beschrijving van de "aanbodzijde" werd bij de stan van het project een eigen instellingsenquete ontwikkeld, die zich laat kenmerken als de grootste gemeenschappeljjke deler van de gebruikelijke, veelal sector-gebonden, nationale enquetes van onder andere het CBS, het NZI en koepelorganisaties. Deze enquête fungeert in de praktijk als instrument voor dossiervorming en werd in drie fases ingevuld. In de eerste fase werden door de onderzoeker(s) afschriften van de relevante nationale enquétes en van jaarverslagen en dergelijke opgevraagd, waaruit zoveel mogelij $k$ informatie werd overgebracht naar de instellingsenquete. Deze fase verliep in het algemeen zonder all te veel

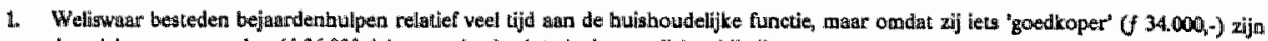
dan glekenwerzorgenden (f $36000_{1}$ ) komen die absolute bedragen dienterbij elkas. 
problemen, uitgezonderd de verzameling van financiele gegevens die men vaak niet zonder meer wilde verstrekken. In de tweede fase werd het door de onderzoeker reeds gedeeltelijk ingevulde dossier, bestaande vit verschillende enqueteformulieren voor verschillende jaren, naar de betreffende instelling opgestuurd met de vraag deze zo veel mogelijk aan te vullen. In de fase bleek het erg belangrijk te zijn om aan te dringen op het aanstellen van eén contactpersoon voor het onderzoek omdat de gegevens vaak door verschillende afdelingen binnen de organisatie gecontröleerd en aangevuld moesten worden. Over het algemeen bestonden er goede contacten met deze contactpersonen, maar konden er problemen ontstaan bij tussentijdse personeelswisselingen. De kans hierop bij een langlopende onderzoek als het onderhavige is vrij aanzienlijk. In de derde fase werden gesprekken gehouden met de instellingen om ontbrekende onderdelen alsnog te bespreken en zo mogelijk in te vullen (hetzij met concrete gegevens, hetzij door benadering). Ook was het pas in deze fase mogelijk om de functionele verdeling van werkzaamheden van het personeel te bespreken.

Hoofdprobleem bij de analyse van de 'aanbodzijde' van de ouderenzorg is het feit dat de zeer uiteeniopende organisaties in de ouderenzorg zeer uiteenlopende informatiesystemen hanteren, die voor sectoroverstijgende onderzoeksvragen welhaast onoverkomelijk bleken te zijn. Ook is de mate en het tempo van automatisering tussen de verschillende sectoren erg. verschillend. Enerzijds is men bij de gezinsverzorging reeds zo ver gevorderd dat op clientniveau gegevens beschikbaar zijn over de situatie van de cliẹt, de gebodlen hulp en de daaraan verbonden kosten. Anderzijds is het in de bejaardenoordsector nog altijd eerder uitzondering dan regel dat de instellingsadministratie (inclusief bewonersregistratie) geautomatiseerd is. Vaak bestaan er vrij strikt gescheiden registratiesystemen voor enerzijds financieel-administratieve doeleinden en anderzijds voor de registratie van clienten, bun kenmerken en de hulpverlening op individueel niveau. Ook is de financiele administratie in de meeste gevallen voornamelijk opgezet om te kunnen voldoen aan de verantwoordingsvereisten die door externe financiers (met name de overheid) gesteld zijn; deze zijn tot op heden echter zeer globaal en niet of nauwelijks toegesneden op een clientgroepgebonden of een functionele benadering van het produktieproces van zorgorganisaties (Janssen en Van Merode, 1989; Huijsman en Janssen, 1990). Bij dit alles moet echter de kanttekening geplaatst worden dat het automatiseringsproces in de gezondheidszorg en zeker in de welzijnszorg relatief jong is en een snelle ontwikkeling doormaakt.

Op grond van de ervaringen van de afgelopen jaren wordt de aanbeveling gedaan om tot een meer uniforme registratie-systematiek te komen die het mogelijk maakt om voor onderzoeksvragen, mar niet in de laatste plaats ook voor beleids- en planningsdoeleinden gegevens te genereren die wel met elkatar in verband zijn te brengen. Dit vereist niet alleen een meer uniforme clientregistratie (zoals bijvoorbeeld bij de Mental Health Case Registers in Groningen en Maastricht gerealiseerd is), maar ook een meer uniforme verslaglegging wan 'produktie' en kosten. Pogingen om voor dat laatste een functionele indeling te hanteren zouden dan wellicht met minder grote onzekerheidsmarges plaats kunnen vinden. 
8 


\section{Deel C}

\section{De vraagzijde van de ouderenzorg}

In dit deel staat de 'vraagzijde' van de ouderenzorg in de gemeente Maastricht centraat, gebaseerd op secundaire analyses van gegevens over thuiswonende ouderen (al dan niet met een posistitief advies voor opname in het bejaardenoord) met een zekere mate van invaliditeit, bewoners van bejaardenoorden en op te nemen patienten van het verpleeghuis. 


\section{Begrippen, methoden en datamateriaal}

\subsection{Inleiding en afbakening}

Er bestaat omvangrijke literatuur aangaande de determinanten van het gebruik van woorzieningen door ouderen. De leidende onderzoeksvraag is daarbij steeds welke factoren uit de leefsituatie van invloed zijn op de vraag naar en het gebruik van voorzieningen. Men hanteert daarbij het behoefteconcept dat uitgaat van verstoringen in gezondheidstoestand en welzijn (Donabedian, 1973), hetgeen tot uiting komt in een discrepantie tussen een feitelijke en gewenste toestand. Behoefte is echter een containerbegrip (Post en Willemse, 1986) en levert afbakeningsproblemen op. Daarbij zijn verschillende invallshoeken mogelijk, waarwoor de literatuur een belangrijk aantal mogelijkheden biedt (zie paragraaf 3.2). Zo wordt onderscheid gemaakt tussen ervaren (subjectieve) behoeften, normatieve (objectieve) behoeften, uiltgesproken ('expressed') behoeften en comparatieve behoeften (Bradshaw, 1972; Mackenbach, 1982). In de bespreking van (mogelijke) dimensies van de leefsituatie gaat de primaire interesse uit naar die aspecten waarover in de literatuur aanwijzingen gegeven worden dat zij van invloed zijn op de afweging om gebruik te maken van voorzieningen, hetzij informele, hetzij formele in de extra- of intramurale sector. Een grove indeling van belinwloedende factoren betreft het onderscheid in somatische, psychische en sociaal-economische factoren en factoren in relatie tot de woonsituatie. Hoofdstuk $14 \mathrm{geeft}$ een literatuuroverzicht van inzichten in deze dimensies. In het onderhavige hoofdstuk worden ter voorbereiding op de (secundaire) analyses enige kanttekeningen geplaatst bij een aantal onderwerpen, namelijk: de gehanteerde begrippen (paragraaf 13.2), eventuele verklaringsmodellen en -theorieen, inclusief die met betrekking tot de afhankelijkheid van ouderen (paragraaf 13.3), de analyse-technieken (paragraaf 13.4) en daarvan in het bijzonder de zogenaamde LISREL-methode (paragraaf 13.5) en tenslotte het gebruikte datamateriaal (paragraaf 13.6).

\subsection{Gehanteerde 'behoefte'-begrippen}

De zorgbehoefte is het gevolg van een discrepantie tussen de feitelijke en gewenste situatie, die verder beinvloed wordt doot het aspiratieniveau van de betrokkene en de 'spiegel' wartegen deze de feitelijke situatie afzet, namelijk de situatie van een referentiegroep (Braam, 1981; Van Linschoten e.a., 1988). Afhankelijk wan de vraag wie de discrepantie tussen feitelijke en gewenste situatie beoordeelt, kan de zorgbehoefte onderscheiden worden (Donabedian, 1973) in 'objectieve" behoefte (volgens de maatstaven van een deskundige) en "subjectieve" behoefte (volgens het oordeel van de betrokkene(n) zelf). Er worden twee vormen van "objectieve" hulpbehoefte onderscheiden uitgaande van het type deskundige dat het oordeel velt: dat kan enerzijds een professionele hulpverlener zijn (bijwoorbeeld een arts of de 'intaker' bij gezinsverzorging) en enerzijds de onderzoek(st)er, die haar/zijn oordeel daarbij baseert op gestandaardiseerde meetinstrumenten (men spreekt dan wel van een "geobjectiveerde' behoefte). Ook deze 'objectieve' bepaling van de behoefte kent subjectieve kanten, die echter in zekere mate worden ingeperkt indien zij gebaseerd is op gestandaardiseerde meetinstrumenten of indien er vastomschreven regels en procedures worden gehanteerd bij de indicatiestelling; de wetenschappelijke onderzoeker zal de gemaakte keuzes in principe altijd moeten expliciteren en onderbouwen. Naast objectieve en subjectieve behoefte kunnen nog een "witgesproken' behoefte (is gelijk aan vraag) en een 'vergelij- 
kende" behoefte (door een onderzoeker-epidemioloog vast te stetien) onderscheiden worden (Bradshaw, 1972; Mackenbach, 1982). Als de hiertoven beschreven tweede vorm van het begrip 'objectieve' behoefte in relatie wordt gebracht met het gebruik van voorzieningen, dan kont het tesultaat hiervan overeen met het 'vergelijkende' behoeftebegrip.

De voorgaande behoeftebegrippen ajn bepaald niet wederzijds witsluitend (Bradshaw, 1972). Indien er cen behoefte is zonder dat deze resulteert in een vraag spreekt men van cen "Iatente" behoefte (Mackenbach, 1982) of een 'werborgen vraag' (Denis, 1985); er wordit dan gerefereerd aan het 'jisberg fenomeen' (Post en Willemse, 1986; Madkerbach, 1982). Daartbij speelt bovendien mee dat vaak slechts een zodanig tehoeftepatroon geuit wordt dat er en retle kans op oplossing ervan bestaat: behoefte en aanbed staan in wisselwenking (Achterhuis, 1980; Van Linschoten e.:., 1988; De Swaan e.a., 1979). Een niet-gehonoreerde of afgewezen behoefte wordt ook wall angeduid als 'unmet need', deze kan zowel op objectieve als op subjectieve gronden gebaseend zijn. In figuur 13.1 wordt een overzicht gegewen van de hier gehanteerde begrippen en de in de hteratur (maar niet in het vervolg van deze publikatie) gebruikte synoniemen.

In het onderzoek onder ouderen in de gemeente Maastricht waarvan in deze studie een secundaire analyse wordt gepresenteerd, wordt een aantal van de bovengenoemde behoeftebegrippen gehanteerd. Via een postenquete (Frederiks en Te Wierik, 1988) wordt de 'geobjectiveerde' behoefte gekwantificeerd aan de hand van een validiteitsbeoordeling, die gebaseerd is op het aantal beperkingen in het algemeen dagelijks leven (ADL) en huishoudelijk of instrumenteel (LADL) functioneren. Via het stellen van vragen over het feitelijk gebruik wordt het resultaat van "uitgesproken" behoefte in beeld gebracht. De 'subjectieve" behoefte die niet vervuld is (dat wil zeggen dat er een afgewezen of verborgen vraag bestaat of dat er een 'latente" behoefte aanwezig is) wordt direct gevraagd. Tenslotte leidt de combinatie van gebruikcijfers en de 'objectieve' behoefte tot 'vergelijkende" behoefte. Dit resulteert in de identificatie van ouderen die wel (I)ADL-beperkingen maar geén hulp hebben. De postenquete is vervolgens gebruikt om ouderen te selecteren voor een diepgaander mondeling interview, waarin ook de gehanteerde behoefte- en wraagbegrippen verder uiltgewerkt zijn (Frederiks, 1990).

In deze studie wordt een uitgebreide secundaire analyse gegeven van de interviewgegevens over vier groepen ouderen: (a) zelfstandig wonende ouderen met een 'geobjectiveerde' behoefte en/of met een (toegekende) vraag naar of feitelijk gebruik van thuiszorg-

gehanteerd

objectieve behoefte

subjectieve behoefte

uitgesproken behoefte

vergelijkende behoefte synoniem(en)

normatieve behoefte

behoeftebepaling door professional

(unmet) need

ervaren of gepercipieerde behoefte

felt (unmet) need, want

vraag, manifeste vraag, expressed need, demand

(kan op basis van alle voorgaande termen) comparative need

Figuur 13.1. Gehanteerde behoeftebegrippen en in de literatuur gebruikte synoniemen 


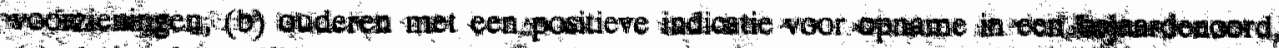

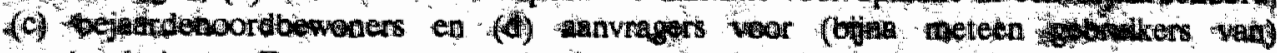
verpleeghyiszorg. Deze groepen worden 4 parggraf 13.6 nader toegehicht.

\section{Voddawingenodellen woor wooreleningengebruik}

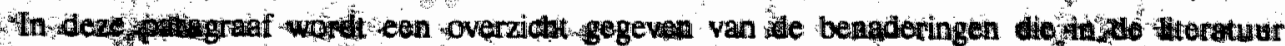

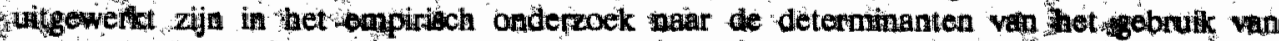

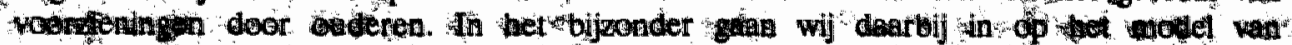
Andwrsen en zijh medewerkers (Amderson en Newman, 1973; Anderten ell, 1075) en.

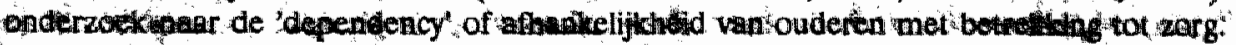

\subsection{4: Het model wan Amdersen}

Een ved getbraikt verkdaringsmodel voor thet gebrulk van voorzioningen betrot thet model van Andersen en Newman (1973). Dit model biedt de mogelijkheid on de sindividuete gebruiksverschillen te bezien in een conceptueel schema van drie onderling sanæenthangende groepen van factoren, namelijk (a) predisponerende of persoonsvariabelen ("predisposing'), (b) faciliterende factoren of structurele variabelen ('enabling') en behoeftefactoren ('need'). De meest frequent gehanteerde Nederlandse begrippen voor deze modelcomponenten zijn: persoonsvariabelen, structuurvariabelen en behoeftevariabelen (Klaassen-Van den Berg Jeths, 1989). In het model van Andersen en Newman is geprobeerd om verschillende benaderingen ter verklaring van het gebruik van voorzieningen te integreren. Het model heeft daarmee vooral een heuristische waarde dat een conceptueel schema biedt als referentiekader. Een dergelijk conceptueel model is een kwalitatieve, niet-specifieke beschrijving van een systeem (hier het systeem van de ouderenzorg). Het descriptieve karakter van het model, dat een afbeelding beoogt te zijn van 'open' sociaal systeem (Boudon, 1986), is de reden voor de twee belangrijkste conclusies die op basis van de uitgebreide literatuur over (empirisch) onderzoek naar het gebruik van voorzieningen getrokken kunnen worden: de verklaringskracht in termen van verklaarde variantie is in het algemeen laag en eventuele voorspellende pretenties worden worden vaak gelogenstraft.

De belangrijkste benaderingen die in het model van Andersen en Newman geintegreerd zijn (Klaassen-Van dien Berg Jeths, 1989; Mootz, 1981 en 1984; Picauly, 1987) betreffen de demografische benadering (op basis van persoonskenmerken), de sociaal-psychologische benadering (uitgaande van de houdingen en attituden over gezondheid en gezondheidszorgvoorzieningen door middel van het zogenaamde 'Health Belief Model'; later is deze benadering veel scherper uitgewerkt, met name door Ajzen en Fishbein, 1980), de sociaalculturele benadering (uitgaande van de opvattingen en normen in sociale groepen gespecificeerd naar nationaliteit, etniciteit, godsdienstige overtuiging en dergelijke) en de financieeleconomische benadering (veelal gericht op verschillen tussen ziekenfondsverzekerden en particulier verzekerden, uitgaande van de hoogte van eigen risico en retributies). Veellal is sprake van specifieke combinaties van diverse invloeden, zodat de verschillende benaderingen in hun onderlinge samenhang moeten worden beschouwd, hetgeen het verklaren en voorspellen van individueel hulpzoekend gedrag niet vergemakkelijkt (Mootz, 1984). Het model van Andersen en Newman (1973) wordt door de meeste onderzoekers geprefereerd boven de hierboven beschreven afzonderlijke benaderingen (ondanks de vele bezwaren die eveneens geuit zijn; zie vervolg), omdat deze als het ware gelintegreerd worden in een 'completer' model (SOOM, 1986). 


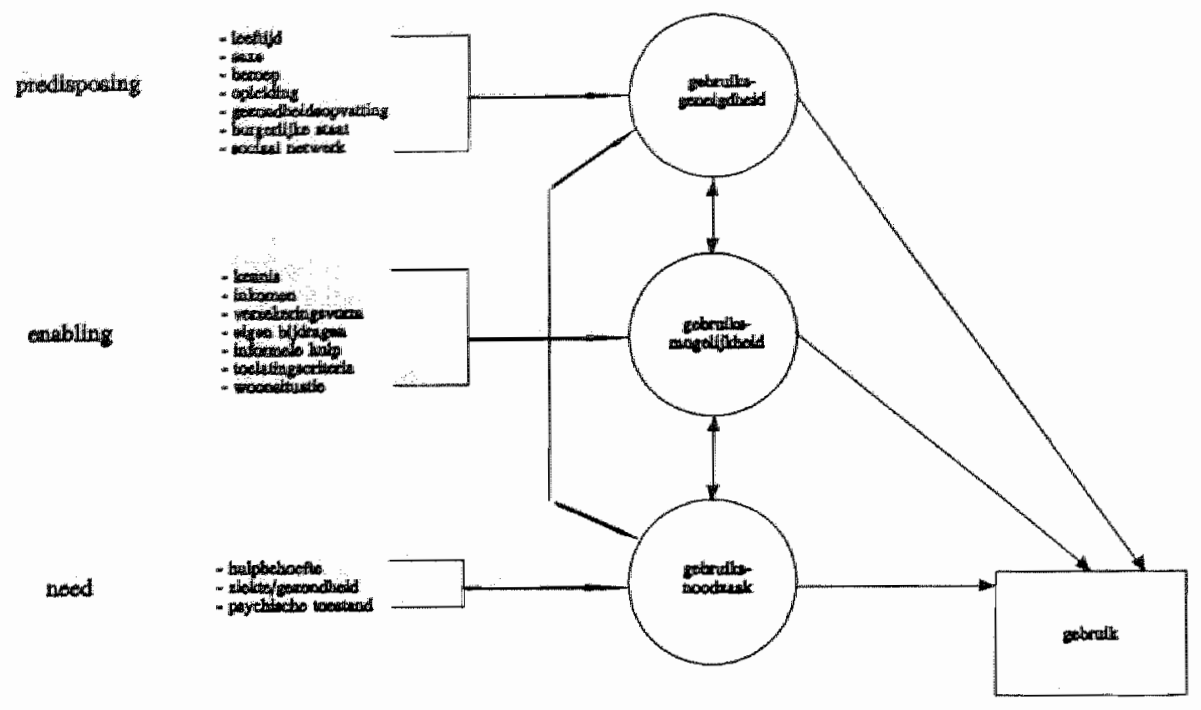

Figuur 13.2. Het model van Andersen en Newman (1973)

In figuur 13.2 wordt het model van Andersen en Newman (1973) schematisch weergegeven. In de 'predisposing' of persoonswariabelen worden de demografische, sociaal-culturele en sociaal-psychologische benaderingen bijeengebracht, resulterend in de 'gebruiksgeneigdheid'. Deze wordt bepaald door demografische kenmerken (sexe, leeftijd, burgerlijke staat), sociale variabelen (opleiding, beroep, geloof, familie-grootte, ras) en de waarden en normen ten opzichte van ziekte (inclusief kennis over ziekten en houding ten opzichte van gezondheidszorgvoorzieningen).

De 'enabling" of structurele variabelen zijn van invloed op de mate waarin men toegang heeft tot voorzieningen. Hierbij worden verschillende factoren van belang geacht, namelijk bevorderende factoren, zoals kennis en inkomen, en belemmerende factoren of restricties, zoals toelatings of indicatiecriteria, de verzekeringsvorm, de hoogte van retributies en de ganwezigheid van alternatieven (inclusief informele bulp). Net als de persoonsvariabelen zijn de structurele variabelen onafhankelijk van ziekte of invaliditeit.

Do 'need' of behoeftevariabelen werden door Andersen en Newman (1973) oorspronkelijk aangeduid net de term 'illness level', doch dit is later vervangen door de hier gehanteerde begrippen. Behoeftevariabelen, zoals beperkingen in het dagelijks functioneren, ziektesymptomen, handicaps en de algemene gezondheidstoestand, kennen een 'subjectieve" component (zelf-evaluatie) en een 'objectieve" component. De behoeftevariabelen leveren in vrijwel alle onderzoeken die geent zijn op hell model van Andersen en Newman de belangrijkste bijdragen aan de verklaring van verschillen in het gebruik wan voorzieningen, hoewel er een grote verscheidenheid bestaat in de variabelen die in deze onderzoeken gebruikt zijn (Klagssen-Van den Berg Jeths, 1989).

Bij het model van Andersen en Newman zijn in de loop der jaren veel kanttekeningen geplaatst. Het model zou niel geschikt zjin om het voorzieningengebruik van subpopulaties in plaats van een gehele bevolking te verklaren, omdat in het eerste geval factoren ten onrechte buiten beschouwing blijven (Evashwick e.a., 1984). Het meeste onderzoek ontbeert multivariate analyses (Branch e.a., 1981), maar als dat wel gebeurt dan blijken subjectieve en psychologische factoren nauwelijks een rol te spelen (Mechanic, 1979). Meer algemeen is 
de kritiek dai het model te eenvoudig is, terwijl de factoren complex zijn, moeilijk meetbaar en onderling samenhangen (Van den Heuvel, 1989). Een ander belangrijk bezwar tegen de gangbare uitwerkingen van het Andersen/Newman model betreft het feit dat de beschilkbaarheid van informele hulp zelden wordt opgenomen als modelvariabele (Bass en Noelker; 1987). Nog vreemder is het feit dat de informele hulp veelal geen bijorage aan de werklaring van voorzieningengebruik levert als deze variabele well wordt opgenomen (Klaassen-Van den Berg Jeths, 1989). Voor hel geringe verklaringsvermogen zijn nog enige redenen aan te voeren (Klaassen-Van den Berg Jeths, 1989): (a) het (gedrags-)model is theorie-arm zonder toetsbare hypothesen over de relaties tussen de onafhankelijke variabelen, die eigenlijk slechts min of meer systematisch worden opgesomd (Krout, 1984) en de afhankelijke variabele (gebruik van woorzieningen); (b) het model is oorspronkelijk slechts voor medische voorzieningen opgesteld; (c) het model is niet bruikbaar voor subgroepen in plats wan de gehele bevolking, zonder dat de (verklaarde) variantie al bij voorbaat gereduceerd wordt. Voorts is er een wijziging opgetreden in het relatieve gewicht van structurele ('enabling') variabelen ten gevolge van de ontwikkelingen van het sociale zekerheidsstelsel (Evashwick e.a., 1984). De conclusie moet dan ook enigszins teleurstellend zijn: het gedragsmodel van Andersen en Newman is noch in z'n oorspronkelijke, noch in aangepaste versies, in staat gebleken de variabiliteit in het voorzieningengebruik op bevredigende wijze te verklaren. Onderzoek dat niet expliciet op dit model gebaseerd is, levert in een aantal gevallen een betere verklaring voor het gebruik (Klaassen-Van den Berg Jeths, 1989). Wel is duidelijk dat er een beperkt aantal variabelen bestaat dat een sterke samenhang vertoont met het gebruik van voorzieningen; de aanpak om deze te benutten is echter hoofdzakelijk gestoeld op empirisch en niet op theoretisch inzicht. Ook het onderhavige onderzoek laat zich door deze pragmatische aanpak kenschetsen.

\subsubsection{Het begrip "afhankelijkheid" van zorg}

De bestudering van de behoefte-begrippen (paragraaf 13.2) maakt enerzjjds de verschillem in de theoretische invalshoeken zichtbaar (zie ook paragraaf 13.3.1), maar heeft anderzijds als centraall thema dat hoe dan ook een afhankelijkheid van zorgverlening door anderen dan de betrokkene zelf ontstaat. Deze notie heeft geleid tot het begrip 'dependency' (Anderson, 1971; Munnichs, 1976; Mooney, 1978; Wenger, 1986; Wilkin, 1987), dat hier letterlijk vertaald wordt als 'afhankelijkheid' (Rutten en Huijsman, 1987; Huijsman, 1988a en 1989a). In de hoofdstukken 1 en 3 bleek dat het bevorderen van de zelfstandigheid en zelfredzaamheid van ouderen in het het ouderenbeleid centraal staat. Men streeft er met andere woorden dat de afhankelijkheid van (professionele) zorg bij ouderen verminderd wordt. In de literatuur vormt het begrip 'afhankelijkheid" ("dependency') dan ook een belangrijk concept. Het voordeel van het begrip 'afhankelijkheid' is het multidimensionele karakter ervan (Mooney, 1978; Snell, 1985), hoewel men zich ook hier, net als bij het begrip "behoefte", veelal beperkt tot én of een beperkt aantal indicatoren (Wright, 1981; Wenger, 1986). In Nederland is door anderen het concept afhankelijkheid bij ouderen als zodanig niet onderzocht, maar richt men zich op de kwantificering van concepten als "behoefte" ( 0 .a. Van Linschoten e.a., 1988) en 'belang' (Coolen, 1986), die zeer dicht bij het door ons gehanteerde concept liggen. Ook in dit Nederlandse onderzoek (zie o.a. Van der Vlist, 1984; Van den Bos e.a., 1986; Coolen en Duipmans, 1987) beperkt men zich tot een of een beperkt aantal indicatoren voor de behoefte aan hulpverlening. Dit zijn meestal de zogenaamde beperkingen in algemeen dagelijkse levensverrichtingen, zoals zichzelf wassen of aan- en uitkleden (ADL-beperkingen) en beperkingen in huishoudelijke of instrumentele activiteiten, zoals boodschappen doen of huishoudelijk werk (LADL-beperkingen).

Over de theoretische en praktische concepten van afhankelijkheid bestart echter verwarring. Anderson (1971) definieert 'dependency' als: 'A state in which actions by others are a 


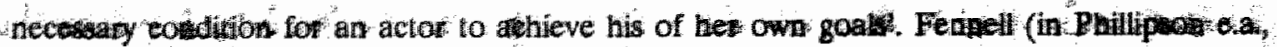

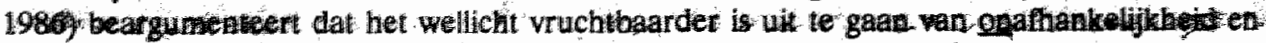
de monenten wawop hierin verandering komt: "... if we admit the concept of independence

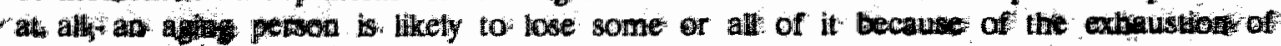
resource and the depletion of redundancy in access to resource systems ...." Over de

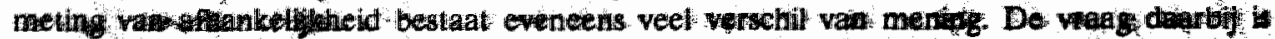

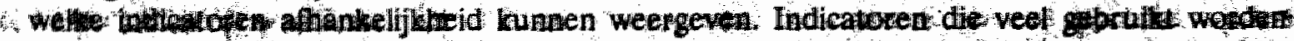

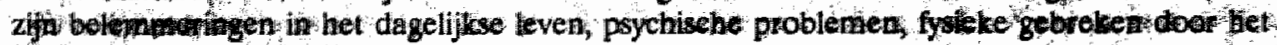
oudw wordicen dengelijke.

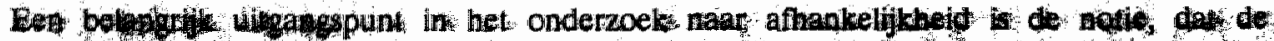

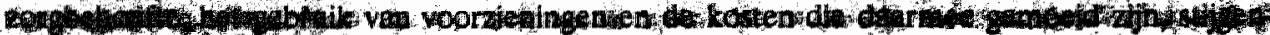

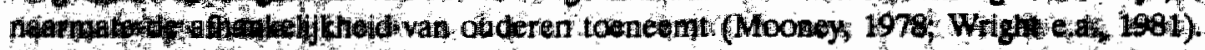

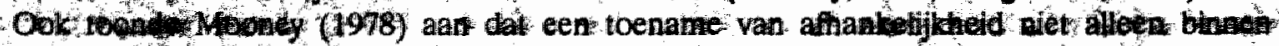

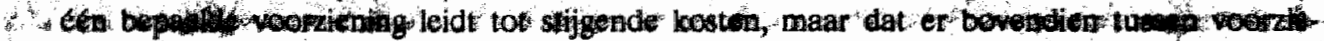

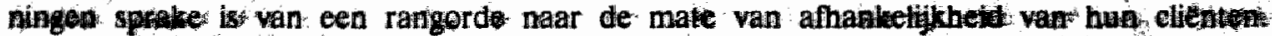

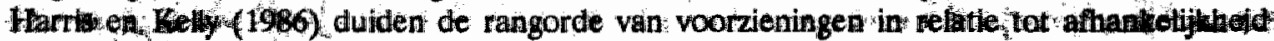

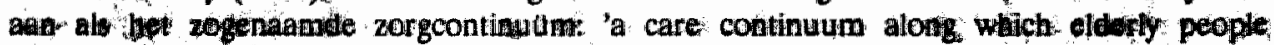

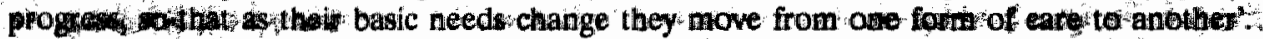

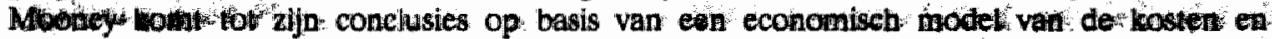

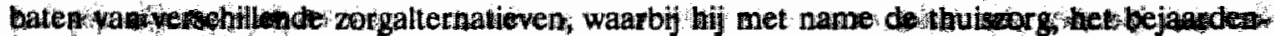

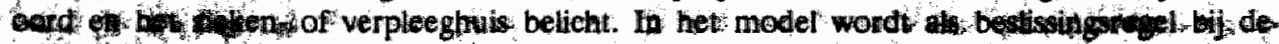

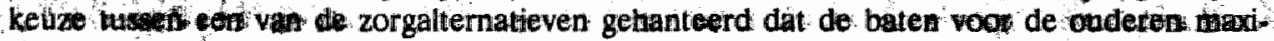

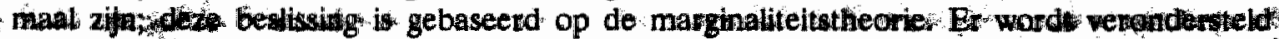
4. dat de kouten toenemen met de mate van afhankelijkheid. Hêtzelfđe woind in princip gedaan voov de baten, in ieder geval voor een zekere range van afhankelijkhoid, maer het is: zeer goedmogelijh dat na een bepaald punt de opbrengsten afvalken constant bljyen of

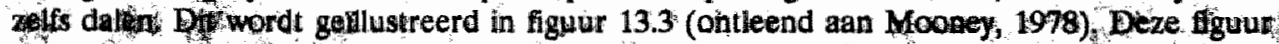

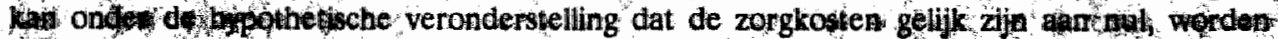

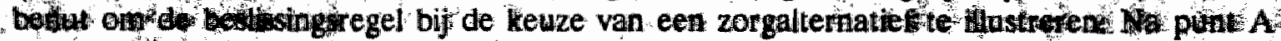

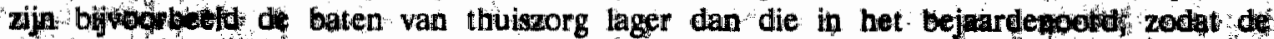

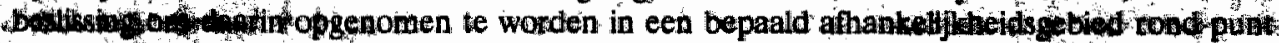

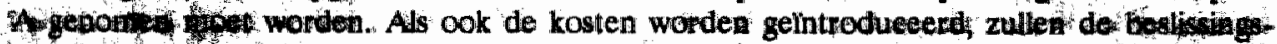

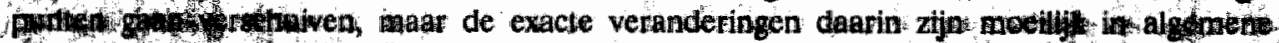

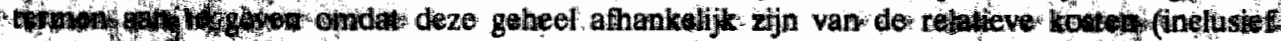

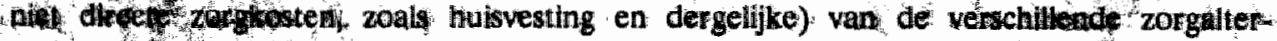

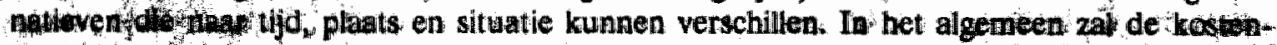

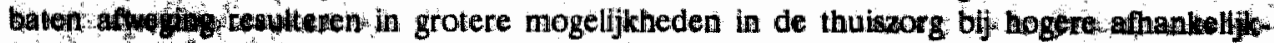

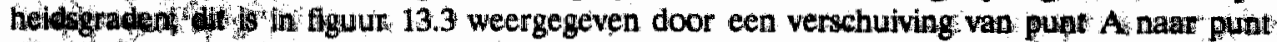

A. Ools wees Nederland zijm min of meer vergelijkbare analyses vertich naev deze zogenaandy tomslagpunten' in de zorgverlening (Van der Vlist, 1984, CCB, 1989),

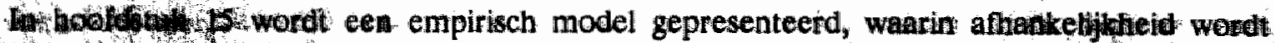

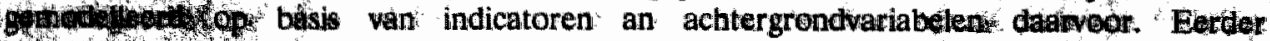

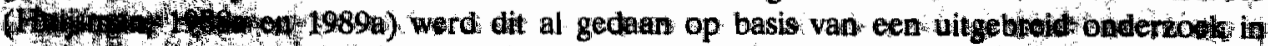

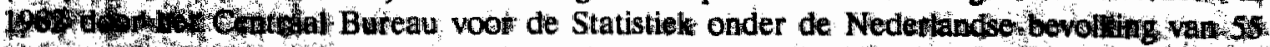

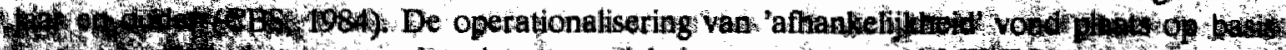

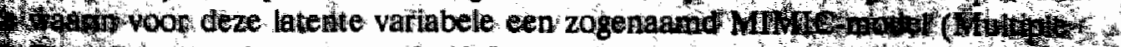

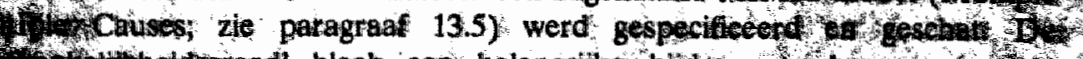

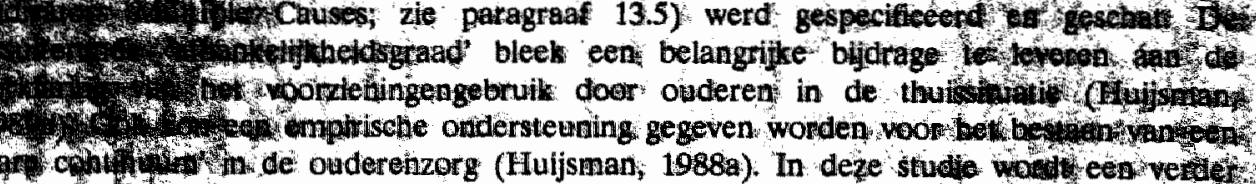

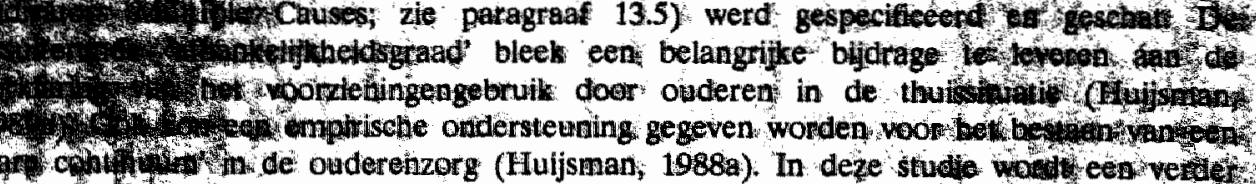

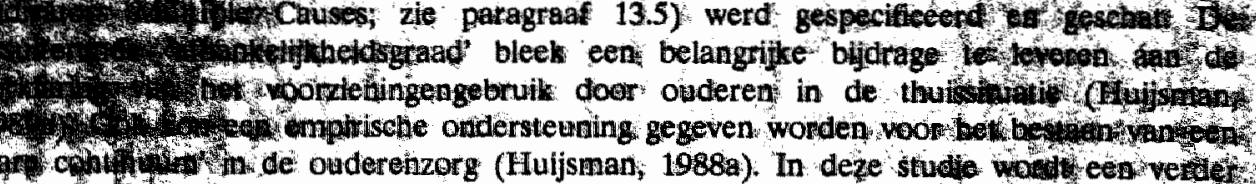




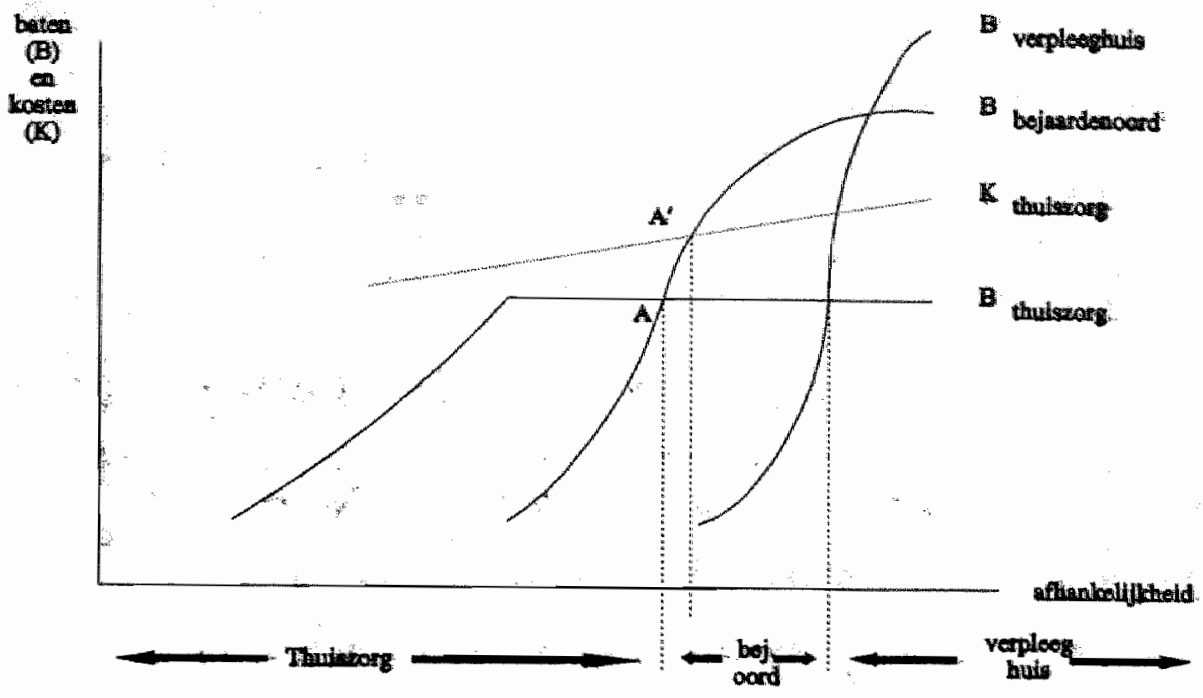

Figuur 13:3. Illustratie wan het vexband twssen afhankelikheid en voorzioningengebruik (ontleend aan: Mooney, 1978)

uitgewerkt model gepresenteerd; dat ditgaat van gegevens van zelfstandig wonende ouderen, positief geindiceerden voor en bewoners van bejaardenoorden en verpleeghuispatienten in de gemeente Maastricht. Een belangrijke uitbreiding op bet oorspronkelijke model betreft het aanbrengen van een ondenscheid in de "afhankelijkbeid" door middel van een aantal* dimensies van afhankelijktheid op liehamelijk en psychisch terrein (zie hoofdstuk 15). Voorzieningen in de ouderenzorg zijn dan, uitgaande van de notie van het zorgcontinuum, te ordenen naar de combinatie van de somatische en psychische afhankelijkheidsgraad waarin door hen wordt voorzien De diseussie over zo'n piaatsbepaling zal zich niet zoneer richten-op duidelijk zware situaties waarin én dimensie de overhand heeft of waar de problemen dermate groot zijn dat ingrijpende beslissingen nodig zijn maar zal zleh met name concentreren op het diffuse middenveld, waar somatische en psychische problemen in wrij ernstige mate ển in combinatie voorkomen (Houben e.a., 1984). Het aangrijpingspunt voor substitutie laat zich in dit model als volgt aanduiden: substitutie is mogelijk watar verschillende voorzieningen hulp bieden in gelijksoortige behoeftesituaties van ouderen, dat wil zeggen op die gebieden in het "care continutum' waar de afhankelijkheidsintervallen van voorzieningen elkaar overlappen. Voorts is van belang welke blinde vlekken er op welke plaatsen in het zorgcontinuum bestaan. Dit zijn afhankelijkheidsgebieden waar geen enkele voorziening hulp biedt, maar waar dat gezien de mate van afhankelijkheid wel nodig is (wie dit beoordeelt, bliff hiler buiten beschouwing). Bij de bespreking van de verschillende behoefte-begrippen in paragraaf 13.2 werd dit aangeduid als 'unmet need'.

\subsection{Analyse technieken}

De in het vervolg van deze studie gehanteerde statistische technieken varieren van eenwoudige basis-analyges van gemiddelden en standaarddeviaties en onderzoek naar de: samenhang tussen de verschillende items door midde van correlatiematrices tot faetoranalyse en schaaltechnieken. Op deze plaats worden verschillende technieken beknopt be- 
sproken, met name factoranalyse en een aantal schaaltechnieken. Deze bespreking kan kort zijn, omdat deze technieken vrij algemeen toegepast worden en goed gedocumenteerd zijn. De LISREL-methode wordt gedetailleerder besproken (paragraaf 13.5).

\section{Factoranalyse}

Factoranalyse is een statistische techniek die gebruikt wordt om een beperkt aantal factoren of constructen te identificeren, die zelf niet observeerbaar zijn, maar gebruikt kunnen worden om een relatief groot aantal variabelen die deel uitmaken van een complex fenomeen te representeren. Men gaat er met andere woorden vanuit dat er een hypothetische of latente variabele, een factor, bestaat. Elk item is uit te drukken als een lineaire combinatie van een beperkt aantal niet waarneembare factoren. Het verschil met het regressiemodel is dat de factoren niet onafhankelijk van elkaar zijn, maar elk een dimensie van én complex fenomeen vertegenwoordigen ("common factors'). Daarbij wordt een zo gering mogelijk aantal factoren nagestreefd om zo de grootst mogelijke simplificatie te vergemakkelijken. De factoren moeten echter ook enige betekenis hebben op basis van theoretische overwegingen en (van te voren) opgestelde hypothesen. Om dat laatste te bereiken dienen de factoren vaak geroteerd te worden, waardoor de items zonder informatieverlies veel eenduidiger 'laden' op een bepaalde factor. Factoranalyse gaat uit van een correlatiematrix, omdat immers de sterkte van de samenhang tussen items bepaalt of er sprake is van gemeenschappelijke factoren. De partiele correlaties (dat wil zeggen de paarsgewijze correlatie tussen items die overblijft, als rekening gehouden wordt met de samenhangen met andere items) dienen dan in vergelijking tot de totale correlaties zo klein mogelijk te zijn. Uiteindelijk doel is om met een zo beperkt mogelijk aantal factoren zo veel mogelijk van de totale variantie te verklaren. Het criterium daarbij is de zogenaamde eigenwaarde van een factor, die minimaal gelijk aan 1 moet zijn, omdat de betreffende factor anders minder variantie verklaart dan de opgenomen variabelen of schaal-items afzonderlijk. 
Betrouwbasheid van schallen

Nog los van de vraag welke gewichten toegekend moeten worden ara de afronderijke itenis van een schaal, is het mogelijk de betrouwbaarheid van een eventuele schaal wast te stellen. Eén methode schat de betrouwbaarheid van een schaal in termen van de consistentie van de afzonderijke items, die verondersteld worden alle betzelfo aspect te meten. De mate van interne consistentie of bomogeniteil wordt vastgesteld met Cronbach's alpha-coefficient, waarvan de waarde altijd ligt tussen 0 en 1 . Cronbach's $\alpha$ is gebaseerd op de gemiddelde covariantie tussen de items van een schaal (of op de gemiddelde correlatie als de itens gestandaardiseerd zijn), waarvoor de volgende formule gebruikt wordt (met het aantal items gelijk aan $\mathrm{k}$ ):

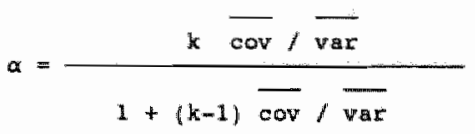

Uit de formule (Cronbach, 1951) blijkt dat $\alpha$ afhankelijk is van bet aantal items, zodat cen hoge waarde mogelijk is als er veel een items worden opgenomen, ook al is de gemiddelde interitemcorrelatie laag. Hoe dichter de waarde van de alpha-coefficient bij een ligt, hoe homogener de schaal is. Omdat een toets echter ontbreekt, bedient men zich van de vuistregell dat de alpha-coefficient groter moet zijn dan 0,7 a 0,8 . Bij 10 tot 15 items worat zelfs een grenswaarde van 0,85 aanbevolen (Swanborn, 1988). Per item kan worden nagegaan of verwijdering hiervan de homogeniteit van de schaal van resterende items zou bevorderen.

\section{Schaaltechnieken}

Veel gebruikte schalen, samengesteld uit clusters van items, worden in deze studie tevens onderworpen aan drie analysetechnieken: Mokken-, Rasch-en Guttman-schaalanalyses. Schaalanalyse is mogelijk als men een cumulatief groeikarakter voor het voorkomen van bepaalde kenmerken of persoonlijkheidstrekken veronderstelt. Dat will zeggen dat kenmerken zodanig kunnen worden gerangschikt, dat het hebben van een bepaald kenmerk impliceert dat ook andere kemmerken aanwezig zijn. Eenvoudigheidshalve gaan wij ervan uit dat dichotome uitspraken beschikbaar zijn, zoals het wel of niet hebben van een kenmerk of het wel of niet kunnen uitvoeren van een handeling. Er zijn echter ook multivariate varianten van de Mokkenschaal ontwikkeld (Molenaar, 1982), die eveneens gellustreerd worden.

Een mogelijkheid om hierrarchische relaties statistisch te onderzoeken betreft de zogenaamde Guttman-techniek (Guttman, 1945; Edwards, 1957; Torgerson, 1958). Idealiter zijn antwoorden voor bijwoorbeeld vijf items dan te rangschikken in een orthogonale matrix wan enen en nullen volgens het voorbeeld in tabel 13.1. In concreto betekent dit dat alle respondenten die slechts een item kunnen uitwoeren, alleen item E zouden passeren en geen ander. De niet-stochastische Guttman-methode resulteert in een summatieve schaal van antwoorden 0 of 1 op een aantal items, welke schaal dan ook direct verkregen kan wor-

Tabel 13.1. Illustratie Guttman-hierarchie

\begin{tabular}{|c|c|c|c|c|c|}
\hline \multirow{2}{*}{$\begin{array}{l}\text { Schaal } \\
\text { score }\end{array}$} & \multicolumn{5}{|c|}{ Antwoordpatroon item } \\
\hline & A & $\mathrm{B}$ & $c$ & $D$ & s \\
\hline 5 & 1 & 1 & 1 & 1 & 1 \\
\hline 4 & 0 & 1 & 1 & $i$ & 1 \\
\hline 3 & 0 & 0 & 1 & 1 & 1 \\
\hline 2 & 0 & 0 & 0 & 1 & 1 \\
\hline 1 & 0 & 0 & 0 & 0 & 1 \\
\hline 0 & 0 & 0 & 0 & 0 & 0 \\
\hline
\end{tabular}


dendiar de Hemsconcs op te tellen. De Gutman-methode taat echter ook de achteriggende rangonde nate moeilyktheidsgraad zien, zodat bijwoorbeeld bij do ADL-items uikpraken mogelijk zijn dal als iemaud zichzelf niet zonder moeite volledig kan wessen, het waarsehijnlijk is dat bifuch ook niet moeiteloos binnenshuis han verplatsen. Is het antwoord op een relatief moeilik item bekend, dan" "weet" men dat ook voor makkelijkere items. Ter beoordeling van schendingen van de perfecte. Guttmansehaal aja enkele maststaven ontwikteld (Melver en Carmines; 1981 ).

In de praktijk zal het idede Gutman-patroon naturartijk niet of zelden aangetroffen worten. Een variant die welweuten toestaat, is de zogenaamde Mokken-analyse (Mokken, 1971). Een sterke Mokkom-schaakkomt overeen met de strenge eisen van Gukman Deze

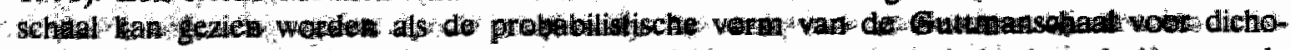
tome datg of nier algemeen als een stoctastische, non-parametrische behadering van de

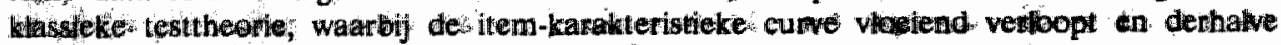

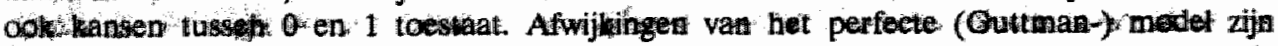
weer te geven doon middel van de statistiseh grootheid Loevinger's H, die zowel voor de gehele schaal als wor afzonderhife items berekend kan worden als 1 minus het quotient van de werkelfike en verwachte fouten (Swanborn; 1988). Indien $\mathrm{H}=1$ dan is en sprake van een penfecte schats Indien $\mathrm{H}=0$ dan zijn de items onderling onafhenkellk. Eer hoge $\mathrm{H}$ voor een item duidt op een goede inpastbarheid van het item in ce schaal. Mokken (1971) geeff daarbij als vuistregellial $H$ groten dan 0.5 en stgnificant groter dan nul dient te zijn. Net -als bij de Guttman-schaalsordent de Mokdren-analyse desubjecten en items op basis van de totalsoone van een persoon op cen latent continulum. In tegenstelling tot de eerder besproken faetoranalyse hoeven de verbanden tussen items en factoren (latente trekken) niet lineair te zijn. Wel dienen de items te voldoen aan de eis van dubbele monotonie, dat wil zeggen dat zij stijgende functies van de latente variabele zijn en elkaar niet snijden (zie flgtur 13.3): Deze hypothese kan anderzocht worden me de zogenaamde P-matrix die, als de item-eurves elkaar niet snjjien, zowel van links naar rechto als van boven naar beneden oplopentle kansen geeft voot parrsgewijze positieve antwoorden op telkens twee van alle naar moeilijklideidsarad geordende items.

De laatste schaaltachniek die besproken wordt; betreft de zogenaamde Rasch-analyse, die evenals de Mokken-analyse stoehastisch is. Met de Rasch-methode kan echter niet alleen de rangorde var items en personen bepalet worden, maar kunnen bovendien parametrische sebalthgen gegeven worden voor itemparameters of moellijheidsgraad (0), de persoonsparameters of persoonssuore (0) en de asymptotische schattiagen van de standaardfouten en betrouwbaarheldsintervalten De eisen die aan de data gesteld worden zijn bij deze schaalmethodiek het stringentste Verondersteld wordt dat de totaalscore van de persoon alle informatie over zowel de itemkarateristiek (moeilijkheid van het item in totale schaal) als de persoonskarakteristieken (positie van persoon op totale schaal) in zich heeft (afdoendheid of sufficiency). Itemseores hebben alle een logistisch patroon met dezelfde hellingshoek, waarbij het enige relevante gegeven is het verschil tussen persoonscore en itemmoeilijkheid. Een aantrekkelijke manier om de moeilijkheidsgraden van de verschillende items en de persoonparameters gezamenlijk te presenteren, betreft een grafische weergave langs een lijn van logarithmisch getransformeende waarcien Een voorbeeld hiervan is opgenonen in, figuur 13.5. Boven de lijn worden steeds de-versohillend items weergegeven,

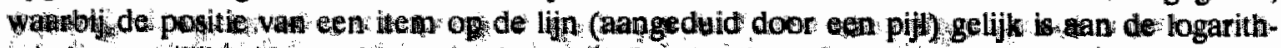

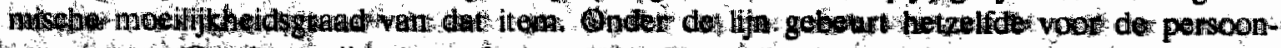

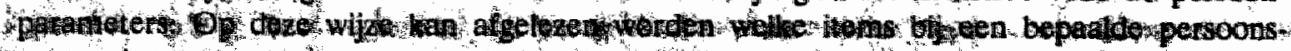

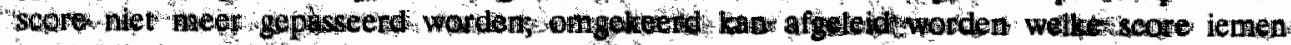
heett als bekend is welk itom net niet meer gepasseed wordt in hoofdistul 14 wordt van

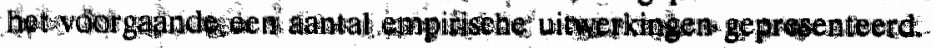




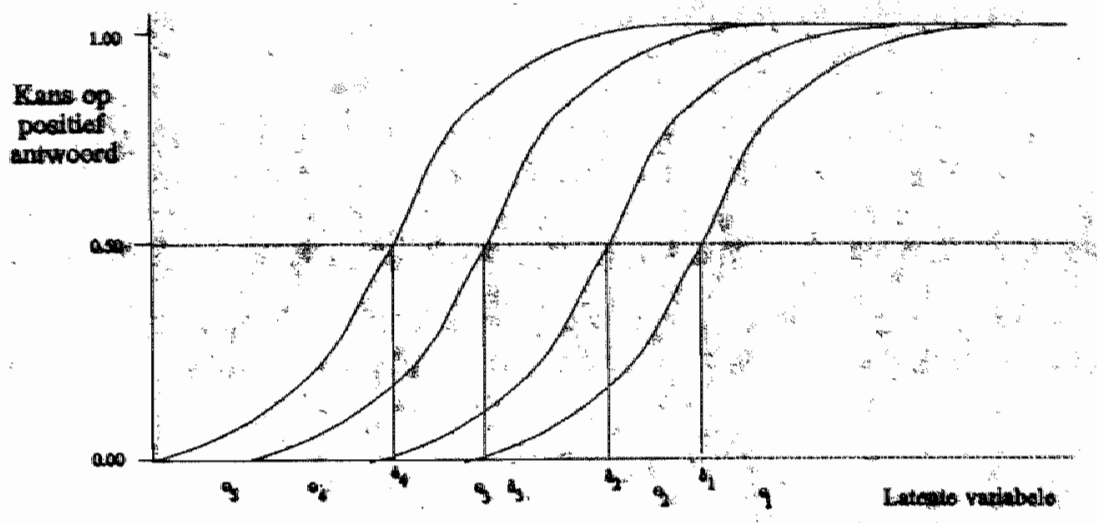

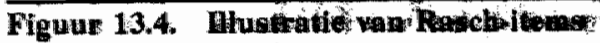

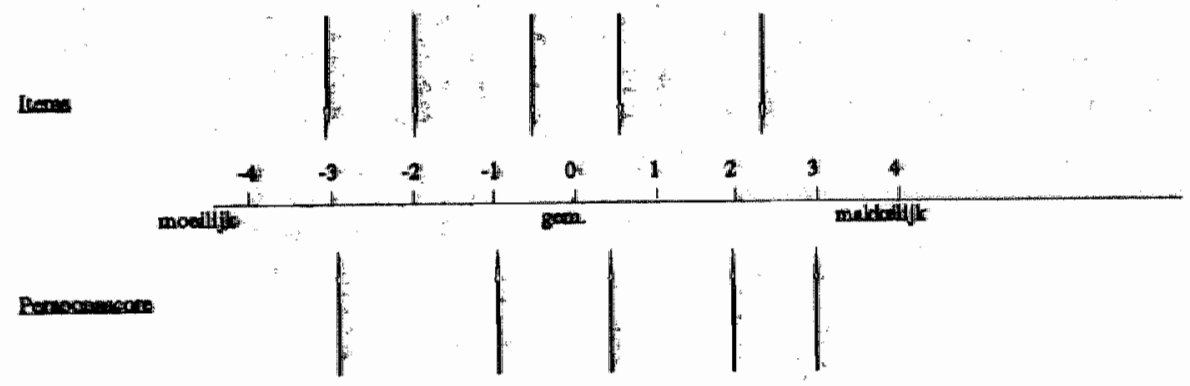

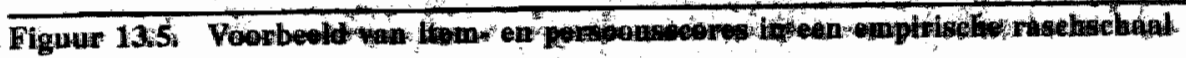

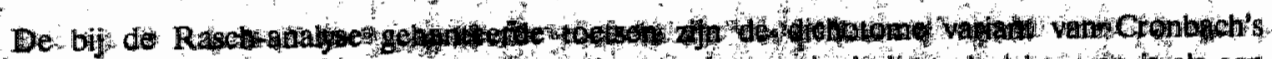

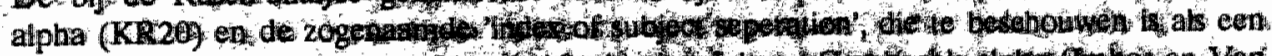

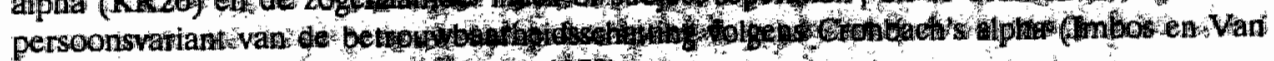

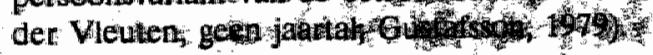


In de analyse van de 'afhankelijkheid' wan ouderen speelt een aantal methodische en empirische problemen een rol, waarmee rekening gehouden dient te worden bij de keuze wan de statisusche technieken. Een belangrijk probleem betreft het complexe karakter van het theoretische contruct dat dat inherent niet-waarneembaar is. Onderzoek naar dit type grootheden is behept met het probleem dat het (langs indirecte weg) empirische maten moet gebruiken om het achterliggende theoretische construct in beeld te brengen. Een bekend voorbeeld is met name empirisch onderzoek naar 'gezondheid"; deze is niet goed in een maat weer te geven, maar kent wel vele indicatoren. Er kunnen drie verschillende empirische modellen (Van Doorslaer, 1987) gebruikt worden om dergelijke latente variabelen 'zjchtbaar' te maken, waarbij het voorbeeld van 'de gezondheid' wordt aangehouden: (a) het indicatorenmodel, waarin verschillende gezondheidsindicatoren afzonderlijk gebruikt worden om het gebruik van voorzieningen te verklaren; (b) het factormodel, waarin verschillende aspecten of variabelen gecombineerd worden tot een gezondheidsindex, gebruik makend van factor- of principale componentenanalyse; (c) het model van structurele vergelijkingen voor de latente variabelen, waarin de aard en de richting van de samenhang tussen verschillende (latente) kenmerken worden gespecificeerd en waarin naast het meetmodel (in wezen het factormodel van indicatoren voor een bepaald theoretisch construct) zeer expliciet én gelijktijdig een structureel model van oorzaken gespecificeerd en getoetst kan worden. Dit model wordt het MIMIC-model genoemd, warin Multiple Indicators en Multiple Causes samen gebracht worden in sets van structurele relaties.

De schattingsmethode voor deze klasse van modellen staal bekend onder de naam LISREL (Jöreskog, 1970; Jơreskog en Sorbom, 1981). De LISREL-analyse kent enkele belangrijke voordelen: (a) het 'zichtbaar" maken van latente variabelen, (b) het rekening houden met de simultane interacties tussen oorzaken en indicatoren, (c) het 'verklaren' van de onderliggende causaliteit die de varianties tussen de verschillende variabelen zou kunnen veroorzaken, (d) het specifiek onderzceken van de structurele relaties tussen de latente variabelen (Liang, 1986). LISREL kent echter ook enkele nadelen, die het gevolg zijn van de vrij strikte eisen die aan de data gesteld worden: (a) normaliteitseis ten aanzien van de verdelingen van geobserveerde variabelen (schending leidt tot conservatieve toetsresultaten; Boomsma, 1983), (b) normaliteitseis met betrekking tot latente variabelen. Het gevolg is dat de chi-kwadraat toets vaak tot (onterechte) verwerping van het model leidt, hetgeen wordt versterkt bij grote steekproeven (Joreskog en Sörbom, 1981, p. I.39). Dit laatst genoemde probleem kan gedeeltelijk ondervangen worden door de chi-kwadraat $\left(\chi^{2}\right)$ te delen door het aantal vrijheidsgraden, welke ratio bij een waarde van 1 tot 3 zou wijzen op een goede 'fit" van het model (Carmines en McIver, 1981). Hiervoor bestaan echter geen strikte regels; ook waarden van 5 of nog hoger worden genoemd (Bollen, 1989).

Het LISREL-model bestaat uit twee delen, namelijk het meetmodel, waarin wordt gespecificeerd hoe de latente variabelen (hypothetische constructen) gemeten worden in termen van geobserveerde wariabelen, en het structuurmodel, waarmee de causale relaties tussen de latente variabelen onderling en tussen de 'achtergrondkenmerken' en latente variabelen worden weergegeven. Er zijn twee soorten latente variabelen mogelijk, enerzijds voor $\mathrm{m}$ afhankelijke variabelen $\eta_{1} \ldots \eta_{m}$ (in deze studie de dimensies van 'afhankelijkheid'), anderzijds voor $\mathrm{n}$ onafhankelijke variabelen $\xi_{i} \ldots \xi_{\mathrm{n}^{*}}$. Deze vectoren $\boldsymbol{\eta}$ en van latente variabelen vormen een systeem van lineaire structurele relaties (Joreskog en Sörbom, 1981):

(1) $\eta=\mathrm{B} \eta+\Gamma \xi+\zeta \quad \operatorname{met} \zeta \sim \mathrm{N}(\mathrm{o}, \psi)$

De elementen van de coefficienten-matrix $B$ betreffen de directe causale effecten tussen de latente afhankelijke variabelen onderling en die van de $\Gamma$-matrix betreffen de directe causalle effecten van de latente onafhankelijke variabelen op de latente afhankelijke 
variabelen. In de plaats van de latente variabelen worden de varabelen $Y_{1}$ en $X_{4}$ waargenomen, zodanig dat:
(2) $\mathrm{Y}=\Lambda_{\mathrm{y}} \mathrm{n}+\mathrm{e}$
net e- N(0, $)$
(meetmodel voor $y_{i}$-variabelen)
(3) $X=\Lambda_{x} \xi+0$
met $8-\mathbb{N}\left(0, \theta_{3}\right)$
(meetmodel voor $x_{i}$-wariabelen)

Deze meetmodellen kunnen worden opgevat as factormodellen waarin bovendien rekening gehouden kan worden met meetfouten (en 8 ) in de geobserveerde variabelen (Joreskog en Sorbom, 1981). Een voorbeeld van een hypothetisch LISREL-model is in figuur 13.5 opgenomen.

Het algemene LISREL-model is gedeñnieerd door de hiervoor besproken vergelijkingen, waarbij voorts de volgende veronderstellingen gemaaki worden: (a) de meetfouten $(\zeta, \notin, 8)$ zin niet gecorreleerd met de latente variabelen ( en $\eta$ ), (b) de drie soorten meetfouten zjin niet onderling gecorreleerd en (c) de B-matrix heeft op de diagonaal nullen en de identiteitsmatrix minus de B-matrix is aiet singulier. De algemene LISREL-methode kent verschillende verschijningswormen, zoals (tweede orde) factormodellen en (uni- of multivariate) regressiemodelten. Formeel gesteld is LISREL een rekenprogramma dat onder bepaalde condities de onbekende parameters kan oplossen: de causale relaties moeten op grond van de theorie vastgelegd worden; LISREL kan slechts toetsen of deze hypothesen bij de data passen. Voordat het model geschat wordt, moet bovendien eerst onderzocht worden of het geldentificeerd is (Bollen, 1989).

Het beoordelen van de modelresultaten moet op vele verschillende wijzen gebeuren en betreft de parameterschattingen, de standaardfouten of t-waarden (alleen in de Maximum Likelihood schattingsprocedure), de correlatiecosfficienten en de totale aanpassing van het modell aan de data. Dit laatste kan aan de hand van de maat 'Adjusted Goodness of Fit Index" (AGFI), die het deel van de verklaarde (co-)varianties aangeeft en de Chi-kwadraat $\left(x^{2}\right)$. Aanbevolen wordt om beide als globale maten te hanteren; omdat de AGFI een onbekende verdeling heeft en $\chi^{2}$ zeer gevoelig is voor de grote steekproefaantallen (in dit geval de ratio met het aantal wrijheidsgraden nemen) en afwijkingen van de normale verdeling (Bollen, 1989; Boomsma, 1983; Joreskog en Sörbom, 1981). Zo'n globale aanpak houdt in dat steeds naar de veranderingen in de toetsgrootheden gekeken wordt bij iedere volgende aanpassing van het model en kan plaatsvinden aan de hand van modificatieindices. Deze mogen niet groter zijn dan vijf en geven per modelparameter aan hoe groot de verwachte afname van de $\chi^{2}$ is als een parameter wordi vrijgelaten bij hel schatten (gegeven de andere schattingen; Joreskog en Sorbom, 1981). Het is echter een puur statistische methode van modeicorrectie, die met enige voorzichtigheid gevolgd moet worden en dan steeds in combinatie net theoretische overwegingen zodat de parameterwaarden en parametertekens steeds kunnen worden geinterpreteerd.

\subsection{Datamateriaal}

Complementair aan het in dit boek beschreven onderzoek bij de instellingen voor ouderenzorg beeft in Maastricht tevens een onderzoek plaatsgevonden dat de vraagzijde in beeld brengt via enquetes bij ouderen zelf. Dit onderzoek, getiteld 'Zorgbehoefte van en zorgveriening aan ouderen", kende als vraagstelling: 'Welke factoren leiden bij een gelijke invaliditeit bij ouderen tot een verschillende gebruik van voorzieningen?' Zeer recent is mw. C. Frederiks op dit onderzoek gepromoveerd (Frederiks, 1990).

Het onderzoek aan de vraagzijde kende verschillende stadia. Eerst is via een postenquête onder thuiswonende ouderen (op basis van een naar leeftjd gestratificeerde aselecte steek- 


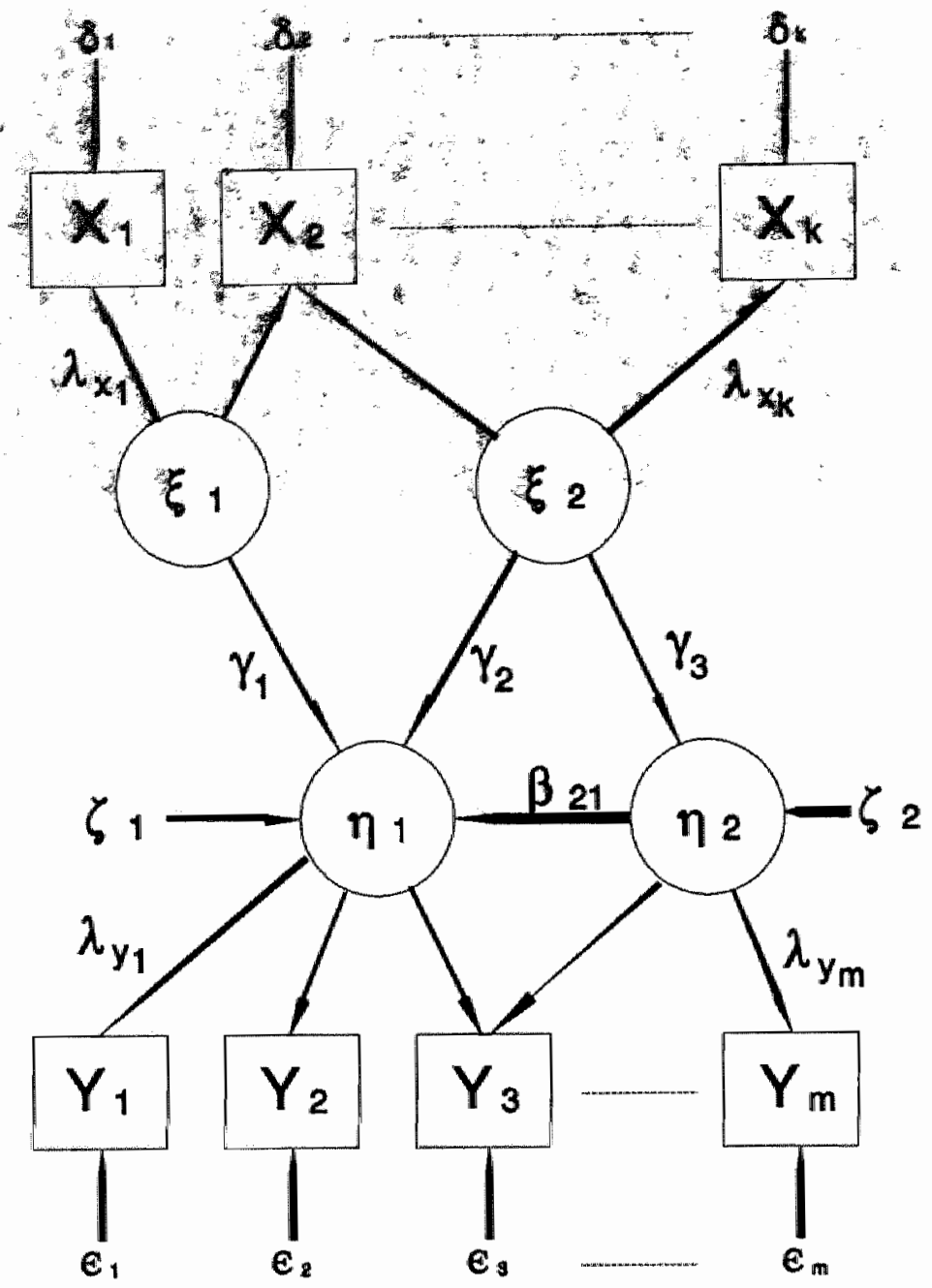

Figuur 13.6. Hypothetisch LISREL-model

proef uit het bevolkingsregister van 2451 ouderen vanaf 55 jaar; respons $78,1 \%$ ) een selectie gemaakt van relevante groepen thuiswonende ouderen die in aanmerking kwamen voor een uitgebreider mondeling interview (Frederiks en Te Wierik, 1988). Deze procedure is gekozen om te voorkomen dat een groot aantal interviews zou worden afgenomen bij vitale ouderen, die achteraf niet in de analyse betrokken zouden worden (Bisscheroux en Frederiks, in Schroots e. $a_{{ }_{3}}$ 1989). In eerder onderzoek hadden de betreffende onderzoek(st)ers aangetoond dat een postenquête en de zo dadelijk te bespreken selectiecriteria een goed instrument vormen voor vervolgonderzoek (Bisscheroux en Frederiks, 1986). Toch blijft 


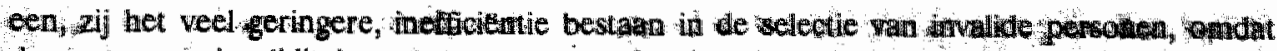
de mate van invaliditeit met een pastenquete in sommige gevallen owerschat wont ton opzichte wan mondelinge interviews (Bisscherowx en Fredewiks, 1989; Van Sonsbeek, 1988).

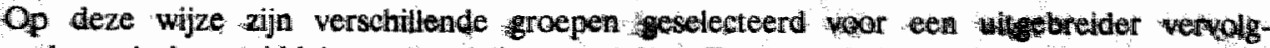

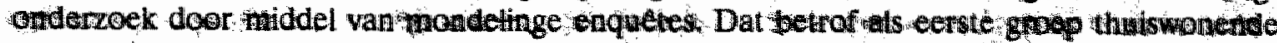
ouderen die geen professionele hulp van gezinsverzorging of wijkvenpleging gerapporteerd hadden, maar wel een sekene mate van invaliditet. As wtteria dasmoor wenden te

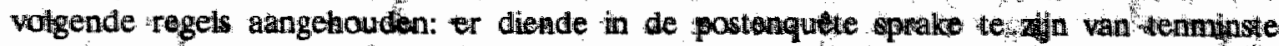

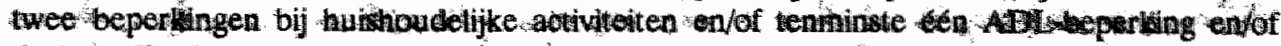
de betreffende oudere rapperterde bowsefte te hebben an (meer) hulp "Ten tweede werd op basis van de postenquate een groepsanengesteld die meldidengetwik te maken wan gezinsverzorging en/of wijkerpleging. Op basis van de zojuikt genwende ctiteria win in totaal 690 thuiswonende ouderen $(62,9 \%)$ zijn geselecteerd. Van deze uit postenquete geselecteerde groep, deels bestaande wit gebruikers van professionele zotg, deels foestande uit ouderen met een zekere invaliditeit maar zonder formele hulp, is uiteindelijk bij 450 mensen $(71,4 \%)$ en mondeting anterview afgenomen.

Na hun pilotstudie in de gemeente Geleen besloten de betreffende onderzoek(st)ers (zie Frederiks, 1990) ook de aanvragers van wijkverpleegkundige zorg en gezinsverzorging, alsmede bejaardenoordbewoners bij het onderzoek te betrekken. Tevens werden in het parallelonderzoek van Te Wierik gegevens verzameld van aanvragers voor opname in een bejaardenoord of een verpleeghuis. Door de aanvragers te betrekken in het onderzoek werd beoogd meer inzicht te krijgen in de omstandigheden die leiden tot het gebruik van professionele zorg. Voor het werzamelen van adressen van aanvragers is men afhankelijk van de medewerking van zorgverlenende instanties, omdat de 'trefkans' bij een eenmalig verzonden postenquete te gering is. $\mathrm{Bij}$ de bejaardenoorden en het verpleeghuis waren de problemen niet dusdanig groot dat er geen onderzoekspopulaties van aanvragers van beide voorzieningen kon worden samengesteld (zie vervolg), maar om verschillende redenen is er bij de aanvragers van professionele thuiszorg sprake van een vrijwel algemene nonrespons (Frederiks, 1990). Deze beoogde deelbestanden zijn dan ook niet gerealiseerd.

De totale onderzoekspopulatie bestaat derhalve uit vier deelbestanden, namelijk (a) thuiswonende ouderen die een zekere mate van invaliditeit hebben en/of gebruik maken van gezinsverzorging en/of wijkverpleging, (b) aanvragers voor opname in een bejaardenoord, (c) bewoners van bejaardenoorden en (d) aanvragers voor opname in het verpleeghuis. De wijze waarop het eerste bestand, in het vervolg aangeduid als het 'basisbestand', tot stand kwam is reeds aan de orde geweest; de andere deelbestanden worden nu kort toegelicht.

\section{De positief geïndiceerden voor opname in bejaardenoord}

Het onderzoek bij aanvragers voor opname in een bejaardenoord wond plaats in de periode november 1986 tot en met mei 1988 en richtte zich in de oorspronkelljke opzet op de positief geindiceerden (Te Wierik en Frederiks, 1990). In de onderhavige studie zijn echter tevens de aanvragers voor opname in een bejaardenoord uit het basisbestand betrokken; dit wordt zo dadelijk geexpliciteerd. Voor het oorsponkelijke deelbestand werden ouderen om priwacy-redenen benaderd door de maatschappelijk werkenden van de indicatiecommissie. Indien medewerking geweigerd werd noteerde men de reden daarvoor. De belangrijkste waren de geestelijke toestand $(38 \%)$ en een weigering om de interviewer te ontvangen $(40 \%)$. De gehele procedure heeft tot grote uitval geleid $(60 \%)$. Een belangrijke reden hiervoor was dat het vragen om medewerking aan onderzoek door de maatschappelijk werkenden ervaren werd als een moeilijke opdracht die tevens conflicteert met het eigenlijke doel van het huisbezoek (Te Wierik en Frederiks, 1990). Van de opgegeven personen is vervolgens $83 \%$ feitelijk ondervraagd. Naar de indruk van de oorspronkelijke onderzoeksters heeft er door de terughoudendheid van de indicatiecommissie selectieve 
non-respons plaatsgevonden, hetgeen met name tot onderschatting van de geestelijke problematiek leidt (Te Wierk en Frederiks, 1990).

Wast de personen in het oorspronkelijke deelbestand van positief gelndiceerden bleken er in het basisbestand ook nog 35 ouderen te zjin die rapporteerden dat zij een aanvraag hadden ingediend. Desbetreffende personen zijn uit het basisbestand verwijderd. Nadere inspectie van deze respondenten leerde dat zes van hen reeds waren opgenomen in het oorspronkelijke deelbestand van positief geñdiceerden. Het totale deelbestand van positief geindiceerden plus andere alanwragers voor opname in een bejaardenoord telt derhalve 164 respondenten ( 135 plus 35 minus 6 dubbeltellingen).

Het is niet per definitie zo dat de resterende subgroep van 29 aanvragers (die afkomstig waren uit het basisbestand) geen positief advies zal krijgen. In hoofdstuk 9 was aangetoond dat circa 75\% van alle aanvragers voor opname in een bejaardenoord uiteindelijk een positief advies krijgt. Hoewel voor een klein gedeelte niet vast staat dat dat zo is, zal het gehele deelloestand $(\mathrm{N}=164)$ steeds aangeduid worden als dat van de van positief gelndiceerdem.

\section{De bejaardenoordbewoners}

Van de totale populatie van bejaardenoordbewoners in Maastricht (iets meer dan 1100; zie hoofdstuk 10), is in 1987 een aselecte steekproef van ongeveer $30 \%$ getrokken (Frederiks e.a., 1988). Deze steckproeftrekking vond plaats door de directeur/directrice van de deelnemende tehuizen (acht wan de tot nog toe tien algemene bejaardenoorden) of in plaats daarvan door een andere medewerker en volgens instructies van de onderzoekers. Wanneer men in het tehuis vond dat de bewoner op grond van zijn/haar toestand niet mee zou kunnen doen of als de betrokkene zelf weigerde, werd de daarvoor opgegeven reden geregistreerd. Uiteindelijk is bij 207 bewoners een interview afgenomen, terwijl de respons per instelling sterk varieerde van 56 tot $87 \%$ (gemiddeld $70,6 \%$ ). De gevolgde procedures hebben er waarschijnlijk toe geleid dat de steekproef niet geheel representatief is voor de totale Maastrichtse populatie van bejaardenoordbewoners, omdat de helft van de redenen voor nonrespons de lichamelijke en/of psychische invaliditeit betrof. Er worden binnen het deelbestand tussen de tehuizen weliswaar significante bewonersverschillen aangetroffen naar demografische kenmerken zoals leeftijd en burgerlijke staat, maar die zouden vooral toe te wijzen zijn aan de verschillen tussen de instellingen in de 'leeftijd' en andere kenmerken van de acconmodatie, zoals bijwoorbeeld het aantal tweepersoonskamers (Frederiks e.a., 1988). In hoofdstuk 10 kwamen wij op het punt van verschillen tussen de bejaardencorden, uitgaande van gegevens rond de jaarwisseling van 1989/1990, tot enigszins afwijkende bevindinger. Er zijn echter grote verschillen in het onderzoeksstramien die -naast het verschil in tijd-mede de oorzaak kunnen zijn voor de afwijkende bevindingen. Tenstotte bleek dat een persoon uit dit deelbestand een aanvraag voor opname in het verpleeghuis had ingediend; deze persoon is naar dat betreffende deelbestand, dat zo dadelijk besproken wordt, overgebracht, zodat het deelbestand van bejaardenoordbewoners uiteindelijk 206 personen telt.

\section{De op te nemen verpleeghuispatiènten}

Het bestand van 157 op te nemen verpleeghuispatienten is opgebouwd in de periode van februari 1987-juli 1988 (Te Wierik, 1990). Om wille van de privacy werden de mensen ( 55 . plus) via de maatschappelijk werkenden van het verpleeghuis tijdens het huisbezoek gevraagd mee te werken aan het onderzoek. Terminale patienten zijn uitgesloten van het onderzoek. Het deelbestand kent zowel somatische als psycho-geriatrische patienten. Omdat de maatschappelijk werkenden het moeilik (en conflicterend met het huisbezoek) vonden om de op te nemen patienten extra te belasten met het onderzoek, is het aannemelijk dat de representativiteit verder verminderd is (naast de uitsluiting van terminale patienten) door een ondervertegenwoordiging van complexe opname-situaties (Te Wierik, 1990).

Bij de respondenten in dit deelbestand is dezelfde vragenlijst afgenomen als bij de andere groepen ouderen, maar moest vaker een beroep gedaan worden op een tweede respondent; dit betrof meestal de centrale verzorger. Een tweede respondent heeft bij ruim $80 \%$ van de 
verpleeghuispatienten een rol gespeeld (zie tabel 13,2). De interviews werden door getrainde interviewers afgenomen in de thuissituatie, of in een aan de opmame voorafgaande intramurale setting of zo kort mogelijk na de opname in het verpleeghuis. Van de respondenten is niet alleen een deel afkomstig uit een ziekenhuis $(\mathrm{N}=71)$, maar komt ook een klein deel uit andere intramurale settings zoals het Psycho-medisch Streekcentrum Vijverdal of een ander verpleeghuis $(\mathrm{N}=8)$; in alle gevallen dat een intramuraal verblijf woorafging aan de opname in het verpleeghuis (50\%), zijn de vragen over het voorzieningengebruik, de woonsituatie en het sociale netwerk beantwoord met betrekking tot de periode voor het betreffende intramurale verblijf (in de meeste gevallen dus bet ziekenhuis).

Overigens is een deel van de verpleeghuispatienten afkomstig uit het bejaardenoord $(N=45$; $28,5 \%$ van het deelbestand; zie tabel 13.2). Dit biedt de mogelijkheid on de overgang tussen de beide intramurale voorzieningen nader te bestuderen (zie hoofdstuk 15).

Er zijn bij de analyse van dit deelbestand nog meer zaken van belang die kort worden toegelicht. Ten eerste is de situatie waarin de respondent verkeert vaak zo slecht dat het bij sommige vragen bepaald niet 'kies' zou zijn geweest deze te stellen. Als de psychische toestand slecht is, is het bovendien niet erg zinvol c.q. niet mogelijk om beparalde vragen te stellen; zo is bijvoorbeeld in de regel geen zelfbeoordelingsschaal over de psychische toestand voorgelegd aan ouderen die met een psycho-geriatrische indicatie (dementie) worden opgenomen. Ten tweede zijn slechts 24 respondenten rechtstreeks onderviaagd, zodat alleen voor hen antwoorden beschikbaar zijn van zelfbeoordelingsschalen zoals die voor de psychische toestand. Ten derde is een tweede respondent valk niet geheel op de hoogte van privé-zaken zoals het exacte inkomen of opleidingsniveau, zodat bij dit soort vragen relatief veell antwoorden ontbreken.

Omdat in alle gevallen de opname vroeg of laat werd gerealiseerd, wordt in het vervolg niet gesproken van 'aanvragers van opname in het verpleeghuis' of van 'op te nemen verpleeghuispatiënten' (Te Wierik, 1990), maar wordt het deelbestand kortheidshalve aangeduid als dat van de verpleeghuispatiënten. Daarmee zijn deze ouderen echter geenszins representatief voor de al langer aanwezige patienten, terwijl (zoals reeds aan de orde kwam) ook de representativiteit ten opzichte van andere net opgenomen patienten in sommige gevallen in het geding is. Dit alles noopt tot een zekere terughoudendheid en voorzichtigheid bij analyses met betrekking tot het deelbestand zelf (zoals bij schaalconstructies) en in relatie tot de andere deelbestanden. Waar mogelijk worden de gegevens wel benut, maar bil het schatten van het uiteindelijke model zal de betrouwbaarheid opnieuw moeten worden bezien.

\section{De gehele onderzoekspopulatie en generaliseerbaarheid}

Bij het samenvoegen van de vier deelbestanden wordt een respondent, zoals hierwoor werd uitgelegd, als het ware ingedeeld in de 'zwaarste' categorie, dat wil zeggen in het verpleeghuis als hij tevens voorkomt in het bejaardenoord (bij het oorspronkelijke bestand van $N=157$ komt er op deze wijze nog eén bij uit het bejaardenoord) of in het deelbestand van positief gehndiceerden voor opname in het bejaardenoord als hij/zij ook voorkomt in het 'basisbestand' van zelfstandig wonende ouderen. In de analyses wordt zoveel mogelijk uitgegaan van het totale bestand van 943 respondenten. Bij sommige variabelen is dit echter vooral bij verpleeghuispatienten problematisch; de redenen hiervoor werden al aangeduid.

Het hoofddoel van deze studie is het verschaffen van inzicht in de determinanten van het gebruik van voorzieningen door ouderen om op grond daarvan een simulatiemodel te ontwikkelen (zie hoofdstuk 1). Op de betrouwbaarheid en generaliseerbaarheid van de gebruikte gegevens wordt in een simulatiemodel een zware hypotheek gelegd, met name als het model voor beleidsdoeleinden benut dient te worden.

Ter beantwoording van het vraagstuk van generaliseerbaarheid van de onderzoekspopulatie zijn verschillende aspecten van belang: (a) is deze populatie representatief voor de gehele bevolking, (b) zijn de deelbestanden representatief voor de verschillende groepen in de totale bevolking, (c) zijn de deelbestanden voldoende omvangrijk om te zorgen voor rede- 


\begin{tabular}{|c|c|c|c|c|}
\hline & thild arronend & $\begin{array}{l}\text { indicatie } \\
\text { bej. pord }\end{array}$ & $\begin{array}{c}\text { In een } \\
\text { bej. pord }\end{array}$ & $\begin{array}{l}\text { opnasue in } \\
\text { verpl.husis }\end{array}$ \\
\hline 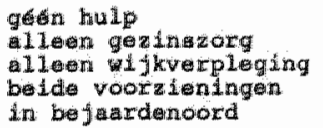 & $\begin{array}{r}301 \\
71 \\
26 \\
17 \\
-\end{array}$ & $\begin{array}{l}78 \\
44 \\
12 \\
30 \\
-\end{array}$ & $\begin{array}{l}= \\
= \\
206\end{array}$ & $\begin{array}{l}17 \\
14 \\
26 \\
25 \\
45\end{array}$ \\
\hline totat & 415 & 164 & 206 & 158 \\
\hline $\begin{array}{l}\text { Warvan vla } 2 \\
\text { copondent (in })\end{array}$ & 22,7 & 32,9 & 9,7 & 04.2 \\
\hline
\end{tabular}

* Toetand voor opname of voor het daraan voorafgande intramurale verbliff ( $N=79$ )

lijke betrouwbaarbeidsmarges. Bij het eerste punt wordt in herinnering geroepen dat via een postenquete een voorselectie heeft plaatsgevonden zodat het onderzoek beperkt is tot die ouderen die voorzieningen" (willen) gebruiken en/of een zekere mate van invaliditeit hebben. Dit blijkt op te gaan woor bijna $1 / 3$ van alle zelfstandig wonende ouderen (benadering via de postenquete). Hoewel de voorselectie een goed te verdedigen aanpak is -zeker in het licht van de onderzoeksvraagstelling die ten grondslag heeft gelegen aan de dataverzameling; zie Frederiks (1990) en het begin van deze paragraaf-kan er echter een probleem ontstaan als de gegevens benut worden voor het schatten van de invloed van toekomstige demografische ontwikkelingen. Deze worden immers geraamd voor de gehele bevolking (op basis wan bevolkingsprognoses van het CBS; zie hoofdstuk 2), zodat moet worden verondersteld dat de verdeling in de gehele bevolking tussen geén en een of meer validiteitsbeperkingen constant zal bljiven. Over deze verdeling dient derhalve bij het maken van simulaties van het voorzieningengebruik een additionele veronderstelling gemaakt te worden om het mogelijk te maken de resultaten te generaliseren. Dit komt aan de orde op de daarvoor geeigende plaats, namelijk in paragraaf 15.6 .

Het gehele bestand is opgebouwd in een periode van bijna twee jaar, beginnend in de tweede helft van 1986 met de postenquete en de daaropvolgende interviews bij thuiswonende ouderen en eindigend mel de laatste verpleeghuispatienten in juli 1988. Dit tijdsverloop is inherent aan het intensieve karakter van mondelinge interviews en het geleidelijk 'vollopen' van de bestanden van aanvragers van opname in een bejaardenoord of verpleeghuis. Toch wordt de verwachting uitgesproken dat in deze periode geen noemenswaardige veranderingen zjin opgetreden in de structuur van de ouderenzorg in Maastricht; bij de analyse van de "aanbodrijde" in deel $B$ van deze studie zijn cok geen aanwijzingen gevonden voor grote veranderingen.

Bij de tweede vraag of de verschillende deelbestanden representatief geacht mogen worden is hiervoor all uitgebreid stilgestaan. Hier volstaan wij met de conclusie dat deze vraag voor het basisbestand van thuiswonende ouderen zonder meer positief kan worden beantwoord. Bij de andere drie deelbestanden hebben zich in meer of mindere mate problemen voorgedaan in selectieprocedures en uitval. Bij de bewoners van bejaardenoorden zijn die echter niet zodanig geweest dat de representativiteit in ernstige mate in het geding is gekomen, zodat ook voor dit deelbestand kan de vraag positief beantwoord worden. Het deelbestand van positief gelndiceerden woor opname in een bejaardenoord is waarschijnlijk niet geheel representatief, met name niet met betrekking tot het geestelijk functioneren dat door selec-

1. Hieronder zijn begrepen: gexirnswernorging wijkverpleging bejaardenoord (indugief indieatiecommissie dsarvoor) en verpleeghuis. 
tieve uitval overschat wordt. Het deelbestand van de op te nemen verpleeghuispatienten kent de meeste problemen, docin dat is in het licht van de ernstige lichamelijke en geestelijke problematiek van deze groep niet onbegrijpelijk. Voor een deel van de problemen is een oplossing via een tweede respondent gevonden, doch hierdoor blijwen privacy-gevoelige vragen en belevingswragen onbeantwoord. Ook in dit bestand treedt een onderschatting van de geestelijke problematiek op. Voorts zijn terminale patienten uitgesloten. Samenvattend kan gesteld worden dat dit declbestand met enige terughoudendheid moet worden bezien.

Tot slot wordt kort stilgestaan bij de derde vraag, namelijk of de omvang van de verschillende deelbestanden voldoende groot is om hanteerbare betrouwbaarheidsmarges te behouden in de analyses. Deze vraag lijkt zonder meer bevestigend te kunnen worden beantwoord voor de voorzieningen die centraal stonden in de oorspronkelijke onderzoeksvraag, namelijk gezinsverzorging, wijkverpleging, bejaardenoord en verpleeghuis. Deze voorzieningen worden in deze studie aangeduid als de basiswoorzieningen voor ouderen. Combinaties van deze voorzieningen (gezinsverzorging en/of wijkverpleging en/of een positief opnameadvies) en minder gangbare voorzieningen zoals dagbehandeling en het gebruik van dienstencentra van het GOW worden echter veel minder vaak gerapporteerd, zodat de analyses daarover met veel grotere onzekerheidsmarges behept zijp. In hoofdstuk 15 komen wij daarop terug. 


\section{Belangrijke factoren in de leefsituatie van ouderen}

\subsection{Introductie}

In het voorgaande hoofdstuk bleek dat onderzoek naar de factoren die van invloed kunnen zijn op het voorzieningengebruik dikwijls is gebaseerd op het model van Andersen (Andersen en Newman, 1973; Andersen e.a., 1975). Uitgaande van dergelijk onderzoek in het buitenland (Andersen e.a., 1975; Evashwick e.a., 1984) en in Nederland (Arts e.a., 1989; Bisscheroux en Frederiks, 1985; Breemhaar e.a., 1989; Klaassen-Van den Berg Jeths, 1989; Van den Heuvel, 1987; Van Linschoten e.a., 1988) is een selectie gemaakt van de meest relevante aspecten van de leefsituatie van ouderen. Deze aspecten zijn potentiele dimensies. van de afhankelijkheid van ouderen, die mogelijk van invloed zijn op de vraag naar en het gebruik van professionele zorgvoorzieningen en worden in dit hoofdstuk in detail besproken en geanalyseerd. De verdienste van Andersens model ligt met name op het vlak van de ordening van relevante factoren; de verklaringskracht daarentegen blijkt in empirisch onderzoek tot op heden niet erg groot geweest te zijn (zie paragraaf 13.3).

De factoren die als relevant worden aangemerkt en in dit hoofdstuk nader worden onderzocht betreffen: demografische kenmerken zoals leeftijd, sexe, burgerlijke staat en omvang van het huishouden (paragraaf 14.2); instrumentele en algemeen dagelijkse activiteiten, afgekort tot respectievelijk IADL en ADL (paragraaf 14.3); andere indicatoren voor de lichamelijke gezondheid en het medicijngebruik (paragraaf 14.4); het psychisch functioneren (paragraaf 14.5); de woonsituatie zowel in huis als in de directe omgeving (paragraaf 14.6); de sociaal-economische situatie (paragraaf 14.7); het sociaal netwerk (paragraaf 14.8) en ten slotte de informele hulpverlening (in paragraaf 14.9). Per dimensie is de opbouw van het betoog steeds gelijk: na een inleiding over de in de literatuur aangetroffen inzichten met betrekking tot de onderhavige dimensie, worden de (schaal-)constructies van variabelen voor deze dimensie en de onderlinge samenhangen daarbinnen besproken. Vervolgens wordt een overzicht gegeven van de in de literatuur beschreven relaties met andere dimensies uit de leefsituatie van ouderen en wordt het bestaan van deze verbanden op hun relevantic getoetst met behulp van het eigen onderzoekmateriaal.

Doelbewust wordt in deze gehele analyse van de determinanten niet of nawweliks gerefereerd aan de relaties met het gebruik van voorzieningen. Ook wordt expliciet gesproken van relaties in plaats van causale verbanden. Beide onderwerpen komen in het volgende boofdstuk aan de orde (hoofdstuk 15). Een kanttekening is nog op zijn plaats en betreft de wijze waarop 'verbanden' worden gekwantificeerd. Dit gebeurt steeds aan de hand van correlatie-matrices die berekend zijn op grond van paarsgewijze verwijdering van ontbrekende gegevens per tweetal variabelen waarvoor de samenhang wordt weergegeven. Lijstgewijze verwijöering van ontbrekende gegevens zou met name bij verpleeghuispatienten, maar ook in de andere deelbestanden tot een aanzienlijke reductie in het aantal respondenten leiden. In hoofdstuk 15 komen wij op de gevolgen van deze aanpak terug. 


\subsection{Demografische kenmerken}

\subsubsection{Inleiding}

Onder demografische kenmerken worden begrepen: de leefijd, de sexe, burgerlijke staat en samenstelling van het huishouden. Deze kenmerken hangen bij ouderen sterk samen. De levensverwachting bij geboorte is voor mannen (ongeweer 73,5 jaar in 1988, CBS) aanzienlijk lager dan voor vrouwen (ongeveer 80,0 jaar). Voor deze verschillen tussen de sexen worden diverse factoren aangevoerd, zoals onder andere leefgewoonten (roken), werkomstandigheden, cultureel bepaalde rollen en biologische verschillen (Siegel en Hoover, 1982. Tas, 1988). Voor ouderen is de levenswinst veel geringer geweest dan bij jongeren (Lopez en Hanada, 1982): alechts $10 \%$ van de totale toename van de levensverwachting in de westerse landen kan worden toegeschreven aan de levenswinst bij 65-plussers (De Vries, 1985). De levensverwachting voor 65 -jarigen bedroeg in 1988 voor mannen 15 jaar en voor vrouwen 19 jaar (CBS, 1989). De sexeverschillen zjin derhalve ook bij ouderen van belang, zij het dat verwacht wordt dat deze lets zullen afnemen (Klaassen-Van den Bergh Jeths, 1989). Door het verschil in levenswerwachting neemt met het stijgen wan de leeftijd de verhouding tussen vrowwen en mannen in een leeftijdsgroep toe van ongeveer $1: 1$ in de categorie 50-55 jaar tot 2,5:1 bil 90-plussers (CBS, 1989). In de middenvariant van de meest recente bevolkingsprognose van het CBS (1989) wordt verondersteld dat bij ouderen vanaf 85 jaar deze verbouding nog groter zal worden en bij 90-plussers zal stijgen tot bijna 3,5:1 in het jaar 2050 (zie verder hoofdstuk 2).

Leeftijdsinvloeden bij ouderen zijn op twee manieren nader te preciseren. Allereerst leidt leeftijd tot een stijgende kans op validiteitsbeperkingen, lichamelijke gezondheidsproblemen en verminderd psychisch functioneren. Leeftijdseffecten op voorzieningengebruik zijn dan ook hoofdzakelijk effecten van gezondheidsproblemen in de meest ruime zin: indien bijvoorbeeld het aantal validiteitsbeperkingen en de leeftijd in regressie- of variantie-analyse gelijktijdig gebruikt worden als potentiele verklarende variabelen voor het gebruik van voorzieningen, dan levert de leeftijd vaak geen afzonderlijke significante bijdrage meer (Coolen en Toersen, 1989; Janssen e.a., 1989; Van Linschoten e.a., 1988), maar hierop zijn ook talrijke uitzonderingen (Andersen en Newman, 1973; Breemhaar e.a., 1989; Van den Heuvel, 1989; Klaassen-Van den Berg Jeths, 1989; De Klerk en Huijsman, 1989). De tweede kanttekening betreft het onderscheid tussen cohort- en leeftijdseffecten (Hermkens en Rekers, 1989; KJasssen-Van den Berg Jeths, 1989). Ouderen zijn in termen van scholings - en inkomensmogelijkheden in relatief ongunstige tijden geboren, hebben twee wereldoorlogen meegemaakt, maar de postmoderne industriele en technische ontwikkelingen van de laatste 10 a 15 jaar juist niet bewust en niet-participerend in het arbeidsproces beleefd (Becker, 1989). Verschillen in inkomens- en onderwijsniveau's zijn hoofdzakelijk het gevolg van cohorteffecten (Herweijer, 1990; Ponmer, 1990), hetgeen ook geldt woor gedrags- en attitudekenmerken van ouderen (SCP, 1989).

\subsubsection{Onderlinge samenhang bij demografische kenmerken}

Het voorgaande samenvattend zijn de volgende relaties tussen demografische kenmerken van belang: met de leeftijd neemt het aandeel van vrouwen toe door hun hogere levenswerwachting; vrouwen bebben een grotere kans om hun partner te overleven zodat er een werband bestaat tussen leeftijd en sexe enerzijds en burgerlijke staat en alleenstaand zijn anderzijds; de omvang van het huishouden (hier aangegeven met het aantal huisgenoten exclusief de respondent en een eventuele partner) neemt door voorgaande mechanismen af met het toenemen van de leeftijd, maar ook door het 'lege nest" (verlaten wan ouderlijk huis 


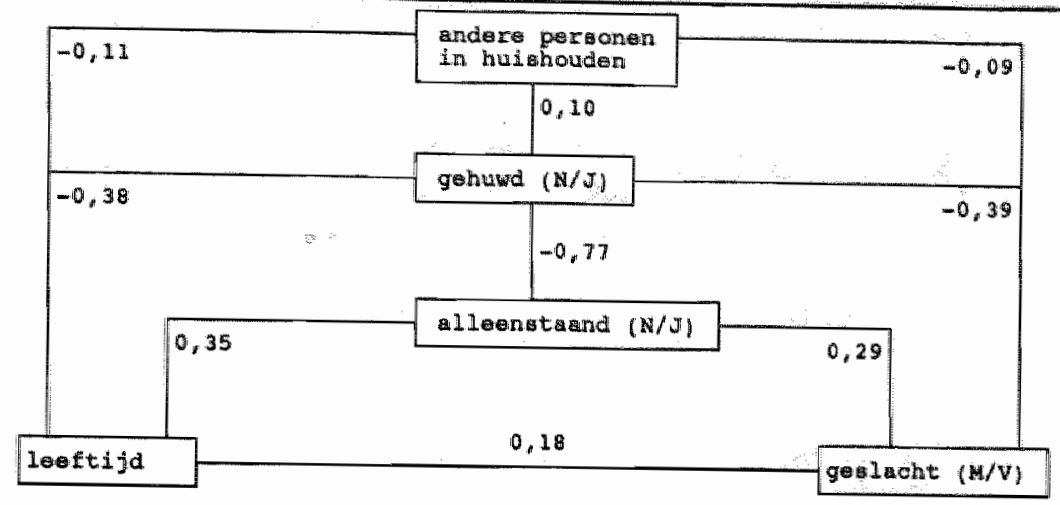

Figuur 14.1. Onderlinge relaties tussen demografische kenmerken

door kinderen). Figuur 14.1 brengt de onderlinge verbanden via correlatiecoeflicienten in beeld voor de totale onderzoeksgroep $(\mathrm{N}=943)$. Alle besproken verbanden keren terug, maar enkele behoeven toelichting. Niet (meer) gehuwd zijn leidt er niet automatisch toe dat de respondent alleenstaand is (anders was de correlatie nog hoger geweest) en dit lijkt met name toe te wijzen aan vrouwen, gezien het vrij grote verschil in correlatie tussen enerzijts geslacht en anderzijds alleenstaand of gehuwd zijn.

\subsubsection{Samenhang tussen demografische en andere variabelen}

In deze paragraaf worden de meest belangrijke verbanden tussen enerzijds demografische kenmerken en anderzijds de andere aspecten van de leefsituatie (social netwerk, sociale status, validiteit en gezondheid, etcetera) slechts beknopt besproken. Bij de afzonderlijke besprekingen over de andere leefaspecten komen de verbanden met leeftijd, geslacht en dergelijke uitgebreider aan de orde.

Met de leeftijd neemi in het algemeen het gebruik van voorzieningen sterk toe (CBS, 1988; Huijsman 19896 ; Klaassen-Van den Berg Jeths, 1989; STG, 1985, 1987, 1988). Voor veel afzonderlijke voorzieningen is dat eveneens goed gellustreerd, zoals bij gezinsverzorging (Huijsman en Dolmans, 1990), bejaardenoorden (Huijsman, 1988b), wijkverpleging (NK, 1988), gezondheidszorgvoorzieningen zoals huisarts, specialist en zlekenhuis (CBS, 1988) en ambulante geestelijke gezondheidszorg (NVAGG, 1988). Het samengaan van gezondheidsproblemen en alleenstaand zijn leidt tot een groter beroep op en een grotere kans tot toelating in de intramurale sector; ook de opnamedrempel wordt bij alleenstaanden lager gelegd (Merkus, 1974).

Met betrekking tot het sociaal netwerk is geconstateerd dat ouderen die verweduwd zijn wrijwel hetzelfde contactpatroon hebben als gehuwde ouderen (Braam e.a., 1981, p. 88; Shanas, 1968). Duurzame relaties worden vooral aangetroffen tussen mensen die qua leeftijd, burgerlijke staat en/of sociaal-economische status in dezelfde positle verkeren (Braam e.a., 1981; Janssen, 1989; Rosow, 1974). Het eigen gezin blijft echter de hoeksteen in het sociale netwerk; compensatie voor het verlies van een partner wordt in het sociaal netwerk moeilijk gevonden noch binnen, noch buiten het familieverband (Braam a.a., 1981, p. 91; Dooghe en Vanderleyden, 1978; Knipscheer, 1980). Ongehuwden en gescheiden ouderen onderhouden slechts iets hechtere contacten met broers en zussen, zodat per saldo voor 
deze groepen toch een lets ongunstiger sociaal netwerk resulteert dan voor gebuwden (Bram e.a. 1981 , p. 89; Riley e.a. 1968 ).

Eenzaamheid vertoont bij zelfstandig wonende ouderen navwelijks samenhang met leeftijd. Enerajds kan sprake ziljn van veranderingen in verwachtingspatronen ("onvermijdelijk", "hoort erbij"), anderzijds worden eenzame ouderen relatief vaker in een bejaardenoord opgenomen (Braam e.a., 1981; Coolen, 1984).

Eenwamheid hangt sterk samen met burgerlijke staat en komt het meest voor bij gescheidenen gevolgd door verweduwden en daarna bij gehuwden (De Jong-Gierveld, 1978; Shanas, 1968). Sterke eenzaambeidsgewoelens treden het meest nadrukkelijk op bij het gelijktijdig optreden van een 'ongunstige' burgerlijke staat (gescheiden of verweduwd), alleenstaand, feitelijke gezondheidshandicaps en een negatieve gezondheidsbeleving. Eenzaamheid houdt verband met een zwak contactpatrocon (zowel in frequentie als in verscheidenheid) (CBS, 1977). Het contactpatroon is echter niet doorslaggevend; bij vergelijkbaar sociaal netwerk zijn oudere weduwen eenzamer dan oudere gehuwde vrouwen (Knipscheer, 1988; Munnichs, 1972). Sociaal verlies is veel belangrijker dan sociaal isolement, waardoor met name bij recent verweduwde oudere vrouwen de eenzaamheid het hoogste is (Ankersmit, 1979).

\section{3. (Instrumentele) Activiteiten van het Dagelijks Leven}

\subsubsection{Inleiding}

Pionier in het onderzoek naar de zogenaamde Activiteiten van het Dagelijks Leven (Activities of Daily Living; ADL) is ongetwijfeld Katz, van wiens hand sinds 1962 vele artikelen zijn verschenen. De activiteiten van het dagelijks leven (ook wel" algemeen dagelijkse levensverrichtingen) worden omschreven als de handelingen die lemand dagelijks moet verrichten teneinde zijn lichaam voldoende te verzorgen (Merkus, 1974). Over de vraag welke activiteiten tot de ADL gerekend moeten worden, bestaat in de literatuur echter geen eenduidigheid. De discussie richt zich met name op mobiliteitsvraagstukken en op de vraag of de eis van dagelijkse uitvoering noodzakelijk is, waarbij aangetekend wordt dat ook andere factoren, zoals cultuurpatronen, hierbij een rol kunnen spelen.

De ADL-index werd aanvankelijk gehanteerd in studies naar de oorzaken van ziekte en naar de effecten van mogelijke behandelingsprotocollen (Katz e.a., 1962; Katz e.a., 1963), en bestond in het begin uit een zeer beperkt aantal van zes items, namelijk zichzelf wassen, kleden, toilletgang, zich verplaatsen, incontinentie en eten. In een latere fase werden met name mobiliteitsitems uitgewerkt (Brook e.a., 1979; Nagi, 1976; Rosow en Breslau, 1966) en opgenomen als aanvulling op de ADL-schaal (Jette en Branch, 1981; Katz, 1983). Sommige auteurs namen ook items op die betrekking hebben op het zintuiglijk functioneren (Chirikos en Nestel, 1985). De ADL-index vertoont een interne hierarchie (Katz e.a., 1963, 1969 en 1970; Staff of the Benjamin Rose Hospital, 1959, 1960) en geeft aan dat functieverlies in een bepaalde volgorde optreedt en bet eventueel herstel van functies in de omgekeerde volgorde plaats vindt. In empirisch onderzoek worden dan ook schalen gevonden die voldoen aan stringente normen van bijvoorbeeld Guttman-analyse (zie hoofdstuk 13). Voorbeelden van gevalideerde schalen zijn de 'scale of self care tasks' (Heuman en Boldy, 1982 ) met de items wassen, aan- en uitkleden, voetverzorging en mobiliteit of de zogenaamde MOSES-schaal (Heimes e. $a_{\text {.y, }}$ 1987) met vijf dimensies waaronder een ADL-schaal met wassen, kleden, incontinentie, in en uit bed gaan en lichaamsverzorging (nagels, haar e.d.). Geconcludeerd wordt dat 'the ADL-index is based on primary biological and psychosocial function, reflecting the adequacy of organized neurological and locomotor response' (Katz e.a., 1963). Er wordt daarbij bovendien gewezen op parallellen met de antropologie en in de ontwikkeling van kinderen (Katz en Akpom, 1976). Deze parallel is voor een aantal onder- 


\begin{tabular}{|c|c|}
\hline $\begin{array}{l}\text { Instrumentele } \\
\text { activiteiten }\end{array}$ & $\begin{array}{l}\text { Algemene dagelijkse } \\
\text { activitelten }\end{array}$ \\
\hline $\begin{array}{l}\text { 1. vloer dweilen } \\
\text { 2. de was doen } \\
\text { 3. boodrchappen doen } \\
\text { 4. tofzuigen } \\
\text { 5. bed versehonen } \\
\text { 6. oten koken }\end{array}$ & 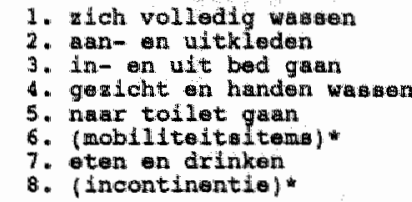 \\
\hline
\end{tabular}

- Toevoegingen ten annzion van ochema (coolem, 1989)

zoekers de reden om bijvoorbeeld incontinentie als een ADL-item te beschouwen (Leering, 1968 en 1969; Helmes e.a., 1987). Een andere detaillering betreft het onderscheid tussen primaire activiteiten die terug te voeren zijn op het primitief dierlijk bestaan (eten, toiletgang etc.) en de activiteiten die deels cultureel bepaald worden (kleden, wassen). Prevallentiecijfers voor de eerste ADL-items vertonen naar tijd en plaats weinig fluctuatie en hebben in tegenstelling tot de tweede groep nauwelijks verband met sexe (Akpom e.a., 1973; Branch e.a., 1984; Jette en Branch, 1981; Katz e.a., 1963; Wenger, 1986). Er zijn derhalve veel aanwijzingen (Spector e.a., 1987) dat tussen ADL-items een rangorde bestaat naar moeilijkheidsgraad, ook indien mobiliteitsitems opgenomen worden (Brook e.a.., 1979). Zo is bijwoorbeeld zichzelf wassen een moeilijker handeling dan kleden, dat weer moeilijker is dan eten (Staff of the Benjamin Rose Hospital, 1959 en 1960). Een ordening naar complexiteit van ADL-handelingen leidt tot een schaal van kenmerken, waarmee de hulpbehoefte te kwantificeren is. Ook in Nederlands onderzoek zijn deze verbanden vastgesteld (Bisscheroux en Frederiks, 1985; Coolen, 1989; Faasse, 1977; Huijsman en Visser, 1990; Leering, 1968 en 1969; Leering e.a., 1974; Merkus, 1974; Van Drunen en Van Montfoort, 1980 en 1981). Ook verbijzonderd naar groepen van ouderen blijft de hierarchie in tact; dit geldt voor zelfstandig wonenden (o.a. Frederiks, 1990), bejaardenoordbewoners (zie hoofdstuk 10) en verpleeghuispatienten (Van Drunen en Van Montfoort, 1980, 1981). Tabel 14.1 laat de meest voorkomende handelingen in hun onderlinge hierarchie zien, waarbij in het algemeen geldt dat uitval op een hoger genummerde handeling ook uitval bij lager genummerde handelingen met zich meebrengt (Coolen, 1989).

Bij de instrumentele activiteiten van het dagelijks leven (LADL), in Nederlands onderzoek ook wel aangeduid als huishoudelijke activiteiten (HHA), speelt het probleem dat de diversiviteit in te onderscheiden handelingen zeer groot is en dat daardoor het gevaar optreedt dat schaalconstructie berust op meer toevallige omstandigheden en (sterker dan bij ADL-schalen) leidt tot 'kanskapitalisatie'. Bovendien worden beperkingen bij instrumentele activiteiten deels cultureel bepaald (Fillenbaum, 1985; Koyano e.a., 1988; Wenger, 1986). De literatuur over LADL-beperkingen is dan ook minder omvangrijk dan die van ADL en gevalideerde instrumentele schalen zijn schaars. De eerste gevalideerde schaal (Lawton en Brody, 1969) betrof acht items, te weten telefoneren, boodschappen doen, (warme) maaltijdbereiding, het huis schoonhouden, de was doen, gebruik van (openbaar) vervoer, zelfmedicatie en afhandeling van financiele zaken. Deze schaal, die sexe-afhankelijk ingevuld is door bij mannen drie items niet op te nemen (de was, huishouden en maaltijd), heeft een sterke Guttmanstructuur, goede interbeoordelaarsbetrouwbaarheid en en significante samenhang met andere meetinstrumenten voor fysiek, psychisch en sociaal functioneren.

Empirisch onderzoek (Fillenbaum, 1985) maakt hat aannemelijk dat LADL-items een andere dimensie weergeven dan ADL-items en dat zij in factoranalyse een eigen bijdrage leveren. Bovendien werd ook voor de instrumentele activiteiten een sterke Guttman-schaal 
bereikt bestaande uh 5 items, namelijk (nar afnemende moeilikheidsgraad): huishouden, transport, boodschappen doen, maaltijubereiding en financiele zaken. Er zijn overigens aarwijzingen dat sommige LADL-items andere aspecten dan het fysieke functioneren meten. Zo is het mogelijk dat beperkingen bij telefoneren, financieel beheer en zelfmedicatie deels bepaald worden door cognitieve functiebeperkingen (Fillenbaum, 1985; Manton en Soldo, 1985; Pfeffer e.a., 1982; Wenger, 1986; Wilkin, 1987).

De laatste jaren word: bet steeds duildelijker dat de LADL- en ADL-schalen samen te voegen zijn tot eén lotaalschaal (met subschalen) ter beoordeling van de fysieke waliditeit van ouderen in ruimste zin (Coolen, 1986; Cornoni-Huntley e.a., 1985; Fillenbaum, 1985; Spector e.a., 1987; Frederiks, 1990; Huijsman en Visser, 1990). Deze nieuwe validiteitsschaal zou dan uit drie dimensies bestaan, waarbij naast ADL en LADL de mobiliteit een aparte dimensie vormt (Lawton en Brody, 1969; Katz, 1983; Pfeffer e.a., 1982). Het voordeel van deze gecombineerde schaal is bovendien dat een breder continutum aan problemen bestreken wordt, omdat de oorspronkelijke ADL-schaal zich meer richt op zwaardere beperkingen met relatief lage prevalentiecijers, zelfs bij hoogbejaarden (Katz, 1983; Koyano e.a., 1988).

\subsubsection{Constructie (I)ADL-schalen}

In thet Maastrichtse onderzoek (Frederiks e.a., 1988, 1989) zijn in totaal 17 (I)ADL-items opgenomen, waaronder acht ADL-items (in en uit bed stappen, zichzelf wassen, aan- en witkleden, toiletgang, eten en drinken, binnenshuis verplaatsen, traplopen en lezen) en negen instrumentele items (koken, broodmaaltijd maken, stoffen, dweilen, verwarming verzorgen, boodschappen doen, de was doen, bed opmaken en administratie doen). Dit zijn dezelfde vragen die waren opgenomen in het (voormalige) Besluit Opneming. Bejaardenoorden, waarbij 'zich binnenshuis verplaatsen' is aangevuld met traplopen en de instrumentele activiteiten bovendien aangevuld zijn met 'administratie doen'. Schaalanalyse op basis van het gehele bestand $(N=943)$ laat zien dat de betrouwbaarheid van de gecombineerde schaal (Cronbach's alpha $=0,93$ ) groter is dat die van de afzonderlijke ADL-schaal $(\alpha=0,90)$ en IADL-schaal $(\alpha=0,85)$. Bovendien kan in de gecombineerde (I)ADL-schaal geen verbetering meer bereikt worden door een item weg te laten; dit is wel het geval bij de afzonderlijke ADL-schaal en betreft dan lezen en eten/drinken. Factor-analyse op alle items levert drie factoren op, waarbij uit de oorspronkelijke subschalen enkele items bij de derde factor wordlen ondergebracht: dat betreft de ADL-items eten en lezen en de IADL-jtems verwarming verzorgen, broodmaalijd klaarmaken en administratie doen. De totalle verklaarde variantie is $61,9 \%$, waaraan de laatste (rest-) factor slechts $6,4 \%$ bijdraagt.

Tabel 14.2. Itemverdeling" over de totale somschaal $\operatorname{van}(\mathrm{I}) \mathrm{ADL}$

\begin{tabular}{|c|c|c|c|c|c|c|c|c|c|c|c|c|c|c|c|c|c|c|c|}
\hline & & & & & $\cos$ & op & apentat & A & W $4: 017$ & Haus & & & & & & & & & \\
\hline & 0 & 1 & it & 3 & 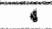 & 5 & 5 & 7 & : & 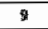 & 10 & 1.1 & 12 & 13 & 14 & 15 & 16 & 17 & $\operatorname{Toten} 2$ \\
\hline 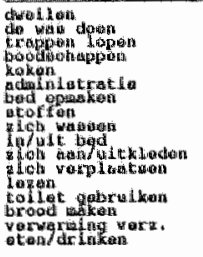 & $\begin{array}{l}= \\
\vdots \\
\vdots \\
\vdots \\
\vdots \\
= \\
= \\
= \\
=\end{array}$ & $\begin{array}{r}17 \\
1 \\
1\end{array}$ & 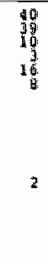 & 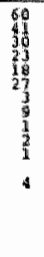 & 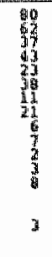 & $\begin{array}{r}75 \\
64 \\
517 \\
45 \\
25 \\
38 \\
32 \\
20 \\
10 \\
5 \\
8 \\
8 \\
1 \\
1\end{array}$ & 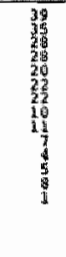 & 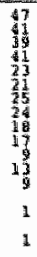 & $\begin{array}{l}44 \\
42 \\
36 \\
16 \\
31 \\
21 \\
23 \\
25 \\
24 \\
14 \\
12 \\
11 \\
17 \\
2 \\
4 \\
4 \\
1\end{array}$ & 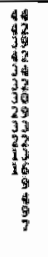 & $\begin{array}{l}43 \\
42 \\
43 \\
43 \\
3 \\
31 \\
31 \\
36 \\
263 \\
27 \\
29 \\
13 \\
6 \\
1 \\
1\end{array}$ & 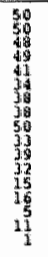 & $\begin{array}{l}45 \\
45 \\
49 \\
37 \\
74 \\
30 \\
40 \\
49 \\
43 \\
40 \\
19 \\
4 \\
3 \\
4 \\
3\end{array}$ & 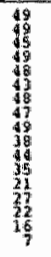 & $\begin{array}{l}82 \\
d 1 \\
42 \\
12 \\
37 \\
40 \\
12 \\
12 \\
17 \\
17 \\
36 \\
75 \\
36 \\
21 \\
15 \\
9\end{array}$ & 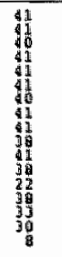 & 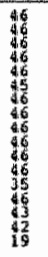 & $\begin{array}{l}91 \\
91 \\
91 \\
91 \\
91 \\
91 . \\
91 \\
911 \\
91 \\
91 \\
91 \\
91 \\
91 \\
91\end{array}$ & 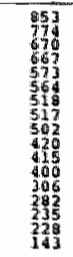 \\
\hline antaced radpondenteon & 38 & 27 & 98 & 73 & 9:8 & 76 & $\$ 0$ & $4 \pi$ & 4 & 45 & $a$ & 50 & 45 & $\$$ & 42 & al & 46 & 91 & 943 \\
\hline
\end{tabular}


Tabel 14.2 geeft de mogelikheid de hierarchie van de 17 tems te onderzoeken, door per item de frequentieverdeling over de gehele somschaal van alle (I)ADL-items te bekijken. Vervolgens zijn de items grofweg geordend van hoge naar lage prevalentieciffers. Slechts 38 personen $(4 \%)$ heeft geen enkele beperking en derhalve nul punten op de totale somschaal. Het gemiddeld aantal beperkingen is 8,6 (std.dev. $=5,3$ ). De mediaan ligt bij 5 beperkingen. In hoofdstuk 13 werd gellustreerd welk patroon in de tabel verwacht wordt indien sprake zow zijn van een sterke schaai (zie figuur 13.1): onder de diagonaal dienen geen of slechts weinig waarnemingen te zijn. Enkele items zijn niet "netjes' over de schaal verdeeld en doorkruisen derhalve het hierarchische patroon. Deze items, te weten lezen, admuinistratie en verwarming verzorgen, zjjn verder buiten beschouwing gelaten. Ook eten/drinken is aan bet begin van de schaal enigszins afwijkend, maat discrimineert juist aan het eind van de schaal goed en wordt daarom niet uitgesloten van de schaalanallyse.

Het blijkt dat de (I)ADL-items elkaar gedeeltelijk overlappen: aan het begin van de schaal treffen wij ook ADL-items aan (traplopen) en aan het eind van de schaal LADL-items (verwarming en broodmaaltijd klaarmaken).

Uit het literatuuroverzicht bleek het van belang te zijn om bij de constructie van (I)ADLschalen rekening te houden met de setting waarin de ouderen verblijven "In tabel 14.3 worden voor de totale onderzoeksgroep en de subgroepen (thuiswonend, positief gemdiceerd, bejaardenoordbewoners en verpleeghuispatienten) de prevalentiecijfers weergegeven.

De (vooralsnog) geselecteerde items zijn daarbij gerangschikt naar de volgorde waarin gemiddeld voor het gehele bestand het optreden van beperkingen plaats vindt. Globaal bezien wordt deze volgorde ook binnen de afzonderlijke deelbestanden aangetroffen.

Het beeld laat zich als volgt samenvatten: als eerste vallen dweilen en de was doen af (dit laatste bij thuiswonende vrouwen in een later stadium; niet in tabel); bij mannen treden er vervolgens beperkingen op in het blok koken, stoffen en bed opmaken, gevolgd door trap. lopen, boodschappen doen en zichzelf wassen. Thuiswonende vrouwen houden het eerste blok handelingen (koken, stoffen, bed opmaken) langer vol en krijgen juist eerder beperkingen in het tweede blok (traplopen, boodschappen en zichzelf wassen). Het volgende blok betreft (mobiliteits-)beperkingen bil aan- en uitkleden, in en uit bed stappen en zich binnenshuis verplaatsen en is het een na laatste soort activiteiten dat uitwalt. In alle groepen, uitgezonderd zelfstandig wonende wrowwen waar verstoring optreedt door de eerder genoemde huishoudelijke activiteiten (stoffen en koken), treden de mobiliteitsbeperkingen als blok op, maar de volgorde daarbinnen kan per groep verschillen. Het laatste valt in alle

Tabel 14.3. Itemverdeling* over totale somschaal van (1)ADL

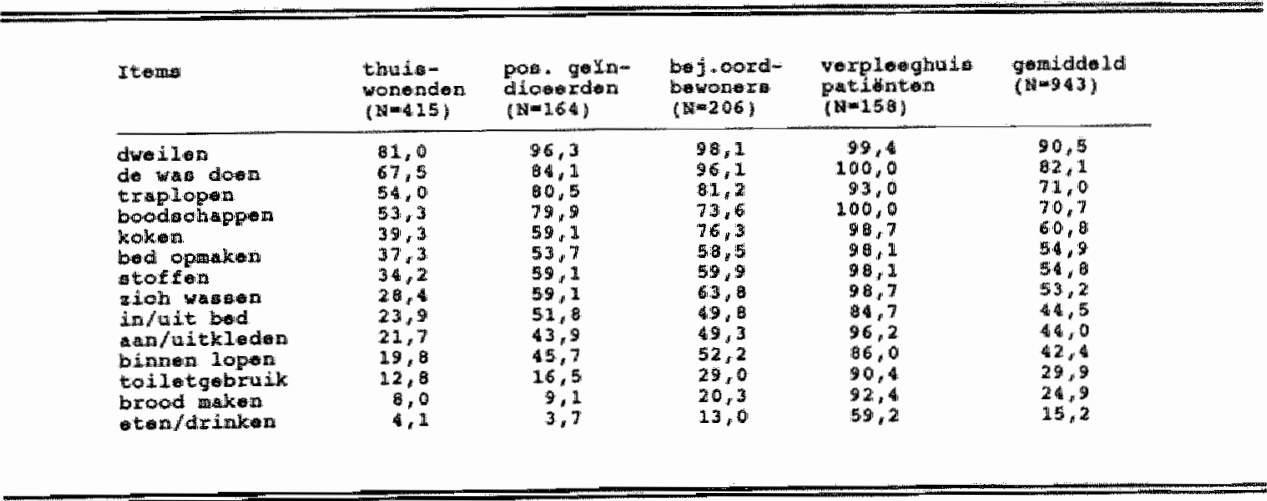




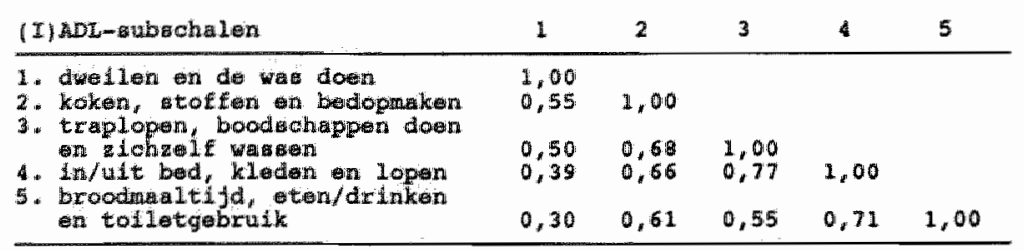

* Pargarijae correlatien gehele bestand

groepen het blok uit waarin begrepen zijn broodmaaltijd klaarmaken, gebruik maken van toilet en eten/drinken (de wegatieve activiteiten in de bewoordingen van Katz, 1963).

De hierarchie in (1)ADL-items komt goed terug in de correlaties tussen deze items: naarmate de afstand tussen twee items op de totale schaal groter is, is de correlatiecosfficient kleiner (zie bijlage 6). Een zelfde patroon komt naar voren indien de hiervoor samengestelde blokken bezien worden (zie tabel 14.4).

Mokken- en Rasch-analyse staan geen ontbrekende antwoorden toe, hetgeen bij (I)ADLitems voorkomt bij 27 respondenten, waarvan 17 in het verpleeghuis. In het onderstaande zijn deze buiten beschouwing gelaten (zodat $\mathrm{N}=916$ ). Op grond van de Mokken-analyse via de MSP-zoekprocedure (Debets en Brouwer, 1989) wordt geen van de (I)ADL-items uitgesloten van opname in de totale schaal. Ondanks de hoge Loeverings' H-coefficient voor de totale schaal $(\mathbf{H}=0,70$; rho $=0,94)$, hebben enkelle items een beduidend lagere partiele $\mathrm{H}$ coefficient, met name als de positie van dat item in de totale schaal meegewogen wordt. Net als in de voorgaande analyses betreft dat het LADL-item 'verwarming verzorgen', dat als een na makkelijkste item $\left(H_{i}=0,79\right)$ na "eten" $\left(H_{i}=0,88\right)$ en woór "broodmaaltijd klaarmaken" $\left(H_{i}=0,83\right)$ geplaatst wordt, en het LADL-item 'administratie' $\left(H_{i}=0,51\right)$ dat als elfde item na 'bed opmaken' $\left(\mathrm{H}_{\mathrm{i}}=0,65\right)$ en voor 'koken' $\left(\mathrm{H}_{\mathrm{i}}=0,59\right)$ geplaatst wordt.

Hiermee zijn tevens de laagste $\mathrm{H}_{\mathrm{i}}$ 's aangegeven. Het weglaten van de twee LADL-items leidt tot een iets sterkere schaal $(\mathrm{H}=0,73$; rho $=0,94)$, waarin echter nog een aantal schendingen tegen de (additionele) veronderstelling van dubbel-monotone items optreedt. Items, die deze stringentste Mokken-eis schenden zijn de items 'bed opmaken" $\left(H_{i}=0,67\right)$, in/uit bed stappen' $\left(H_{i}=0,73\right)$ en 'traplopen' $\left(H_{i}=0,66\right)$. Dit zijn bovendien steeds items waarvoor een ander item met een vergelijkbare moeilijkheidsgraad aanwezig is; voor 'bed opmaken' is dat 'stoffen'; voor 'in/uit bed stappen' is dat 'aan- en uitkleden' en voor 'traplopen' tenslotte 'boodschappen doen'. De resterende schaal is sterk $(\mathrm{H}=0,77$; rho $=0,92)$ en kent vrijwel geen schendingen van de dubbele-monotonie-eis, vitgezonderd het "koken" en 'stoffen' aan het moeilijkste eind van de schaal (na achtereenvolgens 'dweilen', 'de was doen' en 'boodschappen doen') hetgeen eerder verklaard werd uit sexe-verschillen.

Rasch-analyse leidt tot dezelfde conclusies: de betrouwbaarheidsintervallen rondom de moeilijkheidsgraad van de genoemde items overlappen elkaar grotendeels. Bovendien is bij Rasch-analyse de optie mogelijk om verschillende groepen met elkaar te vergelijken, hetgeen gedaan is voor sexe en (bij thuiswonenden) al of niet geindiceerd zijn voor het bejaardenoord. Ook binnen deze subgroepen bljwen de bevindingen gelden, maar wordt de eerder gemelde sexe-gevoeligheid voor én blok itenas ('koken', 'stoffen', 'bed opmaken') 
Tabel 14.5. Samenvatting van test-resultaten voor gecombineerde (1)ADL-schaal

\begin{tabular}{|c|c|c|c|c|c|c|c|}
\hline \multirow[b]{2}{*}{ Itearas } & \multirow{2}{*}{$\begin{array}{l}\text { Preva- } \\
\text { Lentie }\end{array}$} & & \multirow[b]{2}{*}{$\mathrm{H}_{\mathbf{i}}$} & \multirow{2}{*}{$\begin{array}{l}\text { item-total } \\
\text { correlatio }\end{array}$} & \multicolumn{3}{|c|}{ Rach-maina 1 yoi } \\
\hline & & & & & diffe. $\log$ & $950-1 n t$ & terval \\
\hline 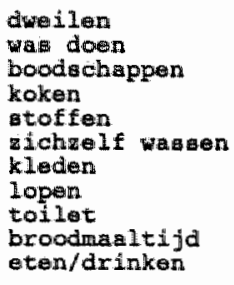 & $\begin{array}{l}0,90 \\
0,82 \\
0,70 \\
0,60 \\
0,54 \\
0,52 \\
0,43 \\
0,41 \\
0,29 \\
0,24 \\
0,14\end{array}$ & 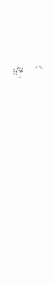 & $\begin{array}{l}0,79 \\
0,74 \\
0,72 \\
0,65 \\
0,71 \\
0,78 \\
0,80 \\
0,76 \\
0,87 \\
0,85 \\
0,90\end{array}$ & $\begin{array}{l}0,37 \\
0,47 \\
0,58 \\
0,59 \\
0,69 \\
0,77 \\
0,78 \\
0,71 \\
0,72 \\
0,65 \\
0,52\end{array}$ & $\begin{array}{r}-4,19 \\
=3,04 \\
=1,94 \\
=1,07 \\
=0,54 \\
=0,37 \\
0,56 \\
0,73 \\
2,27 \\
3,00 \\
4,60\end{array}$ & 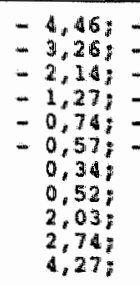 & $\begin{array}{r}-3,91 \\
-2,82 \\
-1,74 \\
-0,88 \\
-0,31 \\
-1,17 \\
0,77 \\
0,95 \\
2,51 \\
3,26 \\
4,93\end{array}$ \\
\hline totaal & & & (rho' & $921 \quad \alpha=0,89$ & & $\operatorname{sg} \mathrm{j}=0,84$ & \\
\hline
\end{tabular}

veel duidelijker en toetsbaar': significant moeilijker voor vouwen is "boodschappen doen" $(t=5,8)$, 'traplopen' $(t=4,2)$ en 'dweilen' $(t=4,1)$. In tabel 14.5 worden alle voorgaande resultaten van de Mokken- en Rasch-analyse samengevat voor de 11 geselecteerde items.

Figuur 14.2. geeft de Rasch-moeilijkheidsschaal (logarithmisch) met de locaties van de items (zie ook de tabel) en de persoonsscores (tussen haakjes het aantal bijbehorende respondenten). Het discriminerend vermogen van de items kon zo nog beter beoordeeld wordlen: tussen 'koken" en "stoffen" bevindt zich geen respondent zodat een van de twee items zou kunnen vervallen; hetzelfde geldt voor 'kleden' en 'traplopen'. Indien dit echter gebeurt, loopt de sterkte van de schaal iets terug ( $\operatorname{van} \alpha=0,90$ tot $\alpha=0,86$ ). Tenslotte laat de figuur zien, dat een item ontbreekt om te discrimineren tussen de persoonsscores van 7 of 8 punten (hetgeen nfet het gevolg is wan voorgenoemde selectie van items; ook indien alle (I)ADL-items gebruikt worden blifft het probleem bestaan).

Op grond van voorgaande analyses kan geconcludeerd worden dat er twee alternatieven zijn voor het samenstellen van (I)ADL-schalen. Enerzijds zijn vijf afzonderlijke schalen denkbaar waardoor rekening gehouden kan worden met sexe-specifieke patronen. Samenvattend betreft het de volgende clusters van items: (1) dweilen en do was doen; (2) koken, stoffen en bed opmaken; (3) traplopen, boodschappen doen en zichzelf wassen; (4) in en uit bed stappen, aan- en uitkleden en binnenshuis lopen en (5) broodmaaltijd klaarmaken, etten en drinken en toiletgebruik. Anderzijds blijkt het ook mogelijk te zijn eén gecombineerde (I)ADL-schaal te maken met sterke eigenschappen. Deze bestaat uit elf items, namelijk de voorgaande items exclusief bed opmaken, traplopen en in/uit bed stappen.

\subsubsection{Relaties met andere aspecten uit de leefsituatie}

(1)ADL-beperkingen leveren als benadering voor de hulpbehoefte in onderzoek naar het gebruik van woorzieningen over het algemeen verreweg de grootste bijdrage aan de verklaarde variantie (zie voor een overzicht van diverse studies: Klaassen-van den Berg Jeths, 1989). Ook recent Nederlands onderzoek laat zien dat (I)ADL-schalen verreweg de

1. Dit gebeurt in bet. PMLprogramme (PC-wersie; Molentar, 1989) wila een toets waarvan de verdeling lijkt op dit wan de Students* t-

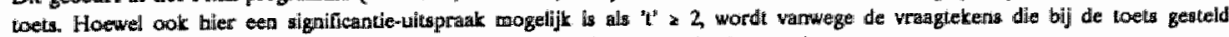
Kunnen worden (Molenaar, 1989) een minimale kritische waarde wan $t=4$ gethanteerd 


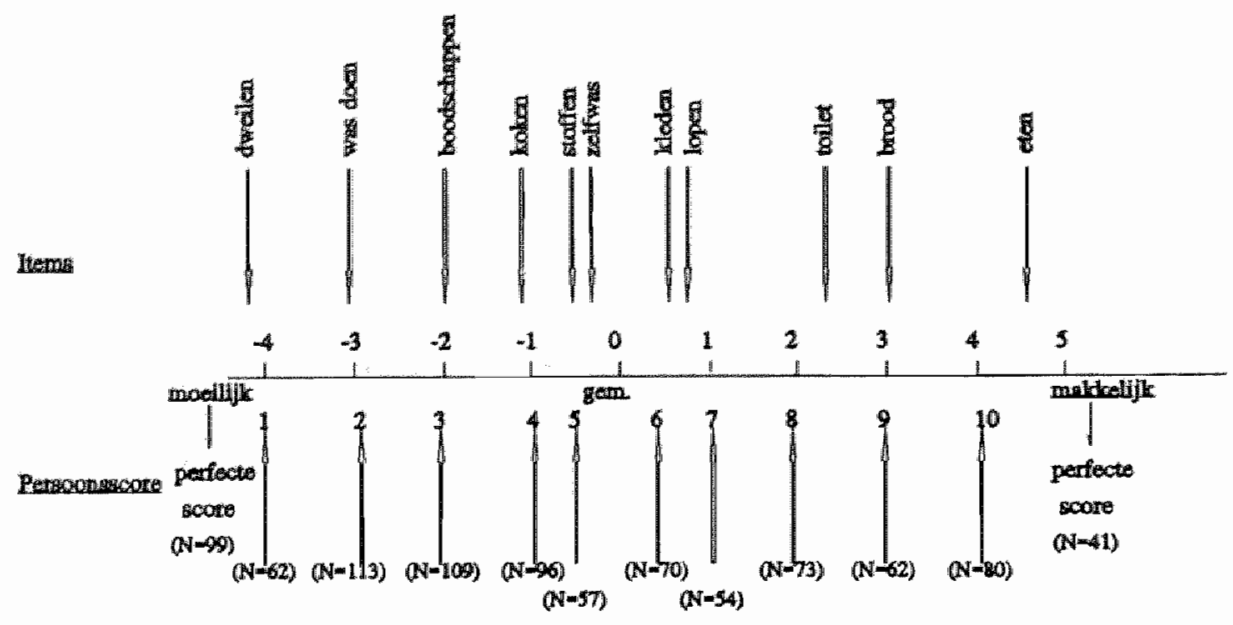

Figuur 14.2. (I)ADL: item- en persoonspatronem in Rasch-analyse

meest belangrijke verklaring bijeden voor het voorzieningengebruik bij ouderen (Van Linschoten e.a., 1988; De Klerk en Huijsman, 1989; Coolen e.a., 1989). De rol van (I)ADLschalen blijft ook dominant indien gecorrigeerd wordt voor leeftijd, geslacht of samenlevingsworm (Bisscheroux en Frederiks, 1986; Breemhaar e.a., 1988; De Klerk en Huijsman, 1989; Van Linschoten e.a., 1988).

Uit de literatuur blijkt dat demografische kenmerken van invloed zijn op de mate van beperkingen op huishoudelijk en algemeen dagelijks functioneren: de (I)ADL-beperkingen lopen op met de leeftijd en zijn bij ADL hoger en bij LADL lager voor vrouwen dan voor mannen. Het aantal beperkingen is hoger als de subjectieve gezondheidsbeleving lager is (Linschoten e.a., 1988, p. 57; Naafs, in Schroots e.a., 1989, p. 315-321). Alleenstaanden hebben wellicht niet meer (I)ADL-problemen (indien gecorrigeerd wordt voor leeftijd en sexe), maar wel minder mogelijkheden om deze op te vangen waardoor zij eerder gebruik maken van voorzieningen.

Ook voot andere aspecten bestaan er aanwijzingen voor min of meer sterke verbanden met (I)ADL-scores. Te noemen zijn: somatische of chronische aandoeningen (Bosma, 1988; Coolen en Toersen, 1989; Van den Bos e.a. in Schroots e.a. 1989, p. 343-348), psychosociale toestand (Van Linschoten e.a., 1988; Van Linschoten en Van den Heuvel, 1990; ook in verzorgingstehuizen: Frederiks e.a., 1988; Huijsman, 1990), eenzaamheid (Coolen en Toersen, 1989) en persoonlijkheidswariabelen (Van Linschoten e.a., 1988, p. 57). Over de sociaal-econonische status als belnvloedende factor bestaat al lang discussie (Mackenbach en Van der Maas, 1987; Van der Maas, 1989), die tot wisselende conclusies leidt: algemeen wordt echter aangenomen dat het verband tussen sociaal-economische status (inkomen, opleiding, beroepsgroep) en het aantal (I)ADL-beperkingen niet erg sterk is (Coolen en Duipmans, 1987; Thijssen, 1986).

Thans wordt bezien in hoeverre de in de literatuur gesuggereerde verbanden ook in het eigen onderzoek worden aangetroffen. Op basis van correlatie-matrices is figuur 14.3 opgesteld, waarbij voor eventuele verbanden (zonder deze oorzakelijk te noemen) de 


\begin{tabular}{|c|c|c|c|c|c|c|}
\hline \multirow[t]{2}{*}{$\sqrt{-0,10}$} & & $-0,19$ & $=-2.22$ & & $-0,14$ & Tohumed (WT) \\
\hline & $1-0,21$ & 0,21 & 0.23 & & & 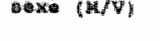 \\
\hline 0,34 & 0,20 & 0,20 & 0,20 & 0,12 & 10,12 & dised exd \\
\hline \multirow[t]{2}{*}{ IIATUL 1} & IADL 2 & IADI I & TADS 4 & IADL & (1) ADSL & \multirow{3}{*}{$\begin{array}{l}\text { bow-0oon. } \\
\text { atutan }\end{array}$} \\
\hline & & $-0,20$ & $=0,2,1$ & & $-a_{1} 30$ & \\
\hline 0,22 & 0,64 & 0,40 & 0,44 & 0,63 & 0,35 & \\
\hline 0,13 & 0,16 & 0,22 & 0,21 & 0,17 & 0,32 & 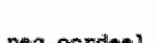 \\
\hline 0,20 & 0,34 & 0,42 & 0,38 & 0,29 & 0,0 & Hon \\
\hline$-0,21$ & $-0,22$ & $1-0,27$ & $\mid-0,24$ & $-0,22$ & $-0,30$ & A4t-mon \\
\hline 0,10 & 0.27 & 0,20 & 0,22 & 0,16 & 0,21 & \\
\hline
\end{tabular}

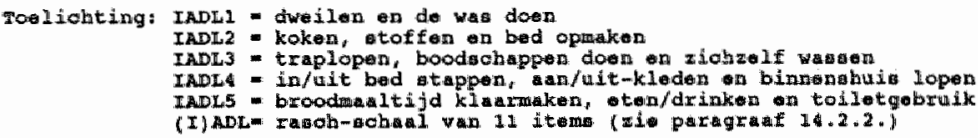

\section{Figuur 14.3. Significante samenhangen tussen (I)ADL-schalen en andere aspecten}

grootte van de correlatie-coefficient is aangegeven. Daar wij thans met name geinteresseerd zijn in verbanden met de (I)ADL-schalen zoals die hiervoor zijn afgeleid, worden onderlinge relaties tussen de andere variabelen buiten beschouwing gelaten. Verbanden die nfet worden gevonden, zijn in de figuur ook niet aangegeven. De bevindingen zijn als volgt samen te vatten. Er worden geen significante verbanden gevonden met het wel of niet bewonen van een aanleunwoning of serviceflat, gescheiden of ongehuwd zijn en thet gebruik van medicamenten tegen nervositeit of depressiviteit. Er zijn ook geen significante verbanden tussen de mate wan (I)ADL-beperkingen en het doen van een aanvraag woor gezinsverzorging of opname in het bejaardenoord. Bij gezinswerzorging kan echter de kanttekening worden geplaatst dat slechts weinig respondenten een aanvraag hierwoor hebben geraporteerd.

De significante samenhangen zijn ter afronding kort te schetsen. Bij de demografische kenmerken is de samenhang tussen de (I)ADL-(sub)scha(a)l(en) en leeftijd immer signiffcant. Sexe-patronen komen niet tot uitdrukking in de eerste en vijfde subschaal, terwijl de resterende verbanden elkaar in de gecombineerde schaal blijken op te heffen. Van eventucle rolpatronen bij (I)ADL-handelingen kan worden aangenomen dat deze zichtbaar worden door de samenhang met al of niet gehuwd te bezien: zowel in de gecombineerde als in enkele subschalen blijkt deze significant te zijn. Met betrekking tot de sociaal-economische status blijkt de samenhang significant te zijn; dilt wordt met name veroorzaakt door de derde subschaal en in iets mindere mate door de vierde. Alle subschaten en de gecombineerde (DADL-schaal blijken in sterke mate significant samen te hangen met de ziekteduur, het subjectieve oordeel over de gehele situatie, de Zung-en AMT-score en de mate van eenzaamheidsgewoelens. De hoogte van de correlatiecoefficienten (afgezien van het teken) vertoont bij de laatste vier genoemde aspecten uit de leefsiltuatie van ouderen een vast patroon: de grootte loopt op van de eerste tot de derde subschaal en neemt daarna weer af. 


\subsection{Andere indicatoren voor lichamelijk functioneren}

\subsubsection{Inleiding}

Naast de hiervoor besproken (I)ADLsschalen zijn er nog andere indicatoren voor het lichamelijke functioneren. Ziekte en gezondheidsproblemen kunnen worden opgevat als verschillende stadia van in de tijd vertopende processen (Van der Plaats, 1975; Sipsma, 1973). Er zijn drie benaderingen mogelijk om de lichamelijke gezondheid te operationaliseren (Liang, 1986): (a) het medische model, waarbij gezondheid betekent dat ziekte afwezig is (veelal op basis van zelfrapportage door de respondenten); (b) het sociaal-functionele model, waarbij gezondheid wordt afgemeten aan de mate van de mobiliteit, het vervulten van sociale rollen en taken; (c) het psychologische model, gemeten via de subjectieve gezondheidsbeleving van de respondenten, vaak in vergelijking tot de eigen gezondbeid vroeger of de gezondheid van leeftijdsgenoten. Een enigszins vergelijkbaar anderscheid betreft de drie begrippen "disease' vanuit de biomedische invalshoek en vanuit de sociaalwetenschappelijke invalshoek "illness" (indiwiduele beleving van een waargenomen ziekteverschijnsel) en 'sickness' (de sociale gevolgen). Deze drie begrippen kunnen in acht mogelijke combinaties voorkomen met als meest saillante voorbeeld dat van 'simulatie': medisch gesproken is er niets aan de hand, de persoon in kwestie voelt zich prima, maar onttrekt zich toch aan zijn of haar sociale verplichtingen. In beide terminologieen behoren de in de vorige paragraaf besproken (I)ADL-beperkingen tot de sociale definitie van (on-) gezondheid of 'sickness' (Arts e.a., 1989; Klaassen-van den Berg Jeths en Kraan-Jetten, 1985; Tax e.a., 1981; Naafs, 1989). Leefsituatie-onderzoek is eigenlijk niet geschikt voor het pellen van de medische dimensie (Coolen, 1986, p. 72).

In de WHO-definitie van gezondheid (WHO, 1948: "health is a state of complete physical, mental and social well-being and not merely the absence of disease or infirmity") komen de verschillendle gezondheidsdimensies duidelijk naar voren (Brook e.a., 1979). Het verschil tussen objectieve en subjectieve gezondheid is vaak onderzocht. In de literatuur zijn sterke aanwijzingen te vinden dat ouderen de neiging hebben hun gezondheid te overschatten (Dooghe en Vanderleyden, 1978; Cockerham e.a., 1983; Fuldauer, 1966; Kane en Kane, 1981; Leavey en Wilkin, 1988; Maanen, 1985; Naafs, 1989; Picauly, 1987). Mogelijk kan hierbij een rol spelen dat de eigen evaluatie van gezondheid in de meeste onderzoeken dient plaats te vinden op basis van én vraag (Brook e.a., 1979; Van den Bos, 1988). Daarbij worden bovendien verschillende referentiekaders aangeboden: (a) geen referentiekader ('hoe vindt u uw gezondheid?'); (b) het verleden als referentiekader ('hoe vindt u uw gezondheid in vergelijking met vroeger?'); (c) leeftijdsgenoten als referentiegroep ("hoe vindt u uw gezondheid in vergelijking tot die van uw leeftijdsgenoten?"). De laatste vorm is in het onderhavige onderzoek gehanteerd. Extensieve onderzoek naar de subjectieve gezondheidsbeleving (Ware en Karmos, 1976) laat echter zien dat ook hierbij weer verschillende dimensies van belang zijn (zie ook: Brook e.A., 1979; Lawton e.a., 1984; Leavey en Wilkin, 1988). Daarbij speelt de verwevenheid met psychologische mechanismen en het psychisch functioneren een grote rol (Arts e.a., 1989; Lehr, 1980; Williams, 1983).

\subsubsection{Constructie van en onderlinge samenhangen tussen gezondheidsindicatoren}

In het onderzoek (Frederiks e.a., 1988; Frederiks, 1990; Te Wierik en Frederiks, 1989) is over de lichamelijke gezondheid een aantal vragen gesteld, namelijk naar de gezondheidsbeleving, het gebruik van medicijnen, de aanwezigheid van een chronische ziekte, het aantal weken dat men het laatste jaar door ziekte is uitgevallen, het gehoor en actieve lichaamsbeweging. Deze vragen refereren aan bepaalde aspecten van gezondheid en hebben 
niet de pretentie de algehele gezondheidstoestand te meten. De vragen spreken min of meer voor zich, waar nodig wordt een toelichting gegewen.

De vraag naar gezondheidsbeleving luidt: "Als $U$ Uw gezondheid vergelijkt met die van Uw leeftijdsgenoten, is deze dan goed of slecht?" met vijf antwoordmogelijkheden die varieren wan 'uitstekend' tot 'slecht'. Leeftijdsgenoten blijken bij zelfevaluatie de bellangrijkste referentiegroep te zijn (Fillenbaum, 1979; Shanas e.a., 1968). Naast een algemene vraag naar voorgeschreven medicijnengebruik is van twee soorten medicjinen, de antidepressieve en sedatieve, het gebruik verder gelnwentariseerd. Indien de vraag naar medicjnengebruik bevestigend was beantwoond, werd aan de ouderen gevraagd: "Zijn hier medicijnen bij tegen nervositeit, slapeloosheid en depressie?". Wanneer deze vraag bevestigend werd beantwoord werden de namen van deze medicijnen genoteerd. Aan de hand van het repertorium werd een indeling gemaakt in antidepressieve geneesmiddelen en sedatieve geneesmiddelen (met name slaapmiddelen).

De vraag naar de aanwezigheid van een chronische ziekte luidt: "Heeft $U$ een chronische aandoening of handicap?". Na bevestiging werd gevraagd welke aandoening of handicap, gedeeltelijk ter controle van het antwoord, maar ook ter verdere specificatie, die hier niet uitgewerkt wordt, omdat geen codering heeft plaats gevonden. Wij beperken ons hier derhalve tot het wel of niet hebben van een chronische aandoening of handicap. Om een indruk van het functioneren van het gehoor te krijgen is gevraagd: "Hoe is Uw gehoor?", met vijf antwoordmogelijkheden, varierend van 'uitstekend' tot 'slecht'. Om na te gaan of ouderen nog lichamelijk bewegen is hun gevraagd of zij al of niet nog doen aan regelmatige sport- of bewegingsoefeningen. Wanneer deze vraag in een bepaalde situatie te navrant leek (bedlegerigheid, ernstige invaliditeit) werd het stellen ervan achterwege gelaten. Dit geldt voor zo goed als alle verpleeghuispatienten.

In tabel 14.6 wordt een overzicht van de frequentie van de genoemde gezondheidsaspecten gegeven voor elk van de deelbestanden en de gehele steekproef. Deze tabel is voorts uitgebreid met het gebruik van gezondheidszorgvoorzieningen (die niet belicht worden in de beschrijving van de kernvoorzieningen in deel $C$ ). In het algemeen geldt dat de thuiswonenden beter scoren dan de positief gelindiceerden, die op hun beurt weer beter af zijn dan de verpleeghuispatienten (bij wie een aantal aspecten onbevraagd is gebleven; zie paragraaf 13.6). De bejaardenoordbewoners "passen' niet goed in het algemeen heersende beeld van voortschrijdende gezondheidsachteruitgang naarmate men in 'zwaardere' voorzieningen komt (Breemhaar e.a., 1989; Huijsman, 1988a). Veelal nemen bejaardenoordbewoners een tussenpositie in tussen thuiswonenden en positief gelindiceerden en bij enkele

Tabel 14.6. Gezondheildsaspecten in de steekproeven (prevalentie in \%)

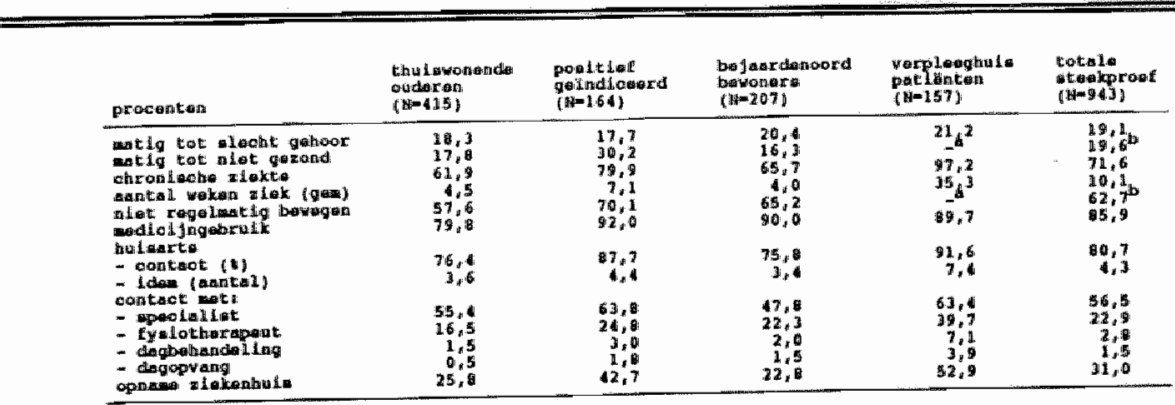

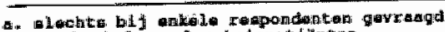

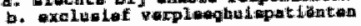




\begin{tabular}{|c|c|c|c|c|c|c|}
\hline & 1 & 2 & 3 & 4 & 5 & 6 \\
\hline 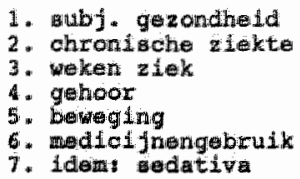 & $\begin{array}{l}1,00 \\
0,32 \\
0,30 \\
0,21 \\
0,20 \\
0,25 \\
0,25\end{array}$ & $\begin{array}{l}1,00 \\
0,29 \\
- \\
0,15 \\
0,27 \\
0,17\end{array}$ & $\begin{array}{l}1,00 \\
0,26 \\
0,10 \\
0,14\end{array}$ & $\begin{array}{l}1,00 \\
0,13 \\
0,08 \\
=\end{array}$ & $\begin{array}{c}1,00 \\
0,12 \\
-\end{array}$ & $\begin{array}{l}1,00 \\
0,31\end{array}$ \\
\hline
\end{tabular}

aspecten scoren zij zelifs beter dan thuiswonenden (subjectieve gezondheid, aantal weken ziek, huisartsbezoek en contact met specialist of een ziekenhuisopname). De bevindingen lijken een bevestiging te geven van de conclusies van andere auteurs (Van Loveren-Huijben e.a., 1988; Te Wierik en Frederiks, 1989 en 1990; Wimmers e.a., 1987; De Jong-Gierveld en Kamphuis, 1986) dat de opname een positief effect heeft op de gezondheid of de subjectieve beleving daarvan. Anderzijds kan verscherping van de indicatiestelling een reden zijn voor de verschillen tussen thuiswonenden, positief geindiceerden en bejaardenoordbewoners.

De volgende stap in de analyse betreft de onderlinge samenhangen in het onderhavige onderzoek tussen de variabelen met betrekking tot het lichamelijk functioneren (anders dan (I)ADL-beperkingen). In tabel 14.7 zijn de significante correlaties $(\mathrm{p}<0,01)$ samengebracht tussen subjectieve gezondheidsbeleving, aanwezigheid van chronische ziekte, het aantal weken dat de respondent het laatste jaar ziek is geweest, problemen met het gehoor, of men regelmatig aan beweging doet en het gebruik van verschillende soorten medicijnen. De beoordeling van de gezondheid in vergelijking tot leeftijdsgenoten blijkt samen te hangen met aile andere variabelen, maar met name met de vragen over ziekte. Ook het functioneren van het gehoor speelt een rol, maar hangt verder nauwelijks samen met de andere variabelen. Dit lijkt in overeenstemming te zijn met de bevinding van Lehr (1980) dat de gezondheidsbeleving met name belnwloed wordt door vermindering van de bewegingsvrijheid (hier: $r=0,20$ ) en vermindering van zintuiglijke capaciteit; bij dit laatste richten wij ans hier uitsluitend op het gehoor: $r=0,21$. De belangrijkste onderlinge samenhangen worden gevonden tussen de subjectieve gezondheidsbeleving, het al of niet aanwezig zijn van chronische aandoeningen en het antal weken in het afgelopen jaar dat men door ziekte geveld was (conform Arts e.a, 1989). Andere variabelen hangen hoofdzakelijk met slechts een van de genoende drie kenmerken samen: gehoor met gezondheidsbeleving, beweging niet met chronische ziekte maar vooral met ziekteduur en medicijngebruik niet met de ziekteduur. Liang (1986) presenteerde een MIMIC-model voor lichamelijk functioneren van ouderen dat de ook hier gevonden verbanden benut om een model te construeren met vijf latente gezondheidsvariabelen (chronische ziekten, ziektedagen, IADL- en ADL-beperkingen en subjectieve gezondheid), Dit model is te typeren als een recursief model met de subjectieve gezondheidsbeleving als ultieme afhankelijke varjabele (zie hoofdstuk 15).

\subsubsection{Relaties met andere variabelen}

Onderzoek naar het verband tussen objectieve en subjectieve gezondheid is veelal wormgegeven als onderzoek naar het verband tussen enerzijds de (I)ADL-beperkingen of de medisch-diagnostische bevindingen als objectieve maat en anderzijds de gezondheidsbeleving en andere subjectieve evaluatievragen met betrekking tot de gezondheid (Picauly, 1987). De verbanden hiertussen zijn sterk, maar dit betekent niet dat met beide gezondheidsmaten het zelfde gemeten wordt (Hunt, 1980; Liang, 1986; Naafs, 1989; Te Wierik en Frederiks, 
1990). Er is met andere woorden duidelijk sprake van verschillende gezondheidsdimensies. De zelf-evaluatie van gezondheid is waarschijnlijk een generale evaluatie en niet gebonden aan een afzonderlijke dimensie (lichamelijk, psychisch of sociaal) wan gezondheid (Brook e.a., 1979; Ware e.a., 1978; Ware en Karmos, 1976). Hierdoor wordt de gezondheidsbeleving een belangrijke indicator voor het welbevinden (Van den Bos, 1989; Larson, 1978) en bowendien geldt dit in sterkere mate als de leeftijd toeneemt (Spreitzer en Snyder, 1974; Cockerham e.a., 1983). De causaliteitsrelatie tussen gezondheid en welbevinden is echter, onder andere door het ontbreken van longitudinaal onderzoek, nog niet verhelderd (Arts e.a., 1989; Deeg, 1989). In het onderhavige onderzoek (zie figuur 14.4) worden de in de literatuur gemelde sterke relaties tussen objectieve en subjectieve gezondheidsindicatoren gereproduceerd: de (I)ADL-schaal correleert hoog met de gezondheidsbeleving $(r=0,35$; $\mathrm{p}<0,001$ ) en de aanwezigheid en duur van (chromische) ziekte hangt sterk samen met gevoelens van depressiviteit (Zung: $r=0,30 ; p<0,001$ ), het oordeel over de totale situatie ( $r=0,20 a 0,24 ; p<0,001)$ en eenzaamheidsgevoelens $(r=0,12$ a 0,$13 ; p<0,001)$.

Het sociale netwerk (contactfrequentie, diversiteit van contacten, sociale steun) heeft volgens verschillende auteurs een belangrijke relatie met gezondheid (Blazer, 1982; Cobb, 1976; Minkler e.a., 1983; Schaefer e.a., 1981), waarbij het causale karakter en de richting daarvan echter niet zonder discussie zijn (Brook e.a., 1979; Minkler e.a., 1983). In het

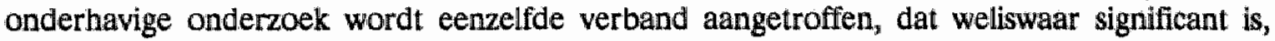
maar niet erg groot $(r=0,10 ; p<0,001)$. Een effect van dezelfde orde wordt aangetroffen met betrekking tot het aantal weken dat men het afgelopen jaar door ziekte geveld was. De psychische componenten in de gezondheidsbeleving (Brook e.a., 1979; Lawton e.a., 1984; Lehr, 1980) komen in dit onderzoek eveneens aan het licht. De subjectieve gezondheidsbeleving hangt in zeer sterke mate samen met de Zung-schaal (zie paragraaf $14.5 ; r=0,50$ ) en eenzaamheidsgevoelens $(r=0,31)$.

De demografische kenmerken (sexe, burgerlijke staat, alleenstaand zijn en leeftijd) hangen geen van alle samen met de drie geselecteerde gezondheidsindicatoren. De enige uitzondering hierop betreft een significante samenhang tussen leeftijd en subjectieve gezondheidsbeleving $(r=-0,21 ; p<0,001)$. Door de richting van dit verband worden bevindingen uit de literatuur gereproduceerd met betrekking tot het fenomeen dat ouderen naarmate zij ouder worden hun gezondheid (relatief) gunstiger gaan beoordelen, vaak in weerwil van de optredende beperkingen (Dooghe en Vanderleyden, 1978; Fuldauer, 1966; Maanen, 1985; Naafs, 1989; Picauly, 1987). Tenslotte biliken er nog significante relaties te bestaan tussen enerzijds

\begin{tabular}{|c|c|c|c|}
\hline$-0,21$ & & & 10ottijd \\
\hline $\begin{array}{l}\text { abject leve } \\
\text { gondheid }\end{array}$ & $\begin{array}{l}\text { anweit ighe id } \\
\text { chron. ziekte }\end{array}$ & $\begin{array}{l}\text { antal wokou } \\
\text { ziokt in } 1 \text { jour }\end{array}$ & \multirow{3}{*}{ (I) ADD-Dohad } \\
\hline 0.35 & 0,36 & 0,55 & \\
\hline \multirow[t]{2}{*}{0,50} & 0,29 & 0,30 & \\
\hline & & 0,10 & Bung \\
\hline 0,31 & 0,12 & 0,13 & \multirow{2}{*}{$\begin{array}{l}\text { eonzanahoid } \\
\text { uantal oontuoten }\end{array}$} \\
\hline$-0,10$ & & $\|-0.00$ & \\
\hline$-0,11$ & $-0,24$ & & \multirow{2}{*}{$=00 .-\infty, 00$ n tatu } \\
\hline 0.39 & 0,20 & 0,24 & \\
\hline
\end{tabular}

Figuur 14.4. Relaties tussen gezondheidsindicatoren en andere variabelen 
de sociaal-economische status (en construct gebaseerd op inkomen, opleiding en beroep; tie paragraaf 14.7) en anderzijes de subjectieve gezondheidsbeleving $(r=-0,11)$ en het anwezig zjin van een chronische ziekte $(t=-0,14)$.

\subsection{Psychisch functioneren}

\subsubsection{Inlleiding}

Er bestaan verschillende aanwijzingen dat het gebruik van zorgvoorzieningen door ouderen tewens wordt belinvloed door variabelen van psychische aard (Van den Heuvel, 1989). Bij ouderen lijkt bij het stijgen van de leeftijd een verschuiving van normen plaats te vinden (Maanen, 1985), waardoor zij in toenemende mate hun gezondheid afmeten aan hun geestelijk functioneren. Een soortgelijke verschuiving van normen kan mogelijk ook de tevredenheid bij ouderen over hun huisvestingssituatie verklaren. Ondanks de bevinding dat ouderen dikwijls slechter gehuisvest zijn dan jongeren, zijn zij in overgrote meerderheid tevreden met hun woning, ongeacht de leeftijd (zie paragraaf 14.6).

Directere aanwijzingen voor de rol van psychologische factoren zijn kort aan te stippen (Bisscheroux en Frederiks, 1986; Veldkamp, 1977); thuiswonende ouderen zonder hulp voelen zich minder depressief en eenzaam dan thuiswonenden met hulp of bejaardenoordbewoners; bij ouderen, die recent in het ziekenhuis hadden gelegen lag de opnamewens voor een bejaardenhuis hoger dan bij ouderen waarvoor dit niet gold (Veldkamp, 1977). Een en ander bleek niet samen te hangen met de validiteit van de respondenten.

Onder 'psychisch functioneren" kunnen verschillende aspecten worden begrepen, waarvan de belangrijkste zijn: stress, depressie en depressieve klachten, cognitieve beperkingen of dementie, eenzaamheid, psycho-sociale problematiek (cognitie, stemming en sociaal contact; met name het onderzoek in bejaardenoorden van Van Loveren-Huyben e.a., 1988a), zelfwaardering en welbevinden. Bij deze deelaspecten van het psychisch functioneren bestaat zowel een medisch-diagnostische invalshoek (dementie) en een psychiatrische invalshoek (depressie) als een sociaal-maatschappelijke invalshoek (eenzaamheid, welbevinden etc.). Vanwege de verwevenheid van eenzaamheid met kenmerken van het scciaal netwerk, wordt eenzaamheid niet hier besproken maar in paragraaf 14.8. Meer algemeen wordt gewezen op de sterke relatie tussen welbevinden en tevredenheid aan de ene kant en het psychisch functioneren aan de andere kant (Bosma, 1988; Furer en Tax, 1987; Hosman, 1983; Ter Heine, 1983; Te Wierik en Frederiks, 1989). Het psychisch functioneren is met andere woorden een multidimensioneel aspect van de leefsituatie (Arts e.a., 1989; Coleman, 1987; Lawton e.a., 1984; Tempelman, 1987).

Aparte aandacht is in zogenaamd levenslooponderzoek gevestigd op de invloed die belangrijke levensgebeurtenissen hebben op het psychisch functioneren (zie bijvoorbeeld Munnichs en Uildriks, 1989). In de literatuur worden vier gebeurtenissen als het belangrijkste geschetst, te weten: (a) het 'lege nest" waarbij kinderen het ouderlijke buis verlaten, (b) pensionering, (c) ziekte of invaliditeit en (d) verweduwing (Bengston en Treas, 1980; Knipscheer, in: Munnichs en Uildriks, 1989, p. 61-67).

Thijssen (1985) heeft op basis van panel-gegevens uit het leefsituatie-onderzoek onder 65plussers (CBS, 1984) onderzacht of tengevolge van de vier genoemde levensgebeurtenissen in de periode 1976-1982 veranderingen zijn opgetreden in het welbevinden van ouderen. Bij verweduwden treedt een significante achteruitgang op in het moreel en er is een toename in eenzaamheid en verveling; bij mensen die in die periode met invaliditeit te kampen kregen, verslechterden het moreel en de gezondheidsevaluatie significant. Het lege nest en pensionering worden niet als 'stressful' aangemerkt. 
De relatie tussen sociaal netwerk en psychisch functioneren staat enigszins ter discussie: ondanks ons cultureel vooroordeel ten opzichte van een hartelijk en intiem familieleven; is er verbazingwekkend weinig expliciete evidentie uit onderzoek naar voren gekomen, dat ouderen zonder een ondersteunend netwerk van naaste verwanten zich psychologisch gezien in een nadelige positie zouden bevinden" (Bengston en Kuypers, in Munnichs en Uildriks, 1989 , p. 68-80).

\subsubsection{Schaalconstructie psychisch functioneren}

In thet onderzoek (Frederiks, 1990) zijn diverse vragen opgenomen die relevant zijn als potentiele variabelen voor het weergeven van het psychisch functioneren. Daarbij kan een onderscheid worden aangebracht tussen enerzijds variabelen die een directe meting van aspecten van het psychisch functioneren beogen (zoals depressiviteit, gemeten via de Zungschaal, en geheugenstoornissen, gemeten via de AMT-schaal) en anderzijds variabelen die op een meer indirecte wijze een weergave van het psychisch functioneren geven (tevredenheid, situatie-oordeel en dergelijke).

\section{Zung 's Selfrating Depression Scale}

Depressiviteit is gemeten met de Selfrating Depression Scale volgens Zung (1965) De schaal bevat 20 uitspraken waarvan iemand moet aangeven of die zelden of nooit, soms, vaak of bijna altijd van toepassing zijn. Afhankelijk van de positieve of negatieve formulering worden per uitspraak 1 tot 4 punten toegekend, zodat de totale Zung-score loopt van 20 tot 80 punten ${ }^{2}$. Een hogere score maakt de aanwezigheidskans voor depressie groter, waarbij bij ouderen de grens van minimaal 47 punten wordt aangehouden (bij jongeren geldt een lager afkappunt van 40 punten; Kitchell e.a., 1982). In ons onderzoek komt van de zelfstandig wonenden $16,1 \%$ boven de grens, bij positief gelndiceerden $43,5 \%$ en bij bewoners van bejaardenoorden $21,2 \%$. Bij de verpleeghuispatienten is vanwege de lichamelijk en/of geestelijke toestand veelal geen ZUNG-lijst afgenomen (zie paragraaf 13.6), zodat van slechts weinig respondenten binnen dit deelbestand $(17,2 \%)$ een bovendien vaak relatief gunstige Zung-score bekend is; van ben komt $37,0 \%$ boven de kritische grens (vanaf 47 punten). Kempen en Suurmeyer (1989) vinden bij nieuwe gebruilkers van extramurale zorg een cijfer van circa $20 \%$. In de onderhavige studie wordt eveneens een grote schaalconsistentie gevonden $(\alpha=0,82)$. Ook in alle deelbestanden wordt een vergelijkbare $\alpha$-cosfficient gevonden, uitgezonderd bij verpleeghuispatienten $(\alpha=0,75)$.

De schaal lijkt overigens voor verbetering vatbaar: een aantal items heeft lage item-totaalcorrelaties $(r<0,30)$; bij dichotomisering van de items bij zelfstandig wonenden tussen nooit het gevoel en soms tot altijd het gewoel te hebben dat gevraagd word, valt de totale schaal precies uiteen in twee schalen met enerzijds alle negatief geformuleerde items en anderzijds alle positief geformulleerde items. Elders is iets dergelijks nog niet eerder aangetroffen. Ten derde ontstaan er bij factor-analyse maar liefst vijf verschillende dimensies, waarvan drie met steeds slechts drie items. Ten vierde wijkt de factorindeling van de items sterk af van de bevindingen elders (Zung, 1967; Steurer e.a., 1980; Blumenthal, 1975). Tenslotte zijn ook de test-analyses (Mokken en Rasch-type) bepaald onbevredigend.

De bevindingen worden thans beknopt samengevat. Ontbrekende Zungscores, die in de Mokken- en Rasch-analyses verwijderd moeten worden, komen wederom het meest voor bij verpleeghuispatienten (130 maal). Alle respondenten met ontbrekende antwoorden (151 maal) zijn verwijderd (zodat $N=792$ ). De Mokken-analyse voor polychotome items (Mole-

2 Zung zeft hanteer is. zijn publikaties een relatieve score door de witkomsin per persoon te delen door bet maximale ananial puniten

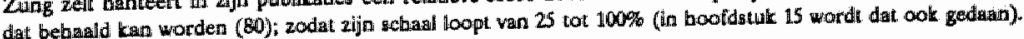


naar, 1982, 1986) kan ten volle benut worden bij de Zungschaal, hetgeen met de MSPverste 1.50 (Debets en Brouwer, 1989) voor het eerst mogelijk is geworden. De polychotome Rasch-analyse selecteert wiff items $\left(1,3,18 \mathrm{t} / \mathrm{m}\right.$ 20) uit de totale Zung-lijst $\left(\mathrm{H}=0,38_{*}\right.$ tho $=0,76$ ) en stelt vervolgens nog schalen samen, die ellk uit twee items bestaan. De MSPzoekprocedure breekt daarna af. Hieruit wordt geconcludeerd, dat de Zung niet voldoet aan de strenge eisen van het Rasch-model. Dichotomisering biedt nauwelijks soelaas: negen items (naast de eerder genoemde tevens de items 10,12,14 en 17) worden samen gebracht tot en schaal $(H=0,41$, rho $=0,75)$ en de resterende items worden weer paarsgewijs (13 met 15, 2 met 5,4 met 9, etc.) samengevoegd. Door middel van de Rasch-analyse zijn de problemen met de schaal inzichtelijk te maken: de moeilijkheidsgraad varieert nawwelijks tussen de items (van $-1,87$ tot 1,15 ) en kent veel overlappingen met name aan het moeilijkste einde), terwijl de persoonsscores een veel grotere spreiding kennen (van $-3,31$ tot 3,23 ) en ook veel grotere betrouwbaarheidsintervallen hebben, die driekwart of meer van de hele schaal beslaan. Hercodering (score 1 en 2 samen versus de rest) biedt nauwelijks perspectief (zie figuur 14.5). Nadere analyse van de Nederlandse versie van de Zung is derhalve gewenst, maar valt buiten het bereik van deze studie.

Dijkstra (1974) acht desalniettemin de Zungschaall ook voor Nederland een betrouwbaar, valide en bruikbare test. Toch zijn er auteurs (o.a. Van den Bos, 1988) die uit de totale schaal van 20 items een drietal items geselecteerd hebben die het sterkst zouden discrimineren onder de oudere bevolking. De items betreffen: (1) voelt u zich neerslachtig. en somber; (2) heeft $u$ huilbuien of het gevoel dat $u$ ieder moment wel in huilen uit kunt barsten; (3) ik ben rusteloos en ongedurig (het eerste, derde en dertiende item uit de Zungschaal; gedichotomiseerd). Deze drie vormen een sterke schaal (Van den Bos, 1989, p. 73), hetgeen hier slechts gedeeltelijk bevestigd wordt $(\alpha=0,63)$. Als alternatief voor de totale Zungschaal wordt deze verkorte versie nader bezien. Volgens de indeling van Van den Bos (1989, p. 73) komen depressieve gevoelens ( 2 of 3 punten) voor bij $46,6 \%$ van alle

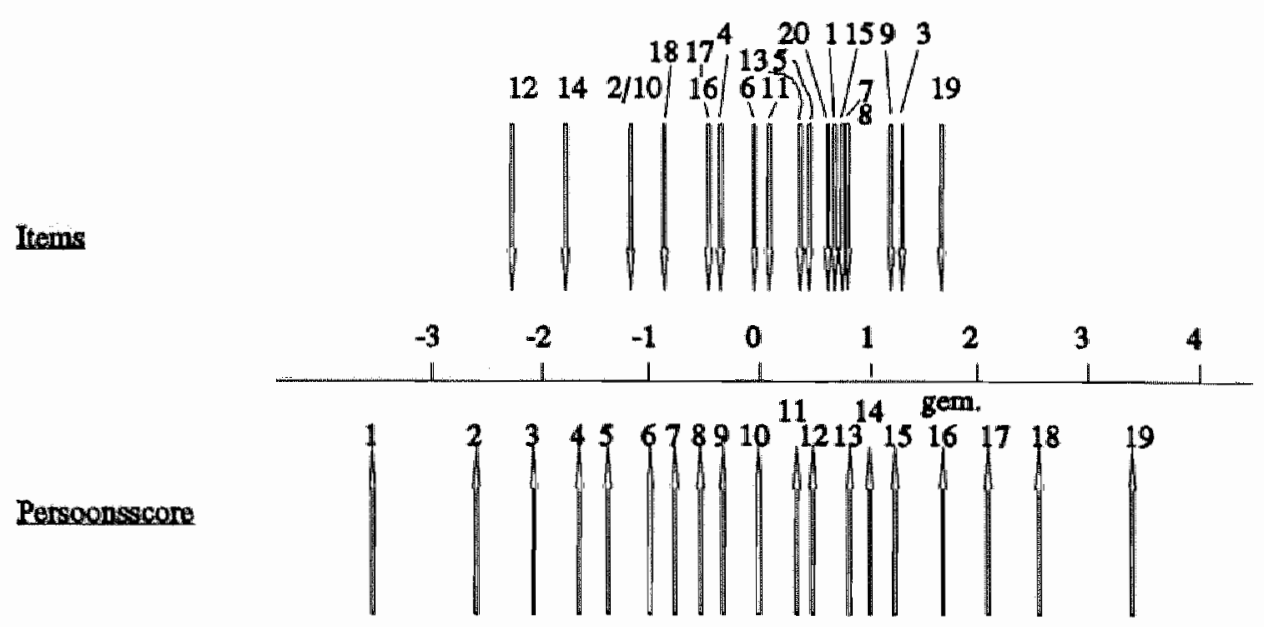

Figuur 14.5. Zung: item- en persoonspatronen in Rasch-analyse (excl. verpleeghuispatiënten) 
respondenten (Van den Bos vindt 34\%). Bij mannen is dat aanzienlijk lager dan bil vrouwen $\left(36,4 \%\right.$ versus $\left.52 \% ; x^{2}=27,0 ; p<0,001\right)$. In paragraaf 14.5 .3 komen wij terug op deze relaties met achtergrond- en andere variabelen.

\section{Abbreviated Mental Test van Quereshil en Hodkinson}

Uit een aantal korte schalen die een indruk geven van de aanwezigheid van geheugenstoornissen is gekozen voor de Nederlandse versie (Te Wierik en Frederiks, 1989) van de Abbreviated Mental Test (AMT) volgens Quereshi en Hodkinson (1974), die betrekking heeft op korte en lange termijn geheugen, inprentingsvermogen en oridntatie. Met tien vragen is per vraag steeds én punt te scoren; hoe hoger de totale score, hoe kleiner de kans op geheugenstoornissen. De AMT-score hangt sterk samen met de Zung-score (Bisscheroux en Frederiks, 1986).

De AMT blijkt ook in de Nederlandse situatie een goede en consistente schaal te zijn: $\alpha=0,74$; alle item-totaal correlaties zijn minimaal 0,30 en weglaten van een item leidt niet tot verbetering van de betrouwbaarheid. Bij verpleeghuispatienten is slechts voor 31 personen $(19,7 \%)$ een AMT-score bekend; het gemiddelde is voor hen 8,0 punten $(\alpha=0,72)$. De schaal werkt het beste bij positief gelndiceerde mensen $(\alpha=0,80)$ en het slechtste bij ouderen die al in een bejaardenoord zijn opgenomen $(\alpha=0,63)$.

In de afzonderlijke deelbestanden leidt het weglaten van items op grond van lage item-totaal correlaties uit de AMT-schaal tot de volgende verbeteringen van de consistentie van de schaal: bij zelfstandig wonende ouderen past als enige het tweede item (orientatie in de tijd) minder goed (resterende schaal: $\alpha=0,66$ ); bij positief geindiceerden kunnen het derde item (korte termijn inprenting) en het achtste item (lange termijn geheugen) verwijderd worden ( $\alpha$ verbetert van 0,63 tot 0,66 ); bij verzorgingtehuisbewoners zijn alle items dermate hoog gecorreleerd met de totale schaal dat geen verbetering mogelijk is (de consistentie is in deze setting het hoogst: $\alpha=0,80$ ); bij verpleeghuispatienten zijn het vijfde item (eigen adres), het zevende item (geboortedag) en het derde en achtste item minder goed inpasbaar ( $\alpha$ van 0,72 naar 0,77 ). Factoranalyse op het totale bestand genereert drie dimensies in de AMTlijst die als volgt te typeren zijn:

(a) hoe laat is het nu; herkenning personen; terug tellen van 20 tot 1 ;

(b) orientatie met vier items (wat is uw leeftijd; welk jaar is het nu; wat is uw adres; wanneer bent $u$ jarig);

(c) korte en lange termijn geheugen met drie items (adres herhalen; begin WO I; wie is onze koningin).

Ontbrekende antwoorden, die bij de Mokken- en Rasch-analyse niet verwerkt kunnen worden, kwamen bij de AMT-lijst voor bij 147 respondenten, van wie 126 uit het deelbestand voor het verpleeghuis. Deze respondenten zijn buiten beschouwing gebleven (resulterend in $\mathrm{N}=796$ ). Mokken-analyse neemt alle items op in de schaal, maar levert geen bevredigende resultaten op: $\mathrm{H}=0,48$ met $\mathrm{H}_{1}$ variërend van 0,34 tot 0,61 en rho $=0,77$. Dergelijke H-coefficienten behoren volgens Mokken's vuistregels tot 'gemiddelde' schalen (Mokken, 1971); bij een sterke schaal is $\mathbb{H}$ groter dan 0,50. Het zwakste item ("hoe laat is het $n u ? ; H_{i}=0,34$ ) schendt tevens de eis van dubbele monotonie van de itemcurve (NB: bij de klassieke test-theorie viel dit item bij zelfstandig wonenden eveneens uit de schaal). In iets mindere mate verstoort ook het zesde item (twee personen herkennen) de P-matrix (zie hoofdstuk 13) en bovendien volgt dit item volledig het eerste item ('wat is uw leeftijd "). Indien beide items weggelaten worden, resulteert een sterke schaal $(H=0,52$; rho $=0,75)$ met eveneens bevredigende partiéle $H$-coefficienten (varierend van 0,46 tot 0,62 ) en zonder schendingen van de dubbele-monotonie eis in de P-matrix. Uit de Rasch-analyse (tabel 14.8) blijkt dat de moeilijkheidsgraden van de afzonderlijke items elkaar nauwelijks. overlappen. Toch blijven de mogelijkheden om via de AMT-lijst respondenten van elkaar te onderscheiden beperkt, omdat de zogenaamde 'index of subject separation' (een soort $\alpha$ coefficient voor respondenten in plaats van items; zie hoofdstuk 13) laag is $(0,33)$. De 


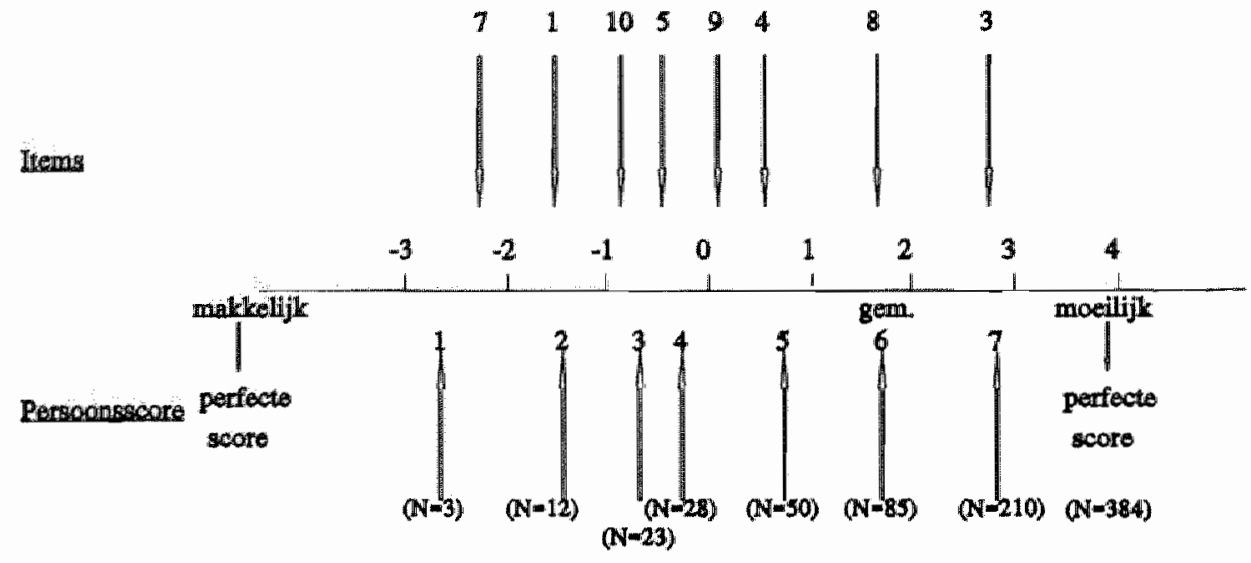

Figuur 14.6. AMT: Item-en persoonspatronen in Rasch-analyse

problemen komen goed naar voren in figur 14.6: er is geen item om de laagste persoonsscore te creeren; rond het nulpunt zijn teveel items en er is geen discriminerend utem voor de persoonsscore 5 of 6 (waarbij het weglaten van bijv. het vijfde item geén soellaas $(\alpha=0,28)$ biedt. Tenslotte kan vermeld worden, dat de rangorde van items niet anders is voor mannen dan voor vrouwen en dat voor de laatste alleen het achtste item (begin WO I) aanzienlijk moeilijker is $(\mathfrak{l}=4,1)$. Voor de andere items bestaat geen verschil in moeilijkheidsgraad. Wel is de persoonsalpha (index of subject separation; zie hoofdstuk 13) bij vrouwen $(0,40)$ veel beter dan bij mannen $(0,13)$. Samenvattend kan gesteld worden dat de AMT nog verder verbeterd kan worden. Omdat beoogd wordt én schaal voor het gehele bestand te benutten, wordt in het vervolg gewerkt met de aangepaste versie van de AMT-schaal uit de Rasch-en Mokken-analyse (zonder het tweede en zesde item).

Tabel 14.8. Samenvatting van test-resultaten voor AMT-schaal

\begin{tabular}{|c|c|c|c|c|c|c|}
\hline & & & & & Raseh & -analyee \\
\hline & ens. & jentio & $\mathbf{H}_{1}$ & correlatia & diff. $(\log )$ & 958-interval \\
\hline $\begin{array}{l}(3) \\
(8) \\
(4) \\
(9) \\
(5) \\
(10) \\
(1) \\
(7)\end{array}$ & $\begin{array}{l}\text { herhaal adrea } \\
\text { begln wo I } \\
\text { weIk jaax nu } \\
\text { naam koningin } \\
\text { olgen adrea } \\
\text { terugtalian } \\
\text { u leeftijd } \\
\text { wanneer jarig }\end{array}$ & $\begin{array}{l}0,60 \\
0,75 \\
0,67 \\
0,90 \\
0,92 \\
0,94 \\
0,97 \\
0,98\end{array}$ & $\begin{array}{l}0,62 \\
0,48 \\
0,58 \\
0,46 \\
0,49 \\
0,50 \\
0,53 \\
0,53\end{array}$ & $\begin{array}{l}0,42 \\
0,42 \\
0,59 \\
0,46 \\
0,47 \\
0,45 \\
0,38 \\
0,29\end{array}$ & $\begin{array}{r}2,88 \\
1,78 \\
0,51 \\
0,06 \\
-0,41 \\
-0,83 \\
-1,62 \\
-2,37\end{array}$ & $\begin{array}{r}2,65 ; 3,11 \\
1,55 ; 2,00 \\
0,25 ; 0,77 \\
-0,22 ; 0,35 \\
-0,72 ;-0,10 \\
-1,17 ;-0,49 \\
-2,04 ;-1,21 \\
-2,90 ;-1,85\end{array}$ \\
\hline tot & aral & & $\begin{array}{l}0,52 \\
=0,751\end{array}$ & $a=0,72$ & $\alpha$ (pere & 3) $=0,3.3$ \\
\hline
\end{tabular}


In de vragenlijst zijn nog enkele andere vragen opgenomen die meer indirect naar het psychisch functioneren van de respondent zouden verwijzen (Te Wierik en Frederiks, 1989). Dit betref de zelfbeoordeling van de gehele situatie, de mate van eenzaamheid, de mate van tevredenheid met de woonsituatie en het inkomen. Ook de interviewtijd en het gebruik van een tweede respondent zouden kunnen wijzen op psychische problemen. Bij de (zelf-) beoordeling van de algemene toestand (Veldkamp, 1977) kan uit drie antwoordalternatieven worden gekozen: (1) ik vind alles bij elkaar, dat alles hier heel redelijk op zijn pootjes terecht komt; (2) de algemene toestand: laat toch nog te wensen over; (3) het kan zo echt niet langer doorgaan. Eenzaamheid kan nooit, soms of vaak optreden (wij roepen in herinnering dat dit aspect in paragraaf 14.8 uitgebreider zal worden besproken). De tevredenheidswragen zijn gedichotomiseerd.

\section{Samenhang tussen psychische indicatoren}

Tabel 14.9 geeft de onderlinge samenhang tussen de geselecteerde potentiele indicatoren voor het psychische functioneren. Het voorgaande resumerend zijn als indicatoren voor het psychisch functioneren de volgende variabelen geselecteerd: twee gestandaardiseerde schalen namelijk die van Zung en de Nederlandse versie van de AMT, eenzaamheid (waarop in paragraaf 14.8 wordt teruggekomen), tevredenheid met de woonsituatie en het inkomen, het subjectieve oordeel over de gehele situatie. Omdat het idee bestaat dat het benutten wan een tweede respondent en de duur van het interview eveneens een indicator zijn voor het psychisch functioneren, worden ook deze in de analyse betrokken. In overeenstemming met de besproken literatuur worden sterke correlatie-coefficiènten gevonden tussen de drie belangrijkste indicatoren, namelijk de Zungschaal, mate van eenzaamtheid en de beoordeling van de totale situatie. De AMT-lijst blijkt een andere dimensie te meten en hangt alleen samen met eenzaamheid $(r=-0,15 ; p<0,001)$. Ontevredenheid over de woonsituatie vormt een van de aspecten die door de respondent zelf lijkt te worden meegenomen (gezien de hoogte van de correlatiecoefficient: $r=0,27$ ) in de totale beoordeling van de gehele situatie. De tijd die het interview in beslag nam blijkt een aardige indicator te zijn woor de Zungscore $(r=0,11 ; p<0,001)$ en eenzaamheid $(r=0,10 ; p<0,001)$; het gebruik van een tweede respondent hangt slechts significant samen met de AMT-score $(r=0,18 ; p<0,001)$.

\subsubsection{Samenhang tussen psychisch functioneren en andere variabelen}

Depressieve klachten hangen volgens versehillende auteurs sterk samen met chronische ziekte en lichamelijke beperkingen (Van den Bos, 1989; Kitchell e.a., 1982). De aanwezigheid van een chronische aandoening heeft een belangrijk effect op verschillende functies op

Tabel 14.9. Onderlinge samenhang tussen variabelen met betrekking tot psychisch functioneren*

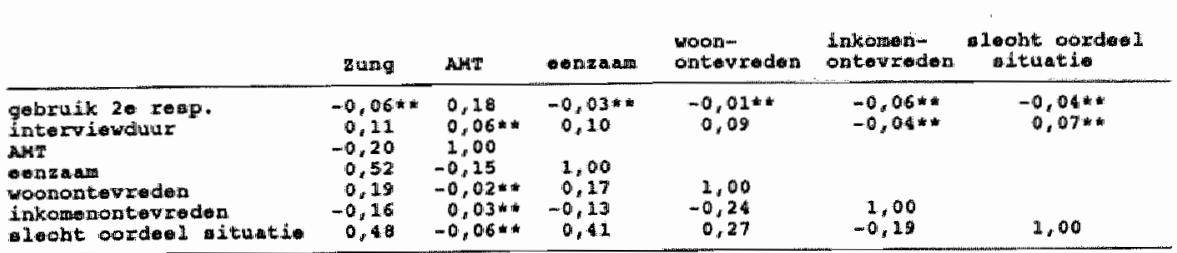

* paragewijz* oorrelatien minimalo $1=396)$

wide signifiount $(P>0,01)$ 


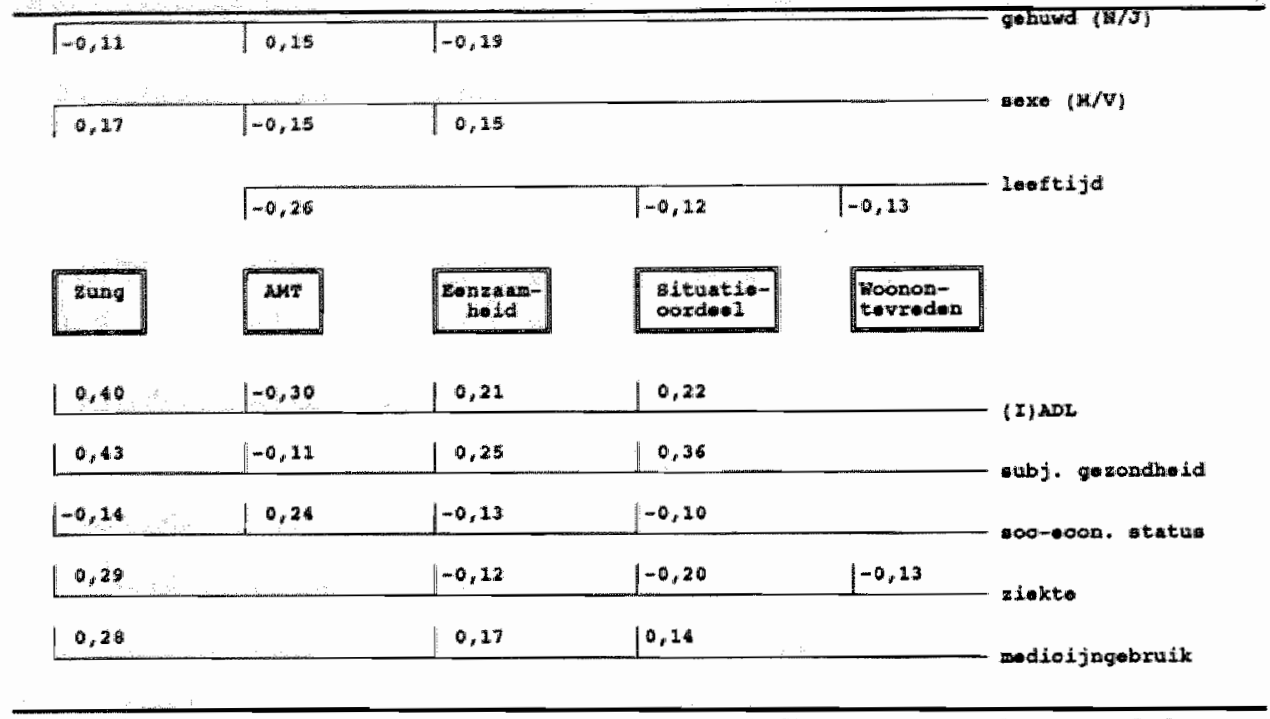

\section{Figuur 14.7. Sigaificante relaties tussen psychische indicatoren en andere variabelen}

oudere leeftijd, met name op het cognitief functioneren (Birren e.a., 1963). Lichamelijk functioneren blijkt tevens veruit de belangrijkste variabele te zijn voor het verklaren van het welbevinden van ouderen (Coleman, 1976). De leeftijd van de respondent, controlerend voor het lichamelijk functioneren, heeft een significant positief effect op welbevinden en het verwachte negatieve effect op cognitief functioneren (Coleman in Munnichs en Uildriks, 1989, p. 199-206). Depressieve klachten bij chronisch zieke ouderen kunnen zowel een reactie op als een symptoom van de lichamelijke ziekte zijn (Van der Mast e.a., 1989).

In dit onderzoek (zie figuur 14.7) worden deze verbanden eveneens in sterke mate aangetroffen als het gaat om (I)ADL-scores en de (relatieve) gezondheid, zoals die door de respondent wordt vergeleken met die van leeftijdsgenoten. Ziekte (incidentie en duur) is wel gerelateerd aan Zungscore, eenzaamheid en het algemene cordeel over de gehele situatie, maar staat niet in verband met de AMT-score. Mannen hebben minder depressieve klachten dan vrouwen, maar in veel studies, in tegenstelling tot onze bevindingen, zijn deze verschillen niet significant (Zung, 1967; Te Wierik en Frederiks, 1989). Vrouwen scoren ook slechter in termen van AMT-items en de mate van eenzaamheid. Er is geen sexe-invloed op het oordeel over de gehele situatie of op de tevredenheid met de woning. Leeftijd staat nfet in verband met Zung-scores, maar wel met de AMT-items en in veel mindere mate met eenzaamtheid en de andere psychische variabelen. Verschillen naar burgerlijke staat of sociaal economische status zouden eveneens afwezig zijn (Zung, 1967; Steurer e.a. 1980), maar hier worden significante verbanden tussen enerzijds opleidingsniveau en sociale groep (zie paragraaf 14.7) maar niet inkomen, en anderzijds de Zung-en AMT-scores gevonden. Het sterkste verband dat hier aangetroffen is, betreft de significant positieve samenhang tussen (I)ADL-problemen en de Zungscore; ook elders is dit een van de sterkste relaties (Kempen en Suurmeyer, 1989; "Te Wierik en Frederiks, 1988; Bisscheroux en Frederiks, 1986). 


\subsubsection{Inleiding}

Uit bestaand onderzoek komen aanwijzingen dat de woonsituatie van invloed is op de hulpvraag, met name die voör het bejaardenoord (Mootz en Timmermans, 1981). Na de Tweede Wereldoorlog werd de ouderenzorg vooral als een huisvestingsprobleem gezien en daarom stimuleerde de overheid de doorstroming van ouderen naar nieuw gebouwde bejaardenhuizen en kleine aangepaste woningen. In 1950 woonde $5 \%$ en in de jaren zeventig $10 \%$ van de 65 -plussers in een bejaardenoord (zie hoofdstuk 4 ). In het recentere ouderenbeleid staat het streven zolang mogelijk zelfstandig te wonen centraal. In de jaren zeventig en tachtig is daarom een grote verscheidenheid aan woonvormen ontstaan, die een tussenpositie innemen tussen de gewone woning en het bejaardenoord en qua bouwwijze, technische voorzieningen, serviceverlening en lokatie in de wijk zijn afgestemd op de behoefte van ouderen. Naar voorzieningenniveau is een zekere hierarchie in typen ouderenhuisvesting te onderscheiden (CBS, 1979; Mootz en Timmermans, 1981; KlaassenVan den Berg Jeths en Kraan-Jetten, 1985):

1. normale woningen;

2. woningen met eenvoudige bouwtechnische aanpassingen wat betreft indeling en situering (vaak klein met maximaal 3 kamers);

3. bejaardenwoningen, aangepast aan de verminderde validiteit en mobiliteit van de bewoner; bij voorkeur in nabijheid van openbare voorzieningen en diensten en voorzien van een alarmeringssysteem;

4. aanleunwoningen, als 3 maar gebouwd bij een bejaardenoord, van waaruit diensten verleend kunnen worden (maaltijdverzorging, buishoudelijke hulp, aansluiting op alarmsysteem);

5. servicefiats, met een overigens grote varieteit aan gemeenschappelijke voorzieningen en huishoudelijke hulp, vaak enigszins gelijkend op het dienstenpakket van een bejaardenoord.

In de jaren tachtig zijn daar nieuwe woonvormen bijgekomen: groepswonen voor ouderen, beschermd wonen bij verpleeghüs of in de wijk en geintegreerde huisvesting en zorg in het zogenaamde Zorghuis. Diverse onderzoeken laten zien dat deze aangepaste vormen van huiswesting van invloed zijn op de hulpvraag. Uit onderzoek onder Amsterdamse ouderen. bleek onder meer dan ruim $20 \%$ van de bewoners van aanleunwoningen, bijna $10 \%$ van de bewoners van serviceflats en $6 \%$ van de bewoners van een gewone bejaardenwoning positief gemdiceerd konden worden voor opname in een bejaardenoord (Verzijden en Mohrs, 1977)

Een nadere specificatie van ouderen naar (I)ADL-probleemcategorieen laat zien dat de relatie tussen woonproblemen en zorgvraag met name bestaat bij matige handicaps (Coolen en Duipmans, 1987). Omgevingsfactoren zoals een slechte woonsituatie, verval van de buurt: en het wegvallen van vrienden in de buurt, blijken de opnamewens mede té bepalen, maar er bestaat onduidelijkheid over de sterkte van deze effecten (Houben, 1987; Koehler en Van der Pennen, 1988).

Bij de beoordeling van de woonsituatie is het van belang twee elementen te onderscheiden, namelijk kenmerken van de woning en die van de woonomgeving (Coolen en Smid, 1989). Naast het woningtype gaat het met name om de volgende aspecten van de woning:

a. de kwaliteit van de woning, onder meer afhankelijk van de ouderdom van de woning, het aanwezig zijn van gebreken of overlast (tocht, stank, lekkage, lawaai, enzowoorts) en basisfaciliteiten (centrale verwarming, telefoon, douche of bad en aparte keuken). Bij dit 
laatste kan echter de kanttekening geplaatst worden dat deze basisfaciliteiten vrijwel altijd aanwezig zijn, zodat het belang ervan niet in significante verbanden wordt teruggevonden (De Klerk en Huijsman, 1989).

b. de eigendomsvorm van de woning.

c. de woonlasten of huurquote, afhankelijk van vier componenten: inkomen, huursubsidie, huurniveau en bijkomende woonlasten met betrekking tot onderhoud, servicecontract, verwarmingskosten en dergelijke.

d. aanvwllende woontechnische voorzieningen zoals extra grepen, verlaagde drempels en sanitair, brede deuren, verlaagde bellen, lichtknoppen en dergelijke.

Ouderen lijken op de genoemde punten in een achterstandssituatie te verkeren (KlaassenVan den Berg Jeths en Kraan-Jetten, 1985; Vis, 1981; WRR, 1982). Zij wonen vaak in oude, vooroorlogse huizen die vaker te groot dan te klein zijn (CBS, 1984) en niet altijd vooraien zijn van basisfaciliteiten. De kwaliteit van de woning is bij ouderen derhalve relatief minder goed. Dit lijkt in tegenspraak te zijn met hetgeen zojwist onder punt a gesteld werd; een verklaring zou kunnen zijn dat de woonsituatie niet doorslaggevend is omdat er gelijktijdig nog meer problemen bestaan op de verschillende dimensies van afhankelijkheid. In de drie grote steden is de woonsituatie op verschillende punten nog slechter en wonen ouderen vier maal vaker dan in de rest van het land in meergezinswoningen van voor 1946 met allerlei vormen van overlast. Vaak wonen deze ouderen in renovatiewijken, waar $47 \%$ van de hoofdbewoners ouder dan 54 is (Ministerie van CRM, 1982).

Met het toenemen van de leeftijd neemt het eigen woningbezit af; gemiddeld heeft $60 \%$ van de 55-plussers een huurwoning (Klaassen-Van den Berg Jeths en Kraan-Jetten, 1985). Bij 65-plussers (in 1986) heeft ongeveer $37 \%$ een eigen huis, met grote variatie naar urbanisatiegraad (CBS, 1987). In de toekomst zal het eigen huisbezit onder ouderen waarschijnlijk verder toenemen (Hooimeyer en Linde, 1988). Het bezit van een eigen huis belinvloedt eveneens de vraag naar het bejaardenoord; deze invloed zou bovendien groter zijn dan die van gebreken of ongemakken in de woning (Klaassen-Van den Berg Jeths, 1989, p. 127). Bijna een derde van de ouderen heeft een huurquote boven $16 \%$, terwijl $27 \%$ huursubsidie ontvangt en ouderen bovendien vaak het hoogste bedrag krijgen, zodat bijna de helft van de totale uitkeringen in het kader van de huursubsidie naar ouderen vanaf 65 jaar vloeit. Desalniettemin is de tevredenheid over de woning, de woonsatisfactie, bij ouderen relatief groot. Slechts $10 \%$ is in enige mate ontewreden. Dit percentage is weliswaar niet erg afwijkend van dat bij jongere huishoudens, maar de woonsituatie verschilt wel degelijk. Enerzijds wijdt men dit aan lagere aspiraties bij ouderen (Lawton, 1985; Priemus, 1976); anderzijds kent men een geringe betrouwbaarheid toe aan gegevens over woonsatisfactie (Arts e.a., 1989; Coolen en Smid, 1989).

De tevredenheid in de huursector is echter lager dan bij eigen woningbezitters en ditzelfde geldt voor kleinere ten opzichte van grotere woningen en voor woningen met verschillende woonlagen zonder lift ten opzichte van getijkvloerse woningen. Hoewel de woonsatisfactie derhalve wel enige relevante informatie verschaft, kan zij bijvoorbeeld het verhuisgedrag niet voorspellen (Coolen en Smid, 1989). Er zijn tot slot aanwijzingen dat de verhuisgeneigdheid afneemi met de leeftijd, zelfs als de validiteit verslechtert (Munnichs, 1984; Rowless, 1980).

Als tweede dimensie werden verschillende kenmerken van de woonomgeving als belangrijk bestempeld. In de literatuur wijst men op de volgende kenmerken:

a. de infrastructuur van voorzieningen, zoals de nabijheid van winkels, post- of bankkantoren, apotheek, dienstencentra enzovoorts.

b. de sociaal-demografische structuur, zoals de samenstelling van de wijk naar leeftijd, de mate van burenhulp.

c. de urbanisatiegraad (stedelijk karakter, dorpsgemeenschap), die bijvoorbeeld den aanwezigheid van bepaalde typen woningen belinvloedt.

d. de nabijheid van openbaar vervoer en andere verkeerstechnische zaken (inclusief veiligheid). 
Er is in bet onderhavige onderzoek op verschillende manieren gepoogd de kwaliteit wan de woning en de woonomgeving in beeld te brengen. Met betrakking tot de woning relf is gevraagd naar: (a) welk type woning, met als mogelijkheden gewone woning (al of niet geheel gelijkvloers), etagewoning (via trap of lift bereikbaar), bejaardenwoning, aamieunwoning, verzorgingstehuis of anders; (b) de tevredenheid over de woning zelf; (c) de woonduur in jaren; (d) de aanwezigheid en noodzakelijkheid van een achttal voorzieningen, namelijk: telefoon, verlaagde drempels, alarminstallatie, speciale handgrepen of steunen, centralle verwarming, slaapkamer gellijkvloers met woongedeelte, antislip in badkamer en verhoogd toilet. Voor de laatste genoemde aspecten van de woonsituatie zijn twee variabelen geconstrueerd die het aantal voorzieningen aangeven dat in de woning aanwezig is of nodig geacht wordt, maar niet aanwezig is.

Over de woonomgeving zijn verschillende vragen gesteld. Met betrekking tot winkels voor lewensmiddelen, postkantoor en bushalte is gevraagd of deze (a) aanwezig zijn binnen 10 minuten loopalstand, (b) door de respondent zelf bereikt kunnen worden en (c) of de aanwezigheid van deze voorzieningen belangrijk geacht wordt. Vervolgens is gevraagd of er leveranciers (bakker, groenteboer, melkboer of SRV-wagen) aan de deur komen en of daarvan gebruik gemaakt wordt of zou worden als ze wel langs zouden komen.

Het gemis aan voorzieningen in de buurt is een volgend aspect, warbij expliciet gevraagd is naar de huisarts, dienstencentrum, bejaardenclub, winkels, apotheek, bankjes, bushalte (deze kwestie is in de vragenlijst dus tweemaal aan de orde geweest!) of andere voorzieningen. Als variabele wordt in de analyse het aantal gemiste voorzieningen in de buurt gehanteerd.

Voorts is gevraagd of men tevreden is met de buurt watrin men woont en indien dat niet het geval is, wat dan het belangrijkste probleem vormt (te weinig contacten, onveilig, te veel jonge of oude mensen, lawaal, te weinig groen of andere zaken). Omdat het merendeel (78,6\% van alle respondenten) tevreden is en de belangrijkste reden voor ontevredenheid hoofdzakelijk het gemis aan contacten betreft $(5,5 \%)$ en er veel ontbrekende antwoorden zijn $(10,8 \%)$, wordit in de analyse uitgegaan van de dichotome uitspraak wel of niet tevreden over de buurt.

Tenslotte is gevraagd of men er wel eens aan denkt te verhuizen en zo ja, om welke reden dat is en waarbeen men dan zou willen verhuizen (welk type woning). Deze vragen zijn niet aan de aanvragers voor opname in een bejaardenoord of verpleeghuis gesteld. Van alle respondenten zegt $8,6 \%$ te willen verhuizen, met name naar een bejaardenwoning, flat of een andere huisvestingsworm die $k$ leiner is dan de huidige. Deze verhuiswens leeft vooral bij ouderen die thans een gewone woning van verschillende verdiepingen bewonen ( $48 \%$ van de potentiele verhuizers; $14,4 \%$ van de huidige bewoners). Opmerkelijk is dat $3 \%$ wan de bejaardenoordbewoners een verhuiswens (niet naar het verpleeghuis) heeft geuit.

Het type woning staat centraal in de analyse van onderlinge relaties tussen de onderzochte woonvariabelen. Het voorgaande resumerend zijn de volgende variabelen van belang:

(a) met betrekking tot de woning zelf: het aantal voorzieningen dat aanwezig is of gemist wordt en de woonduur. Woonlasten zijn volgens de literatuur ook van belang, maar hiernaar is in het onderhavige onderzoek niet gevraagd.

(b) met betrekking tot de woonomgeving: het aantal leveranciers dat werkelijk aan huis komt of als zodanig gemist wordt, de aanwezigheid, bereikbaarheid of wenselijkheid van een drietal belangrijke wijkvoorzieningen (winkel, postkantoor, bushalte) en het eventuele gemis van een zevental andere wijkwoorzieningen (waaronder dokter, dienstencentrum en apotheek).

(c) evaluatieve aspecten: tevredenheid met de woning, tevredenheid met de buurt waarin men woont en het bestaan van een eventuele verhuiswens. 
Tabel 14.10. Signiffeante correlaties tussen woonvariabelen voor zelfstandig wonenden en positiel geindiceerden (minimale $\mathrm{N}=548$ )

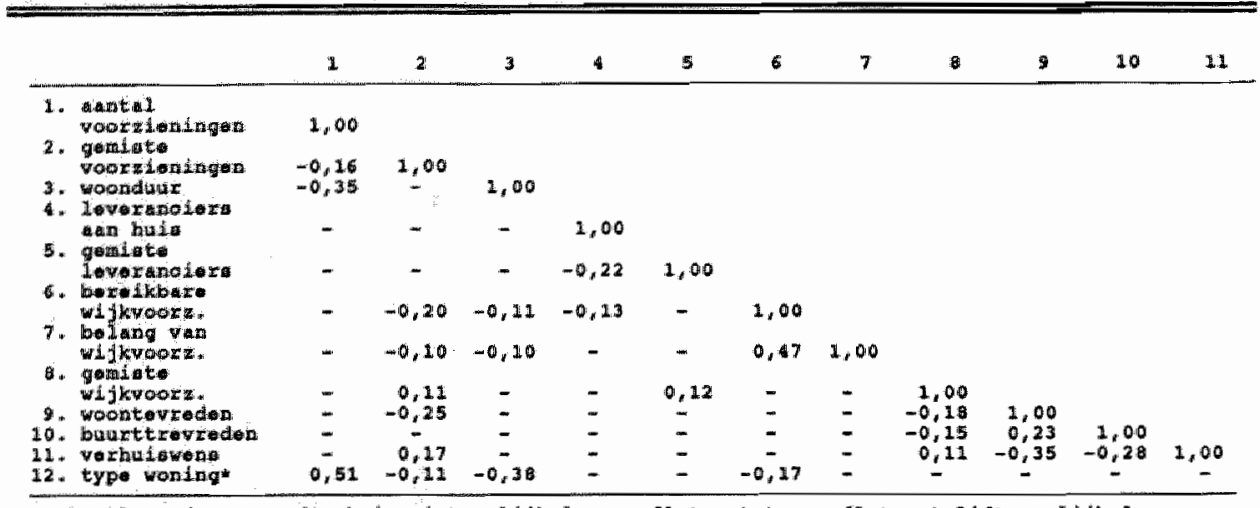

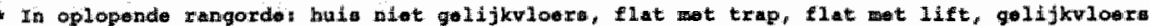

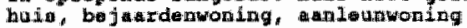

Bij het deelbestand woor verpleeghuispatienten dient men twee zaken in gedachte te houden (zie paragraaf 13,6). Ten eerste zijn veel (woon-)vragen niet gesteld omdat dat gezien de toestand van de respondent niet acceptabell werd geacht door de onderzoeksters. $\mathrm{Zo}$ is bijvoorbeeld wel gevraagd of bepaalde voorzieningen in buis aanwezig zijn (eventueel via een tweede respondent), maar is de vraag of men dat, indien dat niet zo is, nodig acht, niet gesteld.

Ten tweede hebben de wel beantwoorde woonvragen bij circa $50 \%$ van de verpleeghuispatienten betrekking op de woonsituatie vóór het aan de verpleeghuisopname voorafgaande ziekenhuisverblijf. Voor de huidige bewoners van bejaardenoorden zijn de woonvragen minder relevant omdat zij in goed geoutilleerde appartementen verblijven, buurtvoorzieningen of winkels aan huis voor hen niet noodzakelijk zijn en zij ook niet of nauwelijks willen verhuizen. Deze deelbestanden blijven daarom buiten beschouwing, zodat de in tabel 14.10 gepresenteerde samenhangen tussen de verschillende woonvariabelen slechts betrekking hebben op zelfstandig wonende ouderen, eventueel in het bezit van een positief advies voor opname in een bejaardenoord $(\mathrm{N}=548)$.

De evaluatievragen blijken onderling sterk samen te hangen: ontevredenheid over de woning en de omgeving hangen samen en zijn beide van invloed op de wens te verhuizen. Deze verhuiswens hangt tevens (maar in mindere mate) samen met het missen van wijkvoorzieningen en technische voorzieningen in de woning. De tevredenheid over de woning hangt verder samen met het aantal voorzieningen dat men in de wijk en de woning mist: dit laatste houdt weer verband met de beschikbaarheid van voorzieningen. Opmerkelijk is het feit dat het type woning niet van invloed is op de tevredenheidsaspecten, maar voornamelijk op het voorzieningenniveau van de woning en de bereikbaarheid van wijkvoorzieningen. Het negatieve teken van deze correlatie zegt wellicht iets over de vaak aparte lokatie van speciale aanleun- of bejaardenwoningen, maar is wellicht nog meer bepaald door de mate van validiteit van de bewoner.

Het type woning is wel van belang voor de wens te willen verhuizen $(r=-0,14)$ als de positief gellndiceerden buiten beschouwing blijven. Voor dit deelbestand geldt tevens en in afwijking van de resultaten hierboven dat er significante verbanden bestaan tussen onbereikbaarheid van voorzieningen en de tevredenheid met de buurt $(r=-0,12)$, tussen het gemis aan voorzieningen en de wens te verhuizen (veel sterker dan hierboven: $r=0,25$ versus $r=0,11$ ) en tussen het type woning en de verhuiswens $(r=-0,14)$. De woonsituatie blijkt derhalve van 
enige invloed te zijn op het al of niet gelndiceerd zijn voor een bejaardenoord; deze invloed is er alleen voor de bereikbaarheid van wijkvoorkieningen en ontevredenheid over de buurt, niet voor het gemis aan voorzieningen in huis of in de wijk, noch voor het type woning of de daarin aanwezige voorzieningen (in tegendeel, positief gelndiceerden hebben juist meer woonaanpassingen; $r=0,16$ ).

Samenvattend wordt geconcludeerd dat de woonsituatie door vijf kermvariabelen kan worden weergegeven: het aantal gemiste woon- en wijkvoorzieningen, de tevredenheid over de woning en de wijk en de wens te verhuizen (in factoranalyse worden deze vijf variabelen ook in éen factor ondergebracht (verklaarde variantie: $41 \%$ ) terwijl de resterende acht woonvariabelen tot vier andere factoren gerekend worden). Figuur 14.8 laat bij wijze van afsluiting de verbanden zien tussen de kernvariabelen, die in het vervolg steeds aftonderlijk beschouwd zullen worden, voor alle (nog) zelfstandig wonenden $(N=546)$ en voor deze groep, uitgezonderd de positief geindiceerde ouderen $(\mathbb{N}=392)$.

\subsubsection{Relaties tussen kernværiabelen woonsituatie en andere variabelen}

Er is niet veel recent Nederlands onderzoek naar de relatie tussen allerlei woonvariabelen en andere aspecten van de leefsituatie van ouderen. Een uitzondering is vermeldenswaardig en wordt hier vrij veelvuldig aangehaald; het betreft de studie van Coolen en Smid (1989) naar de samenhangen tussen wonen en zorg voor ouderen. In hoofdlijnen komen hun bevindingen op het volgende neer: er is geen relatie tussen de woonvorm (geordend van gewone woning, bowenwoning of flat tot bejaardenwoning, aanleunwoning en serviceflat) en de hulpbehoefte, uitgedrukt in (I)ADL-handicaps; er is wel een verband tussen deze woonvormen en het gebruik van extramurale zorg (hoger naarmate naar meer voor ouderen geschikte woningen gekeken wordt) en de sociaal-economische status (hoe hoger het inkomen hoe lager de kans op aangepaste woonvormen). Beide verbanden zijn weliswaar significant, maar niet erg sterk. Woninggebreken (last van bijvoorbeeld tocht; gemis aan woontechnische voorzieningen) hebben geén effect op gebruik van extramurale zorg, geén relatie met hulpbehoefte, maar wel met het inkomen. Woonongemakken (problemen met gebruik van aanpassingen of door ongelijkvloerse woonvertrekken) hebben ten hoogste een bescheiden effect op voorzieningengebruik, maar deze worden deels veroorzaakt door validiteitsbeperkingen. Voorts is het hulpgebruik door ouderen die in gelijke inkomens-en

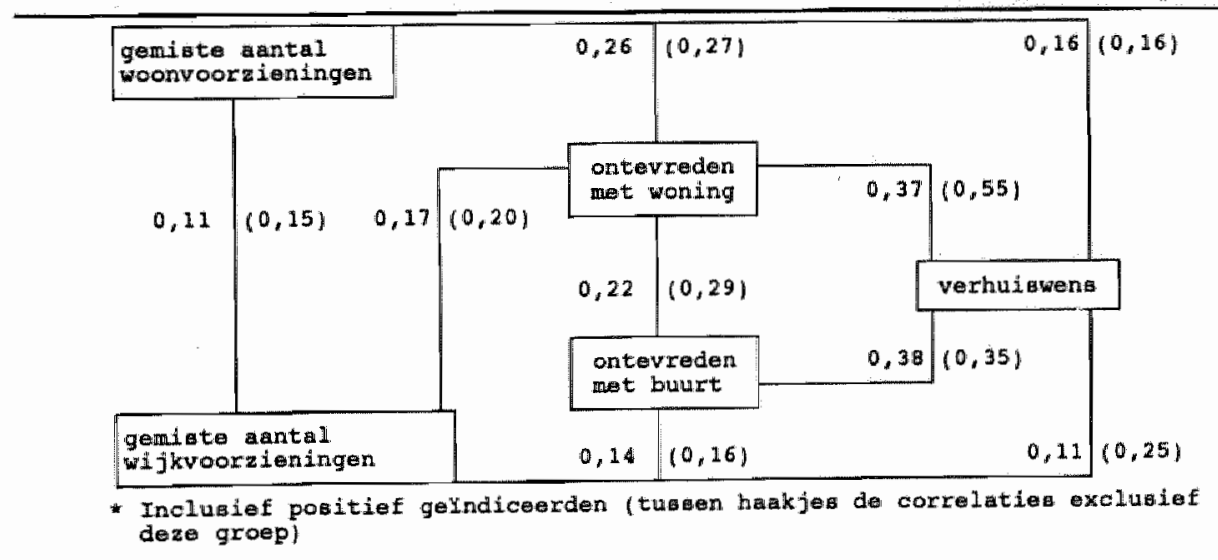

Figuur 14.8. Kernvariabelen woonsituatie: onderlinge significante correlaties bij (nog) zelfstandig wonende ouderen* 


\begin{tabular}{|c|c|c|c|c|c|}
\hline & 0.11 & & & & \multirow{4}{*}{ 1.ueftifid } \\
\hline & $-0,21$ & $-0,16$ & & & \\
\hline 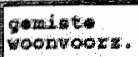 & goratioto & $\begin{array}{l}\text { onitedited der } \\
\text { wonding }\end{array}$ & $\begin{array}{l}\text { onterredon } \\
\text { bugre }\end{array}$ & werlntale & \\
\hline 6,27 & & & & 0,23 & \\
\hline 0,22 & 0,12 & 0,18 & 10.17 & $0,3:$ & $(I) A D L$ \\
\hline 0,17 & 0.13 & 0,15 & $0,1$. & 0,31 & \multirow{2}{*}{ 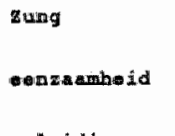 } \\
\hline \multirow[t]{2}{*}{$-0,17$} & & & & $-0,12$ & \\
\hline & & & & {$[-0,15$} & opleidiog \\
\hline$-0,11$ & $1-0,12$ & & & & \multirow{2}{*}{ - } \\
\hline$-0,16$ & $-0,14$ & $1-0,15$ & $-0,15$ & $-0,28$ & \\
\hline 0,24 & 0,13 & 0,23 & 0,12 & 0.22 & 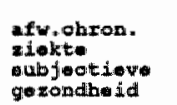 \\
\hline 0,22 & 0,11 & 0,26 & 0,20 & 0,35 & mo. oordeol \\
\hline
\end{tabular}

Figuur 14.9. Significante verbanden tussen woonvariabelen en andere variabelen bij zelfstandig wonende en positief geïndiceerde ouderen

validiteitsgroepen verkeren ook niet afhankelijk van de woonomgeving (bereikbaarheid voorzieningen, ook niet indien tevens de woongebreken en woonongemakken meegewogen worden). Samenvattend concluderen Coolen en Smid dat 'de kenmerken van de woonsituatie op zijn best slechts een bescheiden effect hebben op de mate waarin ouderen extramurale zorg benutten' (Coolen en Smid, 1989, p. 44). Dezelfde conclusie trekken de auteurs met betrekking tot opnamevragen (p. 55).

De woonomgeving kan als een veelzijdig voorzieningensysteem met fysieke en sociale aspecten fungeren (Lawton, 1985, in Arts e.a., 1989), maar de nabijheid en bereikbaarheid van lokale voorzieningen staat niet eenduidig in relatie met het welbevinden in het algemeen (Lawton, 1977). De urbanisatiegraad zou volgens het leefsituatie-onderzoek bij ouderen in 1982 geen significante relatie met het gebruik van extramurale zorg hebben (CBS, 1984), betgeen in uitgebreidere secundaire analyses op hetzelfde materiaal in grote lijnen bevestigd wordt (Perenboom e.a., 1989). Op een aantal punten (met name op medisch terrein, zoals bij het gebruik wan tandarts en ziekenhuis) worden wel consumptieverschillen aangetroffen tussen ouderen op het platteland en ouderen in de stad, ook indien gecorrigeerd wordt voor gezondheidsverschillen en verschillen in sociaal-economische status (Perenboom e.a., 1989).

Met betrekking tot de sociale structuur van de woonomgeving is relatief veel onderzoek gedaan, echter zelden specifiek voor ouderen. Nieuwbouwwijken en moderne voorsteden tenderen naar een zwakke sociale samenhang door het qua herkomst vaak gemengde karakter van de bevolking, het relatief gesloten gezinskarakter (privacy, korte vestigingsduur) en het ontbreken van gemeenschappelijke belangen. In oudere buurten is dat minder het geval door de band met de buurt, geringe doorstroming en open gezinskarakter. De ouderen die wel over intensieve buurtrelaties beschikken, blijken toch een smalle basis voor integratie te hebben, omdlat slechts enkele lijnen naar de buurtgenoten als bulp- en vertrouwensrelatie fungeren (Braam e.a., 1981; CBS, 1977 en 1978; Knipscheer, 1980). Ook buurtrelaties 
werken maar als een gebrekkige compensatie voor weinig contacten met kinderen en/of andere familieleden. De binding met de buurt is echter groter naarmate de samenstelling van de buurt homogener is (Blan, 1973; Hochschild, 1973; Nauta, 1973; Rosow, 1967) of indien er een wijziging in de gezinssamenstelling wan de oudere optreedt (bifwoorbeeld verlies partner; Rosow, 1967). Tenslotte lijkt er sprake te zijn van een negatieve relatie tussen de mate van buurtrelaties en bovenlokalle relaties in club- en verenigingsverband (Braam e.a., 1981; Rosow, 1967). Samenvattend is de conclusie echter dat een leeftijdshomogeen woonmilieu niet zonder meer gunstig hoeft te zijn voor de mate van infornuele hulp, met name niet bij ouderen met duidelijke fysieke handicaps (Coolen en Smid, 1989; Naafs, 1989).

De significante verbanden die in het onderhavige onderzoek worden aangetroffen tussen woon- en andere variabelen, zijjn weergegeven in figuur 14.9. Allereerst moet opgemerkt worden (niet in figuur 14.9) dat bereikbaarheidsproblemen bij buurtvoorzieningen hoofdzakelijk de neerslag vormen van (I)ADL-problemen (correlatie ongeveer 0,60 ) en geen typisch en afzonderlijk te beschouwen woonkenmerk zijn, hetgeen al bleek uit de afwezigheid van samenhang met andere woonvariabelen. Uit figuur 14.9 bijkt dat de demografische kenmerken nauwelijks van invloed zijn op de woonvariabelen: gehuwden missen vrij vaak wijkvoorzieningen en met het stijgen van de leeftijd neemt dit gemis, alsmede de ontevredenheid met de woning af. Voor andere groepen naar burgerlijke staat, noch voor de verschillende sexen zijn significante relaties met de geselecteerde woonvariabelen aangetroffen. Dit geldt tevens voor de AMT-score, de deelname aan GOWactiviteiten en de ontoereikendheid van het inkomen.

Het aantal gemiste voorzieningen in de woning en de verhuiswens hangen samen met het aantal (I)ADL-beperkingen. De Zungscore en eenzaamheidsgevoelens, de afwezigheid van chronische ziektes en het oordeel over zowel de gezondheid als de algehele situatie hangen samen met alle vijf woonvariabelen; met name tussen enerzijds de verhuiswens en anderzijds de Zungscore, eenzaamheid en het situatie-oordeel worden sterke samenhangen gevonden ( $r>0,30$ ). De verhuiswens is minder sterk bij ouderen met een hogere opleiding of een beter inkomen, maar verder hangen de variabelen met betrekking tot de sociaaleconomische status (zie volgende paragraaf) nauwelijks samen met de woonvariabelen, uitgezonderd het gemis aan voorzieningen.

De woonduur correleert met geen van de potentiele variabelen, uitgezonderd leeftijd (bijna per definitie) en het inkomen $(r=0,16)$. Dit opmerkelijke verband lijkt samen te hangen met hel bezit van eigen huis (hetgeen niet direct gevraagd is); er is immers gevraagd naar besteedbaar inkomen na aftrek van woonlasten, die bij langdurig bezit van een eigen woning (aanzienlijk) lager zijn dan bij huur (Van Fulpen, 1985).

\subsection{Sociaal-economische status}

\subsubsection{Inleiding}

Mikikowski (1972) beargumenteert dat mensen uit lagere sociale klassen in het algemeen in een ongunstige positie verkeren en dat de "bejaardenproblematiek" in wezen een klassenprobleem is. De sociaal-psychologische kenmerken van veroudering zouden derhalve (voor een deel) maatschappelijk bepaald kunnen zijn (Nota Bejaardenbeleid 1975, p. 12) en als zodanig ten dele door veranderingsprocessen te bellnvloeden. In dit licht kan ook de ontwikkeling van het stelsel van sociale zekerheid gezien worden. Voor ouderen is de ontwikkeling wan het AOW- en pensioenstelsel cruciaal geweest. (Nota's Bejaardenbeteid 1970 en 1975) hoewel erkend wordt dat zij desondanks nog in een achterstandssituatie verkeren, ook financieel. De sociaal-economische verschillen lijken te convergeren met de 
leefijd, zodat bij bejaarden de sociale ongelijkheid woor de dood steeds verder opgeheven wordt (Klaassen-Van den Berg Jeths en Kraan-Jetten, 1975, p. 78). Aan de andere kant zijn er ook aanwijzingen dat binnen de totale bevolking de sociaal-economische gezondheidsversehillen de lazitste jaren weer toenemen (Van der Maas, 1989).

Sociaal-economisch bepaalde verschillen in gezondheid staan sinds het begin van de jaren tachtig opnieuw in de belangstelling (De Jong, 1980; Mackenbach en Stronks, 1988; Nota 2000,$1986 ;$ WRR, 1988). Er zijn sociaal-economische verschillen vastgesteld in de prevalentie van chronische aandoeningen (CBS, 1988; SCP, 1988; Van den Bos, 1989), voor sterftecijfers (Van Doorslaer, 1987; Van Poppel, 1982), gebruik van gezondheidszorg (Coolen en Duipmans, 1987; Klaassen-van den Berg Jeths, 1989; Nota 2000, 1986; Mootz en Timmermans, 1981), malar ook bij emotionele labiliteit en algemene gezondheidstoestand (Van der Zee, 1982). De verzekeringsvorm (ziekenfonds versus particulier) blijkt van invloed te zijn op het aantal contacten met de huisarts en op het gebruik van door hem uitgeschreven medicijnen (Van Vliet en Van der Ven, 1986; Rutten en Janssen, 1987). Mootz (1984) heeft echter aannemelijk gemaakt dat het effect van de verzekeringsvorm grotendeels een schijneffect is en verloopt via de sociaal-economische status en de daardoor bepaalde gezondheidsverschillen.

Dimensies van sociaal-economische status (SES) zijn het opleidingsniveau, het beroep en het inkomen. Het beroep wordt daarbij veelal als meest belangrijke variabele beschouwd. Beroepsprestige blijkt ook bij ouderen na pensionering nog van invloed te zijn op de gezondheidstoestand en het woorzieningengebruik (Thijssen, 1986; Huijsman, 1989a).

\section{Opleiding}

Het oplelidingsniveau bepaalt thans woor een groot deel het beroep en inkomen en daarmee samenhangend de variabelen die in dit onderzoek centraal staan, maar bij ouderen is dit verband waarschijnlijk minder dominant omdat vroeger de relatie tussen opleiding en werk minder sterk was en ouderen ondanks een laag aanvangsniveau door langdurige arbeidservaring toch een bepaalde positie kunnen hebben opgebouwd (Thijssen, 1986).

Het opleidingsniveau heeft echter ook een eigen invloed op het gedrag van ouderen: een hogere opleiding leidt tot beter inzicht in en kennis over gezondheid en leefgewoonten (WRR, 1977; Van Doorslaer, 1987). In het model van Andersen e.a. (1975) is de genoten opleiding van invloed op de gebruiksgeneigdheid. Het opleidingsniveau is sinds de Tweede Wereldoorlog sterk gestegen, zodat de gevonden verbanden tussen leeftijd en het opleidingsniveau voornamelijk cohort-effecten zijn (Becker en Hermkens, 1989).

\section{Beroep}

De meest gebruikte indicator in stratificatie-onderzoek is wellicht het (laatst) uitgeoefende beroep. Dit berust op de gedachte dat de maatschappelijke gelaagdheid in sterke mate gebaseerd is op het economisch proces en de positie die men daarin inneemt (Thijssen, 1986). Beroepenclassificaties die veel gebruikt worden zijn die van het ITS (Van Westerlaak e.a., 1976) en het CBS, dat gebaseerd is op onderzoek naar schoolloopbanen (CBS, 1982). Omdat veel vrouwen geen beroep uitgeoefend hebben, wordt voor hen vaak het beroep van een eventuele partner genomen als benadering. In dit geval spreekt men liever van sociale groep dan van beroepsgroep. Hier wordt de eerste indeling gehanteerd, bestaande uit zes niveaus op basis van de volgende beroepskenmerken: "hoofdarbeid' versus "handarbeid', vereiste opleiding, zelfstandigheid van beroep, grootte wan bedrijf, al of niet in loondienst en leidinggeven. De beroepsgroepen zijn: (1) ongeschoolde arbeid, (2) geschoolde arbeid, (3) lagere employées, (4) kleine zelfstandigen, (5) middelbare employés en tenslotte (6) hogere beroepen. Door deze typering van beroepsgroepen wordt in feite een zekere (globale) 
indeling naar prestige weergegeven. Het onderzoek naar het prestige dat wan een beroep ontleend kan worden is echter veel uitgebreider en laat ook veel gedetailleerdere indelingen toe dan die naar beroepsgroepen. Ook voor Nederland is een schaal voor beroepsprestige ontwikkeld (Sixma en Ultee, 1983), maar omdat de feitelijke afleiding hiervan bewerkelijk is; wordt deze aanpak hier niet gevolgd.

\section{Inkomen}

Inkomen blijkt in verschillende studies van wisselende importantie te zijn ter verklaring van voorzleningen gebruikt door ouderen. Andersen en Newman (1973) veronderstellen een indirecte invloed via de 'gebruiksmogelijkheid' ('predisposing'). Een hoger gebruik bij lagere inkomensgroepen werd gevonden door Mootz en Timmermans (1981). Serviceflatbewoners en positief gelndiceerde ouderen hebben een significant lager inkomen dan (andere) zelfstandig, wonende ouderen (Bosma, 1988). De zogenaamde mantelzorg bljijkt vooral ten goede te komen aan de midden- of hogere klassen, terwijl de lagere klassen vaker een beroep doen op de gezinsverzorging (SCP, 1986, p. 33). De bevinding in hoofdstuk 6 dat $65 \%$ van de 65 -plus clienten maximaal AOW heeft, illustreert dit.

In het inkomensbeleid voor ouderen zijn enkele belangrijke markeringen aan te geven vanaf de inwerkingtreding van de eerste Armenwet in 1854 (Commissie Financiering Oudedagsvoorziening, 1987; Nota Bejaardenbeleid 1975; SCP, 1990; zie ook Tijdbalk Ouderenzorg in bijlage 1): de vernieuwde Armenwet (1912); Invaliditeitswet (1913, 1919); Ouderdomswet (1919); Noodwet-Drees (1947); de Algemene Ouderdomswet (1957); structurele verhoging tot bijstandsniveau (1965); structurele verhoging en invoering vakantie uitwerking (1970); tweejaarlijkse aanpassing aan loon- en prijsontwikkeling (1972); verbetering pensioenrechten van duurzaam gescheiden en gehuwde ouderen (1972); reductie ziekenfondspremie (1975); nelto-netto koppeling aan minimumloon (1980), doch sinds 1981 per jaar steeds buiten werking gesteld, waarmee de AOW-uitkering niet meer waardevast is; bruto-korting van $3 \%$ op alle sociale uitkeringen; individualisering van de AOW-uitkering (1985); "eenouderpensicen' en gelijkstelling samenwonenden en gehuwden (1987); inkomensafhankelijke toeslag voor partner jonger dan 60 jaar (1988).

De bedrijfspensioenregelingen zijn vooral in de eerste tien jaar na de oorlog tot stand gekomen en bij de invoering van de AOW omgebouwd tot aanvullende pensioenvoorzieningen. In 1985 bestond het gemiddelde inkomen van 65-plussers (bruto $f 28.740$ ) voor $57 \%$ uit $\mathrm{AOW}, 26 \%$ aanwullend pensioen, $18 \%$ overige inkomsten (met nanne vermogen). Het aandeel van de $\mathrm{AOW}$ in het gemiddeld inkomen van ouderen is sinds 1980 constant (SCP, 1990). De tot op heden veelvuldig uitgesproken verwachtingen over de toekonstige inkomensontwikkelingen bij ouderen, zijn recent getemperd (Rekers en Hermkens, 1989; SCP, 1990). Het SCP verwacht een inkomensverbetering (afhankelijk van de gevolgde methode) van 0 tot $0,8 \%$ per jaar. Uitsluitend uitgaande van de opleidingsontwikkeling wordt een stigging van $0,4 \%$ verwacht (zie ook paragraaf 15.6). Met name in de vermogenssfeer bestaan grote onzekerheden, zodat ook in de toekomst de AOW waarschijnlijk het belangrijkste inkomensbestanddeel zal blijven.

Ondanks de bescheiden te noemen inkomensontwikkeling bij ouderen, is in het algemeen dankzij het stelsel van sociale zekerheid de afhankelijkheid tussen (oudere) ouders en hun kinderen verminderd. Dit leidt ertoe dat mantelzorg door kinderen niet meer economisch afdwingbaar is en veel meer dan vroeger berust op de sociaal-emotionele aspecten (Van der Kruis en Mandemaker, 1986). 
In deze paragraaf worden de ondertinge samenhangen bekeken tussen opleiding, inkomen en sociale groep. De literatuur geeft uiteenlopende aanwijzingen met betrekking tot de afweging tussen een samengestelde variabele voor sociaal-economische status (SES) of afzonderlijke indicatoren daarvoor. Enerzijds wijzen de zeer hoge correlaties tussen de indicatoren onderling (zie tabel 14.11) op de mogelijkheid van een latente SES-variabele. Anderzijds bilikt uit bet model van Andersen en Newman (1973), zoals dat in hoofdstuk 13 beschreven is, dat de SES-indicatoren refereren aan verschillende modelaspecten: zo hangt de gebruiksgeneigdheid samen met het opleidingsuiveau en wordt de gebruiksmogelijkheid onder meer bepalald door het inkomen, dat van belang is voor de mogelijkheid om alternatieven aan te boren en van invloed kan zijn op de hoogte van de eigen bijdrage (bijvoorbeeld bij de gezinsverzorging). Zo concludeerde het CBS (1988) dat het opleidingsniveau van invloed is op het benutten van medicijnrecepten en op het aantal specialistencontacten, terwijl het gebruik van fysiotherapeuten en wijkverpleging wooral door inkomen wordt bepaald. Ook elders worden de verschillende mechanismen van de verschillende SESvariabelen aangetroffen (Van Linschoten e.a., 1988).

Het opleidingsniveau is volgens de gebruikelijke CBS-indeling bevraagd en kent acht niveaus, oplopend van lager onderwijs (al of niet lager beroepsonderwijs) tot hoger beroepsen universitair onderwijs. Het beroep is ondervraagd en gecodeerd op basis van de beroepenklapper van het ITS (Van Westerlaak e.a., 1976). Voor vrouwen is, indien zij niet zelf een beroep uitoefen(d)en, het beroep van de man als benadering voor de resulterende sociale groep genomen. Figuur 14.10 geeft aan hoe vaak dat gebeurd is.

Inkomensvragen leveren bij enquetes veel problemen op. In het onderhavige onderzoek is een poging gedaan de non-respons te minimaliseren door alleen het besteedbare inkomen in de vragenlijst te laten invullen. Interviewer en respondent berekenden dit gezamenlijk door de netto-inkomsten uit $\mathrm{AOW}$ en andere bronnen te salderen met huur, andere woonlasten (gas, water, licht) en ziektekosten. Ook bij deze procedure blijft uiteindelijk de vraag bij $9,8 \%$ ongevraagd (met name bij verpleeghuispatienten), terwijl $15 \%$ geen antwoord wil geven en nog eens $16,2 \%$ zegt het niet te weten (waarvan ruim $80 \%$ vrouwelijk).

De indicatoren woor sociaal-economische status hangen in belangrijke mate onderling samen (tabel 14.11). Het opleidingsniveau kent de hoogste correlatiecoefficienten, namelijk met het beroep van de respondent zelf $(0,64)$ of van zijn/haar partner $(0,31)$ en met de (eventueel uit de combinatie van beide beroepen gedestileerde sociale groep $(0,54)$. Opvallend is de grote samenhang tussen SES-indicatoren voor de respondent en de partner onderling. In

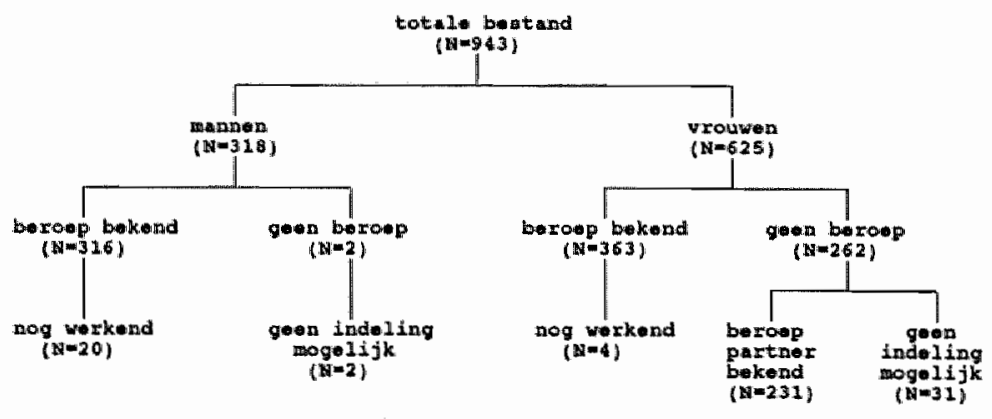

Figuur 14.10. Indeling in sociale (beroeps-)groep 
Tabel 14.11. Correlaties tussen SES-variabelen voor respondent en eventuele partner*

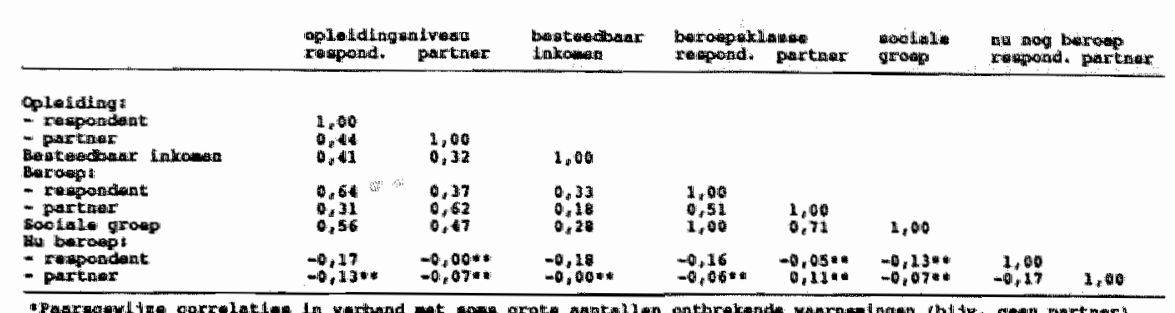

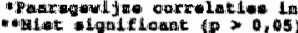

vergelijking tot andere onderzoeken zijn de correlaties tussen de SES-indicatoren vrij laag; dit duidt op enige mate wan 'status-inconsistentie' (Braam e.a., 1981; Dowd, 1980; Thijssen, 1986). Voor meetprocedures en onderzoek naar de determinanten van het voorzieningengebruik kan het daarom in sommige gevallen zinvol zijn de drie dimensies voor sociaaleconomische status afzonderlijk te blijven beschouwen. Zo werd al eerder toegelicht dat de SES-variabelen in het model van Andersen en Newman (1973) verschillende rollen spelen, namelijk bij de geneigdheid of de mogelijkheid tot gebruik, terwijl de eigen bijdrage weer een nieuwe drempel kan opwerpen bij de gebruiksnoodzaak. Omdat anderzijds de onderlinge samenhangen tussen SES-variabelen groot is, wordt het alternatief van een samengestlelde SES-variabele niet uitgesloten. Deze is eenvoudig geconstrueerd uit de som van het voor het aantal huishoudleden gecorrigeerde inkomen (score 1-5) ${ }^{3}$, het opleidingsniveau (score 1-8) en de sociale groep (score 1-6). De SES-schaal loopt dan van minimaal 3 tot maximaal 19 punten.

\subsubsection{Samenhang tussen SES en andere variabelen}

Uit voornamelijk buitenlands onderzoek blijkt dat de sociaal-economische status van invloed is op ziekte, levensduur, morbiditeit ten gevolge van chronische aandoeningen (KlaassenVan den Berg Jeths en Kraan-Jetten, 1985) en de kans in de WAO opgenomen te worden (Zielhuis, 1980). Thijssen (1986) concludeert dat de validiteit en lichamelijke en psychische gezondheid van ouderen in hogere strata gemiddeld lets beter is dan die van ouderen in lagere strata, waarbij zelfstandigen een tussenpositie innemen. Bosma (1988) rapporteert een significant verband tussen SES en psychisch functioneren en psychiatrische problematiek, doch niet tussen SES en lichamelijke gezondheid. Het SCP (1988) wijst erop dat thans de belangrijkste oorzaken voor sociaal-economische gezondheidsverschillen (zoals slechte huisvesting, eenzijdige voeding, fysiek zwaar werk met slechte werkomstandigheden) eigenlijk zijn weggenomen, zodat het minder eenvoudig is de SES als precieze oorzaak van de verschillen aan te wijzen. Het gezamenlijk effect van verschillende determinanten tegelijkertijd is thans veel meer verantwoordelijk voor gezondheidsverschillen, ook bij ouderen (Mootz en Timmermans, 1981).

Ouderen in hogere strata zijn maatschappelijk en socilal actiever: zij doen vaker onbetaald werk, zijn iets vaker lid van organisaties, gaan vaker uit en hebben een optimistischer toekomstbeeld (Atchley, 1977; Catton, 1972; Thijssen, 1986). Het opleidingsniveau lijkt

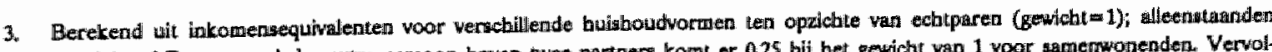

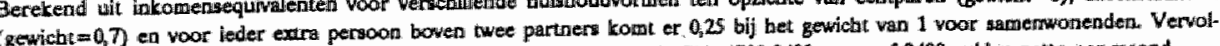

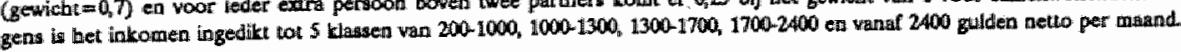




\begin{tabular}{|c|c|c|c|c|}
\hline 10,20 & & 10,13 & 0.09 & 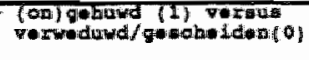 \\
\hline$-0,25$ & $T-0,23$ & $\mid-0,23$ & $-0,13$ & \multirow{4}{*}{ leeftijd } \\
\hline$\longdiv { - 0 , 2 4 }$ & $1-0,22$ & & & \\
\hline oplofding & indinom & roep zeop. & oolale groep & \\
\hline$-0,12$ & $1=0,19$ & & & \\
\hline \multicolumn{4}{|l|}{0,11} & \multirow{7}{*}{$\begin{array}{l}\text { (I) ABD } \\
\text { afw, obrod, ziekto }\end{array}$} \\
\hline & & $-0,11$ & & \\
\hline$[-0,12$ & $-0,15$ & & & \\
\hline$[-0,16$ & & $-0,11$ & & \\
\hline$[-0,14$ & {$[-0,216$} & $1=0,17$ & $-0,14$ & \\
\hline 0,18 & 0,16 & 0,22 & 0,15 & \\
\hline \multicolumn{4}{|l|}{$-0,10$} & \\
\hline
\end{tabular}

Figuur 14.11. Relaties tussen SES-indicatoren en andere variabelen

daarbij het belangrijkste stratificatie criterium te zijn, terwijl bij inkomen de vrijetijdsbesteding het belangrijkste is.

Op basis van paarsgewijze correlatie-berekeningen (minimaal: $N=396$ ) zijn in figur 14.11 de belangrijkste (significante) verbanden tussen SES-indicatoren en andere aspecten van de leefsituatie van ouderen in beeld gebracht. Er zijn geen significante relaties gevonden tussen enerzijds de SES-indicatoren en anderzijds de gezondheidsbeleving, de tevredenheid over de woonsituatie of het bieden van hulp aan anderen. Over het algemeen zijn de gepresenteerde samenhangen weliswaar significant, maar (zeker in vergelijking tot die bij de (I)ADLschalen) van bescheiden omvang. Opleiding blijkt de belangrijkste verbanden met andere kenmerken te geven, gevolgd door het beroep (met name bij psychische aspecten). Deze bevinding gaat gedeeltelijk in tegen de literatuursuggestie dat beroep het meest belangrijke zou zijn. Inkomen heeft significante verbanden met de leeftijd en het geslacht van de respondent, maar niet met het feit of men al of niet gehuwd is (er is immers gebruik gemaakt van inkomensequivalenten). Ook hangt inkomen significant samen met het aantal (I)ADLbeperkingen, het medicijngebruik, de deelname aan GOW-activiteiten (die derhalve met name door lagere strata wordt gerapporteerd) en de AMT-score.

\subsection{Sociaal netwerk}

\subsubsection{Inleiding}

Behalve lichamelijke veranderingen treden bij het ouder worden talrijke veranderingen in de sociale situatie op (Braam e.a., 1981). Echter, iemand die vroeger actief was en veel contacten had, heeft dat op latere leeftijd vaak ook (Neugarten e.a., 1964). Volgens. Sipsma 
(1973) is er met het ouder worden een natuurlijke vermindering van het aantal en de kwallteit van contacten, leidend tot 'sociale deprivatie'. Dit sluit aan bij de 'disengagement" theorie (Cumming en Henry, 1961), die een tendentie tot terugtrekkend gedrag postuleert maarmate men ouder wordt. Dit leidt onvermijdelijk tot een wederzijds afnemende interactie tussen de ouder wordende mens en andere mensen in het sociale systeem. Een alternatieve theorie is de activiteitentheorie (Havighurst, 1963) waarbij: sociale integratie essentieel geacht wordt voor het succesvoll omgaan met ouder worden. Daarbij kan wel sprake zijn wan enige vorm van terugtrekken, maar hiervoor komen nieuwe en andersoortige relaties in de plaats, die noodzakelijk geacht worden voor het in stand houden van de sociale orde en het individuele geluk of welbevinden. In een overzichtsartikel over de onderzoeksresultaten in het kader van de disengagement-theorie (Larson, 1978) blijkt dat een positieve samenhang tussen welbevinden en sociale contacten globaal wel teruggevonden wordt, maar dat dat sterk afhankelijk is van het soort relatie (familie versus vrienden en buren). Aan dit type onderzoek kleven echter enkele bezwaren, zoals de eenzijdige belichting van de frequentie van contacten, zonder de functies of de kwaliteit daarvan in beschouwing te nemen (Liang e.a., 1980; Arts e.a., 1989; Broadhead e.a., 1983). Ook wordt als bezwaar geuit dat de disengagementtheorie 'slechts' een beschrijvende theorie zonder toetsbare hypothesen is. De activiteitentheorie is een normatieve theorie, waarin sociale integratie een subjectieve waarde heeft die niet volledig door objectieve variabelen als het aantal contacten gemeten kan worden (Liang e.a., 1980).

In het vervolg wordt gesproken van 'sociaal netwerk' om daarmee het belang aan te geven van de naar aard en inhoud verschillende relaties rond een persoon (Klein Beernink, 1983 in De Jong-Gierveld, 1984). Sinds de definitie van gezondheid door de WHO (1948) heefit het sociaal netwerk een belangrijke rol speelt in het onderzoek naar de gezondheidstoestand en het voorzieningengebruik (Kaplan, 1985), waarbij als centrale hypothese geformuleerd wordt dat sociale relaties geassocieerd worden met een betere gezondheidssituatie en welbevinden vanwege de steun die zij bieden (Kaplan e.a., 1977; Seeman en Berkman, 1988). Onder ouderen bevinden zich veel cenpersoonshuishoudens door het wegvallen van de partner. Deze alleenstaanden doen veel vaker een beroep op formele hulp (Coolen, 1989; Fennis, 1973; Klaassen-Van den Berg Jeths en Kraan-Jetten, 1985). Het sociaal netwerk vervult verschillende functies (Braam e.a., 1981): (a) sociaal-emotionele functies (geborgenheid); (b) instrumentele functies (huisvesting, voeding, verzorging). Knipscheer (1980) onderscheidt bij sociale relaties vijf dimensies: inhoud, richting of wederkerigheid, duurzaamheid, intensiteit en frequentie. Structurele factoren zoals de totale omvang van het sociale netwerk en het aantal contacten zijn gerelateerd aan de beschikbaarheid van instrumentele en emotionele steun (Seeman en Berkman, 1988), waarbij kinderen met name de eerste functie op zich nemen en vrienden en andere familieleden meer gericht zljn op de emotionele functie van het sociale netwerk. Veelal beperkt men zich bij empirisch onderzoek tot de frequentie van sociale relaties, die ook wel wordt gevat onder het begrip 'objectieve isolatie' uitgedrukt in een relatief gering aantal contacten met anderen (De JongGierveld, 1984). Naast 'objectieve isolatie' wordt 'subjectieve isolatie" of eenzaamheid onderscheiden. Howel eerder (paragraaf 14.5) aan de orde kwam dat eenzaamheid ook veroorzaakt kan worden door verminderd psychisch functioneren, wordt eenzaamheid als aspect bij de beoordeling van het sociaal netwerk belangrijker geacht (De Jong-Gierveld, 1984). Bij de bespreking van verbanden tussen aspecten van het sociaal netwerk en andere variabelen zal dit nader worden onderzocht.

In het leefsituatie-onderzoek onder 55-plussers in 1982 bleek dat bij het ontvangen van bezoek van familie, buren en kennissen nauwelijks verschillen naar sexe bestaan, maar dat eventuele verschillen wel iets toenemen met de leeftijd, en dat er geen duidelijk verband bestaat tussen leeftijd en het ontwangen van bezoek (CBS, 1984). Er zijn twee uitzonderingen: vrouwen krijgen iets meer bezoek van buren en kennissen van de eigen leeftijd en met het stijgen van de leeftijd komen kleinkinderen lets vaker op bezoek bij zelfstandig wonenden (CBS, 1984, p. 49). Bejaardenoordbewoners krijgen over de gehele linie minder 
bezoek dan zelfstandig wonende ouderen, maar ook in bejaardenoorden bestaan nauwelijks verschullen naar sexe en leeftijd. Het zelf afleggen van bezoeken aan (klein-)kinderen, familie en anderen vertoont in het algemeen dezelfde (afwezige) relaties met sexe en leeftijd, zij het dat ouderen in de allerhoogste leeftijdscategorie $e_{n}$ iets minder actief zijn. Bij bejaardencordbewoners wordt wel een sexeverschill voor het bezoek aan medebewoners gevonden (vrouwen leggen meer bezoeken af).

\section{Eenzaarmheid}

Eenzaamheid wordt algemeen in verband gebracht met een problematisch sociaal netwerk. De indiwiduele persoonlijke beleving wan de omvang en de aard van het sociaal netwerk bepaalt echter het onderscheid tussen alleen zijn en eenzaamheid. Eenzaamheid wordt door De Jong-Gierveld (1984, p.45) omschreven als 'het subjectief ervaren van een onplezierig of ontoelaatbaar gemis aan (kwaliteit van) bepaalde sociale relaties". Daarbij is niet alleen de omvang van het sociale netwerk (contactfrequenties), maar ook de mate van intimiteit of kwaliteit van belang. Het gaat daarbij om de discrepantie tussen gewenste en gerealiseerde contacten met andere mensen. De Jong-Gierveld onderscheidt drie dimensies binnen het eenzaamheidsbegrip:

1. emotionele kenmerken van eenzaamheid (angst, verdriet, ongelukkig, niet gewaardeerd)

2. akard van de gemiste relatie(s), zoals met betrekking tot een partner, gemis aan gezelligheid, verlatenheid

3. het tijdsperspectief van eenzaamheid (uitzichtloos, tijdelijke aard, berusting)

De tweede dimensie vormt een noodzakelijke doch niet voldoende voorwaarde voor eenzaamheid. Afhankelijk van de leeftijd, sociale situatie, leefsituatie en stemming kan de tolerantiegrens voor gemis verschillen (De Jong-Gierveld, 1984, p. 47).

In empirisch wetenschappelijk onderzoek ligt de nadruk op eenzaamheid als gemisgevoelens in de relaties met andere mensen. Hiervoor zijn verschillende meetinstrumenten ontwikkeld, die veelal uitgaan van een multidimensionaal construct. Vanuit sociologisch standpunt bestudeerd (Marcoen, 1989) is ook nagegaan of eenzaamheid onder ouderen gerelateerd is aan factoren zoals leeftijd, geslacht, burgerlijke staat en woonsituatie (Ankersmit, 1979; CBS, 1977 en 1983; Thijssen, 1983). Eenzaambeid blijkt vaak een reden te zijn om opname in een bejaardenoord aan te vragen: ouderen op een wachtlijst zijn aanzienlijk eenzamer dan zelfstandig wonenden zonder opnamewens, terwijl reeds opgenomen ouderen een tussenpositie innemen (Coleman, 1976). De feitelijke overgang naar een verzorgingstehuis lijkt een zekere reductie van eenzaamheidsgevoelens te bewerkstelligen (De Jong-Gierveld en Kamphuis, 1986), waarbij een sterke samenhang bestaat met het totale sociaal-psychologische welbevinden (Ankersmit, 1984; Mast e.a., 1972; Van Loveren-Huyben e.a., 1985). Recentere onderzoeken omtrent de invloed van eenzaamheild op het doen van een aanvraag voor opname in een bejaardenoord laten zien dat die eenzaamhied aanwezig is bij een vijfde (Bosma, 1988) tolt een kwart van de aanvragers (Koehler en Van der Pennen, 1988). Door een vergelijkbaar aantal ouderen wordt eenzaamheid ook echt genoemd als reden voor het doen van een aanvraag (20\%; Te Wierik en Frederiks, 1989).

\subsubsection{Constructie van sociaal netwerk variabelen}

Uit het beknopte literatuuroverzicht komt naar voren dat een aantal aspecten belangrijk is ter beoordeling van het sociale netwerk. Globaal is een onderscheid aan te brengen tussen de morfologische eigenschappen van het gehele sociale netwerk (ook wel genoemd: noodzakelijke voorwaarden) en de interactie-eigenschappen van sociale steun. Mogelijke criteria bij de beoordeling van het sociaal netwerk in sociaal-wetenschappelijk onderzoek betreffen met name de omvang van het netwerk (hoeveel personen), de diversiteit van het netwerk (verschillende personen), het aantal contacten met diverse geledingen in het sociale netwerk, 
de wederkerigheid van die contacten (zowel bezoek ontvangen als zelf alleggen) en de Inhoud van sociale relaties, waarbij emotionele en instrumentele functies mogelijk zijn.

In dit onderzoek (Frederiks, 1990) is eigenlijk alleen gevraagd naar het laatste type functies, waarop bij de analyse van zelfzorg en informele hulp (paragraaf 14.9) gedetailleerd wordt ingegaan. De emotionele functies van het sociale netwerk blijven derhalve onbelicht. Dit geldt tevens voor de evaluatie van de omvang, aard en inhoud van de contacten; ook hierower zijn op geen enkele wijze vragen gesteld. Deze beperkingen liggen echter opgesloten in de aard van de onderzoeksvraag; het sociaal netwerk is niet het belangrijkste onderzoeksthema, maar wordt gezien als én van de mogelijke determinanten in de verklaring van het voorzieningengebruik door ouderen (Frederiks, 1990).

De omvang van het netwerk is bezien aan het aantal kinderen, schoon- en kleinkinderen dat de respondent heeft en de omvang van het huishouden (al of niet een partner, eenpersoonshuishouden of aantal huisgenoten). Voor alle geledingen in het sociaal netwerk is voor de contactfrequentie (gemiddelde op maandbasis) is de volgende indeling gehanteerd: (0) niet van toepassing (de respondent heeft bijvoorbeeld geen kinderen); (1) er zijn wel personen, maar er is geen contact; (2) minder dan een maal per week contact; (3) tơt twee maal per week; (4) twee maal per week contact of meer, maar niet dagelijks; (5) dagelijks een of nog meer contacten. Bij overige familie is de correctie voor afwezigheid (0) niet mogelijk, omdat hierover geen vragen gesteld zijn.

De gemiddelde contactfrequenties zijn voor de verschillende deelpopulaties in het onderzoek (thuiswonenden, positief geindiceerden, bejaardenoordbewoners en verpleeghuispatienten) vaak significant verschillend (zo blijkt uit kruistabellen-analyse): dit geldt voor het ontwangen van bezoek van kinderen in Maastricht $\left(x^{2}=57,0 ; p<0,001\right)$ en het bezoek aan deze categorie $\left(x^{2}=74,9 ; p<0,001\right)$, voor het bezoek van kleinkinderen $\left(x^{2}=39,3 ; p<0,001\right)$ en van overige familieleden $\left(x^{2}=56,7 ; p=0,03\right)$. Het geldt niet voor bezoek dan kinderen buiten Maastricht $\left(x^{2}=17,8 ; p=0,12\right)$. In tabel 14.12 zijn de gemiddelde bezoekfrequenties op maandbasis (rechte telling) voor de verschillende geledingen uit het sociale netwerk. vermeld. Daarbij dient hel speciale karakter van het deelbestand voor verpleeghuispatienten (zie paragraaf 13.6) in herinnering geroepen te worden: (a) bij circa de helft hebben de antwoorden betrekking op de situatie voór het aan het verpleeghuis voorafgaande ziekenhuisverblijf, zodat eigenlijk het sociaal netwerk van een redelijk gezonde oudere beschreven wordt (hetgeen bijvoorbeeld blijkt uit het zelf op bezoek gaan bij kinderen en andere fami-

Tabel 14.12. Typering sociaal metwerk per deelpopulatie

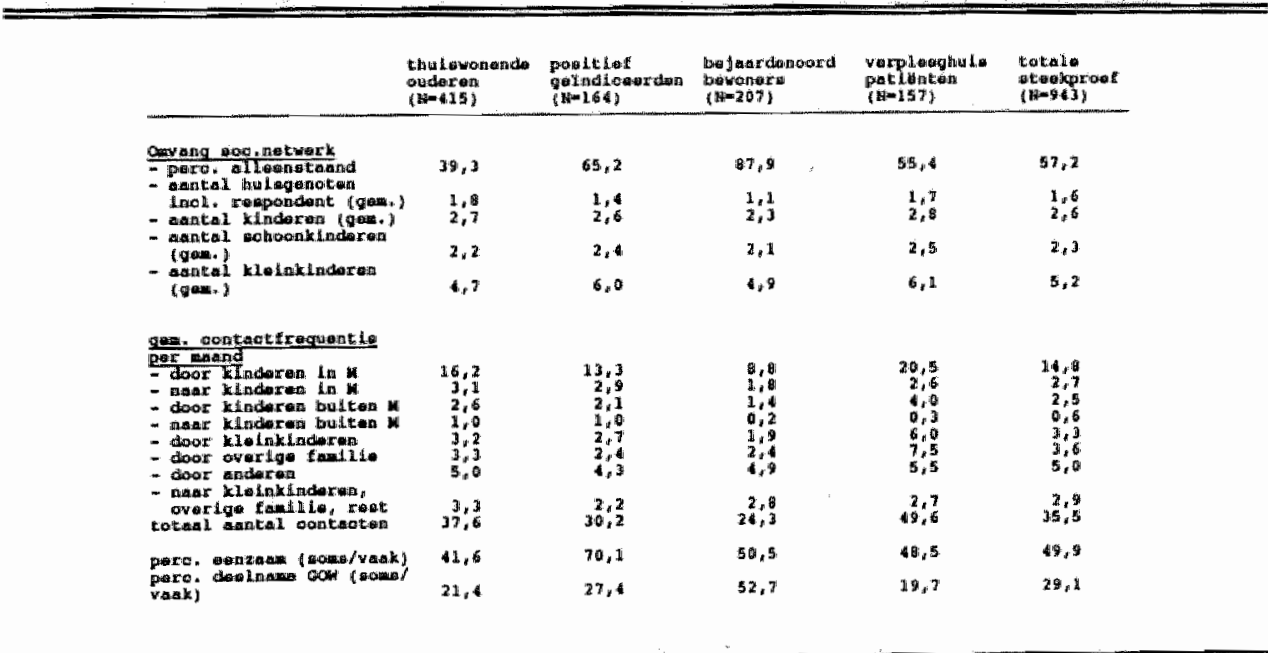




\begin{tabular}{|c|c|c|c|c|c|c|c|c|c|c|c|c|c|}
\hline$\therefore$ & 1 & 2 & 1 & 4 & 5 & 6 & 7 & 8 & 9 & 10 & 21 & 3.2 & 13 \\
\hline 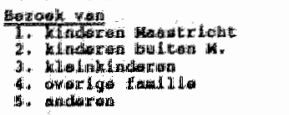 & 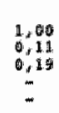 & $\begin{array}{l}1,00 \\
0,20 \\
0,30 \\
0\end{array}$ & $\begin{array}{c}1,00 \\
0,1,2 \\
+\end{array}$ & $\begin{array}{l}1,00 \\
0,118\end{array}$ & 1,00 & & & & & & & & \\
\hline 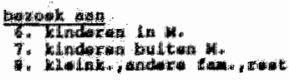 & $\begin{array}{c}0.11 \\
=\end{array}$ & $\begin{array}{l}0 \\
0,100 \\
0\end{array}$ & $\begin{array}{c}0,12 \\
= \\
=\end{array}$ & $\begin{array}{r}13 \\
-21\end{array}$ & $\underset{0 .}{*} 39$ & $\begin{array}{l}1,100 \\
0 ; 13 \\
0 ; 20\end{array}$ & $\begin{array}{l}x, 09 \\
0,27\end{array}$ & 1,00 & & & & & \\
\hline 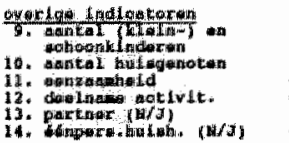 & $\begin{array}{r}0.13 \\
0,36 \\
-0,12 \\
-0,13 \\
-0,23\end{array}$ & $=$ & $\begin{array}{l}0,11 \\
0,19 \\
= \\
= \\
0,13\end{array}$ & $\begin{array}{r}-0,21 \\
-0,09 \\
-12 \\
-12\end{array}$ & $\begin{array}{c}-0,1,1 \\
-0,1,2 \\
= \\
0,010\end{array}$ & $\begin{array}{c}-0,10 \\
0,11 \\
-\end{array}$ & $\begin{array}{l}= \\
= \\
=\end{array}$ & $\begin{array}{c}-0,13 \\
-0,11 \\
= \\
=\end{array}$ & $\begin{array}{l}1100 \\
= \\
=\end{array}$ & $\begin{array}{r}1,00 \\
-0,22 \\
-6,10 \\
-0,01\end{array}$ & $\begin{array}{l}1,00 \\
-0,19 \\
0,20\end{array}$ & $\begin{array}{r}1, n 0 \\
-0,15 \\
0,122\end{array}$ & $\begin{array}{r}1,40 \\
-0,77\end{array}$ \\
\hline
\end{tabular}

lie), terwijl nadien de situatie sterk kan zijn gewijzigd; (b) bij een aantal respondenten zijn sommige vragen niet gesteld omdat dat vanwege de toestand van de betreffende persoon niel kies werd geacht (geldt onder andere voor deelname aan GOW-activiteiten en eenzaamheid); (c) belevingsvragen zoals over eenzaamheid kunnen niet door een tweede respondent worden beantwoord.

In tabel 14.13 zijn de onderlinge samenhangen tussen alle variabelen van het sociaal netwerk weergegeven. Hierover is het volgende op te merken. Ten eerste blijken de correlaties van contactfrequenties op ontwangend gebied zeer laag te zijn, uitgezonderd het bezoek van kleinkinderen (zelfstandig) en het bezoek van kinderen in en buiten Maastricht. Hiermee komt de meer-generationele viering van verjaardagen tot uitdrukking. Bij het ontvangen van bezoek gaat het derhalve duidelijk om gescheiden bljwende geledingen in het sociaal netwerk. Bezoek van overige familie lijkt een zekere compensatie te geven voor een kJeinere omvang van het netwerk. Bij het zelf afleggen wan bezoek ligt dat geheel anders. Als wordt geconstateerd dat de respondent zelf bezoek brengt aan kinderen buiten Maastricht, dan is de kans groot dat dat ook gebeurt aan kinderen binnen Maastricht en aan andere (tezamen genomen) categorieen in het sociaal netwerk. Met name het contact met anderen dan eigen familie is in sterke mate wederzijds. Hier lijkt bovendien sprake van een vervanging van het contact met de eigen kinderen en kleinkinderen (de correlaties tussen bezoek van deze categorieen en bezoek aan de andere categorieen zijn niet significant). Het verschillende karakter van het contact met allerlei geledingen blijkt ook uit de samenhangen met eenzaamheid (alleen significant bij bezoek van kinderen in Maastricht, bezoek van overige familie of buiten de familiekring en bezok aan anderen dan de kinderen). De deelname aan activiteiten van het bejaardenwerk lijkt zowel een vervanging van het sociaal netwerk (significant bij bezoek van Maastrichtse kinderen en het aantal huisgenoten), als een versterking van het sociaal netwerk (bezoek aan kinderen in Maastricht en aan nietfamilieleden) te kunnen zijn. Het aantal huisgenoten heeft een positief effect op het ontvangen van bezoek, vooral van kinderen in dezelfde gemeente (met als 'prijs' dat zij minder bezoek krijggen van de oudere) en de mate van eenzaamheid. Als er nog een partner is komt er ook significant meer bezoek van kinderen buiten de stad en van overige familie, is de eenzaamheid minder en neemt men minder deel aan GOW-activiteiten.

Er is geén verband tussen deelname aan GOW-activiteiten en eenzaamheid. Tenslotte lijken eénpersoonshuishoudens extra in het nadeel: deze krijgen minder bezoek van kinderen en overige familie, gaan daarom wel iets vaker op pad naar kinderen in Maastricht en zijn significant eenzamer dan niet-alleenstaanden. Het totaal aantal bezoeken dat men ontvangt van het gehele sociale netwerk hangt significant samen met eenzaamheid $(r=-0,11 ; p<0,01)$, 
de omwang van het netwerk $(r=0,45)$, het aantal huisgenoten $(r=0,25)$ en alleenstaand zjin $(r=-0,19 ; \mathrm{p}<0,001)$. Het totaal aantal afgelegde bezoeken is in het gehele bestand nfet gerelateerd aan bet alleenstaand zijn, maar wel als de verpleeghuispatienten buiten beschouwing blijven $(r=0,10 ; p<0,01)$, en hangt samen met deelname aan activiteiten van het GOW $(r=0,10 ; p<0,01)$ en het onivangen aantal bezoeken $(r=0,39)$.

Voor het vervolg van de asalyse dient een gekozen te worden voor een beperkt aantal variabelen die het sociale netwerk van ouderen kunnen weergeven. Op grond van het voorgaande is gekozen voor een vijftal variabelen, namelijk: (1) het aantal bezoeken dat men in totalal ontvangt (van het gehele netwerk van (klein-)kinderen, overige familie en anderen); (2) het totaal aantal bezoeken dat men zelf aflegt; (3) de diversiteit van de contacten (uitgedrukt in het aantal geledingen uit het sociaal netwerk); (4) de deelname aan GOW. activiteiten en (5) de mate van eenzaamheidsgevoelens bij de respondent.

\subsubsection{Relaties tussen socilsal netwerk en andere variabelen}

Gezien het feit dat met het toenemen van de leeftijd het aantal sociale relaties afneemt (Braam e.a., 1981; Knipscheer, 1980), verwacht men ook een toename van het voorkomen van eenzaamheid met het ouder worden. Deze hypothese wordt door sommige studies wel (Ankersmit, 1979; Tews, 1971) en door andere studies niet (Braam e.a., 1981; Dooghe en Vanderleyden, 1978) ondersteund; de samenhang tussen het absolute aantal gerealiseerde contacten en eenzaamheid is over het algemeen slechts zwak (De Jong-Gierveld, 1984). De sexegebondenheid van de gerealiseerde contacten is wel van belang (Woldringh en Knapen, 1980): mannen onderhouden contacten met mannen, wrouwen met vrouwen. Vrouwen hebben betere sociale netwerken dan mannen (Wenger, 1984; Broadhead e.a., 1983). Daarbij wordt tevens geconstateerd dat vriendinnenrelaties 'rijker' en stabieler zi.jn, waardoor alleenstaande vrouwen beter in staat zijn een bevredigend sociaal netwerk op te bouwen dan alleenstaande mannen (Austrom, 1981; De Jong-Gierveld, 1984). Bij een vergelijkbare onvang van het sociale netwerk bij oudere vrouwen is een verschil in de mate van eenzaamheid aangetroffen naar burgerlijke staat: (recent) verweduwde vrouwen zijn het eenzaamste (Ankersmit, 1977). Thijssen (1986) heeft echter aannemelijk gemaakt dat sexeverschillen bij sociale contacten en eenzaamheid berusten op de samenhang van geslacht met andere kenmerken zoals leeftijd en burgerlijke staat. Verder liet Thijssen (1986) zien dat de frequentie van sociaal contact altijd dezelfde invloed op eenzaamheid heeft, ongeacht de burgerlijke staat, gezondheid of urbanisatiegraad. Het vóorkomen van eenzaamheidsgevoelens hangt het sterkst samen met bet sociaal contact met overige familie (anders dan eigen kinderen).

Een gunstiger sociaal-economische status gaat gepaard mett een sterker en gevarieerder verenigingsleven, terwijl eenzaamheid minder vaak voorkomt (Braam e.a., 1981, p. 106). Volgens Lee (1983; in Arts e.a., 1989) zijn deze verbanden echter niet eenduidig en met name aanwezig bij de onderste en bovenste extremen van de sociaal-economische status (Berkman, 1986).

Over de relatie tussen gezondheid enenerzijds en de omvang en het karakter van het sociaall netwerk anderzijds verschillen de bevindingen in de literatuur aanzienlijk (Sarason en Sarason, 1985). Bij ouderen zijn met betrekking tot de subjectieve gezondheidsbeleving relaties gevonden met sociale steun (Antonueci en House, 1983), waarbij de kwaliteit van deze steun belangrijker is dan de omvang (Antonucci, 1985) en met het aantal sociale contacten (Minkler e.a., 1983). Sociale steun heeft, controlerend yoor andere variabelen, mogelijk ook een positieve invloed op de levensduur (Blazer, 1982; Schaefer e.a., 1981). Kaplan (1985) beargumenteert echter dat het sociaal netwerk sinds de WHO-definitie voor gezondheid (1945) ten onrechte een component van gezondheid genoemd wordt. In de zeer 
uitgebreide literatuut over sociale netwerken van ouderen zijn nog enkele belangrijke verbanden veelvuldig adn te treffen: het contact met de eigen kinderen neemt toe met de leeftijd en na verweduwing (Wenger, 1984), de diversiviteit van contacten loopt terug met de leeftija (CBS, 1976) en er zijn nauwelijks significante werbanden tussen variabelen met betrekking tot het sociaal netwerk en het psychisch functioneren of welbevinden (Arts e.a, 1989; Lee, 1980; Lee en Ellithorpe, 1982; Wenger, 1984).

In het onderhavige onderzoek worden de (significante) samenhangen tussen enerzijds de sociaal netwerk variabelen (totaal aantal ontvangen of afgelegde bezoeken, diwersiteit van het netwerk, deelname GOW-activiteiten en eenzaamheid) en anderzijds andere factoren uit de leefsituatie van ouderen (zoals de demografische kenmerken, het aantal LADL-beperkingen en het psychisch functioneren) weergegeven met behulp van figuur 14.12. Met betrekking tot de demografische kenmerken blijkt dat de huwelijkse staat positief samenhangt met het aantal ontwangen bezoeken, de diversiteit van de sociale contacten en de afwezigheid van eenzaamheidsgevoelens. De deelname aan GOW-activiteiten is bij gehuwden significant minder vaak genoemd. Bij dit aspect van het social netwerk worden voorts significante relaties gevonden met de sexe van de respondent, de sociaal-economische status (negatief) en met de subjectieve oordelen over de gezondheid en de totale situatie (beide positief).

Sexe heeft in dit onderzoek geen relatie met het totaal aantal ontvangen of afgelegde bezoeken en de diversiteit van het gehele sociale netwerk. Ook voor het contact met afzonderlijke geledingen wit het sociale netwerk zijn geen significante sexe-invloeden gevonden. Deze ten opzichte van de literatuur afwijkende bevinding kan mogelijk verklaard worden door het feit dat bij de inventarisatie van personen met wie men contact heeft, niet naar de sexe van de mensen gevraagd is.

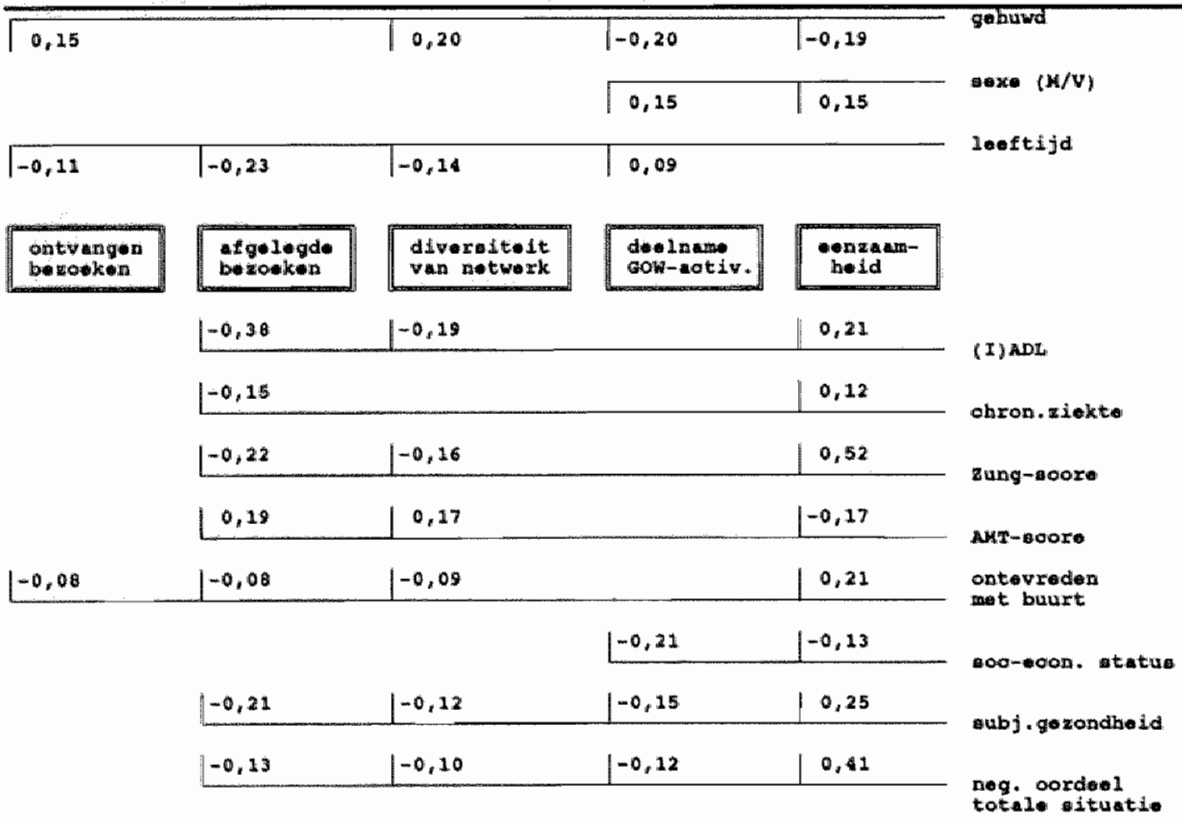

Figuur 14.12. Significante samenhangen tussen sociaal-netwerkvariabelen en andere determinanten uit de leefsituatie van ouderen 
Betreffende het totaal aantal ontvangen bezoeken zijn geen significante samenhangen met andere factoren uit de leefsituatie gevonden, uitgezonderd met de mate van (on)tevredenheid ower de buurt waarin men woont (het betreft dan vooral het bezoek van anderen dan familie-leden; $r=-0,12, p<0,001)$. Het totaal aantal afgelegde bezoeken wordt in belangrijke mate beïnvloed door de lichamelijke en psychische toestand van de respondent, maar niet door de sociaal-economische status. Hetzelfde geldt voor de diversiteit van sociale contacten, maar in mindere mate en niet significant met betrekking tot de aanwezigheid van een chronische ziekte.

Tenslotte blijkt het voórkomen en de mate van eenzaamheidsgevoelens samen te hangen met alle andere factoren uit de leefsituatie, uitgezonderd de leeftijd van de respondent (conform Braam, e.a., 1981; Dooghe en Vanderleyden, 1978). Eenzaamheid is significant positief gecorreleerd met het aantal LADL-beperkingen, de aanwezigheid van chronische ziekte(n), de Zungscore (in zeer sterke mate), de aanwezigheid van geheugenstoornissen (via AMT-score; nota bene: hoe hoger de AMT-score hoe minder geheugenstoornissen), de mate van (subjectief beleefde) ongezondheid en het oordeel over de gehele situatie. Naarmate de sociaal-economische status hoger is, zijn de eenzaambeidsgevoelens echter significant lager.

\subsection{Zelfzorg en informele hulp}

\subsubsection{Inleiding}

Informele hulp betreft hulp en ondersteuning van de partner, kinderen, familie, buren, wrienden en kennissen en staat onder tal van andere termen bekend (niet-professionele hulp, nuldelijnszorg, mantelzorg, officieuze zorg). Is een van de informele helpers, de term die hier aangehouden wordt, aan te wijzen als hoofdpersoon dan wordt ook wel gesproken van 'centrale verzorg(st)er' (Janssen, 1988). Dit is veelal een vrouw, hetzij de echtgenote, hetzij een (schoon)dochter (Janssen, 1985; Knipscheer, 1984). De informele hulp blijkt vooral ten goede te komen aan personen uit de midden of hogere sociaal-economische klassen $\left(S_{C P}, 1986\right)$. Er wordt expliciet gestreefd naar een verschuiving van formele naar informele hulpverlening (Janssen, 1985; Knipscheer, 1984; Langeveld, 1985; Verhaar, 1985; Wevers e.a., 1985); cok de overheid kent dit streven (zie hoofdstuk 3). Er is een aantal redenen te noemen voor de beperkte mogelijkheden van substitutie in de richting van informele hulp (zie voor een literatuuroverzicht: Goudriaan, 1989 en 1990; SCP, 1984), zoals afnemend kindertal (zie ook STG, 1985), verweduwing, economische onafhankelijkheid van kinderen, overbelasting (Janssen, 1985) en privacy-karakter van persoonlijke verzorging. Toch is de omvang van informele hulp niet onaanzienlijk: bij circa 50 tot $70 \%$ van de mensen die hulp ontvangen, betreft dat informele hulp, eventueel in combinatie met gezinsverzorging of wijkverpleging (Hattinga Verschure, 1984; SCP, 1988). De grenzen van de informele hulp worden bepaald door de zwaarte en de duur van die hulpverlening (Janssen, 1985; SCP, 1988), maar ook door economische aspecten (Kwekkeboom, 1987; Kuijvenhoven, 1988; Schrijvers, 1987). De rol van formele hulp kan enerzijds stimulerend zijn (Janssen, 1985; Nuyens, 1988), anderzijds leiden tot terugtrekking van informele hulp (Coolen, 1982). Interessant fenomeen is verder dat het aantal twee- of drie generatiehuishoudens, met name bij 80-plussers, sinds 1983 weer stijgt (SCP; 1988; zie ook hoofdstuk 2). Dit alles leidt er toe dat het moeilijk is om eenduidige en generaliseerbare conclusies te trekken over zowel de voorwaarden waaronder en de situraties waarin informele hulp tot stand komt, als over de effecten ervan. 
Er zijn globalil vier modellen voor de relaties tusisen informele en formele hulpverlening te onderscheiden (Noelker en Bass, 1989):

a. complementaire model (dual specialization') van gescheiden taken, uitgevoerd door gescheiden blijwende systemen van formele en informele hulp.

b. supplementaire model, watin routine-matige hulp en gespecialiseerde zorg onderscheiden worden die beide tijdsintensief kunnen zijn of anderszins additionele hulp vereisen. In dit model wordt de routine-matige hulp informeel opgevangen en de gespecialiseerde zorg formeel.

c. substituerende model (met name het onderzoek van Greene, 1983), waarin familiehulp vervangen wordt door professionele hulp, vooral door stijgende arbeidsparticipatie van vrouwen en demografische ontwikkelingen (dalend kindertal; STG, 1985).

d. geen relatie, omdat informele hulp plaatsvindit onafhankelijk of juist in weerwil van de mogelijkheid om formele hulp te krijgen (afhankelijk van culturele waardenpatronen, toetredingsbarrieres in zorgcircuits en familiebanden).

\subsubsection{Zelfzorg en informelle bulp: patronen en constructie van variabelen}

In de enquete (Frederiks, 1990) is bij alle IADL-handelingen gevraagd wie de belangrijkste en eén na belangrijkste uitvoerd(st)er is van de daar genoemde huishoudelijke activiteiten (zoals boodschappen doen, koken en dergeljjke): de respondent zelf, de partner, andere huisgenoot, niet-inwonende familie, vrienden of buren en vrijwilligerswerk. In dezelfde lijst. van mogelijke uitvoerenden zijn bovendien gezinsverzorging, wijkverpleging, betaalde particuliere hulp, bejaardenverzorgende of verpleegkundige uit bejaardenoord en dergelijke opgenomen, maar die zijn hier niet relevant (komen wel terug in de analyse van het voorzieningengebruik). Bij de ADL-handelingen wordt alleen naar de belangrijkste uitvoerder gevraagd. Per genoemde uitvoerder is bekeken of deze hulp geeft en zo ja, bij hoeveel taken. Deze twee soorten variabelen zijn gecorrigeerd voor de mogelijkheid dat er geen huisgenoot (noch partner, noch lemand anders) aanwezig is ter onderscheiding van de mogelijkheid dat deze er wel is, maar geen huip geeft. In het licht van de besproken literatuur moet met spijt vastgesteld worden dat het geslacht van de informele helper buiten beschouwing is gebleven. In tabel 14.14 wordt voor het gehele bestand (inclusief intramurale sectoren) in beeld gebracht wie de meest belangrijke uitvoerder is van de (I)ADL-taken.

Opgemerkt wordt dat in deze analyse nog alle (I)ADL-items betrokken worden; in latere instantie beperken wij ons tot de 11 handelingen waarvoor eerder op basis van het Raschmodel een gecombineerde (I)ADL-schaal is ontwikkeld (zie paragraaf 14.3). Ook mogelijke vormen van professionele hulpverlening worden hier tezamen genomen (een gedetailleerde analyse hieromatrent volgt in hoofdstuk 15). Tenslotte wordt vermeld dat het vrijwilligerswerk buiten beschouwing wordt gelaten omdat dat slechts énmaal is genoemd.

In tabel 14.14 komt bij de antwoordmogelijkheid dat de respondent zelf de belangrijkste

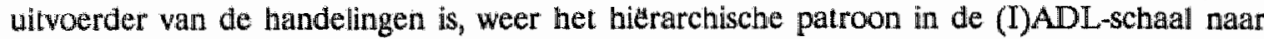
voren: zelf doet de respondent niet erg vaak meer het dweilen $(6,6 \%)$ en de was $(18 \%)$, ongeveer $1 / 3$ van de respondenten doet zelf de boodschappen en het koken van een warme nualtijd, 40 tot $50 \%$ doet zelf de administratie, stoft en maakt het bed op en circa $70 \%$ verzorgt zelf de broodmaaltijd en de verwarming. Bij de ADL-handelingen loopt het percentage respondenten dat deze handelingen zelf doet op van $58 \%$ bij traplopen (waarbij deze vraag overigens bij $36 \%$ niet van toepassing is, bijwoorbeeld vanwege het feit dat de woning gelijkvloers is) tot $94 \%$ bij eten en drinken; het komt relatief vaak voor dat 80 tot $85 \%$ van de respondenten rapporteert dat het betreffende ADL-item zelf gedaan wordt.

De hulp van de partner is met name bij de instrumentele activiteiten groot congecorrigeerd voor het feit of er wel een partner is), varierend van $6,7 \%$ bij het verzorgen van de 
Tabel 14.14. Hulppatronen per (I)ADL-handeling: procentuele aandelen van de belamgrijkste uitvoerenden per handeling

\begin{tabular}{|c|c|c|c|c|c|c|c|c|}
\hline & $x \in \mathbb{f}$ & partmer & $\begin{array}{l}\text { mals } \\
\text { genot }\end{array}$ & fandile & burem & $\begin{array}{l}\text { paret } \\
\text { talp }\end{array}$ & $\begin{array}{l}\text { thand } \\
\text { torg }\end{array}$ & $\operatorname{lnt}$ tratar \\
\hline 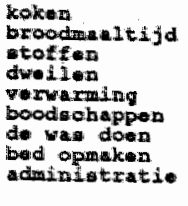 & $\begin{array}{r}32,7 \\
70,7 \\
43,4 \\
6,6 \\
72,4 \\
32,0 \\
10,4 \\
47,6 \\
41,5\end{array}$ & $\begin{array}{r}15,3 \\
10,5 \\
13,6 \\
10,7 \\
6,5 \\
13,6 \\
14,1 \\
14,4 \\
13,9\end{array}$ & $\begin{array}{l}5,9 \\
4.0 \\
4,8 \\
6,3 \\
3,9 \\
7,2 \\
6,8 \\
4,7 \\
6,0\end{array}$ & 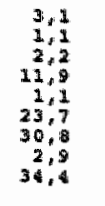 & $\begin{array}{l}0,4 \\
0,1 \\
0,3 \\
1,4 \\
0,1 \\
3,9 \\
1,5 \\
2,0\end{array}$ & $\begin{array}{r}1,2 \\
0,3 \\
4,0 \\
12,0 \\
0,5 \\
2,3 \\
18,0 \\
2,1 \\
0,2\end{array}$ & $\begin{array}{r}5,3 \\
0,3 \\
0,3 \\
2,3 \\
0,6 \\
4,5 \\
4,3 \\
4,3 \\
0,3\end{array}$ & $\begin{array}{r}3,6 \\
14,1 \\
23,6 \\
3,5,5 \\
1,4 \\
12,6 \\
5,0 \\
21,4 \\
1,6\end{array}$ \\
\hline 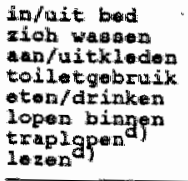 & $\begin{array}{l}84,6 \\
71,5 \\
80,6 \\
36,1 \\
93,7 \\
34,3 \\
58,3 \\
80,5\end{array}$ & $\begin{array}{l}3,2 \\
2,0 \\
3,7 \\
1,9 \\
0,9 \\
2,1 \\
1,7 \\
0,2\end{array}$ & $\begin{array}{l}1,8 \\
1,3 \\
2,4 \\
1,6 \\
0,6 \\
1,1 \\
1,3 \\
=\end{array}$ & $\begin{array}{l}1,1 \\
1,3 \\
0,8 \\
0,9 \\
1,1 \\
0,7 \\
1,4 \\
-\end{array}$ & $\begin{array}{c}= \\
0,1 \\
0,1 \\
0,1 \\
-1 \\
0,1 \\
=\end{array}$ & $\begin{array}{c}0,1 \\
0,1 \\
0,1 \\
0,1 \\
0,1 \\
= \\
=\end{array}$ & $\begin{array}{c}0,60) \\
11,50) \\
2,50) \\
0,2 \\
0,1 \\
0,4) \\
=\end{array}$ & $\begin{array}{r}7,7 \\
11,1 \\
9,4 \\
7,0 \\
3,6 \\
2,1 \\
0,2 \\
0,1\end{array}$ \\
\hline
\end{tabular}

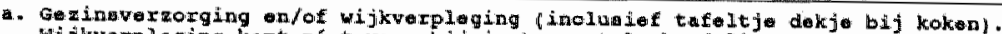

Wijkvapleging kort nifet voor bij ingtrumentole bandelingen (oerate blok van koken tot

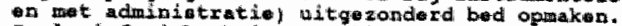

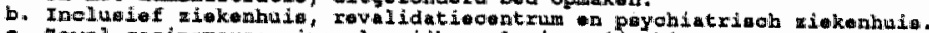

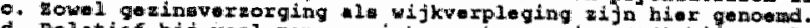

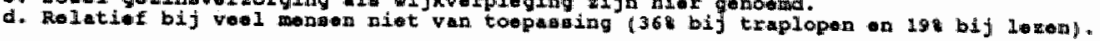

verwarming tot $15,3 \%$ bij koken. Andere huisgenoten (ongecorrigeerd voor hun aanwezigheid) zijn als belangrijkste uitwoerder genoemd bij 4 tot $7 \%$ van de instrumentele taken. De inschakeling van familie is zeer groot, met name bij het doen van de administratie (34\%; bij) thuiswonenden ook altijd nog 20\%), het doen van de was (31\%; thuiswonenden $22 \%$ ) en het doen van boodschappen (24\%; thuiswonenden 19\%). Particuliere hulp wordt vooral genomen voor de was en het zwaardere huishoudelijke werk. Tenslotte blijkt de hulp van buren weinig genoemd te worden als belangrijkste, uitgezonderd bij het doen van boodschappen (4\%; nauwelijks variatie tussen de deelbestanden). Als er professionele hulp als belangrijkste uitvoerder van (I)ADL-taken genoemd wordt, betreft dat met name het dweilen en ander huishoudelijk werk. Het gaat bij de thuiszorg overigens natuurlijk altijd om het zelfstandig wonende deel van het totale bestand (het laatste is de basis van het huidige betoog), zodat de gepresenteerde cijfers in tabel 14.14 (bijvoorbeeld $18 \%$ bij dweilen) in het deelbestand van zelfstandig wonenden hoger liggen (voor het voorbeeld op $26 \%$ ). In het bejaardenoord en verpleeghuis tezamen $(38,6 \%$ van alle respondenten) wordt lang niet altijd professionele instrumentele bulp gegeven: de percentages varieren van $1,4 \%$ bij administratie en $5 \%$ bij het doen wan de was tot ongeveer $33 \%$ bij dweilen en koken.

Bij de algemene ADL-taken is de zelfredzaamheid (dat wil zeggen het feit dat de respondent rapporteert dat de betreffende activiteit door hem/haar zelf verricht wordt) aanzienlijk groter. Als er ADL-bulp door anderen gegeven wordt, is deze vaak professioneel en veel minder afkomstig van informele hulpwerleners. Met name bij het wassen is dit aan de orde. Bij deze taak, maar ook bij het in en uit bed stappen, het aan- en uitkleden en het traplopen worden zowel de gezinsverzorging als de wijkverpleging als belangrijkste uitvoerder of hulp genoemd. De hulp van buren, particuliere hulp en familie is bij ADL-ondersteuning vrijwet te verwaarlozen.

Over de omvang van informele hulp zijn nog enige extra vragen gesteld, namelijk (a) welke uitvoerder het laatste jaar het meest geholpen heeft bij instrumentele en andere ADLactiviteiten tezamen, (b) welke uitwoerder bij ziekte of bedlegerigheid de persoonlijke en (apart gevraagd) de huishoudelijke verzorging van de respondent overneemt, (c) wie in geval van nood bereikt kan worden (twee personen of instanties mogelijk) en tenslotte (d) 
wan wie men eventuele extra hulp (indien nodig) zou willen krijgen. Vragen over de toereikendhetd van en tewredenheid over de informele hulp, eventuele knelpunten en dergelijke zjo in dil onderzoek niet gesteld.

Nadere analyses zijn verricht met betrekking tot de mogelijkheden die er naar inschatting wan de respondent bestaan om hulp te krijgen als dat nodig zou zijn. Gevraagd is: "Als U een week of langer ziek of bedlegerig bent, wie zorgt er dan voor u persoonlijk en voor Uw huishouding?" Men kon zowel informele als formele hulpverieners aangeven en daarbij niet alleen de belangrijkste, maar ook een tweede persoon. Tussen de personen die persoonlijke ADL-hulp zouden geven enerzijds en personen die huishoudelijke of instrumentele bulp zouden geven anderzijds, zijn interessante netwerken van informele en formele hulp te zien. Deze netwerken worden belicht woor thuiswonende ouderen, inclusief positief gelndiceerden. De bevindingen zijn als volgt te schetsen. Diegenen die op instrumenteel gebied meer zelfzorg $(8,6 \%)$ rapporteren, verwachten meer hulp van familie en vrienden of buren. Deze worden als eerste maar niet als tweede persoon genoemd en zullen naar verwachting zowel op persoonlijk als op huishoudelijk vlak hulp bieden als dat nodig is; familieleden en vrienden of buren zijn overigens ook de personen die in geval van nood het eerst bereikt kunnen worden. Het enige significante verband tussen het feit dat iemand zelfzorg rapporteert bij huishoudelijk activiteiten en hulp verwacht van een tweede persoon betreft de persoonlijke hulp door de wijkverpleging $(r=-0,16 ; p<0,001)$. Naarmate men meer zelf doet wordt wel significant vaker de wens geuit (meer) gezinsverzorging te krijgen $(r=0,14$; $\mathrm{p}<0,001)$. Als men al hulp heeft van de gezinsverzorging, dan zal indien persoonlijke hulp ten gevolge van ziekte nodig is niet alleen deze voorziening ( $r=0,43)$, maar ook de wijkverpleging ingeschakeld kunnen worden $(r=0,34)$, terwijl het omgekeerde veel minder wordt gerapporteerd $(r=0,15 ; \mathrm{p}<0,001)$ en dan vooral als huishoudelijke hulp nodig zal zijn $(r=0,17 ; p<0,001)$. Hulp van familie en tafeltje dekje (of via restaurant) gaat vaak samen $(\mathrm{r}=0,18 ; \mathrm{p}<0,001)$. Reeds bestaande hulp van familieleden kan ook bij ziekte opgeroepen worden, waarbij de partner als tweede persoon bij huishoudelijke hulp 'achter de hand' blijft $(r=0,29)$. De familie fungeert bij aanwezigheid van gezinsverzorging als tweede vangnet op huishoudelijk vlak $(r=0,17)$; ouderen met betaalde particuliere hulp noemen nauwelijks andere mogelijkheden, uitgezonderd de partner op wie in tweede instantie bij huishoudelijke activiteiten zal worden teruggevallen $(r=0,16 ; p<0,001)$. Indien er al hulp van vrienden of buren aanwezig is, geldt dit in nog sterkere mate en worden er in het geheel geen anderen genoemd (noch bij persoonlijke, noch bij huishoudelijke hulp), doch kennelijk volstaat dit omdat ook geen wens geuit wordt voor meer hulp van wie dan ook (het betreft overigens slechts $4,3 \%$ van alle ouderen).

Bij de constructie van de variabelen voor zelfzorg en informele hulp door partner, huisgenoot, familie of buren is aansluiting gezocht bij de eerder gepresenteerde (I)ADL-schaal van 11 geselecteerde items (zie paragraaf 14.3). Dit betreft hulp bij koken, broodmaaltijd maken, stoffen, dwejlen, boodschappen doen, de was doen, zichzelf wassen, aan- en witkleden, toiletgebruik, eten en drinken en zich binnenshuis verplaatsen. De informele hulp wordt uitgedrukt in het aantal handelingen (maximaal 11) waarbij de genoemde personen helpen, resulterend in vier variabelen voor informele hulp uit vier verschillende bronnen. Dit aantal verschillende bronnen is vervolgens als vijfde variabele geconstrueerd.

In tabel 14.15 wordt een overzicht gegeven van de aanwezigheid wan de verschillende vormen van informele hulp. Gemiddeld heeft $22 \%$ hulp van de partner (bij de 302 respondenten die een partmer hebben is dat $69,5 \%$ ) en $6 \%$ hulp van een andere huisgenoot ( $54 \%$ bij de 101 respondenten die een huisgenoot hebben). Hulp van andere familieleden buiten het eigen huishouden komt vrij vaak voor $(42,5 \%)$, maar burenhulp (circa $6 \%$ ) daarentegen nauwelijks. Een kwart van alle respondenten heeft een betaalde particuliere hulp; bij positief gelndiceerden is dat zelfs $30 \%$. De antwoorden over particuliere hulp worden bij de 


\begin{tabular}{|c|c|c|c|c|c|}
\hline & $\begin{array}{l}\text { thuitio- } \\
\text { wonend } \\
(\mathbb{N}=45)\end{array}$ & $\begin{array}{l}\text { poajtief } \\
\text { gexndiceera } \\
(N-16)\end{array}$ & $\begin{array}{l}\text { be } 9 \text {. oond } \\
\text { benonera } \\
(\mathrm{k}=207)\end{array}$ & $\begin{array}{l}\text { verpiegh } \\
\text { pativaten } \\
(\mathrm{N}=157)\end{array}$ & 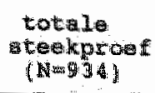 \\
\hline $\begin{array}{l}\text { gemildald ameal } \\
\text { I I hot-beperkingenia }\end{array}$ & 3,7 & 5.6 & 6,3 & 10.2 & 5,7 \\
\hline 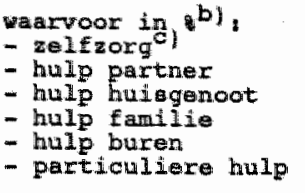 & $\begin{array}{r}75,5 \\
35,9 \\
9,4 \\
30,8 \\
20,6 \\
20,5\end{array}$ & $\begin{array}{r}4,5,0 \\
14,6 \\
4,9 \\
4,5 \\
6,7 \\
30,5\end{array}$ & $\begin{array}{c}25,1 \\
6,3 \\
58,0 \\
7,7 \\
44,0 \mathrm{~d}\end{array}$ & $\begin{array}{r}1,2 \\
15,3 \\
9,6 \\
51,0 \\
6,4 \\
8,9\end{array}$ & $\begin{array}{r}35,2 \\
22,3 \\
6,2 \\
82,5 \\
5,9 \\
25,5\end{array}$ \\
\hline $\begin{array}{l}\text { antal informele } \\
\left.\text { brommen }(\text { grem })^{9}\right)\end{array}$ & 0,80 & 0,70 & 0,72 & 0,82 & 0,77 \\
\hline
\end{tabular}

a. de afgeleide Rasch-ochaal met 11 activiteiten (rie pacagraaf 14.3)

b. belangrijkete witwoerder; combinaties zijn mogelijk, dus som groter dan 100

c. alleom instrumentole activitelten

d. hoofdrakelifk de uitbesteding wan wasgaed $(43,58)$

e. mogelijkheden: partner, huiagenoot, familie on buren

bejaardenoordbewoners overigens vertekend door het feit dat deze ouderen de uitbesteding van het wasgoed ook daaronder begrepen. De hulp van familie betreft bij de bejaardenDordbewoners hoofdzakelijk het doen van boodschappen (34\%) en de was (48\%). Bij de ouderen die positief geindiceerd zijn voor opname in een bejaardenoord is de hulp wan een pariner $(14,6 \%)$ aanzienlijk lager dan bij thuiswonende ouderen $(35,9 \%)$, terwijl familiehulp veel vaker woorkomt $(44,5 \%$ versus $30,8 \%)$ en er ook vaker particuliere hulp is $(30,5 \%$ versus $20,5 \%$ bij thuiswonende ouderen).

Voor de geconstrueerde variabele met betrekking tot het aantal verschillende informele hulpbronnen is het van belang dat er bij instrumentele activiteiten twee en bij de andere ADL-activiteiten slechts én persoon genoemd kon worden en dat wij ons beperken tot de 11 items uit de Raschschaal. Op deze wijze geconstrueerd blijkt het aantal gerapporteerde informele hulpbronnen maximaal twee te zijn, hoewel er hier vier onderscheiden worden: hulp door partner, huisgenoot, familie of buren komt derhalve in bepaalde gelimiteerde combinaties voor. Een informele bron heeft $63,5 \%$ van alle respondenten, twee bronnen heeft $6,7 \%$, maar bijna een dercle $(29,8 \%)$ heeft helemaal geen informele hulp. Het gemiddelde aantal informele bronnen komt op 0,8 . De verdeling van bet aantal informele hulpbronnen per deelbestand is overigens niet significant anders voor thuiswonenden, bejaardenoordbewoners of verpleeghuispatienten $\left(\chi^{2}=10,2 ; p=0,12\right)$.

De samentiang tussen de verschillende bronnen van informele hulp kan nader worden bestudeerd aan de hand van de correlatiematrix in tabel 14.16, waarin alleen de significante verbanden vermeld zijn. Er worden twee varianten belicht, namelijk: (a) zijn de betreffende hulpbronnen well of niet ingeschakeld (dichotome uitspraak) en (b) bij hoeveel verschillende taken er informele hulp wordt geboden. Beide varianten kennen steeds de zelfide significante correlaties, maar daarop zijn twee uitzonderingen die steeds de informele hulp van een huisgenoot (anders dan partner) betreffen: ten eerste staat de aanwezigheid van deze hulp niet in relatie tot het feit of iemand zelf nog activiteiten verricht en ten tweede staat de omvang van deze hulp niet in verband met het totaal aantal informele hulpbronnen dat ingezet is. Een afnemende zelfzorg wordt met name ondervangen door toenemende hulp wan de partner $(r=-0,61 ; p<0,001)$ of van een eventuele andere huisgenoot $(r=-0,35 ; p<0,001)$. Het verband tussen afnemende zelfzorg en toenemende informele hulp door andere familieleden 
Tabel 14.16. Significante verbanden tussen informele hulpwormen in twee varianten

\begin{tabular}{|c|c|c|c|c|c|c|}
\hline & 1 & 2 & 3 & 4 & 5 & 6 \\
\hline \multicolumn{7}{|l|}{ gantezlotheld yen hulp } \\
\hline 1. zolfzorg & 1,00 & & & & & \\
\hline $\begin{array}{l}\text { 2. hulp yan partiner } \\
\text { 3. hulp yan hulgonoot }\end{array}$ & $-0,22$ & 1,00 & 700 & & & \\
\hline - hulp van familio & $-0,09$ & $-0,30$ & $=$ & 1,00 & & \\
\hline $\begin{array}{l}\text { 5. hulp van buren } \\
\text { 6. antal Inf brannen }\end{array}$ & $-0,09$ & 0,57 & 0,35 & 0,56 & $\begin{array}{l}1,00 \\
0,25\end{array}$ & 1,00 \\
\hline \multicolumn{7}{|l|}{ orryang van de hulp } \\
\hline $\begin{array}{l}\text { 1. zelfzorg } \\
\text { 2. hidp van partner }\end{array}$ & $\begin{array}{r}1,00 \\
-0,61\end{array}$ & 1,00 & & & & \\
\hline 3. hulp van hudegenoot & $-0,35$ & - & 1,00 & & & \\
\hline - hulp van familie & $-0 ; 12$ & $-0,20$ & - & 1,00 & & \\
\hline $\begin{array}{l}\text { 5. hulp yan buren } \\
\text { 6. antal Inf. bronnen }\end{array}$ & $-0,29$ & $\overline{0,33}$ & $\overline{-}$ & 0,39 & $\begin{array}{l}1,00 \\
0,19\end{array}$ & 1,010 \\
\hline
\end{tabular}

buiten het huishouden van de respondent is minder sterk, doch ook significant $(r=-0,12)$. Deze vorm van informele hulp wordt echter niet gegeven als de partner informele hulp levert $(r=-0,09)$ of in die gevallen $-\mathrm{en}$ in veel sterkere mate dan het juist aangegeven verband- dat er informele hulp van een andere huisgenoot aanwezig is $(r=-0,30)$. Opvallend is dat noch de aanwezigheid, noch de omvang van de hulp door vrienden en/of buren significante verbanden vertoont met andere vormen van informele hulp. Hulp door vrienden en/of buren komt derhalve min of meer onafhankelijk van andere hulpbronnen tot stand.

\subsubsection{Samenhang tussen informele hulpverlening en andere variabelen}

Eerder kwam al aan het licht dat de totale omvang van en het aantal contacten met het sociale netwerk gerelateerd zijn aan de beschikbaarheid van informele hulp; er is echter geen sprake van een éen-op-én relatie of, zoals sommige auteurs doen voorkomen, van een tautologie (Seeman en Berkman, 1988).

In figuur 14.13 zijn de belangrijkste significante verbanden aangegeven tussen enerzijds de variabelen voor zelfzorg en informele hulp en anderzijds de in de voorgaande paragrafen besproken andere determinanten voor de leefsituatie van ouderen. De analyse beperkt zich ter wille van de inzichtelijkheid tot de aanwezigheid van informele hulp. De demografische variabelen kennen veel significante relaties met de aanwezigheid van zelfzorg en informele hulp: met het stijgen van de leeftijd neemt de informele hulp van de huisgenoot $(r=0,57)$, familie $(r=0,24)$ toe, maar wordt de kans op hulp van een partner kleiner $(r=-0,18)$; vrouwen hebben een grotere mate van zelfizorg $(r=0,14)$, minder hulp van de partner ( $r=$ $0,46)$, maar meer hulp van een eventuele huisgenoot $(r=0,34)$ en overige familie $(r=0,14)$. Per saldo is de negatieve relatie tussen sexe en hulp van een partner dermate groot dat het verband tussen sexe en het aantal verschillende informele hulpbronnen eveneens significant negatief is, ondanks de eerder aangegeven positieve verbanden met betrekking tot hulp van een huisgenoot en overige famille. Met het toenemen van (I)ADL-beperkingen neemt de informele hulp over de gehelle linie toe, uitgezonderd het feit dat er geén significant verband is tussen het aantal beperkingen en de aanwezigheid van burenhulp. Ook de diversiteit van hulpbronnen neemt toe met de ernst van de (I)ADL-problematiek. 


\begin{tabular}{|c|c|c|c|c|c|c|}
\hline$\sqrt{-0,08}$ & & $\sqrt{-0,63}$ & $1-0,25$ & $\mid-0,11$ & 0,28 & geriwa (J/Ry \\
\hline \multirow[t]{2}{*}{$a_{n}+1$} & $T-0,46$ & 0,34 & 0,24 & & $-0,1$ & \multirow{4}{*}{$\begin{array}{l}\text { Lexe }(M / v) \\
\text { Lewtija }\end{array}$} \\
\hline & $-0,18$ & 0,57 & 0,24 & & & \\
\hline $\begin{array}{r}2011- \\
20 x g\end{array}$ & $\begin{array}{l}\text { buip } \\
\text { pertnex }\end{array}$ & $\begin{array}{l}\text { hulp } \\
\text { husisgetuoot }\end{array}$ & foulpo & $\begin{array}{l}\text { huilp } \\
\text { bureng }\end{array}$ & Mrovini & \\
\hline$-0,60$ & 0,15 & 0,30 & 0.13 & & 0.11 & \\
\hline \multicolumn{6}{|l|}{$-0,15$} & \multirow{4}{*}{ 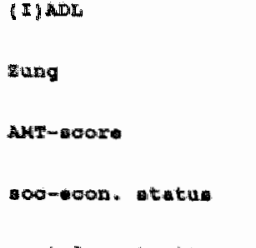 } \\
\hline \multirow[t]{3}{*}{ L.,19 } & \multicolumn{5}{|c|}{$-0,11$} & \\
\hline & \multirow[t]{2}{*}{0,18} & & \multicolumn{3}{|l|}{$-0,23$} & \\
\hline & & & 0,11 & $\|-0,14$ & 10,16 & \\
\hline \multicolumn{6}{|l|}{$-0,22$} & \multirow{2}{*}{$\begin{array}{l}\text { obron. Eiekte (B/T) } \\
\text { wubj. gezondheid }\end{array}$} \\
\hline$-0,17$ & 0,15 & & & & 0,09 & \\
\hline
\end{tabular}

\section{Figuur 14.13. Significante relaties tussen enerzijds de aanwezigheld van zelfzorg en informele hulp en anderzijds enkele andere variabelen}

De psychische toestand (Zung- of AMT-score) is alleen van invloed op de zelfzorg; de informele hulp is hieraan niet significant gerelateerd, uitgezonderd het opvallende verband tussen AMT-score (hoe hoger, hoe beter het cognitief functioneren) en de familiaire informele hulp $(r=-0,11, p<0,001)$. Er bestaat een significant positief verband tussen de sociaal-economische status en de hulp van de partner $(r=0,18)$, terwijl het verband met de hulp van familieleden negatief is $(r=-0,23)$ : lagere sociale klassen hebben meer informele hulp binnen de familie en hogere sociale klassen betrekken hun huip vaker van buiten de familie, bijvoorbeeld via een particuliere betaalde hulp $(r=0,19 ; p<0,001$; niet in figuur 14.13) Een dergelijke verdeling op basis van sociaal-economische status is ook elders gerapporteerd (zie bijwoorbeeld: SCP, 1986). De burenhulp tenslotte vertoont gétn significante samenhang met de aanwezigheid van chronische ziekte of met de (I)ADL-schaal, hetgeen in overeenstemming is met de bevindingen van andere auteurs dat deze vorm van informele hulp betrekking heeft op beperkte huishoudelijke ondersteuning zoals een boodschap doen, maar niet op ADL-ondersteuning. Tenslotte blijkt het totaal aantal sociale contacten dat een oudere gemiddeld per maand heeft significante verbanden te vertonen met hulp van de familie $(r=0,11)$ en de hulp van buren $(r=-0,14)$; per saldo is het aantal verschillende informele hulpbronnen groter naarmate het sociaal netwerk omvangrijker is.

\subsection{Samenvatting}

In dit hoofdstuk is geprobeerd om op een systematische wijze zicht te krijgen op allerlei determinanten betreffende de leefsituatie van ouderen in de meest ruime zin. Op basis van secundaire analyse van individuele gegevens over ruim 900 ouderen in de gemeente Maastricht (voorgeselecteerd door middel van een post-enquete op validiteit en/of voorzieningengebruik; zie hoofdstuk 13 en publikaties van de oorspronkelijke onderzoekers Frederiks en Te Wierik) zijn acht clusters van determinanten geanalyseerd. Dit betreft achtereenwolgens de volgende aspecten: demografische kenmerken, (I)ADL-beperkingen, overige indicatoren 
Queter var deteralianten

1. domograt iche kenmerken

2. (Inatruantele) Letiviteiten van hot Dagelifke Leven

3. andero lind 3 eatoren your

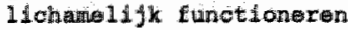

4. peychisoh functioneren

5. Wons ituatie

6. Motal-oenomische atas

7. Goial netwerk

Q. informs le hulp geselectererde vartabelen

eexe $(H / V)$, leeftijo (vijtjaardinterval), allagnataand $\mathrm{z} i \mathrm{fn}$ (W/J), gehwwd $(N / J)$

raschachaal met 11 item in vije aubscinalen: (a) dweilen, was doen; (b) kokera, etoffen, bed opmaken: (c) traplopen, boodschappen doen, gichzelf wasan; (d) in en wit bed ot pen, aan/uitkleden, lopen; (e) broodmaltijd maken, eter/drinken, tolletgebruik

chronische iekto (N/J), antal ziektoweken in en jaar, bubjectieve gezomdheid, gehoor, rege Imatige beweging, modicijngebrulk

Zungscore (mono- of dichotaom 47 punten all grens,, AKT-Ecore, oordeel over mituatio

gemiste woon- en/at wijkyoorzieningen, ontevredentueid over wonen("), ontevredenheid over buurt, verhulewens:

opleiding, sociale groep o.b. $\mathrm{v}$. beroep, (gerins-) inkomen, SES-construct:

ontvangen en/of afgelegde bezoeken, diversitejt van netwerk, deelname Gowactiviteiten, enzamheid $(*)$

anwezlgheld of owvang van hulp blj 11 it terus wan raøchtype (I)ADL-achad (zie punt 2): zelfzorg, partner, huiggenoot, familie, buren, particuliere betaalde hulp, asntal verechil lende informele hulpbronnen

(") Veel auteure noemem wariabele ook wel ali indicator voor peychiech functioneren.

Figuur 14.14. De in deze studies gebruikte clusters wan determinanten en geselecteerde variabelen

voor lichamelijke gezondheid, het psychisch functioneren, de woonsituatie, de sociaaleconomische status, het sociaal netwerk en de informele hulpverlening. De aanpak is daarbij steeds hetzelfde geweest: eerst werd de bestaande literatuur over het betreffende cluster besproken, vervolgens werden de variabelen daarvoor geconstrueerd en op bun onderlinge samenhang beoordeeld, op grond waarvan in de derde stap efen of een beperkt aantal determinanten voor het betreffende aspect geselecteerd werd(en). Deze werden tenslotte door middel van correlatiecoefficienten gerelateerd aan de andere aspecten van de leefsituatie van ouderen. In het volgende hoofilstuk worden deze in verband gebracht met het gebruik van voorzieningen door ouderen.

Een kort resume van dit hoofdstuk kan zich om wille van de overzichtelijkheid slechts richten op de resultaten in termen van de geselecteerde variabelen voor de verschillende clusters van determinanten op de belangrijkste significante verbanden daartussen. Het onderstaande schema (figuur 14.14) geeft aan welke variabelen zijn geselecteerd voor de verschillende clusters van (potentiele) determinanten in de verklaring van het voorzieningengebruik door ouderen. De achterliggende constructies zijn in het hoofdstuk uitgebreid toegelicht. Een zorgvuldige procedure werd daarbij van belang geacht om op deze wijze de beschikking te krijgen over goed uitgewerkte variabelen (die in veel gevallen voldoen aan stringente schaaleigenschappen). In empirisch sociaal-wetenschappelijk onderzoek naar de invloed van de verschillende determinanten voor het voorzieningengebruik wordt vaak licht voorbijgegaan aan de verwevenheid tussen deze determinanten; slechts in de gebruikelijke discussie over bijvoorbeeld de schattingsresultaten pleegt men hieraan tegemoet te komen 
Ook in dit hoofustuk is duidelijk naar voren gekomen dat veel van de in de literatuur terug te vinden determinanten of variabelen in belangrijke en soms zeer sterke mate onderling verweven zijn; de conclusie dat "alles met alles samenhangt" geldt dan cok zeker in de analyse van het gebruik van voorzieningen door ouderen. De meest belangrijke verbanden tussen de verschillende clusters van determinanten worden kort aangeduid (voor een gedetailleerder overzicht wordt verwezen naar de afzonderlijke paragrafen in dit hoofdstuk). Demografische variabelen zoals leeftijd en geslacht kennen minder vaak significante verbanden met andere determinanten. Leeftijd hangt vooral samen met de AMT-score, de (I)ADL-schaal, het oordeel over de gehele situatie, het opleidings en inkomensniveau, het aantal afgelegde bezoeken en informele hulp. Het gehuwd zijn hangt samen met de (I)ADL-schaal, de Zung- en AMT-score, opleiding, eenzaamheid en andere aspecten van het sociaal netwerk en informele hulp. Sexe (man/vrouw) heeft significante correlaties met bepaalde subschalen van de (I)ADL-schaal, de Zung-en AMT-score, eenzaambeid, de sociaal-economische status, deeiname aan GOW-activiteiten en informele hulp.

De sociaal-economische status hangt in significante mate samen met de (I)ADL-schaal, de subjectieve gezondheid, de aanwezigheid van chronische ziekte(n), met sommige variabelen uit de woonsituatie (zoals met de wens te verhuizen), het psychische functioneren (vooral met betrekking tot opleidingsniveau), eenzaamheid en de deeiname aan GOW-activiteiten. Van de variabelen met betrekking tot de woonsituatie kent de verhuiswens de sterkste verbanden, namelijk met de (I)ADL-schaal, chronische ziekte, het psychisch functioneren, de sociaal-economische status en de beleving van de gezondheid en de totale situatie.

Tot besluit blijkt uit deze studie dat de grootste correlatiecoefficienten worden gevonden tussen de (I)ADL-schaal en andere indicatoren voor het lichamelijk functioneren en indicatoren voor het psychisch functioneren. Hieruit wordt de conclusie getrokken dat de samenhang tussen (indicatoren voor) enerzijds de lichamelijke afhankelijkheid en anderzijds de psychische afhankelijkheid de belangrijkste samenhang betreft in de gehele leefsituatie van ouderen. Vanuit deze bevinding start de analyse in het volgende hoofdstuk. 


\section{Voorzieningengebruik door ouderen}

\subsection{Inleiding}

In dit hoofdstuk zijn wij toegekomen aan de leidende onderzoekswraag: "is liet mogelijk een simulatiemodel van voorzieningen voor ouderen te ontwikkelen dat kan dienen als instrument voor de voorbereiding en evaluatie van maatregelen op het terrein wan het ouderenbeleid?" (zie hoofdstuk 1). Ter beantwoording van deze vraag wordt een stapsgewijze aanpak gevolgd, waarin bezien wordt of de in het voorgaande boofdstuk ontwikkelde determinanten een bijdrage leveren aan de verklaring van het voorzieningengebruik door ouderen. Er wordt eerst een globale verkenning van dit gebruik gemaakt, uitgaande van de correlaties tussen enerzijds allerlei mogelijke (clusters van) individu-gebonden determinanten en anderzijds de gegevens over het feitelijk gebruik van de in deze studie opgenomen voorzieningen door de betreffende individuen. Daarbij worden de richting en de sterkte (via de overschrijdingskansen) van verbanden aangegeven in plaats van de feittelijke correlatiecoefficięnten (paragraaf 15.2). Vervolgens wordt aan de hand van lineaire en logistische regressie-analyse bepaald welke combinaties van determinanten gezamenlijk de hoogste bijdrage leveren aan de verklaring van het voorzieningengebruik (paragraaf 15.3 ). Daarbij zijn we niet alleen gelinteresseerd in de verklaring van het gebruik van afzonderlijke voorzieningen (bijwoorbeeld wanneer gebruikt een oudere wel of niet gezinswerzorging), maar ook in de verklaring van de hulpintensiteit (bijwoorbeeld als iemand gezinsverzorging gebruikt, kan dan ook het aantal uren daarvan verklaard worden?) en bowenal zijn we gelnteresseerd in de vraag of er een 'care continuum' bestaat, zowel in termen van hoofdcategorietn van gebruik (thuiszorg, bejaardenoord, verpleeghuis) als met betrekking tot de aan zorg verbonden kosten. Dit laatste onderwerp wordt afzonderlijk besproken in paragraaf 15.4. In de paragrafen 15.5 en 15.6 komen zogenaamde MIMIC-modellen aan bod, waarmee enkele simulaties worden uitgevoerd. Op deze wijze kunnen de mogelijkheden worden verkend om te komen tot een simulatiemodel voor het gebruik van voorzieningen door ouderen.

De te bestuderen voorzieningen worden in drie verschillende clusters onderscheiden:

(a) basisvoorzieningen, namelijk de gezinswerzorging, de wijkwerpleging, het bejaardenoord en het verpleeghuis; ook de indicatiecommissie is in deze categorie ondergebracht, omdat zij als voorportaal dient voor het bejaardenoord als basiswoorziening of anderszins kan doorverwijzen naar de thuiszorgvoorzieningen (zie hoofdistuk 9);

(b) overige voorzieningen die specifiek voor ouderen bedoeld zljn, namelijk dienstencentra van het gecoördineerd ouderenwerk (GOW), de warme maaltijdvoorziening (via 'Tafeltje Dekje' of het dienstencentrum), de Sociaal Geriatrische Dienst (SGD) die is ondergebracht bij het RLAGG, de dagverzorging in het bejaardenoord en de dagbehandeling in het verpleeghuis. Deze cluster bevat derhalve niet alleen yoorzieningen die in de thuissituatie kunnen worden geleverd, maar ook voorzieningen die bijvoorbeeld door zowel bejaardenoordbewoners als thuiswonende ouderen kunnen worden gebruikt (zoals dagbehandeling in verpleeghuis).

(c) overige voorzieningen die aan te merken zijn als algemeen toegankelijke gezond. heidszorgvoorzieningen, namelijk de huisarts, de specialist, het ziekenhuis en fysiotherapie. Ook het gebruik van medicijnen door ouderen wordt belicht.

De drie clusters van te bestuderen voorzieningen worden in het wervolg aangeduid als basisvoorzieningen, overige voorzieningen voor ouderen en gezondheidszorgvoorzieningen. Voordat afzonderlijke voorzieningen worden bestudeerd, is het wellicht vruchtbaarder om eerst een growere indeling te maken, waarbij de vraag beantwoord wordt wanneer iemand 
thuis bliff $(N=415)$, wanneer een aanvraag of positieve indicatie voor het bejaardenoord plaatsvind $(\mathrm{N}=164)$, onder welke omstandigheden die opname gerealiseerd is $(\mathrm{N}=206)$ en wanneer iemand in een verpleeghuis komt $(N=158)$. Hiermee wordt derhalve de indeling van de totate onderzoeksgroep in de vier deelbestanden geanalyseerd met als onderzoeksvragg welke (combinaties van) determinanten zorgorragen voor deze indeling.

\subsection{Voorzieningengebruik en determinanten daarvoor: een globale verkenning}

In deze paragraaf wordt een eerste selectie gemaakt van de aspecten uit de leefsituatie die mogelijk kumnen fungeren als determinanten van voorzieningengebruik door ouderen. De in het voorgaande hoofdstuk ontwikkelde variabelen met betrekking tot de demografische factoren, de (I)ADL-beperkingen, overige gezondheidsindicatoren, het psychisch functioneren, de sociaal-economische status, de woonsituatie, het sociaal netwerk en de informele hulp worden per cluster van voorzieningen steeds beoordeeld op hun mogelijke relevantie bij de verklaring van het gebruik.

Een eerste indruk over het voorzieningengebruik kan verkregen worden uit figuur 15.1 , waarin ouderen met verschillende combinaties van voorzieningen zijn weergegeven naar hun gemiddelde score op de (I)ADL-schaal (horizontaal) en de gemiddelde score op de Zungschaal. Deze keuze is gebaseerd op de veelvuldig vastgestelde importantie van (I)ADLschalen in empirisch onderzoek naar voorzieningengebruik; deze behoefteindicatoren blijken de belangrijkste rol te spelen in het zorggebruik van ouderen (Branch e.a., 1981; Greene, 1983; Evashwick e.a., 1984; Van Linschoten e.a.; Coolen, 1989; Huijsman en Visser, 1990; Frederiks, 1990). Hoewel hetzelfde min of meer geldt voor de geestelijke toestand (hier weergegeven door de gevalideerde en ook in Nederland bruikbaar gebleken Zungschaal), is de literatuur hierover toch minder eenduidig (Frederiks, 1990). Voor een eerste globale verkenning van het woorzleningengebruik is de keuze van een lichamelijke en psychische component in de zorgbehoefte echter vooralsnog bruikbaar.

Indien, zoals in figuur 15.1 gebeurt, de verschillende clientgroepen van de bestudeerde voorzieningen worden weergegeven naar de gemiddelde (I)ADL- en Zungscore, dan blijkt sprake te zijn van een zekere hierarchie in voorzieningen. Ouderen met alleen gezinsverzorging (zonder andere hulp en zonder een positief advies voor het bejaardenoord) hebben gemiddeld 4,2 (I)ADL-beperkingen en een Zung-score van ongeveer 38. Ouderen die in het verpleeghuis werden opgenomen hebten daarentegen de hoogste (I)ADL-score (gemiddeld 10,2 ) en worden in de Zung-score slechts overtroffen door patienten in dagbehandeling en ouderen met zowel gezinswerzorging als wijkverpleging als een positief advies voor het bejaardenoord. Hierbij dient echter met nadruk aangetekend te worden dat de Zungscore voor verpleeghuispatienten niet representatief geacht wordt: de Zung is slechts bij een klein aantal patlènten afgenomen (psycho-geriatrische patienten zijn bijwoorbeeld niet ondervraagd met dit -door de respondent zelf in te vullen- instrument) en dit betreft bovendien relatief gezonde ouderen, zodat de Zungscore voor de verpleeghuispopulatie wordt onderschat (zie paragraaf 13.6). Met deze kanttekening in gedacht, lijkt het aannemelijk dat verpleeghuispatienten zich in het zwaarste uiterste van het "care continutum" bevinden, zowel in termen van (I)ADL-beperkingen als wat betreft psychisch functioneren.

De ouderen met zowel gezinswerzorging als wijkverpleging als een positief advies hebben ongeveer een zelfde gemiddelde (I)ADL-score als (a) ouderen zonder positief advies (wel gezinsverzorging en wijkverpleging) en (b) ouderen met alleen wijkverpleging. Het onderscheid tussen deze drie zorgcombinaties wordt gevonden in het percentage alleenstaanden: ad (a) is dat $61 \%$ en ad (b) slechts $25 \%$ terwijl dat bij de gebruikers van zowel gezinsverzorging als wijkverpleging, die bovendien een positief advies hebben $84 \%$ is. De huishoudvorm is ook van belang voor het onderscheid tussen thuiswonende ouderen zonder 


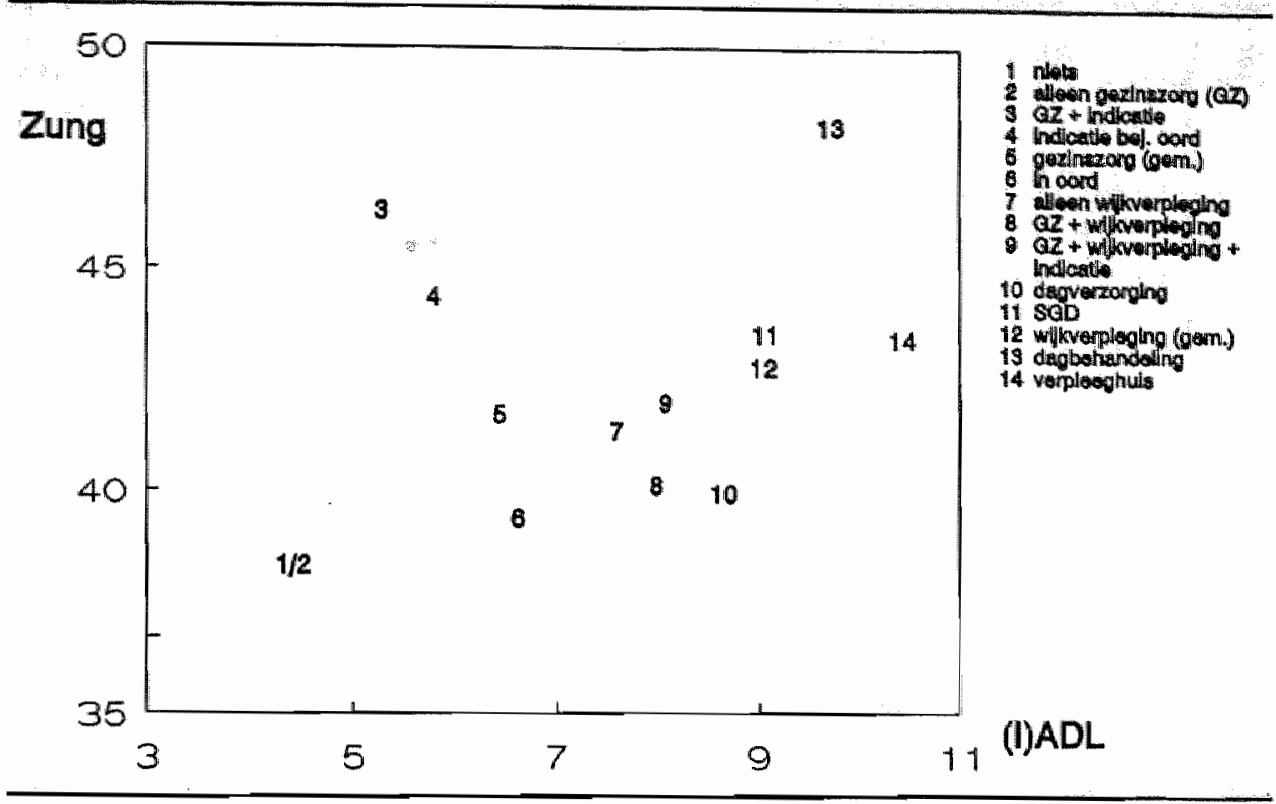

Figuur 15.1. Positionering van cliëntgroepen naar ZUNG- en (I)ADL-score's

professionele hulp en ouderen met uitsluitend gezinszorg (zonder positief advies): beide hebben een zelfde (I)ADL-score $(4,2)$ en Zung-score $(38,2)$, maar bij de clienten van de gezinsverzorging is $62 \%$ alleenstaand en bij de groep zonder hulp $39 \%$.

De volgende stap in de analyse betreft de verkenning van de relaties van de in het voorgaande hoofdstuk besproken determinanten met het feitelijk gebruik van voorzieningen in de verschillende clusters. Allereerst worden de (paarsgewijze) correlaties tussen determinanten en gebruik gepresenteerd in de vorm van de richting (positief, negatief of geen verband, dat wil zeggen een $r<0,03$ ) en de sterkte van het verband (in termen van overschrijdingskansen). In tabel 15.1 is dat voor het gehele bestand gedaan voor de basisvoorzieningen, alsmede voor de variabele INTRA, waarmee wordt aangegeven in welk. deelbestand de respondent zich bevindt ${ }^{1}$. Voor deze laatste variabele zijn verreweg de meeste determinanten van significante betekenis, uitgezonderd de subjectieve gezondheid, de sociale groep waarin men verkeert, het aantal ontvangen bezoeken, de meeste variabelen met betrekking tot de woonsituatie (behalve het aantal gemiste voorzieningen in de woning en de verhuiswens; dit moet met name worden toegeschreven aan de positieve rapportage hierover door bejaardenoordbewoners), de aanwezigheid van buren- of vriendenhulp en van particuliere (betaalde) hulp. Clienten van de gezinsverzorging $(\mathrm{N}=203)$ onderscheiden zich op de volgende aspecten: het betreft meer wrouwen dan mannen, meer alleenstaanden, hogere (I)ADL- en Zungscores, grotere eenzaamheid en een slechter oordeel over de gehele situatie, terwijl de opleiding en sociale groep significant en de aanwezigheid van particuliere hulp negatief samenhangen met de aanwezigheid van gezinsverzorging. Met betrekking tot de woonsituatie is er een significant posititief verband met het feit of iemand in een speciale woning voor ouderen woont en hoeveel voorzieningen er in de woning gemist worden. Bij de wijkverpleging $(\mathrm{N}=139)$ worden op dezelfde wijze significante

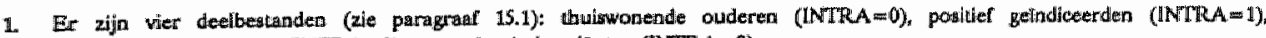
bejaardenoordbewoners (INTRA =2) en verpleeghuispatienten (INTRA =3). 
Tabel 15.1. Selectie vall mogeljke determinanten roor gebruik van basisvoorzieningen ${ }^{*}{ }^{\text {u. }}$ richting en significantie ${ }^{\text {by }}$ van correlaties

\begin{tabular}{|c|c|c|c|c|c|c|}
\hline & 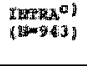 & 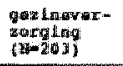 & 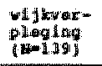 & 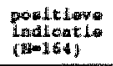 & 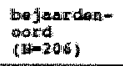 & $\begin{array}{l}\text { verpilate } \\
\text { bidis } \\
\text { (t)-15aid }\end{array}$ \\
\hline 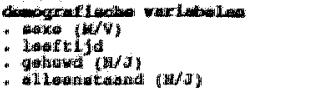 & 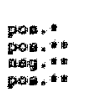 & 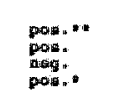 & 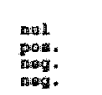 & 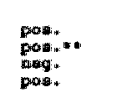 & 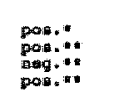 & 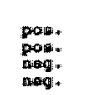 \\
\hline 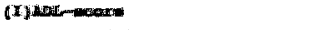 & Do: of : * & pas." & poo... & aist & pors." & parmin $\cdots$ \\
\hline 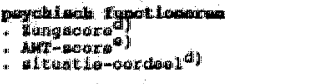 & 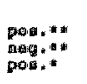 & 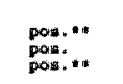 & 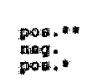 & 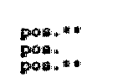 & 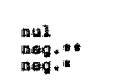 & 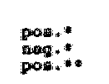 \\
\hline 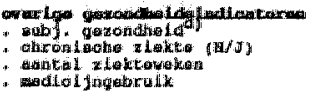 & 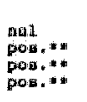 & 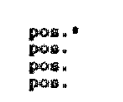 & 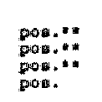 & 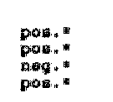 & $\begin{array}{l}\text { moxy. } \\
\text { and } \\
\text { pois. } \\
\text { paia : }\end{array}$ & 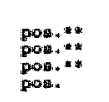 \\
\hline 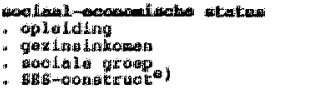 & 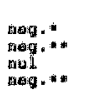 & 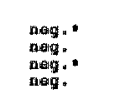 & 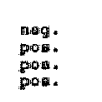 & 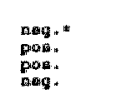 & 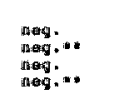 & 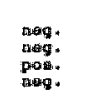 \\
\hline 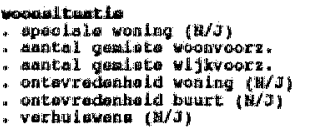 & 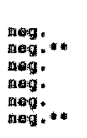 & 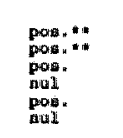 & 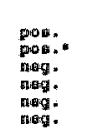 & 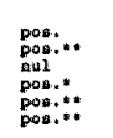 & 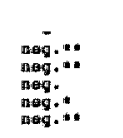 & 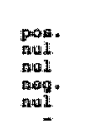 \\
\hline 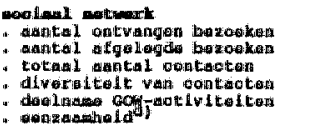 & 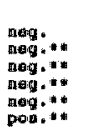 & 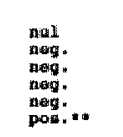 & 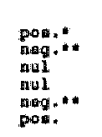 & 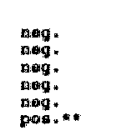 & 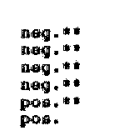 & 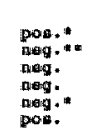 \\
\hline 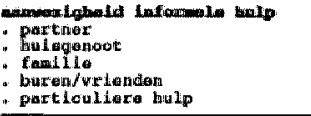 & 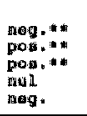 & 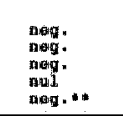 & 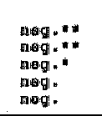 & 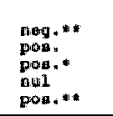 & $\begin{array}{l}\text { neig * * * } \\
- \\
\text { pout * * } \\
\text { nuli } \\
\text { nusi }\end{array}$ & 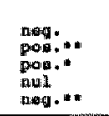 \\
\hline 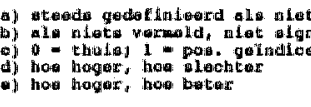 & 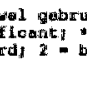 & & 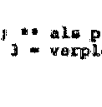 & 13 & i. & $0,0.1$ \\
\hline
\end{tabular}

positieve relaties gevonden woor de (I)ADL- en Zungscores, het oordeel over de situatie en de gezondheid, de aanwezigheid van een chronische ziekte, het aantal weken dat men het laatste jaar ziek was, het aantal in de woning gemiste voorzieningen en het aantal ontvangen bezoeken* negatieve verbanden zijn er met het aantal afgelegde bezoeken, deelname aan GOW-activiteiten en allerlei vormen van informele hulp (uitgezonderd die van buren).

Ouderen met een positieve indicatie voor opname in een bejaardenoord $(\mathrm{N}=164)$ hebben ten opzichte van alle andere ouderen een hogere leeftijd, een hogere Zungscore, een grote mate van eenzaamheid, een slechter oordeel over de situatie en de gezondheid, vaker een chronische ziekte, maar minder weken dat ze door ziekte niet konden functioneren en een hoger medicijngebruik; hun opleidingsniveau is lager, er zijn verschillende problemen in de woonsituatie, de hulp van een partner is bij positief geindiceerden minder vaak aanwezig, maar het omgekeerde geldt voor familiehulp en particuliere hulp. Bij de vergelijking tussen bejaardenoordbewoners $(\mathrm{N}=206)$ en anderen blijkt wan significant belang te zijn: alle demografische variabelen (in het bejaardenoord meer vrouwen, alleenstaanden en niet-gehuwden, bij een hogere leeftijd), de (I)ADL-score en de AMT-score voor het geheugen (slechter in bejaardenoord); voorts is het oordeel over de situatie minder gunstig de sociaal-economische status lager en zijn alle indicatoren voor het sociale netwerk significant slechter.

De variabelen over de woonsituatie worden echter veelal in positieve zin beantwoord. 
Verpleeghuispatienten $(\mathrm{N}=158)$ onderscheiden zich van alle andere respondenten op de scores voor (I)ADL, Zung en AMT, op het oordeel over de gehele situatie en allerlei andere gezondheidsindicatoren (uitgezonderd medicijngebruik); zij krijgen meer bezoek, maar leggen zelf minder bezoek af en hebben tenslotte meer hulp van familie en een huisgenoot (anders dan partner), maar minder particuliere hulp. Overigens moet worden opgemerkt dat paarsgewijze correlaties voor het deelbestand van verpleeghuispatienten veelal betrekking hebben op kleine aantallen respondenten door het ontbreken van veel antwoorden; met betrekking tot sommige vragen zoals over de verhuiswens is bet gezien de precaire situatie van verpleeghuispatienten bovendien vaak bepaald 'onkies' om deze te stellen, hetgeen dan ook achterwege is gelaten (zie paragraaf 13.3). De bevindingen moeten daarom enigszins gerelativeerd worden, maar geven wel de globale tendenties weer.

De richting en sterkte van de correlatiecoefficięnten tussen determinanten en overige voorzieningen voor ouderen zijn weergegeven in tabel 15.2. Een mogelijk probleem bij deze voorzieningen betreft het feit dat slechts weinig ouderen gerapporteerd hebben hiervan gebruik te maken, waardoor een verband wel erg sterk moet zijn om significant te worden. De verschillende voorzieningen binnen dit cluster worden beknopt belicht.

Bezoekers van de dienstencentra van het gecoördineerd ouderenwerk $(\mathrm{N}=58$; uitgezonderd de maaltijdgebruikers, die apart bezien worden) onderscheiden zich van anderen in het feit

Tabel 15.2. Selectie van mogelijke determinanten voor gebruik van overige voorzieningen voor ouderen ${ }^{\text {a) }}$ : richting en significantie ${ }^{\text {b) }}$ van correlaties

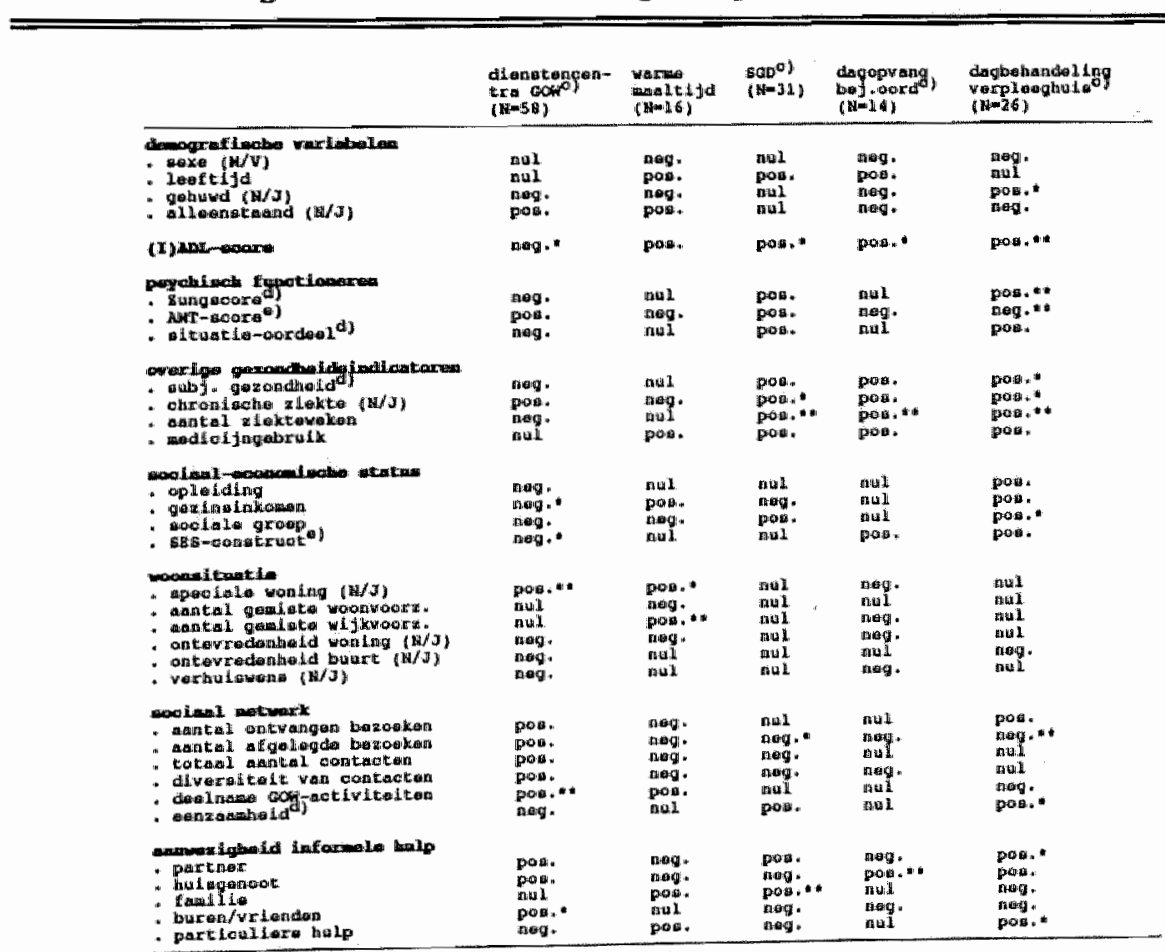

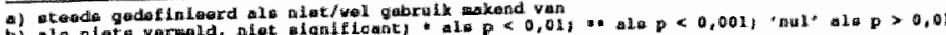

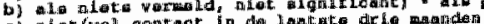

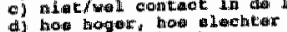

a) bow hoogers, has boter 
dat 2ij minder (I)ADL-beperkingen hebben, een lagere sociaal-economische status (met name en lager unkomen), valker in een speciale ouderenwoning gehuisvest zijn en meer thulp van buren of vrienden. Bij de gebrukers van een warme maaltijd $(\mathrm{N}=16)$ is geen van de correlaties significant (bij $\mathrm{p}=0,01$ ), uitgezonderd twee variabelen met betrekking tot de woonsituatie. Dit betreft het wonen in een speciale woningen en het aantal wijkwoorzieningen dat de respondent mist; beide hebben een positieve relatie met het maaltijgebruik.

Significante verbanden voor gebruikers van de Sociaal Geriatrische Dienst betreffen de (I)ADL-score, de aiawezigheld van chronische ziekte, het aantal ziekte-weken, het aantal afgelegde bezoeken (negatief) en de aanwezigheid van familiehulp (positief). Dagverzorging in een bejaardenoond $(\mathbb{N}=14)$ is significant gerelateerd aan de (I)ADL-scote, het aantal ziekte-weken en de aanwezigheid van bulp door een huisgenoot (positief). Met dit laatste zou een ontlastend effect van dagverzorging op het thuismilieu weerspiegeld kunnen worden (Nuyens, 1988; Coolen, 1989). Dagbehandeling in het verpleeghuis ( $N=26)$ wordt vaker gerapporteerd door gehuwden, gaat gepaard met slechtere scores voor (I)ADL, Zung; AMT en eenzaamheid, een slechtere gezondheidstoestand (uitgezonderd medicijngebruik); het betreft voorts ouderen uit hogere sociale groepen die minder afgelegde bezoeken rapporteren, terwijl er waker hulp wan de partner of een betaalde hulp aanwezig is.

Tabel 15.3. Selectie van mogelijke determinanten voor gebruik van gezondheidszorgvoorzlleningen ${ }^{2)}$ : richting en sigmiffeantie ${ }^{\text {b) }}$ van correlaties

\begin{tabular}{|c|c|c|c|c|c|}
\hline & 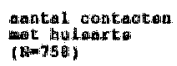 & 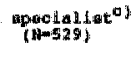 & 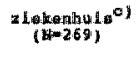 & $\begin{array}{c}\text { (yolotherapliot } \\
\{(t-212\}\end{array}$ & 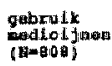 \\
\hline 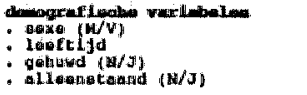 & 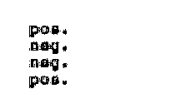 & 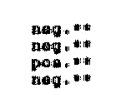 & $\begin{array}{l}n \in g \\
n \in 0 \\
n \in 0\end{array}$ & $\begin{array}{l}\text { pon. } \\
\text { nog. } \\
\text { naid. } \\
\text { noli. }\end{array}$ & 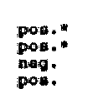 \\
\hline (I) MDL-manxis: & poon.t" & popts. on & prow... & pord a tith & pos : " " * \\
\hline 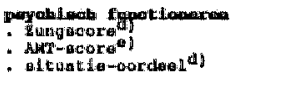 & 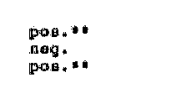 & $\begin{array}{l}\text { poov. o:t } \\
\text { poos. with } \\
\text { pous. }\end{array}$ & 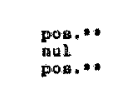 & 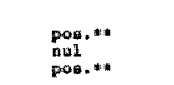 & 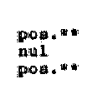 \\
\hline 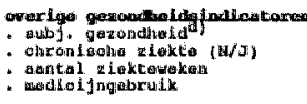 & 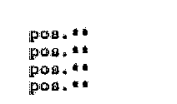 & 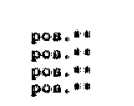 & 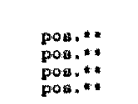 & 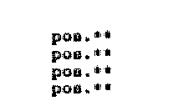 & 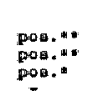 \\
\hline 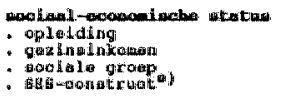 & 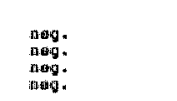 & $\begin{array}{l}\text { pow. } \\
\text { poos." } \\
\text { prow. } \\
\text { poos. }\end{array}$ & 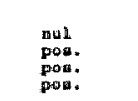 & $\begin{array}{l}\text { pour. } \\
\text { peng. } \\
\text { pour. } \\
\text { pos. }\end{array}$ & 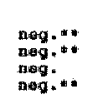 \\
\hline 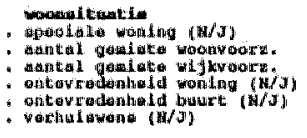 & 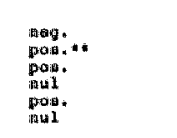 & 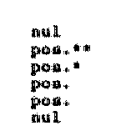 & 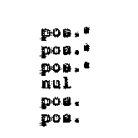 & 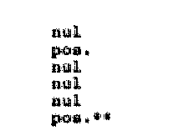 & 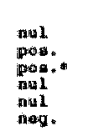 \\
\hline 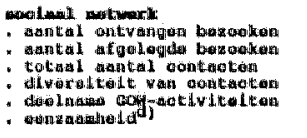 & 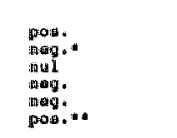 & 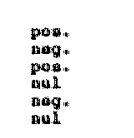 & 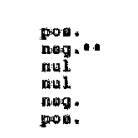 & 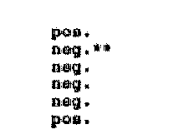 & 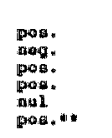 \\
\hline 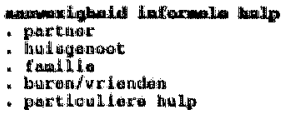 & 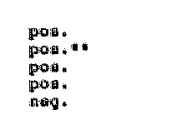 & 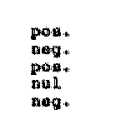 & 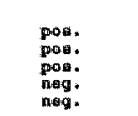 & $\begin{array}{l}\text { pow: } \\
\text { pois. } \\
\text { pow: } \\
\text { null } \\
\text { null }\end{array}$ & 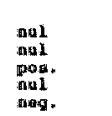 \\
\hline 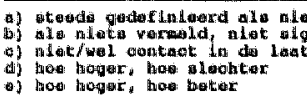 & 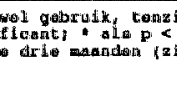 & rin & 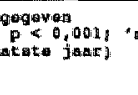 & $=0,01$ & \\
\hline
\end{tabular}


Het gebruik door ouderen van algemeen toegankelijke gezondheidszorgvoorzieningen (zle tabel 15.3) wordt in het algemeen gekenmerkt door beperkte set van significante determinanten, namelijk de (I)ADL-score, alle andere gezondheidsindicatoren (inclusief het subjectieve gezondheidsoordeel) en de Zungscore. Sommige variabelen met betrekking tot de woonsituatie, met name die over het aantal gemiste voorzieningen in de woning of de wijk, vertonen eveneens significante verbaden met het gebruik van medische gezondheidszorg. Indicatoren voor de sociaal-economische status zijn vrijwel nooit significant, uitgezonderd bij medicijngebruik (negatie). De variabelen met betrekking tot het sociale netwerk zijn eveneens niet significant, uitgezonderd het aantal door de respondent zelf afgelegde bezoeken (significant negatief bij huisarts, ziekenhuis en fysiotherapie). Deze variabele zegt echter waarschijnlijk meer over de mobiliteit en daarmee de ADL-validiteit dan over het functioneren van het sociaal netwerk. Wel krijgt men over het algemeen meer bezoek, maar kennelijk van een meer beperkte groep mensen omdat de diversiteit van de contacten vaak negatief samenhangt met het gebruik van gezondheidszorgvoorzieningen. Geen van de variabelen voor informele hulp is significant gerelateerd aan het gebruik van de betreffende voorzieningen, uitgezonderd het positieve verband tussen het aantal contacten met de huisarts en de hulp van een huisgenoot (positief). Tenslotte zijn demografische variabelen miet significant gecorreleerd met het aantal huisartscontacten, opname in een ziekenhuis en gebruik van fysiotherapie. Contact met een specialist wordt echter vaker gerapporteerd door mannen, jongere respondenten, gehuwden en niet-alleenstaanden. Bij medicijnengebruik daarentegen rapporteren vrouwen en oudere respondenten vaker gebruik.

\subsection{Regressie-modellen ter verklaring van het gebruik}

Na de voorgaande, meer globale verkenning, wordt thans een eerste aanzet gegeven voor de ontwikkeling van een model van voorzieningen voor ouderen. Dit gebeurt eerst door middel van eenvoudige lineaire regressie-modellen. Als afhankelijke, te verklaren variabelen wordt steeds het gebruik van een van de voorzieningen uit de drie clusters genomen. Dit zijn in de meeste gevallen dichotome variabelen, waarvoor idealiter geen lineaire regressie-modellen maar zogenaamde logitmodellen gebruikt dienen te worden; er kan echter aangetoond worden dat de resultaten van beide modellen elkaar in de praktijk niet veel ontlopen als de afhankelijke variabelen niet al te scheef zijn, met andere woorden als een redelijk percentage van de respondenten aangeeft de betreffende voorziening te gebruiken (dit is bijvoorbeeld het geval bij de basisvoorzieningen en de gezondheidszorgvoorzieningen). Indien minder dan $20 \%$ van de respondenten gebruik rapporteert, worden de voorwaarden voor lineaire regressie op grove wijze geschonden (Cleary en Angel, 1984). De geschatte regressie-coefficienten zijn bijvoorbeeld inefficient en de lineaire specificatie garandeert niet dat de geschatte waarde voor de afhankelijke variabele tussen 0 en 1 blijft. De betreffende variabele heeft dan het verloop van een S-curve (vergelijkbaar met de itemkarakteristiek en curves zoals die bij Rasch-modellen geformuleerd zijn; zie hoofdstuk 13). Door logistische 
transformatie van de afhankelije variabele kan een dergelijke S-curve worden benaderd. De kans op gebruik ( $p$ ) of anders gezegd de proportie van de steekproef waarvoor geldt dat deze de betreffende voorziening gebruikt is dan gelijk aan:

$$
p=\frac{1}{1+e^{\left(4+a x_{1}\right)}}
$$

waarbij $X_{\text {, }}$ de onathankelijke (verklarende) variabelen weergeeft.

Lineaire transformatie leidt dan tot de volgende regressie-vergelijking:

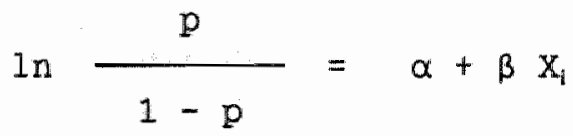

Schatting van dit model windt plaats door middel van iteratieve procedures waarmee de waarschijnljkkheidsfunctie $L(\alpha, \beta)$ maximeerd wordt (maximum likelihood-methode; zie bijvoorbeeld Wonnacott en Wonnacott, 1981). In het vervolg wordt deze schattingsmethode vooral gebruikt bij het tweede voorzieningencluster, de overige voorzieningen voor ouderen (zoals dagbehandeling), waarvan slechts kleine proporties gebruik maken. Ook bij meer algemeen gebruikte voorzieningen zoals gezinswerzorging wordt bezien in hoeverre de resultaten van gewone kleinste kwadraten methode verschillen van die van de logistische maximum likelihood-methode.

Tenslotte dient nog een kanttekening geplaatst te worden bij de wijze waarop wordt omgegaan met het probleem van ontbrekende gegevens bij bepaalde variabelen. Dit betreft met name de psychische variabelen (vooral bij verpleeghuispatienten) en de gegevens met betrekking tot de indicatoren voor sociaal-economische status. Lijstgewijze verwijdering van respondenten met ontbrekende waarden op een van onafhankelijke variabelen zou zelfs bij thuiswonende ouderen lejden tot een gigantische reductie van de schattingspopulatie (van de 579 respondenten blijven er minder dan 50 over met gegevens voor alle variabelen zoals. die in deze paragraaf gebruikt zijn). De literatuur biedt geen eenduidige oplossingen voor dit probleem (Bollen, 1989); sommige auteurs stellen voor te werken met paarsgewijze correlaties, anderen suggereren de ontbrekende waarnemingen te vervangen door gemiddelden voor de onderzoekspopulatie, ofwel op basis van de gehele populatie, ofwel voor deelpopulaties atzonderlijk. In deze studie wordt gewerkt met substitutie door steekproefgemiddelden die per deelbestand afzonderlijk berekend en ingevoerd zijin. Indien onbekend is geblewen of een van de vele ondervraagde voorzieningen door de betreffende respondent gebruikt wordt, dan is verondersteld dat dat niet het geval is. In tabel 15.4 wordt een overzicht gegeven van de gemiddelde waarden en bijbehorende standdaarddeviaties van de in de analyses gebruikte variabelen; dit gebeurt zowell voor de afzonderlijke deelbestanden als voor de gehele onderzoekspopulatic van Maastrichtse ouderen.

De regressie-analyses worden veelal uitgevoerd op basis van de bestanden voor zelfstandig (thuis-)wonende en positief gemdiceerde ouderen tezamen $(N=579)$ als het voorzieningen in de thuissituatie betreft, of woor het gehele bestand $(\mathrm{N}=943)$ als het gaat om opname in bejaardenoord of verpleeghuis, om de gezondheidszorgvoorzieningen of als het de constructen INTRA en de in paragraaf 15.4 te presenteren kostenvariabele betreft.

Allereerst is op basis van de gewone lineaire regressie-methode gepoogd een verklaring te vinden voor de indeling van respondenten in de vier verschillende deelbestanden (door middel van de variabele INTRA); hierbij zijn de variabelen in stapsgewijze regressie 
Tabel 15.4. Gemiddelden en standaarddeviaties van de gebruikte variabelen

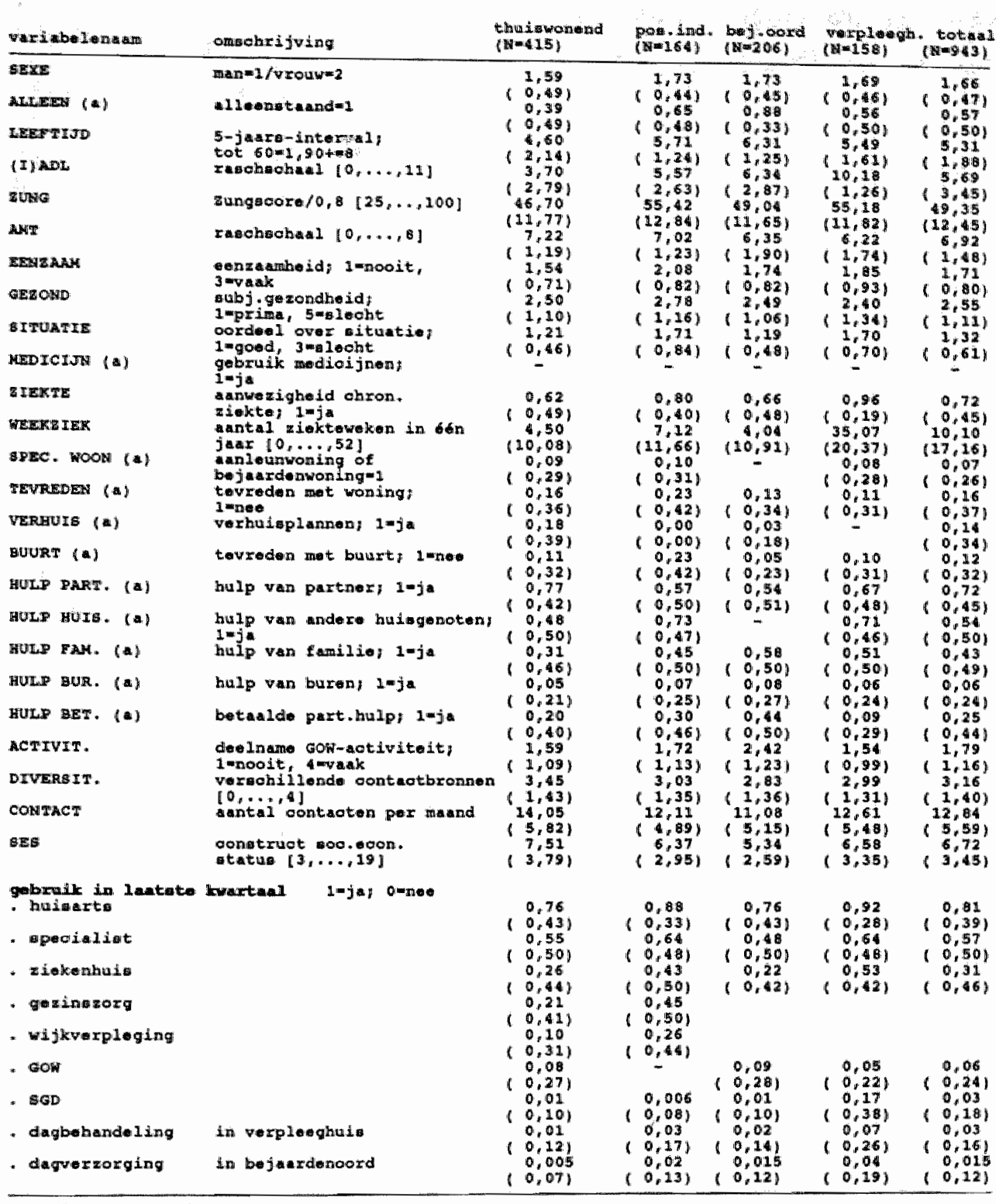

(a) Diebotome variabole

opgenomen onder de voorwaarde dat zij een significante bijdrage leveren aan de afhankelijke variabele. Dit betekent dat alle opgenomen regressie-coefficiënten significant zijn (t-waarde groter dan twee). De resultaten zijn in de eerste kolom van tabel 15.5 weergegeven. De verklaarde variantie is circa $55 \%$ hetgeen hoog genoemd kan worden en wordt met name veroorzaakt door de (I)ADL-schaal $\left(R^{2}=0,40\right)$ daarna gevolgd door alleenstaand zijn (toename in $R^{2}$ bedraagt 0,04 ). 
De logistische schattingsresultaten voor de basisvoorzieningen zijn eveneens in tabel 15.5 opgenomen (kolom $2 \mathrm{t} / \mathrm{m}$ ) en zijn als volgt samen te vatten. In alle gevallen is de (DADL schaal van groot belang en wordt vaak als eerste in de stapsgewijze regressie-procedure geselecteerd: De groote van de regressiecoefficient voor het aantal (I)ADL-beperkingen loopt op van 0,09 bij positief geindiceerden, ruim 0,20 bij de bejaardenoordbewoners en gebruikers van gezinsverzorging en 0,46 bij wijkverpleging tot 0,62 bij verpleeghuispatienten. Hiermede wordt het 'care continuom' (zie hoofdstuk 1) weergegeven, maar tevens blijkt datt de impact van (I)ADL-beperkingen voor het bejaardenoord geringer is dan voor extramurale voorzieningen (De Klerk en Huijsman, 1989). Voor het bejaardenoord en het positief advies daarvoor zijn, in tegenstelling tot de extramurale voorzieningen, de psychische determinanten tenminste zo belangrijk: bij de verklaring voor geindiceerde respondenten leveren eenzaamheid en het oordeel over de gehele situatie een significante bijdrage.

Bij het bejaardenoord hebben de Zungscore en het situatie-oordeel een significant, maar negatief effect, hetgeen een onverwacht resultaat genoemd mag worden. Wellicht weerspiegelt zich hierin het feit dat er selectieve respons is opgetreden nadat bovendien de recrutering van potentiele respondenten (door de directeuren van de instellingen zelf) ook niet geheel ad random heeft plaatsgevonden (zie hoofdstuk 13; Frederiks e.a., 1988). Een andere werklaringen zou kunnen zjin dat na een crisissituatie tijjens de aanvraagprocedure de geestelijke toestand en dus het psychisch functioneren door opname ten goede is gekeerd (Wimmers e.a., 1987; De Jong-Gierveld en Kamphuis, 1986; Te Wierik en Frederiks, 1990). Het feit dat de AMT-score in het bejaardenoord wel en in het verpleeghuis niet wordt geselecteerd, terwijl voor de laatste voorziening woorts de Zung-score een negatief teken heeft, is het resultaat wan de steekproefeigenschappen van de betreffende verpleeghuispopulatie (zie paragraaf 13.6).

Andere vermeldenswaardige bewindingen worden kort besproken. Allereerst blijkt bij gezinsverzorging en opname in hei bejaardenoord het feit van belang te zijn of de persoon in kwestie alleenstaand is; bij positief gelndiceerden of verpleeghuispatienten speelt dat geen rol van betekenis. De leeftijd heeft alleen bij gezinsverzorging geen significant effect. Bij hel verpleeghuis is sprake van een negatief teken, hetgeen wordt veroorzaakt door lagere gemiddelde leeftijd in deze groep (tabel 15.4). Psychische factoren spelen bij extramurale zorg geen rol of zijn zelfs contra-indicatief (Zung-schaal bij wijkverpleging). Het aantal weken dat het afgellopen jaar door ziekte gekenmerkt werd, is van significant positieve invloed op het gebruik van wijkverpleging en het verpleeghuis, alsmede voor een positief advies voor opname in het bejaardenoord. Een negatief teken daarentegen wordt gevonden bij gezinsverzorging. Op deze voorziening is als enige de sociaal-economische status van invloed: gezinsverzorging wordt met name door ouderen uit lagere strata gebruikt. Mensen uit hogere strata maken gebruik wan een particuliere betaalde hulp, welke op basis van het significant negatieve teken alls een substituut voor gezinsverzorging kan worden aangemerkt. Opmerkelijk is verder dat deze particuliere hulp een significant positieve bijdrage levert aan de verklaring van het positieve advies voor opname in het bejaardenoord. De hulp van een partner is van significante invloed op (advies voor) opname in het bejaardenoord en verpleeghuis, maar niet op het gebruik van extramurale voorzieningen. Allerlei andere vormen van informele hulp blijken alleen relewant te zijn bij gezinsverzorging (negatief). Bij wijkverpleging is géen van de informele hulpbromnen van invloed. Tenslotte wordt vermeld dat geen enkele woonvariabele in deze stapsgewijze procedures geselecteerd wordt. De overige vijf voorzieningen voor ouderen (GOW, maaltijd, SGD, dagopvang, dagbehandeling) zijn alle geschat op basis van logistische regressie op het totale bestand, maar tevens is afzonderlijk gekeken naar de deelbestanden voor thuiswonende ouderen (inclusief positief geindiceerden). Ook deze regressies zijn uitgevoerd nadat eventuele ontbrekende waarden op respondentniveau vervangen zijn door de gemiddelden die in het betreffende deelbestand werden aangetroffen woor die personen wan wie wel antwoorden beschikbaar waren. 
Tabell 15.5. Schattingsresultaten voor basiswoorzleningen"

\begin{tabular}{|c|c|c|c|c|c|c|}
\hline & 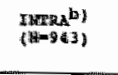 & 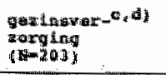 & 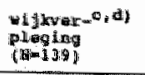 & 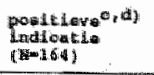 & 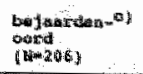 & 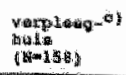 \\
\hline 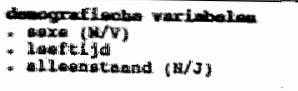 & $\overline{0}: 173$ & $\begin{array}{l}0,575 \\
1.032\end{array}$ & 0.970 & 0.37 & 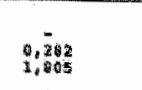 & $-x_{0}=$ \\
\hline 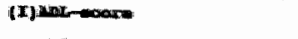 & $0,3,8$ & 0,233 & 0,461 & 0.00 & 由,29\% & 0,60 \\
\hline 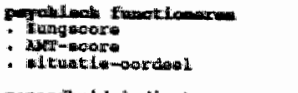 & $\begin{array}{c}-0,0.7 \\
=\end{array}$ & 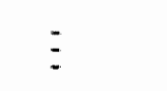 & $\begin{array}{c}-9,0126 \\
-\end{array}$ & 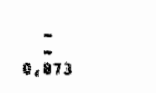 & $\begin{array}{l}-0,023 \\
-0,212 \\
-0,518\end{array}$ & $\begin{array}{r}-6,001 \\
1,06 \mathrm{~B}\end{array}$ \\
\hline 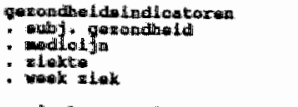 & $\begin{array}{l}-0,122 \\
0.253\end{array}$ & $\overline{-}$ & $\begin{array}{c}-\overline{0} \\
0,0028\end{array}$ & $=$ & $=$ & 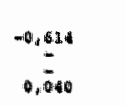 \\
\hline 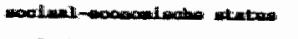 & $-0,0047$ & $-0,010$ & - & 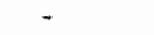 & 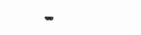 & $=$ \\
\hline 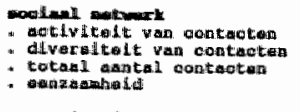 & $\begin{array}{c}0.107 \\
= \\
=\end{array}$ & $\begin{array}{l}0,0912 \\
-0,0918\end{array}$ & $=$ & $=$ & $\begin{array}{c}0,55 \\
-10,060 \\
=\end{array}$ & $\begin{array}{l}- \\
=\end{array}$ \\
\hline 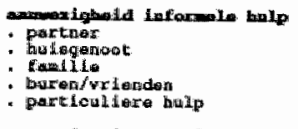 & $\begin{array}{c}-0,103 \\
= \\
=\end{array}$ & $\begin{array}{l}-2 * 598 \\
-10,21 \\
-1,403\end{array}$ & $\begin{array}{l}= \\
= \\
=\end{array}$ & $\begin{array}{c}-0,026 \\
= \\
= \\
0,605\end{array}$ & $=$ & $\begin{array}{c}-1,651 \\
\vdots \\
-2,174\end{array}$ \\
\hline 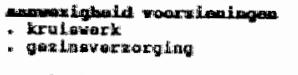 & $\overline{-}$ & 0.976 & 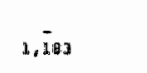 & 0,790 & $\overline{-}$ & $\overline{-}$ \\
\hline 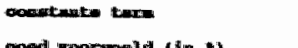 & $x^{2}-0 \times 0$ & $-2,351$ & $-6,301$ & $-15,702$ & $-2,4+20$ & $-6,059$ \\
\hline 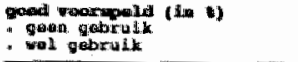 & $\mathbb{R}^{2}=0,548$ & $\begin{array}{l}92,6 \\
43,8\end{array}$ & $\begin{array}{l}95.0 \\
319.8\end{array}$ & $\begin{array}{l}3 \pi, 0 \\
40,2\end{array}$ & 91,5 & $\begin{array}{ll}98,1 \\
916,13\end{array}$ \\
\hline
\end{tabular}

Het gebruik van de betreffende voorzieningen blijkt met de hier gevolgde procedures niet goed verklaard te kunnen worden; de verklaarde variantie is zeer gering. Weliswaar worden via stapsgewijze logistische regressie een aantal variabelen geselecteerd die significant zijn, maar het percentage goed voorspeld gebruik blijft $0 \%$ (het percentage goed voorspeld niet gebruik $100 \%)^{2}$. De predictieve waarde, die aangeeft welk percentage van de gevallen waarbij het model voorspelt dat er geen gebruik is in werkelijkheid ook geen gebruik rapporteerde (Sacket e.a., 1985), is derhalve gering. Hierbij kan een rol spelen dat er uberhaupt weinig gebruikers van overige voorzieningen zijn; in de gehele onderzoekspopulatie betreft dat: $6,2 \%$ voor het GOW; $1,7 \%$ voor de warme maaltijd; $3,3 \%$ bij de $\mathrm{SGD} ; 1,5 \%$ voor de dagverzorging in het bejaardenoord en tenslotte $2,8 \%$ voor de dagbehandeling in het verpleeghuis. Voor de resultaten met betrekking tot GOW, maaltijd, dagverzorging en dagbehandeling maakt het geen verschil of de analyse op het gehele bestand of voor thuiswonenden apart wordt uitgevoerd. Voor het gebruik van de SGD ligt dat niet anders, ook als er rekening mee wordt gehouden dat deze voorziening vooral gebruikt wordt door de verpleeghuispatienten (17\%; driekwart van alle SGD-clienten). Variabelen die hier van invloed zijn, betreffen het aantal ziekteweken en de aanwezigheid van wijkwerpleging, maar ook hier is het percentage goed voorspeld gebruik nihil.

Het gebruik door ouderen van algemeen toegankelijke gezondheidszorgvoorzieningen is wederom door middel van stapsgewijze logistische regressie geanalyseerd, waarbij is

2. Op bagis van de in de regressle opgenomen variabelen wordt de kans op gebruik geschat Deze acthauting wordt verwolgens afgerond Lot nul of én waarbil o,S als grens wordt aangebouden. De geschatte en gigeromde kans op gebruik word verwolgens vergeliken

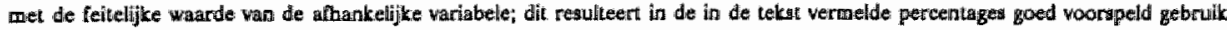
en goed voorspeld niet-gebrulk 
Tabel 15.6. Logistische schattingen voor overige voortieningen voor ouderen")

\begin{tabular}{|c|c|c|c|c|c|}
\hline & 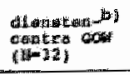 & 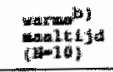 & $\operatorname{sen}$ & 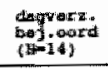 & 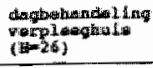 \\
\hline 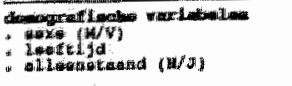 & $=$ & 110 & $\Xi$ & : & $\vdots$ \\
\hline 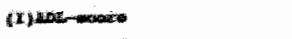 & -19.207 & - & - & - & 0,437 \\
\hline 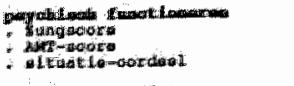 & $=$ & $\bar{z}$ & $=$ & $=$ & 0,024 \\
\hline 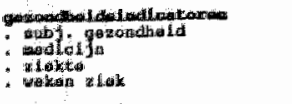 & $\sum_{213}$ & $\Xi$ & $=$ & $\overline{\overline{0}} \overline{0}$ & $=$ \\
\hline 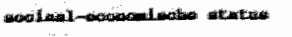 & - & - & - & - & 0,148 \\
\hline 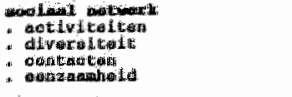 & $\bar{z}$ & $\bar{z}$ & $\vdots$ & 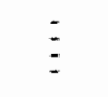 & $\bar{z}$ \\
\hline 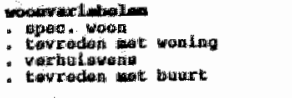 & $\frac{1,759}{5}$ & $\vdots$ & $\begin{array}{l}\bar{z} \\
\bar{z}\end{array}$ & $\bar{z}$ & 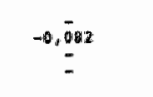 \\
\hline 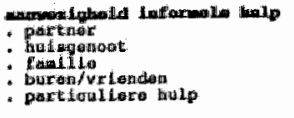 & $\begin{array}{l} \pm \\
=\end{array}$ & $\frac{-}{2 * 427}$ & 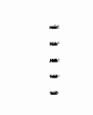 & $\begin{array}{l}0.769 \\
=\end{array}$ & $\begin{array}{c}0.794 \\
\vdots \\
-\end{array}$ \\
\hline 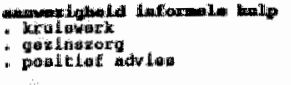 & \pm 0 & $\Xi$ & 1,011 & $=$ & $\bar{z}$ \\
\hline 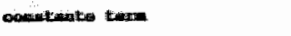 & $-3,2: 27$ & $-12,300$ & $-3,012$ & $-5,166$ & $-51,6.99$ \\
\hline 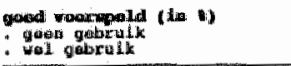 & $\begin{array}{r}100 \\
0\end{array}$ & $\begin{array}{r}101 a_{0} a \\
0, a\end{array}$ & $\begin{array}{r}100,0 \\
0 \\
0\end{array}$ & $\begin{array}{r}100,0 \\
6,0 \\
\end{array}$ & $\begin{array}{r}100,0 \\
0,0\end{array}$ \\
\hline
\end{tabular}

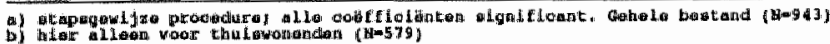

uitgegaan van het gehele bestand (zie tabel 15.7). Nimmer geselecteerd werden variabelen betreffende bet sociaal netwerk, de woonsituatie en alle onderscheiden vormen van informele hulp. Uitzondering op deze regel betreft de significante positieve invloed van de aanwezigheid van eenzaamheidsgevoelens op het contact met de huisarts. Voorts zijn de onderlinge relaties tussen voorzieningen zoals tussen de specialist en het ziekenhuis vaak belangrijker dan de determinanten voor lichamelijk en psychisch functioneren. Uitzondering hierop betreft het contact (in het afgelopen kwartaal) met de huisarts, hetgeen behvloed wordt door eenzaamheid, subjectieve ongezondheid, medicijngebruik en her aantal weken dai men ziek is geweest. De percentages goed voorspeld gebruik varierren van $13 \%$ bij fysiotherapie, ongeveer $25 \%$ bij de huisarts en $30 \%$ bij het ziekenhuis.

Vrouwen gebruiken meer medicijnen, maar gaan minder naar de specialist. Alleen bij de fysiotherapie wordt een significant effect (positief) gewonden voor de sociaal-economische status, ook na correctie voor leeftijd (negatief effect) en bestaan er positieve invloeden van het aantal (I)ADL-beperkingen en de aanwezigheid van een chronische ziekte (niet van het aantal ziekteweken). Samenvattend kan gesteld worden dat de geselecteerde determinanten slechts een geringe bijdrage leveren aan de verklaring van het gebruik door ouderen van algemeen toegankelijke gezondheidszorgwoorzieningen. Onderlinge verwijspatronen tussen huisarts, specialist en ziekenhuis blijken belangrijker te zijn. Toch kan op basis van deze stapsgewijze logistische regressie ongeveer een kwart van de variabiliteit in bet gebruik van deze voorzieningen verklaard worden. Dit is aanzienlijk beter dan bij de overige voorzieningen voor ouderen (zoals dienstencentra en dagbehandeling), maat slechter dan bij de basis. voorzieningen (zoals gezinsverzorging en bejaardenoord). 
Tabel 15.7. Logistische schattingen voor gebruik gezondheidszorgvoorzienungen

\begin{tabular}{|c|c|c|c|c|c|}
\hline & 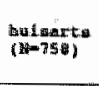 & 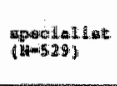 & 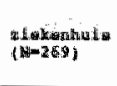 & 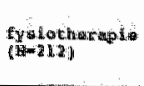 & 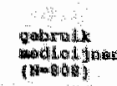 \\
\hline 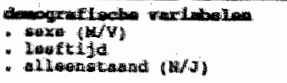 & $=$ & $\begin{array}{l}-9,631 \\
-0,426\end{array}$ & $=$ & $-0,1+2$ & $\begin{array}{c}0,5 \leq 5 \\
=-\end{array}$ \\
\hline 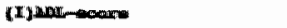 & $=$ & - & - & 0,210 & $-\infty$ \\
\hline 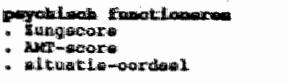 & $=$ & $0,8,1.1$ & $\begin{array}{r}0.026 \\
-0,791\end{array}$ & 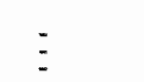 & $\begin{array}{c}0,103 \\
=\end{array}$ \\
\hline 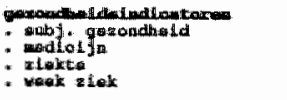 & $\begin{array}{l}0,174 \\
0,031 \\
0,018\end{array}$ & $\begin{array}{l}0,156 \\
1,130 \\
1,230 \\
0,003\end{array}$ & $=$ & 0,626 & $\begin{array}{l}0,3155 \\
0,5 \sin 5\end{array}$ \\
\hline 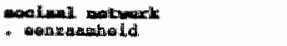 & 0.402 & - & - & - & $\approx$ \\
\hline 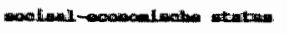 & - & - & - & 0,073 & - \\
\hline 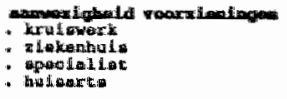 & 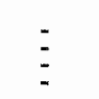 & $\begin{array}{l}1,380 \\
0,35 x\end{array}$ & $1_{1,432}$ & $\bar{z}$ & 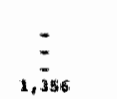 \\
\hline nowetreate trarn & $-1,027$ & $-2,160$ & $-2,921$ & $-3,6547$ & $-3,633$ \\
\hline 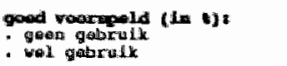 & $\begin{array}{l}26,0 \\
95,6\end{array}$ & $\begin{array}{l}159 ; 2 \\
76 ; 9\end{array}$ & $\begin{array}{l}92,1 \\
30,1\end{array}$ & $\begin{array}{l}97 n^{10} \\
13 n^{2}\end{array}$ & $\begin{array}{l}25,2 \\
97,5\end{array}$ \\
\hline
\end{tabular}

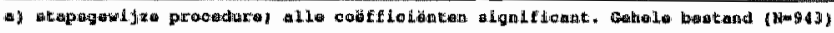

Afrondend kan uit de voorgaande analyses geconcludeerd worden dat het gebruik van de basisvoorzieningen zich in het algemeen redeljk tot goed laten verklaren. De belangrijkste determinanten betreffen de (I)ADL-score, overige gezondheidsindicatoren, psychische variabelen, informele hulpbronnen (inclusief particuliere hulp) en wisselende combinaties van demografische variabelen. Niet of nauwelijks relevant zijn de variabelen voor de woonsituatie en het sociale netwerk; de sociaal-economische status is alleen van belang bij de verklaring van gezinsverzorging. Kruiselings leveren ook de extramurale voorzieningen een significante bijdrage aan de verklaring van het gebruik, terwijl bij de positief geindiceerden de gezinsverzorging als het ware als "voorportaal' fungeert.

Het gebruik van de overige voorzieningen voor ouderen (zoals dagverzorging, GOW en dergelijke) blijkt in deze studie niet verklaard te kunnen worden. Weliswaar worden enkele determinanten geselecteerd in de gevolgde stapsgewijze logistische procedure, mat het onderscheid tussen wel of geen gebruik kan hiermee nimmer voorspeld worden, zodat de predictieve waarde van de modellen gering is. Mogelijk spelen de zeer kleine aantallen (maximaal $6 \%$ voor GOW) hierbij een rol. Opmerkelijk is wel de bevinding dat informele hulp een positief effect heeft: dit geldt voor dagwerzorging met betrekking tot de hulp van andere huisgenoten en voor dagbehandeling in bet verpleeghuis met betrekking tot de hulp wan een partner. Hiermee wordt bljkbaar een onllastend effect op het thuismilieu van deze voorzieningen gereproduceerd (Nuyens, 1988; Nuy e.a., 1984).

\subsection{Constructie van een kostenvariabele}

Door aan gebruik wan woorzieningen en, indien mogelijk (met name bij extramurale voorzieningen), aan de omvang van het gebruik een 'prijskaartje" te koppelen, wordt in deze paragraaf een kostenvariabele voor de ouderenzorg geconstrueerd en vervolgens wederom gerelateerd aan de verschillende determinanten. Een dergelijke variabele kent verschillende voordelen. Ten eerste wordt op deze wijze een koppeling tot stand gebracht tussen vraag- 
en tanbodtactoren (prijzen). Ten tweede vindt via de prijzen als het ware een weging van voorzieningengebruk in het 'care continutum' plaats, waardoor verschillende gebruikersgroepen nader kunnen worden gedifferentieerd. Dit punt kan worden verduidelijkt aan de hand van figuur 15.1, die aan het begin van dit hoofdstuk werd gepresenteerd. Daarin werden bij dezelfde (I)ADL-score verschillende zorgcombinaties aangetroffen: alleen wijkverpleging, gezinswerzorging plus wijkverpleging en datzelfde plus een positief opnameadvies. Door nu ook de omvang van de hulpverlening en de verschillende kostprijzen erbij te betrekken, wordt het mogelijk deze groepen nader te preciseren en mogelijkerwijs te differentieren. Ten derde wordt door de geconstrueerde kostenvariabele het probleem onderwangen dat de schattingen voor het gedichotomiseerd voorzieningengebruik moeilijk te beoordelen zijn. Hierwoor in de plaats komt éen kostenconstruct, waaraan tenslotte ook een inhoudelijk aantrekkelijk punt toegeschreven wordt: op basis van verschillende combinaties van scores op de determinanten zou, indien het verklaringsmodel krachtig genoeg is, de mogelijkheil kunnen worden geschapen om de hoogte van individuele 'zorgsubsidies' of clientenbudgetten vast te stellen, waarmee de persoon in kwestie vervolgens de (geprefereerde) zorg zou kunnen kopen.

De constructie wan de kostenvariabele is als volgt tot stand gekomen. Alle mogelijke combinaties van voorzieningen, vermenigvuldigd met de betreffende kostprijzen die zo aanstonds worden toegelicht, zijn naar jaartotalen omgerekend en vervolgens weer terugberekend naar dagprijzen, om tot eenzelfde noemer te komen. Dit is noodzakelijk omdat bijvoorbeeld bij gezinsverzorging antwoordmogellikheden zijn aangeboden die variëren van een halve dag per 14 dagen tot 4 of 5 halve dagen én weekend/avondhulp per week. De andere veronderstellingen die gemaakt moesten worden om de kostenvariabele te construeren zijn de volgende:

a. Gezinsverzorging: een halve dag (de antwoordbasis in de enquete) is gelijk gesteld aan 2,5 uur effectieve zorgverlening a $f 28$,- per uur (zie hoofdstuk 6). Het hoogst mogelijke antwoord luidt 4 of $\mathbf{5}$ halve dagen plus weekend-en/of avondbulp en is gelijkgesteld aan 15 uur per week. Het onderscheid tussen traditionele en alpha-hulp (zie hoofdstuk 6) is in de vragenlijst waarop dit deel van de studie gebaseerd is niet opgenomen.

b. Wijkverpleging: antwoordbasis is het aantal contacten dat op twee wijzen verbijzonderd is, namelijk door enerzijds onderscheid te maken tussen verpleegkundige handelingen en ADL-ondersteuning en door anderzijds verschillende frequentiemogelijkheden te onderscheiden (minder dan een maal, és maal per week en twee of meer keer per week). De contactduur (NK, 1989; Meijer, 1990) voor een verpleegkundige handeling is ongeveer 21 minuten en voor ADL-ondersteuning ongeveer 35 minuten; bij beide dient ook nog reistijd (gemiddeld 8 minuten) en administratie (gemiddeld 4 minuten) meegerekend te worden. Door voor beide soorten contacten de ratio ten opzichte van een gemiddeld contact van in totaal 40 minuten en à raison van circa $f 55$,- (zie hoofdstuk 7 ) te nemen, kan een kostprijs berekend worden van $f 45$,- voor een verpleegkundige handeling en van $f 65$-voor ADL-ondersteuning. Tenslotte kent de wijkverpleging een orienterend contact dat gemiddeld 49 minuten neemt (inclusief reistijd) en uitkomt op $f 67,50$.

c. Combinaties van gezinsverzorging en wijkverpleging komen voor bij 42 respondenten, waarbij per combinatie de berekeningen zoals die hiervoor werden aangegeven, uitgevoerd zijn (zie tabel 15.8).

d. Bejaardenoord: de gemiddelde dagprijs van $f 81,60$ (zie hoofdstuk 9) is gecorrigeerd voor het aandeel van de totale huisvestingskosten $(28,4 \%)$ en de voedingskosten $(8,1 \%)$ en komt dan wit op gemiddeld $f 51,80$ per dag. Vervolgens is de classificatie methode voor bejaardenoordbewoners (zie hoofdstuk 10) benut om de kostprijs per dag te differentieren naar de lichamelijke en psycho-sociale zorgbehoefte. Verondersteld is dat de kritische grens voor de ZUNGschaal (zie paragraaf 14.5) gerelateerd is met die voor de cognitieschaal van de BPS (zie hoofdstuk 10), zodat psycho-sociale problematiek aanwezig geacht wordt bij een ZUNG-score vanaf 48 punten. De (I)ADL-dimensie in de 
Tabel 15.8. Kostprijs in guldens per dag voor verschillende combinaties van gealnsverzorging en wijkverpleging

\begin{tabular}{|c|c|c|c|c|c|c|}
\hline \multirow[b]{2}{*}{ 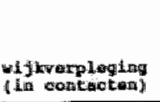 } & \multicolumn{6}{|c|}{ 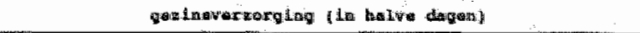 } \\
\hline & 1 \& per & $1 \times$ per & 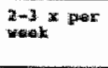 & $\operatorname{lig}_{x} x p a x$ & 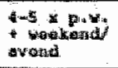 & Dilat \\
\hline ardiantat: L & $=-a 1)$ & 20,35 & 25,30 & is & ail & 0,38 \\
\hline 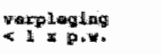 & - & -a) & 28,75 & $-\$$ & $-a 1$ & 3,25 \\
\hline $\begin{array}{l}\text { varploging } \\
1 \times p_{n}\end{array}$ & $=\Delta$ & $-4)$ & 31,40 & $=4)$ & $\Rightarrow$ & 4,45 \\
\hline 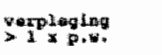 & $-n$ & 26,15 & 41,10 & 61.05 & $-a$ & 20,25 \\
\hline $21 \times p \cdot v$ & -a) & 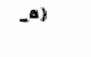 & 31,15 & $-\infty$ & 60.65 & 4,20 \\
\hline 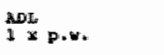 & -1 & 19,20 & 34,15 & -4 & 681,05 & $\$, 20$ \\
\hline$>1 \times p$ & a) & 33,00 & 49.45 & 67,90 & Ox, ans. & 23,00 \\
\hline Diwet & 6.40 & 10,00 & 34.95 & $45, a 0$ & 5, , w & - \\
\hline
\end{tabular}

a. kount nlat voor in dit enderasolik

classificatie voor bejaardenoordbewoners is (analoog aan die in hooldstuk 10) als volgt vormgegeven: geén ADL-beperkingen als lichtste categorie, 10 of meer IADL-beperkingen als zwaarste groep en de rest als middengroep. Het woorgaande resulteert in zes groepen bejaardenoordbewoners (zie tabel 15.9). De aandelen van deze groepen zijn vrijwell gelijk aan die in de oorspronkelijke classificatie in hoofdstuk 10. Deze procedure is niet alleen gevolgd voor de mensen in het betreffende deelbestand $(N=206)$, maar ook voor die verpleeghuispatienten die vanuit het bejaardenoord zijn opgenomen ( $N=45$, dat is $28,5 \%$ van het betreffende deelbestand). In tabel 15.9 is tussen haakjes de verdeling van de respondenten vermeld indien deze groep meegeteld wordt. In het vervolg wordt aangenomen dat diegenen van wie geen ZUNG-score bekend is, boven de kritische grens van deze schaal (47) vallen (dit zijn voornamelijk de opgenomen verpleeghuispatienten). De kostprijs wordt berekend door per subgroep in de classificatie de verhouding van de gemiddelde meerzorg voor deze groep ten opzichte van het overall gemiddelde van 51,6 minuten per dag te nemen (zie hoofdstuk 10, tabel 10.14) en deze ratio te vermenigvuldigen met dat deel in de totalle gecorrigeerde kostprijs per dag of 51,80 ) dat bestaat uit personeelslasten $\left(f 34_{7} 70\right.$ ). De resulterende kostprijzen per subgroep staan vermeld in het tweede deel van tabel 15.9 en lopen op van $f 21$, in de

Tabel 15.9. Indeling bejaardenoordbewoners" en differentiatie kostprijs

\begin{tabular}{|c|c|c|c|c|}
\hline & $\begin{array}{l}\text { geem ADL } \\
\text { beperkingon }\end{array}$ & $\begin{array}{l}\text { Eax. } 9 \text { (I) AOL- } \\
\text { bepexkingen }\end{array}$ & $\begin{array}{l}10 \text { of } 11 \text { ( Ij) Abin- } \\
\text { beporkingem }\end{array}$ & Tot:al \\
\hline 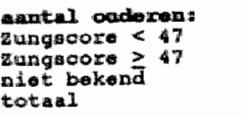 & $\begin{array}{rl}53 & (53) \\
4 & 4 \\
2 & (2) \\
59 & (59)\end{array}$ & $\begin{array}{r}88(88) \\
19(20) \\
112(121)\end{array}$ & $\begin{aligned} 18 & (20) \\
15 & (17) \\
3 & (34) \\
36 & (71)\end{aligned}$ & $\begin{array}{r}156(158) \\
41(44) \\
5(49) \\
206(251)\end{array}$ \\
\hline 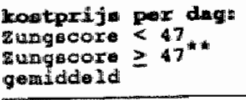 & $\begin{array}{l}21,00 \\
24,75 \\
21,40\end{array}$ & $\begin{array}{l}46,00 \\
68,70 \\
50,70\end{array}$ & $\begin{array}{l}101,20 \\
122,10 \\
115,15\end{array}$ & $\begin{array}{l}45,55 \\
78,55 \\
51,80\end{array}$ \\
\hline
\end{tabular}


groep zonder ADL of psychische problemen (25,7\% wan de bewoners) tot $f 122$, in de groep met beide problemen in ermstige mate (ruim $8 \%$ van alle bewoners). Respondenten bij wie een van de "sleutels" in de classificatie niet bekend is, krijgen de gemiddelde prijs toegewezen die voor de betreffende kolom (als Zungscore onbekend is) of rij (indien $\mathrm{ADL}$-score onbekend is) in tabel 15.9 vermeld staat.

e. Voor het verrichten van een indicatie-advies voor opname in het bejaardenoord of verpleeghuis, wordt een gemiddelde prijs van $f 350$, gerekend (zie bijlage 3).

f. Voor andere voorzieningen zijn kostprijzen opgenomen zoals die in hoofdstuk 4 gepresenteerd zijn. Dil betreft dagverzorging ( $f$ 44,- per dag), dagbehandeling ( $f$ 122, per dag), de Socialal Geriatrische Dienst (op jaarbasis gemiddeld $f 3.650$,- per client), Algemeen Maatschappelijk Werk ( $f 950$,- per client per jaar) en de speciale woningen voor ouderen (aanleunwoningen en zogenaamde 'bejaardenwoningen'), waarvoor de servicekosten ongeveer $f 4.600$, - per jaar bedragen (zie hoofdstuk 4 ).

g. Voor gezondheidszorgvoorzieningen zijn enkele veronderstellingen gemaakt, namelijk voor een huisartscontact $f 30$,- per keer, voor specialist $f 600$,- op jaarbasis ( 4 a 5 contacten) en voor fysiotherapie $f 30$,- per contact, waarbij bovendien verondersteld is dat dat ongeveer 20 maal in een kwartaal plaatsvindt (in de enquete is gevraagd of men de laatste drie maanden contact heeft gehad, nfet hoe vaak).

h. Bij verpleeghuispatixnten wordt een aantal varianten onderscheiden. In herinnering wordt geroepen het feit dat het ouderen betreft die ten tijde van bet enqueteren op het punt stonden opgenomen te worden (zie hoofdstuk 13), zodat eigenlijk via de hierwoor beschreven procedure geconstrueerde kostenvariabele een oude situatie beschreven wordt. Ondat deze opname ook feitelijk gerealiseerd wordt, zal daarom eerst een model geschat worden waarin de respondenten uit het betreffende deelbestand alle cen kostprijs van $f 154$, - voor opname in het verpleeghuis (na aftrek van huisvestings- en voedingskosten) krijgen toegewezen. Hierop is echter nog een variant denkbaar: het is immers mogelijk dat deze specifieke groep van net opgenomen of nog op te nemen patienten niet voldoet aan de gemiddelde kenmerken van al langer aanwezige patienten (deze assumptie wordt impliciet gemaakt als het gemiddelde tarief in rekening wordt gebracht); als variant wordt daarom een kostprijs toegerekend die gelijk is aan het hoogste bedrag dat in het bejaardenoord is aangetroffen, namelijk $f 122$,- per dag (het tarief voor de 'zwaarste' bewonerscategorie). Als derde variant wordt voor verpleeghuispatienten dezellfe procedure gevolgd als voor respondenten uit de andere deelbestanden (bovenstaande stappen a $t / \mathrm{m} \mathrm{g}$ ). Als daarbij géen kostprijs is toe te rekenen, omdat op allerlei gebruikswragen geen antwoord is gegeven $(\mathrm{N}=4)$ dan is het gemiddelde dagtarief voor verpleeghuisopname opgenomen ( $f 154$, na correctie voor huisvesting en voeding).

De volgens bovengestelde regels geconstrueerde variabele wordt in twee varianten beschouwd, eén met en eén zonder de kosten voor gezondheidszorg zoals die ad g geformuleerd zijn. In tabel 15.10 wordt voor de verschillende deelbestanden een overzicht gegeven van gemiddelde waarden en standaarddeviaties voor beide Kostenvarianten.

Twee zaken moeten nog belicht worden: ten eerste zijn de bedragen berekend op basis van een gemiddelde dag in het afgelopen jaar, ten tweede is gén rekening gehouden met een eventuele opname in het ziekenhuis (hetgeen met name bij de verpleeghuispatienten van belang is), omdat hiervoor onvoldoende informatie voorhanden is (alleen de dichotome uitspraak wel of geen opname; geen duur, reden en dergelijke). Dit laatste punt verklaart waarschijnlijk de vrij geringe verschillen tussen de beide kostenvarianten (voor gehele bestand $f 1,63$ per dag, dat wil zeggen ongeveer $f 600,-$ op jaarbasis). In tabel 15.11 zijn de schattingsresultaten vermeld waarbij ter verklaring van de kostenvarianten wederom dezelfde determinanten zijn opgenomen als thiervoor.

Indien wordt uitgegaan van het gehele bestand, dan zijn de resultaten aanzienlijk beter als voor verpleeghuispatienten een vast bedrag van $f 122,-$ gehanteerd wordt in plaats van de 


\begin{tabular}{|c|c|c|c|c|c|}
\hline 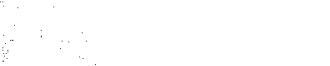 & $\begin{array}{l}\text { thwis:- } \\
\text { wonend }\end{array}$ & $\begin{array}{l}\text { poettidef } \\
\text { geindiceser }\end{array}$ & $\begin{array}{l}\text { bejaranden- } \\
\text { pora }\end{array}$ & $\begin{array}{l}\text { verplear- } \\
\text { hols }\end{array}$ & $\begin{array}{l}\text { totale } \\
\text { homatiand }\end{array}$ \\
\hline 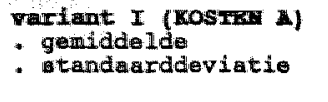 & $\begin{array}{r}7,19 \\
1,54\end{array}$ & $\begin{array}{l}16,77 \\
19,53\end{array}$ & $\begin{array}{l}55,18 \\
33,64\end{array}$ & $\begin{array}{l}82,67 \\
56,46\end{array}$ & $\begin{array}{l}31,99 \\
42,38\end{array}$ \\
\hline 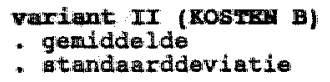 & $\begin{array}{r}8,66 \\
14,77\end{array}$ & $\begin{array}{l}1,57 \\
15,81\end{array}$ & $\begin{array}{l}56,58 \\
3,86\end{array}$ & $\begin{array}{l}0.86 \\
56,00\end{array}$ & $\begin{array}{l}33,52 \\
42,99\end{array}$ \\
\hline
\end{tabular}

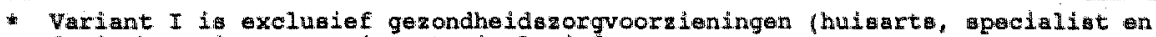
fysiotherapiel en variant II inclualef.

* Indier dezelifa rekenregels als voor andere reppondenten gevalgd wordt (ajo tekst)

Tabel 15.11. Verklaring van de kostenvariabelen" via stapsgewijze OLS-regressle"

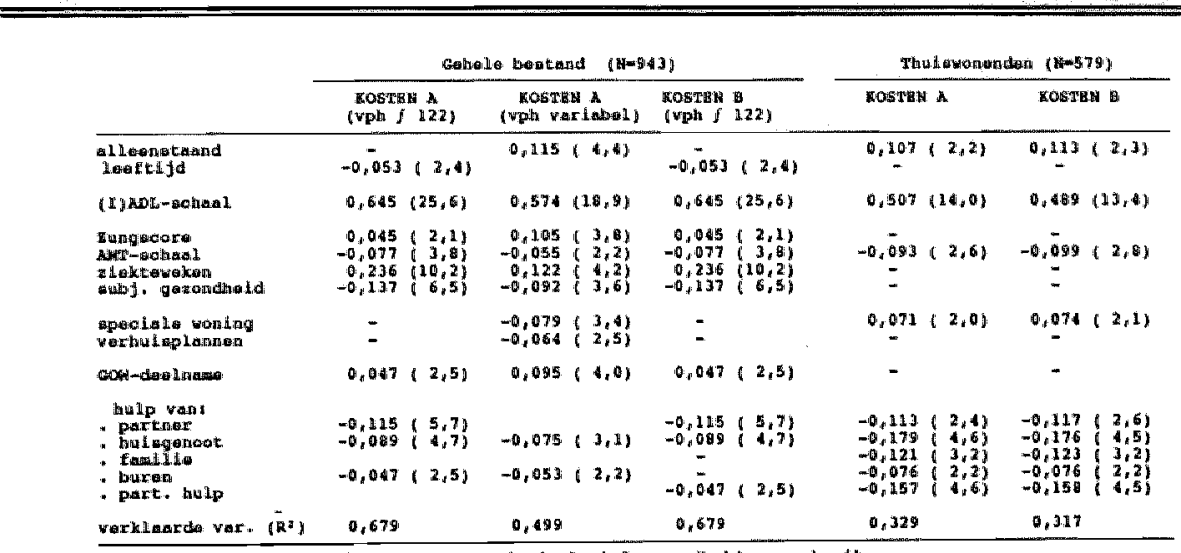

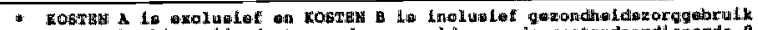

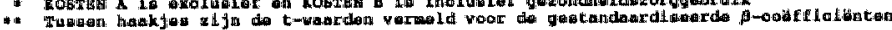

uitkomsten van de (variabele) procedureregels. De verklaarde variantie is in het eerste geval bijna $70 \%$ en in het tweede geval ongeveer $50 \%$. De belangrijkste determinant is ook nu weer (net als bij de verklaring van afzonderlijke voorzieningen) de (I)ADL-schaal; hiermee wordt bij benadering 70 tot $80 \%$ van de totale verklaarde variantie tol stand gebracht. Na de (I)ADL-schaal wordt in de stapsgewijze regressie of een van de gezondheidsindicatoren (aantal ziekteweken of subjectieve gezondheid) of een van de demografische kenmerken (alleenstaand zijn of leeftijd) opgenomen. Voor het gehele bestand is de verklaarde variantie hoger dan voor thuiswonenden afzonderlijk, maar ook daarvoor is het resultaat bevredigend te noemen $\left(\mathrm{R}^{2}=0,32\right)$. In beide situaties worden ongeveer dezelfde variabelen geselecteerd; naast de huishoudvorm en de (I)ADL-schaal, zijn dat voorts. de AMT-schaal (hoe meer geheugenstoornissen, hoe lager de schaalwaarde, hoe hoger de kosten voor zorgverlening), de woonsituatie (het bewonen van een speciale woning voor ouderen leidt bij thuiswonenden tot hogere kosten, maar in de gehele steekproef tot lagere kosten, hoewel niet altijd significant) en bij de thuiswonende ouderen alle bronnen voor informele en particuliere hulp. Vooral dit laatste is interessant omdat eerder getoond werd dat informele hulp lang niet altijd relevant is voor de verklaring van het voorzieningengebruik. Informele hulp is dus niet zozeer van belang voor de keuze van een voorzjening maar well woor de 
cmvang van de formele zorgverlening (de kosten worden immers 'gedrukt'). Er is derhalke sprake van aanvullende professionele zorg; er zijn binnen deze onderzoekspopulatie geen empirische aanwijzingen om de hypothese van het substituerende model (zie paragraaf 14.9.1) tussen informele en formele hulp te staven. Voor het gehele bestand worden nog twee gezondheidsindicatoren extra opgenomen: het aantal ziekteweken heeft een significant kostenverhogend effect, maar een positieve subjectieve beleving van gezondheid drukt de kosteri. Dit laatste hangt wellicht samen met een onderschatting van de gezondheid ten opzichte van leeftijdsgenoten bij ouderen in 'zwaardere' settings. Samenvattend kan gesteld worden dat het kostenconstruct een werkbare methode is on de ouderenzorg te benaderen. De verklaringsgraad is goed en bijna altijd hoger dan die voor afzonderlijke voorzieningen. De allerbelangrijkste determinanten zijn de (I)ADL-beperkingen, alleenstaand zijn of de leeftijd (die onderling samenhangen) en informele hulp.

\subsection{Een MIMIC-model voor afhankelijkheid}

In het voorgaande zijn de afzonderlijke effecten van de verschillende determinanten op het voorzieningengebruik belicht. In de regressie-analyse bleken zowel de IADL- en andere fysieke gezondheidsindicatoren als de determinanten met betrekking tot psychisch functioneren steeds in wisselende combinaties een bijdrage te leveren aan de verklaring van voorzieningengebruik. Deze observatie maakt het waarschijnlijk dat we te maken hebben met een set indicatoren die zowel het fysieke als het psychische functioneren weergeven; ten minste twee latenten liggen hier als het ware achter: én latente variabele voor lichamelijke (zorg-) afhankelijkheid en eén latente variabele voor psychische (zorg-)afhankelijkheid (Rivnyak e.a., 1989)

Het theoretische concept afhankelijkheid werd in een eerder stadium van het onderzoek uiltgedrukt in eén dimensie, die werd geoperationaliseerd met behulp van de zogenaamde MIMIC (Multiple Indicators MultIple Causes) benadering. Dit model bestaat uit twee, onderling en intern samenhangende, submodellen, namelijk het structuurmodel van oorzaken en/of achtergrondsvariabelen en het meetmodel met indicatoren voor afhankelijkheid. Deze benadering is aangewezen omdat 'afhankelijkheid' een latente variabele is, een theoretisch construct dat niet meetbaar is, maar indirect weergegeven wordt door de submodellen. Voor dergelijke modellen is een specifieke schattingsmethode vereist: LISREL (Jơreskog en Sörbom, 1981). Schattingen voor dit eerste model van afhankelijkheid van ouderen waren gebaseerd op gegevens uit het CBS-leefsituatie-onderzoek bij ouderen (hier 55-plus) in 1982 (CBS, 1982). Als achtergrondsvariabelen werden onder andere leeftijd, sociaal economische status en de omvang van het sociale netwerk gebruikt. Indicatoren voor afhankelijkheid werden in deze exploratieve fase gezocht in ADL- en LADL-scores, somatische klachten en de "lust tot ondernemen". Veel van deze variabelen waren geconstrueerd via cluster- en schaaltechnieken (Huijsman, 1986). De resultaten van dit vooralsnog eenvoudige model waren bevredigend: de tekens van coefficienten komen overeen met de literatuur en de bijdragen van de variabelen aan de verklaringsgraad zjjn alle significant (Huijsman, 1989a). Niet alleen kan met de afhankelijkheidsgraad uit het MIMIC-model via logistische schattingen een goede bevredigende verkJaring voor het voorzieningengebruik worden gegeven, maar het model leende zich ook om de eerder besproken theorie van het 'care continuum' van Harris en Kelly' (1986) empirisch te toetsen. Naarmate de afhankelijkheid stijgt, 'klimmen' ouderen steeds verder omhoog: het gebruik van zware zorg neemt toe en hulp wordt steeds meer in combinatie gegeven.

In deze paragraaf wordt de hypothese dat er twee latente afhankelijkheidsvariabelen bestaan empirisch getoetst. Als indicatoren voor lichamelijke afhankelijkheid $\left(\eta_{1}\right)$ worden gebruikt: het aantal (I)ADL-beperkingen, het aantal ziekteweken, de aanwezigheid van chronische ziekte en de subjectieve beleving van gezondheid; als indicatoren voor de psychische 

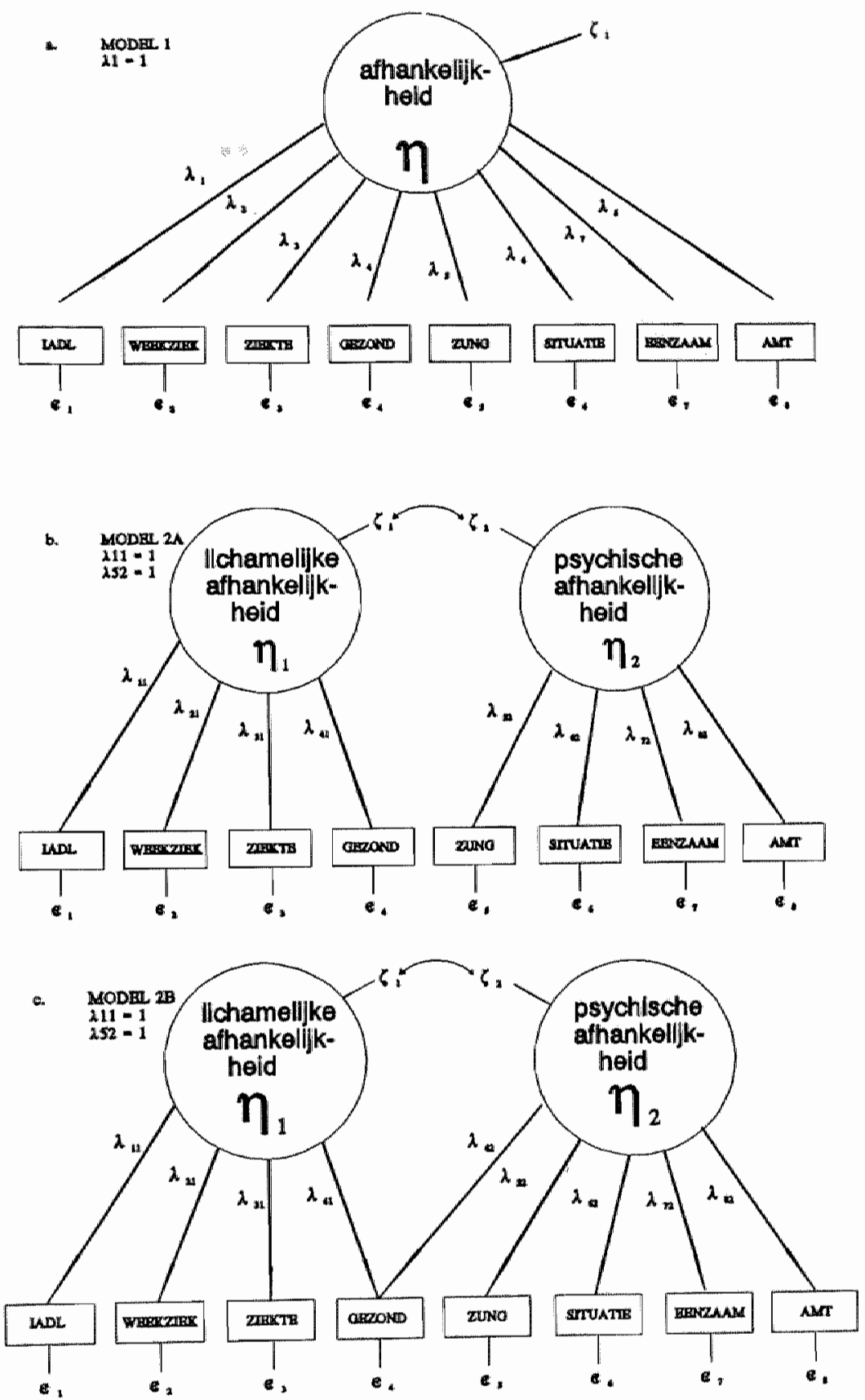
afthankeliykheid $\left(\eta_{2}\right)$ worden gebruikt: de Zungscore, het oordeel over de totale situatie, de nate van eenzaamheid en de AMT-score. De subjectieve gezondheidsbeleving zou de betangrijkste variabele zijn die beide dimensies van afhankelijkheid verbindt (zie paragraaf 14.4.1); ook deze hypothese kan wia de LISREL-methode getoetst worden. Hiertoe worden eerst drie modellen onderzocht: in model 1 wordt verondersteld dat alle acht variabelen als indicatoren voor een latente variabele beschouwd kunnen worden; in model $2 \mathrm{~A}$ wordt verondersteld dat er sprake is wan een lichamelijke en psychische afhankelijkheidsdimensie met voor ieder een unieke set indicatoren; model $2 \mathrm{~B}$ is gelijk aan model $2 \mathrm{~A}$, maar veronderstelt een zekere overlap tussen beide dimensies die met name tot uitdrukking kom: in het subjectieve gezondheidsoordeel. In figuur 15.2 zijn de drie modellen weergegeven.

Om de latente variabeten richting en schaal te geven dient een van de coefficienten gefixeerd te worden (Joreskog en Sorbom, 1981). Hiervoor wordt steeds de (I)ADL-schaal genomen $\left(\lambda_{11}=1\right)$ en in de modellen $2 \mathrm{~A}$ en $2 \mathrm{~B}$ bovendien de Zungschaal $\left(\lambda_{52}=1\right)$. De schattingsresultaten voor de basismodellen staan vermeld in tabel 15.12. De verschillen tussen de modellen onderling kunnen getoetst worden aan de hand van het verschil in de $\chi^{2}$-toetsen, dat zelf weer $\chi^{2}$-verdeeld is met een vrijheidsgraad (Saris en Stronkhorst, 1984, p. 276). Hieruit blijkt dat model $2 \mathrm{~B}$ beter past dan $2 \mathrm{~A}$ (verschil in $\chi^{2}$ is ongeveer 100; $p<0,001)$ en dat $2 A$ weer beter past dan model $1\left(\Delta \chi^{2}=165 ; p<0,001\right)$.

Model $2 \mathrm{~B}$ kan werder verbeterd worden door de AMT-score buiten beschouwing te laten: de door de latente variabele verklaarde variantie is slechts $5 \%$ tegen minimaal $22 \%$ bij alle andere varjabelen. De $\chi^{2}$-loets verbetert dan van 147,6 naar $53,2(p<0,001)$, zodat deze aanpassing niet verworpen moet worden. Ook deze $\chi^{2}$-waarde is nog te hoog om het model te accepteren, dat wil zeggen dat de hypothese verworpen moet worden dat het model de geobserveerde correlatiematrix gegenereerd zou hebben. In LISREL kunnen de mogelijkheden voor modelverbetering onderzocht worden met de "aanpassingsindices" voor iedere gerestricteerde parameter (Joreskog en Sörbom, 1981; zie ook hoofdstuk 13). Allereerst dient vermeld te worden dat bij model $2 \mathrm{~A}$ de grootste aanpassingsindex berekend wordt juist voor hell effect van $\eta_{2}$ op de subjectieve gezondheid $\left(\lambda_{42}\right)$; door deze parameter vrij te laten (het enige verschil met model $2 \mathrm{~B}$ ) wordt een verbetering in de $\chi^{2}$ bereikt van 98,9 zodlat het aangepaste model niet verworpen hoeft te worden. Model $2 \mathrm{~B}$ kan verder verbeterd worden door de covariantie tussen twee paren storingstermen vrij te laten, namelijk die tussen het oordeel over de totale situatie en de Zungschaal $\left(\boldsymbol{\theta}_{65}\right)$ en die tussen het gezondheidsoordeel en de aanwezigheid van een chronische ziekte $\left(\boldsymbol{\theta}_{43}\right)$. Het aangepaste model (figuur 15.3) wordt niet meer verworpen en zorgt er voor dat de geobserveerde correlatiematrix op bevredigende wijze wordt gereproduceerd.

Tabel 15.12. Schattingsresultaten voor de meetmodellen van afhankelijkheild

\begin{tabular}{|c|c|c|c|c|c|c|c|c|c|c|}
\hline & \multicolumn{2}{|c|}{ wothel 1} & \multicolumn{4}{|c|}{$=0$} & \multicolumn{4}{|c|}{$=0 \mathrm{de} 12 \mathrm{~B}$} \\
\hline & 1 & towandide & $i_{11}$ & t-wasarde & $u_{12}$ & $t-$ tasurdo & 111 & $t$-waingede & $i_{12}$ & to-Wiatar a d \\
\hline 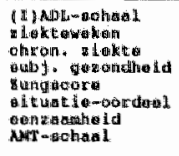 & $\begin{array}{r}1,000 \\
0.1055 \\
0,701 \\
1.053 \\
1.104 \\
0,957 \\
0.1893 \\
-0.006\end{array}$ & $\begin{array}{l}(12,0) \\
(10,2) \\
(11,0) \\
(16,2) \\
(11,0) \\
(12,2) \\
(6,3)\end{array}$ & $\begin{array}{l}1,000 \\
0,866 \\
0,6315 \\
0,722 \\
= \\
= \\
=\end{array}$ & $\begin{array}{l}(15,3) \\
(12,1) \\
(13,5)\end{array}$ & $\begin{array}{c}= \\
= \\
1,000 \\
0,8102 \\
0,810 \\
0,304\end{array}$ & 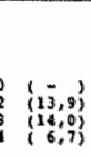 & $\begin{array}{l}1,000 \\
0,931 \\
0,576 \\
0,291 \\
= \\
=\end{array}$ & $\left(\begin{array}{l}1 \\
(1, \\
(1,6)\end{array}\right.$ & $\begin{array}{r}- \\
- \\
0.598 \\
1,000 \\
0,831 \\
0,324 \\
-0,312\end{array}$ & $\begin{array}{l}(9,6) \\
(1,5) \\
(14,7) \\
(1,6) \\
(6,1)\end{array}$ \\
\hline$l_{21}^{11}$ & $\begin{array}{c}0.353 \\
\cdots\end{array}$ & 10.80 & & $\begin{array}{l}0.576 \\
0.560 \\
0.131\end{array}$ & $\begin{array}{l}\left\{\begin{array}{l}11,1\} \\
10,7\} \\
11,0\}\end{array}\right. \\
(1,0)\end{array}$ & & & $\begin{array}{l}0.647 \\
0.550 \\
0.303\end{array}$ & $\begin{array}{l}(11,5) \\
(13,6) \\
(11,5)\end{array}$ & \\
\hline $\begin{array}{l}x^{2} \\
\text { The thagreation } \\
\text { wae I }\end{array}$ & $\begin{array}{c}410,36 \\
2,0 \\
0.758\end{array}$ & & & $\begin{array}{c}245,49 \\
10 \\
0.815\end{array}$ & & & & $\begin{array}{c}147,59 \\
18 \\
0,921\end{array}$ & & \\
\hline
\end{tabular}




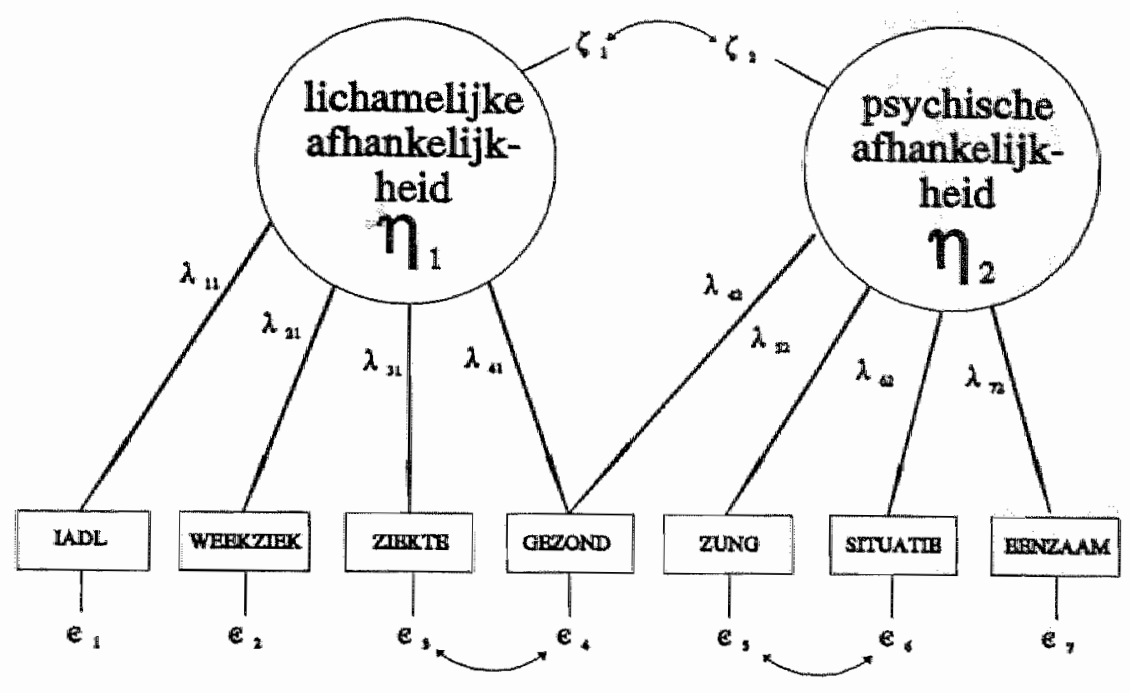

Figuur 15.3. Meetmodel voor afhankelijkheid

In tabel 15.13 worden de schattingsresultaten voor het meetmodel van afhankelijkheid gepresenteerd. Dit aangepaste model is geschat voor zowel het gehele bestand $(N=943)$ als voor de thuiswonende ouderen, inclusief de positief geindiceerden $(\mathbb{N}=579$ ). Bij de totale steekproef diende nog een covariantie in de matrix van storingstermen meegeschat te worden (tussen het oordeel over de gehele situatie en de (I)ADL-schaal: $\theta_{61}$ ) waardoor de $x^{2}$ verbeterde van $23,0(p=0,011)$ tot $8,62(p=0,47)$. De parameterschattingen voor beide modellen wijken nauwelijks van elkaar af op eén uitzondering na: de subjectieve gezondheidsbeleving wordt bij zelfstandig wonende ouderen in sterke mate verklaard door de lichamelijke afhankeiijkheid $\left(\lambda_{41}=0,50\right)$ en minder door psychische afhankelijkheid $\left(\lambda_{42}=0,41\right)$, terwijl dat in het gehele bestand (inclusief bejaardenoordbewoners en verpleeghuispatienten) precies omgekeerd is $\left(\lambda_{41}=0,28\right.$ en $\left.\lambda_{42}=0,50\right)$. Fieruit lijkt geconcludeerd te kunnen worden dat de psychische component in de gezondheidsbeleving belangrijker wordt naarmate men in 'zwaardere' settings verkeert.

Tabel 15.13. Meetmodel van afhankelijkheid voor hele bestand en zelfstandig wonenden

\begin{tabular}{|c|c|c|c|c|c|c|c|c|}
\hline & \multicolumn{4}{|c|}{ 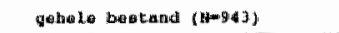 } & \multicolumn{4}{|c|}{ 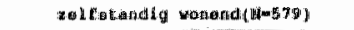 } \\
\hline & $a_{21}$ & E-wastites & $t_{21}$ & $t-\omega s i t c d \theta$ & 11 & 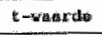 & $x_{21}$ & 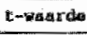 \\
\hline 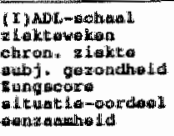 & $\begin{array}{l}4.900 \\
0,797 \\
0,1536 \\
0.279 \\
= \\
=\end{array}$ & $\begin{array}{l}\{1, y\} \\
\{13,9) \\
(11, n\} \\
(3,2)\end{array}$ & $\begin{array}{c}- \\
= \\
0,503 \\
1,000 \\
0 ; 909 \\
0,693\end{array}$ & $\begin{array}{l}(7,7) \\
(-5,) \\
(15,0) \\
(11,0)\end{array}$ & $\begin{array}{l}1,000 \\
0,009 \\
9,636 \\
0,501 \\
= \\
=\end{array}$ & $\left(\begin{array}{l}(-) \\
8,6) \\
7, y) \\
(4,8)\end{array}\right.$ & $\begin{array}{l}= \\
= \\
0,415 \\
y_{1}, 000 \\
0,678 \\
0,649\end{array}$ & $\begin{array}{r}5,5 y \\
(17,2) \\
0,4 y\end{array}$ \\
\hline $\begin{array}{l}1_{11}^{11} \\
n_{21} \\
0_{65} \\
0_{61}\end{array}$ & $\begin{array}{r}0,609 \\
0,659 \\
0,327 \\
-0,0,164 \\
0,416 \\
-0,089\end{array}$ & 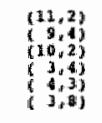 & & & $\begin{array}{r}0,466 \\
0,752 \\
0,303 \\
-0,207 \\
0,133 \\
-\end{array}$ & $\left\{\begin{array}{l}6,7) \\
3,3 y \\
8, z y \\
3,5) \\
3,7)\end{array}\right.$ & & \\
\hline$x^{2}$ & $\begin{array}{l}1,62 \\
10.9916\end{array}$ & $(p=0, n)$ & & & $\begin{array}{c}11,54 \\
0,591\end{array}$ & $(p=0,02)$ & & \\
\hline
\end{tabular}


Zonder hier ower een causaliteilsrelatie te kunnen spreken, blijkt er wel een samenhang te zijn tussen de twee latente wariabelen die als volgt benaderd kan worden (Bollen, 1989):

$$
\mathbb{R}^{2}\left(n_{1} \times n_{2}\right)=\frac{\Psi_{21}^{2}}{\Psi_{11} \Psi_{22}}
$$

De samenhang tussen beide dimensies van afhankelijkheid kan dan berekend worden alls 0,236 voor het gehele bestand en 0,298 bij de (nog) zelfstandig wonende ouderen. Hieruit wordt geconcludeerd dat het inderdaad zinvol is afzonderlijke dimensies te onderscheiden, dic in mindere mate onderling samenhangen dan de daarvoor gebruikte indicatoren.

De volgende stap in de analyse betreft het toewoegen van het structuurmodel. Op deze wijze wordt en zogeheten model met Multiple Indicators and Multiple Causes (MIMICmodel) opgezet (Jöreskog en Goldberger, 1975). De technische details van deze klasse van modellen kwamen reeds aan de orde in paragraaf 13.5 . In het structuurmodel zijn niet alleen de achtergrondkenmerken ${ }^{3}$ voor afhankelijkheid opgenomen, maar kunnen ook de relaties tussen de latente variabelen onderling worden gemodelleerd. Het gaat dan om het model $\mathrm{m}=\mathrm{B} \eta+\Gamma \mathrm{X}$, waarin $\eta$ staat voor de vector van latente variabelen en $\mathrm{X}$ de vector van (exogene) achtergrondkenmerken weergeeft. Als achtergrondkenmerken worden de volgende variabelen gespecificeerd (zie ook de bespreking van determinanten in hoofdstuk 14): leeftijd, waarvoor in ieder geval een positief effect op lichamelijke afhankelijkheid $\left(\eta_{1}\right)$ verwacht wordt, terwijl het voor de psychische afhankelijkheid $\left(\eta_{2}\right)$ goed mogelijk is dat het leeftijulseffect negatief is (Arts e.a., 1989; Maanen, 1985); sexe; sociaal-economische status, waarvoor een negatief effect op beide latente variabelen wordt verwacht; alleenstaand zijn, waarvoor in ieder geval een positief effect op psychische afhankelijkheid $\left(\eta_{2}\right)$ verwacht wordt; het aantal contacten (negatieve invloed op $\eta_{2}$ ); het gehoor en de mate van beweging die beide van positieve invloed op de beide latente variabelen zouden dienen te zijn.

Om de mogelijkheden van het MIMIC-model te bezien, worden de belangrijkste gebruiksvariabelen ingebracht. Hiervoor dient in LISREL een 'trucje' toegepast te worden door voor iedere voorziening een nieuwe latente variabele te maken en precies gelijk te stellen aan de feitelijke waarneming hiervoor, zonder een meetfout te specificeren, dus $\eta_{i}=y_{i}$.

Het model wordt verder ontwikkeld voor thuiswonende ouderen, waarbij de basisvoorzieningen de meest interessante zijn. Hiervoor zijn drie afhankelijke quasi-latente variabelen gemaakt, namelijk of de respondent niet of wel gebruik maakt van de gezinswerzorging $\left(\eta_{3}\right)$, of men niet of wel gebruik maakt wan wijkverpleging $\left(\eta_{4}\right)$ en of iemand niet of wel een positief advies voor opname in een bejaardenoord heeft $\left(\eta_{5}\right)$. Net als in het voorgaande betrefiten het derhalwe steeds dicotome uitspraken ower het gebruik van de belangrijkste basisvoorzieningen in de thuissituatie. Onderstaande legenda geeft de gebruikte symbolen en benamingen nog eens weer.

3. Bewiltist wordt hier geqproken over "achteirgrondkenmerken' In bet MIMIC-model zou eigenlijk gesparoken moeten wotden wan

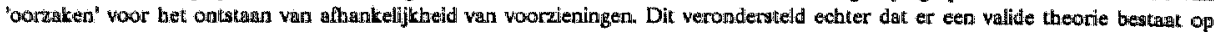
grond waarvan toetsbare bypothesed en cawsale relaties geformuleerd kunnen worden. Ben dergelijke alomvattende theorie is er echiter niet; zelifs het modtel wan Andersen en Newnan is slechis een model om de mogelijke determinanten te ordenen (zie bootdstuk 3), Bovendien zijp causale werbanden niet an te tonen op basis wan en dwarsmede op een moment; bilervoor is eem longitudinusi of een experimentele onderzoeksopzet met controfegroepen (bijkoorbeeld bij interventes) noodzakelijk. Wel maken aterte

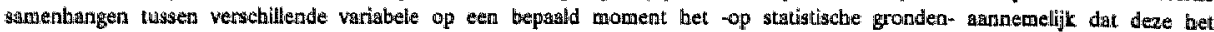

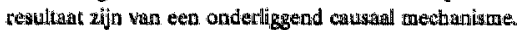




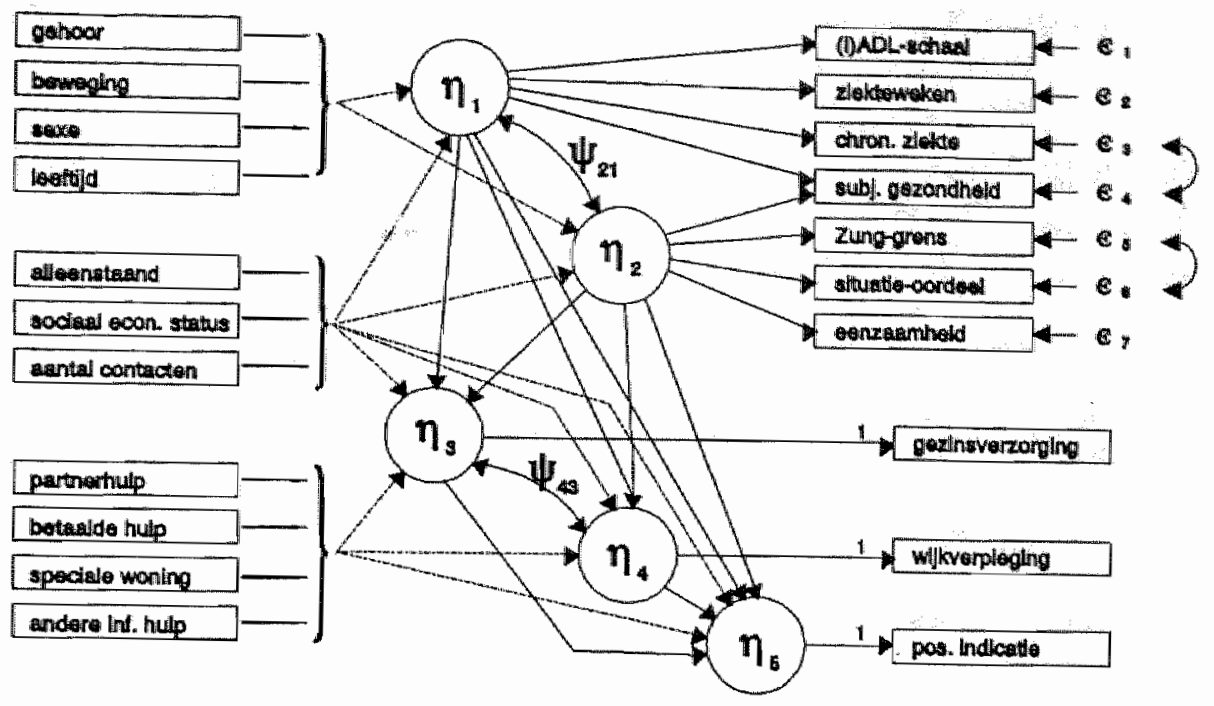

Figuur 15.4. Een volledig MIMIC-model voor thuiswonende ouderen

Legenda van gebruikte $\eta$-variabelen

$\begin{array}{ll}\eta_{1} & \text { lichamelijke afhankelijkheid (latente variabele) } \\ \eta_{2} & \text { psychische afhankelijkheid (latente variabele) } \\ \eta_{3} & \text { gebruik van gezinsverzorging (niet/wel) } \\ \eta_{4} & \text { gebruik van wijkverpleging (niet/wel) } \\ \eta_{5} & \text { positieve indicatie voor bejaardenoord (niet/wel) }\end{array}$

In figuur 15.4 wordt het MMIC-model grafisch weergegeven (voor de leesbaarheid is er voor gekozen om niet vanuit elk achtergrondkenmerk een pijl te trekken naar de verschillende $\eta$-variabelen, doch om dit per cluster te doen; dit betreft de niet-doorgetrokken pijlen). Het gepostuleerde model verdient nog verdere toelichting. Naast de eerder besproken achtergrondkenmerken voor afhankelijkheid wordt de verwachting gepostuleerd dat ook voor de gebruiksvariabelen enkele achtergrondkenmerken te benoemen zijn; onderzocht worden: informele hulpbronnen, betaalde particuliere hulp en de speciale woonvorm. De eerder genoemde achtergrondkenmerken voor beide dimensies van afhankelijkheid zouden ook van invloed op het gebruik kunnen zijn. Dit zal met name gelden voor het feit of iemand alleenstaand is en voor de sociaal-economische status.

Op grond van de eerder gepresenteerde regressie-analyses kunnen additionele assumpties opgesteld worden met betrekking tot de latente variabelen onderling (de $\mathbb{B}$-matrix). Ten eerste bleek dat zowel lichamelijke als psychische determinanten als gebruik van gezinsverzorging een belangrijke bijdrage leveren aan de verkJaring van een positief indicatieadvies. Vervolgens bleken gezinsverzorging en wijkverpleging kruiselings elkaar te verklaren, maar omdat het een cross-sectioneel onderzoek is, kan geen volgtijdelijk verband gelegd worden. In plaats daarvan wordt de covariantie tussen de storingstermen voor deze twee variabelen meegeschat $\left(\Psi_{43}\right)$. Een zelfde aanpak wordt gevolgd voor de twee latente 
Tabel 15.14. Schattingsresultaten structurele model (t-waarden tussen haakjes)

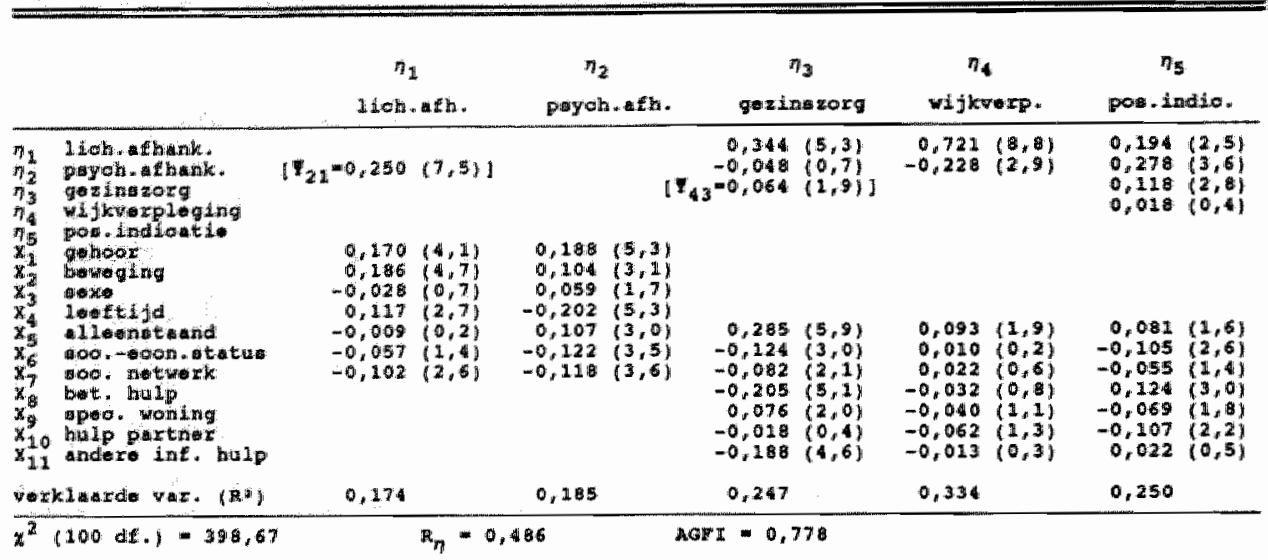

afhankelijkheidsvariabelen, omdal geen zinvolle causale relatie tussen beide te formuleren is (dus vrije parameter $\Psi_{21} ; \beta_{21}=0$ )

In tabel 15.14 worden de schattingen voor het structurele deel van het model gepresenteerd. De eerste vijf regels bevatten de schattingen voor de B-matrix en de rest die voor de r-matrix. Per kolom wordt voor iedere latente variabele aangegeven welke effecten daarop uitgaan van de exogene achtergrondkenmerken $\mathrm{X}_{i}$ en eventuele andere latente variabelen. Ten slotte wordt aangegeven hoeveel variantie per latente variabele door het model verklaard wordt.

In het algemeen valt op dat de resultaten een grote mate van overeenkomst hebben met die in de regressie-analyse van afzonderlijke voorzieningen. De lichamelijke afhankelijkheid $\left(\eta_{1}\right)$ heeft een significant positief effect op het gebruik van gezinsverzorging $\left(\eta_{3}\right)$, wijkverpleging $\left(\eta_{4}\right)$ en het verkrijgen van een positieve indicatie $\left(\eta_{5}\right)$. De psychische afhankelijkheid $\left(\eta_{2}\right)$ is niet van invloed op gezinsverzorging, is contra-indicatief voor het gebruik van wijkverpleging en van significant positieve invloed op het opname-advies, waarvoor gezinsverzorging bovendien als 'voorportaal' beschouwd kan worden, gezien de significante coefficient van $\eta_{3}$ op $\eta_{s^{*}}$ Deze relatie met het opname-advies is ook voor wijkverpleging positief, maar niet op een significant niveau. Als achtergrondkenmerken (hoewell een theoretisch kader hiervoor ontbreekt; zie boofdstuk 13) voor lichamelijke en psychische afhankelijkheid worden in beide gevallen significante positieve effecten gevonden van een slecht gehoor, verminderde beweging en de sexe van de respondent ( $\operatorname{man}=1$ en vrouw $=2$; zodat vrouwen een hogere athankelijkheidsgraad hebben, maar alleen bij de psychische afhankelijkheid significant). De leeftijd heeft een significant positief 'effect' op de lichamelijke afhankelijkheid, maar een significant negatief 'effect' op de psychische afhankelijkheid.

Het feit dat de oudere alleenstaand is, heeft significant positieve 'effecten' op de beide afhankelijkheidsdimensies en op het gebruik van gezinsverzorging, maar is in dit simultane stelsel van lineaire vergelijkingen niet meer van significante (wel positieve) invloed op het gebruik van wijkverpleging en het verkrijgen van een positief advies voor opname in het bejaardenoord. Een hogere sociaal-economische status leidt niet alleen tot significant minder gebruik van gezinsverzorging en een minder grote kans op een positief opname-advies, maar ook tot lagere waarden op beide afhankelijkheidsdimensies, hoewel niet significant op de lichamelijke component. Het aantal contacten heeft wel op beidle variabelen een significant negatieve invloed, als ook op het gebruik van gezinsverzorging. Een beter sociaal netwerk 
leidt weliswaar tevens tot een lagere kans op een opname-advies, maar niet op een significant niveau $(t=1,4)$. Net als in de afzonderlijke regressie-analyses vinden wij in het model bet substitutie-effect tussen gezinsverzorging en een particuliere, betaalde bulp terug. Ook conform de logistische schattingen is er een positief effect van de aanwezigheld van particuliere hulp op een opname-advies. Het bewonen van een ganleun- of bejaardenwoning gaat gepaard met een grotere kans op gebruik van de gezinsverzorging en een lagere indicatie-kans; beide effecten zijn bovendien significant. Informele hulp wordt tenslotte onderscheiden in hulp van de partner (significant bij wijkwerpleging en opname-advies) en het aantal andere informele bronnen (familie, buren, huisgenoten) dat aanwezig is (alleen significant negatief voor gezinsverzorging).

Ook in termen van verklaarde variantie verschilt het model niet veel van de regressieanalyses in paragraaf 15.3. De totale verklaarde variantie van de structurele vergelijkingen tesamen $\left(R^{2}\right)$ is 0,53 en de 'adjusted goodness of fit index bedraggt 0,8 . De $\chi^{2}$ is vrij hoog, maar deze toets wordt niet erg betrouwbaar geacht als de variabelen niet normaal verdeeld zijn (Bollen, 1989; Joreskog en Sorbom, 1981). Een oplosining is om te kijken naar de verhouding ten opzichte van het aantal vrijheidsgraden: "We judge a ratio (i.e.: $x^{2}$ gedeeld door het aantal vrijheidsgraden) of around 5 as beginning to be reasonable, based on our experience in inspecting sizes of residuals which accompany varying $\chi^{2}$ values" (Wheaton e.a., 1977 , p. 99). Omdat in het gepresenteerde model de ratio gelijk is aan circa 4 $(=398,7 / 100)$, lijkt het model redelijk bij de data te passen, ondanks het feit dat het op basis van de $\chi^{2}$-waarde formeel verworpen dient te worden.

\subsection{Effectsimulatie met betrekking tot voorzieningengebruik}

In de voorgaande analyses en tabel 15.14 werden alleen de directe effecten gerapporteerd. Veel variabelen beinvloeden echter ook langs indirecte weg andere wariabelen. Deze indirecte effecten dienen bij de directe effecten opgeteld te worden om de totale effecten the verkrijgen. Een voorbeeld kan illustratief werken: het feit of iemand alleenstaand is heeft directe effecten op de mate van lichamelijke en psychische afhankelijkheid en op het gebruik van gezinsverzorging; het totale effect van alleenstaand staan is dan gelijk aan: $\gamma_{35}$ $+\left(\gamma_{1 s} \cdot \beta_{31}\right)$. In figuur 15.4 worden met andere woorden alle mogelijke combinaties van pijlen vanuit 'alleenstaand zijn' (via andere variabelen) naar de te analyseren variabelen 'afgewandeld'. Om dit op zinvolle wijze te doen, dient wel uitgegaan te worden van de gestandaardiseerde schattingen. Deze worden gegeven in tabel 15.15 voor een aantal geselecteerde achtergrond- en latente variabelen.

Tabel 15.15. Gestandaardiseerde totale en direete effecten van de afhankelijkheidswariabelen en enkele x-variabelen op $\eta$ 's

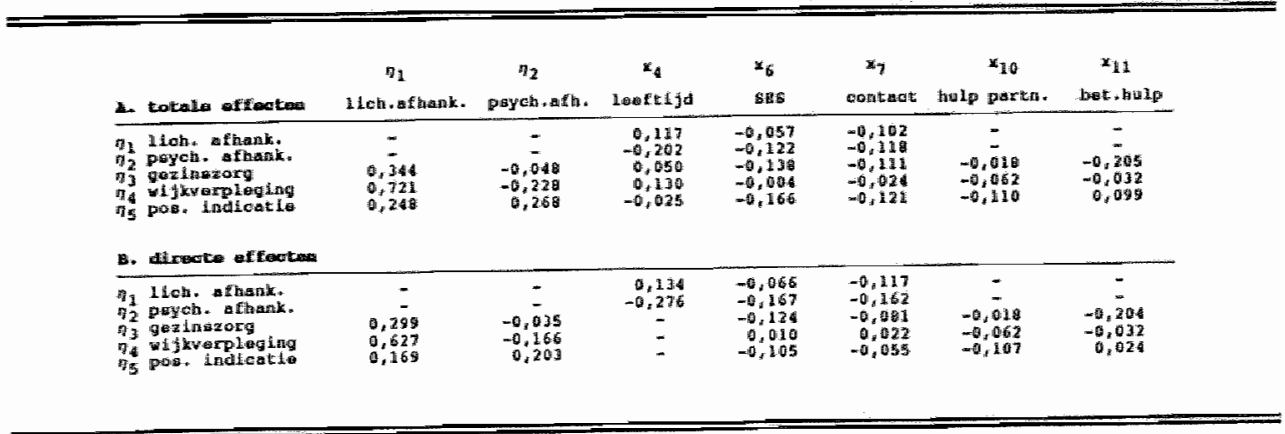


Bij de beoordeling van eventuele werschillen tussen directe en totale effecten dient bedacht te worden dat het model recursief is in de n-variabelen. Dit betekent dat $x$-variabelen die aan het begin van de 'ketting' van $\eta$-variabelen van inwloed zijn, geen verschil tussen directe en totale effecten kennen (bijwoorbeeld effecten van sociaal-economische status op affhankelijkheid). Nakmate de effecten van variabelen verder doorwerken in het model worat het verschil tussen directe en totale effecten groter (bijwoorbeeld effecten van leeftijd en sociale contacten). De grootste verschillen tussen directe en totale effecten worden in dit model aangetroffen bij de sociaal-conomische status en het aantal contacten. De effecten van het aantal sociale contacten worden in het totale model zodanig versterkt dat bij een positief indicatie-advies meer dan cen verdubbeling van het directe (negatieve) effect plaatsvindt.

Het model bied tenslotte de mogelijkheid om de trends in een aantal belangrijke variabelen in le brengen en te beoordelen op hun invloed op het gebruik van voorzieningen. Het puur demografische ramingsmodel uit de hoofdstukken 4 en 12 wordt hiermee uitgebreid met een simulatie-model voor de relevant geachte maatschappelijke ontwikkelingen. Omdat het MIMIC-model een lineair model is, kan worden gewerkt met de procentuele mutaties in de verklarende variabelen, die gesaldeerd moeten worden met de mutaties die op basis van het demografische model verwacht worden (in hoofdstuk 12 werd een gemiddelde toename in het gebruik geraand van ongeveer $2 \%$ per jaar). Als illustratie van de pottenties van het model worden simulaties gepresenteerd voor veranderingen in de achtergrondvariabelen van het MIMIC-model:

(a) een stijging wan de gemiddelde leeftijd binnen de populatie (als het ware de dubbele vergrijzing simulerend, naast de toename in het aantal ouderen uit hoofdstuk 2),

(b) een verbetering van de inkomenspositie van ouderen,

(c) een versterking van het sociale netwerk van ouderen,

(d) een uitbreiding van de inzet van particuliere betaalde hulp.

Als tijdshorizon wordt de eeuwwisseling aangehouden. Voor de vier zojuist aangegeven effecten die worden bestudeerd, zijn de volgende veranderingen tot 2000 te berekenen op grond vain nader te expliciteren veronderstellingen:

ad a. dubbele vergrijzing bimnen de populatie ouderen

Uit de verdeling van ouderen over de verschillende leeftijdscategorieen in hoofdstuk 2 (tabel 2.6) kan een toename in de gemiddelde leeftijd binnen de populatie van ouderen berekend worden van $1 \%$ in een periode van 13 jaar (1988-2000).

ad b. verbetering van de inkomenspositie

Indien verondersteld word dat het inkomen een én-op-een relatie heeft met de sociaaleconomische status (zie hoofdstuk 14), dan kan via deze modelvariabele het effect op voorzieningengebruik van een verbetering in de inkomenspositie gesimuleerd worden. De meest recente prognose met betrekking tot de inkomenspositie van ouderen is opgesteld door het Sociaal en Cultureel Planbureau (Pommer, 1990) en resulteert in een gemiddelde toename van (slechts) $0,4 \%$ per jaar. Er zijn echter veel onzekerheden, met name in de sfeer van vermogensinkomsten. De inkomensverbetering zal, afhankelijk van de berekeningswijze, nat schatting gemiddeld tussen de 0 en $0,8 \%$ per jaar bedragen (Pommer, 1990 , p. 35). Voor de periode $1988-2000$ kunnen daarom wellicht het beste drie varianten onderscheiden worden: (b1) een nul-variant; (b2) een gemiddelde variant van 0,4\% per jaar, hetgeen een totale toename van $4,9 \%$ in de onderzochte periode inhoudt en (b3) de maximum-variant op basis van een toename van $0,8 \%$ per jaar of $10 \%$ in de gehele periode tot het jaar 2000.

ad c. versterking sociaal netwerk

Over de mogelijkheden om een versterking van het sociaal netwerk van ouderen te bewerkstelligen, lopen de meningen witeen (zie bijwoorbeeld STG, 1985 en 1987) zodat geen goede 
inschatting is te maken over de veranderingen in het gemiddeld aantal sociale contacten van ouderen. In deze studie beperken wij ons tot een scenario waarin verondersteld wordt dat een versterking met $10 \%$ in de periode $1988-2000$ gerealiseerd wordt.

\section{ad d. vergroting inzet particullere betaalde hulp}

Het is aannemelijk dat een verbetering van de inkomenspositie van ouderen zal kunnen leiden tot een verschuiving tussen het gebruik van formele hulp, met name gezinswerzorging, en particuliere hulp; ook in deze studie wordt tussen beide een significante relatie aangetroffen (zie ook: STG, 1985). Ook kan een verscherping van de indicatie-criteria voor de gezinsverzorging, maar ook het bejaardenoord, er toe leiden dat hulpbehoevende ouderen naar alternatieven, waaronder particuliere betaalde hulp, gaan uitzien. Tenslotte is de markt in de ouderenzorg en meer in het algemeen in de gehele gezondheidszorg sterk in beweging en worden commeriele vormen van hulpvertening ontwikkeld. Samenvattend kan geconcludeerd worden dat er een trend lijkt te zijn in de richting van een toenemend gebruik van particuliere betaalde hulp. Uitspraken over de omvang hiervan zijn echter op weinig gronden gebaseerd, zodat ook hier -net als onder punt c- bij wijze van illustratie een toename van 10\% in de periode 1988-2000 wordt gepostuleerd.

Als illustratie van de mogelijkheden van het hiervoor ontwikkelde model wordt het gebruik van de gezinsverzorging en de wijkverpleging belicht en gaan wij in op de op grond van het model te verwachten ontwikkelingen in het aantal af te geven positieve adviezen voor een opname in het bejaardenoord. De werkwijze die daarbij gevolgd is combineert enerzijds de op demografische gronden en bij constant veronderstelde leeftijdsspecifieke bereikscijfers verwachte toename in het aantal clienten vanaf 65 jaar (zie tabel 12.2) met anderzijds de totale effecten zoals die op basis van de geschatte cosfficienten in het MIMIC-model berekend zijn (zie tabel 15).

Op deze wijze wordt voor gezinswerzorging op basis wan de demografische raming over de periode 1988-2000 een toename in het aantal cliènten verwacht van 24,4\% (zie tabel 12.2). De toename in de gemiddelde leeftijd heeft voor gezinsverzorging een te verwaarlozen effect $(0,05 \%)$. Het effect van een verbetering van de inkomenspositie (lopend via de achtergrondvariabele sociaal-economische status varieert van $0,7 \%$ in de middenvariant tot $1,4 \%$ in de maximumvariant. Dit betekent dat de hoogst geraamde inkomenswerbetering per saldo 5 a $6 \%$ van de op grond van demografische ontwikkelingen verwachte toename kan ombuigen. Op dezelfde wijze berekend, zou het effect van een verschuiving naar particulier betaalde hulp met $10 \%$ een effect op het gebruik van gezinsverzorging hebben dat lets. groter is, namelijk $2,1 \%$ (hetgeen neerkomt op een ombuiging van $8,6 \%$ op de demografische raming). Het effect van een versterking van het social netwerk van ouderen komt voor de gezinsverzorging uit op $1,1 \%$. Het totaal van de vier effecten tesamen bedragt naximaal $4,5 \%$ warmee ruim $18 \%$ van de geraamde demografische druk kan worden opgevangen.

Voor het gebruik van de wijkverpleging, uitgedrukt in het aantal clienten, komt de demografische raming over de periade 1988-2000 uit op een toename van 26,2\% (zie tabel 12.2). Dit kan worden niet worden gesaldeerd met een effect van een inkomensverbetering, omdat het effect van sociaal-economische status op het gebruik van wijkverpleging door ouderen werwaarloosbaar is $(-0,004$; zie tabel 15.15$){ }^{4}$ In tegenstelling tot de gezinsverzorging is bij wijkverpleging het effect van particuliere hulp niet groot; een toename daarvan met de gestelde $10 \%$ leidt tot een afname van $0,3 \%$. De toename in de gemiddelde leeftijd heeft

4. De verkjaring hervoor ligt warachijnlijt in bet feit dat er geen eigen bijdrageregelling of een ander "prijs:mechanisme" is; men betaaft gilechts een bescheiden lidmaalschap aan de kruisvereniging (in Maagtricht ongeweer 40 gulden; zie boofdstuk 7 ). 
wel effet op het gebruik van wijkwerpteging en wordt geraamd op 0,1\% (dit effect versterkt de demografische druk). Tot slot is ook het effect van een versterking van het sociaal netwerk (met $10 \%$ ) op het gebruik wan wijkwerpleging niet erg groot $(0,2 \%$ ). Samenwattend blikt het saldo van de bestudeerde effecten $(0,5 \%)$ niet of nauweliks van invloed te zijn op de uitkomsten van de demografische basisraming, die daardoor voor het gebruik van wijkverpleging door ouderen, gegeven het gehanteerde model van achtergrondwariabelen, als de enige relevante berekening overblijf (met daarbinnen natuurlijk wel de mogelijkheid om andere assumpties met betrekking tot de leeftijdsspecifieke bereikcijfers te maken).

Voor het aantal positief gelndiceerden voor opname in een bejaardenoord was in hoofdstuk 12 geen demogratische raming over de periode 1988-2000 gepresenteerd, omdat hierover in Maastricht geen leeftijdsspecifieke gegevens beschikbaar zijn. Wel kan een globale indicatie gegewen worden op basis van het total aantal positief geindiceerden in 1987 , uitgedrukt in procenten van het aantal 65-plussers; dit cijfer komt uit op 2,0\% (hoofdstuk 9). Veronderstellend dat dit gegeven (het lijkt wat vreemd om over het "bereik" van de indicatiecommissie te spreken) constant blijft in de periode $1988-2000$, kan een toename in het aantal positief geindiceerden berekend worden van 19,1\%. Op basis van tabel 15.15 worden de volgende effecten wan de bestudeerde achtergrondvariabelen berekend: ten gevolge van een inkomensverbetering $0,8 \%$ a $1,7 \%$; door de stijging van de gemiddelde leeftijd een verwaarloosbear effect $(0,025 \%)$ en door een versterking van het sociaal netwerk een effect van $1,2 \%$. Een uitbreiding van particuliere hulp heeft in dit model geen gunstig effect als de de realisatie daarvan zou worden overwogen als een van de instrumenten om de toeloop tot bejaardenoorden te verminderen $(-1,0 \%)$. Daardoor komt het totale effect van de veronderstelde veranderingen in de achtergrondvariabelen in deze berekening uit op slechts $1,9 \%$ (bij de maximumvariant van de inkomenswerbetering), hetgeen resulteert in een ombuiging van $10 \%$ van de demografische druk. Indien de uitbreiding van particuliere hulp buiten beschouwing blijft, dan is het totaal effect van de resterende veranderingen aanmerkelijk groter, namelijk een saldo van $2,9 \%$, gelijk aan $15 \%$ van de demografische druk.

De voorgaande simulaties van de mogelijke effecten van de verschillende veranderingen in achtergrondvariabelen van het model worden samengevat in tabel 15.16. Op grond van deze exercities lijkt de conclusie gewettigd dat maatschappelijke ontwikkelingen op inkomensterrein, op het gebied van betaalde hulp of het sociaal netwerk slechts een klein effect hebben op de demografische druk op voorzieningen, welke het gewolg is van de toename van het aantal ouderen in Nederland.

Tabel 15.16. Geraamde effecten op het gebruik van gezinsverzorging en wijkverpleging en laet aantal positief geindiceerden ten gevolge van wergrijzing en veranderingen in enkele achtergrondvariabelen

\begin{tabular}{|c|c|c|c|}
\hline \multirow[b]{2}{*}{$\begin{array}{l}\text { toename (In ) } \\
\text { ten gevolge van }\end{array}$} & \multicolumn{3}{|c|}{ relatiove toename in a antal } \\
\hline & $\begin{array}{l}\text { gezins- } \\
\text { verzorging }\end{array}$ & $\begin{array}{l}\text { Hijkver- } \\
\text { pleging }\end{array}$ & $\begin{array}{l}\text { poisutiaf } \\
\text { geindiceerden }\end{array}$ \\
\hline vargrifging van bovalking & 24,4 & 26,2 & 19,1 \\
\hline $\begin{array}{l}\text { otijging gemiddelde leeftifd met } 18 \\
\text { verbetering inkomen met } 4,98 \text { a } 10 \% \\
\text { veraterking bociaal netwerk met } 10 \\
\text { uitbreiding betalde hulp met } 108\end{array}$ & $0,7 \underset{1,1}{1,1}, 1$ & 0,1 & $\begin{array}{l}0,8 \bar{z} 1,7 \\
-1,2 \\
-1,0\end{array}$ \\
\hline a.1do van bestudeerde effecten* & 19,9 & 25,7 & 17,2 \\
\hline
\end{tabular}

* Uitgrande van maximunvariant foor inkomen. Kleine margea ten gevolge van afronding 


\subsection{Samenvatting en discussie}

In dit boofdstuk is gepoogd de verschillende onderdelen uit het onderzoek met elkaar te werbinden. De in hoofdstuk 14 ontwikkelde variabelen met betrekking tot de leefsituatie zijn hier als potentiele determinanten voor het gebruk van voorzieningen in beeld gebracht en geanalyseerd. Logistische schattingen voor het gebruik door ouderen van basisvoorzieningen en andere voorzieningen genereren wisselend goede resultaten. Het gebruik van de basisvoorzieningen (gezinsverzorging, wijkverpleging, positieve indicatie voor of feitelijk verbliff in en bejaardenoord en opname in het verpleeghuis) en van de gezondheidszorgvoorzieningen (zoals huisarts, specialist, ziekenhuis en medicingebruik) blijkt op acceptabele wijze verklaard te kunnen worden (percentage goed voorspeld gebruik is ongeveer 45 tot $50 \%$ en percentage goed voorspeld niet-gebruik is circa 90 tot $95 \%$ ). Daarbij zijn de volgende variabelen als de belangrijkste determinanten naar voren gekomen: het aantal (I)ADLbeperkingen, het feit of iemand alleenstaand is (bij gezinsverzorging en positief indicatieadvies), de psychische en lichamelijke gezondheidsindicatoren en de aanwezigheid van informele hulp door de partner of huisgenoot, familie, buren en/of vrienden (niet bij wijkverpleging).

Het gebruik van de overige voorzieningen die speciaal voor ouderen ontwikkeld zijn, kan niet op een bevredigende wijze verklaard worden: weliswaar wordt het niet-gebruik perfect voorspeld (100\%), maar het gebruik wordt nimmer goed verklaard. Naast het feit dat de gevonden aantallen gebruikers van deze voorzieningen zeer laag zijn, kan nog een aantal andere redenen aangedragen worden voor deze onbevredigende resultaten. Allereerst was het onderhavige onderzoek met name toegespitst op de basisvoorzieningen. In verband hiermee zijn de vragen over de overige voorzieningen zeer summier (alleen het gebruik over de afgelopen drie maanden en de vraag of men meer of minder wil gaan gebruiken). Ten derde kan het mogelijk zijn dat deze betrekkelijk nieuwe voorzieningen nog zo in ontwikkeling zijn, dat andere factoren dan de individuele indicatoren belangrijker zijn (zoals bijwoorbeeld het naar elkaar verwijzen tussen professionele organisaties). Tenslotte speelt bij dergelijke zeer lage bereikspercentages het probleem van multicollineariteit (dat wil zeggen dat veel determinanten onderling sterk verweven zijn) een veel grotere rol dan bij de basisvoorzieningen. De set van verklarende variabelen moet dan zorgvuldig gekozen worden om te woorkomen dat de iteratieve schattingsprocedure bij logistische regressie "vastloopt".

Het gebruik door ouderen van gezondheidszorgvoorzieningen bleek redelijk voorspeld te kunnen worden. De determünanten zijn veel sterker gericht op de somatische aspecten, hetgeen in de lijn der verwachting lag, maar ook is gebleken dat bij deze voorzieningen de onderlinge verwijspatronen een minstens even belangrijke rol spelen.

Twee innovatieve elementen in het onderzoek genereren interessante resultaten. Het eerste onderdeel betreft de constructie van een kostenvariabele op individueel niveau (zie paragraaf 15.4), die net als het voorzieningengebruik verklaard is uit de determinanten. De werklaringsgraad is bijzonder hoog $(0,68$ voor het gehele bestand; 0,33 voor thuiswonende ouderen) en wordt niet belinvloed door de mogelijkheid om de kosten voor gezondheidszorg (huisarts, fysiotherapie en specialist) al dan niet mee te rekenen. Hieruit wordt geconstateerd dat de kosten van de medische gezondheidszorg en de kosten van andere vormen van ouderenzorg in belangrijke mate parallel lopen. Het kostenconstruct biedt mogelijkheden on de huidige discussie met betrekking tot de stelselwijzigingen in Nederland te voeden met instrumentarium. Immers, op grond van de scores op de determinanten uit de leefsituatie zou nu een bedrag aan individuele ouderen kunnen worden toegekend, in plaats wan een woorziening ('zorgsubsidie').

Het tweede onderscheidende onderwerp betreft de constructie van een meet- en structuurmodel voor lichamelijke en psychische afhankelijkheid en de invloed daarwan op het gebruik 
van voorzieningen. Howel dit zogenaamde MMIC-model zich nog in een ontwikkelingsfase bevindt, zijn loch enige interessante zaken aan het licht gekomen. Ten eerste bleek in de constructie vin het meetmodel voor afhankelijkheid dat de subjectieve gezondheidsbeleving een duidelijke indicator is voor zowel lichamelijke als psychische athankelijkheid en dat deze laatste component belangrijker wordt naarmate de respondent zich in een 'zwaardere' setting bevindt. Het gebruik van basiswoorzieningen in een MIMIC-model woor thuiswonende ouderen wordt goed verklaard en geeft in hell algemeen dezelfde resultaten als afzonderlijke schattingen voor deze voorzieningen. Het voordeel van een MIMIC-model ligt echter in het feit dat ook de totaal-effecten van onafhankelijke variabelen in beeld komen als het gehele simultane model wordt doorlopen tot herleide vormvergelijkingen. Met name de totale effecten van socialal-economische status en sociaal netwerk op het gebruik van woorzieningen zijn in het MIMIC-model groter dan de aanvankelijke directe effecten.

Op basis van het model is bij wijze van illustratie een effect-simulatie gemaakt van veronderstelde verandering in vier achtergrondwariabelen, namelijk een toename van de gemiddelde leeftijd, een werbetering van de inkomenspositie van ouderen, een versterking van het sociaal netwerk van ouderen en een uitbreiding van particuliere betaalde hulp.

Voor deze veranderingen zijn berekeningen uitgevoerd voor de periode 1988-2000, uitgaande van onderzoeksresultaten voor de eerste twee achtergrondvariabelen (waarvoor op deze wijze in min of meerdere mate "harde" voorspellingen mogelijk zijn) en uitgaande van assumpties voor de andere twee achtergrondvariabelen (waarvoor dus gén voorspelling wordt gemaakt, mar een scenario met een enigszins arbitraire basis).

Voor de periode 1988-2000 werden de veranderingen als volgt (cumulatief) gekwantificeerd: de gemiddelde leeftijd stjgt met $1 \%$; het inkomen met maximaal $10 \%$, hoewel een middenvariant van 4,9\% zeer wel realiteit zou kunnen worden (Pommer, 1990); en de scenario's voor de versterking van het sociaal netwerk en uitbreiding van particuliere hulp gaan beide uit van $10 \%$. Op grond van demografische prognoses met betrekking tot voortschrijdende vergrijzing en uitgaande van constant blijvende bereikcijfers kan de demografische druk op de voorzieningen berekend worden voor de periode 1988-2000 (wederom cumulatief). Deze druk varieert van $19 \%$ voor het aantal positief gelndiceerden tot $26 \%$ voor het aantal clienten van de wijkverpleging. Per saldo zullen volgens de gepresenteerd berekeningen geen grote effecten verwacht mogen worden van de geraamde en anderszins veronderstelde veranderingen in de bestudeerde achtergrondvariabelen. Het saldo der effecten is nog het grootst voor gezinsverzorging, waar bijna een vijfde van de demografische druk zou kunnen worden omgebogen (vooral via inkomen en particuliere hulp). Bij het aantal af te geven positieve adviezen voor opnamen in bejaardenoorden is dat maar een tiende; hier zijn met name de maatschappelijke weranderingen op sociaal en sociaal-economische terrein van belang. Het uitbreiden van particuliere betaalde hulp heeft een averechtse uitwerking op de toeloop naar de bejaardenoorden via de indicatiecommissie dat qua omvang bowendien niet onbelangrijk is. Indien deze "maatregel" niet wordt meegenomen in de effectsimulatie, dan resulteert een ombuiging van de demografische druk van $15 \%$ in plaats van $10 \%$. Een verklaring voor het 'falen' van dit instrument voor het terugdringen van de vraag naar bejaardenoorden zou kunnen zijn dat het met name de lagere sociale klassen zijn die een dergelijke aanvraag doen (de analyses in dit en het vorige hoofdstuk ondersteunen deze hypothese), waardoor een "vluchtgedrag' naar het bejaardenoord ontstaat ten gevolge van de negatieve inkomenseffecten van mér betaalde particuliere hulp. Bij de wijkverpleging wordt slechts een miniem effect van het totale pakket aangetroffen (slechts $2 \%$ ombuiging van de vergrijzingsdruk); voor deze voorziening lijkt gemakshalve te kunnen worden volstaan met een puur demografische benadering. Bij dit alles is bovendien uitgegaan van de meest gunstige variant voor de inkomensontwikkeling.

Het voorgaande impliceert voor de overheid dat de belnvloedingsmogelijkheden, gericht op het verminderen van de demografische druk op het gebruik door ouderen van de in de 
analyse betrokken voorzieningen, niet erg groot zijn. Het zelide werd eerder (hoordstuk 4) en ook elders (Goudriaan, 1989 en 1990; Huijsman en De Klerk, 1989) geconcludeerd met betrekking tot de mogelijkheden van allerlei substitutie-vormen. Gesteld kan daarom worden dalt de kosten van de ouderenzorg hoe dan ook fors zullen toenemen; de tot op heden ontwikkelde substitutie-vormen en de gunstige invloeden wan een werbetering in de inkomenspositie, een versterking van het sociaal netwerk en een uitbreiding van particultere hulp zullen deze kostenstijging slechts in beperkte mate kunnen opvangen. Uitbreiding van particuliere betaal hulp als eventueel instrument om de toeloop op bejaardenoorden via de indicatiecommissie te verminderen, heeft een averechts effect dat qua omvang niet onbelangrijk is; als deze maatregel niet wordt meegenomen $i$. De grootste mogelijkheden die hier worden berekend betreffen het gebruik van de gezinsverzorging, waar ten hoogste bijna een vijfde van de op grond van demografische ontwikkelingen verwachte toename zou kunnen worden opgevangen door de combinatie van de veronderstelde effecten van de vier bestudeerde achtergrondvariabelen (leeftijd, inkomen, particuliere hulp en sociaal netwerk). Een minder gunstige inkomensontwikkeling dan hier voorgesteld (en niet op voorband uit te sluiten is; Pommer, 1990) zou een deel van de sturingsmagelijkheden echter weer teniet doen.

Verschillende relativerende kanttekeningen zijn echter op hun plaats. Zoals reeds eerder werd gesteld is het in 'open' sociale systemen zoals de ouderenzorg onmogelijk om deterministische en voorspellende uitspraken te doen. Voor dergelijke heuristische modellen worden in empirische onderzoek in het algemeen slechts magere verklaringsgraden aangetroffen, omdat de regelmaat laag is. Met enige voorzichtigheid kunnen slechts tendensen zichtbaar gemaakt worden, onder de stringente veronderstelling dat het model naar tijd en plaats constant blijft. Dit is echter bijna per definitie niet het geval in de ouderenzorg. Bovendien zijn de modelspecificaties gebaseerd op een lokaal onderzoek met specifieke eigenschappen ten aanzien van de samenstelling van de verschillende deelbestanden. Daarbij moet worden bedacht dat de onderzoekspopulathes werden voorgeselecteerd op een zekere mate van validiteit en/of voorzieningengebruik en dat de representativiteit van de verschillende deelbestanden niet altijd vast staat (zie paragraaf 13.6). Tevens is het onderzoek gebonden aan de lokale situatie en kenmerken van de ouderenzorg in z'n totaliteit; weliswal is het uitgevoerd in een redelijk grote gemeente, waarin alle relevante voorzienigen functioneren, maar het model kan waarschijnlijk niet zonder meer een landelijke geldigheid toegeschreven worden. Daarvoor is herhalde toetsing van het model noodzakelijk. Dit geldt bovendien te meer als de decentralisatie verder doorgevoerd wordt. Reeds nu bestaat immers op lokaal niveau de vrijheid am als indicatiecommissie eigen regels (waar deze vroeger wettelijk waren vastgellegd) te stellen bij de toelating tot bejaardenoorden. Ook de indicatiestelling voor thuiszorg kent zeer verschillende en regionaal of lokaal varierende verschijningswormen.

Ten slotte dient opgemerkt te worden dat er is uitgegaan van een lineair model; bij dynamisering van veranderingsprocessen zouden de cumulatieve effecten groter kunnen zjjn. 


\section{Algemene samenvatting en conclusies}

\subsection{Inleiding}

Deze studie is gebaseerd op de resultaten van het project Model van Voorieningen voor Ouderen dat in opdracht van de voormalige Stuurgroep Onderzoek Oudenwordende Mens (SOOM; thans via WVC) is uitgevoerd door de vakgroep Economie van de Gezondheidszorg van de Rijksuniversiteit Limburg. De leidende vraagstelling van dit onderzoek, dat plaatswond in de periode mei 1986 - december 1990, was of het mogelijk is een simulatiemodel van voorzieningen voor ouderen te ontwikkelen dat kan dienen als instrument voor de woorbereiding en evaluatie van maatregelen op bet terrein van het ouderenbeleid. Het onderzoek is uitgevoerd in de gemeente Mastricht, waar alle relevant geachte voorzieningen woor ouderen aanwezig zijn op een met de rest van Nederiand te vergelijken niweau. Het onderzoek wordt benaderd vanuit een economische invalshoek; de vraag voor de toekomst is daarbij boe binnen een bepaald financieel kader zo goed mogelijk kan worden aangesloten op de wensen en behoeften van ouderen. Voor de analyse zijn dan drie onderwerpen relevant, die de centrale thema's van deze studie opleveren. Ten eerste wordt onderzocht door welke factoren de mate van afhankelijkheid van zorgveriening bij ouderen wordt belnwloed. Ten tweede wordt bestudeerd op welke wijze voorzieningen aansluiten op de afhankelijkheid van ouderen. Tenslotte wordt bezien met welke inzet van personeel en/of andere middelen en tegen welke kosten de zorgverlening aan ouderen met een bepaalde mate van afhankelijkheid tot stand komt. Voor elk van deze drie centrale thema's zijn verschillende probleemstellingen geformuleerd.

Het eerste thema betreft de demografische ontwikkelingen en de invloed daarvan op het gebruik van voorzieningen door ouderen. De Nederlandse samenleving kenmerkt zich onder andere door een toenemend aantal ouderen ('vergrijzing") en binnen deze populatie neemt het aantal hoogbejaarden nog eens extra toe ('dubbele vergrijzing'). Hoewel ook in deze studie aangetoond is dat de vergrijzing een zeer geleidelijk proces is dat zich de komende decennia niet anders zal ontwikkelen dan in de jaren sinds de Tweede Wereldoorlog, is men over het algemeen bevreesd voor dle gevolgen van het absoluut en relatief toenemend aantal ouderen op met name de voorzieningen in de gezondheids- en welzijnszorg. Om dit thema te bestuderen zijn in hoofdstuk 1 de volgende probleemstellingen geformuleerd:

(1) Weike demografische trends ten aanzien van ouderen hebben zich tot op heden afgetekend ("dubbele' vergrijzing) en zullen zich in de nabjje toekomst voordoen?

(2) Hoe groot is, gegeven de demografische ontwikkelingen, het bereik van de belangrijkste voorzleningen in de ouderenzorg op nationaal en lokaal niveau?

De uitwerking van deze onderzoeksvragen vond plaats in hoofdstuk 2 (demografische trends), in hoofdstuk 4 (nationale inventarisatie van onder andere de bereikcijfers) en in deel B van deze studie (hhofdstukken $5 \mathrm{t} / \mathrm{m} \mathrm{12}$ ) waar voor de basisvoorzieningen voor ouderen (gezinsverzorging, wijkverpleging, gecoordineerd ouderenwerk, indicatiecommissie, bejaardenoorden, dagbehandeling en verpleeghuis) eveneens word ingegaan op de bereikcijfers daarwan in de gemeente Maastricht. Voor verschillende woorzieningen, zoals de gexinswerzorging, wordt het bereilk op het lokale niveau echter veel gedetalleerder in beeld gebracht dan in de nationale inventarisatie mogelijk bleek te zijn.

Het tweede thema betreft de individu-gebonden factoren die van invloed zijn op het gebruik van voorzieningen. Dit thema valt uiteen in twee onderdelen, namelijk (a) de kennis over de gezondheidstoestand en behoeften van ouderen en (b) de invloed daarvan op het gebruik 
van voorzieninger. Dit een uiterst relevante en noodzakelijke verbijzondering van het demografische model; naast de demografische kenmerken zoals leeftijd, sexe en burgerlijke staat, die in de bereikcjffers gebrukt worden, kunnen daardoor ook andere aspecten van de leefsituatie worden betrokken in de analyse wan bet gebruik van voorzieningen. Als overkoepelend denkconstruct werd het begrip "afhankelijkheid" of "dependency" gentroduceerd. Problecmstellingen die met betrekking tot dit thema zijn geformuleerd betreffen:

(3) Welke aspecten van de leefsituatie van ouderen kunnen worden aangemerkt als determinanten van het gebruik van voorzieningen door ouderen en welke operationalisering kan hiervoor worden gebruikt?

(4) Welke verbanden bestaan er tussen deze determinanten of hoe groot is de verwevenheid tussen de verschillende aspecten van de leefsituatie?

(5) Welke van deze determinanten leveren een daadwerkelijke bijdrage als indicatoren woor de afhankelikheid van ouderen in de verklaring van het voorzieningengebruik?

(6) Spelen naast deze determinanten ook nog andere factoren een rol, zoals verwijs. patronen tussen de voorzieningen?

Deze probleemstellingen worden voornamelijk op lokaal niveau bestudeerd en uitgewerkt in Deel $C$ op basis van gegevens van verschillende groepen ouderen in de gemeente Maastricht. Dit onderzoek werd uitgevoerd door de onderzoeksters Frederiks en Te Wierik en tevens ter beschikking gesteld van dit onderzoek.

Het derde thema betreft de structuur van de aanbodaijde van de ouderenzorg. Er is een gebrek aan kennis over het huidige zorgpatroon: door welke structuur wordt het huidige systeem gekenmerkt, hoeveel en welk soorten clienten gebruiken welke diensten, hoe verlopen de clientstromen tussen de voorzieningen en met welke inzet van middelen en kosten gaat het gebruik van voorzieningen, gedifferentieerd naar clientcategorieen, gepaard? Tevens is een functionele benadering van de ouderenzorg geintroduceerd om inzicht te krijgen in de dienstwerlening wan voorzieningen en de kostenopbouw. Voor het derde thema worden de volgende probleemstellingen opgesteld:

(7) Wat zijn de belangrijkste kenmerken van de verschillende clientgroepen in de ouderenzorg (zowel persoons- als hulpverleningskenmerken op individueel niveau)?

(8) Hoe verlopen de clientstromen naar, door en uit de verschillende voorzieningen?

(9) Wat zijn op voorzieningenniveau de 'inputs' in termen van personeel en andere middelen en de 'outputs' in termen van 'produktie' en kosten?

(10) Hoe groot zijn de huidige kosten van de ouderenzorg en welke toename kan daarin op grond van demografische ramingen worden werwacht?

(11) Welke zorgfuncties leveren de voorzieningen en zijn deze te kwantificeren?

Alleen probleemstelling 11 wordt uitsluitend op lokaal niveau belicht; de andere wraagstellingen worden, zij bet in wisselende mate van detaillering, zowel op nationaal als lokaal niveau bestudeerd.

De onderzoeksopzet kende een twee-sporen-aanpak: enerzijds is de aanbodzijde van de ouderenzorg geanalyseerd en zijn daartoe de verschillende voorzieningen voor ouderen onderzocht (met name gezinswerzorging, wijkverpleging, gecoordineerd ouderenwerk en bejaardenoorden; lets minder gedetailleerd de indicatiecommissie voor bejaardenoorden en het verpleeghuis) op nationaal niveau en in de gemeente Maastricht; anderzijds is een secundaire analyse gemaakt van de gegevens uit complementair onderzoek dat bij ouderen zelf gedaan is op basis van volledig gestructureerde, gesloten en zowel schriftelijke als mondelinge vragenlijsten (Frederiks e.a., 1988; Te Wierik en Frederiks, 1988, 1990; Frederiks, 1990). Dit boek bevat ten behoeve van de tweede onderzoekslijn een secundaire analyse van gegevens over thuiswonende, eventueel positief gelndiceerde ouderen, bejaardenoordbewoners en recent opgenomen verpleeghuispatienten. Beide onderzoekslijnen worden in dit hoofdstuk bij wijze van samenvatting van de gehele studie belicht. 


\subsection{Onderzoekslijn 1: de aanbodzijde van de ouderenzorg}

Primair uitgangspunt bij de analyse van voorzieningen in de gemeente Maastricht was de idee dat de instellingen veel materiaal beschikbaar hebben via de tegultere informatiesystemen. Om daarin structuur aan te brengen is een eigen instellingsenquete ontwikkeld, die als instrument voor dossiervorming dienstig bleek te zijn. De ervaring na vier jaar onderzoek is echter dat er problemen kunnen ontstaan zodra er vragen gesteld worden die buiten de reguliere informatiestromen om gaan. Mogelijk heeft de vrijwilligheid van deelname aan het onderzoek hierbij een rol gespeeld; anderzijds is het mogelijk dat de deelname voor individuele instellingen te weinig direct rendement oplevert. Als dit in de loop van het onderzoek wel zichtbaar werd leverde dat vaak een nieuwe impuls op. Zo is voor de gezinsverzorging een wijkbudgetteringsmodel in ontwikkeling en kregen de bejaardenoorden eind 1989 weer interesse in het onderzoek. Gesteld kan worden dat de beleidsrelevantie van (de gegevens uit) informatiesystemen in de gezondheids- en welzijnszorg niet altijd in voldoende mate erkend wordt; in sommige gevallen is zelfs sprake van het fenomeen 'data-kerkhof.

Het meest problematische onderdeel bleek de kwantificering van de personeelsinzet naar functies van ouderenzorg te zijn. De gepresenteerde gegevens (zie hoofdstuk 5 en 12) zijn daarom tentatief, hoewel de uitkomsten ongeveer overeen komen met suggesties van andere auteurs. Ook blijkt het op instellingsniveau, mede door de bepaald niet optimale informatiesystemen in de verschillende zorgsectoren, niet altijd mogelijk te zijn om de zorgverlening en de daaraan verbonden kosten te verbijzonderen naar afhankelijkheidsgroepen. De beste resultaten ten aanzien van dit onderwerp zijn behaald bij de gezinsverzorging en de bejaardenoorden. Door allerlei problemen met de gegevens. verzameling bij instellingen die ten behoeve van ouderen werkzaam zijn, is tijdens het onderzoek relatief veel energie in deze onderzoekslijn gestoken. Deel B van het proefschrift doet daar verslag van. Per voorziening worden hier de meest saillante resultaten belicht.

Bij de gezinsverzorging (hoofdstuk 6) is wooral gebruik gemaakt van het sinds 1986 volledig operationele geautomatiseerde informatiesysteem, waarin een koppeling plaats vindt van individuele clientgegevens (LIER-systeem) en administratieve gegevens inzake retributies en produktieve hulpverlening. Deze extramurale voorziening wordt meer en meer een basisvoorziening voor ouderen: bij traditionele gezinswerzorging bestaat $85 \%$ en bij alphahulp zelfs bijna $100 \%$ uit ouderen (65-plus). Dit betreft met name alleenstaande, ongehuwde ouderen (met een bereik van ruim $11 \%$ ) en dan met name alpha-hulp. Over het algemeen bevinden de clienten zich in lage inkomensgroepen: $65 \%$ van de 65 -plus clienten heeft de AOW als maximum inkomen (de sociaal-economische status komt in deel $\mathrm{C}$ ook terug als een significante negatieve determinant voor het gebruik van gezinsverzorging). De duur van de hulpverlening is bij ouderen over het algemeen lang (ongeveer 4 jaar) en beslaat gemiddeld ruim 5 produktieve uren per week tegen ongeveer $f 30$,- per traditioneel hulpuur of $f 20$,- per alpha-hulpuur. Naarmate men ouder wordt, krijgt men meer hulp en wordt het aandeel van de puur huishoudelijke alpha-hulp kleiner.

Ten behoeve van de analyse van het gebruik van wijkverpleging (hoofdstuk 7) is het wijkadministratiesysteem (het WAS) van het kruiswerk benut (periode 1984-1988). Ouderen vormen ongeveer $1 / 3$ van het clientenbestand en leggen beslag op bijna $80 \%$ van alle contacten. Ook bij Ouderen komt een eenmalig contact op jaarbasis nog vrij vaak voor (20\%), doch bijna de helft heeft meer dan 10 contacten. Het gemiddelde aantal per jaar ligt op ongeveer 35 contacten per oudere, die gemiddeld ruim 2 jaar in zorg blijft. Het bereik van wijkverpleging ligt op 14,5\% van alle 65-plussers als uitgegaan wordt van clienten of op 5,2 contacten per oudere inwoner. De groep clienten die in de onderzochte periode van 5 jaar continu in zorg was, is in aantal niet groot (7\%), maar legt beslag op bijna $30 \%$ van de capaciteit. Ouderen zijn in deze groep zeer belangrijk ( $90 \%$ van de contacten) en hebben 
gemiddeld ongeveer 80 contacten per persoon op jaarbasis. Deze contacten zijn hoofdzakelijk van lichamelijk-verzorgende aard (65\%) en voorts betreft het verpleegkundige handelingen en het toedienen van medieijnen (elk ongeveer $13 \%$ ). In de loop van de onderzochte periode wordt, net als landelijk, een intensivering van de zorg, gepaard aan een verschuiving naar meer bewerkelijke handelingen zoals lichamelijke verzorging vastgesteld. Als kostprijs wordt een gemiddelde van $f 55$,- per contact aangehouden (een contact duurt inclusief reistijd, administratie en dergelijke ongeveer 40 minuten).

Het bereik van de dienstencentra van het gecoordineerd ouderenwerk (hoofdstuk 8 ) ligt op circa $3 \%$ van alle 65 -plussers en stijgt tot de leeftijd van $75-79$ jaar om vervolgens te dalen; daarnaast is er nog een niet onaanzienlijk deel van de bezoekers (circa 30\%) dat jonger is dan 65 jaar. Bijna 70\% van de bezoekers is vrouwelijk en hoewel alleenstaanden net de minderheid vormen ( $47 \%$ ), is het bereik ten opzichte van de bevolking voor deze subgroep groter $(3,2 \%)$ dan voor samenwonenden (bijna $2,5 \%)$. De gemiddelde bezoekfrequentie is twee maal per week en, net als het bereik, hoger naarmate de leeftijd hoger is. De belangrijkste reden voor het bezoek betreft gezelligheid, recreatie of andere ontspanning, maar ook het nuttigen van een maaltijd ( $8 \%$ van de bezoekers) en deelname aan Meer Bewegen voor Ouderen (9\%) worden relatief vaak gerapporteerd door de circa 700 respondenten van een onderzoek in de eerste helft van 1988. Tevens is bij hen het gebruik wan andere voorzieningen onderzocht, namelijk gezinsverzorging, wijkverpleging en wijkfuncties van bejaardenoorden. Een vijfde rapporteerde gebruik van eén van deze voorzieningen en nog eens ruim $3 \%$ gebruik van meer dan de genoemde voorzieningen. Gezinsverzorging komt bij tweederde van de gebruikers voor; wijkverpleging daarentegen nauwelijks en bovendien slechts in combinatie met gezinsverzorging. Het voorzieningengebruik is bij de alleenstaande bezoekers van dienstencentra drie maal zo groot als bij samenwonenden.

De indicatie-commissie (oude-stijl) is slechts kort aan bod geweest (hoofdstuk 9), omdat het informatie-systeem dat daar gehanteerd werd niet erg uitgebreid is. Per jaar wordt aan bijna $2 \%$ van alle ouderen in Maastricht een positief advies tot opname in het bejaardenoord verstrekt. Deze opname wordt na ongeveer gemiddeld 8,5 maand gerealiseerd. Het tot eind 1989 gevolgde gezamenlijke opnamebeleid beeft hier gunstige effecten gehad: de criteria zijn verder verscherpt tot de meest urgente gevallen, de wachttijd is afgenomen (was eerst meer dan een jaar), de doorstroom in de sector is verbeterd (hoewel na ongeveer 5 jaar dit effect weer grotendeels is weggelekt) en er zijn geen significante verschillen meer tussen de 'nieuwkomers' in de verschillende instellingen (alle 11, op een kleine instelling na, hebben aars het onderzoek meegewerki!). Met enige veronderstellingen (zie hoofdstuk 9), worden de gemiddelde kosten per verstrekt advies op ongeveer $f 350$,- geraamd.

De bejaardenoorden zijn in twee stappen geanalyseerd: globale bereikcijfers, gegevens met betrekking tot de herkomst bij opname en bestemming bij ontslag, wijkfuncties, personeelsinzet en kosten werden gepresenteerd voor de periode 1984-1988 (hoofdstuk 10); de op individueel niveau verzamelde kenmerken van bijna alle bewoners (demografische variabelen, validiteit en psychisch functioneren) van de tehuizen werden aan een meer gedetailleerde analyse onderworpen (hoofdstuk 10). Deze analyse wordt nu kort samengevat.

Voor bejaardenoorden zijn individuele meerzorggegevens en personeelsbeoordeling over de psycho-sociale toestand (via de zogenaamde BPS-lijst) van 1100 bewoners gecombineerd tot een classificatie in zes groepen. Ongeveer $30 \%$ van de bewoners heeft nauwelijks individuele meerzorg nodig, maar aan de andere kant is er een groep van ongeveer $14 \%$ die bijna 2,5 uur meerzorg per dag nodig heeft en daardoor een potentiele doelgroep voor het verpleeghuis lijkt te zijn. Op basis van de classificatie is een gedifferentieerde kostprijsberekening naar zes afhankelijkheidsgroepen mogelijk geworden waar voorheen slechts een globaal gemiddelde kostprijs per dag in het bejaardenoord beschikbaar was. De gemiddelde kosten bedragen ongeveer $f 81,60$ per dag en bestaan voor ruim $60 \%$ uit personeelslasten. 
Het werpleeghuis (hoofdstuk 11) is eveneens op basis van schriftelijk materiaal wan de instelling zelf geanalyseerd. De bevindingen wijken nauwelijks af van landelijke gegewens die in hoofdstuk 4 worden gepresenteerd. Ruim $90 \%$ van alle patienten bestaat uit 65 -plussers, zodat de gemiddelde leeftijd met 80 jaar hoog is. Het bereik loopt op van $1 \%$ voor de jongste categorieën tot $9 \%$ bij 85 -plus. Het gemiddelde tarief bedraagi $f 202,50$ per dag bij opname en $f$ 122,- per dag bij dagbehandeling en bestaat voor $70 \%$ uit personee:slasten.

In het samenvattend hoofdstuk bij deel A (hoofdstuk 12) wordt het leeftijdsspecifieke gebruik van de besproken voorzieningen gepresenteerd en benut om op basis van demografische ramingen voor het jaar 2000 inzicht te krijgen in de mogelijke ontwikkelingen in het gebruik van voorzieningen voor ouderen. Door dubbele vergrijzing zal met name de capaciteit van gezinsverzorging, wijkverpleging, bejaardenoorden en verpleeghuizen sterker moeten groeien (gemiddeld ongeveer $2 \%$ per jaar) dan de aanwas in het aantal oudere inwoners (circa 1,5\% per jaar). De kosten van ouderenzorg (waarbij de gezinsverzorging, de wijkverpleging, het GOW, de bejaardenoorden, het verpleeghuis, het flankerend beleid en de dagbehandeling zijn inbegrepen) bedragen in de gemeente Maastricht thans ongeveer 72,4 miljoen gulden, waarvan driekwart ten laste van de intramurale zorg komt (landelijk ruim $80 \%$ ). Voor een enigszins tentatieve, maar illustratieve, benadering van de kostenverbijzondering naar 10 zorgfuncties, wordt verwezen naar paragraaf 12.4.

\subsection{Onderzoekslijn 2: de vraagzijde van de ouderenzorg}

Empirisch onderzoek naar de leefsituatie van ouderen in het algemeen en naar de determinanten voor het gebruik van voorzieningen in het bijzonder wordt gekenmerkt door een exploratief karakter omdat een theoretisch kader zo niet ontbreekt dan toch zwak ontwikkeld is. Veel onderzoek is gebaseerd op het conceptuele model van Andersen en Newman (1973), waarin verschillende theoretische invalshoeken geintegreerd worden. Vanwege het feit dat de ouderenzorg zich laat karakteriseren als een 'open' sociaal systeem (Boudon, 1986), is de mate van regelmaat en de voorspelbaarheid daarvan per defitie relatief laag, omdat er relatief veel wanorde of systeem-ruis is (Becker, 1989). Het is dan ook niet voor niets dat de verklaringsgraad die in empirisch onderzoek naar voorzieningengebruik wordt aangetroffen niet zo groot is (Klaassen-Van den Berg Jeths, 1989; Picauly, 1987). Ook het onderhavige onderzoek waarover in deel C van deze studie verslag gedaan wordt, is te kenschetsen als een exploratief empirisch onderzoek. Het betreft een uitgebreide secundaire analyse van gegevens over diverse groepen ouderen in de gemeente Maastricht, die complementair aan het onderhavige project verzameld zijn door onderzoek(st)ers van de vakgroep Epidemiologie van de Rijksuniversiteit Limburg (Frederiks, 1990; Frederiks e.a., 1988; Te Wierik en Frederiks, 1989 en 1990). De vier groepen ouderen die geanalyseerd zijn, betreffen: (a) thuiswonende ouderen met tenminste twee huishoudelijke of een algemene beperking in het dagelijks functioneren of gebruikmakend van extramurale voorzieningen of daartoe de wens uitend $(\mathrm{N}=415$; geselecteerd voor mondelinge interviews op basis van de resultaten van een grootschalige schriftelijke enquete onder circa 2450 thuiswonende ouderen; Frederiks en Te Wierik, 1989); (b) ouderen die een positief advies hebben gekregen voor opname in een bejaardenoord $(\mathrm{N}=164)$; (c) bejaardenoordbewoners $(\mathrm{N}=206)$ en (d) ouderen die op het punt staan om opgenomen te worden of recent zijn opgenomen in het verpleeghuis $(\mathrm{N}=158)$. Het laatste deelbestand is om verschillende redenen enigszins problematisch (zie hoofdstuk 13), maar toch in de analyse betrokken. De gegevens zijn niet zonder meer te generaliseren naar de gehele bevolking. Naast de gebruikelijke representativiteitsproblemen, waarop hier niet verder wordt ingegaan (zie publicaties van oorspronkelijke onderzoeksters Frederiks en Te Wierik en hoofdstuk 13 van dit boek), speelt bij ouderen die (nog) thuis wonen het onderzoeksontwerp een belangrijke rol. Deze groep is immers via een postenquête geselecteerd op een antal criteria, waardoor 
per waldo $32,9 \%$ wan de respondenten van deze enquete in aanmerking kwam. Van deze potentiele groep heeft $71,4 \%$ meegewerkt aan de mondelinge vragenlijst. Als werondersteld wordl dat er geen selectieve non-respons heeft opgetreden, noch bij de postenquete, noch bij het mondelinge verwolg darop, dan kan worden aangenomen dat het determinantenonderzoek niet beinvloed wordt door de steekproefcriteria. Wel dient natuurij|k voor bet verrichten van simulaties een vertalalag gemaakt te worden om het bereik van voorzieningen in de totale populatie te berekenen (door te vermenigvuldigen met ongeveer een derde). Een andere oplossing kan zijn om met procentuele mutaties te werken; deze pragmatische aanpak is in deze studie gevolgd.

Er is in Deel $C$ relatief veel aandacht besteed aan de determinanten voor het gebruik van voorzieningen. Achtereenvolgens is ingegaan op demografische kenmerken, (I)ADLbeperkingen, overige (lichamelijke) gezondheidsindicatoren, psychisch functioneren, woonsituatie, socialal-economische status, sociaal netwerk en informele hulp. Voor elk van de acht besproken clusters van determinanten werd een overzicht gegeven van de literatuur, werden de onderlinge verbanden binnen het betreffende cluster besproken, op grond waarvan een beperkt aantal representatieve variabelen geselecteerd is (in een aantal gevallen voldoen deze aan stringente schaaleisen a la Rasch) en werd inzicht gegeven in de significantie van verbanden tussen determinanten uit de verschillende clusters (ze hoofdstuk 14).

Op basis van de inzichten uit de literatuur met betrekking tot (a) de relevante aspecten in de leefsituatie van ouderen, (b) de belangrijkste indicatoren daarvoor, (c) de operationalisatie daarvan ten behoeve van betrouwbare en valide variabelen c.q. potentielle determinanten sterke en (d) de onderlinge samenhangen tussen zowel de determinanten onderling als in relatie tot gebruikspatronen in de ouderenzorg, is een selectie gemaakt van een verzameling van ongeveer 25 potentiele determinanten. Deze zijn vervolgens benut om te bezlen welke bijdrage zij daadwerkelijk leveren aan de verklaring van het gebruik van voorzieningen door ouderen. Daarbij werden drie clusters van voorzieningen onderscheiden, namelijk de basisvoorzieningen (gezinsverzorging, wijkverpleging, positief advies voor en feitelijke opname in het bejaardenoord en verpleeghuis), de overige voorzieningen die speciaal voor ouderen ontwikkeld zijn (GOW, maaltijdvoorziening, SGD, dagverzorging in het bejaardenoord en dagbehandeling in het verpleeghuis) en alls derde de voor elke burger algemeen toegankelijke gezondheidszorgvoorzieningen (huisarts, specialist, ziekenhuis, fysiotherapie en tenslotte medicijnengebruik). Omdat bijna alle gebruiksvariabelen dichotoom zijn, is logistische regressie-analyse toegepast. De resultaten hiervan zijn kort aan te duiden. Het gebruik van de basisvoorzieningen wordt in het algemeen goed verklaard (percentage correct voorspeld gebruik varieert van bijna $40 \%$ bij wijkverpleging tot ruim $50 \%$ bij het bejarardenoord). De belangrijkste determinant is in de eerste plaats de (I)ADL-schaal (Rasch-type), waarmee meer dan de helft van de verkJaarde variantie tot stand gebracht wordt. Het feit dat iemand alleenstaand is verkJaart voorts het gebruik van gezinsverzorging en het bejaardenoord. De leeftijd is van significant positieve invloed op wijkverpleging, positief advies woor en feitelijke opname in het bejaardenoord, maar negatief voor het verpleeghuis. Dit laatste wordt wellicht mede veroorzaakt door de steekproefkarakteristieken. Van de overige (lichamelijke) gezondheidsindicatoren levert het aantal weken dat men in het afgelopen jaar door ziekte 'geveld' was, veelal een significante bijdrage aan het verklaringsmodel (uitgezonderd bij het bejaardenoord), maar bij de gezinsverzorgüng betreft dat een negatieve bijdrage (hoe langer men ziek is, hoe kleiner de kans op gebruik van gezinsverzorging). Wijkverpleging is ook significant vaker aanwezig als er sprake is van een chronische ziekte. Psychische factoren, zoals de Zung- en AMT-score, de subjectieve gezondheid ten opzichte van leeftijdsgenoten en hel oordeel over de gehele situatie, spelen vaak een significante rol, uitgezonderd bij gezinsverzorging, maar in wisselende combinaties, zodat er niet eén als meest belangrijke kan worden gekenmerkt. De onderlinge correlaties tussen deze psychische determinanten is overigens erg groot, uitgezonderd de AMT-score. 
De sociaal-economische status is van negatieve invloed op het gebruik wan gezinsverzorging en het bejaardenoord. De determinanten met betrekking tot bel sociale netwerk en de woonsituatie leveren over het algemeen geén significante bijdrage aan het voorzieningengebruik. Daarop bestaat ến uitzondering: ouderen in een spectaal voor hen bestemde woning gebruiken over hel algemeen vaker gezinswerzorging en hebben minder valk een positieve indicatie voor het bejaardenoord. Informele hulp blijkt niet van belang te zijn bij de keuze van wijkverpleging, naar wel bij het gebruik van gezinsverzorging (negatief effect van hulp door huisgenoot of familie (niet door partner) en negatier voor betalde particuliere hulp), het afgeven van een positief opname-advies (negatief effect van partnerhulp en positief effect van particulier betaalde thulp) en de opname in het verpleeghuis (negatieve effecten van betaalde hulp en hulp van huisgenoot).

Hel gebruik wan de speciaal voor ouderen ontwikkelde voorzieningen kont in de geanalyseerde onderzoekspopulatie nauwelijks voor (ongeveer 1,5\% beeft dagverzorging, dagbehandeling of SGD-hulp). Ook in de praktijk kennen deze relatief nieuwe en vaak sterk gespecialiseerde voorzieningen lage bereikcijfers. In de stapsgewijze logistische regressieprocedure wordt weliswar een aantal determinanten geselecteerd (met name het aantal ziekteweken, informele hulp van partner of huisgenoot met een positief, kennelijke het thuismilieu ondersteunend effect), maar de verklaarde variantie is laag. De zeer kleine aantallen gebruikers zijn hieraan wellicht debet. Een andere verklaring kan het feit betreffen dat de indicatiestelling voor deze relatief nieuwe voorzieningen wellicht nog niet volledig is uitgekristalliseerd, zodat andere dan de in deze studie opgenomen factoren van invloed zijn op de beslissing van dit type 'tussenvoorzieningen' gebruik te maken. Daarbij kan onder meer gedacht worden aan (afspraken over) doorverwijzingen tussen de verschillende organisaties in de ouderenzorg.

Het gebruik van algemeen toegankelijke gezondheidszorgvoorzieningen blijkt ook voor ouderen op acceptabele wijze verklaard te kunnen worden, maar naast de onderscheiden determinanten, zijn de onderlinge verwijspatronen tussen buisarts, specialist en ziekenhuis minstens even belangrijk. De (I)ADL-schaal speelt in de verkiaring geen rol, hetgeen tevens geldt voor de variabelen met betrekking tot het sociaal netwerk, de woonsituatie en informele hulp. Dit ligt in de lijn der verwachtingen. Naast gezondheidsindicatoren zoals het aantal ziekteweken zijn echter wel de psychische determinanten relevant.

\subsection{Een verbijzondering: de individuele kostenvariabele}

Op basis van de kostprijzen die in de aanbodinventarisatie (deel B van dit proefschrift) afgeleid werden, is een individuele kostenvariabele geconstrueerd waarin allerlei combinaties van zorgverlening in geld zijn uitgedrukt. Ook voor de verzorging in het bejaardenoord is een gedifferentieerde kostprijsberekening gehanteerd uitgaande van zes groepen (drie (I)ADL-klassen, met of zonder psycho-sociale probiemen). Met behulp van gewone kleinste kwadraten-schattingen is, analoog aan de analyse van voorzieningengebruik, de verklaring gezocht in de set van determinanten. De verklaringsgraad is hoog (ongeveer $50 \%$ voor de gehele onderzoekspopulatie en $33 \%$ voor thuiswonende ouderen) en veelal beter dan de verklaring van afzonderlijke woorzieningen. Ook voor de kosten is de (I)ADL-schaal verreweg de belangrijkste determinant, gevolgd door alleenstaand zijn (positieve invloed), de AMT-score, het bewonen van een speciaal voor ouderen bestemde woning en (met name bij thuiswonende ouderen) alle vormen van informele en particuliere hulp (alle van significant negatieve invloed op de kosten van ouderenzorg). De kostenvariabele bleek nauwelijks gevoelig te zijn voor het al of niet opnemen van de kosten voor huisarts, specialist en fysiotherapie. Deze kosten lopen derhalve parallel aan de kosten voor gezinsverzorging, wijkverpleging en dergelijke. Inhoudelijk verdient de kostenvariabele 
tenslotte in het kader van de ontwkkelingen met betrekking tot budgettering en individuele zorgubsidies zeker verdere (onderzoeks-) aandacht.

\subsection{Het MIMIC-model van afhankelijkheid}

\section{structuor}

In het tweede deel van hoofdstuk 15 is een eerste aanzet gegewen voor een model wan voorzleningen voor ouderen. Daarbij is gekozen voor een modellering wolgens de methode van Multiple Indicators and MultIple Causes (MIMIC). Het model is empirisch getoetst voor zelfstandig wonende ouderen die al dan niet gebruik maken van gezinsverzorging en/of wijkverpleging en/of een positief advies hebben voor opname in een bejaardenoord.

Het MIMIC-model kan beschouwd worden als een bouwwerk waarin de uit de twee sporen verzamelde inzichten met betrekking tot woorzieningengebruik en -patronen, alsmede de determinanten daarwoor en de kosten ervan, ineen gepast worden. Allereerst is aangetoond dat gezondheidsindicatoren (inclusief (I)ADL-beperkingen) en psychische determinanten indicatoren zijn voor twee latente variabelen, hier aangeduid als lichamelijke en psychische afhankelijkheid. Daarbij werd de hypothese dat de subjectieve gezondheid aspecten weergeeft van zowel het fysieke als het psychische functioneren, niet verworpen; acceptatie van deze hypothese bleek het meetmodel voor de beide afhankelijkheidsdimensies zelfs aanzienlijk te verbeteren. Opmerkelijk daarbij is de veranderende betekenis van de zelf-beoordeling van de gezondheid: naarmate ouderen in een 'zwaarder' zorgarrangement verblijven, neemt de relatieve betekenis van de psychische component af ten koste van de lichamelijke component in het eigen oordeel van de gezondheid.

Een volledig gespecificeerd model met verschillende achtergrondvariabelen ('causes') en indicatoren voor afhankelijkheid, alsmede het gebruik van basiswoorzieningen woor zelfstandig wonende ouderen, is gepresenteerd als model voor de voorzieningen voor ouderen. De resultaten van dit complexe model zijn om verschillende redenen interessant te noemen: afzonderlijke modelvergelijkingen reproduceren bij benadering de eerder gepresenteerde schattingen voor het gedichotomiseerde gebruik van afzonderlijke voorzieningen; de verklaarde variantie per modelvergelijking is eveneens vergelijkbaar met die uit de aparte regressies; alle tekens zijn in de verwachte richting, hoewel niet altijd significant en ook de toets voor het gehele model is acceptabel indien rekening gehouden wordt met de nietnormale verdeling van de variabelen.

\section{eftectsimulatie}

Op basis van het model zijn simulaties uitgevoerd om de effecten van mogelijke trends op het sociaal-matschappelijk vlak te berekenen en daarmee uitbreiding te geven aan eerder besproken puur demografische ramingen over het voorzieningengebruik door ouderen in het jaar 2000 . Vartanten die bezien zijn betrelfen een verbetering van de inkomenspositie van ouderen, een versterking van hun sociaal netwerk en een uitbreiding van particuliere betalde hulp. Rekening houdend met de toename in het aantal ouderen resulteert in de demografische basisraming een stijging in het voorzieningengebruik door deze bevolkingsgroep die voor de bestudeerde voorzieningen varieert van 19 tot $26 \%$ voor de gebele periode tot de eeuwwisseling. Indien daarbij het (voor de kans op gebruik negatieve) effect van een zich verbeterende sociaal-economische status verdisconteerd wordt, dan kan het gebruik van gezinsverzorging met ongeveer $6 \%$ van de voor deze voorziening berekende demografische druk $(24,4 \%)$ afnemen en de afgifte van een positief advies voor opname in het bejaardenoord met bijna $9 \%$ van die demografische groei $(19,1 \%)$. Er is op basis van het hier gepresenteerde model geen aanleiding gevonden voor de veronderstelling dat een hoger inkomen zal leiden tot een ander gebruik van wijkverpleging (het gebruik hiervan zal volgens de basisraming toenemen met $26,2 \%$ tot het jaar 2000); de wijze van financiering via sociale premies (AWBZ) en lidmaatschapsgelden in plaats van comsumptie-gebonden 
eigen bijoragen zou hieraan debet kunnen zijn. Een uitbreiding van betaalde particuliere hulp met 10\% (hetgeen door een verbeterde inkomenspositie gedeeltelijk vanizelf zal gebeuren) zall bij gezinswerzorging een afname met ruim $8 \%$ ten opzichte van de op grond van demografische gronden voorspelde stijging te weeg kunnen brengen. Een dergelihke matregel zou echter een averechts effect hebben op de toeloop tot het bejardenoord. Dit effect is in het gepresenteerde model van simultane vergelijkingen (er lopen immers ook invioeden van betaalde hulp via gezinsverzorging naar het afgeven van een positieve indicatie) niet onbeduidend te noemen: aan de toename in de demografische basisraming (19,1\%) zou eén procentpunt toenemen als de particuliere betaalde hulp met $10 \%$ wordt uitgebreid. Er ontstaat als het ware "vluchtgedrag" naar het bejaardenoord".

Tenslotte is de invloed van een versterking van het sociaal netwerk met $10 \%$ bezien; deze verandering heeft alleen gevolgen voor het gebruik van gezinsverzorging en de toeloop op bet bejaardenoord en niet op het gebruik van wijkverpleging.

Per saldo zijn de effecten van de geselecteerde achtergrondvariabelen in vergelijking tot de demografische druk bescheiden te noemen; een voorzichtige benadering luidt dat ongeveer 10 tot $15 \%$ daarvan gemitigeerd kan worden door de effecten van een verbetering in de inkomenspositie, uitbreiding van particuliere betaalde hulp en versterking van het uitbreiding van het sociaal netwerk. Deze benadering is gebaseerd op het meest optimistische scenario voor de inkomensontwikkeling bij ouderen; mocht deze tegenvallen, dan wordi een belangrijk deel van de sturingsmogelijkheden die het inkomen lijkt te hebben op het gebruik van gezinsverzorging en opname in het bejaardenoord teniet gedaan. Bij het gebruik van wijkverpleging door ouderen zijn daarentegen geheel geen substantiele effecten aangetroffen, zodat voor ramingen hierover volstaan lijkt te kunnen worden met de puur demografische benadering. Benadrukt wordt dat deze simulaties gebaseerd zijn op eerste berekeningen met een model dat zich nog in de ontwikkelingsfase bevindt. Ook dient met nadruk gewezen te worden op de beperkte basis van het empirische model. Er zijn immers kanttekeningen te plaatsen bij de mate van representativileit van de onderzoekspopulatie, die is voorgeselecteerd op het feit dat men een zekere mate van invaliditeit heeft en/of gebruik maakte van een van de basiswoorzieningen voor ouderen en bij de positief geindiceerden waarschijnlijk een onderschatting van de psychische problematiek met zich mee brengt (zie paragraaf 13.6), Ook kan in strikte zin geen generalisatie plakts vinden omdat bet bestand gebonden is aan de lokale Maastrichtse omstandigheden. Toepassing van hei model op andere locaties en andere momenten vereist derhalve hertoetsing van het model. Dat neemt niet weg dat de tendenties in het model in overeenstemming zijn met de literatuurbevindingen en dat de schattingsresultaten ower het algemeen bevredigend zijn.

\subsection{Suggesties voor vervolgonderzoek}

Suggesties voor verder onderzoek richten zich op de dynamisering van veranderingsprocessen, verfijning van relaties via niet-recursieve modellering, specificatie van mogelijk niet-lineaire effecten van bijvoorbeeld het aantal (I)ADL-beperkingen en op het inbrengen van nieuwe 'modules' van determinanten, waarbij gedacht kan worden aan het oordeel van derden, bijwoorbeeld van de centrale verzorg(st)er, maar ook kan gedacht worden aan medisch-diagnostische variabelen.

Tenslotte verdient het aanbeveling om op instellingsniveau een verfjning van kostprijzen aan te brengen in relatie tot de mate van afhankelijkheid van individuele clienten of homogene clientgroepen. Hoewel daarvoor in deze studie voor een aantal sectoren zoals de gezinsverzorging en de bejaardenoorden reeds een eerste aanzet is gegeven, kan gesteld worden dat het (vooralsnog) in de ouderenzorg in het algemeen niet of nauwelijks mogelijk 
is on op adequate wijze een relatie te legggen tussen enerzijds de produktie- en kostengegevens en anderzjjds de clientkenmerken, waaronder de mate van lichamelijke en psychische afhankelijkheid.

\subsection{Relevantie voor beleid}

De relevantie van de resultaten van deze studie voor thet beleid in de ouderenzorg laat zich op verschillende punten aanduiden. De hoofdvraag van het onderzoek, namelik of het mogelijk is een model van voorzieningen voor ouderen te ontwikkelen dat kan dienen als instrument voor de voorbereiding en evaluatie van beleidsalternatieven, kan positief beantwoord worden onder de verschillende restricties die daarbij gegeven zijn. Daar ligt een ander belangrijk gegeven achter: het model maakt duidelijk op welke determinanten bij de toewijzing van voorzieningen gelet zou moeten worden. Deze leverden immers een significante bijdrage aan de verklaring van het voorzieningengebruik en volgen in dat opzicht een zo langzamerhand omvangrijke hoeveelheid literatuur. In deze studie worden de volgende determinanten als het meest relewant aangemerkt: het aantal algemene en instrumentele beperkingen in het dagelijks leven (verreweg de belangrijkste), het feit of iemand alleenstaand is, psychische indicatoren (gevalideerde Zung- en AMT-schalen), de subjectieve gezondheidsbeleving, het aantal ziekteweken, de aanwezigheid van een cronische ziekte en de informele hulp door partner, buisgenoot, familie, buren en/of vrienden. Hoewel dit de belangrijkste set van variabelen betreft, is het mogelijk dat voor een bepaalde voorziening daarvan een beperktere set volstaat. Door deze variabelen in hun complexe onderlinge samenhang te bezien via het daarvoor geschikte MIMIC-model is het mogelijk gebleken de invloeden van lichamelijke en psychische afhankelijkheid, alsmede van enkele andere belangrijke achtergrondvariabelen (zoals leeftijd, sociaal-economische status en het feit of lemand in een speciale woning voor ouderen woont) kan een goed inzicht gekregen worden in het voorzieningengebruik door ouderen.

Ook is een belangrijke relatie gelegd tussen de verschillende indicatoren voor afhankellijkheid en de kosten van ouderenzorg op individueel niveau. Via kostprijzen werd hierdoor als het ware een koppeling tot stand gebractl tussen de aanbozijde en de vraagzijde van de ouderenzorg. Tot op heden werden deze altijd afzonderlijk bestudeerd.

De kosten op individueel niveau laten zich eveneens verklaren met behulp van de set van zojuist genoemde determinanten. Omdat de werklaringskracht bijzonder goed is, lijkt hiermee een belangrijke mogelijkheid gevonden te zijn om bij een bepaalde afhankelijkheidsgraad niet zozeer een bepaalde voorziening toe te wijzen, maar om een individueel budget beschikbaar te stellenop grond van de waarden die de verschillende relevante determinanten voor de oudere in kwestie aannemen. De zorgsubsidie is derhalve precies toegesneden op de behoeften; de betreffende oudere zou nu zelf zijn zorg kunnen kopen.

In de grensgebieden tussen thuiszorg en intramurale zorg zou dit interessante mogelijkheden scheppen: de op indiwiduele determinantscores gebaseerde zorgsubsidie zou toereikend kunnen zijn, maar desaluiettemin kan de oudere beslissen of hij/zij dit geld toch niet aanwendt om een pakket van zorgfuncties in de thuissituatie te realiseren.

Ook met betrekking tot de aanbodzijde zijn enkele beleidsrelevante onderwerpen behandeld. Naast een verbijzondering van kostprijzen, met name die van het bejaardenoord (warvoor men tot op heden meestal volstond met ruwe schatters voor een gemiddelde), kan de functionele indeling van ouderenzorg gememoreerd worden. Hierover wordt op beleids- en politiek niveau al enige jaren een vrij indringende discussie gehouden waarvoor nog weinig empirisch materiaal voor handen was. In deze studie is gepoogd om een eerste aanzet te geven voor een verbijzondering van de kostenstructuur van voorzieningen naar de werschillende functies die door hen worden geleverd. 


\section{Summary}

\section{A simulation model for the care for the elderly}

\section{- Background}

In 1986 the Steering Group for Research on Ageing of the Ministry of Welfare, Health and Cultural Affairs in the Netherlands granted a research project to the Department of Health Economics of the University of Limburg. Its objective was to develop a simulation model for the care for the elderly, which may help policy makers to test alternative care systems in terms of total costs and the extent to which the needs of the elderly are met. Departing from economic perspectives, we are interested in the question how the needs of elderly can be fulfilled in the most appropriate way, given the financial restrictions confronting the government. To make this possible, the study distinguishes three themes. Firstly, we have to clarify the development of dependency on supporting services in terms of the underlying determinants. Secondly, we have to establish the relationships between these indicators for dependency and the actual use of health care and social services. Finally, we have to establishe the costs of this use of service. So, for the development of a model one has to investigate both the supply and demand side of the market for care for the eiderly. For each theme this study formulated several research-questions, which are discussed below. The study was conducted in the City of Maastricht in the south of the Netherlands and ended in november 1990.

\section{- Data}

In the study three types of data have been used. First national statistics on demografic trends and and consequent use of services by the elderly have been used. These figures can provide us with a global insigth in the national 'production' of care for the elderly, both in the community and within intramural settings, and the way in which this is influenced by demographic trends. Assuming that the share of elderly in the total group of clients can be seen as an indicator for the share of elderly in total costs, these statistics can be used to calculate the national costs of care for the elderly. The second type of data comes from individual organisations of care for the elderly in the City of Maastricht. Thirdly, we conducted a secondary analysis on individual data from different groups of elderly in Maastricht (see for more detail the paragraph: determinants of the use .... etcetera).

\section{- Ageing and health care: global trends}

To structure the first theme concerning ageing and the consequent use of health care by the elderly we addressed the following questions:

which are the most important demographic trends with respect to the absolute and relative number of elderly in the Netherlands?

(2)

what is the consequent current and future use of (social and bealth care) services for the elderly? 
Like most Western European countries the Netherlands are confronted with an increasing number of elderly: in $19457.3 \%$ of the dutch population was aged 65 or more and in 1990 $12.8 \%$. Within this population the share of the very-old (above 85 ) also increased from $3.4 \%$ of all people above 65 in 1945 to $9.3 \%$ in 1990 . The process of (double) ageing will continue untill the middle of the next century; by then $24 \%$ of the population will be above 65. The speed of the ageing process in the next decades will not differ from that of the past decades; only after the year 2010 it will accelerate. By then, people born directly after World War II (i.e. people from the postwar "baby boom") will reach the age of 65 years. The analysis of demographic trends and the description of the development of the Dutch social and health care system and the role of the Dutch government in these developments can be found in part $\mathrm{A}$ of this study.

To analyse the influence of ageing on the use of health care and welfare services, the study examines data at both the national and the local level from health care organizations for the elderly, such as home help services, district nursing, old people's homes and nursing homes. For the local level we have also investigated the use of service centers for elderly in the community and the number of applicants for admittance to old people's homes (in the Netherlands an independent indication-committee has to judge the need for such an admittance). An important figure to reflect the influence of the increasing number of elderly on the use of health care services is the age-specific relative number of users of the services, expressed as the percentage of users in each five year category of the population. Most services reveal figures which increase with every next age category. By means of example we give the relative number of elderly in the old people's homes in 1988 : $0.4 \%$ for $65-69,1.8 \%$ for $70-74,5.8 \%$ for $75-79,15.9 \%$ for $80-84$ and $35.2 \%$ for 85 and above. Similar patterns can be found in the different sectors of home care services, but there these figures show a maximum in the category of 80-84 years and bend backwards after that point. Because the national statistics are very rude we conducted a more detailled study in the City of Maastricht (part B of this study), taking both age, sexe and maritjal status into account. Using demographic projections for the year 2000 (which postulate a national increase in the number of elderly of $1.4 \%$ per year) the influence of ageing will result in an increase in clients which varies from at least $20 \%$ for home help services to a maximum of $30 \%$ for the old people's homes.

\section{- Determinants of the use of health care and social services}

With respect to the second theme of this study the next questions have been formulated:

(3) which characteristics of the life situation of the elderly contribute to the explanation of the use of care and how can we construct reliable scales and variables to reflect these determinants?

(4) which are the most important relationships between these determinants?

(5) which combination of determinants yields the best prediction of the utilization of care?

(6) is it relevant to consider other factors than the selected determinants in the explanation of consumption patterns in health care and social services for the elderly?

The above issues are addressed in part $\mathrm{C}$ of this study which is based on individual data for different groups of elderly. By means of fully structured interviews data were collected from (a) elderly living independently in the community but with some degree of functional limitation and with or without home care services, (b) elderly with a positive indication for special old people's homes but still living independently, (c) elderly already living in these homes and (d) applicants for a place in a nursing home (on waiting list or just admitted). In chapter 13 we discussed some conceptual models to structure the determinants in the utilization of care, such as the Andersen model, and the concept of 'need' and "dependency". 
Based on this review we decided to continue with eigth clusters of indicators for dependency: functional status, other indicators for physical health, mental health, socialeconomic status, housing, social network and informal caregivers. The Hiterature on determinants of utillization has been explored in chapter 14 with three different purposes: to select the most relevant variables within each cluster, to develop scales with proper statisticall features (Rasch-scales) and to inwestigate the intercorrelations berween the different scales within one cluster and between clusters. It is shown that these different kinds of intercorrelations are very important so that one can postulate that "everything depends with everything". Examples of such interrelated determinants are: the (I)ADL-scale (a Raschscale of eleven items of both instrumental and geneneral activities of daily living; a higher score indicates less limitations) with weeks of sickness in the last year preceeding the interview $(r=0.55 ; \mathrm{p}<0.001)$, the (I)ADL-scale with mental functioning, expressed by Zung's depressionscale $(r=0.40 ; p<0.001)$ and the Abbreviated Mental Test for dementia (the higher the score the better: $r=-0.30 ; p<0.001)$. After this selection and construction of determining variables we addressed the fifth research-question in chapter 15. A large part of this empirical analysis is based on logistic regression models.

\section{- A MIMIC-type simulation model}

Part $\mathrm{C}$ of this study also presents the simulation model which is referred to as a model with Multiple Indicators and Multiple Causes, a so called MIMIC-model. This model departs from the concept of 'dependency' (which has been defined and discussed in chapter 13) and introduces two latent constructs, representing the physical and psychic dimensions of dependency of the elderly. Measurement of dependency involves several conceptual problems (compare Wilkin, 1987). Furthermore, dependency is a rather diffuse concept and its definition is very much a function of the objectives for which it is required. In this study we hypothesized that physical as well as psychic aspects are involved. In our approach of measuring these two dimensions of dependency we have tried to incorporate the empirical findings as reported in the literature (and discussed in chapter 14). Firstly the relations between various individual background variables and the resulting dependency rates is established. In assessing dependency we considered age, sex, marital status, socio-economic status, social network, housing, and a number of indicators for morbidity, impairment and disability and psychic functioning, which variables are interrelated. Our approach has been to specify a measurement and a structural model including these causal wariables and these indicators for physical and psychic dependency and to use LISREL to estimate its parameters and to test the goodness-of-fit (see chapter 15). The psychic dimension in the self-assessment of health shows to become more important than the physical dimension when elderly progress in the care continuum. In the resulting MIMIC-model the relation between the two dimensions of dependency and use of services is also being set. In this study the model is limited to elderly living in the comnunity and focuses on the use of family care, district nursing and the positive indication for admittance in an old people's home (but still living independently because of waiting lists etcetera).

In the last part of the study illustrates how the model can be used to calculate the effects of future demographic and other trends on the capacity of services. This simulation of possible effects consists of two consecutive steps. Firstly, supposing that the relative number of users (in percentage of the population divided in age-groups) wil remain constant, it is possible to make a purely demographic prognosis of the number of users in 2000 (reference scenario). Secondly, three different policies are quantified with respect to the income position, the strengthening of social networks and the use of private help. For the improvement of the income position of elderly towards the year 2000 we based ourselves on the prognosis of 
The Soctal and Cultural Planning Bureau formulating three scenario's: zero growth, an increase of $4.9 \%$ and a maximum scenario with a total increase of $10 \%$ towards the year 2000 . Prognosis for the strengthening of the social network and the use of private help lacks relliable sources, we set a scenario with a $10 \%$ increase in both variables towards the year 2000. It is shown that the combined effect of these changes in the life situation of the elderly will yield only a moderate mitigation of the increase in use of health care and social services which is expected on purely demographic grounds. The family care yields the most promising possibilities for policy alternatives: the reference scenario for this service predicts an increase of $24.4 \%$, however, (a) the improvement of income following the maximum scenario will lower this with $1.7 \%$, (b) the strengthening of the social network will yield a reduction of $1.1 \%$ and (c) the increase of private services will result in a further decrease of 2.1\%. Balancing these effects against the demographic trend results in an increase in the use of farnily care by $19.9 \%$, being almost one fifth less than calculated in the reference scenario. On the other hand, there are almost no effects whatsoever on the use of district nursing. We conclude that improvements in the social and economic situation of the elderly will only have moderate effects in relation to the large effects of ageing so that the total costs of care for the elderly will inevitably rise. 


\section{Literatuur}

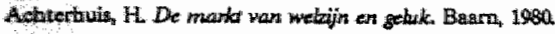

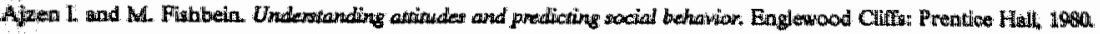

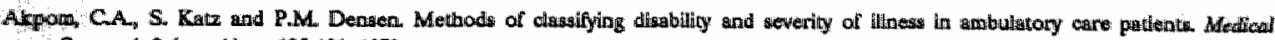
Care, wol 2 (stuppl) P. 125-131, 1973.

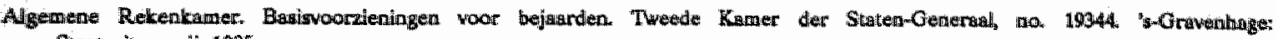
Stag a vitgeverij, 1985.

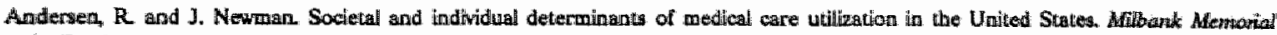
Fund Quantery, vol. 51, p. 95- 124, 1973.

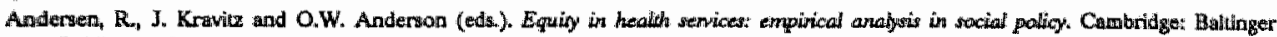
Pulolistuing Company, 1975 .

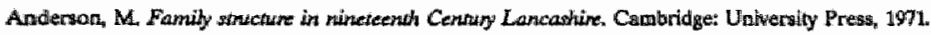

Andenson, W.F. and T. Jadge (eds.), Geriauric Medicine. London: Academic Press, 1974,

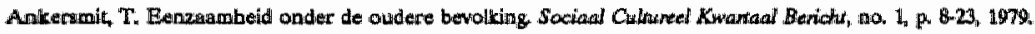

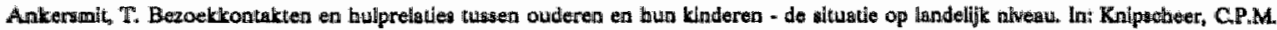

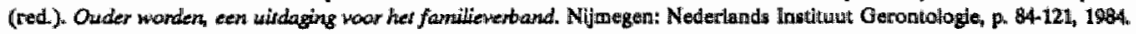

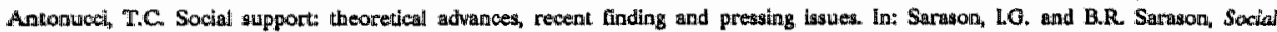

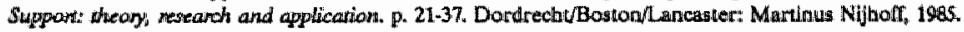

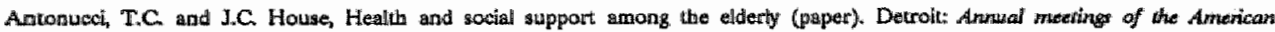
Sociological Sociery, 1983.

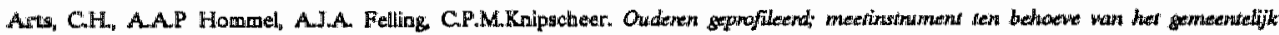
owdenembelejd. Aunsterdam: Vrijde Ungiversiteil 1989.

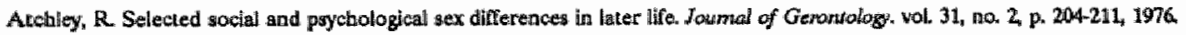

Atebley, R. The social fances in laver life. Califormia: Wadgworth Publishing Inc., 1977.

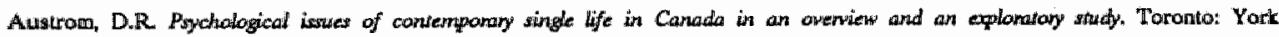
Uniwersity, 1981.

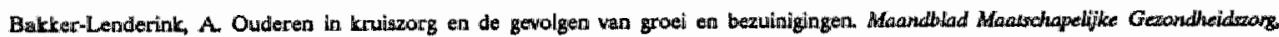
vol 11, no. 9, p. 8-11, 1983.

Dhase, D.M. and LS. Nowlker. "The infuence of famlly caregivers on elder's use of id-bome services: an expanded conceptual framewort. Jowrmal of Heallh and Stacial Behurior, voll 28, p. 184-196, 1987.

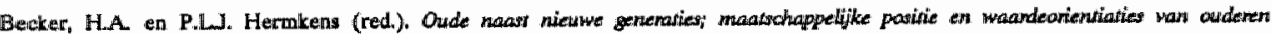
wergeleken met die van jongenen. Utrecbt: Rijksuniversiteit Utrectut, ISOR, 1989.

Benter, H.A. Theoretiseb kader voor analyses van lewenglopen en generaties. In: Beckers, H.A. en P.L. Henakens (red.). Oude naset

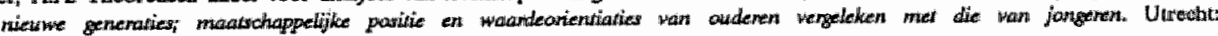
Rijitruniversileit Utrectht, ISOR, $19 \mathrm{A9}$.

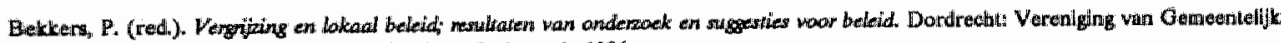
en Gewestellike Bureauss woor Statistiek en Onderzoek, 1986.

Diengigon, V.L and I.A. Kuypers. Generational difference and the developmenial athte. Intemational Jowmal of Aging ayd Mumum Develogment, wol. 2 p. $2492,260,1971$.

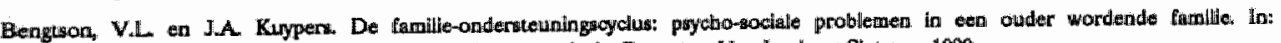
Munanichs, J.MA en C. Uildriks (red.). Paycho-genontalogie. Dewenter: Van Loghum Slaterus, 1989.

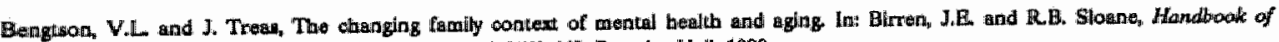
mential thealih and aging p. 400-428 Englewood Clifts NJ: Prentice-Hall, 1980

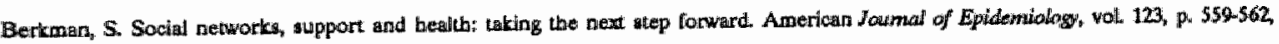
1.9866

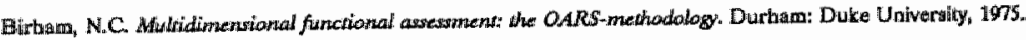

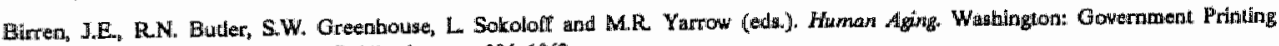
Ofice, Pubilic Healih Service Publication, no. \$86, 1963.

Birren, J.E and W.R. Cinningham, Rezearch on the psychology of aging, Principles, comeepts and theory. In: Birreft, J.E and KWW.

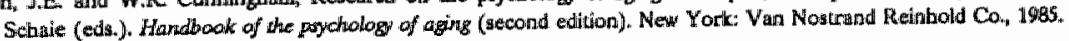

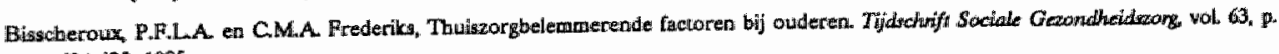
634-635, 1985 . 


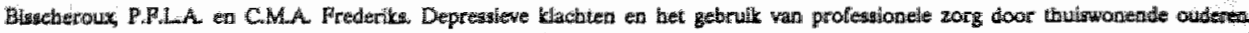

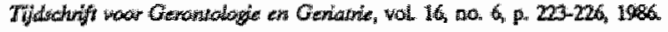

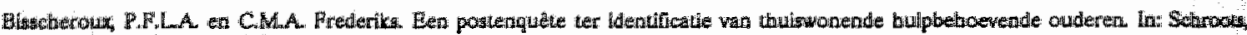

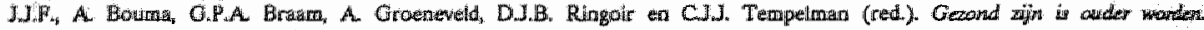

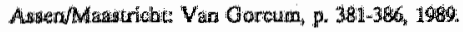

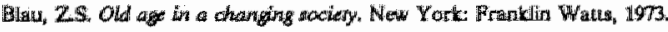

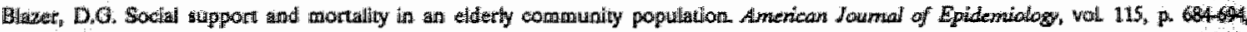
192

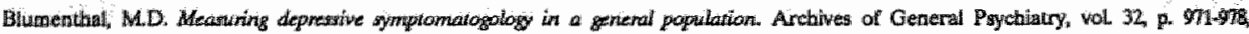
1975.

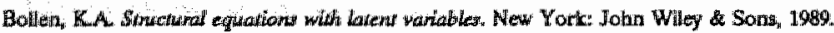

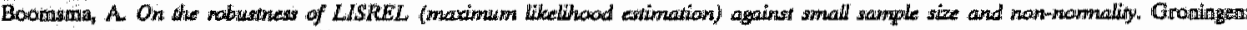

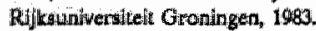

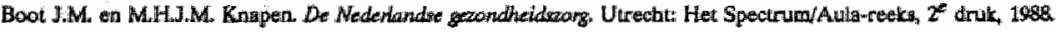

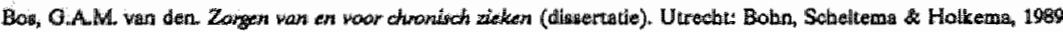

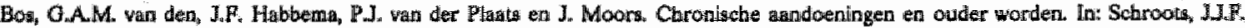

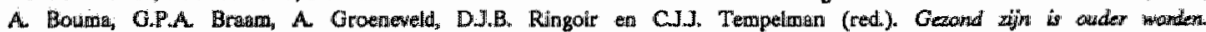
Assendaaserichi: Van Goreum, pi 343-348, 1989.

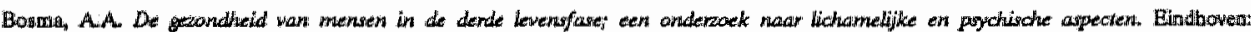
GOD, 1988.

Boudon, R. Theories of social changs; Oxford: Pollty Press, 1986

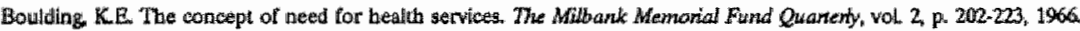

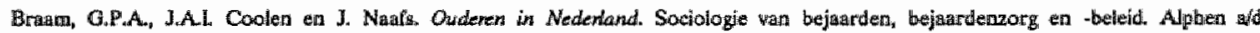
Ruji:Brassel: Samsom, 1981.

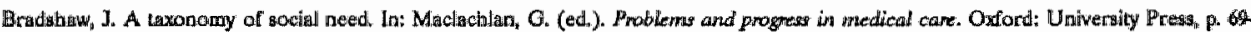
$\$ 2,1972$

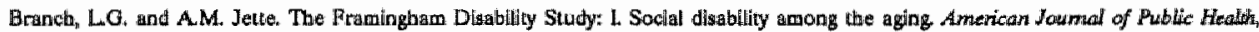
vol. 71, p. $1202-1210,1981$.

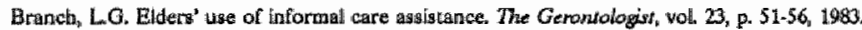

Branch, LG. S. Kata, K. Knlepman and J.A. Papsidero. A prospective study of functional status among community elders. Amernican

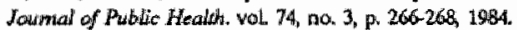

Branch, LuO. Rehative risk tates of monmedical predictors of insitutional care among elderfy persons. Camprehensive Therapy, voli 10, no. 7, p. 33 $40,1984$.

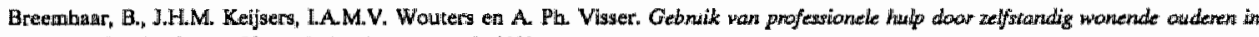

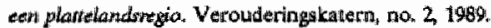

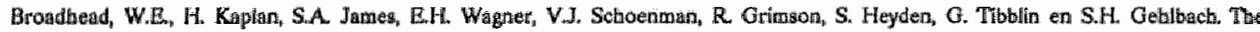

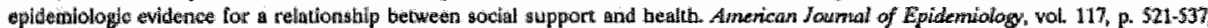
1903

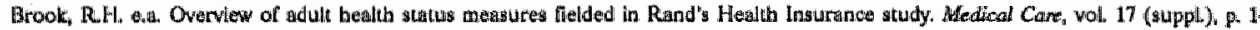
131, $19 \% 9$

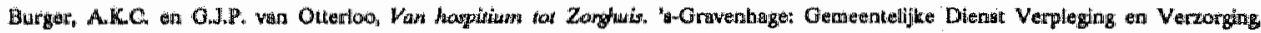
1963.

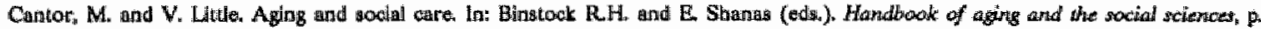
745.781 . New Yorkn wan Notzirand Reingold, 1985.

Cartmines, E.O. and J.P. Melver, Adialyzing models with unobserved variables: analysis of covariance structures, In: G.W. Bobrnstedt en

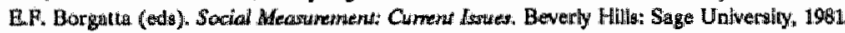

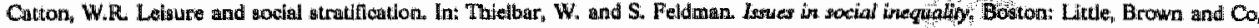
1972

CBS. Bevolking van Nedertand naar gestacint, leeftijd en burgerlijke atast 1830-1969. 's-Gravenllage: Stagtguitgeverij, 1970

CCB (Centrale Commissie Bejgardenoorden). Advies (tho. 72) naar aanleiding van bet vervolgondezzok verricht in bet kader vaun de studle natar een samenhangend oq. integraal (financierings)systeem van voorzieningen (mede) voar ouderen bestemd. Rijsujk, 1989.

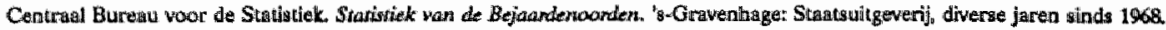

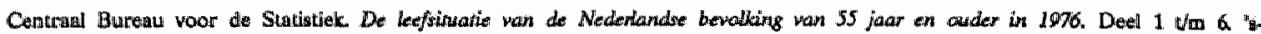
Graverabage: Staatsuitgeverij, diverse jaren. 


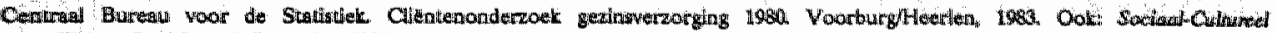

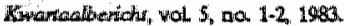

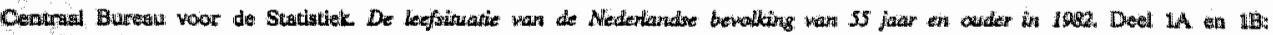

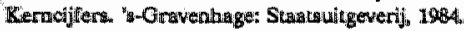

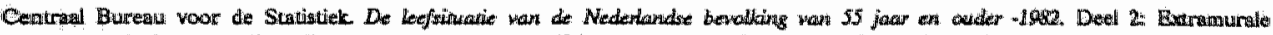

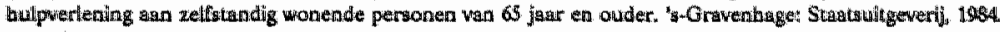

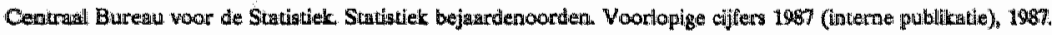

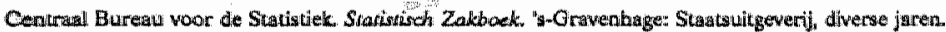

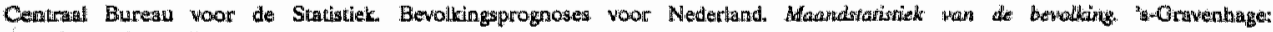
Statatsuitgeverij, diverse jaren.

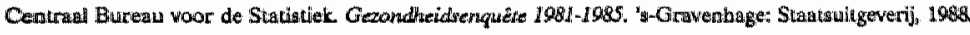

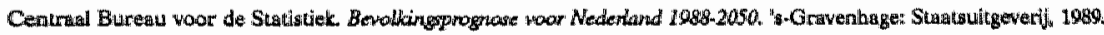

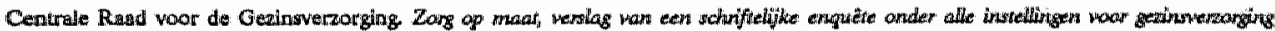

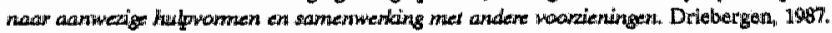

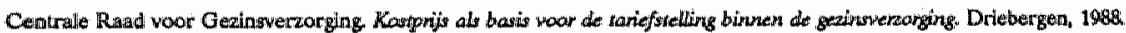

Centrale Raud voor Gezingwerzorging. Infommatiebulletin no. 28. Driebergen, 1988

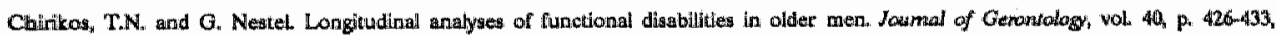
1985.

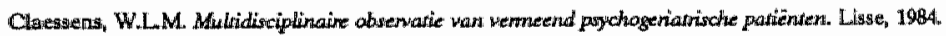

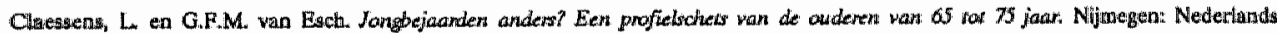
Institumat Gerontologie; 1988

Cleary, P.D. and R. Angell. The analysis of relationships ingowing diabotomous dependent variables. Joumal of Heallh and Sacial Pedhaviour, vol. 25, p. 334.344, 1984.

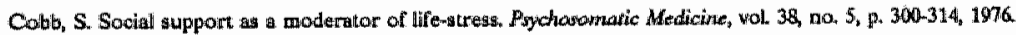

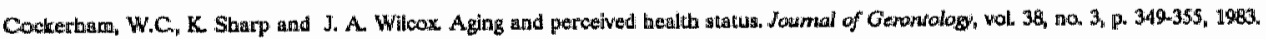

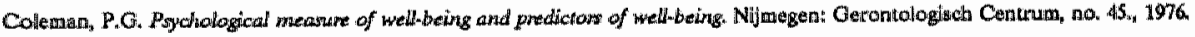

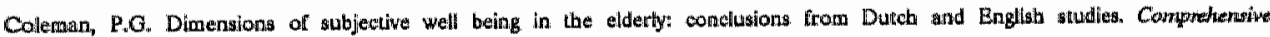
Gerondolog, vol. 1, D. B-12, 1987.

Commissie Structuur en Fimanciering Gezondbeidszorg (Cie. Dekker). Btreidheid ror verandering, "s-Gravenhage, 1987.

Coolen, J.A.L. Samenhang van voorzieningen woor bejaarden. Sacicalogische Gids, vol. 17" p" 47-66, 1980.

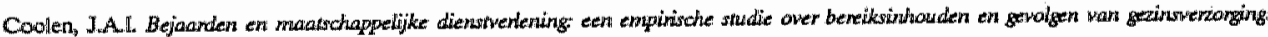
Enschede: T"echnische Universiteit "Twente, 1982

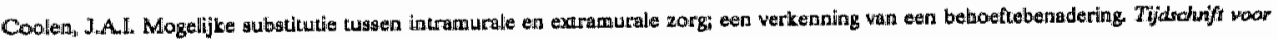
Gerarulogie ex: Geriatic, vol. 15, p. 115-124, 1984 .

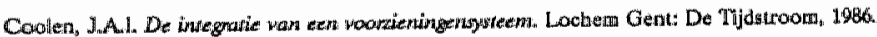

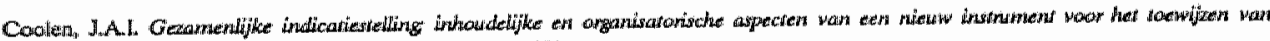
zangroorateningen. Enschede: Universilteil Twente, 1989.

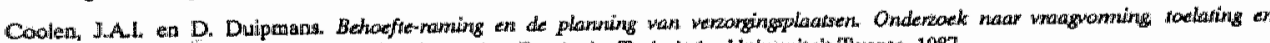

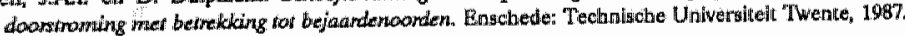

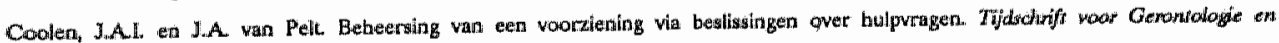
Gieriatrit, vol, 16, $19 \mathrm{BBS}$.

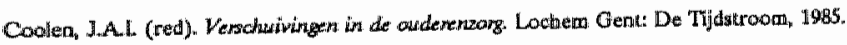

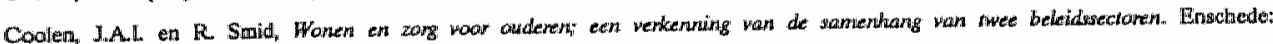
Unwersitell Twente, 1989.

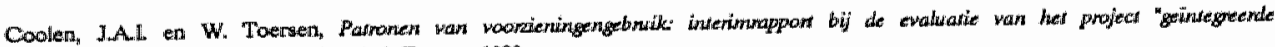

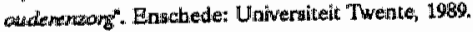

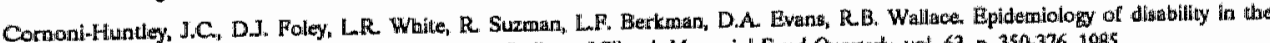

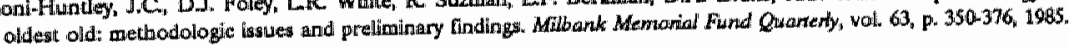

Cronbach, L.J. Coeficient alpha and the internal structure of tests. Psyehonserika, vol 16, p. 297-234, 1951.

Cumming E and W.E. Henry. Growing old, we procese of disengagemem. New York: Basic Books, 1961.

Dasal, H.J. van Zuinig mel zorg. "Srawenhage: NMA WO, 1987.

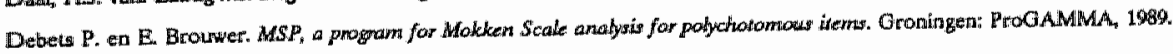




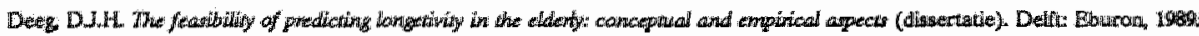

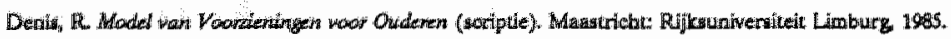

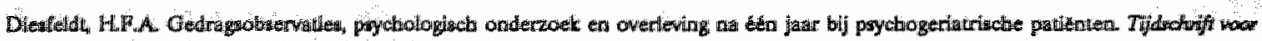

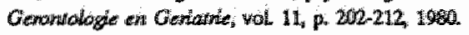

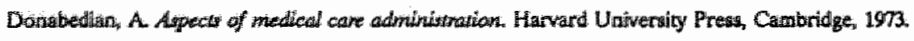

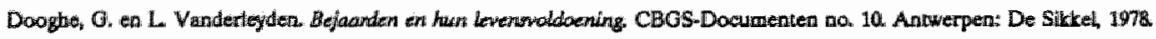

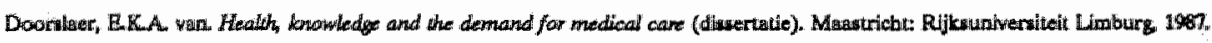

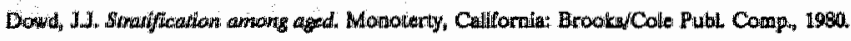

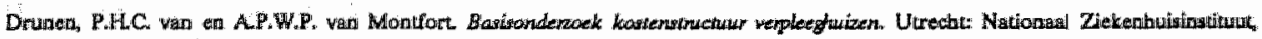
Fic. BO.215, 1900

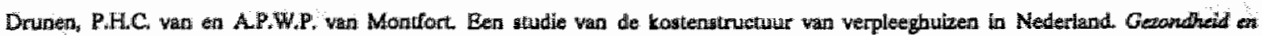
Samienlevings p. 246-261, 198:

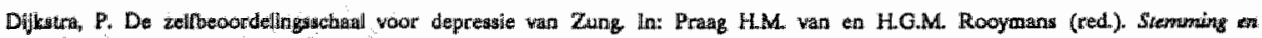
ontutemming Haariem: De Erven Bobn, 1974.

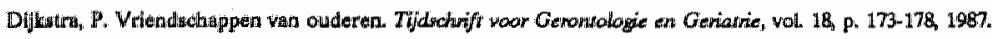

Edhwards, ALL Techniques of atritude and scale canswriction. New York: Appleton Century Crofts, 1957.

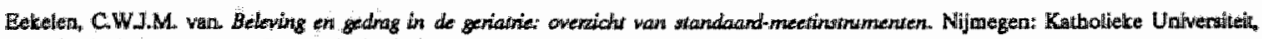
Lnteivakgroep Soclals Gerontologle, 1978

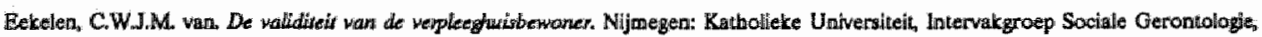
1981.

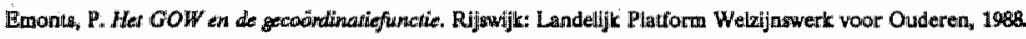

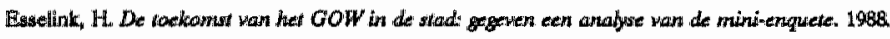

Ewandrou, M. S. Arber, A. Dalle and G.N. Gibert. Who cares for the elderty? Fiamily care prowision and receipt of statutony serwice In:

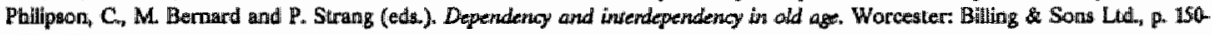
$165,1986$.

Ewang, R.L, R.D. Hendricks, KV. Lawrence and D.S. Bishop. Identilying factors gassociatied with health care use: a bospital-based risk wereening index Social Selente and Medicinc, vol. 27, no. 9. p. 947-954, 1988

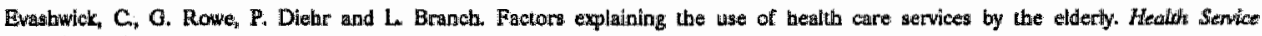
Reseandh, vol. 19, no, 3, p. 357-382, 1984 .

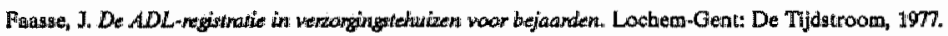

Fennell, G. Structured dependency revised. In: Phillipson, $C_{n}$ M. Bernard and P. Strung (edis.). Depandency and ivatendependency in wild age. London: Croom Helem, p. 54-68, 1986.

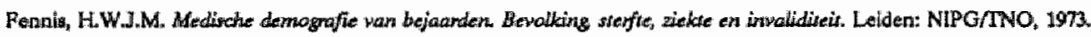

Fllienbaum, G.G. Social context and self-assessments of health among the elderly. Joumal of Health and Social Behawiour, wol 20 , p. 45. $51,1979$.

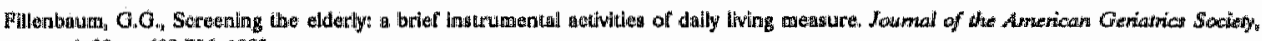
voli 33, p. $698-706,1985$.

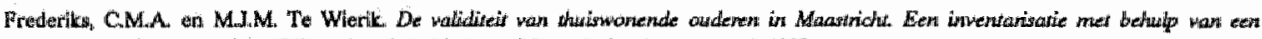

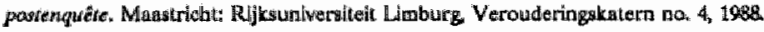

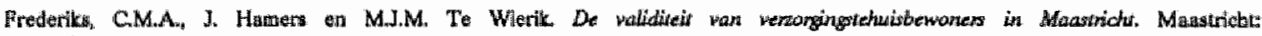
Rijlkiniviversitit Limburg wakgroep Epidemiologie, 1986

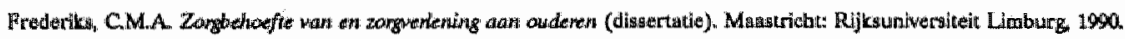

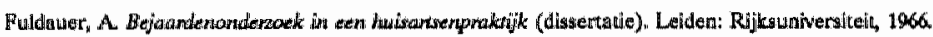

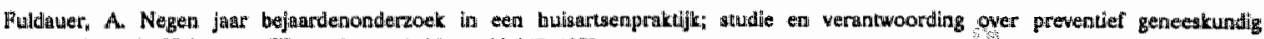
onderzoek Hulsuatis en Hetenuthep, vol. 16, p. 135-147, 1973.

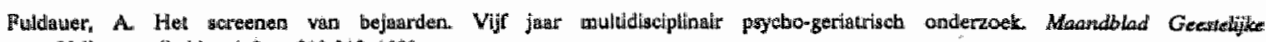
Vollowezond heid, vol 3, p. 210-215, 1980.

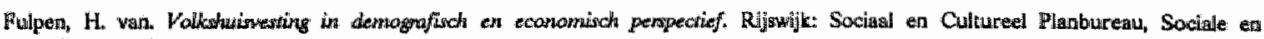
Culturele Studies, no. 8, 1985 .

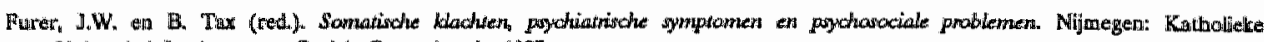
Undversiteid/nstitut voor Sociale Geneeskunde, 1987.

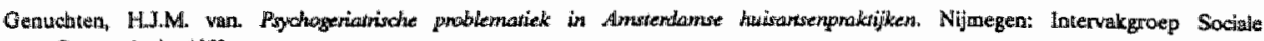
Gerontologie, 1982 


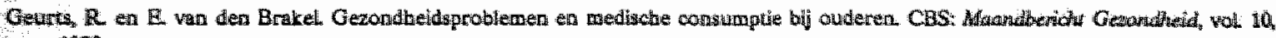
1988.

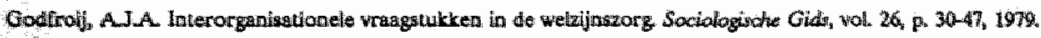

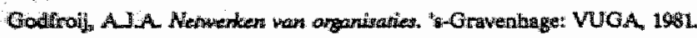

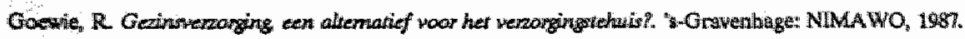

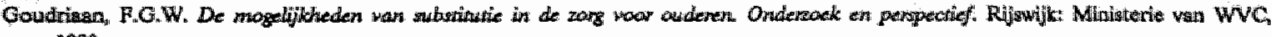
1989.

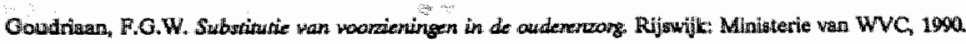

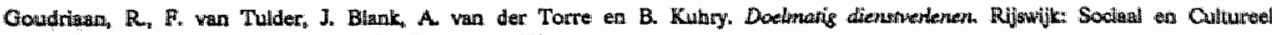
Planburesit, Sociale en Culturele Studie no. 11, 1989.

Greene, V.L Substitution berween formally and informally prowided care tor the impaired elderly in the community. Medical' Cane wel. 21, p. $602-619,1983$.

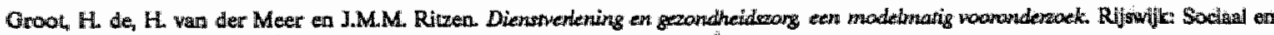
Cuftureel Planburneau, SCP-Cahier no. 24, 1981.

Gurel, L, M.W. Linm and B.S. Linnu Pbysical and mental impairment of function evaluation th the aged: Mhe PAMllB-seale Jowmal of Geronsology" woll. 27, p. 183-90, 1972

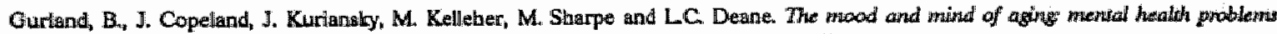
of the cammunity eldenty in New Yonk and London. New York: Hawcrth Press, 1963.

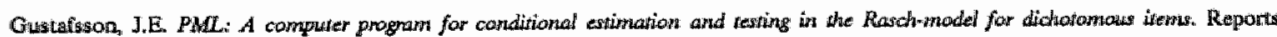
from the Institute of Edveation: University of Goteborg, na, 85, $197 \%$.

Guttman, LA. A basis for analysing test-retest reliability, Psychomerrika, voll 10, p. 255-282, 1945 .

Harris, J. and D. Kelly. Community wre and elderly people: one way tramic? In: Pbilipson, C, M. Bernard and R. Strang (eda). Dezpendency and intendependency in old age. Worcester, Billing and Sons Ltd.. p. 140149, 1986.

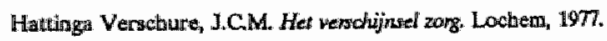

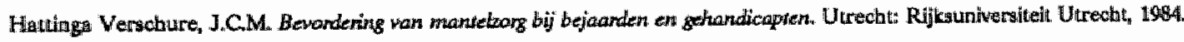

Havighurat, RJ. Successfiul aging. lin: Tibbits C. and W. Donabue (edic). Processes of aging: p. 299-320. New Yort: Williams, 1963.

Hawighurst, R.J., B.L. Neugarten and S.S. Tobin. Disengagement and paiterns of ageing In: Neugarten B.L (ed.). Middle age and ageing p. 161-172 Chicago: University of Chicago Press, 1968

Heine, EJ.H. ter. Wat zijn psycho-sociale problemen. Gezandheid ent Samenieving vol 1, p. 119-122, 1983,

Helmes, E, KG, Cuspo and J.A. Short. Standardization and validation of the multidimentionall observadion wale for alderly aubjects

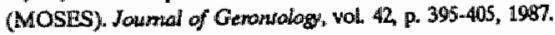

Herweljer, LJ. Edwentie opp Leefitijd. Rijswijk: Sociali en Cultureel Planbureau, SCP-cahier, no. 75, 1990.

Heuman, L and D. Boldy" Housing for the eldendy. Kent Croom-Helm, 1982

Heuvel, W.J.A van den. The Meaning of Dependency. In" Munnichs J.M.A. and W.J.A wan den Heuwel (ed.). Dependengy or Intenteperdentey in OLd Age. The Hague: Martinus Nijhon, p. 162-173, 1976.

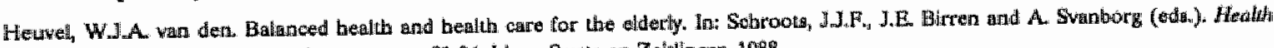

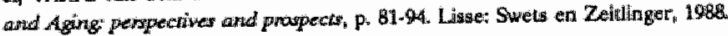

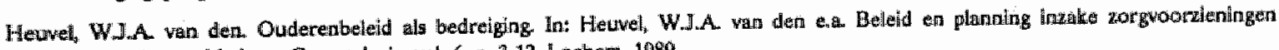

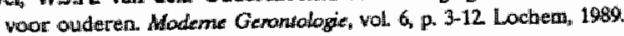

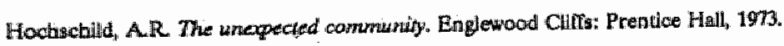

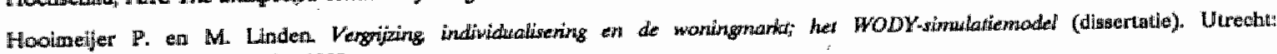
Rijthuninersiteit Uurechl, 1988

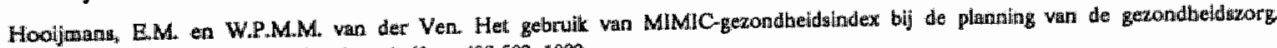

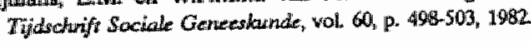

Hosman, C.M.H. Psychasaciale prablematick en hw browkern. Lisise: Swets en Zeitlinger, 1983.

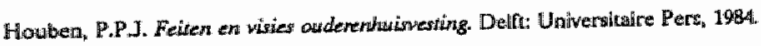

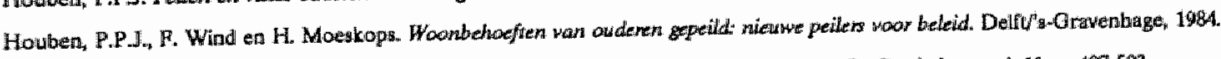

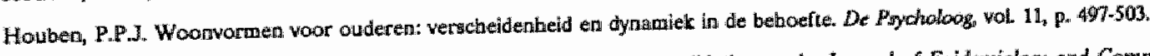

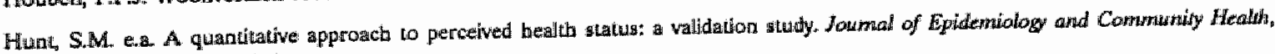
vol. 34, p. $281-286,1980$.

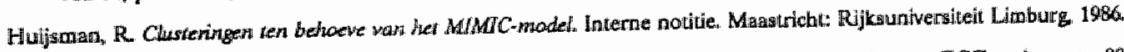

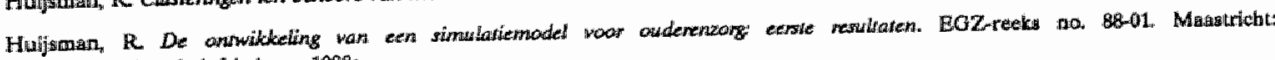
Rujlosuriversiteit Limburers 1988 a 


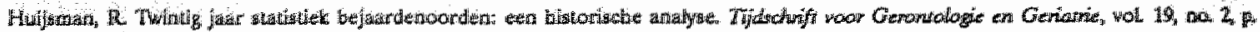

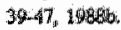

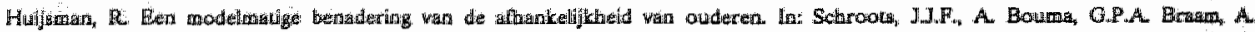

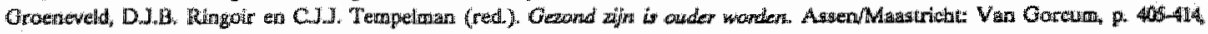
1960 a

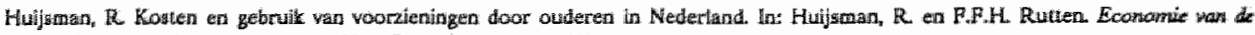

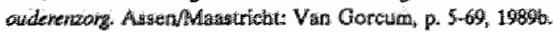

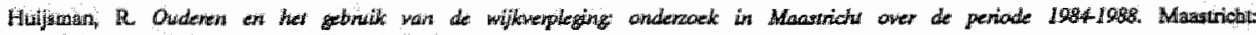

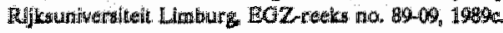

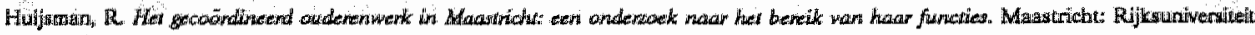

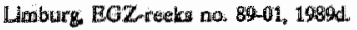

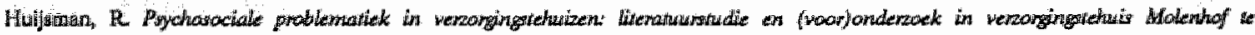

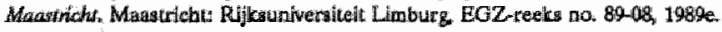

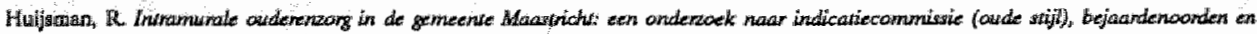

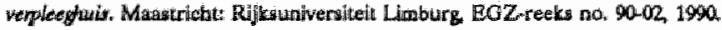

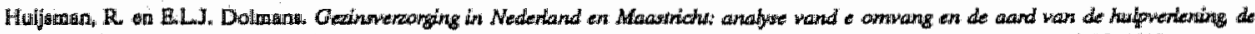

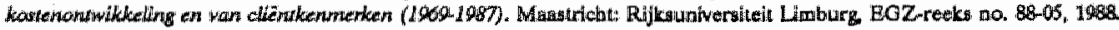

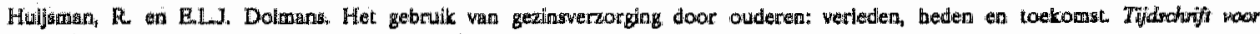
Geromialogie es Genamic vol. 21, p. 17.25, 1904:

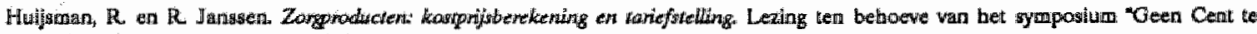
Veel. Eindbowen 4 okitober 199\%.

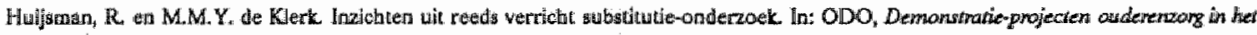

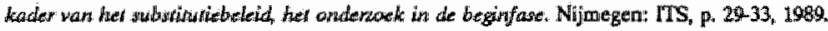

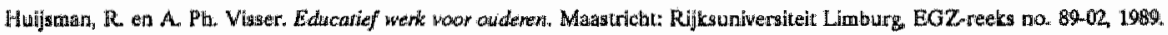

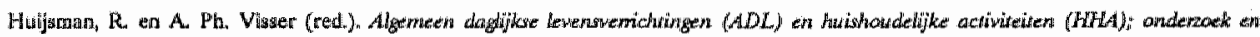

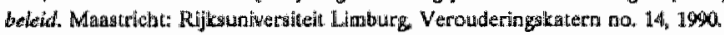

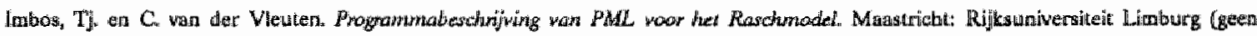
jotartaily.

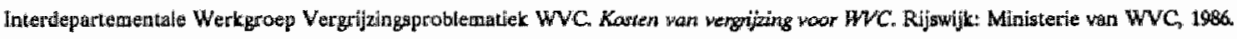

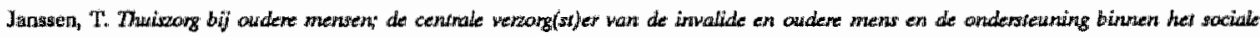
Nenwerk. Niljuegen: Katholieke Uniwersilteit, 1965.

Janssen, T. Thwiszong 'n hele zorgi Nijmegen: TIS, 1988

Jette, AM. and LO. Branch The Framingham Disability Study; IL. Physical disability among the aging American Joumal of Public Heaikh; wol. 71, p. 1211-1216, 1981.

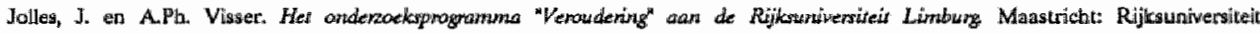
Limburg, 1989.

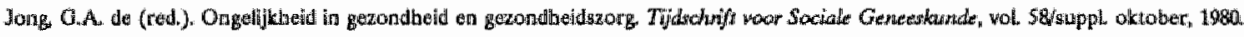

Jong-Olerweld, J. de, Operationalisering van bet begrip eenzaambeid. Sociologische Gids, vol. 25, ph 94-118, 1978

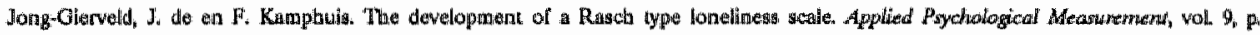
$2800.29 \%, 1985$.

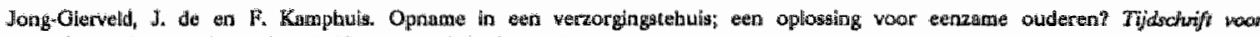

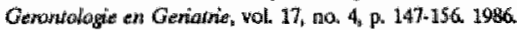

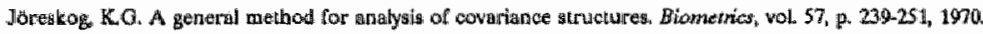

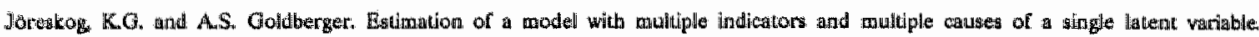
Joumul of the American Stavistical Societho vol. 70, p. 691-63\% 1975 .

Joreskog K G. and D. Sorbom. LISREL User's guide. University of Uppsala, 1981.

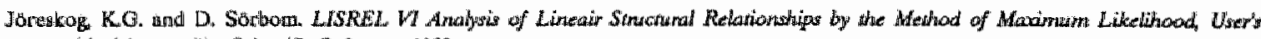
guide. Mooreswille: Scientific Software, 1983.

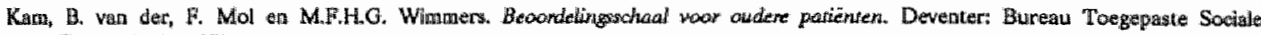
Gerontologie; 1971 .

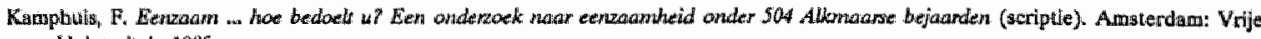
Universiteit, 1985.

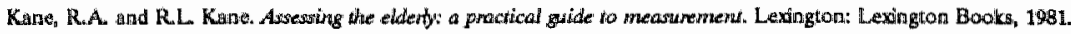

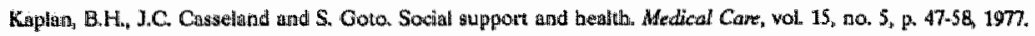




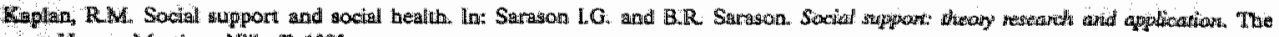
Hague: Martinus. Wijtort, 1985.

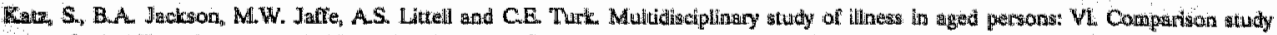

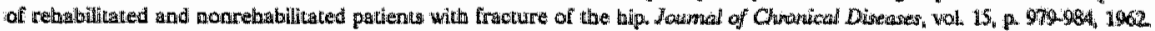

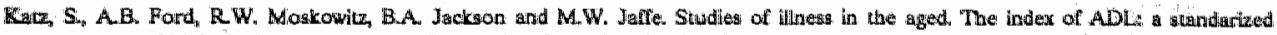

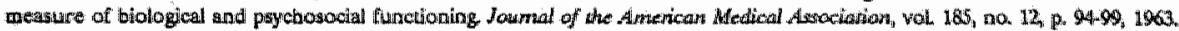

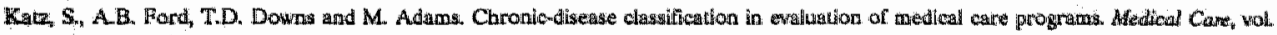
T. na. 2. p. 139143, $196 \%$.

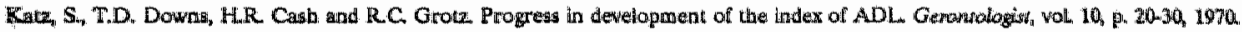

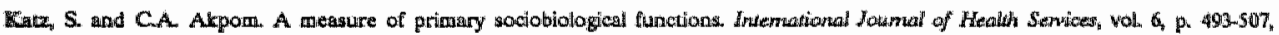
1976

Kratz, Sind C. Akpour. Index of ADL Hedical Cans, wol 14, p. 116-118, 1976

Katc, S. Assessing selfmaintenance Betwities of daily living mobility, and instrumental guctivities of daily living, Jowmal of whe American Geriatrio Socieg, vol, $31.7 .721-727,1983$.

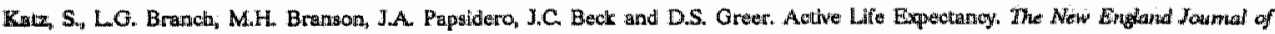
Medicine, vol 17, p. $1218-1224,1983$

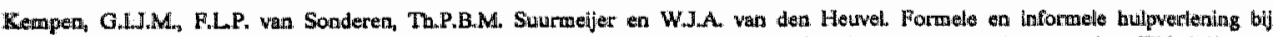

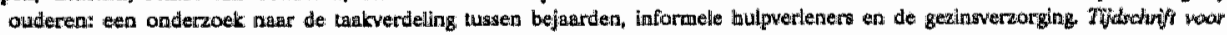
Gevorutologie en Geriasrie, vol. 17, p. 227-232, 1986.

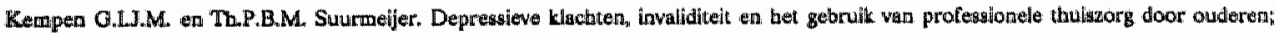

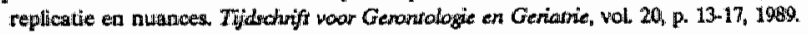

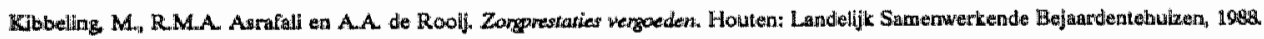

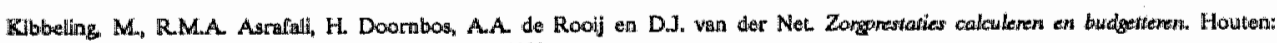
Vereniging wan Nedietlandse Bejardenoorden, 1989.

Kitcbell, MLA. R. Barnes, RC. Veith, J.T. Okimoto and M.A. RHshkind. Sereening for depression in hospitalized gerfatric medical patients. Jowmal of the American Geriarnics Sociefy, wol. 30, p. 174-177, 1982

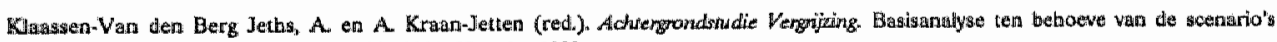
over gezondheid en vergrijzing $1984-2000$. Utrecht, 1985 .

Kagssen-Wan den Berg Jeths, A Zorgroorzieningen voor audenen. Determinanten van gebruife truidige silluatie en toekomstige oncwitkelling. Utrevhtr Rijksuniversiteit Utrecht, Vakgroep Planning Organisatie en Beleid, 1989.

Weim Beernink, M. Nerwenk van infonnele ondenstewnende velasies (scriptie). Amsterdam: Vrije Universiteit, 1984.

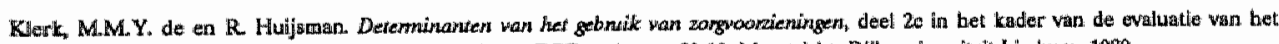
demonstratieproject Totaal Ouderenbeleid Venlo. EGZneeks no. 89-10, Maastricht: Rijksuniversitell Limburg 1989.

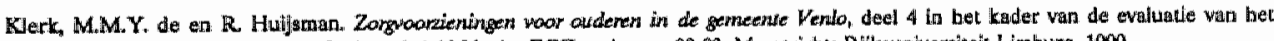
demonstratieproject Totaal Ouderenbeleid Venlo. EGZ-reeks no. 90-03, Masastricht: Rijksuniversiteit Limburg 1990.

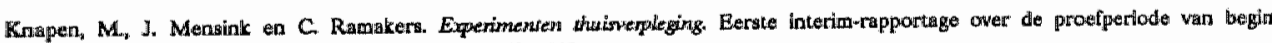
teptember tot eind decenber 1987. Nijwegen: ITS, 1988

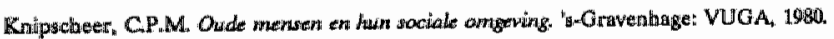

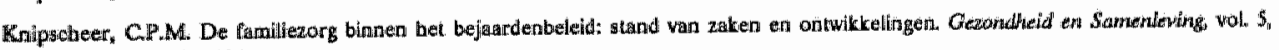
no. 2, p. 80-89, 1984 .

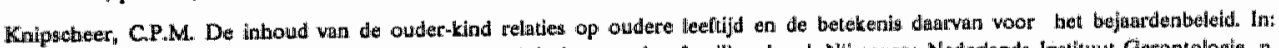

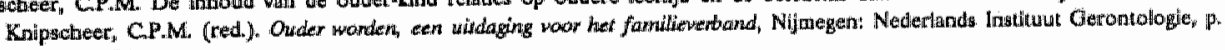
159 - 190,1984 .

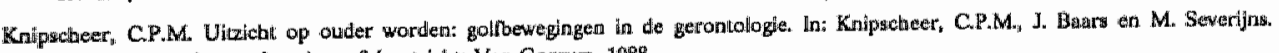

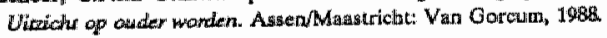

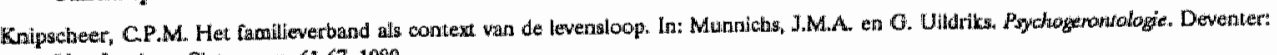
Van Loghurs Slaterus, p.61-67, 1989.

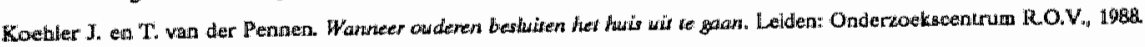

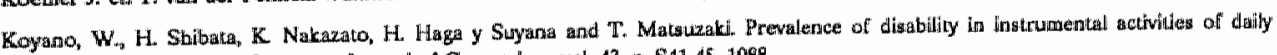
living among elderly Japanesen Joumal of Gerontology, wol. 43, P. S41-45, 1988.

Kroult, J.A Utilzzation of Services by we Elderty. The Social Service Review, vol. 58, no. 2, p. 281-290, 1984.

Kmuis, A van der en T. Mundemiaker. Het oudenentevid gewogen. Nijwegen/Tiburg: ITS/VA, 1986.

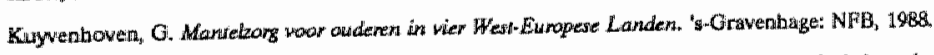

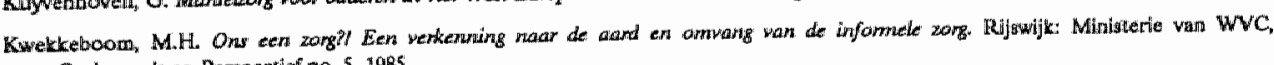
Onderzoek en Perspectief,no. $5,1985$. 


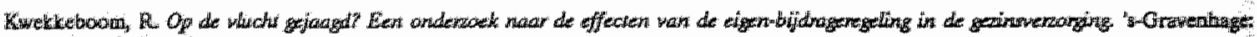
NHWA

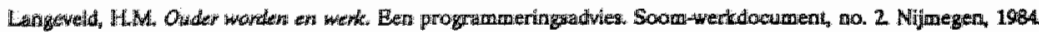

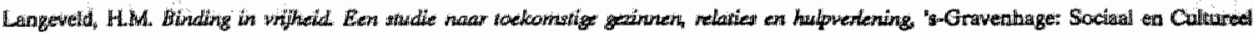

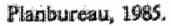

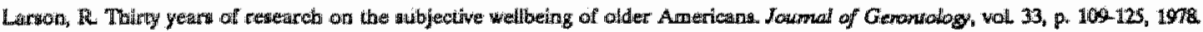

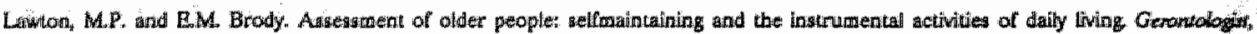

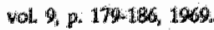

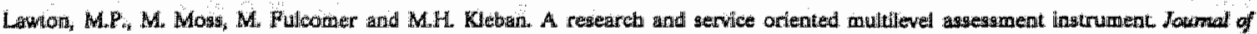

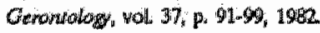

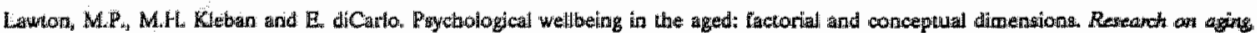

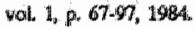

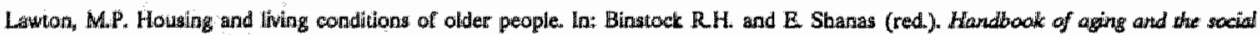
scienes: New Yorte: Van Wottrand Reingold, 1985 .

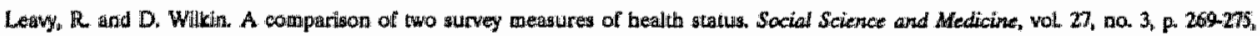
1958:

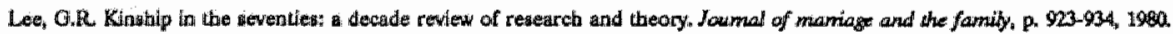

Lee, G.FR anid E. Billthorpe. Integenerrational exchange and subjective well-being among elderly. Joumal of mamiage and the family, ph $217-224,1982$

Lee, G.R Socidi integration and fear of crime among older persons. Joumal of Geronsology, vol, 28, p. 745-750, 1963.

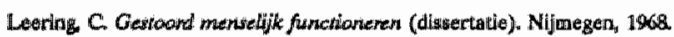

Learing. C. Structurele opbourw wan ADL-scoringen: een onderdeel van de medisch-relewante kennis over de patient. Nedentands Tyd-

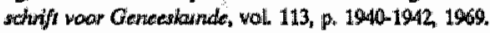

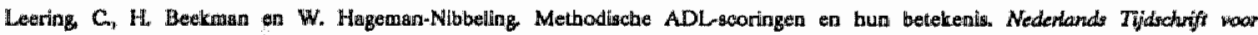
Geneeskarnde, wol, $33, \mathrm{p}, 1254-1250,1974$,

Leering C De beoordeling van de validiteit in de geriatrie: een klinisch gerontalogische bijdrage Nedertands Tyjduchnift wor Gexantologice, vol. 3 p. 150-15\%, 1976

Lehr, U. Psychologie wavi de audemdiom. Dewenter: Van Loghum Slaterus, 1980.

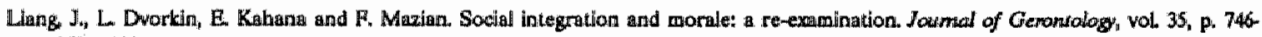
$757,1980$.

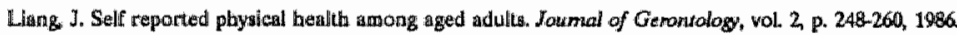

Linschoten, C.F" van, M. Leemeijer en W.J.A van den Heuvel, Behoeften beradend. Groningen: Rijiksuniversiteil Groningen 1988.

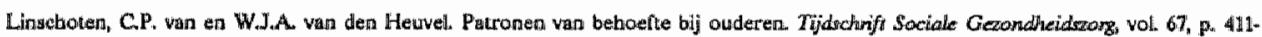
415, 1989.

Lopez A.D. and K. Hanada Mortsiligy patterns and tremds among the aged in developed countries World Healdh Statüstics Quartenty wol 35. no. $3 / 4,2,203-224,1982$

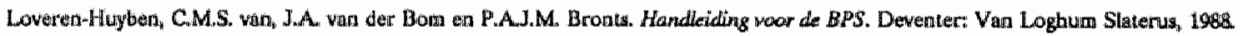

Loveren.Huyben, CMS. win, RM. Tooner en JA wan der Bow. Het verzorgingstehuis: een bron wan toenemende zorg (2).

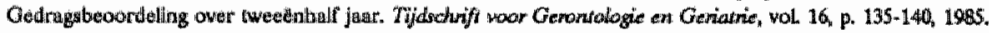

Loveren.Huyben, CM.S. van, J.A. van der Bkom. Het verzorgingshuis: een bron van toenemende zorg (3). Het effect van

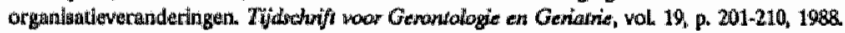

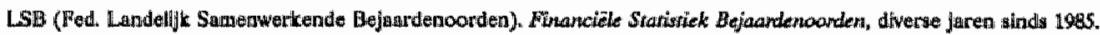

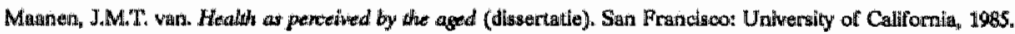

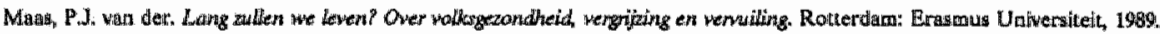

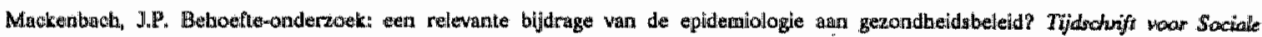
Ganeeskaunde, vol, 60, $19468-574,1982$

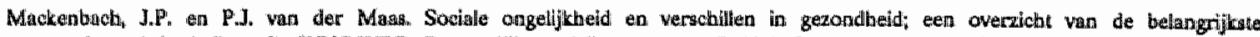

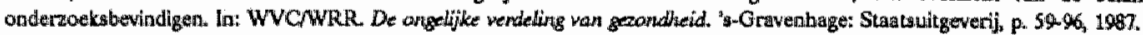

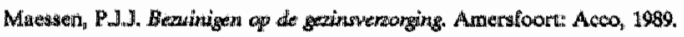

Manton, K and B.J. Soldo. Dynamica of bealth changes in the oldest old: new perspectives and evidence. Mibrank Mernorial Fund"

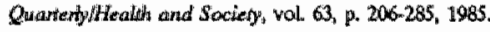

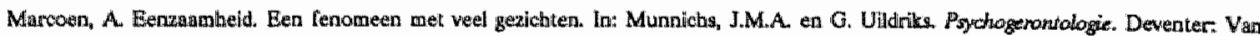
Loghusis Sinterus, p. 308-313, 1989 . 


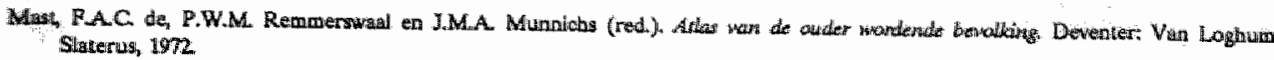

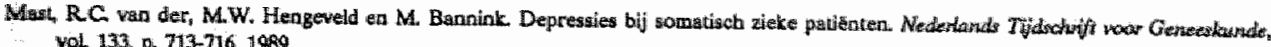
wol 1313, p. $713-716,1989$.

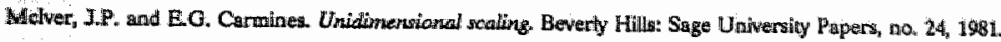

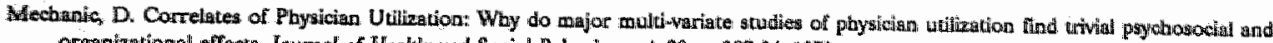
organizatiomal effects Joumal of Healoht and Social Bekrovion, wol. 20, p. 387.96, $197 \%$

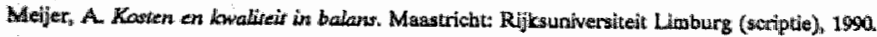

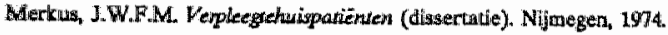

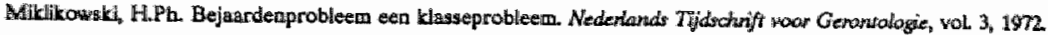

Minister wan WVC Flankemend Bejaandembedeid. Rijiswijk, 1983

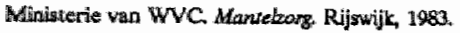

Arinisterie van WVC. Kasten van vergrijzing woor WWC. Rijpwijk, 1986.

Miniaterie wan WVC. Zorg wor Later, zorg wan wu, Rijswijk, 1980

Minkteler, M.A., W.A. Satariano and C. Langhauser. Supportive exchanges an exploration of the relationsbip betwera sotial contacts und

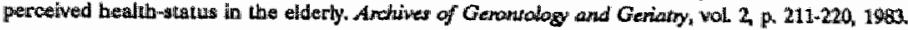

Witchelli, S.C. Social mentorken in uthan sinuations. Manchester. Univeraity Preses, 1969.

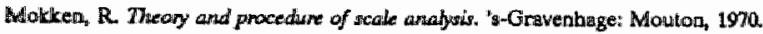

Molenaar, U.W. Mokken scalling newisited. Kuantitatilewe methoden no. 3, p. 145-164, 1982

Molenaar, LW. Een vingeroefening in item response theorie voor drie geordende antwoondcategoriean. In: G.F. Piklicemat en JJA Moors (eds.). Liber amiconum, Jaqu Muirwijk, Groningen: Esonomitrisch Ingtituith, 186a.

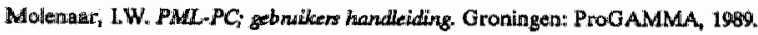

Moangy, G.H. Planning for balance of care of the elderty. Scotrish Jounhal of Folifical Economy, vol, 2S, p. 149-164, 1978

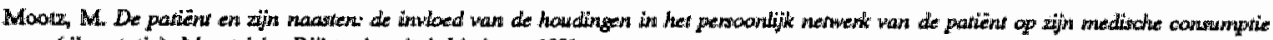
(dissertatie). Mathstricht: Rijhsunwersilielt Lamburg 1981.

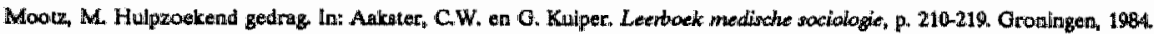

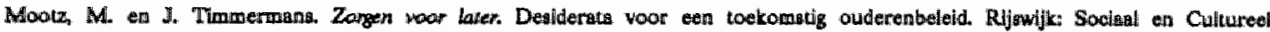
PIanbureaw, SCP-cahier na. 26, 1981.

Mootz M., J.M. Timmermans, LK. Schoenmakers-Salkinoja en J.C. Hessing-Wagner. Samenhang in de zong aubstituticmogelijkhedert op cent wierral iemeinen. Rijowijk: Scciall en Cultureet Planbureau, Stukwert no, 35, 1086

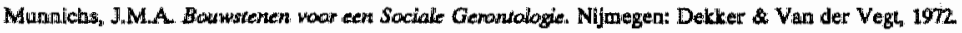

Munnichs, J.M.A. Dependency interdependency and autonomy; an introduction. In: Murnichis, J.M.A and W.J.A was den Heuwel (eds.). Deperidency or inverdependency in ald age. "gmavenbage: Martinus Nijhoff, p. 3-8, 1976.

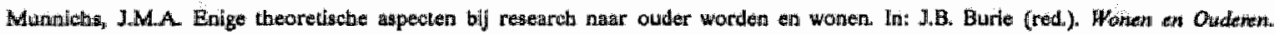
Nignemen: SOOM-Werkdiocument, no, 1, 1984.

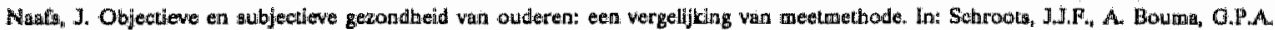

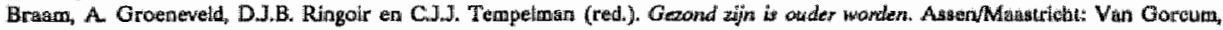
1989. ,p. 315-321, 1989

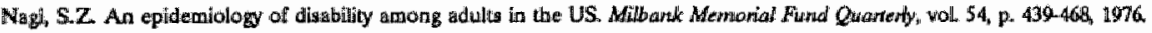

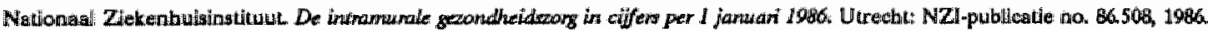

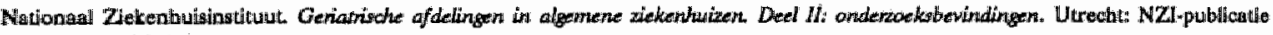
nia. 86486,1986

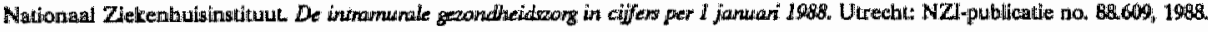

Nationale Kruisyereniging. Kruiswerk in beeld, Bunaik, 1986

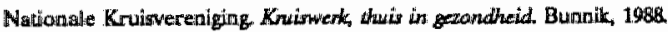

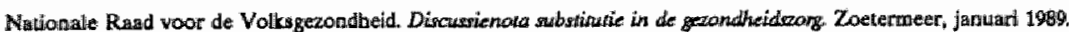

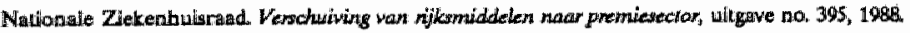

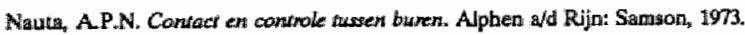

Neugarten, B.L, e. a. Personality in middle and lase Life. New Yark Awerton, 1964.

Noelker L.S. and D.M. Bass. Home care for elderiy persons: linkages between lormal and iniormal care-givers. Joumal of Gumantobs, wol. 44, no. 2 p. S $63-70,1989$.

Nunnally, J.C. Psychometric theory. New York, 1978 


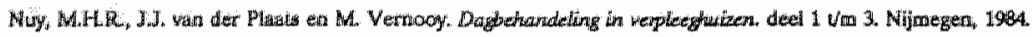

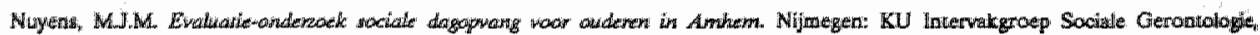
1998

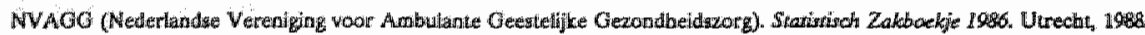

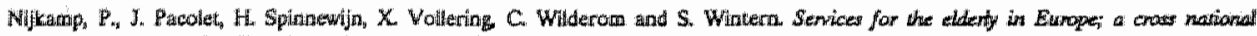

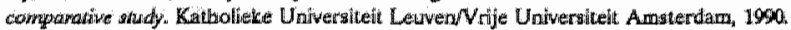

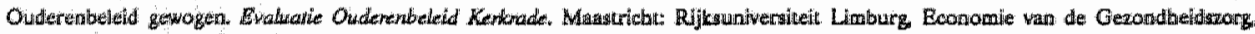

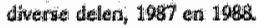

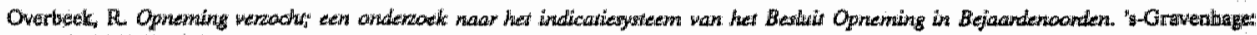
NMAA WO, 1989.

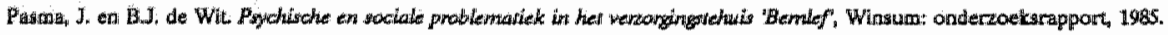

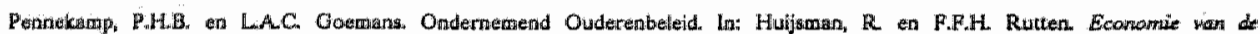
Oudenenzong p. 148-186. Maastrichte Van Gursum, 1989.

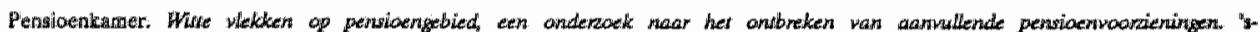
Oravenhage: Social Economische Rand, $198 \%$.

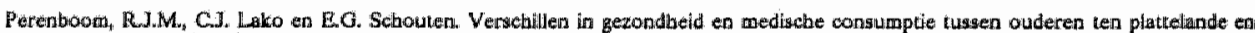

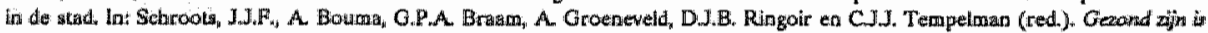

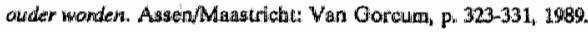

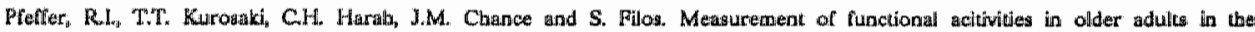

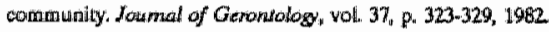

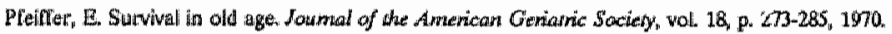

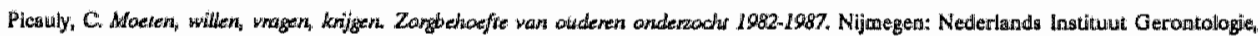
1987.

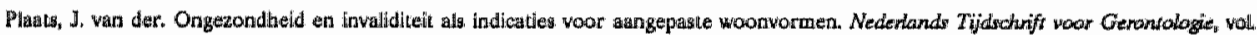
$3,158-165,1975$.

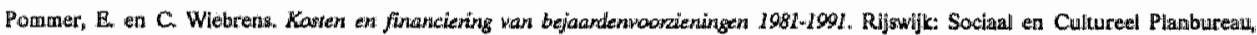
SCP-wathier 39, 1984.

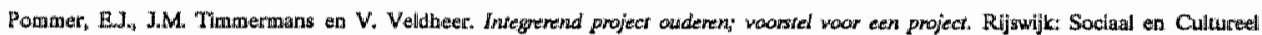
Planbureau, 1987.

Pommer, EJ. Inkosteris op Leefofidd. Rijowijk: Sociad en Cultureel Planbureau, SCP-cabier no. 74, 1990.

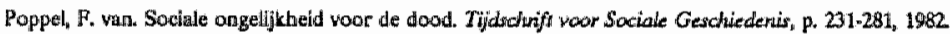

Post, M. en C Willemse. Behoefteronderzoek, een containerbegrip. Medisch Contact, voli, 86, p. 881-883, 1986.

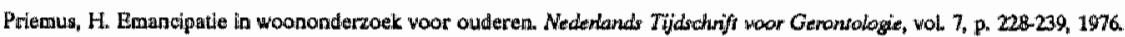

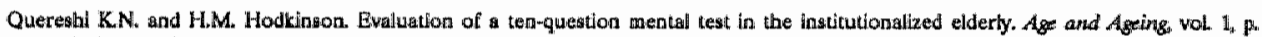
$152-157,1974$.

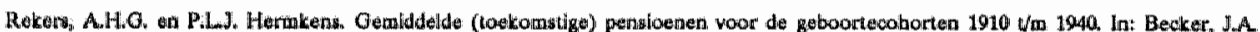

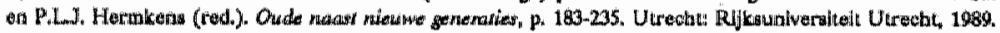

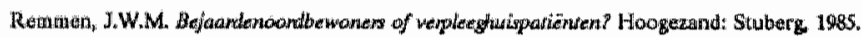

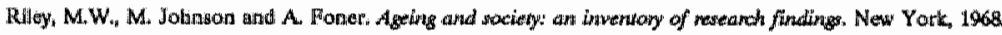

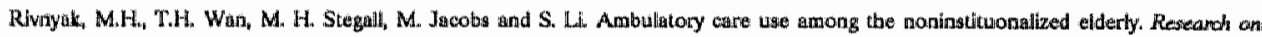
Alging, vol, 11, no. 3, p, 292-311, 1989,

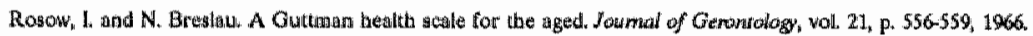

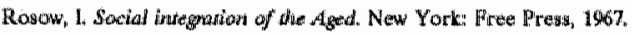

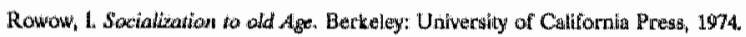

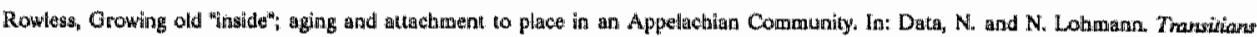
of agigige Now York: Adademic Press, p. 153-170, 1980.

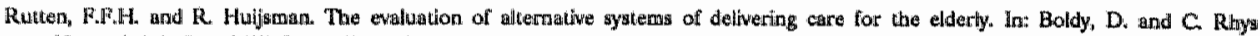

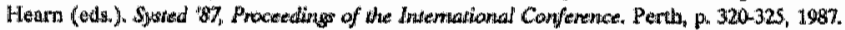

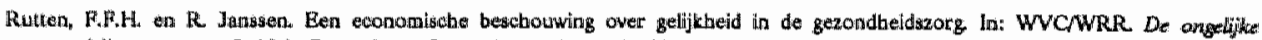

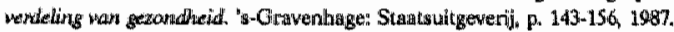

Sacket, D. R. Haynes and P. Tugwell. Clinical epidemiology. Boston: Litle Brow and Co, 1985.

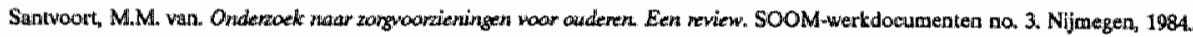

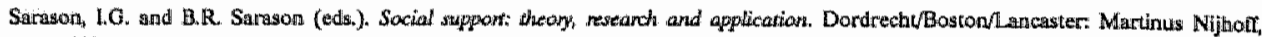
1025. 


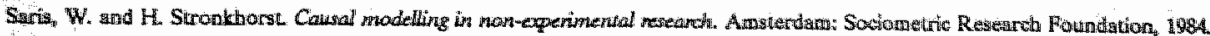

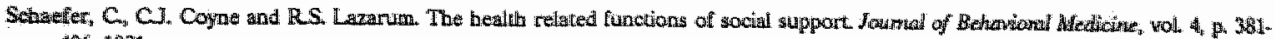
406. 1981.

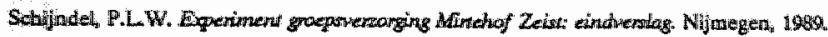

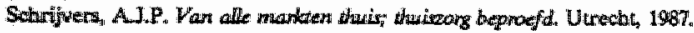

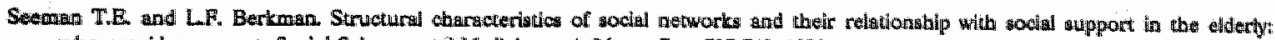
who provides suppork Social Sciences cils Afedicine; wol 24, no. 7, p. 737.749, 1988

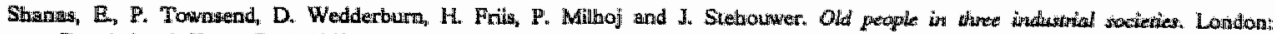
Rousdedge ze Kegan Pul, $196 \%$

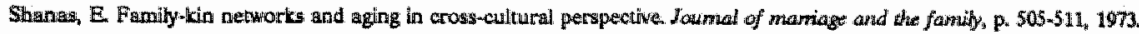

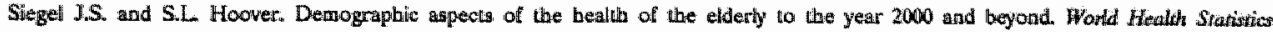
Quartery, vol 35, no. 3/4, p. 133-202, 1982

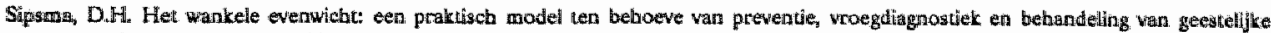
stoornissien bij bejasarden. Nederland Tyjlodinifi weor Gienowolagie, wol. 4, p. 13-23, 1973.

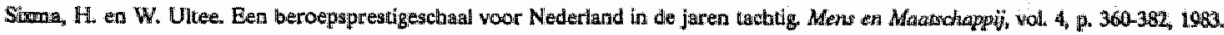

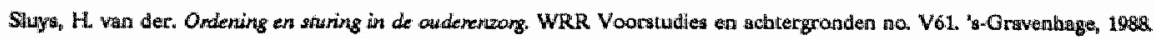

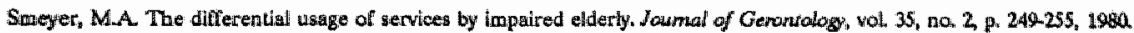

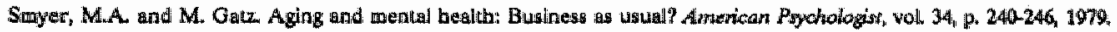

Snell, M.C. Community care for the elderty: costs and dependency. Social Sicience and Medicine, wol. 20, 13. 1313-1318, 1985,

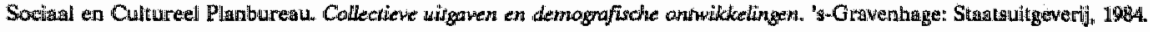

Saciugal en Cuiltureel Planbureau. Saciaal an Culruned Rappont 1986. "s-Gravenhage: Staatsuitgewerij, 1966.

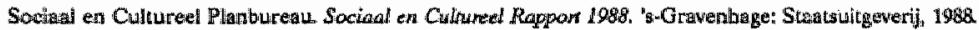

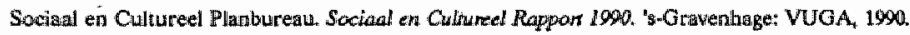

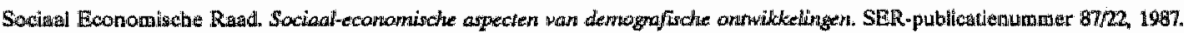

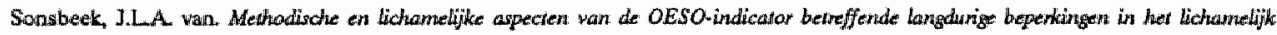
furtichomeren. CBS, mandbericiti gezondbeid, no, 6,1988

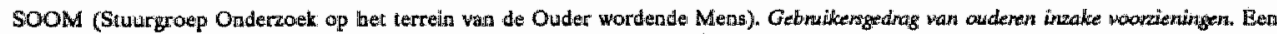
anderzoeksprogramma. SOOM-Werkdocument, na. 9. Nijmegen, 1986.

Spector, W.D., S. Katz, J.B. Merplyy and J.P. Fulton. The bierarebical relationship between activities of dialy liwing and jinstrumental activities of dally living Joumal of Chronical Diseases, wol. 40, p. 481-489, 1987.

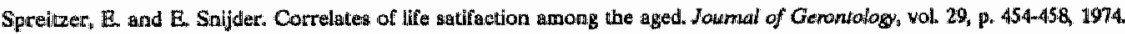

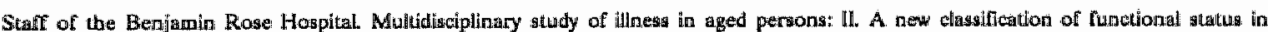
activities of daily Hiving Joumai of Chnonical Diseases, wol, 9, p. 55.62, 1959.

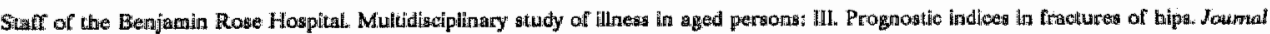

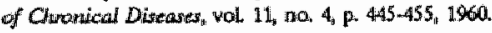

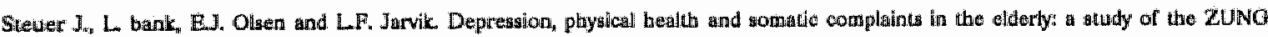

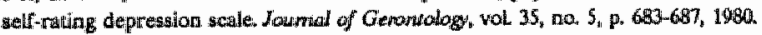

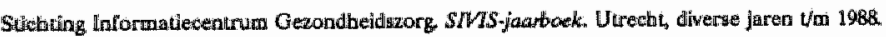

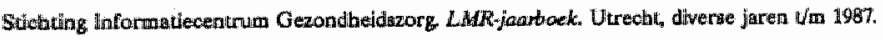

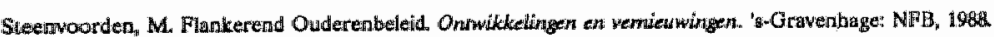

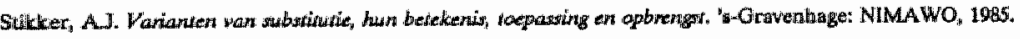

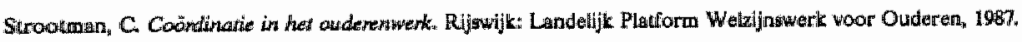

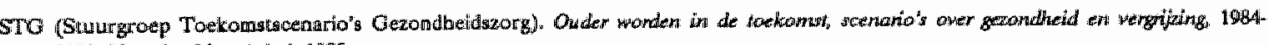
2000. Utrecht: Wass Arkell, 1985.

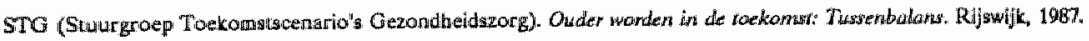

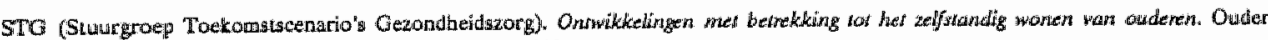
worden in de roekont: Thisenbalans 2 Rijwijij, 1988.

Shraan, A de. Sociologite wan de ponchowherapie. Utrecht: Spectrum, 1979.

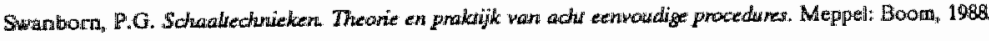

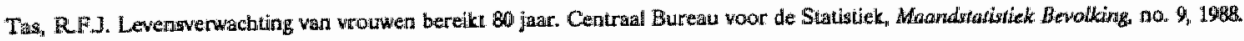


Tax B. LCC.

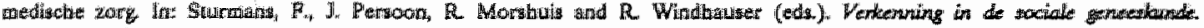
NFigegen, $196 \mathrm{gL}$.

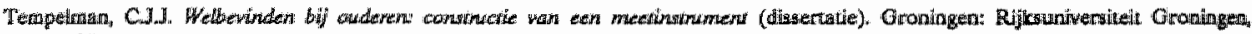
198\%.

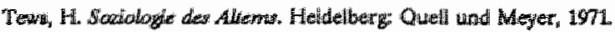

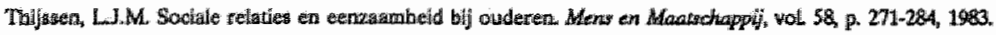

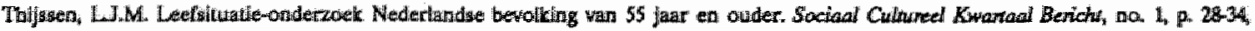
1984.

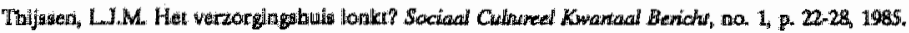

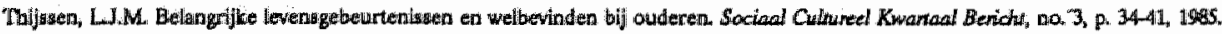

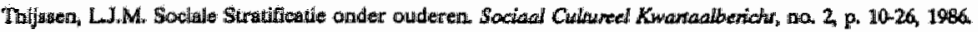

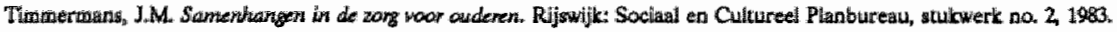

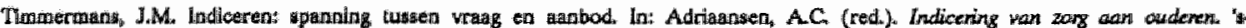
Gravenhage: Programmering College Matschappelijke Dienatvertening 1988

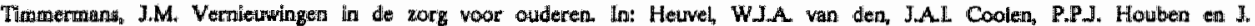

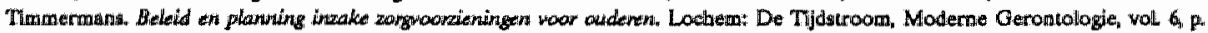
$65-82,1989$

Torgerson, W.S Theory and methads of scalin New York, 1958

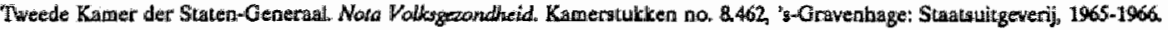

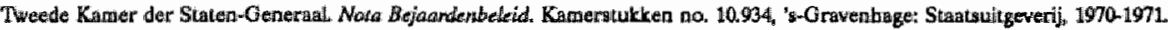

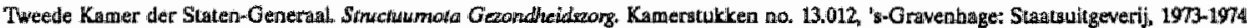

Tweede Kamer der Staten-Generaal. Nota Biejaardembeleid. Kanteratukten no. 13,463, 's-Gravenhage: Staratsuitgeverij, 1974-1975.

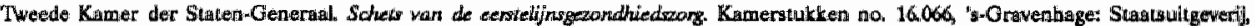
1979-1980.

Tweede Kawer der Staten-Generaal, Nota Bouwgrenen woor een oudenmbeleid. Kamerstulken no. 17.393, 1-3. "Q-Gravenhage: Stnatsuligeterli, 1981-1982.

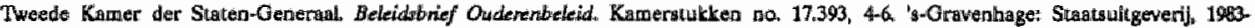
$198 \mathrm{~B}$.

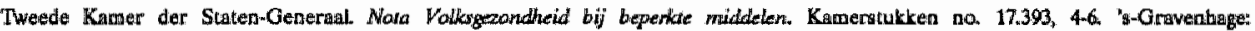
Stabulsuligeverij, $1983-19846$.

Tweede Kamer der Staten-Generabl. Beleidsnota inzahe wetgrwing WVC. "s-Graverabuge: Staatsuitigeterij, 1983-1984a

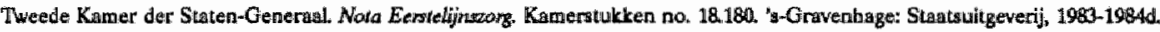

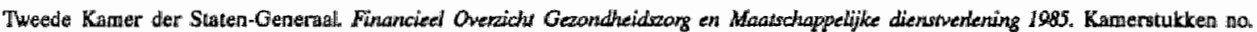
18.600. "G-Orawanhage: Sthatsuiligeverij; 1984-1984-1985.

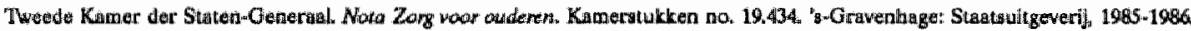

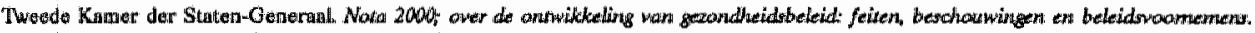
Kametrtuktken no. 19:500 's-Gravenhage: Staatsuiligeverij, 1965-1986.

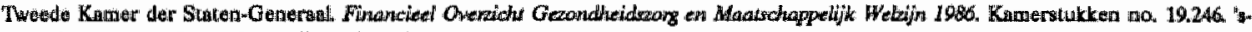
Gravenhage: Staatsulitgeverij, $1985-198 \%$

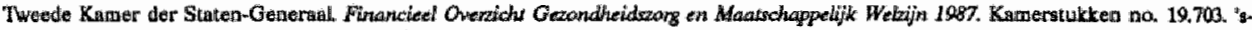
Oravenbage: Sitaatsultgeverij, $1986-1987$.

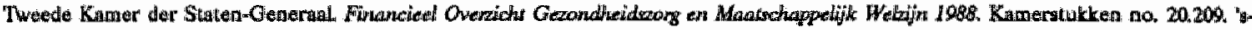
Guavenhagen Statauitgeverij, 1987-1988

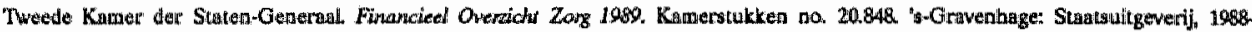
1989.

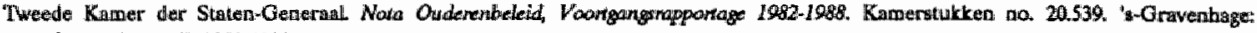
Stanisuitgeverij, $1989-1990$.

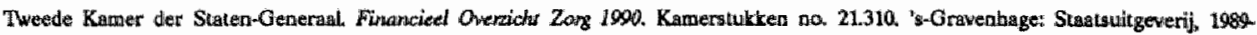
1990.

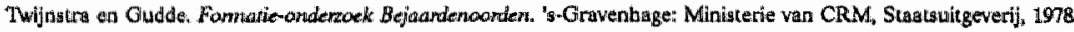

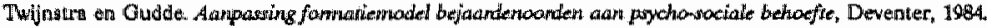

Velikamp Marktonderzoek BV. De Amwiterdanse bejadeden in 1976. Amsterdan, 1977. 


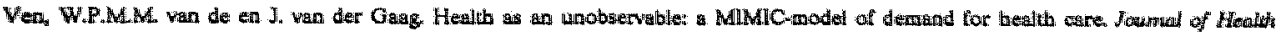
Ecomominicy, woL 1, p. 157-183, 1982

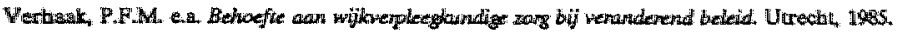

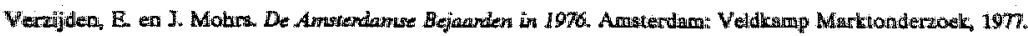

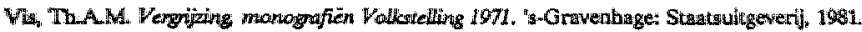

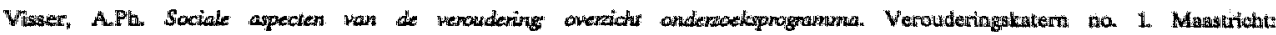
Rijlinsuniversüteit Limburg, 1990

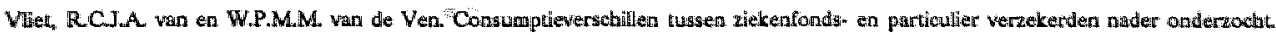

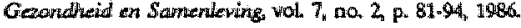

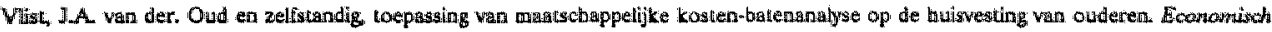
Shativitioche Bevichten 26-9-1984, po 890-894, 1984.

Wries, M.J. de. Het behoud van keven. Utrecht: Bohn, Scheltema en Holkema, 1985.

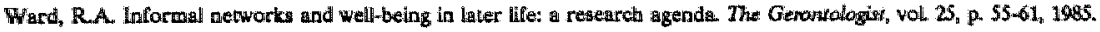

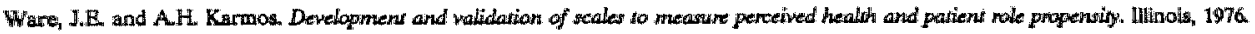

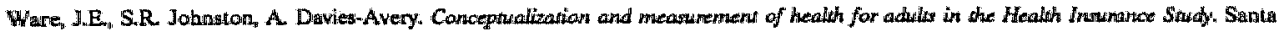
Monita: The Rand Incorporation, 1978

Wenger, G.C. The supportive network coping with old age. Londen: George Allen \& Unwin, 1984,

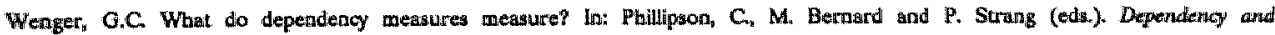
intertiependency in ald age. Worcester: Billing \& Sons Ld., P. 69-84, 1986

Westertatak, J.M. van, J.A. Kropman en J.W.M. Collaris. Blevoepenklapper. Nijmegen: IIS, 1976.

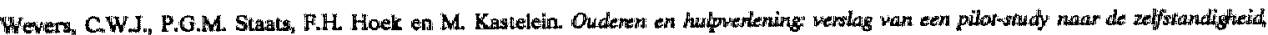

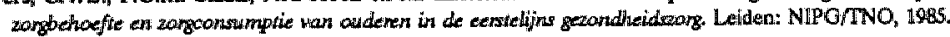

Wheaton, G. e.a. Assessaing reliablitity and stability in panell models with multiple indicators. In: D.R. Heise (ed). Slocialogicall Medhodology. San Francisco: Jossey-Bass, p. 69-83, 1977.

WHO. Corstitration of the WHO" Blasis Dacuments, 1948.

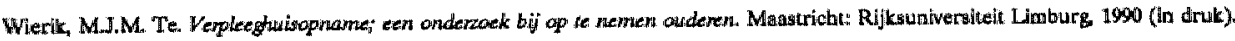

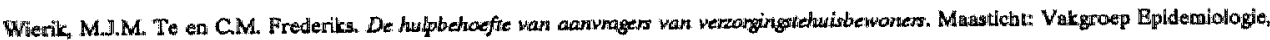
Rijlssuninersiteit Limburg, Verouderingakatern no. S, 1989.

Wherik, M.J.M. Te en CM. Frederiks. De bulpbehoefte en opnamewens wan positief geindiceerden; een vergelijking met werzorgingstebuisbewaners. Tyjdschnift woor Genomologie en Geriatrie, vol. 21, no. 3, p. 115-123, 1990

Whillams $\mathbb{R}$ Concepts of healut: an analysis of lay logic Saciology, vol. 17, p. 185-205, 1983,

Willige, G. wan de, P. Schreurs, B. Tellegen en F. Zwart. Het meten van lilie events: de Vrageraljijt Recent Meegewragkte Gebeurtenissen (VRMG). Nedertands Tijodschifit woor de Psychologie, vol 40, p. 1-19, 1985 .

Wilkin, D. Conceptual problems in dependency research. Social Science and Medicine, vol. 24, p. 867-873, 1987.

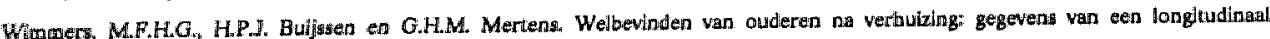

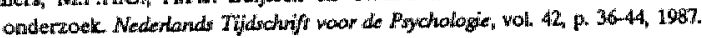

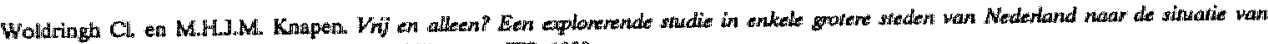
and hawden en hw belewing doandar. Nijmegen: ITS, 1980.

Wonnacotk. T.H. and R.J. Wonnacoth Regression a second course is statistics. New York: John Why and Sons, 1981.

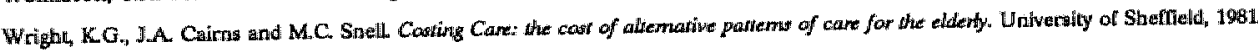

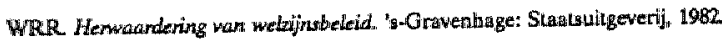

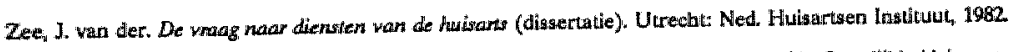

Zjelbuis, RL. Sociale Geneeskunde en sociale ongelijkheid. In: Jong G.A. de (red.). Ongetijkheid in gezondheid en gezondheidrzorg

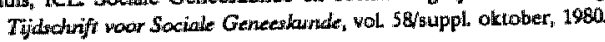

Zung. W.W.K. A self-rating depression seale. Archives of Genemal Psychiam, vol. 12, p.63-70, 1967.

Zung W.W.K. Factors infuencing the self-rating Depression Scale Archives of Gememal Porchiarry, vol. 16. p. 543-547, 1967

Zijde, J. wan der. Waar een wil is, is een wet. Delft: Eburon, 1985. 


\section{Bijlage 1. Tijdbalk ouderenzorg}

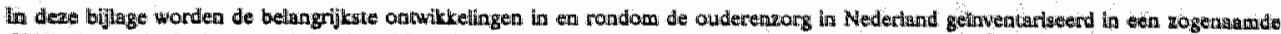

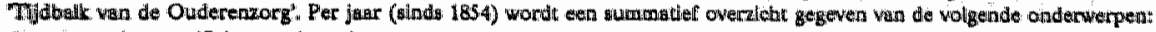

A. wetgeving specifiek voar de ouderenzorg: - peristonwetuen

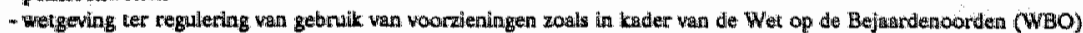

- bujdrage-regelingen in lodter van onerbeüdssubsidiering

- regillingen rond publiek-techtelijte orginen

(1. wetgeving niet-specilite vor ouderenzorg mas met een belangrijke inwoed dasrop:

- welzijingwetten en sociale verzekeringen

- ziektekosten- en ziekenfondswerzekeringen

- (ber-)ystructurecing gezondheidszorg.

- regutering voorzieningen gezondheids- en weliljnszong

- (vollcs-) )lawisvesting, buurubsidieregellingen e.d.

C. offictale nots's en stuklicen van:

- Tweede Kamer der Staten-Gemerail

- Ministeries (CRMANWVC, SoZZ, VoMMUNROM etce)

D. oprichting oq whichting wan de belangrijcate organisatie:

- venenigingen van beroepsigroepen

- Lederaties, verenigingen etci wan inatellimgen

- Lowentorganisatie

- botaden, werenigingen etc wan bejanden/ouderen

- (inter-) departementale stuutgroepen e.d.

- bulp en dienstverteninguorganisaties

E starljaren wan belangrijke innovatieve expecimenten op het gebele terrein wan welxigh van en zorg woor ouderen (bv. startjaar van bet ecrste Dienstencentrum)

De ontwilkelingen op bet terrein van de bierbowen genpemde onderwecpen worden bler niet werdier besthrewen of geangalyseerd, maar slechts opgesomd naar jaar en bron. Veel gebruikce bronnen worden steeds afgekort: Statatsblad (Stb.). Staatscourant: (Stert) en de auklken van de Tweede Kamer der Staten Generaal (TK).

Wet tot Regeling van bet Armenbestuur (Stb. 1854, no. 165)

Statktoezicht op de Volkggezondheid (Stb. 1865, no. 60)

Wet uitoefining geneeskunst (Idem)

Wet voonwasindem bewoegdheild geneeskunat (Stb. 1878, no. 222)

Leger des Hetls

Eerste Vereniging voor Hulwerzorging (Deventer)

Bond voor Staatspensilonering

Gezondheldswel (GW; Stb. 1901, mo. 157)

Nederlandse Vereniging voor Arusenzorg en Weldadlgheid

Algemene Groene Kruis

Armenwet (geheel herzien; Sitb. 1912, no. 165)

Vereniging Nederlandise Gemeenten (VNG)

Invaliditeliswet (IW; Stb. 1913, no. 205)

Gezondbeidswel (berzien en Gezondheidscrad; Stb. 1919, no. 784)

Ouderdomswer (Stb. 1919, no. 628)

Wet tot bescherming diplona verplleegundige (Stb. 1921, no. 702)

Pensionwett (Stb. 1922, no. 2401)

Wit-Gele Kruhig. (Rooms-Kutholiter)

Medische Tuchiwet (Sib. 1928, no. 222)

Ziekicwet (Stb. 1929, no. 374)

Beschiking vaststeling voorwasirden opleiding en examen wjtwerpleging (Sicrt. 1933, no. 221)

Vereniging boofden van tebulizen voor ouderi van dagen

Vereniging wan Directrices wan Tehuizen woor Bejaarden in Nederland

Oranje-Groene Krulis (Protestant)

Ziekenlondsibeslinit (Stb. 1941, no, 809)

Algemene Bond voor Bejemiden

Humaninitus

Protestants Christellike Ouderen Bond

Landelijte Huisartsen Vereniging (LHW)

Nederlaradae Vereniging woor Matachappelifik Werk (voorbeen ver. uilt 1908)

Noodwet Ouderdomswoorziening (Drees (in plats van IW; Stb. 1947, no. 155)

Centrale Raad voor de Gezinswerzorging.

Nederiandse Vereniging voor Gerontologie (NVG)

Wet op de Ziekeniondsrad (Stb. 1947, no. 135)

Kaningin Iulian Fonds (RIF)

Humaniatiache Stichting woor Huigvesting, van Bejaarden (HSHB) 


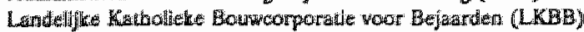

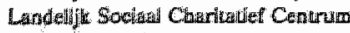

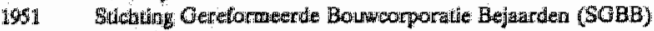

1952 Unile var Kaitholleke Bonden wow Ouderen (Unie KBO)

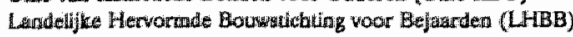

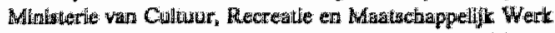

1953 Codrdinatlewet Socidie Verzekering (Stb. 1953 no. 57 )

Protestants-Christelike Pederatie voor langdurig zieken

1954 Nedertandse Federatie Bejtardenbeletd (NPB)

Centrall Organ Samenwerkende Bejaardenorganisaties (COSBO)

Bersts project Tafelije-Delive (Rotherdam)

1956 Centrale Raad voor de Volkgigezondtheid (OW; Stb. 1956, no. S1)

Algermene Ouderdomswet (AOW, wervang Woodwet Drees; Stb.1956, no. 281)

Wet op Ziekenfondswercekertag wor bejararden (Stb. 1956, no. 634)

Kutholleke Vereniging voor Verpleegletultzen (KNV)

Nedertandse Fedieratie van Varpleeg- en Verzorgingstabuizen

1957 Subtuldieregeling Gezinwertorging en gezinahulp 1958 (Stert. 1957, no. 250)

Kitbolleke Vereniging van Bejaardentebuizen (KVB)

Wastonale Ragd voor Mratschappelijic Welzijn

1959 Algenene Weduwen ten Wezenwel (AWW, Sib. 1959, no. 139 en 156)

Protetante Vereniging vain Instellingen voor Bejaardenzorg (PVIB)

1960 Frotestani-Christellje Ouderentond (PCOB)

1961 Voorlopige Brkenning Verpleegtebulzemi (Stb, 1961, no. 248)

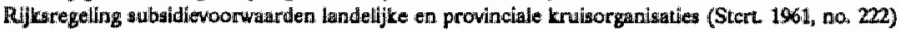

Ontwerp Wet op de Bejaardencoorden (TK, 1962/1963, no, 6621)

Nedertandse Verenlging van Geriater (later Nederlandse Vereniging voor Getiatrie)

1962. Vereniging van economen en administrateurs in bejaardentehuizen (Venab)

1963 Wet op de Bejaardenoorden ( $\mathrm{S} t \mathrm{~b}$. 1963, no. 18)

Wel op de paramedische beraepen (Stb. 1963, no. 113)

1964 Eerste Dienstencentra Bejanarden

Agemene Bijstandswet (ABW; Stb. 1964, no: 312)

Aggmene Vereniging van Instellingen woor Bejaardenzorg (AVIB)

Federatie van SOS Telefonigche Hulpdiensten in Nederland

1965 Wet Zlekenbulistarieven (WZT; Stb. 1965, no. 190)

Bescbikklng voorschriften woningen en verzorgingstehulzen voor bejaarden (Stret. 1965; no, 253)

Ministerie van Cultuur, Recreatie en Mollieu

Algemene Wedumen-en Wezecwet (Stb. 1965, no. 429)

Besluili geldelijke steun volkshuiswesting (Stb. 1965, n.0. \$89)

1966 Verstrektcingenbesluit Zlekenlondiswerzekering (Stb. 1966, no. 3)

Wet Arbeidsongesehiktheidswerzekering (WAO; Stb. 1966, no. 84 en 365)

Bealuit gitatistische gegevens bejaardenoorden. (Stb. 1966, no. 5S.0)

Wet Aggemeen Burgerlijk Pensiaenionds (ABP; Sitb. 1966, no. 6)

Nota Vollesgezondbeid (TK, 1965/1966, no. 8462)

Nationide Rasted woor Montschappelijt Welzijen (NRMW)

4067 Wet overgangsregeling arbeidsongesethilktiveidsverzekering (Stb. 1967, no. 440)

Interdepartementale Stuurgroep Bejagrdenbeleid (ISB, warin CRM, VRO, SoZZ)

Ziektewet (Stb. 1967, no. 479)

Algemene Wet Bjizondere Ziektekosten (AWBZ; Sib. 1967, na, 645)

Voorlopige Rijkstijdrageregeling. Dienstericemtra Bejarden (Stert. 196\%, no. 199)

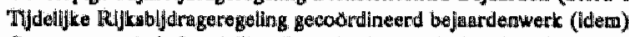

Contectcommissit Landelijke Organdaties ven Bejagrdentebuizen

Nederlands Irstinuut voor Martachappelljk Werk Onderzouk (NIMAWO)

Stichting Natlonale Zlekentulisrad (NZR)

1968 Besluit verpleging ind verpleeginrichtingen Bijzondere Ziektekostenverzekering (Stent. 1968, no. 103)

Vertuakkingenbesluit Blizonder Zilektekostenverzekering (Stb. 1968, no. 239)

Interdepartementale Stuurgroep Bejaardenbeleid ( $\mathrm{SB}_{*}$ Stert. 1968, na. 203)

National Ziekenhuisinstituut (NZI)

Stichling Nederlandse Gezinsraad

Leerntoel Medische Gerontologle RU Utreebt

Stichting Senior Vakantis Plan

1969 Eerste provinciale consulenten voor bejaardenwerk

Eerate projectien (open) gecobrdineerd bejaardenwerk

Natonaal Orgaan Zwakzinuigenzorg (NOZ)

Eersate Nola Bejardenbeleid (TK, 19701971, 10934)

Tijdelijke rijksgroepregeling, bejaarden in bejagndenoonden (via Algemene Bijstandswet; Sibi. 1970, no. 14)

Beslu:t woowaarden gezinsvetpleging Bigzondene Ziektekostenverzekering (Sterc. 1970, no. 55)

Nederlandse Verenlging vari Bejaardenoorden (NeVeB)

Vereniging, vas economen en administrateurs in bejaardentebuiswezen (VEA)

Stiebting, Landelijke Samenwerking Bejasmdentebuizenorganisaties (LSB) 


\section{Wet Ziekenhuiwwoorzientingen (WV $2 \mathrm{~V}$; Stb. 1970, na 268)}

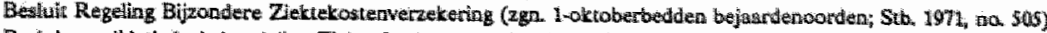

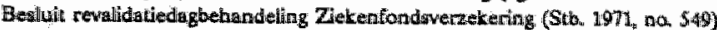

Verealging van Directies van Bijaardeatebulzein (WDB)

Nederlandse Vereaiging Dienstemeentr:

Wet op de Bejaardenoonden (indicatie-cie; Stb. 1972, no. 344)

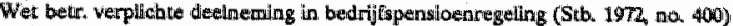

Wei fitscale oudedagoreserve voor zelfstandigen (Stb. $19 \mathrm{~m}, \mathrm{no}, 612$ )

Federatie Landefijke Samenwerking Bej.jardentebuiborganlisaties (LSB)

Landialijke Stichting Opleidingen Bejairderwerk (LSOB)

Nedertands lnstituut woor Gerontologe (NIG)

Sulchting Centrale Rasd voor de Gexinswerzorging (woortheen: zie 1947)

interdepartementale Codrdinatiecommistie Welzijnsbeleid (ICW)

Algemene Bijstandswer (berzien; Stb. 1973, no. 284 en 395)

Beschikkiag dagverblijven gehandictopten (Stert. 1973, no. 23)

Landelijke Beroepsorganisatie voor Werkers in de Gezondheidszorg (LBWG)

Landeljike Stichtiag Opleidingen Bejanardenwerk (LSOB)

Federatie Werkgeverswerenigingen Welzijiassector

Cenurale Commissie Bejaardenoonden ( $\mathrm{CCB}$ )

Koepelorganisalie Masischappetijk Werk (JOLNT)

Coordinailegroep Bejaardenbeleidi CRM (SLCrt. 1974, no. 139)

Structurmota Gezondheidszorg, 1974 (TK, 1973/1974 no. 13012)

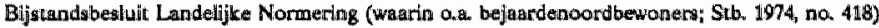

Woonruimtebeschilkkimg (niet-economische gebondentald bejaarden; Sitb. 1974, no. 534)

Rijks groepregelling vijlating oudedsgwoorziening bijzondere groepen (vermogen niet in ABW-uitkering; Stb, 1974, no, 825)

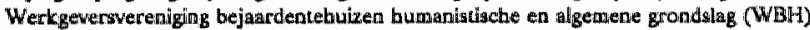

Katholiek Centrum voor Maatselbappelijke Ontwikkelling

1975 Tijdelijke VerstrekkingenWet Matschappelijke Dienswettening (Stb. 1975, no. 157)

Besluil Centrale Commiasle Bejaardenoorden (Stb. 1975, no. 520)

Pas $65+$

Tweede Nota Bejaardenbeleid (TK, 1974/1975, no 13463)

Besluit toezicht opleidingen gezondbeidszorg (\$tert. 1975, no, 162)

Algemene Arbeidsongeschiktheidswet (AAW; Stb. 1975, no. 674)

Beschilking individuele buursubsidie (Stort. 1975, no. 63)

Nationale Ziekenhusstraid (NZR)

Nationale Vereniging Verpleeghuisartsen (NVVA)

1976 Besiluil geldelijke steun volkshuiswesting (Stb. 1976, no, 472)

Besluit Opnewing Bejaardenoorden (BOB; Stb. 1976, no. 619)

Landelijk Steunpunt Vitijwilligerswerk

Stichting Dienstwertening Bejandentebuizen (SDA)

Stichting $55+$ Reizen.

1977 Wettelijke regeling indicatiecommissies bejasdencorden van kracht

Wet op de arbeldsongeschikabeidswerzekering (Stb, 1977, no, 492)

Wet ABP herzien (Stb. 1977, no. 679)

Oncwerp Wet Voorzieningen Gezondbeidszorg (WVG)

Harmonisatieraad Welzijiagbeleid

Oprichting Nationale Kruiswerenigirg

Verstrekcingenbesluit Bijzondene Zjektekostenwerzekering (Stb. 197h, no. 444)

Bestuit dagbetbandeling verpleeginfichuing (Stort 1977, no. 128)

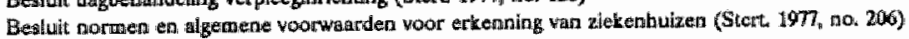

Algemene Nedertundse Bond voor Ouderen (ANBO)

1978 Besluit gezingwertarging en buibboudelifke hulp/AAW (ewhulp; Star. 1978, no. 226)

Besluit geldelijke steun huurwoningen 1975 (f 2000 - regeling)

Federatie (voorbeen Stichting -zle 1970-) LSB

Landelijk Overleg Bewonerycommisales Bejandentebuizen (LOBB)

Nederlandse Organisatio wan Welzijngwericers (NOW)

1979 Besiluit aamwijzing inrichtingen WZV (Sulo. 1979, no. 465)

Wet Zukentulswootzieningen gewijgigd (Sib. 1979, no. 466)

Regeling vervroegde uittreding (VUT; bij 63 jaar) burgerlife owertheidspersoneel (Sib. 1979, mo. 752)

Voorlopig spreidingsplan dagbebandeling verpleegtavizen ( $\$$ terc. 1979, no. 35)

Besluik Hulp vanwege een truisonganizatie Bijzondere Ziektekostenwerzekering (Stert. 1979, no, 250)

Federatie losuellingen Joodse Bejaardenzong (FLB)

Kruiswerk in AWBZ (Stb, 1967, no 655)

Notw Vestigingabeleid

Tijelijke Rijksbijdrageregeling Gecobrdineend Bejaardenwerk (Stcr. 1980, no.9i)

Ontwerp-besluil Voorlopige Raad woor Ouderen (TK, 1979/1980, no. 15800)

Schets van de eerstefijng gezondiheidszong (TK, 1979/1980, no. 16060 )

Algemene Arbeidsongeschiktheidswet (wijziging; Stlt, 1980, no. 28)

Wet Tarieven Gezandheidszorg (NTO; Stb. 1980, no. 646)

Project educatieve woorzienimgen ter voorbereidizg op de penasionering

Erkenning specialisme geriatrie

Landelijke Stichting Meer Bewegen voor Ouderen (MBvO) 


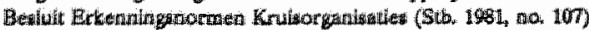

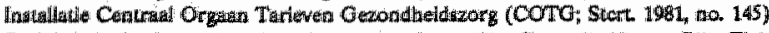

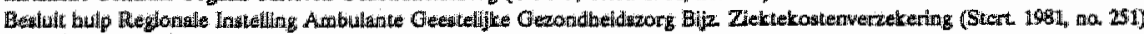

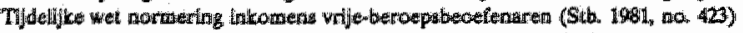

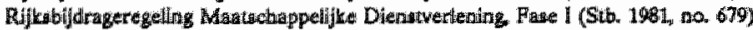

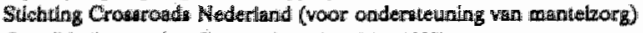

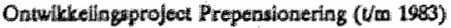

1082. WTo wolledig in werking (5tb. 1482, no. 24 an 25)

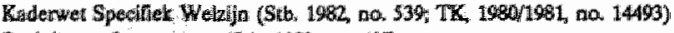

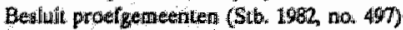

Wet Vooriteningen Gezonde eldzorg (WVG; Stb. 1982, no. S63)

Natoonale Rawd woor de Volksgezondheid (Stb. 1982, no. 622)

Now Boustenen wown cen Ouderenbeleld (TK, 1981/1982, no. 17393)

Stuirgroep Onderzoek Ouder wordente Mens (SOOM)

Herowerweging befwardenbeleid (TK, 1981/1982, no. 16625, no. 54)

Stietaing Landelijk Plattorm Welzijnwerk voor Ouderen (LPWWO)

Rujkabijdrageregethog Maglschappelijke Dienswerlening

Beslult eigen bijdrageregeling bijzondere ziektekogtenwerzekering 1983 (Stert. 1982, now 215; wijkfwneties bejairdenoorden)

Beteidabibit Ouderenbeleid (TK, 1983/1984, no, 17393, no, 4-6)

Nokit AOW-plus-problematiek bejardenverzekering (TK, 1982/83, no. 17989)

Now Valksigezondheld bil beperkte middelen (TK, 1983/1984, no. 18108)

Interimwet Bejaardenoorden (12. 1982/83, no. 18171; Stb. 1983, no. 68T)

Not: Eerstelfjwstong (TK, 1983/1984, no. 18180)

Totatsadkoming Ministerie van Welzijn, Volksgexondheid en Culuur

Befletidnota inzske wetgevigg WVC (0.a. GOW naar gemeente per 1-1-1985)

Nota Flankerendi Bejaardembeleid (Ministerie wan WVC, Rijswijk)

Wet op de Pensioenkamer (Stb. 1983, no. 259)

Budgetiering Agremene Zlekentbuizen (via WZV; Stb, 1983, no. 328)

Landelijke Vereniging Groepswonen voor Ouderen (LVGO)

1984 Wet op de Bejaardenoonden (TK, 198485, no. 18179; Stb. 1984, no. 65.6)

Wijzigling Bealult Opname Bejaardenoorden (Stb. 1984, no. 674)

Bealuit persoonlijke gegewens bejaardenoorden (Stb. 1984, no. 675)

Bdjuragebesluit Bewoners Bejandenoorden (Stb. 1984, no. 677)

Reikwildtrebueslult WBO (Sto. 1984, no. 678)

Be: iluit persoonlijke uilgaven bewoners bejaardenoorden (Stret. 1984, no. 36)

Nota Geestelijke: Volksgezondheid (TK, 1983/1984, no. 18463)

Nota inzake bouwbeleid, bedderreducte en linanclering (TK, 1983/1984, no. 18279),

Nota Woontussenwoorzinnüngen. (TK, 1984/1985, no. 18888)

Besliut eilsen vooul erkenning ziekenhuizen (Strch. 1985, no. 234)

Berste Gulde-project van Ouderien (Amaterdam)

1985 Besluit intrekking ujdelike rjjksbijdragergeling gecoördineerd bejaardenwerk (Stcrt. 1985, no. 5)

Besluit tanwijzing bejaardenoorden met een bijzondere functie (Stcr. 1985, no 14)

Subsidieregeling exploitatiekosten bejaardenoorden met een bijzondere functie (Stert. 1985, no. 14)

Rujks gubsidieregelling Gezinswerzorging (budgettering; Sicrt. 1985, no. 29)

Wet op de Bejaardenoorden e.a in werking

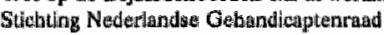

Regelev tav. beleidsvorming witwoeriag en bekostiging van voorzeningen wan maatschappelijke en sociasil-culturele weizijn

$(T K, 19841985$, , 20.18957$)$

Notu Wountussenwoorzianingen (TK, 1984/1985, no. 18888)

Algemene Ouderdomswet (Sib. 1965, no. 180)

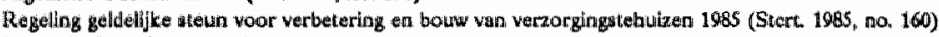

Voorsebriftun nieuwe woningen en woongebousteribejaxardenoorden (Stcrt. 1985, no. 204)

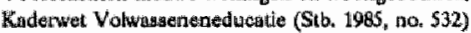

Experiment Studiokriagen Ouderen (Bond van Naderilandse Volksuniversiteiten, BNVU)

Interimbesluit Woontuasenwoorzieningen (Stert. 1986, no. 20)

Intretkkng Oniwerphitit, Gezondhejdszorg en Maatschappelijke Diensivertening (TK, 1985/1986, no. 18957, no. 13)

Basl.gvoorzieningen voor Bejamrden (IK, 1985/1986, no. 19344)

Nola Zorg voor Ouderen (TK, 1985/1986, no. 194:34)

Nota 2000 (TK, $1985 / 1986,190.19500)$

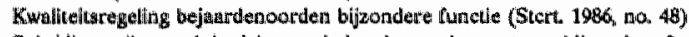

Subsidieregeling exploitatiekasten bejaurdenoorden met een bijzondere functie (Sicrt. 1986, no. T)

Subsidieregeling kosten llankerend beleid (Sterti, 1986, no. 77)

idem voor bejaardenoorden mei een bijzondere functie (Stert 1986, no, 7T)

Beacbikking geldedike steun ouderen bij verbuizing (Sicat, 19:36, no. 1.27)

Sticating Aanwullerde Thusgrors

Wet Miedefinangetering Oververtegenwoordiging Oudere Ziekentondswerzekerden (MOOZ; Stb. 1986, no. 117)

Wet Indfilduele Huursubsidie (Stb. 1986, no. 265)

Rijk:sbijdrageregeling Basiseducatie (Stb. 1986, no 433)

Wei stelswiberzlening sociale zekerbeld (Stb. 1986, no. 567)

Wra in werking (Stb. 1986 no. 710)

Nota Zong voor later, zorg voor nu (Min. van WWC)

Nora Kosten van Vergrijzing woor WVC (Min. van WVC) 
Vereniging Algemene Thuiszorg in Samenwerking (ATS)

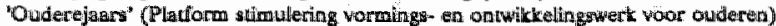

Landeifik Platiorm GWO/Preventie Ouderen (LPOO)

19807

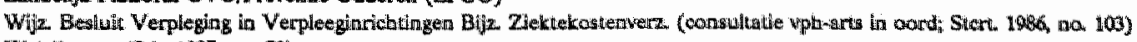

Weirlingswet (Sib. 1987, no. 73)

Voorontwerp-Besiult Adwisering Hulpweriening Ouderen (Min. vain WVC)

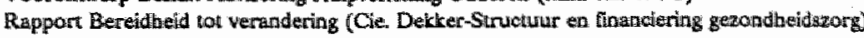

Interdepartementale Suurgroep Ouderenbelieid (ISO; Stcr. 1087, no. 87)

Subsidieregeling ouderenzorg gehandicaptenzorg en algemeen matatsehappelijke bulpvertening (Stert, 1987, no, 25:2)

Studie- en Informaticcentrum Ouderenbeleid NFB (woortheen NFB, 1954)

19198

Voorlopige Ratad voor ber Ouderenbelleid (Sto. 194, na, 28)

Wijziging artiket X Wet Bejasirdenoonden (Stb. 1988, no. 77)

Wijziging leeflujdsgrens bejasardenoorden naar 75 jasr

Nota Ouderenbeleid, Voortgangsrapportage 1982-1988 (TK, 1987/1388, no. 20539)

Besluin indicate-advisering, bejaardenoorden en werpleghuiren (Stb. 1986, no. 45:6)

Harmonisatie eigen bijulisageregeling verpleeghuizen/bejalardenoorden

Nederlands Stamuleringeprogramma Ouderenomderzoek (NESTOR)

1989 National Institumt voor Zorg en Welijijn (NIZW)

Vereniging van Nederlandse Bejaardenoorden (VNB; voorbeen LSB)

Regeling subsidiering gezinswerzorging 1989 (gexinswerzorging in AWBZ; Stcr 1989, no. 16)

Landetijik Overleg Oecoordineerd Ouderenwerk (LOGO; voorben LPWVO) 


\section{Bijlage 2: Instellingsenquête}

\section{INSTELLINGSGEGEVENS}

In het eerste deel van de enquête worden enkele algemene vragen gesteld omtrent de instelling alls zodanig en over de personen die (delen van) de enquete hebben ingevuld.

01 Nam van de lnstelling:

02 Adres en telefoon instelling:

(Zie Toelichting)

telefoon: $\underline{077}$

03 Oprichtingsdatum:

04 Datum voltooling van de laatste

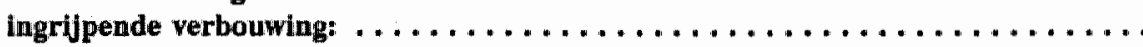

betreffende (zie Toelichting):

05 De grondslag van de instelling is:

De code(s) achter het (de) antwoord(en) omcirkelen

roomskatholiek

protestants-christelijk 2

humanistisch 3

algemeen 4

overig 5

06 De houd(st)er wan de instelling/voorziening is een:

De code(s) achter het(de) antwoord(en) omcirkelen

(Zie Toelichting)

vereniging

stichting

kerkgenootschap

cooperatieve vereniging

naamloze vennootschap of firma

besloten vennootschap 6

$\begin{array}{ll}\text { particulier persoon } & 7 \\ & \end{array}$

gemeente $\quad 8$

burgerlijke instelling (art 2.a Rompwet) 9

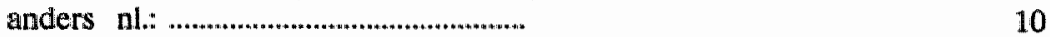


De code(s) achter het(de) antwoord(en) omcirkelen

(Zie Toelichting)

provincie Limburg

regio "Zuid Limburg

gemeente Maastriclit.

aantal wijken van Maastricht

4

eén specifieke wijk of buurt van Maastricht

nl.:

ander gebied

nim:

08 Naam en functie respondent(en):

(Zie Toelichting)

1. $\mathrm{dhr} / \mathrm{mw}$

functie

betreffende welke vragen

datum van invulling

toestelnummer

2. dhr/mw

functie

betreffende welke vragen

datum van invulling toestelnummer

3. $\mathrm{dhr} / \mathrm{mw}$

functie

betreffende welke vragen

datum van invulling

toestelnummer

4. $\mathrm{dhr} / \mathrm{mw}$

functie

betreffende welke vragen

datum van invulling

toestelnummer 


\section{ORGANISATTE}

In dit gedeelte van de enquete worden een aantal vragen gesteld over de organisatie van de instelling cq. voorziening. Het betreffen vragen over de organisatie van de instelling als geheel, over de communicatie tussen personeelsileden van verschillende aiveaus en ower de tot standkoming van beslissingen en de betrokkenheid wan diverse personen daarbij.

09 Wat is de formele organisatiestructuur van de instelling?

Wilt u hiervan een copie bijwoegen; als deze niet beschikbaar is kunt $u$ in het onderstaande kader een schets van de structuur geven (Zie Toelichting).

Wilt a woor iedere afdeling/sectie e.d. de naam van het hoofd geven en aangeven hoeveel mensen tot de betreffende afdeling/sectie e.d. behoren.

\section{Ruimte voor formele organisatiestructuur}

10 Bestaan er buiten de beïnvloedingskanalen zoals die uit de formelle organisatiestructuur blijken, nog andere (informele) wegen waarlangs personen van een bepaalde eenheid invloed uit kunnen oefenen op personen van een andere eenheid of op een ander niveau? (Zie Toelichting voor voorbeelden)

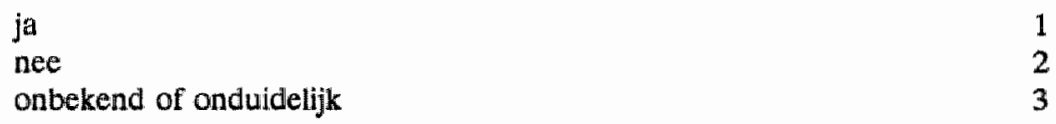

Zo ja, kunt u deze d.m.v. stippellijnen in het schema aangeven?

11 Hoe vaak vindt overleg plaats tussen de personeelsleden van diverse niveans: De code(s) onder het(de) antwoord(en) omcirkelen (Zie Toelichting)

\begin{tabular}{|c|c|c|c|c|c|c|c|}
\hline & $\begin{array}{l}\text { dago- } \\
2 \mathrm{j} j \mathrm{ka}\end{array}$ & 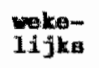 & $\begin{array}{l}\text { manando } \\
11 j \mathrm{ka}\end{array}$ & $\begin{array}{l}\text { Haar } \\
\text { ijjka }\end{array}$ & $\begin{array}{l}\text { jaar- } \\
\text { ijijks }\end{array}$ & ninder & $\begin{array}{l}\text { gean } \\
\text { nort: }\end{array}$ \\
\hline $\begin{array}{l}\text { bestuma- en } \\
\text { directioleden }\end{array}$ & 1 & 2 & 3 & 4 & 5 & 5 & 7 \\
\hline $\begin{array}{l}\text { directieledien en } \\
\text { afdel Ingahoofiden }\end{array}$ & 1 & 2 & 3 & 4 & 5 & 6 & 7 \\
\hline $\begin{array}{l}\text { afdelingahoofden } \\
\text { ander } 1 \mathrm{ing}\end{array}$ & 1 & 2 & 3 & 4 & 5 & 6 & 7 \\
\hline 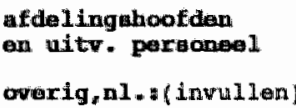 & 1 & 2 & 3 & 4 & 5 & 6 & 7 \\
\hline$\ldots \ldots \ldots \ldots \ldots$ & 1 & 2 & 3 & 4 & 5 & 6 & 7 \\
\hline 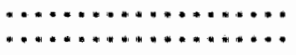 & 1 & 2 & 3 & 4 & 15 & 6 & 7 \\
\hline
\end{tabular}


12. Wordt voor de allocatie van financiële middelen gebruik gemakt van een budgetteringssysteem warbij delen van het budget toegewezen worden aan eenheden (personen of afdelingen) binnen de organisatie?

$\begin{array}{lr}\text { ja } & 1 \\ \text { nee } & 2 \\ \text { onbekend of onduidelijk } & 3\end{array}$

13a Indien een dergelijk budgetteringssysteem gehanteerd wordt, kunt u dan aangeven hoeveel budgethouders er zijn?

minder dan 4

4 tot en met 7

8 tot en met 11

2

12 of meer

3

niet van toepassing

13b Kunt u aangeven hoeveel vrijheild afdelingshoofden genieten bij de besteding van het budget?

De code(s) achter het (de) antwoord(en) omcirkelen

geheel vrije besteding

vrijwel geheel vrij

ongeveer voor de helft vrij

vrijwel niet vrij

verantwoording voor iedere besteding

2

3

vrij tot bepaald max, nl. Fl.

niet van toepassing

14 Maakt het verplegen van patiënten onderdeel uit van het takenpakket van de instelling?

De code(s) achter het (de) antwoord(en) omcirkelen

$$
\text { ja }
$$

nee

15 Indien de voorgaande vraag bevestigend beantwoord is, van welk(e) verpleegsyste(e)m(en) maakt de instelling dan gebruik? (zje toelichting voor genoemde systemen) Meerdere antwoorden mogelijk. De code(s) achter het (de) antwoord(en) omcirkelen.

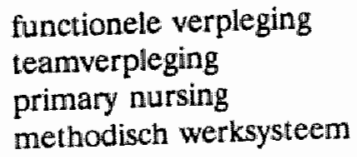


16 Kent de instelling en georganiseerde vorm van werknemersoverleg/-inspratak? (zie troelichting)

Ondernemingsraad

1

Participatieve besluitworming $\quad 2$

Andere vorm, nil.: ...................................................

Nee 4

17 Z jijn patiënten c.q. cliënten of andere niet-professioneell betrokkenen in het bestuur wan de linstelling vertegenwoordigd? De code(s) achter het (de) antwoord(en) omcirkelen

$\begin{array}{lr}\text { alleen patienten } & 1 \\ \text { alleen niet rechtstreeks betrokkenen } & 2 \\ \text { beide groepen } & 3 \\ \text { niet van toepassing } & 4\end{array}$

18 Bestaat naast een eventuele vertegenwoordiging in het bestuur nog cen andere weg waarlangs niet-professionele leden uit de samenleving bij de instelling betrokken zijn? De code(s) achter het (de) antwoord(en) omcirkelen.

$\begin{array}{lr}\text { Kontaktraad } & 1 \\ \text { Instellingsraad } & 2 \\ \text { Adviescommissie } & 3 \\ \text { Wijkraad, buurtbewonerscommissie } & 4 \\ \text { Anders, nl. ............................................... } & 5 \\ \text { Niet van toepassing } & 6\end{array}$

19 Op welke wijze zijn de patiënten/cliënten van uw instelling georganiseerd?

In patientea/clientenoverleg/bewonerscommissie 1

In belangenbehartigingsvereniging 2

Op andere wijze, $\mathrm{nl}$. ......................................... 3

Niet van toepassing 4

20 Hoe vaak vindt overleg tussen de instelling en de georganiseerde patiënten/cliëntem plaats?

Wekelijks

Twee maal per maand $\quad 2$

Maandelijks 3

Drie-maandelijks 4

Half-jæarlijkss 5

Jaarlijks 6

Minder dan jaarlijks $\quad 7$

Niet van toepassing $\quad 8$ 
21 Totale omvang van het persomel per 31 december 19 ..w naar omvang dagtaak, totaal in full-time equivalent (f.t.e) en niet in loondienst (zowel abs. aantal als in f.te.). (Zie Toelichting voor omschrijving personeelsrubrieken)

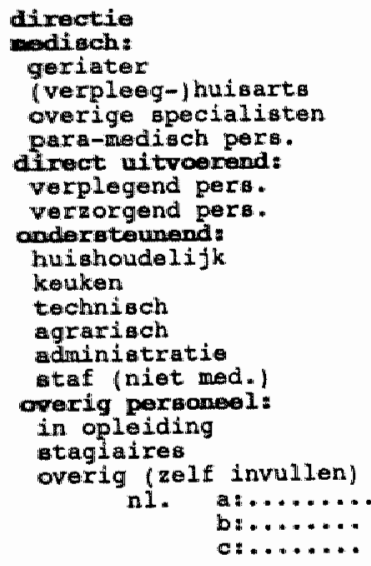


22 Uitwoerend personeel in loondienst per 31 december 19 ... naar omwang dagtaak, totaal aantal ta gemiddelde salarislast per 1 f.t.e., uitgesplitst naar opleiding (gediplomeerd: dp; in oplelding: Lo $0_{n}$ )

(Zie Toelichting)

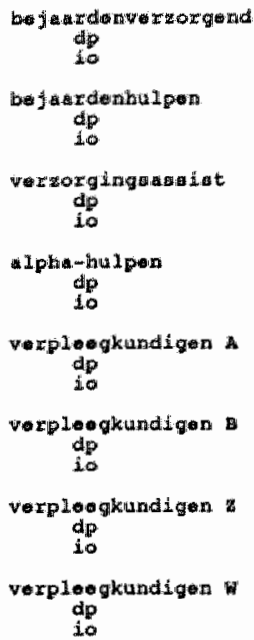

Bubtotaal

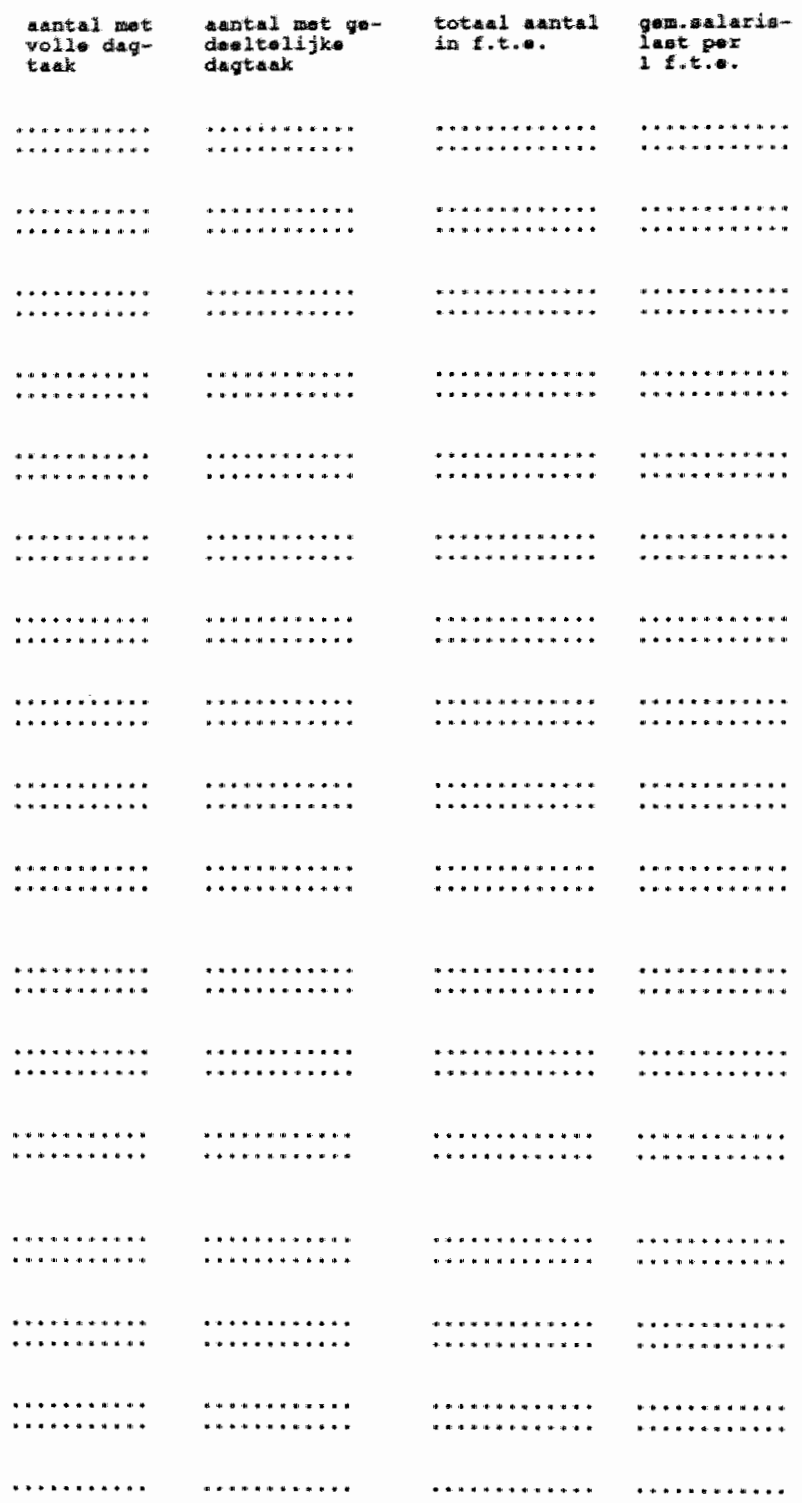


Watotati vorigo pag.

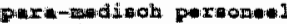
dp

overig vexplegend pext. dio
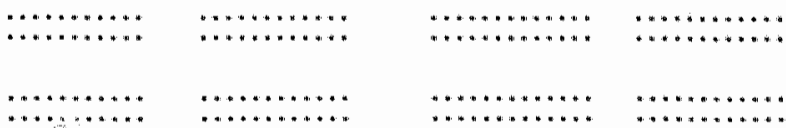

overig verzorgend pere. ip
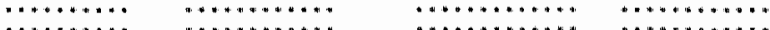

Totedatel

23 In onderstaande tabel wordt gevraagd om het uitvoerend personeel (in totaal beschikbare f.t.e.'s uit kolom 3 van vraag 19) uit te splitsen naar de activiteiten die zij verrichten. Indien noodzakelijk kan volstaan worden met een schatting van deze verdeling. In de Toelichting wordt uitgelegd welke tien groepen wan activiteitem onderscheiden worden en wat hieronder verstaan wordt.

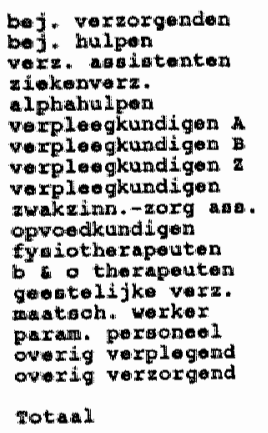

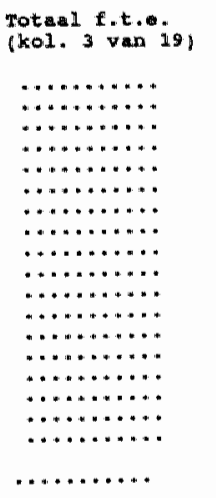

\begin{tabular}{|c|c|c|c|c|c|c|c|c|c|}
\hline 1 & $\frac{1}{2}$ & 3 & $\frac{b}{4}$ & 5 & 6 & 7 & 8 & 9 & 10 \\
\hline & $\cdots$ & * in it & $\cdots$ & $\cdots$ & $\cdots$ & $\cdots$ & $\cdots$ & $* n *$ & \\
\hline . & $\cdots$ & $\cdots *$ & $\cdots$ & $\ldots$ & $\cdots$ & $\approx \cdot$ & $* *$ & 4.4 & \\
\hline$\cdot$ & $\cdots$ & $\cdots$ & $\cdots$ & $\cdots$ & $\cdots$ & $\cdots$ & $\cdots n$ & $\cdots$ & 5100 \\
\hline$\cdots$ & $\cdots$ & $a$ & $\cdots *$ & $\cdots$ & $\cdots$ & $\because *$ & 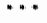 & $\cdots$ & \\
\hline$\cdots$ & $\cdots * *$ & $m$ & $\cdots$ & $\cdots$ & $\cdots$ & $*$ in * & $\cdots$ & $\cdots$ & \\
\hline$\cdots$ & $n: *$ & $\cdots$ & $\cdots$ & $\cdots$ & $\cdots$ & $* * *$ & $\cdots$ & $"$ & \\
\hline$n$ & * " n * & $\cdots$ & $\cdots$ & $\cdots$ & $4=$ & $* *$ & $\cdots$ & $\because \pi$ & \\
\hline$\cdots$ & $\cdots$ & $*$ & $\cdots$ & $\cdots$ & $\ldots$ & $* \cdots$ & $\ddot{*}$ & $*$ & \\
\hline$\cdots$ & $\cdots$ & $\cdots$ & $\cdots$ & $*$ & 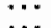 & $\cdots$ & $\because$ & • & \\
\hline$\cdots n$ & $* \cdots$ & $\cdots$ & $\cdots$ & $n$ & $\cdots$ & $\cdots$ & $\ddot{*}$ & $\cdots$ & \\
\hline$\cdots$ & $\cdots$ & $\cdots$ & $\cdots$ & $\cdots$ & $\cdots$ & $\cdots$ & $\because$ & $\because$ & \\
\hline$* *$ & $\cdots$ & $\cdots$ & $\because \cdots$ & $\because$ & $\because$ & $\cdots$ & $\because$ & $\because *$ & \\
\hline$\because$ & $\cdots "$ & 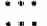 & $\cdots$ & $\cdots$ & $\cdots$ & $\cdots$ & $\cdots$ & 4 & \\
\hline$\because$ & $\cdots$ & $* \pi$ & $\because *$ & " " " & $\because 4$ & $\theta$ & $\ldots$ & $\ldots$ & \\
\hline$\because$ & $\cdots$ & $\cdots$ & $\cdots$ & $" *$ & $*$ & $\because$ & a & 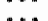 & \\
\hline$\cdots$ & $\because "$ & $\cdots$ & $\cdots$ & $\cdots$ & 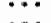 & 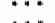 & 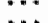 & 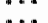 & \\
\hline$\cdots$ & 0.4 & $=\cdots$ & $\because \cdots$ & $* *$ & $* *$ & 4.4 & $\because$ & $\ldots$ & \\
\hline$\cdots$ & $\cdots$ & $\cdots$ & $\cdots$ & $\cdots$ & $\cdots$ & $*$ & $* *$ & $" \cdots$ & \\
\hline * a & $\cdots$ & $\because m$ & $\cdots$ & $\cdots$ & 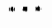 & $\cdots$ & 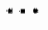 & $\cdots$ & \\
\hline
\end{tabular}

24 Worden er in uw organisatie vrijwilligers ingeschakeld bij activiteiten ten behoeve van patiènten of cliênten:

$$
\text { ja }
$$

nee

25 Alleen bij positieve beantwoording van voorgaande vraag wordt u verzocht onderstaande vragen in te vullen. (Zie Toelichting bij vraag 23 voor functie-omschrijvingen)

Aantal vrijwilligers per 1 jan 19. ..

Aantal vertrokken wrijwilligers in jaar Aantal bijgekomen vrijwilligers in jaar Aantal vrijwilligers per $31 \mathrm{dec} 19 .$. Totaal aantal f.t.e. per $31 \mathrm{dec} 19 .$. 
waarvari (in \% wan totaal f.t.e. per 31 dec 19...) ten behoeve van

$\begin{array}{lc}\text { functie } & 1 \text { : } \\ \text { functie } & 2 \text { : } \\ \text { functie } & 3 \text { : } \\ \text { functie } & 4 \text { : } \\ \text { functie } & 5 \text { : } \\ \text { functie } & 6 \text { : } \\ \text { functie } & 7 \text { : } \\ \text { functie } & 8 \text { : } \\ \text { functie } & 9 \text { : } \\ \text { functie } & 10 \text { : }\end{array}$

\section{CAPACITEIT}

In dit deel van de enquete worden vragen gesteld over de faciliteiten die bij uw instelling voorhanden zijn en het aantal patienten cq. clienten dat daarvan gebruik maakt (kan maken). Voorts wordt gevraagd naar enkele kenmerken van de client- of patientpopulatie die van uw instelling gebruik maakt.

26 Aantal bedden (Zie Toelichting):

bedden voor verzorgden

erkend door AWBZ

beschikbaar aantal bedden

feitelijk aantal bezette bedden (gemiddeld)

bedden voor personeel en logeerbedden

niet van toepassing 
27 Beschikt de instelling over de volgende faciliteiten, en to ja wat is de behandelingscapaciteit

(Zie Toelichting voor omschrijwing van aantal faciliteiten)

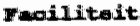

\section{Prol thition}

Eerete bulppost

Froiotherapie/rovalid.

Bottan fuitaluitemd rol

noroutiogat

Hawer: voor verigorgden - mpereopra kamere

twe peramorn. driapie resone vierpexeoon vijfpormoon

of

Exwer voor verpilegelen enpersoon: knomera therparaons distepereoone vierparaons vijt of ater perroons

Manleunoningen/pavil joen

men-ksmex unito

twe-kamer unita

drio-kamer unito

mear-kander utite

Wa

intern op a 1

intern op kamor

intern op zual of kamer

extord

Paybiatrioche diagbehiand.

Geriatrieche degbehand.

Groepobohandeling

Shapuath

Th I fonitobe opvang

$$
\text { of alarigering }
$$

24-ulare ha piverl. /opwang

speo. apparaturir of halpmidale len

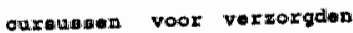

roorliohting

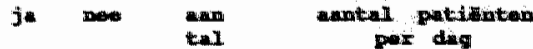

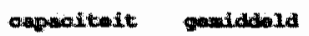

$+\ldots+\ldots+\cdots+\cdots+\cdots+\cdots$

$\cdots \cdots+\cdots+\infty$

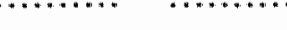

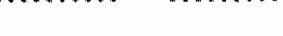

12

$\begin{array}{lll}1 & 2 & \ldots \\ 1 & 2 & \ldots \\ 1 & 2 & \cdots \\ 1 & 2 & \cdots \\ 1 & 2 & \cdots\end{array}$

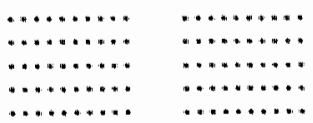

$4 \ldots \ldots \ldots$

*...

$+\cdots+\cdots+\infty+\infty$

$\ldots+\ldots+\cdots$

$+\cdots+\cdots$

$\ldots$

$\cdots$

$\ldots \ldots \ldots$

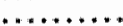

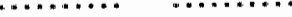

$\ldots \ldots \ldots \ldots \ldots$

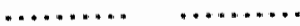

$\ldots+\ldots+m *$

$+\ldots+\cdots+\cdots$

$\ldots$

$\ldots$

$+\ldots+\cdots$

$\ldots \ldots \ldots$

$\cdots$

..........

$n \ldots \ldots \ldots$

$\ldots \ldots \ldots+\cdots$

$\ldots \ldots+\ldots$
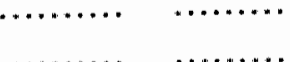

12

1

$$
2
$$

$\ldots$
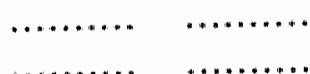

$\begin{array}{lll}1 & 2 & \ldots \\ 1 & 2 & \cdots \\ 1 & 2 & \ldots\end{array}$


$28 \mathrm{ZJjn}$ er vanwege de linstelling speciale toelatingselisen om voor dienstwerlening in aanmerking komen ten aamzien van (meerdere antwoorden zijn mogelijk: oncirliellea):

geslacht

$$
\text { alleen vrouwen }
$$

alleen mannen

niet van toepassing

leeftijd

$$
\text { minimum leeftijd }
$$

medisch

ter beoordeling door interne deskundige

ter beoordeling door externe deskundige

ter beoordeling door indicatiecommissie

niet van toepassing

psychisch ter beoordeling door interne deskundige 11

ter beoordeling door externe deskundige

ter beoordeling door indicatiecommissie

niet van toepassing

sociale en maatschappelijke omstandigheden

ter beoordeling door interne deskundige

ter beoordelind door externe deskundige

ter beoordeling door indicatiecommissie

niet van toepassing

lidmaatschap van een bepaald kerkgenootschap cq. het aanhangen van een bepaalde levensbeschouwing

rooms-katholiek

hervormd

gereformeerd

humanistisch

overig, nl.:

niet van toepassing

woonomgeving binnen het werkgebied van de instelling dan well het hebben wan famille binnen dat werkgebied well van toepassing

niet van toepassing

andere statutaire voorwaarden 
29 Totaal aantal ingeschreven patienten cq. cliênten per 1 Jamuarl 19.. naar leeftidscategorie en geslacht:

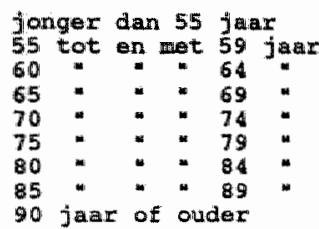

Tataal

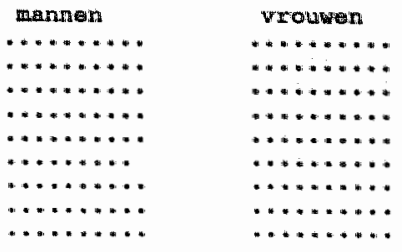

* *.....*

30 Aantal nieuw ingeschreven patiënten cq. cliënten gedurende het jaar 19 ... per leeftijdscategorie en geslacht:

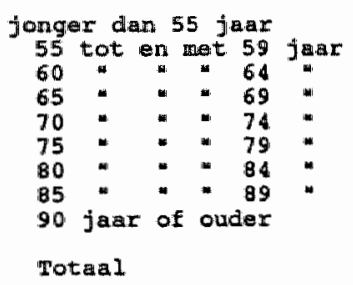

mannen
$\ldots \ldots \ldots$
$\ldots \ldots \ldots$
$\ldots \ldots \ldots$
$\ldots \ldots \ldots$
$\ldots \ldots \ldots$
$\ldots \ldots \ldots$
$\ldots \ldots \ldots$

31 Aantal uitgeschreven patiënten cq. cliënten gedurende het jaar 19 wa. per leeftijdscategorie en geslacht:

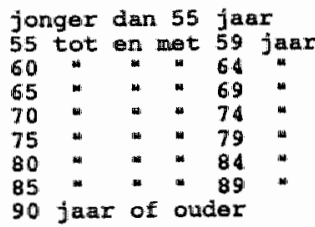

Total

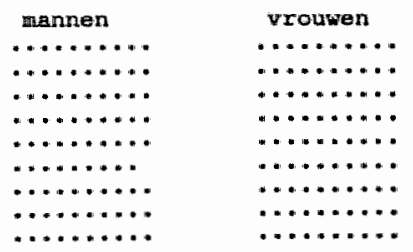




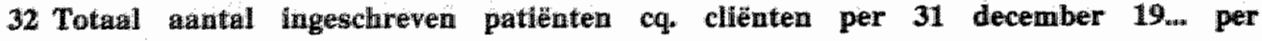
leefujdscategorie en geslacht:

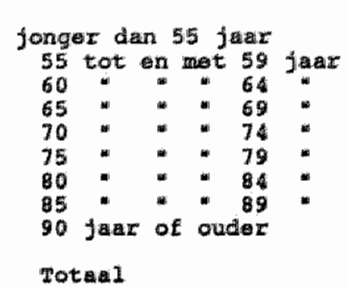

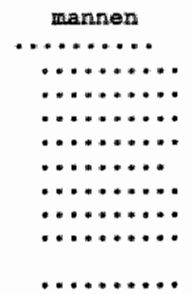

vromben

$\ldots \ldots$

$\ldots \ldots+\cdots$

$\ldots+\cdots+\ldots$

$\cdots+\ldots+\ldots$

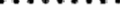

$\cdots \cdots+\ldots$

$\ldots+\ldots \ldots$

$\ldots \ldots \ldots+\cdots$

$\ldots \ldots \ldots$

33 Dienstverlening aan alle patiênten cq. cliënten volgens een aantal maatstaven naar lleeftijd en geslacht van de patiênten cq. cliënten (Gaarne schattüng indien miet precies bekend):

a) totaal aantal uren dienstverlening voor alle patiënten cq. cliënten in 19...:

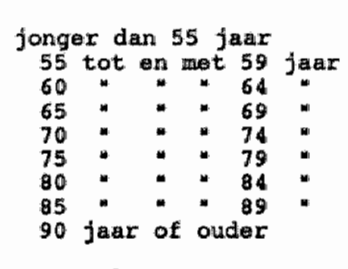
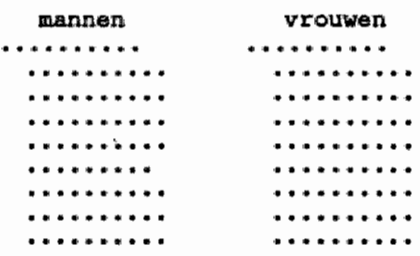

Totan

b) totaal azintal contacten net alle patiênten cq- clïntem in 19...:

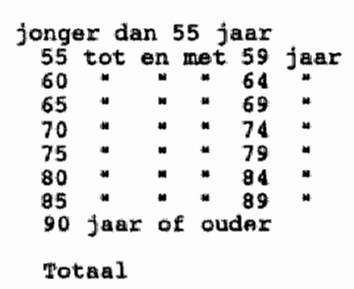

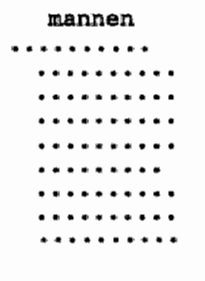

vrouwen

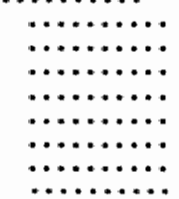


34 Kunt u aangeven boeveel wan de in $19 .$. nileuw ingeschreven patienten/clièten vóor inschrijving de hieronder genoemde omgevingen als verblifflats hadden?

Eigen omgeving (eigen woning, inwonend bij famille e.d.)

waarvan zonder hulp

waarvan met wijkverpleging

waarvan met gezinszorg

waarvan met wijkverpleging en gezinszorg

waarvan met dagopvang, gecoör. ouderenwerk

waarvan met gebruik ambulante g.g.z.

waarvan verder niets bekend

Aanleunwoning.

Bejaardenoord of niet-erkend verpleeghuis

Ziekenhuis

Erkend verpleeghuis of verpleegafdeling

somatisch

psycho-geriatrisch

onbekend

Psychiatrische inrichting

Revalidatie-inrichting

Onbekend

Overig (nl...

Totaal

35 Aantal nieuw ingeschreven patiënten/cliënten waarbij de onderstannde personen/instanties in $19 .$. het initiatief tot opname/inschrijving namen:

Geestelijke verzorging

Soc. cult./opbouwwerk

Algemeen Maatschappelijk Werk

Gezinsverzorging

Tel. hulpdienst

Bejaardenoord of niet-erkend verpleeghuis

gecoordineerd of open ouderenwerk

Wijkverpleging

Huisarts

Medisch specialist

Polikliniek Algemeen Ziekenhuis

RIAGG

Psychiater (zelfstandig of in ziekenh.)

PAAZ

psychiatrisch ziekenhuis

erkend verpleeghuis

zwakzinnigeninrichting

semi-murale instelling GGZ

dagziekenhuis

crisiscentrum

polikliniek psychiatrisch ziekenhuis

volledig eigen initiatief

familie, vrienden, buren

onbekend 
$36 \mathrm{De}$ in 19... uit de instelling vertrokken/uitgeschreven personen naar bestemming of overlijden:

Eigen omgeving (eigen woning, inwonend bij familie e.d.) waarvan zonder hulp waarvan met wijkverpleging waarvan met gezinszorg waarvan met wijkverpleging én gezinszorg waarvan met dagopvang, gecoor. ouderenwerk waarvan met gebruik ambulante g.g.z. waarvan verder niets bekend Aanleunwoning

Bejaardenoord of niet erkend verpleeghuis

Ziekenhuis (blijvend)

Erkend verpleeghuis of verpleegafdeling somatisch

psycho-geriatrisch onbekend

Psychiatrische inrichting

Revalidatie-inrichting

Onbekend

Overleden

Overig (nl.:

Totaal

\section{KOSTEN}

Invullen in hele guldens (afgerond indien nodig)

37 Personeelskosten naar omvang van de dagtaak

$\begin{array}{lll}\begin{array}{l}\text { volledige } \\ \text { dagtaak }\end{array} & \begin{array}{l}\text { gedeelt. } \\ \text { dagtak }\end{array} & \text { totaal }\end{array}$

\begin{tabular}{|c|c|c|}
\hline $\begin{array}{l}\text { lonen en salarissen } \\
\text { sociale lasten } \\
\text { pensioensbijdragen } \\
\text { overige pers.kosten }\end{array}$ & $\begin{array}{l}f \\
f \\
f \\
f\end{array}$ & 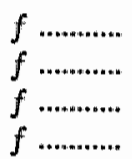 \\
\hline totaal & $f \ldots \ldots \ldots$ & $f \ldots . . . . . . .$. \\
\hline
\end{tabular}

38 Huisvesting huur en leasing onderhoud energie overige huisvestingskosten

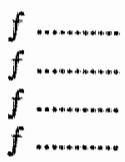


39. Levensonderhoud voeding verzorgden voeding personeel overig

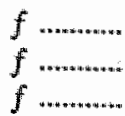

40 Kapitaalkosten (voor zover op lopende rekening) investeringen afschrijvingen interest

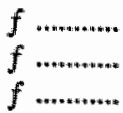

Totaal

$f$

41 Hulpmiddelen geneesmiddelen kunstmiddelen hulpmiddelen overig

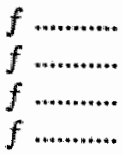

Totaal

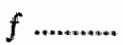

42 Overige kosten (voor zover geen personeelskosten)

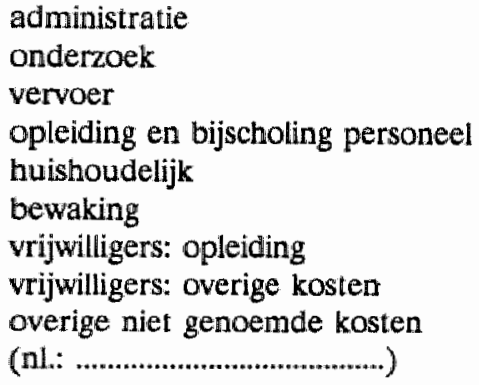

Totaal

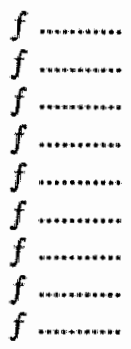

$f$

\section{Kostenverbijzondering}

Indien naast de iraditionele jaarrekening een of ander functioneel rekeningsschema gehanteerd wordt door de instelling, wordt $u$ vriendelijk verzocht hiervan een afschrift/copie toe te voegen aan dit enqueteformulier.

Onderstaande vragen dienen ter bepaling van de aard van het door uw instelling gehanteerde functionele rekeningsschema.

Hoe zijn de kosten verbijzonderd?

Kosten toegedeeld naar afdeling

Kosten toegedeeld naar patientengroepen

Kosten toegedeeld naar type zorgverlening

Kosten op andere manier toegedeeld

nl.:

Niet van toepassing 


\section{IINANCIERING}

Invullen in hele guldens (afgerond indlen nodig)

44 Financiering naar betalende Instantie

overheid: rijk

overheid: provincie

overheid: gemeente

ziekenfondsem

IZAVIZR

particuliere verzekeraars

AWBZ

AAW

eigen bijdrage/retributies

andere gezondheidszorg instellingen

bedrijven buiten gezondheidszorg

overig (nl...................................)

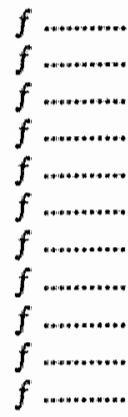

Totaal

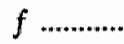

45 Baten van een aantal activiteiten

verpleging en verzorging

medische-spec. hulp afz. in rek.

diagn. verrichtingen afz. in rek.

therap. werrichtingen afz. in rek.

genees-, kunst- en hulpmiddelen

levensonderhoud.

huur en pension

voorlichting

cursussen

kantine e.d.

overig (n).

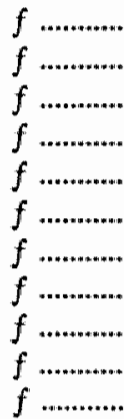

Totaal

$f$ 


\section{Bijlage 3. Berekening van de kosten van indicatie-stelling}

De totale kosten per uitgebracht advies zijn globaal te benaderen op basis van enkele aannames voor personeels- en overige kosien. Zoals in paragraaf 3.2. is uiteengezet, bestaat de indicatiecommissie uit twee maatschappelijk werkenden ( $a f 55.000$,- per jaar), een secretaris $\left(0,8\right.$ fte a $\left.f 50.000_{n}\right)$ ) en een arts (geschat op 0,1 fte $f\left(10.000^{-}\right)$. De totale personeelslasten bedragen dan bij benadering $f 170.000$ - op jaarbasis, waarbij nog eens ongeveer $f$ 10.000,- bureaukosten komen (schatting door de - voormalige - secretaris van de indicatiecommissie). De indicatiecommissie bracht in 1988 in total 587 adviezen uit voor opname in een bejaardenoord, aansluiting op alarmsysteem en tijdelijk wonen in een bejaardenoord. Omdat de verschillende soorten adviezen niet even tijdsintensief zijn, worden voor de berekening van de kosten per advies verschillende gewichten toegekend aan een opname-advies (in totaal 358 maal; gewicht $=1$ ), een alarmeringsadvies (in totaal 144 maal; gewicht $=0,6$ ) en een advies voor tijdelijk wonen ( 85 maal; gewicht $=0,9$ ).

Met de voorgaande assumpties wordt een "kostprijs" per uitgebracht advies berekend wan ongeveer $f 350,-$. 


\section{Bijlage 4. Ruwe tellingen uit de peilingen van individuele meerzorg}

\begin{tabular}{|c|c|c|c|c|}
\hline \multirow[b]{2}{*}{ 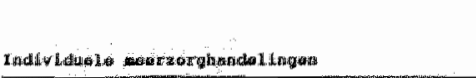 } & \multirow{2}{*}{ 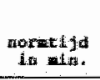 } & \multicolumn{3}{|c|}{ asakal beroniars } \\
\hline & & lakmenordan & estit.00arden & totemina 1 \\
\hline 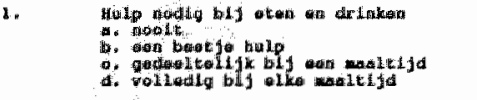 & $\begin{array}{l}19 \\
30 \\
30\end{array}$ & $\begin{array}{l}4.64 \\
2.37 \\
1.30 \\
1.24\end{array}$ & $\begin{array}{l}57 \\
\$ 0 \\
6\end{array}$ & $\begin{array}{l}5.10 \\
2015 \\
19.8 \\
124\end{array}$ \\
\hline 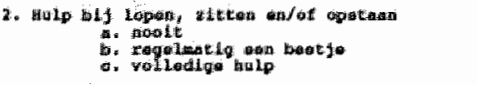 & $s_{n}^{5} 5$ & $\begin{array}{l}513 \\
220 \\
204\end{array}$ & $\begin{array}{l}715 \\
56 \\
26\end{array}$ & $\begin{array}{l}392 \\
276 \\
232\end{array}$ \\
\hline 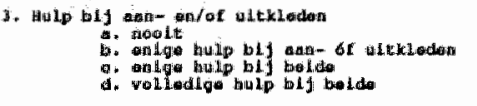 & $\begin{array}{l}2,5 \\
2,5 \\
30\end{array}$ & $\begin{array}{r}411 \\
85 \\
269 \\
143\end{array}$ & 98 & $\begin{array}{r}529 \\
65 \\
300 \\
175\end{array}$ \\
\hline 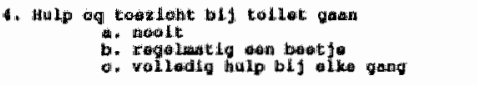 & $\begin{array}{c}0 \\
a_{n} 5 \\
15 \\
19\end{array}$ & $\begin{array}{l}829 \\
141 \\
169\end{array}$ & $\begin{array}{r}103 \\
41 \\
1.9\end{array}$ & $\begin{array}{l}732 \\
182 \\
186\end{array}$ \\
\hline 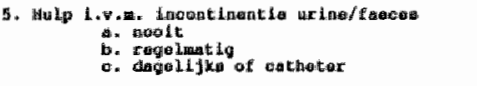 & $\begin{array}{c}0 \\
20,5 \\
20,5\end{array}$ & $\begin{array}{l}582 \\
190 \\
165\end{array}$ & $\begin{array}{r}325 \\
26 \\
12\end{array}$ & $\begin{array}{l}7107 \\
215 \\
1.77\end{array}$ \\
\hline 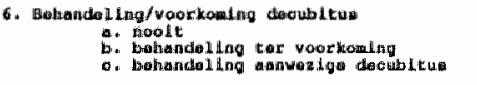 & $\begin{array}{r}40 \\
40 \\
60\end{array}$ & $\begin{array}{r}772 \\
131 \\
34\end{array}$ & $\begin{array}{r}146 \\
1.4 \\
y\end{array}$ & $\begin{array}{l}9.18 \\
145 \\
37\end{array}$ \\
\hline 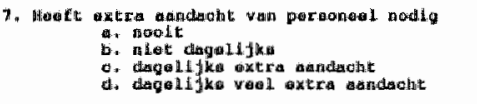 & 20 & $\begin{array}{l}113 \\
272 \\
240 \\
312\end{array}$ & $\begin{array}{l}91 \\
20 \\
22 \\
20\end{array}$ & $\begin{array}{l}2006 \\
31001 \\
262 \\
3132\end{array}$ \\
\hline 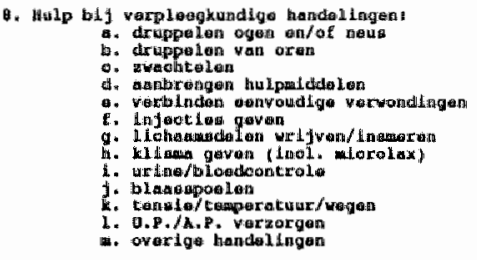 & $\begin{array}{l}2: \\
2: \\
4,5 \\
4,5 \\
4,5 \\
6 \\
6 \\
6 \\
1 \\
6 \\
2 \\
2 \\
8 \\
-\end{array}$ & $\begin{array}{r}102 \\
10 \\
69 \\
170 \\
818 \\
47 \\
314 \\
27 \\
156 \\
10 \\
205 \\
13 \\
33\end{array}$ & $\begin{array}{r}15 \\
1 \\
9 \\
19 \\
8 \\
9 \\
29 \\
1 \\
7 \\
1 \\
2 \\
1 \\
67\end{array}$ & $\begin{array}{r}1.7 \\
9 \\
718 \\
149 \\
916 \\
56 \\
343 \\
218 \\
63 \\
11 \\
107 \\
144 \\
100\end{array}$ \\
\hline 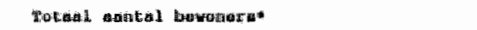 & & 937 & 10,0 & 11.00 \\
\hline
\end{tabular}

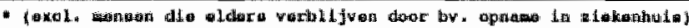




\section{Bijlage 5. Ruwe scores bij Beoordeling Psycho-sociale problematiek in verzorgingstehuizen*}

\begin{tabular}{|c|c|c|c|c|c|c|}
\hline : * & Frag uit Bes-iijot & noost: & ge 2 den & 20 and & 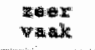 & wask \\
\hline 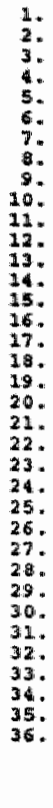 & 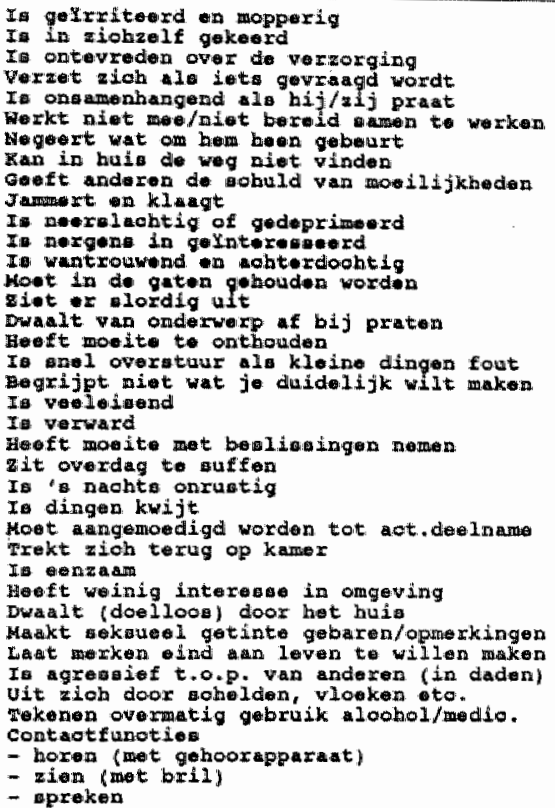 & 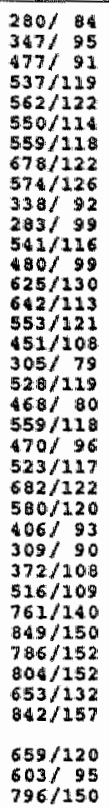 & 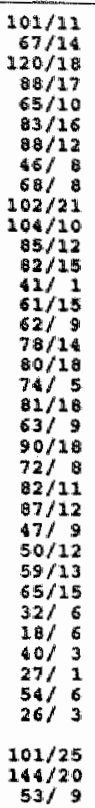 & 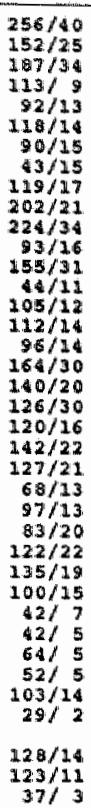 & 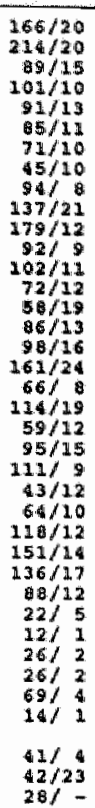 & 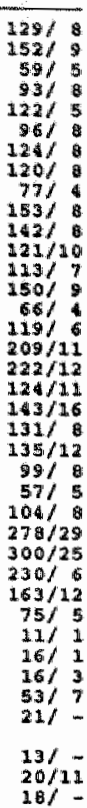 \\
\hline
\end{tabular}

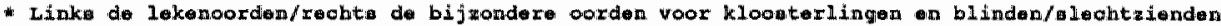




\section{Bijlage 6. Correlatie-matrix tussen de verschillende (I)ADL-items}

\begin{tabular}{|c|c|c|c|c|c|c|c|c|c|}
\hline 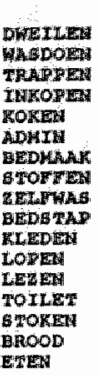 & 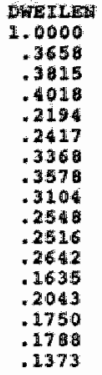 & $\begin{array}{r}1.0000 \\
.2904 \\
.3496 \\
.4569 \\
.2937 \\
.3992 \\
.4314 \\
.3766 \\
.2901 \\
.3307 \\
.3191 \\
.2294 \\
17690 \\
.2445 \\
.2626 \\
.1821\end{array}$ & $\begin{array}{r}1.0000 \\
.5041 \\
.2869 \\
.3010 \\
.4510 \\
.3970 \\
.5123 \\
.5109 \\
.4764 \\
.5431 \\
.2926 \\
.3710 \\
.2731 \\
.2813 \\
.2560\end{array}$ & $\begin{array}{r}1.0000 \\
.3471 \\
.4329 \\
.5182 \\
.4839 \\
.3415 \\
.4490 \\
.4211 \\
.4914 \\
.3214 \\
.3998 \\
.3415 \\
.3652 \\
.2460\end{array}$ & $\begin{array}{r}1.100100 \\
.3557 \\
.4812 \\
.5056 \\
.5004 \\
.3924 \\
.4674 \\
.4524 \\
.3389 \\
.4110 \\
.4132 \\
.4630 \\
.3216\end{array}$ & $\begin{array}{r}1.0000 \\
.3680 \\
.3511 \\
.4324 \\
.3429 \\
.3912 \\
.3797 \\
.3695 \\
.3701 \\
.4023 \\
.4073 \\
.3104\end{array}$ & $\begin{array}{r}1.9000 \\
.5782 \\
.5692 \\
.4729 \\
.5540 \\
.4971 \\
.3228 \\
.4892 \\
.4319 \\
.4874 \\
.3354\end{array}$ & $\begin{array}{r}1.0000 \\
.5628 \\
.4619 \\
.5429 \\
.5420 \\
.3379 \\
.4952 \\
.4330 \\
.4963 \\
.3363\end{array}$ & $\begin{array}{r}1.0000 \\
.7074 \\
.7796 \\
.6324 \\
.4045 \\
.6029 \\
.4647 \\
.4958 \\
.3903\end{array}$ \\
\hline 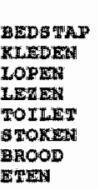 & 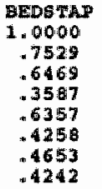 & $\begin{array}{r}\text { THEDEN } \\
1.0000 \\
.6569 \\
.4350 \\
.7087 \\
.5072 \\
.5659 \\
.4471\end{array}$ & $\begin{array}{r}1.0000 \\
.4134 \\
.6251 \\
.4324 \\
.4580 \\
.4507\end{array}$ & $\begin{array}{r}1.0000 \\
.4378 \\
.4656 \\
.4542 \\
.4269\end{array}$ & $\begin{array}{r}1.0000 \\
.0211 \\
.6464 \\
.5892\end{array}$ & $\begin{array}{r}1.0000 \\
.7397 \\
.5484\end{array}$ & $\begin{array}{r}1 \text {. } 00000 \\
\times 5551\end{array}$ & Extan & \\
\hline
\end{tabular}




\section{Curriculum Vitae}

Robbert Huijsman werd op 26 januari 1962 in Rotterdam geboren. Hij bezocht van 1974 tot 1980 het Gymnasium Erasmianum te Rotterdam, waar in juni 1980 het eindexamen Gymnasium Beta behaald werd. Van 1980 tot 1986 studeerde hij aan de Erasmus Universiteit Rotterdam, eerst in de studierichting econometrie, doch vanaf 1981 in de algemene en macro-economie. Naast verschillende functies bij de studentenvereniging SSR vervulde hij tijdens de laatste twee jaar van zijn studie de functie van student-assistent bij prof.drir. J.M.M. Ritzen, in die tijd hoogleraar in de Economie van de Publieke Sector, en deed in dat kader binnen het project 'Menselijk kapitaal en conjunctuurbewegingen' onderzoek naar de invloed van onderwijs op de economische groei.

Sinds mei 1986 werkte hij, als toegevoegd onderzoeker bij de vakgroep Economie van de Gezondheidszorg van de Rijksuniversiteit Limburg, in belangrijke mate aan het in dit proefschrift beschreven onderzoek. Daarnaast leverde hij een bescheiden bijdrage aan het onderwijs en fungeerde sinds januari 1988 tevens als projectcoordinator ten behoeve van de evaluatie van het door het ministerie van WVC geentameerde demonstratie-project Totaal Ouderenbeleid Venlo. In november 1989 organiseerden prof.dr. F.F.H. Rutten en hij het congres 'Economie van de Ouderenzorg', ter gelegenheid waarvan tevens een boek werd uitgegeven met dezelfde titel. Buiten zijn werkkring vervulde hij enkele adviseursfuncties bij organisaties in en buiten de ouderenzorg en bij de uitgeverij VUGA

Vanaf 1 december 1990 is Robbert Huijsman verbonden aan het Institute for Medical Technology Assessment (iMTA) aan de Erasmus Universiteit te Rotterdam. Daar zal hij de komende vijf jaar, met steun van het ministerie van $\mathrm{WVC}_{\text {, het }}$ onderzoeksprogramma 'Economische aspecten van de ouderenzorg' tot ontwikkeling gaan brengen. 